\title{
Mexico: Detailed Assessment Report on Anti-Money Laundering and Combating the Financing of Terrorism
}

This Detailed Assessment Report on Anti-Money Laundering and Combating the Financing of Terrorism for Mexico was prepared by a staff team of the International Monetary Fund using the assessment methodology adopted by the Financial Action Task Force in February 2004 and endorsed by the Executive Board of the IMF in March 2004. It is based on the information available at the time it was completed on September 11, 2008. The views expressed in this document are those of the staff team and do not necessarily reflect the views of the government of Mexico or the Executive Board of the IMF.

The policy of publication of staff reports and other documents by the IMF allows for the deletion of market-sensitive information.

Copies of this report are available to the public from

International Monetary Fund $\bullet$ Publication Services

700 19th Street, N.W. • Washington, D.C. 20431

Telephone: (202) 6237430 • Telefax: (202) 6237201

E-mail: publications@imf.org • Internet: http://www.imf.org

Price: $\$ 18.00$ a copy

\section{International Monetary Fund} Washington, D.C. 



\section{MEXICO}

\section{DETAILED ASSESSMENT}

REPORT ON ANTI-MONEY

LAUNDERING AND

\section{COMBATING THE FINANCING OF TERRORISM}

SEPTEMBER 11, 2008 
Table of Contents

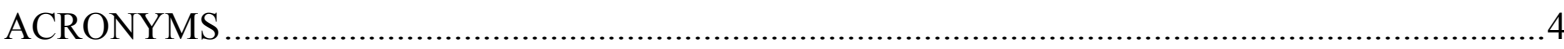

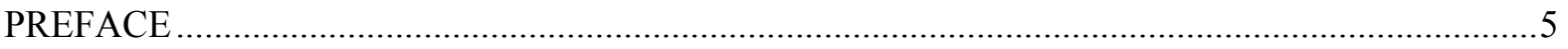

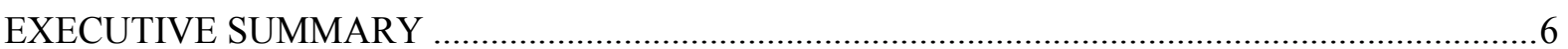

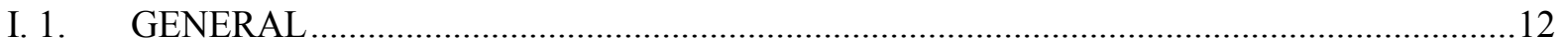

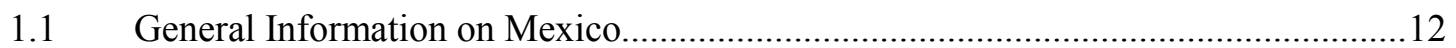

1.2 General Situation of Money Laundering and Financing of Terrorism ........................14

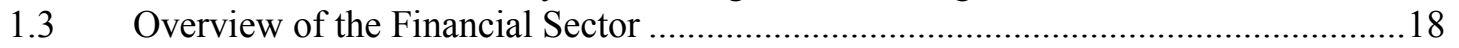

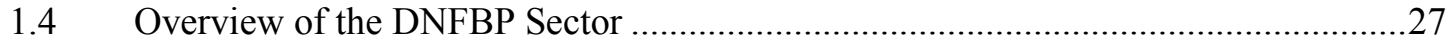

1.5 Overview of commercial laws and mechanisms governing

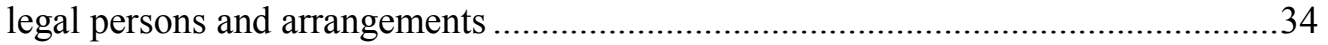

1.6 Overview of strategy to prevent money laundering and terrorist financing ................39

II. 2. LEGAL SYSTEM AND RELATED INSTITUTIONAL MEASURES …............................49

2.1 Criminalization of Money Laundering (R.1 \& 2) ......................................................49

2.2 Criminalization of Terrorist Financing (SR.II) ......................................................62

2.3 Confiscation, freezing and seizing of proceeds of crime (R.3) ................................67

2.4 Freezing of funds used for terrorist financing (SR.III) .............................................

2.5 The Financial Intelligence Unit and its Functions (R.26) ...........................................78

2.6 Law enforcement, prosecution and other competent authorities the framework for the investigation and prosecution of offenses, and for confiscation and freezing (R.27, \& 28) .........................................95

2.7 Cross Border Declaration or Disclosure (SR.IX) .....................................................114

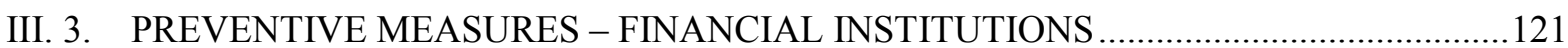

3.1 Risk of money laundering or terrorist financing ......................................................121

3.2 Customer due diligence, including enhanced or reduced measures (R.5 to 8) .........123

3.3 Third Parties and Introduced Business (R.9) ...........................................................158

3.4 Financial Institution Secrecy or Confidentiality (R.4) ..............................................161

3.5 Record keeping and wire transfer rules (R.10 \& SR.VII) ..........................................168

3.6 Monitoring of Transactions and Relationships (R.11 \& 21) ....................................173

3.7 Suspicious Transaction Reports and Other Reporting (R.13-14, 19, 25 \& SR.IV) ..177

3.8 Internal Controls, Compliance, Audit and Foreign Branches (R.15 \& 22)................194

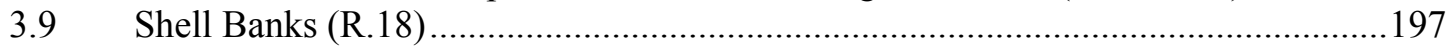

3.10 The Supervisory and Oversight System - Competent Authorities and SROs. Role, Functions, Duties, and Powers (Including Sanctions) (R. 17, 23, 25 \& 29)

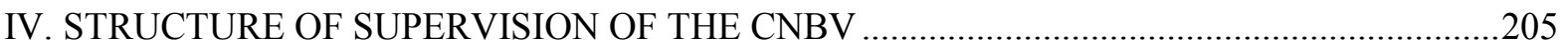

3.11 Money or Value Transfer Services (SR.VI) ………..............................................228

V. 4. PREVENTIVE MEASURES - DESIGNATED NON-FINANCIAL BUSINESSES AND

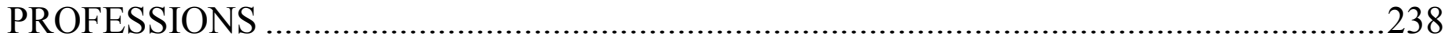

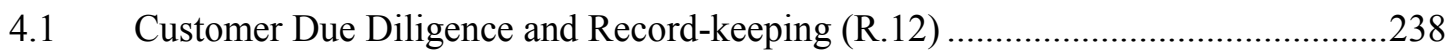

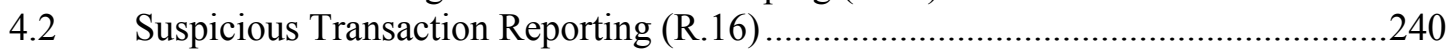

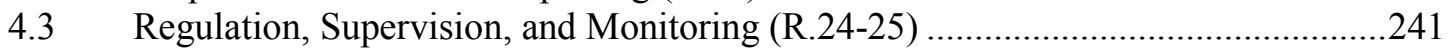

4.4 Other Non-Financial Businesses and Professions-

Modern-Secure Transaction Techniques (R.20).... 
VI. 5. LEGAL PERSONS AND ARRANGEMENTS \& NON-PROFIT ORGANIZATIONS ......243

5.1 Legal Persons - Access to Beneficial Ownership and Control Information (R.33) .243

5.2 Legal Arrangements - Access to Beneficial Ownership and Control Information (R.34)

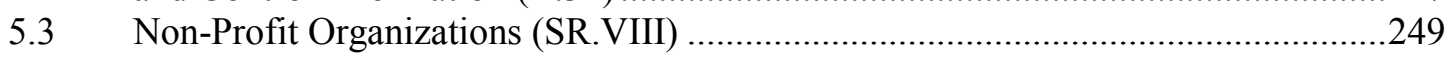

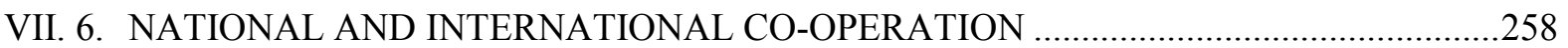

6.1 National Co-Operation and Coordination (R.31) _..................................................258

6.2 The Conventions and UN Special Resolutions (R.35 \& SR.I) ..................................264

6.3 Mutual Legal Assistance (R.36-38, SR.V) ………...................................................26

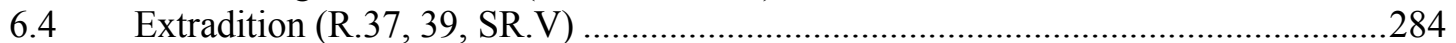

6.5 Other Forms of International Cooperation (R.40 \& SR.V)........................................293

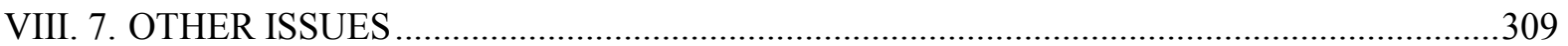

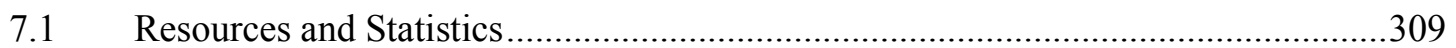

7.2 Other relevant AML/CFT Measures or Issues ............................................................

7.3 General Framework for AML/CFT System (see also Section 1.1) ...........................310

Tables

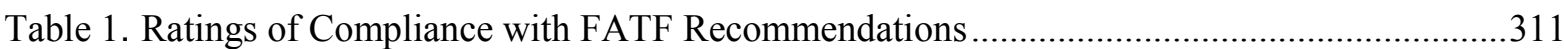

Table 2. Recommended Action Plan to Improve the AML/CFT System ..........................................325

Annexes

Annex 1. Details of All Bodies Met During the On-Site Visit .........................................................338

Annex 2. List of Key Laws. Regulations and Other Related Material used in the Assessment ..........340

Annex 3.Copies of Key Laws, Regulations, and Other Measures ....................................................344 


\section{ACRONYMS}

\begin{tabular}{|c|c|}
\hline $\mathrm{AML} / \mathrm{CFT}$ & Anti-Money Laundering and Combating the Financing of Terrorism \\
\hline $\mathrm{CPF}$ & Federal Criminal Code (Código Penal Federal) \\
\hline CDD & Customer Due Diligence \\
\hline LIC & Law of Credit Institutions (Ley de Instituciones de Crédito) \\
\hline CONSAR & National Retirement Savings System Commission \\
\hline CNBV & National Banking and Securities Commission \\
\hline CNSF & National Insurance and Sureties/Bonding Commission \\
\hline $\mathrm{CPC}$ & Criminal Procedure Code \\
\hline CSP & Company service provider \\
\hline DCG & AML/CFT Regulations (Disposiciones de Carácter General) \\
\hline DGPOI & AML/CFT Unit (Dirección General de Prevención de Operaciones Ilicitas) \\
\hline DNFBP & Designated Non-Financial Businesses and Professions \\
\hline FATF & Financial Action Task Force \\
\hline FI & Financial institution \\
\hline FIU & Financial intelligence unit \\
\hline FSAP & Financial Sector Assessment Program \\
\hline FSRB & FATF-style Regional Body \\
\hline FT & Financing of terrorism \\
\hline GOM & Government of Mexico \\
\hline KYC & Know your customer \\
\hline LEG & Legal Department of the IMF \\
\hline MFA & Ministry of Foreign Affairs \\
\hline MOU & Memorandum of understanding \\
\hline ML & Money laundering \\
\hline MLA & Mutual legal assistance \\
\hline NPO & Nonprofit organization \\
\hline PEP & Politically-exposed person \\
\hline PGR & Office of the Attorney General (Procuraduria General de la Repùblica) \\
\hline ROSC & Report on Observance of Standards and Codes \\
\hline SAT & Tax Administration Service (Servicio de Administración Tributaria) \\
\hline SIEDO & $\begin{array}{l}\text { Deputy Attorney General's Office for the Investigation of Organized Crime } \\
\text { (Subprocuraduría de Investigación Especializada en Delincuencia Organizada) }\end{array}$ \\
\hline $\mathrm{SHCP}$ & Ministry of Finance and Public Credit (Secretaria de Hacienda Credito y Publico) \\
\hline SOFOLES & Limited Purpose Finance Companies (Sociedades Financieras de Objeto Limitado) \\
\hline SOFOMES & Multiple Purpose Finance Companies (Sociedades Financieras de Objeto Multiple) \\
\hline SRO & Self-regulatory organization \\
\hline STR & Suspicious transaction report \\
\hline TD & Money remitter (transmisor de dinero) \\
\hline $\mathrm{TF}$ & Terrorism financing \\
\hline UN & United Nations Organization \\
\hline UNSCR & United Nations Security Council Resolution \\
\hline
\end{tabular}




\section{PREFACE}

This assessment of the anti-money laundering (AML) and combating the financing of terrorism (CFT) regime of Mexico is based on the Forty Recommendations 2003 and the Nine Special Recommendations on Terrorist Financing 2001 of the Financial Action Task Force (FATF) and was prepared using the AML/CFT assessment Methodology 2004, as updated in June 2006. The assessment team considered all the materials supplied by the authorities, the information obtained on site during their mission from January 14 through 30, 2008, and other verifiable information subsequently provided by the authorities. During the mission, the assessment team met with officials and representatives of all relevant government agencies and the private sector. A list of the bodies met is set out in Annex 1 to the detailed assessment report.

The assessment was conducted by a team of assessors composed of three staff of the International Monetary Fund (IMF) and three expert(s) acting under the supervision of the IMF. The evaluation team consisted of: Richard Lalonde (LEG, team leader); Manuel Vásquez, Ernesto López (LEG, financial sector experts); and Mariano Federici (IMF Technical Assistance Officer under LEG supervision, legal expert), Federico Di Pasquale (legal expert under LEG supervision), and Bernardo Mota (financial intelligence unit expert). Mr. Alejandro Montesdeoca, Executive Secretary of the South American FATF-style Regional Body (GAFISUD), and Ms. Rachel Fedewa, from the U.S. Treasury Department and on behalf of the FATF, participated as observers during the assessment visit by prior agreement with the authorities. The assessors reviewed the institutional framework, the relevant AML/CFT laws, regulations, guidelines and other requirements, and the regulatory and other systems in place to deter and punish money laundering (ML) and the financing of terrorism (FT) through financial institutions and Designated Non-Financial Businesses and Professions (DNFBPs). The assessors also examined the capacity, implementation, and effectiveness of all these systems.

This report provides a summary of the AML/CFT measures in place in Mexico at the time of the mission or shortly thereafter. It describes and analyzes those measures, sets out Mexico's levels of compliance with the FATF 40+9 Recommendations (see Table 1), and provides recommendations on how certain aspects of the system could be strengthened (see Table 2). The report was produced by the IMF in the context of the Financial Sector Assessment Program (FSAP) of Mexico. It was presented to the FATF and endorsed by this organization at its plenary meeting of October 2008. The report was also presented to and endorsed by GAFISUD at its plenary meeting of December 2008.

The assessors would like to express their gratitude to the Mexican authorities for their excellent cooperation and assistance throughout the assessment mission. 


\section{EXECUTIVE SUMMARY}

\section{Key Findings}

1. As has been the case in other countries, Mexico now faces an unprecedented threat to its national security and stability from drug trafficking and organized crime. Powerful drug cartels, resorting to extreme violence, have extended their activities across various parts of the country, and these activities pose significant challenges to the Government. This situation reflects the magnitude of financial and economic resources and power at the disposal of drug cartels and organized crime. The economic power of the criminal organizations helps them to continue operating and undermines good governance and the authority of the State.

2. In response, the Mexican government has instituted unprecedented measures to support law enforcement activities against organized crime and drug trafficking. The authorities have recently approved an "Integral Strategy Against Organized Crime" and various key national stakeholders have executed an interagency agreement entitled the "National Agreement for Security, Justice and Legality." The Mexican authorities are also working to complete an AML/CFT National Strategy before the end of 2008 .

3. There is strong political and institutional commitment to tackle crime and money laundering (ML) in Mexico. The authorities have taken a number of measures to counter the significant ML risks connected with drug trafficking, organized crime and related offenses, and they remain alert for any indication of terrorism or financing of terrorism (FT). The authorities perceive the threat of terrorism financing in Mexico arises primarily from terrorist methods supported by organized crime, and from the proximity and close relation with other countries that face serious terrorism threats.

4. Overall, Mexico has made progress in developing its system for combating ML and FT since its last assessment by the FATF in 2004, but further work is needed to strengthen it. First, the laws criminalizing the ML and FT offenses are comprehensive but do not fully meet international standards, and there is scope to significantly improve their implementation. In particular, laws and procedures do not adequately provide for the freezing without delay of terrorist funds or other assets of persons designated in accordance with relevant United Nations Security Council resolutions (UNSCRs). Given the extent of drug trafficking, organized crime and other predicate criminal activities, the ML offenses are not being adequately investigated; the authorities have obtained only 25 convictions for ML since the criminalization of the ML offense in 1989. During the period 2004-2007, prosecutors secured 149 indictments for ML, but only two were related to financial intelligence reports produced by Mexico's financial intelligence unit (FIU).

5. Coordination arrangements among the intelligence, investigation and prosecution agencies have been strengthened recently but need to be further developed as the new relationship evolves. The insufficient resources allocated to investigation units of the Deputy Attorney General's Office for the Investigation of Organized Crime (SIEDO) have impeded Mexico's capacity to conduct investigations and prosecutions of ML offenses in an effective manner. The structure and processes for case management by SIEDO also needs to be improved, and prosecutors and judges could also benefit from additional training on AML/CFT issues. 
6. The FIU has made progress in developing its financial intelligence infrastructure and staff, and it has markedly improved its working relationship with the prosecutorial authorities at the Office of the Attorney General (PGR). The Tax Administration Service (SAT) and the FIU need to work together to ensure the full, timely and secure access to suspicious transaction reports (STRs) from exchange centers, money services businesses and certain other businesses. The FIU currently does not have direct access to criminal records due to legal constraints, except ex-post with respect to cases or subjects informed by the FIU to the PGR. The number of staff remains low relative to the large volume of reports it receives and the other activities assigned to it. However, to help it cope with the volume of STRs, the FIU has considered measures with reporting entities to reduce over-reporting and has adopted an automated "risk-based" system to filter cases that do not merit deeper analysis. As part of a restructuring of the FIU that is expected to conclude at the end 2009, the FIU has embarked upon a project to significantly increase its staff resources.

7. The AML/CFT preventive measures are comprehensive, contain risk-based elements, and are being implemented across all the principal sub-sectors of the financial system. Nonetheless, the AML/CFT regulations are still evolving, particularly for the non-deposit taking sectors, and they should be revised to add clarity and consistency. A key challenge is the lack of staff and resource capacity of the SAT to enforce registration requirements and conduct ongoing AML/CFT supervision of the very large number of foreign exchange centers and remittance operators. This challenge is being compounded by the increasing number of unregulated multi-purpose finance companies (SOFOMES) coming on stream, a product of deregulation of limited purpose finance companies (SOFOLES) that are engaged in e.g., lending, leasing, and factoring. Notwithstanding these challenges, all of the supervisory authorities are implementing fairly comprehensive on-site AML/CFT supervision which is largely focused on regulatory compliance and which could benefit from the introduction of more risk-based processes.

8. There are no AML/CFT legal or regulatory measures, nor supervision, for any of the categories of FATF designated non-financial businesses and professions (DNFBPs) ${ }^{1}$, except for trust services which, by law, can be provided only by licensed financial institutions. The lack of measures with respect to the other categories of DNFBPs represents a significant gap in the AML/CFT regime. In addition, no review has been conducted of the domestic nonprofit organization (NPO) sector to support the adoption of measures to prevent the unlawful use of legal persons in relation to ML and FT.

9. Mexican authorities have been cooperating effectively with authorities from other countries, particularly in the area of mutual legal assistance and extradition involving ML and related crimes.

\section{Legal Systems and Related Institutional Measures}

10. The ML legislation applies to the proceeds of all crimes committed in Mexico and includes all of the designated categories of offenses under the FATF recommendations. The principal ML provisions are contained under Article 400-Bis of the Federal Criminal Code and complemented by the provisions in the Federal Law Against Organized Crime. The Federal Criminal Code applies more severe criminal sanctions for ML that is committed by members of a criminal organization.

\footnotetext{
${ }^{1}$ In Mexico, applicable DNFBPs include real estate agents, dealers in precious metals and stones, lawyers, notaries and other independent legal professionals and accountants, and company services providers.
} 
11. Mexican law allows for the prosecution of persons who commit both the predicate offense and the ML offense (self-laundering). The offense of ML extends to any type of property, regardless of its value, that directly or indirectly represents the proceeds of a crime.

12. Criminal liability for ML or FT currently does not extend to legal persons but recently proposed legislation may allow for it. The law provides for administrative and civil sanctions against legal persons if a member or representative of a legal entity engages in criminal conduct in the name of, on behalf of, or for the benefit of the legal entity.

13. While the ML criminalization provisions are generally broad, there are a few technical deficiencies that could affect implementation. These include the lack of an explicit criminalization of the conducts of "concealment or disguise," and the mere "possession or use of property regardless of the purpose". Mexican criminal law provides a broad range of procedures and tools to attach and forfeit property. However, the legislation does not provide for the forfeiture of property "for the equivalent or corresponding value". In addition, it makes no provision for preventing or voiding contracts or other acts in which the persons involved knew or should have known that as a result of those contracts or acts the authorities' ability to recover property subject to forfeiture would be impaired. Mexico also has not implemented legislation or procedures to enable the freezing of terrorist funds or other assets without delay of persons designated in accordance with relevant UNSCRs.

14. The authorities are committed to increasing the number and significance of prosecutions and convictions for ML. Notwithstanding the 149 indictments for ML issued by the PGR since 2004, there have only been 30 judicial decisions, 25 of which resulted in convictions and five in acquittals. These figures are indicative of a lack of capacity at the judicial level and the need to strengthen evidence used by PGR to support its indictments. Moreover, most of these convictions resulted from uncomplicated investigations arising out of seizures of cash at the airports and borders where the defendants were unable to demonstrate the legal origin of funds. Given the level and sophistication of organized criminal activity in Mexico, these results reflect a disappointing lack of effectiveness in implementation of the ML offense. The ongoing development of a national strategy to combat ML and FT should help lay the foundation for more effective implementation of the ML and FT legislation.

15. There is also currently close collaboration between the FIU and PGR, and the relationship between these two entities has been evolving and improving over time. Nonetheless, it could benefit from more formal arrangements as work processes are developed. Enhanced use of FIU-generated reports would also lead to more effective ML investigations and prosecutions.

16. In June 2007, terrorist financing was criminalized under the Mexican Federal Criminal Code, which distinguishes between "domestic terrorist financing" and "international terrorist financing". Terrorism financing is also a predicate offense to money laundering and is a serious felony under the Federal Code of Criminal Procedures. When committed by members of organized crime, such offenses are subject to more severe sanctions.

17. The international terrorist financing offense extends to any "funds" as that term is defined in the United Nations' (UN) Terrorist Financing Convention. However, the legal provisions do not fully comply with SR II. While the UN's Terrorist Financing Convention focuses on the intention of the act to cause death or serious bodily injuries, the law seems to focus on what is used to carry out the act. The requirement to demonstrate that the terrorist act generates alarm, fear, or terror to a population or 
to a group or sector thereof is not consistent with Article 2 of the UN's Terrorist Financing Convention, as the Convention only requires that "the purpose" of the act, by its nature or context, be to intimidate a population. Moreover, while the FT offense covers the financing of a significant number of terrorist acts, it does not extend the financing conduct to all of the acts that constitute offenses within the scope and definition of the treaties listed in the annex of the UN's Terrorist Financing Convention. Nor does it extend to all situations where a person may willfully provide funds. It only covers the provision of funds through the "financing," "contributing," and "procuring" conducts. This would leave out the provision of funds "by any means" as required by the standard. Moreover, the collection of funds is not covered.

18. The FIU has made progress in developing its financial intelligence infrastructure and staff capacity, including improving its working relationship with the prosecutorial authorities at the PGR. At the time of the on-site visit, it was not fully receiving suspicious activity reports in a timely way sent through the SAT by foreign exchange centers and money remitters. ${ }^{2}$ Moreover, it does not have full legal authority to access criminal records to inform its analytical work. The number of staff relative to the volume of reports it receives and its current and future workload is inadequate, even though the FIU has implemented an automated risk-based system to filter out cases that do not merit deeper analysis. As part of an ongoing restructuring project of the FIU, its staff will be increased significantly.

\section{Preventive Measures - Financial Institutions}

19. The various financial sector laws establish the principal AML/CFT preventive obligations for financial institutions. In turn, the AML/CFT legal provisions are implemented through regulations ("Disposiciones de Carácter General") issued under such laws. All the detailed AML/CFT requirements for financial institutions are contained in these regulations. In addition, the Ministry of Finance and Public Credit can also issue written communications ("Oficios") to financial institutions for, inter alia, clarifying and interpreting the provisions in the regulations. Both laws and the subsidiary regulations are enforceable and sanctionable in accordance with the provisions established in the applicable financial sector laws. The FIU, National Banking and Securities Commission (CNBV), and financial sector representatives jointly issued a set of best practice guidelines to help improve the quality of STRs submitted to the FIU by financial institutions subject to CNBV's supervision.

20. At the time of the mission, the AML/CFT laws and regulations covered all of the known financial activities applicable to Mexico as set out under the FATF definition of "financial institution". The sectoral regulations impose detailed AML/CFT requirements on the financial sector for; inter alia, CDD, record-keeping, large and suspicious transaction reporting, internal controls, compliance management arrangements, and training. However, Mexico has not yet issued implementing AML/CFT regulations for the recently deregulated SOFOMES. Unregulated SOFOMES are non-deposit taking financial institutions (e.g., engaged in lending, leasing, factoring) that are not members of a regulated financial group. The absence of such regulations, combined with a recent sharp increase in the number of SOFOMES in Mexico, constitute a significant vulnerability in the system.

\footnotetext{
${ }^{2}$ More recently, the authorities have indicated that these obstacles had been overcome but the mission is not in a position to verify the effectiveness of the reporting arrangement with the SAT.
} 
21. The Mexican authorities acknowledge the need to upgrade and align the 2004 AML/CFT regulations (e.g. for the securities, insurance, money services sectors) with the 2006 regulations (for the banking, savings and loans, and SOFOLES sectors). There is also a need for greater clarity in some of the provisions, including for internal and cross-sectoral regulatory consistency with respect to CDD for business relationships and occasional transactions, risk-based provisions, and suspicious transaction reporting. The CDD requirements also need to be enhanced in key areas such as for recently established corporate entities that have not completed incorporation requirements, and for insurance policyholders. The authorities expect to issue new regulations by the end of 2008 .

22. Implementation of the regulatory requirements by financial institutions is more advanced in the core financial sector entities (i.e., deposit-taking, insurance, and securities), but less so in some systemically important and risky sectors (i.e., foreign exchange centers, money remitters and unregulated SOFOMES). The authorities estimate that a large proportion of the thousands of foreign currency exchange centers and money remitters have now registered with the SAT (the designated AML/CFT supervisor), but a significant number has not done so.

23. All of the AML/CFT regulations include risk-based elements for purposes of CDD and the authorities are to be commended for implementing such practices. Going forward, these risk-based provisions could be better supported with sector-specific guidelines, and refinements to the simplified CDD regime allowed for in the regulations. The authorities should also consider conducting a systemic assessment of ML and FT risks in Mexico to support the development and implementation of preventive measures regime.

24. Recordkeeping and CDD requirements for introduced business and third parties are generally comprehensive. However, they could be improved, as is now being contemplated by the authorities, by specifically requiring that the necessary CDD information be obtained immediately by the financial institutions. The threshold for recordkeeping and other requirements with respect to wire transfers should be reduced from the equivalent of US $\$ 3,000$ to US $\$ 1,000$ in line with the standard.

25. There is a clear obligation to report suspicions of ML and FT, but the obligation does not extend to suspected financing of international acts of terrorism (except in relation to lists issued by international organizations or foreign countries). Most sectors are actively filing reports but there is a need to improve their quality and reduce the occurrence of "defensive" reporting.

26. There are four principal supervisory authorities responsible for AML/CFT compliance supervision, and for the enforcement of requirements. All of them have broad powers to obtain access to and inspect the businesses under their jurisdiction and to sanction for noncompliance. In practice, they have applied administrative sanctions (e.g., fines) for noncompliance with the AML/CFT regulations. However, most fines have been applied by the CNBV and their average amount has been relatively low, particularly for the larger institutions.

27. Most supervisory agencies have implemented relatively comprehensive on-site supervisory systems for AML/CFT compliance. Supervision by the CNBV is more advanced in terms of processes and capacity, and it has developed a specialized AML/CFT supervisory unit. However, it could enhance its offsite AML/CFT processes, and undertake more risk-based and consolidated AML/CFT supervision.

28. Limited staff resources have prevented the SAT from fully implementing AML/CFT supervision of foreign exchange centers and money remitters. It has about 4,380 such entities subject 
to its supervision, and the transfer of unregulated SOFOMES (currently 634 entities and rapidly increasing) under its supervision will further compound this problem. There is a potential of contagion risk for other financial institutions, e.g., banks that transact with these businesses. Nonetheless, the SAT indicated that it has conducted around 800 inspection visits to-date.

29. With respect to the insurance and bonding sectors, there is a need to strengthen supervision of the channels of distribution, in particular enforcing the training and oversight requirement placed on insurance and bonding companies with respect to their agents. A review of the contracting arrangements between these companies and their agents is also recommended to support implementation of the regulatory requirements.

\section{Preventive Measures - Designated Non-Financial Businesses and Professions}

30. The AML/CFT preventive measures have not been extended to DNFBPs. The only requirement that applies to this group is an obligation under the Income Tax Law to report cash transactions to the SAT in excess of Mex $\$ 100,000$ (equivalent to approximately US $\$ 10,000$ ). This is an obligation imposed on all taxpayers and NPOs. In addition, notaries public are required to report to the SAT every purchase of real estate in Mexico in which they participate regardless of the method of payment. This information is available to the FIU for AML/CFT purposes.

31. All types of DNFBPs are active in the Mexican economy. However, by law the administration of "fideicomisos" can be done only by designated licensed financial institutions. (A "fideicomiso" is broadly similar to a trust). Casinos are prohibited by law, including slot machines, except during regional fairs, in which case they require a temporary license. One to five such casino licenses are issued every year. The authorities are unable to prevent the existence of many unauthorized gamingmachine establishments due to resource limitations and gaps in the applicable legal framework which allow these businesses to pose as games of skill and not of chance. According to the authorities, these businesses are perceived as legitimate by the communities in which they operate, including by financial institutions, and this makes them vulnerable to money laundering and exposes the financial institutions that conduct business with them.

\section{Legal Persons and Arrangements \& Non-Profit Organizations}

32. Mexico has not taken concrete measures to prevent the unlawful use of legal persons in relation to ML and FT. Moreover, competent authorities in Mexico are not able to obtain or do not have access to sufficient, accurate, and current information in a timely fashion, on beneficial ownership and control of legal persons.

33. Legal persons created under Mexican law are not able to issue bearer shares. However, the shareholder of a Mexican entity can be a foreign bearer share company incorporated in a jurisdiction that allows the issuance of such shares. Mexico does not have specific measures in place to help prevent Mexican subsidiaries of such bearer share companies from being used for illicit ML.

34. Only designated licensed financial institutions may administer "fideicomisos" in Mexico. Financial institutions are covered by the preventive measures applicable to them and are hence required to obtain, verify, and retain details of the "fideicomisos", including beneficial ownership and control information. Such information would be available to the competent authorities. However, due 
to the lack of statistics on authorities' requests for information, it was not possible to assess the effective implementation of these measures.

35. Mexico has not undertaken a review of the adequacy of domestic laws and regulations that relate to NPOs, nor has it undertaken outreach to the NPO sector with a view to protecting the sector from FT abuse.

\section{National and International Cooperation}

36. There are no legal impediments for cooperation among the various supervisory bodies and other domestic authorities in Mexico. It was evident prior to and during the mission, that there are adequate processes for national cooperation and that such processes has been very efficient and effective. Cooperation between PGR and the FIU has been enhanced since 2007 and is currently working satisfactorily.

37. Mexican authorities have the power to collaborate with foreign counterparts in their respective areas of competence. In the majority of cases, international cooperation takes place directly between authorities exercising similar responsibilities and functions. They have cooperated with their foreign counterparts in the areas of mutual legal assistance and extradition. Supervisors have also entered into a number of memoranda of understanding with their foreign counterparts, and these have been put into practice especially as it concerns the banking sector. The mission received comments from various countries which highlight the significant improvements in international cooperation with Mexico last year. In particular, these countries underscored the constructive cooperation with Mexico's FIU and the PGR.

\section{1. GENERAL}

\subsection{General Information on Mexico}

38. Mexico was established in 1857 as a federal republic. It is the fifth largest nation in the Americas and the thirteenth largest in the world, comprising 31 states and the Federal District (Mexico City, DF ("Distrito Federal"). It is the third most populous nation in the Americas with a population estimated at 108.76 million (July 2007) of which approximately 76.5 percent lives in urban areas. Mexico occupies a territory of 758,446 square miles (1,964,375 square kilometers) with the three largest cities being Mexico City, Guadalajara, and Monterrey. To the north, Mexico shares a border of 1,959 miles $(3,152 \mathrm{~km})$ with the United States of America, and to the south it has borders with Guatemala and Belize. Its coastline extends over 6,911 miles $(11,122 \mathrm{~km})$ along the Gulf of Mexico and the Pacific Ocean.

39. Mexico has a free market economy strongly linked with its North American Free Trade Agreement (NAFTA) partners-the United States and Canada. In addition, it has entered into 12 free trade agreements with over 40 countries including, Guatemala, Honduras, El Salvador, the European Free Trade Area, and Japan. Its largest trading partner is the United States, accounting for approximately 84.8 percent of total exports and 50.9 percent of total imports. The service sector is the largest component of GDP ( 70.5 percent ), followed by the industrial sector ( 25.7 percent $)$. Agriculture represents 3.9 percent of GDP. ${ }^{3}$ Mexico is the fifth-largest oil producer in the world (3.8 million barrels per day), although reserves are declining. Pemex (Petroleos Mexicanos) is the

\footnotetext{
${ }^{3} 2006$ estimates.
} 
largest company (oil or otherwise) in Mexico and Latin America with annual sales in 2006 reaching Mex $\$ 1,062.5$ billion (US $\$ 100$ billion). The three largest sources of foreign exchange are merchandise exports (including in-bond industries), worker remittances, and tourism. During 2006, revenues from international travelers totaled US\$12.2 billion.

40. Since 1994, the Government of Mexico (GOM) has maintained a floating exchange rate policy, with the Central Bank (Banco de México) intervening occasionally to minimize volatility. The GOM has also promoted market-based mechanisms for stabilizing the exchange rate. Since October 1996, Banco de México has permitted foreign financial institutions to open peso-denominated accounts and to borrow and lend pesos.

41. Mexico's Foreign Investment Law (1993) permits, the ownership by foreign investors of 100 percent of the capital stock of a Mexican company and purchase equity securities traded on the Mexican Stock Exchange. With the authorization of the Ministry of Economy, investment trusts may be established by Mexican banks acting as trustees. The law also sets forth which commercial activities continue to be reserved to the GOM or to Mexican investors and the different activities in which foreign investment may not exceed 10, 2530 , or 49 percent of the total investment.

42. Mexico's Constitution provides for a tripartite government, separated into legislative, executive, and judicial branches. The bicameral Congress of the Federation (or Union) or legislative branch is composed of a Senate and a Chamber of Deputies, which makes federal law, declares war, imposes taxes, approves the national budget and international treaties, and ratifies diplomatic appointments. The executive branch is represented by the President who is the head of state as well as the commander-in-chief of the military forces. The President also appoints, with Senate approval, the Cabinet and other senior officers, and is responsible of executing and enforcing the law. He has the authority to veto bills. The Supreme Court of Justice is comprised by eleven judgesap pointed by the President with Senate approval, who interpret laws and judge cases of federal competency. Other institutions of the judiciary are the Electoral Tribunal, collegiate, unitary and district tribunals, and the Council of the Federal Judiciary.

43. All constituent states of the Federation are largely autonomous in their internal administration and the federal GOM cannot generally intervene in any particular state's affairs. The judiciary is vested upon the tribunals that each state establishes under its constitution. Mexico City is the capital of the country and seat of the power of the Union. It is independently constituted as a Federal District and is governed by a combination of federal and city branches.

44. In the mid-1990s, the federal electoral processes underwent significant changes to increase impartiality and political neutrality. The elections held in 2000 marked the first time since the 1910 Mexican Revolution that an opposition party defeated the ruling Institutional Revolutionary Party (PRI) which had been in power for decades.

45. Organized crime and corruption are among the most urgent concerns facing Mexico which is perceived to have a high incidence of corruption by Transparency International. An important concern of the GOM is the need to combat the corruption at all levels associated with drug trafficking criminal organizations. Measures taken to combat this scourge are included in the Government's National Development Plan aimed at strengthening the institutional framework and national culture for the rule of law. Mexico is also a party to the Inter-American Convention Against Corruption, the OECD Convention Against Bribery of Foreign Public Officials in International Business, and the United Nations Convention Against Corruption.

46. As part of its efforts to strengthen anti-corruption and transparency in the public sector, in July 2007, a decree was issued amending the Political Constitution and legislative framework to 
enhance citizens' freedom of access to information and transparency in governmental affairs. The Constitution establishes legality, honesty, loyalty, impartiality, and efficiency as principles that must be observed by public servants during the performance of their jobs, positions, or commissions. The law also establishes, inter alia, preventive and corrective measures, including the imposition of administrative obligations, responsibilities, and sanctions and the procedures for application of these sanctions. It also establishes a registry of assets of public servants. The Federal Law of Administrative Responsibilities of Public Servants specifies rules of conduct that public servants must observe to safeguard the principles established by the Constitution. Failure to fulfill their obligations leads to the imposition of administrative sanctions.

\subsection{General Situation of Money Laundering and Financing of Terrorism}

47. The largest source of ML in Mexico is believed to be associated with illicit drug trafficking. Mexico is a major drug-producing and transit nation. It has powerful drug cartels involved in the production and trafficking of drugs including transshipment of cocaine from South America to the United States and Europe, being two principal drug trafficking/consuming markets. In this context, Mexico is vulnerable to ML associated with the production, trafficking, and consumption of illicit drugs. The complexity of ML in Mexico has increased as criminal organizations expand their influence and develop new methods to launder their illicit funds, including through linkages with criminal groups based in other countries.

48. Locally produced drugs mainly include marijuana, opium poppy/gum, heroin, and synthetic drugs. Drugs produced in other countries, mainly in South America, and trafficked in and in transit through Mexico to other countries (mainly to the United States) include cocaine and heroin. The latter is also produced in Asia. Precursors and chemicals imported into Mexico for the manufacture of synthetic drugs mainly originate from Europe and Asia. Illicit drug production (esp. heroin and marijuana) is largely concentrated in the mountainous regions of Mexico, especially along the foothills of the Western and Southern Mountain Range (Sierra Madre), with more limited production in the Eastern Mountain Range. Anti-drug operations by the federal government over the last twothree years has resulted in the following seizures and destruction:

\begin{tabular}{|l|r|}
\hline \multicolumn{2}{|c|}{ 2006-2008 } \\
\hline \multicolumn{2}{|c|}{ Seizures } \\
\hline Marijuana (Kg) & 4223506.62 \\
\hline Cocaine (Kg) & 70240.18 \\
\hline Heroin (Kg) & 677.73 \\
\hline Methamphetamines (Units) & 908 \\
\hline & 2383843.83 \\
\hline Marijuana (small) plantations & 53139.96 \\
\hline Marijuana hectares & 179055 \\
\hline Opium poppy (small) plantations & 28426.98 \\
\hline Opium poppy hectares & \\
\hline
\end{tabular}

Source: Mexico.

48. While the principal methamphetamine producing countries are believed to be in Asia, Mexico has also been involved in its production and distribution mainly destined for the U.S. market. 
In March 2007, Mexican authorities seized about US\$ 206 million in cash, allegedly connected with a methamphetamine precursor trafficking organization; considered the largest drug cash seizure in history and reflects the magnitude of the drug production/trafficking situation in the country. To help counter production of methamphetamine, Mexico is strengthening its control over the importation of precursor materials, including prohibiting the importation of pseudoephedrine since January 2008. The government has seized about 1,684 kgs of methamphetamines.

49. Drug trafficking organizations operate throughout Mexico and are believed to be one of the primary sources of ML. These organizations are suspected to have linkages with other criminal organizations particularly in drug producing countries in Latin America and in consuming markets (mainly in the United States and Western Europe). This would complicate the combating of drug trafficking and related money laundering requiring enhanced international cooperation. Violence from organized crime has considerably increased in Mexico as a result of struggles among criminal organizations and actions taken by the current Administration to, inter alia, seize large quantities of illegal drugs (as noted above) and to generally disrupt their operations. The authorities also believe that enhanced awareness of ML in the financial system has limited the capacity of such organizations to use the more traditional financial institutions for ML, which as also affected their capacity to operate.

50. No estimates are available of the level of ML in Mexico originating from drug trafficking and other proceeds-generating crimes. According to the authorities, attempts to generate such estimates have been hindered by the impossibility to develop an appropriate methodology due to insufficient reliable empirical evidence. They assert that it is not possible to obtain estimates on the amount of drug proceeds generated in consuming countries that is transferred directly to Mexico. In addition, a large proportion of the informal economy in Mexico is associated with remittances from Mexican immigrant workers in the United States that use informal transfer systems as a consequence of tighter migration controls in that country.

51. ML in Mexico is believed to be carried out using a variety of schemes and institutions. In the placement stage of ML, bulk cash smuggling from the United States, including through the use of personal carriers ("mules"), is believed to be commonly used. The Mexican authorities indicate that there is insufficient empirical evidence available to determine the amount of proceeds from drug sales in the U.S. that is sent to Mexico. Once in Mexico, illicit funds can be structured and integrated into the local financial system and economy. Some of these funds may be re-exported to other countries such as Colombia and Brazil, or in offshore financial centers. For example, a recent case involved the seizure of millions of U.S. dollars (in cash) being exported from Mexico to Colombia via Panama. A major Colombian drug trafficker based in Brazil was recently arrested and disclosed the use of a network of legal entities to launder U.S.-sourced drug proceeds via Mexico, and "Operation Taco" involved the laundering of EUR 236 million in drug proceeds from Spain to Mexico through the export of precious metals by a network of Spanish, Colombian and Mexican nationals. These cases illustrate the magnitude of illicit resources controlled by criminal organizations, as well as the complexity of their international operations. (Source: Mexico-Detailed Assessment Questionnaire pages 101 to 104.)

52. ML affects a number of financial intermediaries including foreign currency operators (licensed casas de cambio and centros cambiarios), money remittance firms and banks. In 2006, remittances from the United States to Mexico totaled about US\$23 billion. While the transfer of remittances through established financial intermediaries can reduce the incidence of cash smuggling, the volume and speed of such (electronic) transfers also create important ML risk management challenges for financial institutions.

53. Criminals are also believed to use offshore financial centers (OFCs) to launder illicit funds. They transport cash using personal couriers. In some cases, funds originating from the United States 
are transported to Panama (an OFC), Venezuela, Ecuador, and Colombia. Several preliminary investigations are also underway by the Office of the Attorney General (PGR), through its Organized Crime Special Investigations Deputy Attorney Office (SIEDO, Spanish acronym for "Subprocuraduría de Investigación Especializada en Delincuencia Organizada"). These investigations include cases against former GOM officials (PEPs) accused of corruption and who have invested large sums of money in the coastal zone of Baja California Sur and the Mayan Riviera. These PEPs are using front men and trusts to hold their property. (Source: Mexico-Detailed Assessment Questionnaire pages 101 to 104.)

54. The integration of illicit funds in the Mexican economy and financial sector takes many forms. These include the purchase of luxurious automobiles and real estate. Criminals also use bank accounts to launder their funds, including through structuring transactions, and make significant investments under the names of family members, adopting methods and structures similar to those used in the business and industrial sectors. Mexican authorities have also identified an increase in the incidence of foreigners who immigrate to Mexico for purposes of laundering illicit funds generated by crimes committed in their countries of origin. With this wealth, money launderers more easily acquire social acceptance and political protection, making detection and investigation more difficult. (Source: Mexico-Detailed Assessment Questionnaire pages 101 to 104.)

55. As a result of operations initiated solely by the SIEDO involving ML or currency counterfeiting, the following cash seizures and other related investigative and prosecutorial activities had been achieved from January 2004 to August 2007:

\begin{tabular}{|c|c|c|c|c|}
\hline & 2004 & 2005 & 2006 & 2007 (August) \\
\hline Cash Seizure Mexican Pesos & US $\$ 938,000$ & US\$433,808 & US\$148,734 & US\$11,450,138 \\
\hline Cash Seizure US Dollars & US $\$ 593,314$ & US $\$ 9,294,967$ & US $\$ 20,724,770$ & US $\$ 10,893,445$ \\
\hline ML Inquiries & 129 & 89 & 135 & 154 \\
\hline Requests for prosecution & 16 & 14 & 40 & 38 \\
\hline Arrest warrants & 45 & 29 & 91 & 108 \\
\hline Criminal processes initiated & 17 & 25 & 53 & 19 \\
\hline Convictions & 15 & 7 & 9 & 9 \\
\hline
\end{tabular}

(US\$ 1.00 equals about Mex\$10.80 pesos).

56. Other crimes that generate significant illicit proceeds include human trafficking and arms smuggling. The SIEDO includes, inter alia, specialized units dedicated to the investigation of drug trafficking, terrorism, arms smuggling, kidnapping, trafficking in undocumented minors and organs, ML, etc. (Source: Mexico-Detailed Assessment Questionnaire).

57. In an effort to combat ML and organized crime, in March 2007, the Federal Government issued a National Strategy for the Prevention and Combating of Crime, focused mainly on public security and law enforcement issues. (See section 1.6 of this report.) It includes a coordination agreement (March 12, 2007) between the federal preventive police and the investigation arm of the PGR (Procuraduria General de la Republica) to better organize working arrangements and align their investigation and crime prevention efforts. This should allow the police agencies to maximize the use of intelligence and to conduct more effective and coordinated ML investigations.

58. The mission was informed that the federal agencies involved in AML/CFT efforts are drafting an AML/CFT National Strategy that should be completed in September 2008. Broadly, this document is expected to outline the AML/CFT objectives and strategies that the Federal Government 
will implement in the short and medium term, and will include provisions for additional human and other resources for the various agencies involved in prevention and combating of ML and FT. It should also provide for the establishment of an inter-institutional coordination group made up of the various federal agencies involved in AML/CFT. An output of such group will be detailed research and analysis of emerging ML trends, techniques and typologies used by criminals to launder funds, including the identification of geographic concentrations of ML. It will also identify, inter alia, the legal and regulatory measures needed to deal with this problem, as well as propose measures to strengthen the efficiency of existing AML processes.

59. In addition to the draft National Strategy document being developed, the Security Cabinet of the GOM approved in August 2008 an "Integral Strategy Against Organized Crime." This strategy includes as its principal objective the disbandment of the operational, logistical, commercial and financial networks of organized criminal organizations. In August, Mexico also signed an agreement entitled the "National Agreement for Security, Justice and Legality among the three branches of the State (Executive, Legislative and Judicial), the governors of all states of the Republic, associations of municipal governments, representatives of the productive, social and religious sectors. Under such agreement, each of the parties committed to carrying out concrete plans of action within certain deadlines that contain AML/CFT elements including: strengthening of the SIEDO with financial resources, training, forensic services and infrastructure in 18 months; issue of a national strategy against ML (no timeframe); strengthening institutional capabilities of the federal prosecutors to improve the efficacy of judicial sentences in six months; issue of a unique identity card for citizens in three years; consolidation into a single system of criminal information to assure interconnection and exchange of information among federal and state agencies to combat crime in one year. The implementation and effectiveness of the proposed National Strategy, the Integral Strategy Against Organized Crime and the National Agreement for Security, Justice and Legality can only be evaluated over time.

\section{Terrorism and Terrorism Finance}

60. On June 29, 2007, Mexico criminalized both financing of terrorist activities (FT) and international terrorism as serious crimes under the Federal Penal Procedures Code. The law differentiates between rebellion and terrorism.

61. Drug trafficking and the escalation of drug-related violence is seen as threatening national stability and security. Drug trafficking organizations have been using tactics that include e.g., intimidation and murder of law enforcement officers and journalists. They are believed to have operational linkages with other criminal groups considered terrorist organizations by other countries e.g., the FARC in Colombia, and their activities may be blurring the lines between solely violent criminal activity and terrorist activities as defined under the FT UN Convention. To the extent that such activities are terrorist activities, there could be an element of FT involved. No such determination has been officially made as yet.

62. On September 10, 2007, several explosions severely damaged the pipelines and infrastructure of the principal Mexican petroleum company (PEMEX) in the states of Tlaxcala and Veracruz. The PGR initiated a preliminary investigation of these incidences to ascertain elements for the crimes associated with terrorism, property damages, organized crime, and crimes against consumption and national wealth. The results of these investigations indicate that the explosions were not accidental but were the result of intentional acts. Press releases announced that the Popular Revolutionary Army (EPR, for the acronym of Ejercito Popular Revolucionario), claimed responsibility for the "attacks" on PEMEX's premises. The PGR states that it does not yet have sufficient grounds to assign direct responsibility on individuals and is still investigating the incidents. It is not clear whether the authorities consider these acts as rebellion or terrorism, and therefore whether FT was involved. 
63. Given the recent enactment of FT legislation, no statistics on the possible extent of FT are available, nor data to assess the effectiveness of implementation. The PGR has not initiated any criminal proceedings with respect to terrorism or FT. Consequently, there are no specific data on terrorism financing sources, techniques, or trends, nor of the types of financial institutions or other entities uses.

\section{A. 1.3 Overview of the Financial Sector}

64. Mexico has a diverse and relatively sophisticated financial system carrying on most of the financial activities covered by the FATF definition of "financial institution". It consists of four main categories of institutions: $i$ ) banking; ii) nonbanking financial intermediaries; iii) securities, mutual funds and derivatives; and iv) insurance and bonding companies. Most FIs are privately owned and can conduct multiple activities. Two or more types of financial services companies may operate under a single financial services holding company. These financial groups are required to have a holding company and at least two financial institutions which are either a commercial bank, a securities firm, or an insurance company among others. They can be of the same type, except for multiple purpose financial companies (SOFOMES).The chart on the following page provides a more detailed description of the types of financial institutions under each of these categories (see Figure 1).

65. FIs require authorization from the Ministry of Finance and Public Credit (Secretaria de Hacienda y Crédito Público (SHCP)) or from their respective supervisory agencies depending on the type of FI. The main supervisory agencies for these institutions are administrative agencies of the $\mathrm{SHCP}^{4}$ (órganos desconcentrados) as follows:

- National Banking and Securities Commission or "CNBV" (Comisión Nacional Bancaria y de Valores) for banking and nonbanking financial intermediaries, and securities sector.

- National Insurance and Bonding Commission (Comisión Nacional de Seguros y Fianzas) for insurance (including intermediaries) and bonding companies.

- National Retirement Savings Commission (Comisión Nacional del Sistema del Ahorro para el Retiro) for retirement funds.

66. The Central Bank of Mexico (Banco de México or "Banxico") oversees public sector trust funds.

67. Mexican state-owned banks were fully privatized in 1992. The financial regulatory laws now permit the entry of non-Mexican financial groups and financial intermediaries, through Mexican subsidiaries, to engage in various activities in the Mexican financial system, including banking, securities, and insurance activities. Financial sector assets are increasingly being managed by financial groups comprising of at least two types of entities from the following groups: (a) multiple banking institutions, stock brokerage firms or insurance companies; or (b) at least three entities from the following: financial leasing entities, financial factoring entities, foreign exchange firms, sureties/bonding institutions, insurance institutions, deposit warehouses, limited and multi-purpose financial societies (SOFOLES and SOFOMES. See descriptions below.), stock brokerage firms,

\footnotetext{
${ }^{4}$ Organos desconcentrados are administrative agencies of the centralized public administration which are hierarchically subordinated to State Ministries and which have technical autonomy to resolve on matters or in the jurisdictions of each. They do not have independent legal status, as provided under Article 17 of the Organic Law of the Federal Public Administration.
} 
multiple banking institutions, operators and administrators of investment funds and/or retirement funds. 


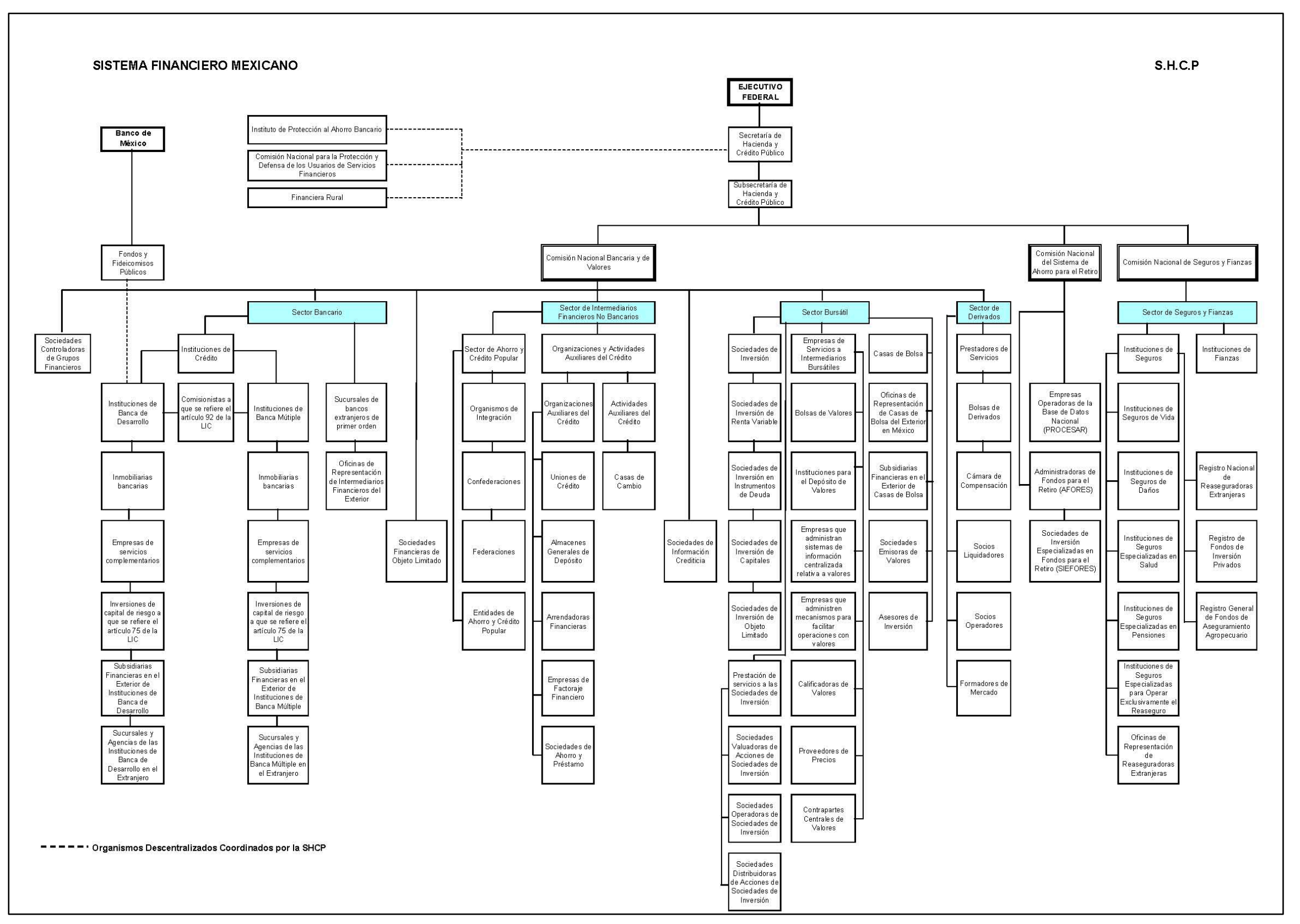


68. (See tables below for details on the number and asset size for each sector subject to the FATF 40+9) Foreign-based institutions control 80 percent of total financial sector assets, the most significant being Spanish (39 percent) and U.S. (22 percent ). Forty commercial banks (i.e., multiple banking institutions) account for nearly half (49.6 percent ) of financial system assets (Mex $\$ 2.841$ billion). Bank penetration remains low with about 8,717 branches throughout the country reaching approximately 20 percent of the population. Niche banks are emerging as important providers of financial services to low and medium-income segments. The largest niche bank serves over 25 percent of this market and five others have been recently authorized. ${ }^{5}$

69. The mutual funds (investment companies) sector is more diverse and is spread among 479 investment companies. However, retirement funds remain concentrated with 21 companies controlling more than 50 percent of total investment assets. Investment companies (mutual funds and retirement funds) account for 29.9 percent of total financial sector assets. Retirement fund companies are managed by AFORES ("Administradoras de Fondos para el Retiro").

70. There are about 95 insurance companies that account for slightly more than 7 percent of system assets. Insurers require the authorization of the SHCP to carry on business dealing with life, property (damages) and accidental insurance. Those that deal with health-related business may do so only through companies organized specifically for such purposes including without limitation, the ownership and management of hospitals, medical, and health insurance. There are about 44,944 insurance intermediaries.

71. Development banks (6) are established as legal entities, engage in various lending activities, and are largely financed by government. There are three main development banks that, inter alia, grant loans to small and medium-sized businesses, as well as to public sector enterprises and governmental agencies, including the provision of low-income housing loans. Some serve as agents for the GOM in certain international transactions, and engage in the grant of export and import-related credits and guarantees to private and public-sector entities.

72. Limited-Purpose Financial Companies (SOFOLES: "Sociedades Financieras de Objeto Limitado") are limited (special) purpose lending corporations. They can raise funds from the public through the sale of financial instruments registered in the National Intermediaries' and Securities' Registry ("Registro Nacional de Valores e Intermediarios"), and are prohibited from taking resources directly from the public through deposits or similar means. SOFOLES lend for specific purposes and sectors in accordance with the terms of their authorization.

73. SOFOLES, including leasing and factoring companies, are undergoing deregulation which will result in two broad categories of institutions: (a) licensed/regulated Multiple Purpose Financial Companies (SOFOMES: "Sociedades Financieras de Objeto Multiple") forming part of a financial regulated financial groups; and (b) unlicensed/unregulated SOFOMEs which do not form part of a financial group. Regulated SOFOMES are/will be supervised by the CNBV for prudential and AML/CFT purposes while unregulated SOFOMES will only be supervised for AML/CFT purposes by the tax authorities (SAT: Secretaria de Administracion Tributaria"). There are some 13 regulated SOFOMES and 634 which are unregulated.

74. As of March 18, 2006, any person acting as a SOFOME in a customary and professional capacity can do so without requiring authorization from the Federal Government. They must state in their names that they are "unregulated." Deregulation of these activities was an explicit policy

${ }^{5}$ Figures as of September 2007. SOURCE: The National Banking and Securities Commission, National Bonding and Insurance Commission, and National Retirement Savings System Commission. 
designed to, inter alia, reactivate the credit system and encourage investment. SOFOMES can raise funds from financial institutions (banks, insurance companies, and bond companies), and through public issues of bonds. Unregulated SOFOMES are subject to the supervision of the SAT for AML/CFT purposes only but as of mission dates, implementing regulations had not been issued by the SHCP as yet.

75. SOFOMES are expressly authorized to carry out one or more of the activities conducted by the limited purpose SOFOLES. As mentioned above, they are required to be licensed and are subject to the supervision of the CNBV only if they maintain financial relationships with credit institutions and controlling companies of financial groups. "Financial relationships" mean any controlling (equity) interests in the capital of a SOFOM by a financial controlling company or credit institution. These companies must state in their names that they are "regulated" entities.

76. The transition process from SOFOLES to SOFOMES is being implemented in the following manner:

a) SOFOLES will continue as regulated entities until July 18, 2013, after which they do one of the following:

i. Transform into a nonregulated SOFOMES that can carry out multiple lending operations.

ii. Transform into SOFOMES that engage in financial activities including leasing and factoring transactions under the Titles and Credit Operations General Law (Ley de Titulos y Operaciones de Credito). Or

iii. Liquidate and wind up their operations.

b) Continue operating as SOFOLES until July 18, 2009, when they must opt for a), b) or c) above. Or

c) Transform into "regulated" SOFOME (part of a financial group) or "nonregulated" SOFOMES.

77. As of mission date there were 24 licensed currency exchange and money remittance businesses (casas de cambio), down from 25 in December 2007, with this number expected to fall even further. Licensing is required for legal entities that engage in currency exchange business with the public in a professional and habitual manner, including such transactions effected through the funds and remittance transfers. Customer identification and other AML/CFT regulatory requirements (DCG 95) only apply (DCG 95) for transactions that equal or exceed the equivalent the equivalent of US\$ 10,000 . No licensing is required when the foreign currency business (centros cambiarios) is limited to spot currency transactions (as listed in Art. 81-A of the General Law on Auxiliary Credit Organizations and Activities) that do not exceed the equivalent of US $\$ 10,000$ per customer per day. They are not allowed to settle such transactions through the transfer or remittance of funds.

78. It is estimated that there are more than 4,380 money transmitters and centros cambiarios (foreign exchange centers) operating in Mexico, of which 3,069 are registered with the SAT. Foreign exchange centers conduct transactions below the US $\$ 10,000$ threshold and are, therefore, not required to be licensed. As with money transmitters and SOFOMES, they are required to register with the SAT and are subject to AML/CFT supervision by the same. Unregistered centros cambiarios and money remitters are a key challenge for the authorities' AML/CFT efforts. The threshold for licensing is believed to have contributed to the relatively low number of licensed casas de cambio (25) when 
compared to the high number of centros cambiarios. (See Rec. 5 for a more detailed analysis of these sectors.)

79. The Mexican Stock Exchange is located in Mexico City and organized as a corporation with shares owned by 32 brokerage firms. The Exchange trades debt and equity securities including stocks and bonds of private sector corporations, equity certificates or shares issued by banks, commercial paper, bankers' acceptances, certificates of deposit, GOM debt, and special hedging instruments linked to the U.S. dollar. The Mexican equity market is one of Latin America's largest in terms of market capitalization, but remains relatively small and illiquid compared to major world markets. Institutional investors are the most active participants in the Mexican Stock Exchange. The Securities Market Law permits the listing of foreign securities on the Exchange upon the authorization of the SHCP, the National Banking and Securities Commission and Banxico. As of December 31, 2006, four foreign securities firms were authorized by the SHCP to maintain representative offices in Mexico.

80. Other main financial institutions operating in Mexico include entities engaged in: popular savings and loans (48); leasing (10); factoring (3); and credit unions (155).

81. The following table sets out the types of financial institutions that can engage in the financial activities that are within the definition of "financial institutions" in the FATF 40+9.

Institutions conducting financial activities outlined in the Glossary of the FATF Recommendations

\begin{tabular}{|c|c|}
\hline Activities Covered Under FATF & $\begin{array}{c}\text { Type of Financial Institutions Authorized to Conduct } \\
\text { Such Activities }\end{array}$ \\
\hline $\begin{array}{l}\text { A. Acceptance of deposits and other repayable } \\
\text { funds from the public (including private banking) }\end{array}$ & $\begin{array}{l}\text { Banking institutions, development banks, popular savings } \\
\text { and loan entities, credit unions, AFORES, investment } \\
\text { societies, warehousing companies. }\end{array}$ \\
\hline $\begin{array}{l}\text { B. Lending (including consumer credit; mortgage } \\
\text { credit; factoring, with or without recourse; and } \\
\text { finance of commercial transactions (including } \\
\text { forfeiting)). }\end{array}$ & $\begin{array}{l}\text { Banking institutions, development banks, popular savings } \\
\text { and loan entities, credit unions, SOFOLES, SOFOMES, pawn } \\
\text { shops. }\end{array}$ \\
\hline $\begin{array}{l}\text { C. Financial Leasing (other than financial leasing } \\
\text { arrangements in relation to consumer products). }\end{array}$ & $\begin{array}{l}\text { Banking institutions, development banks, credit unions, } \\
\text { SOFOMES, financial leasing entities. }\end{array}$ \\
\hline $\begin{array}{l}\text { D. The transfer of money or value including } \\
\text { financial activity in both the formal or informal } \\
\text { sector (e.g. alternative remittance activity), but not } \\
\text { including any natural or legal person that provides } \\
\text { financial institutions solely with message or other } \\
\text { support systems for transmitting funds). }\end{array}$ & $\begin{array}{l}\text { Banking institutions, development banks, popular savings } \\
\text { and loan entities, credit unions, foreign exchange houses, } \\
\text { money remitters. }\end{array}$ \\
\hline $\begin{array}{l}\text { E. Issuing and managing means of payment (e.g. } \\
\text { credit and debit cards, cheques, traveler's } \\
\text { cheques, money orders and bankers' drafts, } \\
\text { electronic money). }\end{array}$ & $\begin{array}{l}\text { Banking institutions, development banks, popular savings } \\
\text { and loan entities, SOFOLES, SOFOMES. }\end{array}$ \\
\hline F. Financial guarantees and commitments & $\begin{array}{l}\text { Banking institutions, development banks, credit unions, } \\
\text { insurance companies, sureties/bonding companies. }\end{array}$ \\
\hline $\begin{array}{l}\text { G. Trading money market instruments (cheques, } \\
\text { bills, certificates of deposit, derivatives, etc); } \\
\text { - foreign exchange; } \\
\text { - exchange, interest rate and index } \\
\text { instruments; } \\
\text { - transferable securities; } \\
\text { - commodity futures trading }\end{array}$ & $\begin{array}{l}\text { Banking institutions, development banks, brokerage firms, } \\
\text { investment/fund societies, foreign exchange houses. }\end{array}$ \\
\hline
\end{tabular}




\begin{tabular}{|c|c|}
\hline Activities Covered Under FATF & $\begin{array}{l}\text { Type of Financial Institutions Authorized to Conduct } \\
\text { Such Activities }\end{array}$ \\
\hline $\begin{array}{l}\text { H. Participation in securities issues and the } \\
\text { provision of financial services related to such } \\
\text { issues. }\end{array}$ & $\begin{array}{l}\text { Banking institutions (including development banks), } \\
\text { popular savings and loan entities, SOFOMES, credit } \\
\text { unions, brokerage firms, AFORES, investment/fund } \\
\text { societies. }\end{array}$ \\
\hline $\begin{array}{l}\text { I. Individual and collective portfolio } \\
\text { management. }\end{array}$ & $\begin{array}{l}\text { Banking institutions (including development banks), } \\
\text { popular savings and loan entities, brokerage firms, } \\
\text { AFORES, investment/fund societies. }\end{array}$ \\
\hline $\begin{array}{l}\text { J. Safekeeping and administration of cash or } \\
\text { liquid securities on behalf of other persons. }\end{array}$ & $\begin{array}{l}\text { Banking institutions, popular savings and loan entities, } \\
\text { brokerage firms, investment/fund societies. }\end{array}$ \\
\hline $\begin{array}{l}\text { K. Otherwise investing, administering or } \\
\text { managing funds or money on behalf of other } \\
\text { persons. }\end{array}$ & $\begin{array}{l}\text { Banking institutions, popular savings and loan entities, } \\
\text { SOFOMES, development banks, credit unions, brokerage } \\
\text { firms, AFORES, investment companies/fund societies, } \\
\text { factoring companies. }\end{array}$ \\
\hline $\begin{array}{l}\text { L. Underwriting and placement of life insurance } \\
\text { and other investment related insurance (including } \\
\text { insurance undertakings and to insurance } \\
\text { intermediaries (agents and brokers)). }\end{array}$ & Insurance institutions and mutual insurance societies. \\
\hline M. Money and currency changing. & $\begin{array}{l}\text { Banking institutions (including development banks), } \\
\text { popular savings and loan entities, foreign exchange } \\
\text { houses and centers. }\end{array}$ \\
\hline
\end{tabular}

82. The following table provides a summary of the various types of main FIs operating in Mexico, the laws under which they operate, and their respective AML/CFT supervisory agencies:

Financial institutions subject to the FATF 40+9, applicable laws and supervisory agencies (2007)

\begin{tabular}{|c|c|c|c|c|}
\hline Institution & No. & $\begin{array}{l}\text { Assets } \\
\text { (USD) }\end{array}$ & Law & $\begin{array}{c}\text { Supervisory } \\
\text { Agency }\end{array}$ \\
\hline $\begin{array}{ll}\text { - } & \begin{array}{l}\text { Banking institutions } \\
\text { (including six } \\
\text { development banks) }\end{array} \\
\text { - } & \begin{array}{l}\text { SOFOLES/SOFOMES } \\
\text { (regulated) }\end{array}\end{array}$ & $\begin{array}{l}46 \\
52\end{array}$ & $\begin{array}{r}312755709 \\
023 \\
\\
\\
19977716 \\
390(1)\end{array}$ & $\begin{array}{l}\text { Law of } \\
\text { Credit } \\
\text { Institutions } \\
\text { or "Banking } \\
\text { Law" (Ley de } \\
\text { Instituciones } \\
\text { de Crédito) }\end{array}$ & CNBV \\
\hline $\begin{array}{l}\text { - Popular Savings and } \\
\text { Loans }\end{array}$ & 48 & $\begin{array}{r}2775000 \\
000\end{array}$ & $\begin{array}{l}\text { Popular } \\
\text { Savings and } \\
\text { Loans Law } \\
\text { (Ley de } \\
\text { Ahorro y } \\
\text { Crédito } \\
\text { Popular) }\end{array}$ & CNBV \\
\hline
\end{tabular}

\footnotetext{
${ }^{6}$ See description in the preceding paragraphs of this section.
} 


\begin{tabular}{|c|c|c|c|c|}
\hline Institution & No. & $\begin{array}{l}\text { Assets } \\
\text { (USD) }\end{array}$ & Law & $\begin{array}{c}\text { Supervisory } \\
\text { Agency }\end{array}$ \\
\hline $\begin{array}{ll}\text { - } & \text { Foreign Exchange } \\
& \text { Firms(regulated Casas } \\
\text { de Cambio) } \\
\text { - } & \text { Leasing } \\
\text { - } & \text { Factoring } \\
\text { - } & \text { Credit Unions } \\
\text { - } & \text { General Deposit } \\
& \text { Warehouses }\end{array}$ & $\begin{array}{r}24 \\
\\
10 \\
3 \\
155 \\
20\end{array}$ & $\begin{array}{r}369705341(2) \\
\\
1361878453 \\
(3) \\
\\
637200737 \\
1820441989 \\
(4) \\
470534070(5)\end{array}$ & $\begin{array}{l}\text { General Law } \\
\text { of Auxiliary } \\
\text { Credit } \\
\text { Organization } \\
\text { s and } \\
\text { Activities } \\
\text { (Ley General } \\
\text { de } \\
\text { Organizacio } \\
\text { nes y } \\
\text { Actividades } \\
\text { Auxiliares } \\
\text { del Crédito) }\end{array}$ & CNBV \\
\hline $\begin{array}{ll}\text { - Foreign exchange } \\
\text { centers (centros } \\
\text { cambiarios. 2,212 } \\
\text { Registered and } 945 \\
\text { estimated un- } \\
\text { registered). }\end{array}$ & $3157^{7}$ & NA & $\begin{array}{l}\text { General Law } \\
\text { of Auxiliary } \\
\text { Credit } \\
\text { Organization } \\
\text { s and } \\
\text { Activities } \\
\text { (Ley General } \\
\text { de } \\
\text { Organizacio } \\
\text { nes y } \\
\text { Actividades } \\
\text { Auxiliares } \\
\text { del Crédito) }\end{array}$ & SAT \\
\hline $\begin{array}{l}\text { - } \quad \text { Money remitters (857 } \\
\text { registered and } 366 \\
\text { unregistered) }\end{array}$ & 1223 & NA & $\begin{array}{l}\text { General Law } \\
\text { of Auxiliary } \\
\text { Credit } \\
\text { Organizations } \\
\text { and Activities } \\
\text { (Ley General } \\
\text { de } \\
\text { Organizacione } \\
\text { sy } \\
\text { Actividades } \\
\text { Auxiliares del } \\
\text { Crédito) }\end{array}$ & SAT \\
\hline
\end{tabular}

${ }^{7}$ Updated statistics based on post-mission data received. 


\begin{tabular}{|c|c|c|c|c|}
\hline Institution & No. & $\begin{array}{l}\text { Assets } \\
\text { (USD) }\end{array}$ & Law & $\begin{array}{c}\text { Supervisory } \\
\text { Agency }\end{array}$ \\
\hline $\begin{array}{ll}- & \text { SOFOMES } \\
& {\text { (unregulated })^{8}}^{8}\end{array}$ & 634 & NA & $\begin{array}{l}\text { General Law } \\
\text { of Auxiliary } \\
\text { Credit } \\
\text { Organizations } \\
\text { and Activities } \\
\text { (Ley General } \\
\text { de } \\
\text { Organizacione } \\
\text { sy } \\
\text { Actividades } \\
\text { Auxiliares del } \\
\text { Crédito }\end{array}$ & SAT \\
\hline $\begin{array}{l}\text { - Mutual/investment } \\
\text { funds }\end{array}$ & 54 & 568703041 & $\begin{array}{l}\text { Investment } \\
\text { Societies } \\
\text { Law (Ley de } \\
\text { Sociedades } \\
\text { de Inversión) }\end{array}$ & CNBV \\
\hline $\begin{array}{l}\text { - } \quad \text { Retirement fund } \\
\text { adminstrators } \\
\text { (AFORES) }\end{array}$ & 18 & NA & $\begin{array}{l}\text { Retirement } \\
\text { Savings } \\
\text { Systems } \\
\text { Law (Ley de } \\
\text { los Sistemas } \\
\text { de Ahorro } \\
\text { para el } \\
\text { Retiro). }\end{array}$ & CONSAR \\
\hline $\begin{array}{l}\text { - Securities brokerage } \\
\text { Firms }\end{array}$ & 32 & 4856261510 & $\begin{array}{l}\text { Securities } \\
\text { Market Law } \\
\text { (Ley del } \\
\text { Mercado de } \\
\text { Valores) }\end{array}$ & CNBV \\
\hline $\begin{array}{ll}\text { - } & \text { Insurance companies } \\
\text { - } \quad \text { Insurance } \\
\text { agents/intermediaries }\end{array}$ & $\begin{array}{r}95 \\
44944\end{array}$ & $\begin{array}{r}40 \\
748 \\
012 \\
512 \\
\text { NA }\end{array}$ & $\begin{array}{l}\text { General Law } \\
\text { of Insurance } \\
\text { Institutions } \\
\text { and Mutual } \\
\text { Societies } \\
\text { (Ley General } \\
\text { de } \\
\text { Instituciones } \\
\text { y Sociedades } \\
\text { Mutualistas } \\
\text { de Seguros). }\end{array}$ & CNSF \\
\hline - $\quad$ Bonding institutions & 14 & $\begin{array}{r}1 \\
019 \\
504 \\
000\end{array}$ & $\begin{array}{l}\text { Bonding } \\
\text { (sureties) } \\
\text { Institutions } \\
\text { Federal Law } \\
\text { (Ley Federal } \\
\text { de } \\
\text { Instituciones }\end{array}$ & CNSF \\
\hline
\end{tabular}

${ }^{8}$ See description in the preceding paragraphs of this section. 


\begin{tabular}{|c|c|c|c|c|}
\hline Institution & No. & $\begin{array}{c}\text { Assets } \\
\text { (USD) }\end{array}$ & Law & $\begin{array}{c}\text { Supervisory } \\
\text { Agency }\end{array}$ \\
\hline & & & de Fianzas) & \\
\hline
\end{tabular}

(1) Balance as of December 2007 with respect to 36 entities that reported information.

(2) Balance as of December 2007 with respect to 22 entities that reported information as have their operations suspended.

(3) Balance as of December 2007 with respect to 9 entities that reported information.

(4) Balance as of December 2007 with respect to 19 entitites that reported information.

(5) Balance as of December 2007 with respect to 119 entities that reported information.

83. The SHCP is responsible for the overall coordination and supervision of Mexico's financial system under the Organic Law of the Federal Public Administration. ${ }^{9}$ Ongoing supervision is conducted by decentralized supervisory agencies (órganos desconcentrados) of the SHCP. The CNBV is the operational supervisor of banking institutions, popular savings and loans, credit unions, SOFOLES, financial leasing and factoring entities, depository warehouses, foreign exchange houses, and securities firms. The CONSAR ("Comision Nacional del Sistema de Ahoro para el Retiro") is the main supervisor for retirement fund administrators (AFORES) and the CNSF (Comision Nacional de Seguros y Fianzas) is responsible for the supervision of the insurance and sureties/bonding institutions).

84. Money remitters, registered foreign exchange centers (centros cambiarios), and some SOFOMES (those that are not part of a regulated financial group) are unregulated and unsupervised except for AML/CFT matters. These entities are subject to AML/CFT requirements and subject to compliance supervision by the SAT (the Tax Administration Service). During the mission, AML/CFT regulations for SOFOMES had not been issued as yet and supervision had not commenced.

85. Details concerning the number of branches and subsidiaries of foreign FIs operating in Mexico and of Mexican FIs operating abroad for the banking, securities, and insurance sectors are as follows:

Mexican law does not allow the establishment of foreign banks branches in México

\begin{tabular}{lcc}
\hline Type of Institution & $\begin{array}{c}\text { Number of branches } \\
\text { abroad }\end{array}$ & $\begin{array}{c}\text { Number of subsidiaries } \\
\text { abroad }\end{array}$ \\
\hline Commercial banks & 5 & 0 \\
Life insurance companies & 0 & 24 \\
Investment companies & NA & NA \\
\hline
\end{tabular}

\subsection{Overview of the DNFBP Sector}

86. Very little information was available to the mission with respect to the number of operators and the magnitude of the market for each category of DNFBP. The information available is summarized in the following table.

\footnotetext{
${ }^{9}$ Banxico (Banco de Mexico is the Central Bank of Mexico) also has non-AML/CFT regulatory responsibilities with respect to monetary and foreign exchange markets, payment systems, financial operations, and products.
} 


\begin{tabular}{|c|c|c|c|}
\hline $\begin{array}{l}\text { DNFBPs } \\
\text { according to } \\
\text { FATF (R. 12) }\end{array}$ & Context & $\begin{array}{l}\text { Subject to } \\
\text { AML/CFT }\end{array}$ & Regulator \\
\hline $\begin{array}{l}\text { Casinos } \\
\text { (above US } \$ 3,000)\end{array}$ & $\begin{array}{l}\text { - One to five temporary licenses granted every } \\
\text { year. } \\
\text { - No. of unauthorized casinos and slot } \\
\text { machines not available. An estimate made by } \\
\text { Secretaría de Gobernación exists but was still } \\
\text { confidential at time of mission }\end{array}$ & No & $\begin{array}{l}\text { Secretaría de } \\
\text { Gobernación } \\
\text { (Ministry of Interior) }\end{array}$ \\
\hline $\begin{array}{l}\text { Real Estate } \\
\text { Agents }\end{array}$ & $\begin{array}{l}\text { The profession is unregulated and no } \\
\text { significant association is known. Real estate } \\
\text { agents do not normally make or receive } \\
\text { payments on behalf of customers. There are } \\
\text { no estimates available of the number of } \\
\text { agents. }\end{array}$ & No & $\begin{array}{l}\text { SAT only for tax } \\
\text { purposes }\end{array}$ \\
\hline $\begin{array}{l}\text { Dealers in } \\
\text { precious metals } \\
\text { or stones } \\
\text { (above } \\
\text { US } \$ 10,000)\end{array}$ & $\begin{array}{l}\text { No data available, but anecdotal evidence } \\
\text { suggests that this is a sizable industry. Large } \\
\text { pawn shops are significant market players in } \\
\text { the precious metals business. }\end{array}$ & No & $\begin{array}{l}\text { SAT only for tax } \\
\text { purposes }\end{array}$ \\
\hline $\begin{array}{l}\text { Notaries } \\
\text { (according } \\
\text { R.12) }\end{array}$ & Total No. of notaries 3603 . & No & $\begin{array}{l}\text { Each respective } \\
\text { state of Mexico, } \\
\text { and SAT only for } \\
\text { tax purposes }\end{array}$ \\
\hline $\begin{array}{l}\text { Lawyers } \\
\text { (according } \\
\text { R.12) }\end{array}$ & Total No. of licensed lawyers 367851. & No & $\begin{array}{l}\text { SAT only for tax } \\
\text { purposes }\end{array}$ \\
\hline $\begin{array}{l}\text { Independent } \\
\text { legal } \\
\text { professionals }\end{array}$ & This category is included in Lawyers]. & No & \\
\hline $\begin{array}{l}\text { (according to } \\
\text { R.12) }\end{array}$ & & & \\
\hline $\begin{array}{l}\text { Accountants } \\
\text { (according to } \\
\text { R.12) }\end{array}$ & Total No. 394939. & No & $\begin{array}{l}\text { SAT only for tax } \\
\text { purposes }\end{array}$ \\
\hline $\begin{array}{l}\text { Company } \\
\text { Services } \\
\text { Providers }\end{array}$ & $\begin{array}{l}\text { They do not exist as a distinct profession; } \\
\text { service is provided by law firms. Services like } \\
\text { the sale of "shelf" companies, registered } \\
\text { agents, nominee directors or partners, are not } \\
\text { common. }\end{array}$ & No & None \\
\hline $\begin{array}{l}\text { Trust Services } \\
\text { Providers }\end{array}$ & $\begin{array}{l}\text { Trust services can only be provided by certain } \\
\text { licensed financial institutions and are therefore } \\
\text { subject to their respective AML/CFT } \\
\text { regulations. }\end{array}$ & Yes & CNBV \\
\hline
\end{tabular}

87. The following additional information with respect to some of the above categories of DNFBPs is relevant for purposes of this assessment. 
88. Casinos: There is no legal definition of casinos in Mexico. The law prohibits all games of chance except those explicitly listed. The activities that are typical of casinos, including slot machines are, in principle, prohibited.

89. The law only authorizes the issuance of temporary permits for betting game halls ("salones de apuestas") when they are part of regional fairs which are rooted in Mexican traditions. These temporary permit holders offer most games expected from a fully fledged casino, including games of cards, dice, and roulette, as well as slot machines, and they can be of a very large magnitude. The most important of these fairs, the San Marcos Fair, is estimated to draw six million local and foreign visitors per year, of which some two million go to play in the casino. No estimate of money generated from these activities is available. Although the total number of temporary casinos could be as high as four per state every year, in practice, no more than five such casinos are normally authorized, and only one was authorized in 2007 (San Marcos).

90. The Ministry of Interior undertakes a fit and proper review of the applicants every year. Based on its general powers under the Regulations of the Gaming Law, the Ministry has recently imposed a contractual obligation on permit holders to keep an accurate registry of the identity of their customers in order to determine whose bets, in light of the amount of such bets, raise the suspicion that transactions with illicit resources are being conducted. The most recent permits issued obligate permit holders to inform the authorities of any behavior or practice of the users that is likely to constitute a felony related with organized crime or transactions with illicit resources. There is, however, no information with respect to the practical implementation of these new requirements.

91. The following are gaming and drawings activities authorized by the Gaming Law and subject to prior authorization from the Ministry of Interior (Secretaría de Gobernación) ${ }^{10}$ :

- $\quad$ Chess, checkers and other similar games; domino, dice, bowling and pool games; any kind of ballgames; person, vehicle and animal races and in general, all kinds of sports.

- $\quad$ Operation of bets in racetracks (greyhound and horses) and squash or front-tennis.

- $\quad$ Operation of remote betting centers ${ }^{11}$.

- $\quad$ Operation of number drawing halls ${ }^{12}$.

- $\quad$ Horse races and cockfights, with bets in temporary venues.

\footnotetext{
${ }^{10}$ There are also two state-owned national drawings: the Lotería Nacional para la Asistencia Pública (National Lottery) and Pronósticos para la Asistencia Pública (game of prediction of the outcome of sporting events). These are governed by a separate set of laws and regulations.

${ }^{11}$ Remote Betting Centers, also known as foreign books, which are establishments authorized by the Ministry of the Interior to obtain and operate exchange of bets in events, sports competitions and games permitted under the Gaming Law (Ley Federal de Juegos y Sorteos), carried out abroad or in national territory, transmitted in real time and simultaneously in video and audio, as well as the practice of number drawing indicated under section IV of article 124 of the Regulations of the said Law.

${ }^{12}$ These are establishments where it is possible to practice number drawings, which are carried out by selling to the public certain cards pre-printed on paper or electronic means with numbers selected at random. The mechanics of such drawings must be carried out in such a way that the participant indicates the numbers that are obtained by picking numbered balls at random and which are communicated to the attendees through an electronic board or other appropriate means, so that the winners of the drawing are the first persons who complete their card with the numbers published on the board.
} 
92. These permits generate annual revenue of approximately US\$50 million for the Mexican government. According to the authorities, the closest establishments to casinos, among the activities allowed in Mexico, are Remote Betting Centers and Number Drawing Halls (commonly known as Foreign Books and Bingos), as well as racetracks (greyhounds or horses) and squash or front-tennis, also known as live entertainment.

93. The Regulations of the Gaming Law (Ley Federal de Juegos y Sorteos) authorize permit holders to receive bets via the Internet, through the telephone, or electronically and obligates them to establish a control system, which must be in writing and contain the description of the rules and procedures that ensure the inviolability and prevent the manipulation of the betting system. Such control must have at least: a) the account number and identity of the bettor and b) the date, time and number of the transaction, the amount betted and the selection requested.

94. Of significant concern for the authorities is the existence of unauthorized betting game halls across the country, consisting of conspicuous establishments with large numbers of slot machines. The government regularly takes enforcement actions to shut them down, only to see them resurface under a different name. Many are even successful in challenging the Ministry's actions in court by claiming that they operate games of skill and not of chance, thereby making the Gaming Law inapplicable to them.

95. The degree of sophistication of these businesses varies, but some of them have several locals across the country and provide customers with electronic cards which store the customer's cash holdings and may be used to place bets at machines in other affiliated establishments. These businesses are illegal and vulnerable to misuse by money launderers, in the authorities' own view. They are perceived as legitimate businesses by the community and by financial institutions in the municipalities where they operate, and that makes them an ideal front to channel cash from illegal sources, in the opinion of the authorities which is shared by the assessment team.

96. For purposes of this assessment, it is important to clarify that these unauthorized gaming halls, which basically offer slot machine games, are not covered by the requirements of FATF R.12 and 16. Therefore, the insufficient capacity of the authorities to enforce the prohibition of slot machines is not relevant to the assessment of compliance with the FATF recommendations. However, the authorities' concern about inherent ML risks should be addressed in accordance to FATF R.20 to the extent that many of these establishments are not clearly illegal, due to existing legal loopholes, even though they have not received a permit from the competent authority.

\section{Independent Professionals (Attorneys, Notaries Public, Commercial Notaries and Accountants)}

97. Article 5 of the Political Constitution of the United Mexican States provides that "no person may be precluded from exercising the profession, industry, commerce, or work such person wishes, provided it is lawful". The Regulatory Laws of Article $5^{\circ}$ of the Constitution, relative to the practice of professions, determine in each state, the professions that require a certificate or degree, the conditions that must be fulfilled to obtain such certificate, and the authorities that will issue it. Each state of the republic is authorized to issue laws and regulations on this matter, for which there are several state laws that regulate professional activities in Mexico.

98. The Federal Executive Power, with the prior opinion from the Dirección General de Profesiones (General Office of Professions), which depends on the Secretaría de Educación Pública (Ministry of Education) and considering the position of the Professional Colleges and the technical commissions organized for each profession, will issue the regulations that define the fields of action of each profession, as well as of the corresponding branches and the limits for the exercise thereof. 
99. In Mexico, to conduct a professional practice, it is necessary to have full capacity to exercise and enjoy one's civil rights; to have a duly registered, validly-issued certificate, and to obtain from the Dirección General de Profesiones (General Office of Professions) the required professional practice license, known as cédula profesional. In addition, to practice one or more specialties, it is necessary to obtain authorization from the Dirección General de Profesiones, which requires evidencing that one obtained the relevant professional certificate and accordingly, that one has completed studies of technical scientific specialization in the science or field of knowledge in question.

100. All professionals are obligated to maintain in strict secrecy the matters their clients confide to them, except for the mandatory reports that the respective laws provide, as established under Article 36 of the Regulatory Law of Article $5^{\circ}$ of the Constitution, relative to the practice of professions in the federal district, replicated under the equivalent laws of the states of the republic.

101. The persons who, without having a validly-issued professional certificate, customarily act as professional, will incur administrative penalties and may even commit the crime of unauthorized appropriation of a profession, provided under Article 250, Section II of the Federal Criminal Code, which is penalized with imprisonment from one to six years and imposes a fine of one hundred to three hundred days.

102. The Dirección General de Profesiones is the national authority in charge of supervising professional practice in Mexico and it also serves as a connection body between the state and the professional colleges. It registers professional certificates, keeps control over the penalties imposed to professionals in the performance of their activities, authorizes the practice of specializations, issues the corresponding personal professional license to practice, which also serves as a means of identification in all professional activities, publishes the resolutions of registration and denials of registration of professional certificates, keeps a file with all the information relative to high school education, teachers' education, and professional education taught in education centers, as well as of the foreign professional schools and universities, and publishes during the month of January of each year, the list of professionals that obtained their certificates in the professional preparation schools during the previous year.

103. here is no mandatory college for independent professionals in Mexico. Article 40 of the Regulatory Law of Article $5^{\circ}$ relative to the practice of professions in the Federal District, replicated under the majority of local laws of the states of the republic, provides that professionals may establish or join associations to exercise their professions, but reiterates that any liability they incur will always be personal.

104. Chapter VI of the Regulatory Law of Article 5 relative to the practice of professions in the Federal District mentions professional colleges. Article 44 of such Law allows professionals of the same field to come together in one or more colleges, without exceeding five professional colleges for each professional branch.

105. The principal purpose of professional colleges includes: a) supervise professional practice to ensure that it is carried out with the highest legal and moral standards; b) promote the issuance of laws, regulations, and amendments thereto relative to professional practice; c) assist the public administration with capacity to promote actions tending to the moralization thereof; d) inform the Ministry of Education or the criminal authorities of any violations to the law; e) propose professional tariffs; f) serve as arbitrator in conflicts between professionals or between professionals and their clients; g) promote culture and relationships with other similar colleges in the country or abroad; h) collaborate with authorities as consultation bodies; i) represent their members or associates before the Dirección General de Profesiones; j) collaborate in the preparation of professional study 
programs; and k) prepare lists of experts by specialty, which will be considered as the only official lists.

106. Professionals are prohibited from using the term "college" outside the groups expressly authorized under Law. The violation of this provision will be penalized with a penalty of up to one thousand pesos.

107. Colegio de Notarios ${ }^{13}$ (College of Notaries Public). The notary public, as an independent professional, has been recognized by Mexican legislation throughout time. Each state is empowered to regulate and authorize notaries in its respective jurisdiction. For example, with respect to Mexico City, since 1946, the Ley del Notariado para el Distrito Federal (Notarization Law for the Federal District) provides that the only way to become a notary public in the Federal District, is to pass a strict opposition exam, developed by the Colegio de Notarios del Distrito Federal together with the authorities of the Government of Mexico City, which guarantees an adequate legal preparation, the honorability and independence of such public officials, who upon obtaining the respective license, must exclusively dedicate themselves to practicing as notaries public, away from any other job, office, or commission with private parties or public institutions, and subject to supervision by the government of the Federal District. Currently, there are 3603 notaries public performing their profession in the 32 States of the Mexican Republic.

\begin{tabular}{|c|c|c|}
\hline & Estados & Notarios \\
\hline 1 & Aguascalientes & 49 \\
\hline 2 & Baja California & 39 \\
\hline 3 & Baja California Sur & 23 \\
\hline 4 & Campeche & 80 \\
\hline 5 & Coahuila & 186 \\
\hline 6 & Colima & 25 \\
\hline 7 & Chiapas & 101 \\
\hline 8 & Chihuahua & 75 \\
\hline 9 & Distrito Federal & 250 \\
\hline 10 & Durango & 47 \\
\hline 11 & Guanajuato & 400 \\
\hline 12 & Guerrero & 19 \\
\hline 13 & Hidalgo & 72 \\
\hline 14 & Jalisco & 324 \\
\hline 15 & Estado de México & 165 \\
\hline 16 & Michoacán & 163 \\
\hline 17 & Morelos & 22 \\
\hline 18 & Nayarit & 45 \\
\hline 19 & Nuevo León & 139 \\
\hline
\end{tabular}

\footnotetext{
${ }^{13}$ http://www.colnotdf.com.mx/
} 


\begin{tabular}{|c|l|r|}
\hline \multicolumn{1}{|c|}{ Estados } & Notarios \\
\hline 20 & Oaxaca & 65 \\
\hline 21 & Puebla & 115 \\
\hline 22 & Querétaro & 94 \\
\hline 23 & Quintana Roo & 45 \\
\hline 24 & San Luis Potosí & 96 \\
\hline 25 & Sinaloa & 148 \\
\hline 26 & Sonora & 97 \\
\hline 27 & Tabasco & 76 \\
\hline 28 & Tamaulipas & 310 \\
\hline 29 & Tlaxcala & 10 \\
\hline 30 & Veracruz & 100 \\
\hline 31 & Yucatán & 39 \\
\hline 32 & Zacatecas & 3603 \\
\hline & TOTAL & \\
\hline
\end{tabular}

108. Forming part of the college of notaries public in the Federal District is mandatory, as provided under the respective Ley de Notariado. There are equivalent colleges in some states, such as Jalisco and Sonora, but not in every state of the Republic, where the selection procedures are not very clear.

109. Notaries public in Mexico are experts in law and must necessarily be attorneys. They draft documents that enjoy public faith, wherein he/she sets forth the legal will of the parties, which benefits society, the authorities, and whoever may consult them by becoming controllers of legality. Notaries public have the prerogative of applying the law, customs, and common practice and jurisprudence (case law) to the instruments they authorize. The following information concerning declarations of notaries should be taken into consideration in this report:

110. Notaries public are required to report to the SAT on all tranactions involving the purchase and sale of real estate in which they participate. These reports are maintained by ge SAT in a database ("DECLARANOT") the main purpose being to check compliance by notaries and their clients with their tax obligations. The SAT and the FIU work together to ensure that the database can provide the FIU with information to strengthen its investigations and financial analysis with respect to real estate transactions.

111. Recently, the SAT has sent information to the FIU for purposes of its activities. The information that notaries provide could be expanded to allow for the production of periodic information to better assist the SAT and the FIU in their respective operations.

112. Colegio de Corredores Públicos (College of Commercial Notaries). The commercial notary is an attorney at law, who after complying with the requirements established under the Ley Federal de Correduría Pública (Federal Law of Commercial Notarization) and the regulations thereof, receives authorization from the Federal Executive Power through the Ministry of the Economy. 
113. The basic duty of commercial notaries is to guarantee legal certainty and security, exercising a legality control in commercial transactions and in other federal matters, providing professional and impartial advice and having the obligation to maintain the professional secret provided by Law, which represents an element of trust for the persons that use their services.

114. For the purposes of the Ley Federal de Correduria Pública the national territory is divided into sections, one for each state and one for the Federal District. Commercial notaries may exercise their functions as mediators, expert's appraisers, legal counselors, and arbitrators throughout the Mexican Republic, but may only act as public attesters in the state in which they received authorization for such purpose.

115. Colegio de Abogados ${ }^{14}$ (College of Attorneys of Mexican Bar Association) In Mexico, there are several colleges of attorneys at law. The most important ones include: the Ilustre $y$ Nacional Colegio de Abogados de México (Illustrious and National College of Attorneys in Mexico) established in the XVIII century and the Barra Mexicana de Abogados (Mexican Bar Association) established in 1922.

116. The purposes of such associations are contained in their bylaws and generally coincide in that they seek to preserve the good name of the profession, defend the collective interests of the group, provide to their associates the necessary moral support and oversee the professional practice, promote the spirit of justice among private parties and among the officers in charge of administering justice, endeavor to maintain the professional practice of law in accordance with moral principles and the doctrine of the legal science, and strengthen legal culture in the country.

117. Colegio de Contadores Públicos (College of Public Accountants) ${ }^{15}$ The Colegio de Contadores Públicos de México, A.C. (College of Public Accountants of Mexico) was founded in 1949. The articles of association of the college indicate the following as its main purposes: to draw together public accountants, maintain and foster the reputation of the profession, unify the professional criteria of the associates, defend their individual and collective interests, and provide them professional, moral, and material assistance. The college has developed a code of ethics which is attached hereto for further reference, identity and quality management manuals that govern the professional activities of its associates. There are accounting associations in other states of the republic with similar characteristics to those mentioned above.

\subsection{Overview of commercial laws and mechanisms governing legal persons and arrangements}

\section{Non-profit Organizations}

118. The third section of Article 27 of the Constitution provides the legal basis for non-profit organizations in Mexico. It recognizes the existence of private charitable institutions, whose purpose is to aid the needy, perform scientific research, promote education, provide reciprocal assistance to associates or any other lawful purpose. Article 2687 of the Código Civil Federal (Federal Civil Code) expressly indicates that charitable associations shall be governed by the corresponding special laws.

\footnotetext{
${ }^{14}$ For the Mexican Bar Association : http://www.bma.org.mx/

For the Ilustre y Nacional Colegio de Abogados de México: http://www.incamex.org.mx/

${ }^{15}$ http://www.ccpm.org.mx/
} 
119. The majority of States in Mexico have their own legislation on private assistance institutions. In general terms, these laws define private assistance institutions as "non-profit entities with individual legal status and capital, which perform social assistance actions with private property without designating the beneficiaries individually." In accordance with the Ley de Instituciones de Asistencia Privada para el Distrito Federal and other equivalent laws in the States of Mexico, private assistance institutions are classified into foundations and associations.

120. The Servicio de Administración Tributaria (Tax Administration Service-SAT) is the original possessor of NPOs information, which is essentially collected on tax regulation grounds; however, such information is also shared with the Financial Intelligence Unit (UIF) for AML/CFT purposes. SAT and UIF are identifying appropriate means to make use of the information already available and analyzing suitable approaches to deal with NPOs and to complete an overall review of the sector and its risks regarding $\mathrm{ML} / \mathrm{FT}$.

121. The SAT holds a registry on the NPOs that are authorized to issue tax deductible receipts and operate throughout the country, classified by federative location, as provided by Article 25, Fraction II of its Internal Bylaws. The registry lists those that are currently operating along with those that have already been revoked or cancelled.

\section{Public Legal Entities and Agencies}

122. Under Mexican law, there is a wide variety of legal entities which can be classified in many different ways. Of such classifications, the broadest relates to the public and private nature of legal entities. Within the category of public entities the main types include the following:

- $\quad$ The Nation (i.e., the Mexican Federation, as referred to the federal state itself).

- Each of the 31 states of the federation (listed in Article 43 of the Federal Constitution) and the Federal District (i.e., the political capital of the country).

- $\quad$ Each of the Municipalities.

- All other public corporations of federal or state level recognized by law. With respect to federal entities - which are referred to as components of the Public "Parastatal" (Paraestatal) Administration - such a category consists of the following types (each with different corporate structure and government): decentralized organisms, enterprises with state participation, national credit institutions (i.e. state-owned banks), national insurance and sureties institutions, (i.e. state-owned) and public "fideicomisos" (i.e. a legal arrangement that is broadly similar in nature to trusts under common law). Each of such federal public corporations is contemplated by the Organic Law of the Federal Public Administration and governed by the Federal Law of Parastatal Entities, according to which they must be registered in the Ministry of Finance and Public Credit (Secretaria de Hacienda y Crédito Público).

\section{Description of Main Private Legal Entities}

123. Private entities include:

- "Societies" (term used under Mexican law to refer to a special type of corporate partnership) of civil or commercial nature. 
- Labor unions, professional associations, and other entities formed by workers or employers.

- $\quad$ Cooperative and mutual societies.

- Other associations with political, scientific, artistic, recreational, or any other legal purpose, provided they are "not unknown" by law.

- $\quad$ Foreign private entities, i.e., private entities governed by the law of the state in which they were incorporated.

\section{Civil Associations}

124. Civil entities are governed by the Federal Civil Code. In addition to the foregoing, there are a few cases of legal entities that may not fit entirely within a public/private classification as they mix certain aspects of such categories. In particular, such mixed entities are: rural communitarian entities referred to as "ejidos" and indigenous communities.

125. In accordance with the Federal Civil Code, associations are formed when several individuals agree to associate themselves in a way that is not entirely temporary, to fulfill a common purpose that is not prohibited under law and that is not predominantly economic.

126. The agreement by which an association is created must be laid down in writing and does not need to be executed before a notary public.

127. Associations may admit and exclude associates; they will be governed by their by-laws, which must be registered in the Public Registry of the Federal District to be valid against third parties. The supreme power of associations resides in the general meeting. The director or directors thereof will have the powers conferred to them under their by-laws and by the general assembly.

\section{Civil Societies}

128. Civil societies are governed by the Federal Civil Code. Through the incorporation agreement, their members mutually agree to combine their resources or efforts to fulfill a common purpose, which is predominantly economic but does not represent commercial speculation.

129. To be valid against third parties, the incorporation agreement must be registered in the Civil Societies Registry (Registro de Sociedades Civiles) within the Public Registry of the Federal District.

130. The obligations of the society will be guaranteed indistinctly by the joint and several unlimited liability of the members who manage the society. The rest of the members will only be liable for the amount of their contribution, unless otherwise agreed.

\section{Commercial Entities}

131. Commercial entities are governed by a single federal statute titled the General Law of Commercial Societies (Ley General de Sociedades Mercantiles). Commercial entities must be incorporated before a notary public and any amendments thereto must be carried out in the same manner. The incorporation agreement (which includes the respective by-laws) must be registered with a special federal public registry administered by the Secretariat of Economy and named the Public Commerce Registry.

132. Mexican legislation recognizes the following types of commercial entities: 


\section{Sociedad en Nombre Colectivo (Collective-Name Society —i.e., General Partnership).}

133. A Collective-Name Society is an entity that exists under a business name and in which all partners are liable jointly and severally, without limitation, for the society's obligations. The name of the society must be formed with the name of one or more of the partners, and when not all the names of the members appear in the society's name, the words " $y$ compañia" (and company) or other equivalent wording must be added.

134. Clauses in the incorporation agreement that eliminate the unlimited joint and several liabilities of partners will not be legally enforceable against third parties. However, the partners may stipulate that the liability of one or more of them will be limited to a certain portion or fee.

\section{Sociedad en Comandita Simple (Simple Joint Society - i.e. Limited General Partnership)}

135. In terms of Article 51 of the Ley General de Sociedades Mercantiles, Simple Joint Societies exist under a business name and are integrated by one or more general partners who are jointly and severally liable, without limitation for the society's obligations and one or more limited partners who are only liable for the payment of their contribution. The business name must be formed with the name of one or more of the general partners, and when not all the names of the partners appear in it, the words " $y$ compañia" (and company) or other equivalent wording must be added. The words Sociedad en Comandita or its initials "S. en C." must always be included in the name of the society.

\section{Sociedad en Comandita por Acciones (Joint Shares Societies - i.e. Limited Stock Partnership)}

136. Limited stock partnerships are formed by one or more general partners who are jointly and severally liable, without limitation, for the society's obligations and one or more limited partners who are exclusively liable for the payment of their shares, as provided under Article 207 of the Ley General de Sociedades Mercantiles. Their business name is formed with the name of one or more of the general partners, and when not all the limited partners' names appear in it, the words " $y$ compañía" (and company) or other equivalent wording must be added. The words Sociedad en Comandita por Acciones (Limited Stock Partnership) or its initials "S. en C por A." must always be added to the business or society name.

137. The capital will be divided into shares, for which some rules of the corporation will apply. However, the shares in a limited stock partnership may not be assigned without the consent of all general partners and two-thirds of the limited partners.

\section{Sociedad de Responsabilidad Limitada (Limited Liability Society)}

138. A limited liability society is formed by partners who are liable only to the payment of their contributions. The ownership interests may not be represented by negotiable or bearer instruments, since they may only be assigned in the cases and with the requirements provided under law. The business name is formed with the name of one or more owners and will be immediately followed by the words "Sociedad de Responsabilidad Limitada" (Limited Liability Society) or the initials "S. de R.L.". If this requirement is overlooked, the owners will be subject to the unlimited liability of general partnerships.

139. Limited liability societies may not have more than 50 owners and their capital will be divided into ownership interests of different categories and value. 


\section{E. Sociedad Anónima (Corporations)}

140. -Corporations exist under a corporate name and are integrated exclusively by shareholders whose obligation is limited to the payment of their shares. The corporate name is formed freely but must be different from that of any other corporation and must be followed by the words Sociedad Anónima (Corporation) or the initials S.A

141. In accordance with the provisions of Article 89 of the Ley General de Sociedades Mercantiles, to form a corporation, a minimum of two shareholders is necessary and each must subscribe at least one share. The capital must not be under fifty thousand pesos and it must be fully subscribed. At least 20 percent of the value of each share must be paid in cash, and the value of each share that is partially or totally payable with assets other than cash, must be fully paid-in.

142. A corporation may be formed by public subscription or offering, or through an instrument executed before a notary public. The shares in which the capital of a corporation is divided are represented by nominative, enforceable certificates that will serve to evidence and transfer the status and rights of shareholders. They must be of the same value and grant the same rights. The supreme governing body of a corporation is the Shareholders Board.

143. The corporation is the most common type of commercial entity observed in the Mexican economy. It is also the most regulated entity of all the other commercial entities described above. Reference to the "anonymous" character of the corporation shall not be interpreted as a confidentiality veil of its shareholders. Such a term, according to legal doctrine, is used to emphasize the separation of the entity from its shareholders and to refer to it as an individual entity for commercial purposes.

\section{Cooperatives}

144. Cooperatives are a form of business organization integrated by individuals with common interests and based on the principles of solidarity, personal effort, and mutual aid. Their purpose is to satisfy individual and collective needs by performing economic actions of production, distribution, and consumption of goods and services, as defined under Article 2 of the Ley General de Sociedades Cooperativas (General Law of Cooperatives). Cooperatives may be: consumer cooperatives, producer cooperatives, or savings and loans cooperatives.

\section{Foreign Companies}

145. The Federal Civil Code (Article 2736) acknowledges the existence of private foreign entities and their operation in Mexico. These are governed by the law of the place in which they are formed; that is, the law of the state in which the requirements of form and substance necessary for their creation for all matters relative to their existence, capacity to hold rights and obligations, operation, transformation, dissolution, liquidation and merger, are met. Under no circumstances shall the recognition of the legal capacity of a foreign entity exceed the capacity granted by the law under which it was formed.

146. In addition, pursuant to Article 250 of the Ley General de Sociedades Mercantiles, legallyformed foreign entities have legal capacity and status in Mexico, but may only carry out business activities provided they get registered in the Public Commerce Registry, with prior authorization from the Secretaria de Economía (Ministry of the Economy), in terms of Articles 17 and 17 A of the Ley de Inversión Extranjera (Foreign Investment Law).

147. Foreign companies are obligated to publish annually the financial statements of the company's business, certified by a Certified Public Accountant (those recognized by the SAT). 


\section{OTHER Legal ARRANGEMENTS}

148. Although under Mexican law only individuals or legal entities are entitled to own property, some other legal arrangements can be established under Mexican law to segregate certain rights or obligations, including property rights of assets. Such arrangements are: "fideicomisos" (an arrangement with similar legal effects as those produced by trusts) and "associations in participation" (i.e. joint ventures).

\section{Fideicomiso}

149. Such an arrangement is regulated under Articles 381 to 407 of the General Law of Credit Instruments and Transactions (Ley General de Títulos y Operaciones de Crédito). Under a fideicomiso, according to Article 381 of such Law, the "fideicomitente" (i.e., the grantor) transfers to a fiduciary institution (equivalent to a trustee in a trust) - which can only be a financial institution explicitly authorized by law to carry out that business (mainly banks) - property or title of one or more goods or rights that are destined for legal and determined purposes, and may be established for the benefit of a third party named "fideicomisario" (equivalent to a "cestui que trust"). Fideicomisos are not legal entities and do not need to be registered in any public registry.

\section{Asociación en participación (Joint Ventures)}

150. Mexican law contemplates joint ventures, which, under Article 252 of the Ley General de Sociedades Mercantiles, is an agreement whereby one person grants a participation in the profits and losses of a business enterprise or of one or more commercial transactions to the persons who contribute goods or services.

151. Joint Ventures have neither legal status nor corporate or business name. They are agreements that must be executed in writing and are not subject to registration.

\section{Corporate Registry}

152. Mexico has a Federal Public Registry of Commerce (the Registry) governed by the Commercial Code, the Regulations of the Public Registry of Commerce, the relevant commercial and business laws (such as the Law of Commercial Companies, the Law of Credit Institutions, etc.) and supplemented by the Federal Civil Code.

153. Pursuant to Article 18 of the Commercial Code, the Registry registers commercial acts and acts related with merchants that require registration under applicable legislation. The operations of the Registry are handled by the Secretariat of Commerce. At the state level and in the federal district, these operations are handled by the authorities in charge of the public registries of property in accordance with applicable coordination agreements. Registration is optional for individual merchants and mandatory for commercial companies and vessels.

\subsection{Overview of strategy to prevent money laundering and terrorist financing}

\section{AML/CFT Strategies and Priorities}

154. In March 2007, the Federal Government issued a National Strategy for the Prevention and Combating of Crime, focused mainly on public security and law enforcement issues. It includes a coordination agreement (March 12, 2007) between the federal preventive police and the investigation arm of the PGR (Procuraduria General de la Republica) to better organize working arrangements and 
align their investigation and crime prevention efforts. This should allow the police agencies to maximize the use of intelligence and to conduct more effective and coordinated ML investigations.

155. The mission was informed that the federal agencies involved in AML/CFT efforts are drafting a AML/CFT National Strategy that should be completed in March 2008. (A copy of the Strategy document was not made available at the time of the mission.) Post mission, the mission was informed that it is now expected to be completed in September 2008. This document is expected to outline the AML/CFT objectives and strategies that the Federal Government will implement in the short and medium term, and will include provisions for human and other resources for the various agencies involved in prevention and combating of ML and FT. The proposed Strategy will also provide for the establishment of an inter-institutional coordination group made up of the various federal agencies involved in AML/CFT. An output of such group will be detailed research and analysis of emerging ML trends, techniques and typologies used by criminals to launder funds, including the identification of geographic concentrations of ML. It will also identify, inter alia, the necessary legal and regulatory measures required to deal with this problem, as well as propose measures to strengthen the efficiency of existing AML processes. Given the work-in-progress nature of this document, the mission is not in a position to make concrete observations with respect to it.

156. In addition to the draft National Strategy document being developed, the Security Cabinet of the GOM approved in August 2008 an "Integral Strategy Against Organized Crime". This strategy includes as its principal objective the disbandment of the operational, logistical, commercial and financial networks of organized criminal organizations. A copy of this document will not be provided to the mission until proper authorization is obtained due to its highly confidential nature. In August, Mexico also signed an agreement titled the "National Agreement for Security, Justice and Legality among the three branches of the State (Executive, Legislative and Judicial), the governors of all states of the Republic, associations of municipal governments, representatives of the productive, social and religious sectors. Under such agreement, each of the parties committed to carrying out concrete plans of action within certain deadlines that contain AML/CFT elements including: strengthening of the SIEDO with financial resources, training, forensic services and infrastructure in 18 months; issue of a national strategy against ML (no timeframe provided); strengthening institutional capabilities of the federal prosecutors to improve the efficacy of judicial sentences in six months; issue of a unique identity card for citizens in three years; consolidation into a single system of criminal information to assure interconnection and exchange of information among federal and state agencies to combat crime in 1 year. The implementation and effectiveness of the proposed National Strategy, the Integral Strategy Against Organized Crime and the National Agreement for Security, Justice and Legality can only be evaluated over time.

157. The President also has a constitutional obligation to issue, at the beginning of his administration (ending 2012), a national development plan that sets the national objectives, strategies, and priorities. The current plan embraces AML/CFT issues mainly through the principles dealing with fundamental preconditions for an effective AML/CFT regime including rule of law and national security. The plan includes the following five guiding principles for public policy:

1. Rule of law and security (includes development of the AML/CFT regime).

2. Competitive economy and creation of employment.

3. Equal opportunity.

4. Environmental sustainability. And

5. Effective democracy and responsible foreign policy.

158. Under the principle of "Rule of law and security", the plan for developing programs that will affect the AML/CFT regime is summarized as follows: 
- Modernize the criminal justice system.

- Develop standardized mechanisms to collect and share reliable and timely information to better understand and combat crime.

- $\quad$ Strengthen the state and public security to more effectively combat drug trafficking and organized crime which has the resources to challenge the authority of state and threaten national security. This has required collaboration of the Armed Forces.

- $\quad$ Safeguard border security, including the southern border, where economic development has a tendency for attracting criminal activities.

- Strengthen international cooperation to preserve security and sovereignty.

- Develop a single well-resourced, ethical, and accountable police force at the federal level.

- Coordinate AML/CFT activities among law enforcement agencies including through better law enforcement, prosecutorial and judicial techniques, methods and strategies to help dismantle criminal organizations.

159. Currently, there are more than 1000 police agencies in the country at the federal, state, and municipal levels which makes coordination and unity of command very difficult. In addition, there are large asymmetries in their salaries, recruitment requirements and procedures, and selection which undermine their effectiveness and public trust. This situation also allows criminals to infiltrate these agencies and undermine their activities. The authorities are now requiring police officers to have a profile consistent with a new focus for police investigations. This includes more professional officers receiving ongoing training in various fields such as analysis, information systems, and investigative techniques to enable them to more effectively carry out their responsibilities.

\section{The Institutional Framework for Combating Money Laundering and Terrorist Financing}

160. Money laundering and financing terrorism are federal crimes. Thus, federal authorities are responsible for directly participating in the prevention of and combat against such crimes, without excluding the collaboration that state or municipal authorities may provide within their respective scope of competence. The national authorities that participate in the prevention of and fight against $\mathrm{ML} / \mathrm{FT}$ are the following:

\section{Ministries}

161. Under constitutional provisions (Article 90) and legal provisions (mainly compiled in a single federal statute titled the Organic Law of the Federal Public Administration - Ley Orgánica de la Administración Pública Federal) the administrative affairs of the federation are handled by secretariats (i.e. ministries) that are considered part of the Centralized Federal Public Administration. The ministries involved in AML/CFT actions are:

162. The Ministry of Finance and Public Credit (Secretaría de Hacienda y Crédito Público SHCP). Through some of its several administrative units (see following paragraphs), the SHCP plays a key role in the prevention and detection of ML/FT activities mainly by issuing AML/CFT regulations applicable to financial institutions and other obligated businesses, supervising their compliance thereof and receiving and analyzing reports and information concerning transactions relating to $\mathrm{ML} / \mathrm{FT}$.

163. The SHCP is in charge of regulating financial institutions and granting authorizations or licenses for the creation and operation of each of them. The Undersecretary of Finance and Public Credit prepares all regulations applicable to financial institutions through the following units: 
- $\quad$ Banking, Securities, and Savings Unit (Unidad de Banca, Valores y Ahorro-UBVA).

- Insurance Pensions and Social Security Unit (Unidad de Seguros Pensiones y Seguridad Social - USPSS).

- $\quad$ Development Banking Unit (Unidad de Banca de Desarrollo - UBD).

164. Although the SHCP is not directly in charge of supervising compliance of the AML/FT regime, such a function is carried out by the following agencies that are part of the structure of the SHCP, and referred to as decentralized bodies (órganos desconcentrados, i.e. agencies with technical autonomy in respect of the policies and lines of action they follow that are governed by boards integrated with government officers - the majority of which are appointed by the SHCP - and, in some cases, representatives of the private sector):

- National Banking and Securities Commission (Comisión Nacional Bancaria y de ValoresCNBV).

- National Insurance and Sureties Commission (Comisión Nacional de Seguros y FianzasCNSF).

- $\quad$ National Retirement Savings System Commision (Comisión Nacional del Sistema de Ahorro para el Retiro-CONSAR).

- $\quad$ Tax Administration Service (Servicio de Administración Tributaria-SAT).

165. The following table lists the authorities in charge of supervising compliance of AML/CFT regime and the entities they supervise:

\begin{tabular}{lr}
\hline \multicolumn{1}{c}{ Financial Entities } & Total \\
\hline Subject to Supervision by CNBV [National Banking and Securities Commission] & 20 \\
General Deposit Warehouses & 10 \\
Financial Leasing Firms & 32 \\
Securities Brokerage Firms & 24 \\
Foreign Exchange Houses & 3 \\
Financial Factoring Firms & 48 \\
Popular Savings and Credit Entities & 6 \\
Development Banking Credit Institutions (i.e., state-owned banks) & 40 \\
Multiple Banking Credit Institutions (i.e., commercial banks) & 39 \\
Limited Purpose Financial Institutions & 13 \\
Regulated Multiple Purpose Financial Institutions & 44 \\
\hline Operators of Investment Funds & 8 \\
Distributors of Investment Funds & 155 \\
Credit Unions & 442 \\
\hline Total & \\
\hline Subject to Supervision by CNSF [National Insurance and Bonding Commission] & 14 \\
Sureties Institutions & 93 \\
Insurance Companies & 107 \\
\hline Total & \\
\hline
\end{tabular}




\begin{tabular}{lr}
\hline \multicolumn{1}{c}{ Financial Entities } & Total \\
\hline $\begin{array}{l}\text { Subject to Supervision by CONSAR [National Retirement Savings System Commission] } \\
\text { Retirement Fund Managing Companies }\end{array}$ & 18 \\
\hline \hline Total & 18 \\
\hline \hline Subject to Supervision by SAT [Tax Administration Service] & 2212 \\
Retail Foreign Exchange Centers (Est. total registered and unregistered: 3157. & \\
The total registered is 2 212) & 857 \\
Money Remitters (Est. total registered and unregistered:1 223. The total & 634 \\
registered is 857) & 3703 \\
\hline Non-Regulated Multiple Purpose Financial Companies & \\
\hline Total &
\end{tabular}

166. The SHCP houses the Financial Intelligence Unit, which is a department that depends on the Minister of Finance and Public Credit.

167. The Ministry of Public Security (Secretaría de Seguridad Pública), under Article 30 Bis of the Ley Orgánica de la Administración Pública Federal (Organizational Law of the Federal Public Administration), is empowered, inter alia, to develop the public security policies and federal criminal policies, including regulation, instruments and actions to efficiently prevent crimes. This agency leads the Public Security National Council and organizes, leads, administers, and supervises the Federal Preventive Police (FPP), which supports competent authorities in the investigation and prosecution of crimes, the arrest of persons and the seizure of property which constitutes the object of, proceeds from, or instrumentalities of, a crime.

168. The Ministry of Foreign Affairs (Secretaria de Relaciones Exteriores) negotiates and signs treaties, agreements, and conventions on behalf of Mexico; acts as the transmitter of rogatory letters; and generally assists in mutual legal assistance and extradition matters.

169. The Ministry of the Interior (Secretaria de Gobernación) has, among its powers, the authority to regulate, authorize, and supervise gambling and betting games and lotteries.

\section{Law enforcement and Operational bodies}

170. The Unidad de Inteligencia Financiera is Mexico's FIU. It is part of the SHCP. It is the national central authority for the reception, analysis, and dissemination of financial information relating to $\mathrm{ML} / \mathrm{FT}$ cases.

171. The Attorney General's Office (Procuraduría General de la República-PGR) is responsible for investigating and prosecuting all federal crimes, including money laundering and terrorism financing. The Deputy Attorney for Special Investigation of Organized Crime Special (SIEDO-Spanish acronym for Subprocuraduría de Investigación Especializada en Delincuencia Organizada) has primary responsibility for criminal money laundering and terrorism financing enforcement.

172. The SIEDO is comprised of six specialized units: the Specialized Unit for the Investigation of Offenses Against Health (the Special Drug Offenses Unit); Specialized Unit for the Investigation of Operations with Resources of Illicit Origin and Forgery or Alteration of Currency (Special AML Unit); Specialized Unit for the Investigation of Terrorism and Traffic of Weapons (Special Antiterrorism Unit that will analyze, along with the AML Unit, the FT cases); Specialized Unit for the 
Investigation of Kidnappings; Specialized Unit for the Investigation of Traffic of Undocumented Persons, Minors and Organs (Special Human trafficking Unit), and Specialized Unit for the Investigation of Vehicle Theft.

173. 1. In addition to these national units, regional offices of the PGR also prosecute money laundering offenses that fall within their locality and are not handled by the national units. The PGR is assisted by the AFI, a police force under its authority and immediate command. Additionally, the PGR is responsible for requesting and receiving mutual legal assistance requests on criminal matters made pursuant to treaties or on the basis of reciprocity.

174. The Federal Investigation Agency (Agencia Federal de Investigación-AFI) is a police force that is a part of the PGR and under the authority and immediate command of the PGR. The AFI is responsible for investigating a number of offenses, including kidnapping and money laundering, but does so only based on the PGR's instructions. Money laundering investigations are carried out through a special unit within the AFI's General Directorship for Police Investigations. This unit coordinates with ministerial authorities in charge of the investigation and prosecution of money laundering, and with INTERPOL-Mexico, which provides information that initiates money laundering investigations.

175. Notwithstanding that the AFI is fomally an agency of PGR, since 2007 a project was initiated to merge AFI and the Federal Preventive Police into a single law-enforcement agency within the Ministry of Public Security. As part of such project, since 2007 AFI and the Federal Preventive Police were placed under one single command although a final decision to leave a law enforcement division under the command of the Federal Office of the Attorney General (PGR) is still to be implemented. That restructuring process has affected the abitility of the PGR to effectively conduct criminal investigations. Consequentely, in July 2008 a permanent team of criminal investigators was was formed with representatives from the Federal Police, PGR and the FIU to investigate ML cases and provide all information in their possession that may be linked to such cases. The main outputs from this team will not be evident until the medium to long term given the nature of such investigations, but noticeable progress has already been noted in the investigation of ML cases.

176. The Federal Preventive Police (Policia Federal Preventiva-PFP) was created on December 13, 1998. It currently depends on the Secretariat of Public Security and is responsible for preventing and combating federal crimes, by means of criminal intelligence, and the control and inspection of persons and merchandise entering or exiting Mexico, policing federal highways and railroads, and providing a support force if required. It has the power to seize currency or monetary instruments that have not been properly declared. The FPP does not specifically gather intelligence for money laundering purposes; however, if found, such information would be forwarded to the UIF. In addition, the Federal Preventive Police is transforming into the "Federal Police" which has adopted the following principal objectives:

- Design, coordinate, direct and control the analytical methodologies and information systems that will facilitate the conduct of investigations of criminal organizations engaged in ML in all its phases including: placement, concealment, structuring and integration of illicit funds. This will also involve streamlining of databases to facilitate understanding of the crimes and gathering of other information to help identify the structures and modus operandi of criminal organizations operating nationally and internationally.

- Apply, inter alia, field investigative techniques and strategies to develop indicators of criminal activities by organized crime and to enable the authorities to attack the core structure of such organizations involved in ML using powers/tools available at the ministerial, judicial and law enforcement levels. 
177. Post mission, the Federal Police was also been granted with additional authority under a recently approved Judicial Reform program In particular, the Federal Police has been granted with constitutional powers to investigate criminal activities, in coordination with the PGR, although the legislation needed to implement such constitutional powers is still being developed. The Federal Police is also developing a team of officers dedicated exclusively to the investigation of ML investigations. FT is not a specific part of such reform initiatives.

178. The General Customs Administration (Administración General de Aduanas) is an administrative unit of the SAT, empowered to receive all declarations of cash or monetary instruments exceeding US\$10,000 in value which are being transported across the border and reports these declarations to the Financial Intelligence Unit. In 1999, Customs created the Supporting Unit for Fiscal and Customs Inspection which implements measures to prevent smuggling of foreign trade merchandise, particularly money, drugs, tobacco, liquor, arms, cars, and jewelry.

179. In October 2007, a Customs Intelligence Unit was created within the SAT which has started to coordinate joint analysis projects with the FIU. Among such projects, it has commenced to implement a Trade Transparency Unit with the customs authority of the U.S. The Trade Transparency Unit began operations in May 2008, and allowed access to the FIU. It has been agreed that a team of FIU analysts will work permanently in that Unit to look at trade-based ML cases. The FIU team is not yet operational within the Unit but the recruitment process for these analysts has began.

180. The Public Sector Assets Management and Disposal Service (SAE-Spanish acronym for Servicio de Administración y Enajenación de Bienes), in accordance with Art. 76 of Federal Law for the Administration and Dsiposition of Public Assets or "Ley Federal para la Administración y Enajenación de Bienes del Sector Público". The main objective of the SAE is to contribute to the strengthening of public finances and property rights through effective and efficient management and transfer of property and enterprises, including through the destruction of assets and liquidation of enterprises assigned to it. The SAE can administer, dispose of or destroy property of the public sector either directly or through trustees, liquidators, or administrators it may appoint. Those trustees, liquidators, or administrators shall preferably be units or entities of the Federal Public Administration, or the state and municipal authorities. SAE will have the following supporting Committees: Committee of Insured Assets; Committee of Donations; Other Committees which are required. The Committee of Insured Assets referred to by Section I of the previous article, will have the following scope: act as a supportive entity to the SAE regarding the administration, transfer, and destruction of the insured, confiscated, and abandoned assets within federal criminal proceedings, which are transferred to that organ; issue the respective opinion regarding the economic compensation for the devolution of such assets, with charge to the corresponding fund.

\section{Other financial sector bodies}

181. Banco de México (Bank of Mexico) is the central bank of Mexico. Its powers and administration are constitutionally autonomous as provided under Article 28 of the Constitution. Its main purposes are to provide the economy with national currency and attain the stability of the purchasing power of such currency. Additionally, it is in charge of promoting a healthy development of the financial system and fostering the good operation of payment systems. Jointly with SHCP, it issues certain regulations and conducts certain supervision for the financial sector.

182. National Commission for the Protection and Defense of Financial Services Users (CONDUSEF-Spanish acronym for Comisión Nacional para la Protección y Defensa de los Usuarios de los Servicios Financieros ) is a decentralized public agency whose purpose is to promote, advise, protect, and defend the rights and interests of the people who use or contract financial products or services offered by financial institutions that operate in Mexico. It also creates and fosters among users an appropriate culture with respect to financial transactions and services. CONDUSEF is 
governed by the provisions of the Ley de Protección y Defensa al Usuario de Servicios Financieros (Law of Protection and Defense of Financial Services Users).

183. Institute for the Protection of Bank Savings (IPAB-Spanish acronym for Instituto para la Protección del Ahorro Bancario) is a decentralized body of the Federal Public Administration, with its own legal status, capacity, and capital. The Ley de Protección del Ahorro Bancario (Law on the Protection of Bank Savings) regulates the powers and structure of IPAB and sets forth a system of protection for bank savings.

\section{Approach Concerning Risk}

184. Mexico has not concluded a systemic review of ML and FT vulnerabilities and risks affecting its financial and other sectors. Such a review is contemplated by the proposed draft National Strategy for the Prevention and Combat of ML/FT expected to be released in September 2008. It has, however, benefited from a mutual evaluation by the FATF with respect to compliance with the AML/CFT standard and has issued AML/CFT regulations for financial institutions that include riskbased elements for customer due diligence. The authorities indicate that they are aware of the main sources of ML risk, particularly those arising from drug trafficking and related criminal activities. Terrorism and terrorism financing are not yet considered to present significant risks, but the escalating violence and tactics used by the powerful drug cartels against civilians, law enforcement and the armed forces could raise the potential for terrorism and related financing activities as defined under the applicable UN Convention and Resolutions.

\section{Regulation and Supervision}

185. The AML/CFT regulations also allow FIs to apply risk-sensitive approaches to compliance with the CDD requirements. These are summarized below (see Rec. 5 for a more detailed description of the risk-based elements):

- $\quad$ Chapter III: (Know Your Client Policy): Each of the AML/CFT regulations allows FIs to take risk into account in applying CDD, and requires them to classify customers from low to high risk, with intermediate ratings allowed. They also require FIs to classify particular categories of customers as high risk such as PEPs and nonresident, high-net-worth clients.

- $\quad$ Chapter II: Customer Identification Policy: Each of the regulations allows FIs to apply a simplified identification regime to 26 categories of financial institutions (both domestic and foreign) and to governmental dependencies or entities.

- $\quad$ DCG 124 Title II: Applicable to Type 2, 3, and 4 Popular Savings and Loan Institutions: These entities are classified by the size of their assets and are progressively larger than Type 1 institutions. For these entities, know-your-customer policies and other AML/CFT requirements are more rigorous than for the smaller Type 1 institutions.

186. The regulatory and AML/CFT regime in Mexico also applies differing requirements to certain financial sectors particularly with respect to licensing and supervision. These are discussed below:

- Currency Exchange and Money Remittance Sectors (Casas de Cambio): Licensing is required for legal entities that engage in currency exchange and money remittance business in amounts of more than the equivalent of US\$10,000 per customer per day in a habitual and professional/specialized manner. Activities connected to operations and services by businesses located in border areas and free zones, as well as firms that regularly conduct business with foreigners (e.g., hotels), shall not be considered habitual and professional and are not required to be licensed. At the time of the mission, there were only 23 licensed currency 
exchange/remittance firms. This number is expected to decline due in large measure to the closure or threat of closure of correspondent accounts in the United States and actions taken by Mexican authorities with respect to casas de cambio that seriously breached their AML/CFT obligations. These entities are authorized by the SHCP (Secretaria de Hacienda y Credito Publico) and are supervised by the CNBV (Comision Nacional de Bancaria y de Valores) including for AML/CFT. CDD is only required for transactions that equal or exceed the US $\$ 10,000$ threshold.

- Currency exchange businesses (centros cambiarios) that conduct transactions less than the equivalent of US $\$ 10,000$ per client per day do not require authorization but are subject to the AML/CFT laws and regulations. They are not licensed but are required to provide notification of their activities to the SAT and are subject to its supervision for AML/CFT purposes. A significant portion of these businesses have still not given notice of their operations and AML/CFT oversight is still developing. There are an estimated 4380 unlicensed operators. (Estimates provided by the SAT. Uncorroborated industry association estimates exceed 7000 .) More than 1300 operations are estimated to be active without notification to the SAT. The SAT has limited staff capacity to supervise these entities.

- Money remittance business (Transmisores de Dinero). Persons engaging in money remittance business are not required to be licensed. They are, however, subject to AML/CFT requirements under the $\mathrm{AML} / \mathrm{CFT}$ laws and regulations but only with respect to transactions that equal or exceed US $\$ 3,000$. It is estimated that there are about 882 registered money remittance firms that meet this category. These are also subject to AML/CFT supervision by the SAT.

- $\quad$ SOFOMES (multipurpose financial (lending) institutions which are replacing the limited purpose institutions "SOFOLES"). As part of a deregulation program, there are both regulated and nonregulted SOFOMES. SOFOMES that are part of a financial group require licensing and supervision by the banking regulator (CNBV). The others do not require licensing and supervision by the CNBV but are subject to the AML/CFT laws. At the time of the mission AML/CFT regulations had not been issued. The SAT has been designated as the supervisor of unregulated SOFOMES for purpose of compliance with the AML/CFT requirements. At the time of the mission, there were an estimated 634 unlicensed SOFOMES and about 13 regulated SOFOMES.

187. As part of its ons-ite inspection program, the National Banking and Securities Commission (CNBV) is implementing supervisory procedures for the review of compliance with the AML/CFT regulations which, as mentioned above, contain risk-based elements. These regulations allow for simplified customer due diligence (CDD) with respect to financial institutions and government-related clients (Annex 1 of the regulations), as well as for enhanced CDD for higher risk clients, including for politically-exposed persons (PEPs). Special risk-based provisions as provided under the regulations are also reviewed with respect to correspondent banking accounts and high net worth individuals.

188. The CNBV uses general supervisory procedures for purposes of inspecting compliance with the minimum regulatory requirements for all financial institutions and more comprehensive procedures for selected entities that present a higher-risk profile, taking into account, inter alia, the kind of transactions and services they offer, geographical coverage, and the size of their assets. Some of the institutions selected for more in-depth review include multiple banking institutions, brokerage firms, and foreign exchange houses that are considered most vulnerable to ML by organized crime.

\section{FINANCIAL INTELLIGENCE UNIT}

189. The FIU indicated that it has adopted a risk management approach to its activities that include a five-step process: $i$ ) identify risks; ii) analyze risks; iii) plan actions accordingly; iv) track 
and report the evolution of the identifiable risks; and $v$ ) control the status of risks and learn from the outcomes. It applies this process mainly to the information and interaction with the parties entitled to receive and use the information provided by such FIU including the PGR (General Attorney's Office), supervisory authorities and, to a certain extent, reporting entities.

\section{Progress Since the Last IMF/WB Assessment or Mutual Evaluation}

190. The second mutual evaluation report (MER) of Mexico was approved by the FATF Plenary on February 27, 2004. As part of this process, the FATF included Mexico under a follow-up program to monitor progress in addressing the identified deficiencies in its AML/CFT regime. Subsequent to the evaluation, Mexico has taken the following measures:

- January 2004: published amendments to Articles 95 and 95 Bis of the Ley General de Organizaciones y Actividades Auxiliares del Crédito (General Law of Auxiliary Credit Organizations and Activities) that incorporates currency exchange centers (centros cambiarios) and money transmitters (transmisores de dinero) to the AML/CFT regime. Regulations have been issued for these sectors and the SAT (Tax Administration Service: Servicio de Administración Tributaria) was designated as the authority responsible for AML/CFT compliance supervision and enforcement.

- $\quad$ May 2004: Issued a decree amending Article 15 of the Internal Regulations of the SHCP (Secretaría de Hacienda y Crédito Público) defining the powers of the Financial Intelligence Unit. The FIU is a unit of the SHCP.

- May 2004: SHCP issued AML/CFT regulations (Disposiciones de Caracter General) under the applicable financial laws for all financial sectors subject to the AML/CFT regime at that time.

- $\quad$ November 2006: SHCP issued two revised AML/CFT regulations, one for FIs covered under Article 115 of the Credit Institutions Law (LIC-Ley de Instituciones de Credito) and one for FIs covered under Article 124 of the Popular Savings and Loan Law (Ley de Ahorro y Credito Popular). These revised regulations enhanced the regulatory requirements and introduced more extensive risk-based elements for CDD.

- June 2004: Signed memorandum of understanding between the Financial Intelligence Unit and the PGR (Procuraduria General de la República) establishing the basis for protecting the information sent to ministerial authorities, and in October 2005, signed another which outlines procedures for routine interaction between the two agencies.

- December 2005: Issued a Decree amending Article 117 and repealing Article 118 of the Law of Credit Institutions with respect to banking and fiduciary secrecy to standardize the provisions for both types of secrets and to define the conditions for lifting such provisions. In particular, Article 117 of the LIC expressly allows exceptions to secrecy requiring credit institutions to provide information through the CNBV (Comisión Nacional Bancaria y de Valores) when requested by a broad range of competent authorities.

191. Credit institutions must respond to requests from the CNBV to provide information sought by the competent authorities indicated above in accordance with its instructions. The CNBV can penalize credit institutions for any failure to respond to a request, in accordance with the provisions under Articles 108 to 110 of the LIC (Credit Institutions Law).

- June 2007: Issued a decree that criminalizes terrorism financing as an autonomous crime by amending Article 139 of the Federal Criminal Code which included a new title called "International Terrorism" to enable the application of sanctions for such crimes. 


\title{
II. 2.LEGAL SYSTEM AND RELATED INSTITUTIONAL MEASURES
}

\author{
2.1 Criminalization of Money Laundering (R.1 \& 2)
}

\subsubsection{Description and Analysis ${ }^{16}$}

\section{Legal Framework}

192. Money laundering has been an offense in Mexico since 1989. The offense was originally set forth as a fiscal offense under Article 115 Bis of the Federal Fiscal Code. However, in 1996, Article 115 Bis of the Federal Fiscal Code was repealed and the money laundering offense was introduced as the crime of "Operations with Resources from Illegal Origins" under Article 400 Bis of the Federal Criminal Code (CPF, Spanish acronym for Código Penal Federal), which remains in effect today. As a result of such legislative amendments, money laundering changed from being mainly a fiscal offense to becoming a criminal offense. Among other things, Article 400 Bis also increased the penalties for money laundering, reduced the number of specific purposes required in the offense, and introduced new procedural elements.

193. The money laundering offense under Article $400 \mathrm{Bis}$ is also complemented by the provisions of Mexico's Federal Law Against Organized Crime (LFDO, Spanish acronym for Ley Federal contra la Delincuencia Organizada) enacted in 1996, which provides higher criminal sanctions for money laundering offenders, among others, considered to be members of a criminal organization.

194. The assessment team notes that Mexico has only implemented a few of the recommendations on criminalization made by the FATF in the context of the last AML/CFT evaluation. On a positive note, however, the assessment team learned that Mexico's Attorney General's Office (Procuraduria General de la Republica) has developped and implemented an initiative aimed at mapping the criminal economy and identifying the flows of proceeds of crime. The results of this initiative are being used as input to inform the development of a National Strategy to Prevent and Combat Money Laundering, which is expected to be completed in September 2008. The strategy will outline in detail Mexico's short and medium-term objectives and action plan for preventing and combating money laundering and will set out the needs for human and technical resources for all of the agencies involved in AML/CFT efforts. It would be desirable for the National Strategy to take into account the recommendations of this assessment report.

195. In September 2003, the Attorney General's Office tabled before Congress an initiative of AML-related reforms to the CPF, the Federal Criminal Procedures Code, the LFDO, and the Organizational Law of the Federal Judicial Power. The proposed reforms would have addressed a number of recommendations in the last FATF AML/CFT evaluation report, including: making legal persons criminally liable; establishing conspiracy as an ancillary offense of money laundering; introducing a minor money laundering offense based on negligence; introducing provisions that would allow confiscation of assets for an amount equivalent to the product of the offense, when such assets have disappeared or cannot be located, among others. However, the intitative is still under consideration by Mexico's Senate and has not yet been considered by Mexico's House of Representatives (Cámara de Diputados).

\footnotetext{
${ }^{16}$ For all recommendations, the description and analysis section should include the analysis of effectiveness, and should contain any relevant statistical data.
} 
196. The reform package was also expected to introduce several special techniques of investigation and additional offenses in the Federal Law Against Organized Crime, such as those related with the diversion of chemical precursors and essential chemical substances, the transportation of weapons, pellets, and cartridges of exclusive use by the armed forces, the dismantling of stolen vehicles, and the sale of stolen vehicle parts. Consideration may also be given to the possibility of applying heavier sanctions to members of criminal organizations convicted of offenses such as drugtrafficking, terrorism, kidnapping, and diverting chemical precursors and essential chemical substances.

197. It should also be noted that a substantial reform on a number of constitutional provisions in connection with the federal judicial system (referred to as the "Judicial Reform") was recently approved by Mexico's Congress. This constitutional reform was published in the Official Gazette of the Federation (Diario Oficial de la Federación) on June 18, 2008. Under the Judicial Reform, criminal trials will be followed orally; police forces are now entitled to investigate crimes under the command of the federal prosecutor (ministerio público); and extension of dominion will apply to assets related to organized crime and drug trafficking, inter alia.

198. In this regard, PGR is preparing a text for the legislation that is needed to implement these constitutional amendments. Such proposed legislation will include new provisions to counter ML/FT that will take into consideration and supersede the AML reform package introduced in September 2003 , referred to above.

199. Criminalization of Money Laundering (c. 1.1-Physical and Material Elements of the Offense): Money laundering is criminalized in Mexico on the basis of the United Nations Convention Against Illicit Traffic in Narcotic Drugs and Psychotropic Substances of 1998 (the Vienna Convention) and the 2000 UN Convention against Transnational Organized Crime (the Palermo Convention). However, there are certain elements of these conventions that have not been implemented under Mexican law.

200. Article 400 Bis of the Federal Penal Code criminalizes the money laundering conduct in the following terms:

"A sanction of five to fifteen years in prison and a one-thousand to five-thousand-days fine shall be imposed on the person who, by himself or through an intermediary, performs any of the following conducts: to acquire, sell, administer, guard, change, deposit, give in guarantee, invest, transport, or transfer within the national territory, or from the national territory to a foreign jurisdiction, or vice versa, resources, rights or assets of any nature, knowing that they proceed from or represent the product of an illicit activity with any of the following purposes: hide or pretend to hide, conceal or impede finding out the origin, location, destination or ownership of said resources, rights or assets, or foster any illegal activity.

The same sanction shall be applied to employees and officials of institutions of the financial sector who wilfully help or assist others to perform the conducts provided for in the paragraph above, regardless of the proceedings and sanctions that may be applicable under the financial legislation in effect.

The sanction provided for in the first paragraph will be increased by half when the illicit conduct is carried out by public servants responsible for preventing, denouncing, investigating or judging perpetrated crimes. In this case, public servants will also be imposed 
an inability to perform a public office, capacity or commission for a term equal to the prison sanction imposed.

In the event of conducts provided by this article, in which the services of institutions part of the financial system are utilized, the previous complaint from the Ministry of Finance and Public Credit will be necessary to proceed criminally.

When said Ministry, in the exercise of its supervisory powers, finds elements that allow presuming the commission of the offenses referred to above, it must exercise its powers of verification under the laws and, if applicable, report the facts that may constitute such offense.

For the purposes of this article, it is understood that resources, rights or assets of any nature, are the product of an illegal activity when there are solid grounds or certainty that they derive, directly or indirectly from, or that they represent, the earnings of a crime, and their legitimate origin cannot be established.

For purposes of this article, the financial system is integrated by credit, insurance and bonding institutions; general deposit warehouses, financial lessors, savings and loans companies, limited purpose financial companies, credit unions, financial factoring companies, brokerage firms and other market intermediaries, exchange houses, savings funds managing companies, and any other financial or exchange brokers."

201. Article 194, Section I, Subsection 32 of the CFPP considers the money laundering offense, among others, to be a serious offense "for all legal purposes, and because they significantly affect the fundamental values of society." This consideration has significant implications, such as the limitation on the ability of defendants to obtain provisional release prior to conviction.

202. As previously mentioned, the money laundering offense under Article 400 Bis of the CPF is complemented by the LFDO. Article 2, Section I of the LFDO provides that when three or more persons, whether permanently or repeatedly, agree to organize or organize themselves to carry out conducts which, either individually or coupled with other conducts, are intended to or result in the perpetration of a money laundering offense, among others, they will be sanctioned, for such reason alone, as members of organized crime.

203. All of the physical and material elements of the offense set out in the Vienna and the Palermo Conventions are explicitly present in Mexico's money laundering offense except for the "concealment or disguise of the true nature, source, location, disposition, movement or ownership of or rights with respect to property," and the mere "possession or use of property regardless of the purpose." The judicial authorities have argued that, while Article 400 Bis does not explicitly refer to such conducts, in practice, the courts would face no difficulties in framing a "possession or a use of property regardless of the purpose" under one of the conducts explicitly mentioned in the existing offense.

204. With regards to the "conversion of property," the authorities have argued that, in the absence of another conduct explicitly mentioned under Article 400 Bis, a conversion would be typically covered by the "change" of resources, rights, or assets. 
205. Part of the doctrine seems to support the authorities' argument by considering a conversion to mean "the change" of the property obtained from the commission of a crime for other property of a different nature.

206. The grammatical interpretation also supports the authorities' argument. Under the Dictionary of the Royal Academy of the Spanish Language (the authoritative reference for the Spanish language), "to change" means, inter alia, "to convert a thing into another thing," and to "convert" means "to transform a thing into something different than what it was." Grammatical interpretations have significant weight in Mexico's legal system and there is case law in Mexico confirming that grammatical interpretations are valid.

207. Moreover, prosecutors and judges interviewed during the on-site visit confirmed that they would not foresee a problem with framing a "conversion" as a "change."

208. The authorities argue that the reason why there is no case law supporting their argument is because their interpretation is so obvious that the issue has never raised any controversies in a Mexican court. However, assessors believe that the reason why there is no case law may also be related to the fact that most of the ML cases in Mexico have involved other types of conducts (mainly the "transportation" of property from a foreign jurisdiction into national territory).

209. The authorities were not able to show any convictions for ML where the conduct in question involved a "change" that could also have been interpreted as a "conversion." However, there is no case law stating the opposite either. Moreover, in reviewing the latest decisions in ML cases in Mexico, assessors found no controversies regarding the way in which the conducts in question were framed by the courts.

210. In light of the above, assessors have decided to accept the authorities' argument that "conversions" of property would be captured by the term "change" under Article 400 Bis.

211. With regards to the "concealment or disguise of the true nature, source, location, disposition, movement or ownership of or rights with respect to property," although Mexico's ML offense refers to "concealment or disguise," it does so only as a purpose for the first of the three needed offenses, and not as the primary conduct. In addition, the provision appears to cover concealment or disguise of only as to some of the required items (origin, location, ownership of rights) but not nature, disposition, or movement and arguably source (although the latter could probably be covered by origin).

212. With regards to the mere "possession or use of property", the authorities have argued that possession is covered because to acquire, sell, administer, guard, change, deposit, give in guarantee, transport, or transfer, possession is always required. However, while a possession may be comprised within any of these conducts, the Conventions require countries to criminalize the mere and standalone possession. All of the conducts referred to by the authorities may require the prior possession but they also require the commission of additional acts that go beyond the mere and stand-alone conduct of possession. In other words, an "acquisition may require a posession," but a stand-alone possession may not require the comission of the additional acts required for an acquisition to take place. The same principle applies to the rest of the conducts referred to by the authorities. What needs to be criminalized is the mere stand-alone possession of property.

213. Apart from this, the specific purposes referred to under Article 400 Bis would have to be present for any of the conducts referred to above to be committed, and this would go beyond the requirements of the Vienna Convention for the "possession or use of property," which demand no purpose at all. 
214. It should be noted that the authorities have not invoked any constitutional principles or basic concepts of the Mexican legal system that would prohibit the specific criminalization of the "possession or use of property with no specific purpose."

215. On a separate note, the purpose in Article 400 Bis of "fostering any illegal activity"would seem broad enough to cover the purpose of the conventions of "helping any person who is involved in the commission of the predicate offense to evade the legal consequences of his or her actions."

216. The Attorney General's Office has drafted a legal initiative that would amend, supplement, and repeal several articles of the CPF and the Federal Criminal Procedures Code (CFPP Spanish acronym for Código Federal de Procedimientos Penales) incorporating into the first paragraph of Article 400 Bis the conducts of "possession," "use for any purpose," "withdrawal," "granting, or accepting loans," "transmitting," and "transferring". This initiative is still awaiting a final opinion in the United Commissions on Justice and Legislative Studies (Comisiones Unidas de Justicia y

Estudios Legislativos) of Mexico's Senate. However, it is expected that the legislation the Executive Branch will propose to Congress in the next legislative period (that will begin in September 2008) to implement the recently published constitutional amendments in respect of the Judicial Reform, will supersede the Attorney General's initiative with a set of provisions more solidly supported by that constitutional reform.

217. An investigation for money laundering can be initiated de oficio by prosecutors of the PGR (i.e. without prior accusation by a victim or an offended party), or on the basis of a complaint. However, if the conduct is carried out using the services rendered by a financial institution, a formal complaint from the SHCP (through the FIU) is required before the case can be brought to court. Article 400 Bis broadly defines institutions of the financial sector to include everything from credit and savings institutions to securities brokerages, deposit institutions, casas de cambio, financial billing and invoice companies, and any other financial intermediary or exchange.

218. While this requirement is not causing significant problems at the moment, it does create a potential risk of damaging the effective implementation of the offense and the authorities should, therefore, consider the possibility of removing it.

\section{The Laundered Property (c. 1.2)}

219. The offense of money laundering under Article 400 Bis extends to any type of property, regardless of its value, that directly or indirectly represents the proceeds of a crime. Property is broadly referred to in the first paragraph of Article 400 Bis of the Federal Criminal Code as "resources, rights or assets of any nature," with no limits with regards to their value. In addition, the sixth paragraph of Article 400 Bis states that "For the purposes of this article, it is understood that resources, rights or assets of any nature, are the product of an illegal activity when there are solid grounds or certainty that they derive, directly or indirectly from, or that they represent, the earnings of a crime, and their legitimate origin cannot be established."

220. The term "resources" has no legal definition and refers to the ensemble of assets and material means of a person. The term "rights" has a legal definition and refers to the subjective right of economic content, consisting of the entitlement of a person known as creditor to request a conduct, an abstention, or the delivery of a thing from another person known as debtor. Finally, the term "assets" is legally defined in the Federal Civil Code under Articles 750 (which defines real estate assets), 752 (which clasifies movable assets by their nature or by a legal disposition), 753 (which defines assets that are movable by nature), and 754 (which defines assets that are movable by a legal disposition. 
221. These definitions are broad enough to cover property of any kind that directly or indirectly represent the proceeds of crime. The authorities have shown that, in most money laundering cases, judicial decisions make no reference to the type of property involved. In cases where a reference was made, most decisions referred to U.S. dollar bills, others referred to movable assets, and a minority of them referred to real estate assets.

\section{Proving Property is the Proceeds of Crime (c. 1.2.1)}

222. To prosecute criminally and, if applicable, convict for the crime of money laundering in accordance with Article 400 Bis of the FPC, it is not necessary that a person be convicted for a predicate offense. The only requirement of the statute is to demonstrate well founded indicia or certainty that the property is derived directly or indirectly or represents the earnings derived from the commission of a crime.

223. In effect, rather than applying to proceeds of criminal offenses, Article 400 Bis applies to "the proceeds of an illicit activity," which is defined as resources, rights or assets of any nature for which there exist well-founded indicia or certainty that they are derived directly or indirectly from or represent the earnings derived from the commission of a crime for which no legitimate origin can be established. This construction of the predicate offense allows the prosecution, upon demonstrating indicia of criminality, to shift the burden of proof to the defendant to establish the legitimate origin of the property. The indicia must be related in a logical form to configure the circumstantial evidence, which serves to prove the illicit origin of the property. The authorities have shown a majority of cases in support of this conclusion.

\section{The Scope of the Predicate Offenses (c. 1.3)}

224. Article 400-Bis is an all-crimes money laundering offense that criminalizes the laundering of the proceeds of any offense criminalized under Mexican law. Accordingly, the predicate offenses for money laundering extend with no limitation to any offense under Mexican legislation capable of generating property from an illegal origin. Mexican legislation has criminalized offenses covering all of the designated categories of offenses in the FATF $40+9$.

\section{Threshold Approach for Predicate Offenses (c. 1.4)}

225. N/A (by virtue of the fact that Mexican law does not limit the crimes that may be considered predicate offenses to the crime of money laundering).

\section{Extraterritorially-Committed Predicate Offenses (c. 1.5)}

226. Offenses committed outside of Mexico can also constitute a predicate offense to money laundering under Article 400-Bis. Criminal offenses committed abroad and which produce an effect in Mexico are subject to the FPC (Article 2). Accordingly, because criminal proceeds generated abroad would have an effect in Mexico when laundered in or through its national territory, such money laundering conduct could be prosecuted and sanctioned under Article 400-Bis. Similarly, offenses committed abroad either by or against Mexican citizens may also be prosecuted and sanctioned in Mexico under Mexican law (Article 4).

\section{Laundering One's Own Illicit Funds (c. 1.6)}

227. The offense of money laundering can be applied to persons who commit the predicate offense. Article 400 Bis is a fully autonomous offense and it does not establish any limit with respect to the money laundering offenders. Accordingly, the money laundering offense may be committed by 
any person, including the offender that commits the predicate offense. Mexico has succesfully prosecuted and convicted self-launderers under the current ML provision.

Ancillary Offenses (c. 1.7)

228. Mexico's CPF criminalizes appropriate ancillary offenses that can be applied to the money laundering offense, among others. The offenses of "attempting," "being an accessory after the fact", "assisting," "aiding and abetting," or "preparing" are all covered by the CPF and can be extended to the money laundering offense.

229. Regarding the "conspiracy to commit an offense" assessors would be willing to consider the authorities' argument that such ancillary offense would be covered under Section 13.I of the CPF which, without explicitly mentioning the word "conspiracy," specifically criminalizes the "agreement or preparation for conducting offenses" as a form of criminal participation.

230. Special attention should be given to the Spanish term "conspiración," which is not equivalent to the English term "conspiracy." Because of that, the term used in the Spanish version of the Vienna and Palermo Conventions is "confabular" instead of "conspirar." In addition, no specific element of the terms "conspire" (or "confabular," for that matter) is contemplated in the Vienna and Palermo Conventions. In this sense, "confabular" - according to the Dictionary of the Royal Academy of the Spanish Language - means "to reach an agreement to undertake a plan, generally illicit" (ponerse de acuerdo para emprender algún plan, generalmente ilícito). That term is similar to the meaning of the English term "conspire" (according to the Oxford Dictionary: "combine secretly to plan and prepare an unlawful or harmful act") and consistent with the conduct that Mexico has criminalized as a form of criminal participation under Article 13.I of the CPF.

231. The "conspiracy to commit" has been expressly criminalized in these words as an autonomous offense under Article 141 of the CPF. However, this type of "conspiracy" cannot be extended to the money laundering offense as it is only applicable to "Crimes against National Security," such as treason, espionage, terrorism, rebellion, sedition, and mutiny.

232. As it was pointed out above, the Spanish term "conspirar," according to the Dictionary of the Royal Academy of the Spanish Language, means "in respect of several persons: unite against an individual to create harm or against their superior or sovereign". In this last sense, the conspiracy offense used in the CPF fits perfectly as a term used in connection with crimes against national security.

233. Regardless of this, the authorities have indicated that a legislative initiative was presented to Congress for the purpose of clarifying this matter by expressly criminalizing the offense of "conspiracy to commit" in relation to certain offenses, such as the offense of money laundering. The initiative is awaiting a final opinion in the United Commissions on Justice and Legislative Studies of Mexico's Senate. However, Mexican authorities expect that such initiative will be superseded by a new initiative that the Executive Branch will present during the next legislative period of Congress (that will begin in September of 2008), in respect of the legislation needed to implement the constitutional amendments recently approved in connection with the Judicial Reform explained above.

234. Additional Element - If an act overseas which does not constitute an offense overseas, but would be a predicate offense if it occurred domestically, lead to an offense of ML (c. 1.8): In order to consider a specific conduct committed abroad as a predicate offense of money laundering in Mexico, such conduct must be not only be illegal in Mexico but also in the country where it was committed. Accordingly, if the proceeds are derived from a conduct that occurred in another country, which is not 
an offense in that other country but which would have constituted a predicate offense had it ocurred domestically, this would not constitute a money laundering offense in Mexico.

Liability of Natural Persons (c. 2.1)

235. Article 400-Bis is an intentional crime that applies to natural persons and requires knowledge that the conduct involves proceeds of an illicit activity.

The Mental Element of the ML Offense (c. 2.2)

236. Pursuant to general provisions in Mexican criminal law (such as Article 286, Federal Code of Criminal Procedures), proof of the elements of a criminal offense can be established by objective circumstances. The use of circumstancial evidence is a usual part of criminal prosecutions, including ML prosecutions, in Mexico.

\section{Liability of Legal Persons (c. 2.3)}

237. Under Mexican law, criminal liability does not extend to legal persons. The Mexican legal system traditionally followed the principle of "societas delinquere non potest" (no criminal liability for legal entities), inherited from the French legal tradition. The impossibility of making a legal entity criminally liable derived from such principle, characterized by an individual and personal conception of criminal liability. This principle was implicitly reflected in Mexico's Constitution and therefore represented a fundamental principle of domestic law.

238. A legislative proposal submitted in 2003 attempted to establish the criminal liability of legal persons in connection with the offenses of money laundering and bribery of foreign public officials in international business transactions, but consensus was never been reached in Congress to pass this proposal precisely because some of its members argued that making legal persons criminally liable would have meant going against fundamental principles of domestic law.

239. However, the authorities now expect that such legislative proposal will be superseded by a new initiative that the Executive Branch will present during the next legislative period of Congress (that will begin in September of 2008), in connection with legislation needed to implement the constitutional amendments recently approved as part of the Judicial Reform explained above. While no specific reference is made in the Constitutional amendments with respect to the possibility of making legal persons criminally liable, the amended constitutional provisions highlight the importance of seeking alternative mechanisms to solve controversies of a criminal nature to assure ways to repair damage (see article 17 of the Constitution). In this respect, the authorities believe that this new constitutional provision could eventually offer Mexico a better chance to promote the passage of legislation making legal persons criminally liable.

240. Notwithstanding the above, the CPF provides that if a member or representative of a legal person engages in criminal conduct in the name of, on behalf of, or for the benefit of the legal entity, the judge can order the suspension or dissolution of the legal person where deemed necessary for public safety reasons (Article 11). In addition, corporations whose directors or managers have committed a criminal offense can be ordered by the courts to pay the fines as reparation for any damages caused (Articles 29, 30, and 32).

Liability of Legal Persons should not preclude possible parallel criminal, civil, or administrative proceedings \& c. 2.4)

241. The absence of criminal liability for legal persons does not preclude civil or administrative liability. For instance, the Federal Civil Code provides that legal persons shall be liable for the 
damages and losses caused in their performance by their legal representatives (Article 1918), or that if an entity is formed for an illegal purpose, the entity will be declared void and put in liquidation at the request of any of its partners or owners or any interested third party (Article 2692). In the same sense, the Company Act (Ley General de Sociedades Mercantiles) sets forth that legal persons having an illegal purpose, or that repeatedly carry out illegal actions, will be null and void and immediately liquidated, at the request of any person, including the Federal Attorney General (Article 3). Other statutes provide for administrative sanctions to legal persons.

Sanctions for $M L$ (c. 2.5)

242. At present, criminal sanctions for the commission of a money laundering offense are only contemplated for natural persons. The basic sanction provided for under Article 400-Bis of the CPF is a term of imprisonment from five to fifteen years and a fine from 1000 to 5000 days of wages. However, in accordance with the LFDO, if the offender is considered a member of a criminal organization he could also suffer an additional sanction of four to eigth years imprisonment and a fine from 250 to 12,500 days of wages, or an additional sanction of eight to sixteen years imprisonment and a fine from 500 to 25000 days of wages (Article 4, Section II) (if the offender has administrative, management, or supervisory functions in the organization). Days wages for purpose of the fines are defined in the $\mathrm{CPF}$ as being equivalent to the net daily income of the convicted person at the time the crime is committed. The sanction is increased by 50 percent when the offense is committed by a government official in charge of the prevention, investigation, or prosecution of crime. Moreover, a convicted government official is barred from holding employment in a public institution for a period equal to the length of the term of imprisonment imposed. Under the LFDO the sanction would also be increased by 50 percent if the offense is committed by a government official that participates in the conducts carried out by organized crime or if minors or disabled persons are used (Article 5). Because Article 194, Section I, Subsection 32 of the CPPF identifies Article 400-Bis as a serious offense, the ability of the defendant to obtain provisional release prior to conviction is also limited.

243. These sanctions are effective, proportionate and dissuasive in relation to other serious crimes in Mexico and relative to similar ML offenses in other countries of the GAFISUD region. The sanctions actually imposed by the courts are effective, proportionate, and dissuasive.

244. Assessment of Effectiveness: Combating crime, and particularly organized crime, is a State policy and a top level priority for the Mexican authorities. The authorities have articulated a strategic approach to addressing this critical challenge that includes a comprehensive focus, high level commitments at all levels of power (including the three powers of the Mexican State) and participation by all of the relevant private and public sectors. The GOM has made commendable efforts to staff its various administrative agencies involved in this effort with technically competent and professional officials which provide a solid foundation for attaining positive results going forward.

245. While there are deficiencies in the ML offense that could be improved, (such as the lack of an explicit criminalization for the conducts of "concealment or disguise", and the mere "possession or use of property regardless of the purpose"), assessors consider that there are no substantive obstacles in the current offense restricting its effective implementation. Mexico criminalised the laundering of, not just narcotics trafficking or a short list of other serious crimes, but the proceeds of all illicit activities. Moreover, the provision allowing indicia of criminality to shift the burden of proof to the defendant to establish the legitimate origin of laundered assets is assisting prosecutors in establishing the elements of the offense.

246. As to the process for criminal investigations and prosecution, it is unusual to see a procedural requirement (such as the requirement for PGR to obtain a formal complaint from the SHCP before bringing a case to court) embodied in the text of a criminal offense. While this requirement may not 
be representing significant problems at the moment, it does create a potential risk of adversely affecting the effective implementation of the law and the authorities should therefore consider removing it.

247. As noted above, the requirement only applies when the conduct under investigation is carried out using the services rendered by a financial institution, regardless of whether the investigation originated within the SHCP (through an intelligence report from the FIU) or independently within PGR. In all such cases, while PGR may initiate a preliminary inquiry and conduct an investigation, it cannot present the case to court for indictment without first forwarding the case to the SHCP for review and issuance of a formal complaint.

248. The authorities gave historic and cultural reasons for the inclusion of this requirement, which are mainly related with what was viewed as a need to protect the stability of the financial system from concerns of prosecutorial abuses that were common in the past.

249. Prior to the establishment of the FIU, the function of issuing formal complaints was conducted by the SHCP's legal department called Procuraduría Fiscal de la Federación (PFF). Upon the establishment of the FIU on May 4, 2004, the SHCP transferred this function to the FIU. This change was important, given that, as a technical unit specialized in the financial system but also in AML issues, the FIU was clearly in a better position to provide useful information and to work cooperatively with PGR. Moreover, the FIU shared with PGR a particular interest in seeing ML cases move forward without undue delay.

250. It was admitted that in the past this requirement may have represented an obstacle to the effective implementation of the money laundering offense. On occasion, PGR requests were declined when the SHCP believed that insufficient elements of the offense had been established. The SHCP also denied requests where it believed that information contained in its databases or gathered from financial institutions did not support PGR's proposed criminal charges. Even where PGR's requests were ultimately granted, the necessity of an SHCP complaint further delayed the PGR investigations and indictments for weeks or months.

251. At present however, both the SHCP and PGR agree that these obstacles have been overcome. As mentioned above, the establishment of the FIU may have been a key factor in overcoming these problems and in contributing to enhancing the broader cooperation between the SHCP and PGR. PGR expressed no concerns to the mission with the application of this requirement and reported no undue delays in receiving formal complaints from the FIU, nor instances where formal complaints were denied.

252. In effect, the mission sensed an environment of strong cooperation among the two institutions. Most cases involving financial institutions are worked jointly from their initial stages between PGR and the FIU, whether initiated de oficio by PGR, from a complaint of a third party, or through an intelligence report from the FIU. This means that by the time PGR requests the FIU to file the formal complaint, the FIU would have already collected the relevant information to support it and would usually be ready to send it within a period of less than 15 days.

253. Despite the close collaboration, however, the assessment team considers that the procedural requirement in the ML offense is an important potential impediment to full money laundering prosecution implementation, even if it is currently not representing an obstacle. While the requirement is maintained, there will always be a risk for it to be used as a way to obstruct the working relationship between the two institutions, as history demonstrates. Therefore, the assessment team strongly recommends the authorities to remove this requirement from the law. 
254. PGR conducts its AML efforts mainly through its "Specialized Unit for the Investigation of Offenses Related to Transactions Carried Out With Resources from Illicit Origin and Forging or Alteration of Currency" (the AML Unit), which operates within the "Office of the Deputy Attorney General for Specialized Investigations of Organized Crime" (also known as "SIEDO", for its Spanish acronym). The AML Unit interacts directly with the FIU in the investigation of ML cases.

255. Post-mission statistics provided by the authorities show that during 2004-2007, the AML Unit initiated a total of 560 preliminary inquiries (Averiguaciones Previas) for ML cases. Of these, 449 did not specify a predicate offense, 65 were connected with drug-related offenses, 39 related to fraud related offenses, and 7 to offenses committed by advisors, officials or employees of credit institutions derived from article 113 of the LIC (credit institutions law).

256. It should also be noted that of the 560 preliminary inquiries mentioned above, only 86 (or 15.3 percent ) were based on (proactive) intelligence reports provided by the FIU, which totaled 525 during the same period. The remaining preliminary inquiries initiated were derived from the following sources: 202 (or 36.1 percent ) from complaints and 272 (or 48.6 percent) from previous investigations. These statistics indicate that, relative to other sources of information, the AML Unit may be underutilizing the ML financial intelligence reports that originate from the FIU and reporting financial sector.

257. The use of FIU reports by PGR's AML Unit for purposes of its law enforcement activities seems to be relatively low but indicates an upward trend in the past four years. The following chart illustrates this increasing trend:

\begin{tabular}{|c|c|c|c|}
\hline Year & $\begin{array}{c}\text { FIU } \\
\text { Reports } \\
\text { Sent to } \\
\text { PGR }\end{array}$ & $\begin{array}{c}\text { PRG } \\
\text { Preliminar } \\
\text { y Inquiries }\end{array}$ & $\begin{array}{c}\text { Percentage } \\
\text { (\%) }\end{array}$ \\
\hline 2004 & 194 & 11 & 5.6 \\
\hline 2005 & 158 & 16 & 10.1 \\
\hline 2006 & 104 & 18 & 17.3 \\
\hline 2007 & 69 & 41 & 59.4 \\
\hline Total & 525 & 86 & 16.3 \\
\hline
\end{tabular}

258. This data shows that during the period 2004-2007, there was a significant decline in the number of FIU reports sent to PGR for investigation and a relatively small increase in the number of inquiries initiated by the PGR from such reports, with the exception of 2007 when the number of inquiries increased sharply to 41 (or 59.4 percent ) of reports provided by the FIU. This could indicate an improvement in the quality of FIU reports as confirmed by the FIU, and/or an increased focus by the PGR on ML cases reported by the FIU.

259. The FIU authorities argue that the decrease in the amount of proactive reports sent to PGR results from the fact that such reports are now focused on quality rather than quantity. The FIU has indeed corrected a number of deficiencies in its processes to achieve this improvement. For example, there are quality checks to avoid sending reports to PGR with a weak analysis, or where the "unusualness" or relevance is not well supported. Reports are also checked for data accuracy, including with respect to the names of persons involved (particularly in those based on journalistic articles). The FIU is also filtering the volume of reports that are only related with tax matters. 
260. During the same period, the AML Unit issued 149 indictments for ML in the context of 132 judicial proceedings. However, only two of these indictments were connected to FIU reports, which further supports the view that FIU-generated reports are not being fully exploited by PGR's AML Unit.

261. Contrary to the statistics on the amount of preliminary inquiries initiated as a result of FIU proactive reports, it is possible that the statistics on the amount of indictments may not be reflecting yet the impact of the above mentioned improvements. The authorities also note that a number of indictments may have no link to proactive reports, but nonetheless benefit from a significant contribution from the FIU.

262. At the judicial level, the statistics also reflect a low level of effectiveness. Notwithstanding the 149 indictments for ML issued by PGR, there were only 30 judicial decisions, 25 of which resulted in convictions and 5 in acquittals. These figures may be reflecting a lack of capacity at the judicial level and/or weaknesses in the evidence used by PGR to support its indictments.

263. The mission further noted that most of these convictions were the result of simple investigations arising in seizures of cash at the airports and borders where the defendant was unable to demonstrate the legal origin of the funds. Given the levels and sophistication of organized criminal activity in Mexico, particularly drug trafficking and related crimes, this reflects that the implementation of the ML offense is still lacking in effectiveness, particularly with respect to large and complex ML operations.

264. In a country with a sophisticated and developed legal, institutional and financial system such as Mexico's, it would be unrealistic to reduce the diagnostic to a single deficiency or to offer one simple solution to address it. The problem is most likely of a systemic nature and related with weaknesses and shortcomings in many areas of the system.

265. The authorities informed that most of the cases reported by the FIU to PGR have not resulted in indictments because, notwithstanding the cases reported by the FIU, PGR could not find evidence of criminal activity (as founded indicia). The authorities acknowledged that a key impediment to effective ML investigations may be related to structural problems affecting PGR's investigative capabilities in general, which is affecting its capacity to investigate all crimes assigned to it, not only ML. For example, the authorities informed that of 100 crimes reported to the competent authorities, only 5 tend to reach a judicial ruling. The authorities also point to structural/capacity problems related to, inter alia: $i$ ) the reorganization in the federal investigation forces (AFI and PFP) and their relationship with prosecutors (e.g., frequent changes in teams that lost track of the progress made in a criminal case); ii) inappropriate resources for SIEDO; iii) the structure and process for case management by SIEDO dating back to the sharp rise in the number and diversity of cases assigned to SIEDO; iv) insufficient coordination with state and municipal authorities (e.g. identification/registration of assets such as real estate and local businesses); $v$ ) a lack of a single identity card and ease in obtaining multiple (and fraudulent) identity cards; vi) inadequate integration of criminal databases available to federal investigators and vii) the large size of the informal economy. Except for the latter, all of these deficiencies seem to be endogenous and under the direct responsibility of the law enforcement authorities. Issues affecting integrity at the law enforcement bodies, such as the high number of desertions of law enforcement officials and the reported infiltrations at PGR by organized crime, are also impacting negatively on Mexico's capacity to investigate and prosecute crime in general. The assessment also revealed a need to conduct more training and awareness-raising for judges and the courts concerning ML and FT offenses, seizures, freezing and confiscation of property that is the proceeds of crime or is to be used to finance terrorism. 
266. Assessors share the authorities' views with respect to these deficiencies and recommend the authorities to work strongly in removing them to improve the effective implementation of the ML offense. The still in draft National Strategy for combating ML should provide proportional priority to addressing these structural and systemic deficiencies in intelligence, law enforcement and judicial process and capacity. Emphasis will be placed on: enhancing the quality of the information provided by the FIU to PGR; improving the resources and capacity of prosecutors and law enforcement officials; defining clear protocols among prosecutors in pursuing ML especially complex criminal investigations involving the financial sector; and strengthening the capacity at the judiciary level. Initiatives with a long-term perspective should also continue to be strengthened to improve the integrity of law enforcement personnel generally. Specific recommendations concerning each of these issues will be formulated in the appropriate sections of this report (See also Recs. 26 and 27). It is noted that, post mission, a National Agreement for Security, Justice and Law was signed on August 21,2008 , that commits the authorities to develop investigation protocols within a six-month period.

\subsubsection{Recommendations and Comments}

267. In order to fully comply with Recommendations 1 and 2, the Mexican authorities should implement the following measures:

- Amend Article 400 Bis of the CPF to incorporate the conduct of "concealment or disguise of the true nature, source, location, disposition, movement, or ownership of or rights with respect to property" as a primary conduct and not as a purpose.

- Amend Article 400 Bis of the CPF to incorporate the conduct of "possession or use of property" into the money laundering offense. The possession or use of property should be criminalized without a specific purpose.

- $\quad$ Reinforce coordination among all relevant actors involved in investigating and prosecuting crime in Mexico and define clearer protocols for the processes followed by each of them.

- Institutionalize the current practices of close collaboration among the FIU and PGR authorities.

- Place additional focus in conducting investigations of money laundering offeses committed through the financial system.

- $\quad$ Foster awareness among prosecutors to generate an interest in pursuing criminal investigations involving the financial system.

- Develop adequate training programs to enhance the capacity of prosecutors and judges to prosecute and adjudicate money laundering cases involving the financial system.

- $\quad$ Consider the possibility of amending the CPF to make legal persons criminally liable for money laundering offenses.

- $\quad$ Amend the CPF to eliminate the requirement for PGR to obtain a formal complaint from the SHCP to bring cases to court when the conduct involved was carried out using the services rendered by a financial institution. 


\subsubsection{Compliance with Recommendations $1 \& 2$}

\begin{tabular}{|l|c|c|c|}
\hline R.1 & Rating & \begin{tabular}{c} 
Summary of factors underlying rating \\
\hline PC
\end{tabular} & $\begin{array}{l}\text { ML offense does not cover the "concealment or disguise of the true nature, } \\
\text { source, location, disposition, movement, or ownership of or rights with respect } \\
\text { to property" nor the "possession or use of property without a specific purpose". }\end{array}$ \\
\hline R.2 & LC & $\begin{array}{l}\text { ML offense is not being effectively implemented, insufficient focus on ML } \\
\text { investigations committed through the financial system, and underutilization of } \\
\text { financial intelligence reports from the FIU. }\end{array}$ \\
\hline
\end{tabular}

\subsection{Criminalization of Terrorist Financing (SR.II)}

\subsubsection{Description and Analysis}

\section{Legal Framework}

268. The terrorist financing offense is very recent in Mexican legislation. In effect, after more than four years of debate in Congress, the law amending the CPF and introducing the terrorist financing offense was finally passed on April 2007 and put into effect on June 29, 2007.

269. The "domestic act of terrorism" has for long been a criminal offense under Mexico's CPF (Article 139) but prior to this recent amendment there was no separate offense for terrorist financing. In fact, while no cases supported this argument, the authorities were relying on the possibility of applying the rules of criminal participation (Article 13.VI of the $\mathrm{CPF}$ ) to the domestic act of terrorism under Article 139 to punish the financing of terrorism. However, this does not meet the standard.

270. Despite the short existence of the new terrorist financing offense, all financial institutions were already required to report to the FIU any transaction presumably linked to terrorism. In effect, the AML/CFT General Provisions (Disposiciones de Carácter General) applicable to all institutions in the financial sector had contemplated this obligation since May 2004. Moreover, a number of financial institutions have developed risk-based models to prevent the financing of terrorism since then.

\section{Criminalization of Financing of Terrorism (c. II.1)}

271. Since June 29, 2007, the Mexican CPF criminalizes the "domestic terrorist financing" (Article 139) and "international terrorist financing" (Article 148 Bis) offenses in the following way:

"Article. 139.- Regardless of the corresponding sanctions for the resulting crimes, a sanction of incarceration from six to forty years and a fine of up to one-thousand two-hundred days shall be imposed on the person who utilizes toxic substances, chemical, biological or similar weapons, radioactive material or instruments that emit radiations, explosives or fire arms, or who by way of fire, flooding or any other violent means carries out acts against persons,

17 These factors are only required to be set out when the rating is less than Compliant. 
things or public services that generate alarm, fear, or terror to the population or to a group or sector thereof, in an attempt against national security or to pressure the authorities to make a determination.

The same penalty will be imposed on whom directly or indirectly finances, contributes or procures economic funds or resources of any nature, knowing that they will be used, partially or totally, to support persons or organizations that operate or commit terrorist acts in national territory."

"Article 148 Bis.- Regardless of the corresponding sanctions for the resulting crimes, a sanction of incarceration from fifteen to forty years and a fine between four-hundred and onethousand two-hundred days shall be imposed to:

I) The person who utilizes toxic substances, chemical, biological or similar weapons, radioactive material or instruments that emit radiations, explosives or fire arms, or who by way of fire, flooding or any other violent means carries out in Mexican territory acts against the property or persons of a foreign State - or of any other international body or organization - that generate alarm, fear, or terror to the population or to a group or sector thereof, in an attempt to damage the authority of the foreign state, or to force such foreing state, or an international body or organization, to make a determination.

II) The person who directly or indirectly finances, contributes or procures economic funds or resources of any nature, knowing that they will be used, totally or partially, to commit international terrorist acts or in support of terrorist persons or organizations that operate abroad, and

III) The person who agrees to or prepares in Mexican territory a terrorist act to be performed or that has been committed abroad."

272. As in the case of the money laundering offense, Article 194, Section I, Subsection 4 of the CFPP, considers these terrorist offenses, among others, to be serious offenses, thereby limiting the ability of defendants to obtain provisional release prior to conviction. These offenses are also complemented by the LFDC as crimes that can be committed by members of organized crime (Article 2, Section I).

273. The following comments in connection with Article 148 Bis apply equally to Article 139 . For purposes of this assessment however, the focus of the analysis will be placed on Article 148 Bis only.

274. The terrorist financing offense under Article 148 Bis is not entirely consistent with Article 2 of the UN's Terrorist Financing Convention. While the Convention focuses on the intention of the act to cause death or serious boily injuries, Article 148 Bis seems to focus on what is used to carry out the act.

275. The requirement for the act in question to generate alarm, fear, or terror to a population, or to a group or sector thereof would require a showing that the alarm, fear or terror has been generated. This is not consistent with Article 2 of the UN's Terrorist Financing Convention either, as the Convention only requires that "the purpose" of the act, by its nature or context, is to intimidate a population. 
276. Moreover, the offense criminalized under Article 148 Bis is not consistent with the UN's Terrorist Fianancing Convention as, while it covers the financing of a significant number of terrorist acts, it does not extend the financing conduct to all of the acts that constitute offenses within the scope of, and as defined in, the treaties listed in the annex of the UN's Terrorist Financing Convention.

277. Mexico signed and ratified the UN's Terrorist Financing Convention which entered into force on February 19, 2003. Mexico has signed and ratified all of the treaties listed in the annex of the UN's Terrorist Financing Convention. Accordingly, the terrorist financing conduct needs to be extended to all of the acts that constitute offenses within the scope of, and as defined in, all of such treaties.

278. The terrorist financing conduct criminalized under Aarticle 148 Bis extends the financing conduct to the commission of "international terrorist acts," or the support of "terrorist persons" or "terrorist organizations that operate abroad." To determine whether this terrorist financing conduct would cover the acts that constitute offenses within the scope of, and as defined in, all of the treaties listed in the annex of the UN's Terrorist Financing Convention, it is crucial to understand the scope of the term "international terrorist act." Article 148 Bis does not explicitly state that the acts criminalized thereunder shall be considered to be "international terrorist acts." However, neither does it state either that international terrorist acts shall be considered to be the acts criminalized thereunder and other acts as well. Accordingly, and following principles of restrictive interpretation of criminal law, it would not be appropriate to extend coverage of the concept of international terrorist act beyond the conducts contemplated under Article 148 Bis. Moreover, in the absence of case law providing a broader interpretation of this term, the only possible interpretation available is to interpret this term narrowly to cover exclusively the conducts defined in the first paragraph of Article 148 Bis (i.e. the act of a person who utilizes toxic substances, chemical, biological or similar weapons, radioactive material or instruments that emit radiations, explosives or fire arms, or who by way of fire, flooding or any other violent means carries out in Mexican territory acts against the property or persons of a foreign State - or of any other international body or organization - that generate alarm, fear, or terror to the population or to a group or sector thereof, in an attempt to damage the authority of the foreign state, or to force such foreing state, or an international body or organization, to make a determination).

279. The conduct criminalized in the first paragraph of Article 148 Bis could also be interpreted to cover the acts defined in the International Convention for the Suppression of Terrorist Bombings of 1997 and the acts defined in the treaties on air and maritime safety. However, Article 148 Bis goes beyond the requirements under such international instruments when it conditions the commission of the international terrorist conduct to the objective element "that generate alarm, fear, or terror to the population or to a group or sector thereof" and the additional subjective element "in an attempt to damage the authority of the foreign state, or to force such foreign state, or an international body or organization, to make a determination".

280. Article 148 Bis does not extend to all situations where a person may wilfully provide funds. Only the provision of funds through the "financing," "contributing," and "procuring" conducts appears to be covered. This would leave out other means of providing funds and would, therefore, not capture the provision "by any means" required by the standard. Moreover, the collection of funds does not appear to be covered at all.

281. The terrorist financing offense extends to any funds as that term is defined in the TF Convention. Article 148 Bis uses the expression economic funds or resources of_any nature, which can broadly be interpreted to cover all of the assets and legal documents or instruments included in the definition of funds of the UN's Terrorist Financing Convention, whether from a legitimate or an illegitimate source. 
282. The terrorist financing offense is criminalized as an autonomous crime and does not require that the funds: $i$ ) were actually used to carry out or attempt a terrorist act(s); or ii) be linked to a specific terrorist act(s). The conduct simply requires that the person who directly or indirectly finances, contributes, or procures the funds have knowledge that they will be used, totally or partially, to commit "international terrorist acts." Note that the offense does not refer to the commission of a specific international terrorist act but rather broadly to "international terrorist acts," meaning any act potentially covered by the conduct defined under Article 148, para. 1 of the CPF.

283. Articles 139 Bis and 148 Ter of the Federal Criminal Code criminalize the conducts of those who conceal terrorists - being aware of their activities or identities - with a sanction of one to nine years of imprisonment and a fine of 100 to 300 days of wage in the case of domestic terrorism (Article $139 \mathrm{Bis}$ ), and five to ten years of imprisonment and a fine of 100 to 300 days of wage in the case of international terrorism (Article 148 ter).

284. The threat of committing national or international terrorism is also criminalized with a sanction of five to fifteen years of imprisonment in the case of domestic terrorism (Article 139 Bis) and a fine of two-hundred to six-hundred days in the case of international terrorism (Article 148 ter).

285. As in the case of money laundering, the offenses of "attempting," "being an accessory after the fact," "assisting," "aiding and abetting," or "preparing" are all covered by the CPF and can be extended to the terrorist financing offense.

Predicate Offense for Money Laundering (c. II.2):

286. Article 400-Bis is an all-crimes money laundering offense that criminalizes the laundering of the proceeds of any offense criminalized under Mexican criminal law. Accordingly, the predicate offenses for money laundering extend with no limitation to any offense under Mexian legislation capable of generating property from an illegal origin, including terrorist financing.

287. Jurisdiction for Terrorist Financing Offense (c. II.3): The terrorist financing offense sanctions "The person who directly or indirectly finances......., the commission of international terrorist acts or the support of terrorist persons or organizations that operate abroad." To assess whether the terrorist financing offense could apply in Mexico, a distinction needs to be made as to whether the financing is conducted from Mexico or from abroad.

288. Should the financing be conducted from Mexico, the offense would apply if such conduct was related to the support of individual terrorist persons or organizations that operate abroad with no difference as to where they are located.

289. However, while the financing in support of an individual terrorist or a terrorist organization contemplates explicitly the possibility for such terrorists or terrorist organizations to be operating "abroad," the financing for the commission of international terrorist acts does not. To the contrary, if as previously mentioned, the definition of "international terrorist act" is interpreted narrowly to cover exclusively the conduct defined in the first paragraph of Article 148 Bis (i.e. the act of a person who utilizes............... or any other violent means to carry out in Mexican territory acts against the property or persons of a foreign State - or of any other international body or organization-......) the financing conduct would apply in this case only to acts that occurred or would have occurred in Mexican territory.

290. On the other hand, should the financing be conducted from abroad, in accordance with the $\mathrm{CPF}$, the offense would still apply if the conduct produces an effect in Mexico (Article 2).

Accordingly, because terrorist financing conducted from abroad would have an effect in Mexico if the financing relates to the commission of terrorist acts which occurred or are due to occur in Mexico, 
such terrorist financing conducted from abroad could be prosecuted and sanctioned under Article 148-Bis. Similarly, offenses committed abroad either by or against Mexican citizens may also be prosecuted and sanctioned in Mexico under Mexican law (Article 4).

291. Therefore, and while clearly a very theoretical possibility, the only cases in which the terrorist financing offense may not apply would be: $i$ ) ones in which a person (non-Mexican) finances from Mexico the commission of a terrorist act that occurred/will occur abroad (and not against any Mexican) without the possibility of identifying an individual terrorist or terrorist organization operating abroad, or ii) ones in which a person (non-Mexican) finances from abroad the commission of a terrorist act that occurred/will occur abroad (and not against any Mexican) or the support of an individual terrorist or a terrorist organization that is located and operates abroad.

\section{The Mental Element of the TF Offense (applying c. 2.2 in R.2)}

292. In accordance with the provisions of Articles 139 and 148 Bis of the Federal Criminal Code, intent in the terrorist financing offense must be determined based on the circumstances under which it is committed, with basis on the objective elements of evidence available. In Mexico, terrorist financing is considered an intentional crime because the criminalized conduct depends on the subject's knowledge that the resources will be utilized, fully or in part, to carry out international terrorist acts or in support of individual terrorists or terrorist organizations that operate abroad.

Liability of Legal Persons (applying c. 2.3 \& c. 2.4 in R.2)

293. Please refer to comments formulated in criteria 2.3 to 2.5 of the previous section on money laundering (above).

Sanctions for FT (applying c. 2.5 in R.2)

294. At present, criminal sanctions for the comission of a terrorist financing offense are only contemplated for natural persons. The basic sanction provided for under Article 139 is a term of imprisonment from six to forty years and a fine up to 1,200 days of wages, whereas, under Article 148-Bis, a term of imprisonment from fifteen to forty years and a fine between 400 and 1,200 days of wages. However, in accordance with the LFDO, (Article 2o.), and for the case of Article 139 of the CPF only, if the offender was considered a member of organized crime he could also suffer an additional sanction of four to eigth years imprisonment and a fine from 250 to 12500 days of wages, or an additional sanction of eight to sixteen years imprisonment and a fine from 500 to 25,000 days of wages (if the offender had administrative, directive or supervisory functions in the organization). Under the LFDO the sanction would also be increased by 50 percent if the offense is committed by a government official that participates in the conducts carried out by organized crime or if minors or handicapped people are used. Fine days are defined in the CPF as being equivalent to the net daily income of the convicted person at the time the crime is committed. Because Article 194 of the CFPP identifies Articles 139 and 148-Bis as serious offenses, the ability of the defendant to obtain provisional release prior to conviction is also limited.

295. These sanctions are proportionate relative to other offenses under Mexican law. However, their effectiveness and dissuasiveness could not be assessed due to the absence of convictions.

296. Assessment of Effectiveness: There have been no terrorist financing cases so far and there are, therefore, no statistics yet. Accordingly, it was not possible to assess how Article 148 Bis operates in practice because it has not yet been used.

297. Nevertheless, discussions with the authorities left the assessment team with the impression that more emphasis could be placed to assessing the country's risks and vulnerabilities to terrorism 
and terrorist financing activities. Given the closeness to the United States, Mexico should exert more effort to assess the degree of its exposure to terrorist and terrorist financing threats.

\subsubsection{Recommendations and Comments}

298. In order to fully comply with Special Recommendation II, the authorities should implement the following measures:

- Amend the terrorist financing conduct in Section 148 Bis of the CPF to focus it on the intention of the act to cause death or serious bodily injury rather than on what is used to commit the act.

- $\quad$ Amend the terrorist financing conduct in Section 148 Bis of the CPF to require a purpose of generating alarm, fear, or terror rather than a showing.

- Extend the terrorist financing conduct in Section 148 Bis of the CPF to the financing of the acts that constitute an offense within the scope of, and as defined in, the treaties listed in the annex of the UN Terrorist Financing Convention consistent with its obligations under SR.II.

- $\quad$ Mexico should conduct an assessment of terrorism and terrorist financing threats and vulnerabilities, partially drawing from the findings of this assessment, in order to estimate its exposure such risks.

- $\quad$ Adopt legislation making legal persons criminally liable for FT.

\subsubsection{Compliance with Special Recommendation II}

\begin{tabular}{|c|c|c|c|}
\hline SR.II & Rating & \multicolumn{1}{c|}{ Summary of factors underlying rating } \\
\hline PC & $\begin{array}{l}\text { The TF offense is not fully consistent with Atricle } 2 \text { of the TF Convention. It } \\
\text { only focuses on what is used for the act (and not on the intentions of the act) } \\
\text { and it requires a showing (rather than a purpose) that the act generated alarm, } \\
\text { fear, or terror to a population. }\end{array}$ \\
$\begin{array}{l}\text { While the TF offense covers the financing of a significant number of } \\
\text { terrorist acts, it does not extend to the financing of the acts that constitute } \\
\text { an offense within the scope of, and as defined in the treaties listed in the annex } \\
\text { of the TF Convention. } \\
\text { No TF investigations to date and therefore cannot conclude that the measures } \\
\text { are effective. }\end{array}$ \\
\hline
\end{tabular}

\subsection{Confiscation, freezing and seizing of proceeds of crime (R.3)}

\subsubsection{Description and Analysis}

299. The term "seizure" (incautación) as a precautionary or preventive measure to immobilize or freeze assets derived from a crime is not contemplated within Mexico's legislation. Instead, Mexican criminal law uses the term "attachment" (aseguramiento), which has similar characteristics and can achieve the same results as a seizure.

300. An attachment, as will be noted below, is a preventive measure used to preserve property that could constitute the proceeds, subject, or instrumentalities of a crime, and which could be forfeited. It can also be used to preserve the scene of a crime and items relating to such crime. An attachment can be issued by ministerial or judicial authority during the course of a criminal case. 
301. Forfeiture (decomiso) is a secondary (accessory) penalty ordered by a criminal judge which results in the definitive loss (deprivation) of property that is the subject, proceeds, benefits, or instrumentalities of a crime, in favor of the State. The legal provisions governing forfeiture are established in Chapter VI of the Federal Penal Code (CPF) "Forfeiture of instrumentalities, subject, and proceeds of crimes." Article 40 of the CPF sets out various assumptions for proceeding with forfeiture, both with respect to instrumentalities of a crime, and items that are the subject or proceeds thereof. Forfeiture of property is possible whether or not their use is prohibited - when the crime is intentional - or when they are under the control of a third party. Prior conviction is required in order to proceed with forfeiture.

302. The final paragraph of Article 4 of the Federal Law against Organized Crime (LFDO) also provides for the forfeiture of the subject, instrumentalities, or proceeds of the crimes committed by criminal organizations. It also provides for the forfeiture of property of the convicted offender including property for which the offender acts as the owner when the offender fails to demonstrate its lawful origin. In addition, Article 29 of the LFDO allows for the attachment of property belonging to members of a criminal organization including property for which the organization acts as its owner, unless it is able to demonstrate its lawful origin.

303. The 2002 Federal Law for the Administration and Sale of Assets of the Public Sector (Ley Federal de Administración y Enajenación de Bienes del Servicio Público-LFAEBSP-) created the Service of Administration and Sale of Assets (Servicio de Administración y Enajenación de Bienes $S A E$ ) as a decentralized agency of the Federal Public Administration with legal status and its own resources. The SAE administers property that has been attached or forfeited in federal criminal proceedings (Article 1(1) of the LFAEBSP). Article 12 of the LFAEBSP establishes, inter alia, that funds obtained from the administration of property shall be used to reimburse the cost of their maintenance and management. Any remaining funds shall be deposited into a reserve fund and given to the person who can demonstrate to have legal rights over such funds/property.

Confiscation of Property related to ML, FT or other predicate offenses including property of corresponding value (c. 3.1)

304. As explained earlier, Mexican laws provide for the ability to forfeit property that has been used in the commission of any crime, including money laundering and the financing of terrorism, as well as the proceeds thereof. These provisions (Article 40 of the CPF, Article 4 of the LFDO, and Articles 181 to 187 of the CFPP) include property derived directly or indirectly from the crime, including income, profits, and other benefits regardless of whether the property is held or owned by a convicted person or a third party. There are no provisions for the forfeiture of property of equal or corresponding value when the property has disappeared or cannot be located. A bill is before Congress contemplating such provisions.

Confiscation of Property Derived from Proceeds of Crime (c. 3.1.1 applying c. 3.1)

305. Forfeiture can only be ordered by a criminal judge, as provided under Article 182-Q of the Federal Code of Penal Procedures (CFPP), which reads as follows:

"Article 182-Q.- The judicial authority, through a decision in the respective criminal proceeding, may order the forfeiture (decomiso) of property, with the exception of property that has produced abandonment under the terms of the Code."

306. Article 40 of the Federal Penal Code provides for the forfeiture of the instrumentalities of the crime, as well as those items that are the subject or proceeds thereof. When such property belongs to a third party, they shall be forfeited when the third party that has control (or has acquired them in any 
way) is covered by any of the concealment assumptions, regardless of the legal status of that third party as owner or holder, and of his/her relationship with the criminal.

307. Independent of the provisions of the Code, Article 4 of the LFDO (organized crime) extends the scope to all property subject to forfeiture including property belonging to the convicted person and property with respect to which he/she acts as the owner, if he/she does not demonstrate the lawful origin of such property. This constitutes a reversal of the burden of proof which is also found in Article 29 of the LFDO for cases of attachment and/or measures taken prior to definitive forfeiture during the course of a preliminary inquiry. In addition, the CFPP also provides for the treatment of the benefits or income generated while the property is attached (Article 182-E).

308. As mentioned above, there are no provisions for the forfeiture of property of corresponding value.

\section{Provisional Measures to Prevent Dealing in Property subject to Confiscation (c. 3.2)}

309. Article 181 of the CFPP establishes that instrumentalities, subjects, or proceeds of crime, as well as property in which there are traces of the crime or which could be related to the crime, shall be attached so that they are not altered, destroyed, or caused to disappear. The administration of attached property shall be carried out in accordance with the Federal Law for the Administration and Sale of Assets of the Public Sector.

\section{Ex Parte Application for Provisional Measures (c. 3.3)}

310. The law allows the attachment of property subject to forfeiture to be made without prior notice, provided that this occurs within the context of a preliminary inquiry, in compliance with the requirements provided under Mexico's procedural law, and that the grounds or reasons for carrying out such attachment are justified. This is permitted when the Prosecutor has knowledge of the probable existence of a crime that must be prosecuted ex officio, or when there are sufficient indications leading to a well-founded presumption that someone is a member of organized crime. In this latter case, the attachment of that person's property may be ordered by the Prosecutor's Office, with prior judicial authorization. (Art. 29 of the LFDO).

311. To proceed with an attachment pursuant to Article 40 of the Federal Penal Code and Article 181 of the Federal Code of Penal Procedures, a preliminary inquiry must have been initiated and the justification and grounds for the attachment must be provided. Article 40 of the CPF empowers the competent authority to proceed with the "immediate" attachment of property that could be subject to forfeiture. In addition, Article 123 of the Federal Code of Penal Procedures expressly empowers the Prosecutor's Office upon learning of the probable existence of a crime, to "immediately" issue all measures necessary in order, inter alia, to prevent the destruction or alteration of "...the traces or vestiges of the criminal act, the instrumentalities or subjects or effects thereof...".

312. After an attachment has been carried out, officers of the Prosecutor's Office, having complied with the requirements established in Article 182 of the CFPP (subparagraphs I, II, III, and IV), must transfer the forfeited or attached property to the competent authority for its administration thereof within the next 72 hours.

313. Once attachment has been ordered, either by the judicial authority or the Prosecutor's Office, they must promptly notify the interested party of the attachment within sixty days of its execution (see Art. 182 A of the CFPP). 


\section{Identification and Tracing of Property subject to Confiscation (c. 3.4)}

314. Law enforcement agencies, the FIU or other competent authorities have adequate powers to identify and trace property that is or may become subject to forfeitures or is suspected of being the proceeds of crime. Article 180 of the Federal Code of Penal Procedures gives the Prosecutor's Office broad powers to demonstrate the facts of the criminal case and the probable liability of the accused, as well as to seek documents and financial information.

315. Article 9 of the Federal Law against Organized Crime establishes that requests from the Federal Prosecutor's Office or the federal judiciary for information or documents relating to the financial system shall be obtained through the Banking and Securities Commission, the National Retirement Savings System Commission, and the Tax Administration Service, within their respective jurisdictions. Requests for tax information or documents must be made through the unit of the Ministry of Finance and Public Credit.

316. Consistent with the above, Article 117 of the Credit Institutions Law requires credit institutions to provide information on transactions and services as appropriate to identify the movement of funds, without violating banking and fiduciary secrecy, when requested by the Office of the Attorney General, state level and federal district level prosecutor's offices, the Office of the Attorney General for Military Justice, the Financial Intelligence Unit, and federal finance authorities, among others.

\section{Protection of Bona Fide Third Parties (c. 3.5)}

317. Mexican laws protect the rights of bona fide third parties consistent with the standards provided under Article 12(8) of the Palermo Convention. Article 40(1) of the Federal Penal Code protects the rights of bona fide third parties by limiting the forfeiture of property owned by a third party to instances in which such third party is covered by any of the concealment provisions. Article 400 of the CPFP deals with cases of concealment and establishes the specific intent required with respect to a third party who has acquired, received, or concealed the proceeds of the crime in which he/she has not participated. In order to prevent being accused of this crime, and to be considered a "bona fide third party," the third party must have conducted a due diligence, taken essential precautions and not have known the unlawful origin of the property.

318. In addition, Article 17 of the Federal Law for the Administration and Sale of Assets of the Public Sector states as follows: "Depositories, liquidators, receivers, and administrators appointed by the SAE may not alienate or encumber real property in their charge. In any case, the rights of third parties shall be respected."

\section{Power to Void Actions (c. 3.6)}

319. Although the above-mentioned laws grant a broad range of powers for attaching and forfeiting property, there are no provisions in the criminal law to prevent or void certain legal actions in which the individuals involved knew or should have known that as a result of those actions the authorities' ability to recover property subject to forfeiture would be impaired. However, federal civil law does provide for the nullification or voidance of certain defective acts between and among individuals, while not leading to criminal prosecution or punitive prosecution by the State. 
Additional Elements (Rec 3)—Provision for a) Confiscation of assets from organizations principally criminal in nature; b) Civil forfeiture; and, c) Confiscation of Property which Reverses Burden of $\operatorname{Proof}($ c. 3.7)

320. Given that forfeiture is a criminal sanction of an accessory nature and that criminal sanctions may only be applied to natural persons and not to legal persons, it would not be possible to forfeit the property of an organization. The laws do not provide for the forfeiture of property without a conviction of any person (civil forfeiture) in addition to the system of forfeiture triggered by a criminal conviction. Given that a forfeiture is a criminal sanction of an accessory nature, a criminal conviction is always required.

321. The Federal Law against Organized Crime provides for the forfeiture of property when an offender under such law cannot demonstrate the lawful origin of the property.

Analysis of Effectiveness:

322. In the last few years, the number and amount of attachments (aseguramiento) of cash and other property has increased, as shown in the following table.

\begin{tabular}{|c|c|c|c|c|c|}
\hline \multicolumn{6}{|c|}{$\begin{array}{l}\text { PROVISIONAL SEIZURES (ATTACHMENTS) DERIVED FROM ML CASES (AML UNIT- SIEDO) } \\
2004-2007\end{array}$} \\
\hline & 2004 & 2005 & 2006 & 2007 & TOTAL \\
\hline US DOLLARS & $\begin{array}{r}\$ 503,314.0 \\
0\end{array}$ & $\begin{array}{r}99,294,967 \\
.23\end{array}$ & $\begin{array}{r}\$ 20,724,770 \\
.02\end{array}$ & $\begin{array}{r}\$ 223,055,990 \\
.00\end{array}$ & $\begin{array}{r}\$ 253,579,041 \\
.25\end{array}$ \\
\hline MEXICAN PESOS & $\$ 938.00$ & $\$ 443.00$ & $\$ 148,734.50$ & $\begin{array}{r}\$ 28,732,100 \\
20\end{array}$ & $\begin{array}{r}\$ 28,882,215 . \\
70\end{array}$ \\
\hline $\begin{array}{l}\text { OTHER CURRENCIES } \\
\text { (EUROS, POUNDS, ETC.) }\end{array}$ & $\$ 6,056.00$ & $\begin{array}{r}\$ 1,028,425 \\
.00 \\
\end{array}$ & $\begin{array}{r}\$ 2,627,020 \text {. } \\
00\end{array}$ & $\$ 522,896.00$ & $\begin{array}{r}\$ 4,184,397.0 \\
0\end{array}$ \\
\hline $\begin{array}{l}\text { NEG. INSTRUMENTS AND } \\
\text { SECURITIES MX\$ }\end{array}$ & $\$ 0.00$ & $\$ 0.00$ & $\$ 0.00$ & $\$ 750,000.00$ & $\$ 750,000.00$ \\
\hline $\begin{array}{l}\text { NEG. INSTRUMENTS AND } \\
\text { SECURITIES US\$ }\end{array}$ & $\begin{array}{r}\$ 6,947,500 \\
.00 \\
\end{array}$ & $\begin{array}{r}\$ 5,168,573 \\
.63 \\
\end{array}$ & $\$ 150,745.95$ & $\$ 6,700.00$ & $\begin{array}{r}\$ 12,273,519 . \\
58 \\
\end{array}$ \\
\hline BANK ACCOUNTS & 121 & 16 & 43 & 92 & 272 \\
\hline VEHICLES & 9 & 20 & 63 & 119 & 211 \\
\hline AIRCRAFT & 2 & 2 & 1 & 1 & 6 \\
\hline BOATS & 0 & 1 & 4 & 0 & 5 \\
\hline JEWELERY & 0 & 80 & 30 & 34 & 144 \\
\hline WORKS OF ART & 0 & 0 & 4 & 0 & 4 \\
\hline REAL ESTATE PROPERTY & 24 & 22 & 41 & 24 & 111 \\
\hline WEAPONS & 0 & 6 & 13 & 9 & 28 \\
\hline AMMUNITION & 125 & 62 & 263 & 1518 & 1968 \\
\hline MISCELLANEOUS & 0 & 0 & 15 & 0 & 15 \\
\hline ELECTRONIC EQUIPMENT & 2 & 4 & 1 & 3 & 10 \\
\hline $\begin{array}{l}\text { COMMUNICATION } \\
\text { EQUIPMENT }\end{array}$ & 6 & 20 & 29 & 9 & 64 \\
\hline $\begin{array}{l}\text { FALSFIED CURRENCY } \\
\text { (PIECES) }\end{array}$ & 0 & 5712 & 0 & 0 & 5712 \\
\hline $\begin{array}{l}\text { COINS IN GOLD AND SILVER } \\
\text { (PIECES) }\end{array}$ & 0 & 0 & 0 & 3576 & 3576 \\
\hline
\end{tabular}


The attachments are supported by the Service of Administration and Sale of Assets (Servicio de Administración y Enajenación de Bienes - SAE) which administers and sells such assets. During 2007, the PGR and the federal judiciary (PJF) delivered to the SAE property on 2362 and 1750 occasions, respectively. During this same period, a total of Mex $\$ 45931$ and US\$181,902 were forfeited and transferred to the SAE, in addition to other non-cash property (e.g. vehicles and jewels).

323. The following table shows the amount of forfeited assets as a result of ML convictions during 20042007.

\begin{tabular}{|l|r|r|r|r|}
\hline \multicolumn{2}{|c|}{ 2004-2007 FORFEITURES IN THE CONTEXT OF ML CASES } \\
\begin{tabular}{|l|r|r|r|r|}
\hline \multicolumn{1}{|c|}{} \\
\hline US DOLLARS & $\mathbf{2 0 0 4}$ & $\mathbf{2 0 0 5}$ & $\mathbf{2 0 0 6}$ & \multicolumn{2}{c|}{$\mathbf{2 0 0 7}$} \\
\hline MEXICAN PESOS & $\$ 276,040.00$ & $\$ 0.00$ & $\$ 4,196,940.00$ & $\$ 21,000.00$ \\
\hline OTHER & $\$ 58,000.00$ & $\$ 0.00$ & $\$ 2,449.50$ & $\$ 0.00$ \\
\hline
\end{tabular}
\end{tabular}

Another indicator of the benefits from asset forfeiture is the amount realized from the sale of such assets. For example, during 2007, about Mex $\$ 66,785,422$ (equivalent of about US\$6.0 million) were generated from such sales. ${ }^{18}$ The following illustrates:

\begin{tabular}{|l|r|r|}
\hline \multicolumn{1}{|c|}{ Property } & No. Items & \multicolumn{1}{c|}{ Sale Value } \\
\hline Vehicles & 1113 & 32314664 \\
\hline Aircraft & 17 & 25813039 \\
\hline Miscellaneous & 1040 & 8657719 \\
\hline \multicolumn{1}{|c|}{ TOTAL } & $\mathbf{1 0 6 7}$ & $\mathbf{6 6 7 8 5 4 2 2}$ \\
\hline
\end{tabular}

324. Total US\$ cash seizures during the period 2004-2007 amounted to approximately US $\$ 67.5$ million, the bulk of which was attached in 2005 and $2007 .{ }^{19}$ In addition, cash attachments by the SIEDO have also increased during the same period totaling about 14.4 million pesos, particularly during 2007 when the amount was approximately 10.3 million pesos or about US\$1 million. A large proportion of these attachments was made at airports and is related to ML offenses.

325. As mentioned in previous paragraphs, there are few cases of forfeiture of assets by the judicial authorities as a result of ML convictions. The reason for this is that there have been very few convictions for ML and forfeitures are secondary penalties that can only be applied if a conviction is

${ }^{18}$ These figures represent updated statistics that now cover all of 2007 , provided by the Mexican authorities in October 2008.

19 These figures represent updated statistics that now cover all of 2007, provided by the Mexican authorities in October 2008. 
issued. There is therefore a significant disparity between the amount of attached assets and forfeited assets. The PRG and judicial authorities have started to raise awareness in their respective institutions on the need to better utilize the attachment and forfeiture tools to combat ML and organized crime in particular. At the same time, recent constitutional reforms will allow for parallel and autonomous legal proceedings for the forfeiture of property. This should overcome the need for a definitive conviction to confiscate property. This would also require, however, coordination and enhanced skills of the law enforcement and financial intelligence agencies to more effectively investigate assets and net worth.

\subsubsection{Recommendations and Comments}

- Mexican criminal law provides a broad range of procedures and tools to attach and forfeit property. However, Mexico should include in its legislation the ability to forfeit property "for the equivalent or corresponding value".

- Mexican legislation should also be amended to include specific provisions for preventing or voiding (nullifying) contracts or other acts in which the persons involved knew or should have known that as a result of those acts the authorities' ability to recover property subject to forfeiture would be impaired.

\subsubsection{Compliance with Recommendation 3}

\begin{tabular}{|c|c|cl|}
\hline & Rating & \multicolumn{1}{c|}{ Summary of factors underlying rating } \\
\hline R.3 & LC & - & $\begin{array}{l}\text { Legislation does not provide for the ability to forfeit assets of equal or } \\
\text { corresponding value. }\end{array}$ \\
- $\begin{array}{l}\text { There are no criminal laws/tools for preventing or voiding contracts and actions } \\
\text { that diminish the ability to recover assets subject to forfeiture. }\end{array}$ \\
\hline
\end{tabular}

2.4 Freezing of funds used for terrorist financing (SR.III)

\subsubsection{Description and Analysis}

326. The reforms to the Federal Penal Code that criminalizes the financing of terrorism entered into force on June 29, 2007, and to date, no criminal cases have been initiated in connection with this offense.

327. Mexico has not implemented any measures that will freeze or seize terrorist-related funds or other assets without delay in accordance with the United Nations resolutions or on the basis of an order or mechanism issued by a competent authority or a court.

328. Neither the legal tools provided in the Federal Code of Penal Procedures (CFPP) nor those found in the Federal Law against Organized Crime cover the freezing of funds used for terrorist financing. None of the legal provisions in the financial laws, e.g., Article 115 of the Credit Institutions Law and Article 124 of the Popular Savings and Loan Law, provide for effective and rapid mechanisms for freezing terrorist funds or other assets without delay.

329. While the authorities agree that there are no specific laws and procedures in place to freeze terrorist funds or other assets, they assert that the basic system for the attachment of property subject to forfeiture (analyzed under Recommendation 3) could be applied to these cases. However, the attachments can only take place in the context of a criminal procedure, which would require at least the initiation of a preliminary inquiry. Moreover, since an attachment order would also need to be substantiated, a certain level of investigation would also be required. 
330. The possibility of a preventive freeze conducted on an administrative basis does not exist, and it is thus impossible for those operating in the financial system to take measures of this type without an order from the Office of the Attorney General of the Republic. No institution, whether a bank, a financial institution, or other another institution, has the power to freeze by itself the funds or other assets of a persons, not even of those appearing on a United Nations' list pursuant to a Security Council resolution.

331. Given the time that it would take to initiate a preliminary inquiry and conduct a basic investigation to substantiate an attachment order, the Mexican system cannot guarantee that the freezing of terrorist funds or other assets can be applied without delay as required by Special Recommendation III. The phrase without delay, for the purposes of S/RES/1267(1999), means, ideally, within a matter of hours of a designation by the Al-Qaida and Taliban Sanctions Committee. For the purposes of S/RES/1373(2001), the phrase without delay means upon having reasonable grounds, or a reasonable basis, to suspect or believe that a person or entity is a terrorist, one who finances terrorism or a terrorist organization.

332. The authorities were not able to show any evidence of freezing actions applied in Mexico. As a result, the assessment team was not able to assess the effective implementation of this measure.

Freezing Assets under S/Res/1267 (c. III.1)

333. Mexico has no effective laws or procedures to freeze without delay or prior notice terrorist funds or other assets of persons designated by the United Nations Al Qaida and Taliban Sanctions Committee, in accordance with Security Council Resolution No. 1267(1999).

Freezing Assets under S/Res/1373 (c. III.2)

There are no effective laws or procedures for freezing without delay or prior notice terrorist funds or other assets of persons designated in the context of Security Council Resolution No. 1373 (2001). Freezing Actions Taken by Other Countries (c. III.3)

334. Mexico has no laws or procedures to examine and give effect to, if appropriate, the actions initiated under the freezing mechanisms of other jurisdictions without delay. A measure of these characteristics would only be possible in the context of a mutual legal assistance request.

Extension of c. III.1-III.3 to funds or assets controlled by designated persons (c. III.4)

335. The ability to extend the freezing actions to funds or other assets wholly or jointly owned or controlled by terrorists or derived or generated from funds or other assets owned or controlled by terrorists, is limited by the legal lacunae and obstacles described above.

\section{Communication to the Financial Sector (c. III.5)}

336. The Ministry of Foreign Affairs is the authority in charge of receiving the lists of terrorists drawn up by the Security Council. However, the only action that the Ministry of Foreign Affairs takes upon receiving such lists is to forward them to the Office of the Attorney General of the Republic (PGR) and to the Ministry of Finance and Public Credit (SHCP) for further dissemination to the financial sector. There are no mechanisms for the Ministry of Foreign Affairs to follow up and verify that the lists were actually disseminated to the financial sector or to confirm whether any matches were detected. 
337. Through a separate channel, the SHCP's Banking, Securities, and Savings Unit receives from the United States Embassy the lists of persons and organizations designated by the United States as potentially being involved in terrorist activities. The Unit disseminates these lists to the financial sector.

Guidance to Financial Institutions (c. III.6)

338. No clear guidance has been provided to financial institutions and other persons or entities that may be holding targeted funds or other assets concerning their obligations in taking action under freezing mechanisms.

De-Listing Requests and Unfreezing Funds of De-Listed Persons (c. III.7)

339. Mexico does not have any procedures for considering de-listing requests and for unfreezing the funds or other assets of de-listed persons or entities.

Unfreezing Procedures of Funds of Persons Inadvertently Affected by Freezing Mechanism (c. III.8)

340. Mexico has no specific procedures for unfreezing the funds or other assets of persons or entities inadvertently affected by a freezing mechanism, upon verification that the person or entity is not a designated person. In such cases, the interested party would need to appear before the competent authority that ordered the freeze and request the lifting of the precautionary measure under the general procedures.

Access to frozen funds for expenses and other purposes (c. III.9)

341. There are no procedures for authorizing access to funds or other assets that were frozen pursuant to S/RES/1267(1999) and that have been determined to be necessary for basic expenses, the payment of certain types of fees, expenses and service charges or for extraordinary expenses, in accordance with S/RES/1452(2002).

Review of Freezing Decisions (c. III.10)

342. Mexico has no procedures for allowing a person or entity whose funds or other assets have been frozen to challenge that measure, other than the general procedural remedies provided for attachments and the provisions of Articles 103 and 107 of the Political Constitution of the United Mexican States providing for "Amparos", which act as a protection mechanism when a constitutional right is affected.

Freezing, Seizing and Confiscation in Other Circumstances (applying c. 3.1-3.4 and 3.6 in R.3, c. III.11)

343. Mexico can only apply the general provisions on attachments and forfeitures (described under Recommendation 3) to terrorist cases. However, the shortcomings identified in the analysis of Recommendation 3 would also apply to these cases.

Protection of Rights of Third Parties (c. III.12)

344. The rights of bona fide third parties are protected by legal provisions in Mexico, as previously indicated in the analysis of Recommendation 3 
Enforcing the Obligations under SR III (c. III.13)

345. The framework for enforcing compliance with the relevant legislation, rules or regulations governing the obligations under SR III would be implemented in Mexico by the competent supervisory authorities as described in the analysis of Recommendations 17, 23 and 29.

Additional Element (SR III) - Implementation of Measures in Best Practices Paper for SR III (c. III.14)

346. Mexico has not implemented the measures set out in the Best Practices Paper for this Recommendation.

Additional Element (SR III) - Implementation of Procedures to Access Frozen Funds (c. III.15)

347. Mexico has not frozen any terrorist funds or other assets yet.

\subsubsection{Recommendations and Comments}

348. In order to comply with Special Recommendation III, Mexico should:

- $\quad$ Establish effective laws and procedures to freeze terrorist funds or other assets of persons designated by the United Nations Al-Qaida and Taliban Sanctions Committee in accordance with S/RES/1267(1999) without delay and without prior notice to the designated persons involved.

- $\quad$ Establish effective laws and procedures to freeze terrorist funds or other assets of persons designated in the context of S/RES/1373(2001) without delay and without prior notice to the designated persons involved.

- $\quad$ Establish effective laws and procedures to examine and give effect to, if appropriate, the actions initiated under the freezing mechanisms of other jurisdictions. Such procedures should ensure the prompt determination, according to applicable national legal principles, whether reasonable grounds or a reasonable basis exists to initiate a freezing action and the subsequent freezing of funds or other assets without delay.

- $\quad$ Ensure that the freezing actions referred to above extend to: (a) Funds or other assets wholly or jointly owned or controlled, directly or indirectly, by designated persons, terrorists, those who finance terrorism or terrorist organizations, and; (b) Funds or other assets derived or generated from funds or other assets owned or controlled directly or indirectly by designated persons, terrorists, those who finance terrorism or terrorist organizations.

- $\quad$ Establish an effective system for communicating actions taken under the freezing mechanisms referred to above to the financial sector immediately upon taking such action.

- Provide clear guidance to financial institutions and other persons or entities that may be holding targeted funds or other assets concerning their obligations in taking action under freezing mechanisms.

- $\quad$ Establish effective and publicly-known procedures for considering de-listing requests and for unfreezing the funds or other assets of de-listed persons or entities in a timely manner consistent with international obligations.

- $\quad$ Establish effective and publicly-known procedures for unfreezing, in a timely manner, the funds or other assets of persons or entities inadvertently affected by a freezing mechanism upon verification that the person or entity is not a designated person. 
- Establish appropriate procedures for authorizing access to funds or other assets that were frozen pursuant to S/RES/1267(1999) and that have been determined to be necessary for basic expenses, the payment of certain types of fees, expenses and service charges or for extraordinary expenses, in accordance with S/RES/1452(2002).

- $\quad$ Establish appropriate procedures through which a person or entity whose funds or other assets have been frozen can challenge that measure with a view to having it reviewed by a court.

- $\quad$ Consider implementing the measures set out in the Best Practices Paper for SR.III. Compliance with Special Recommendation III

\begin{tabular}{|c|c|c|}
\hline & Rating & Summary of factors underlying rating \\
\hline SR.III & NC & 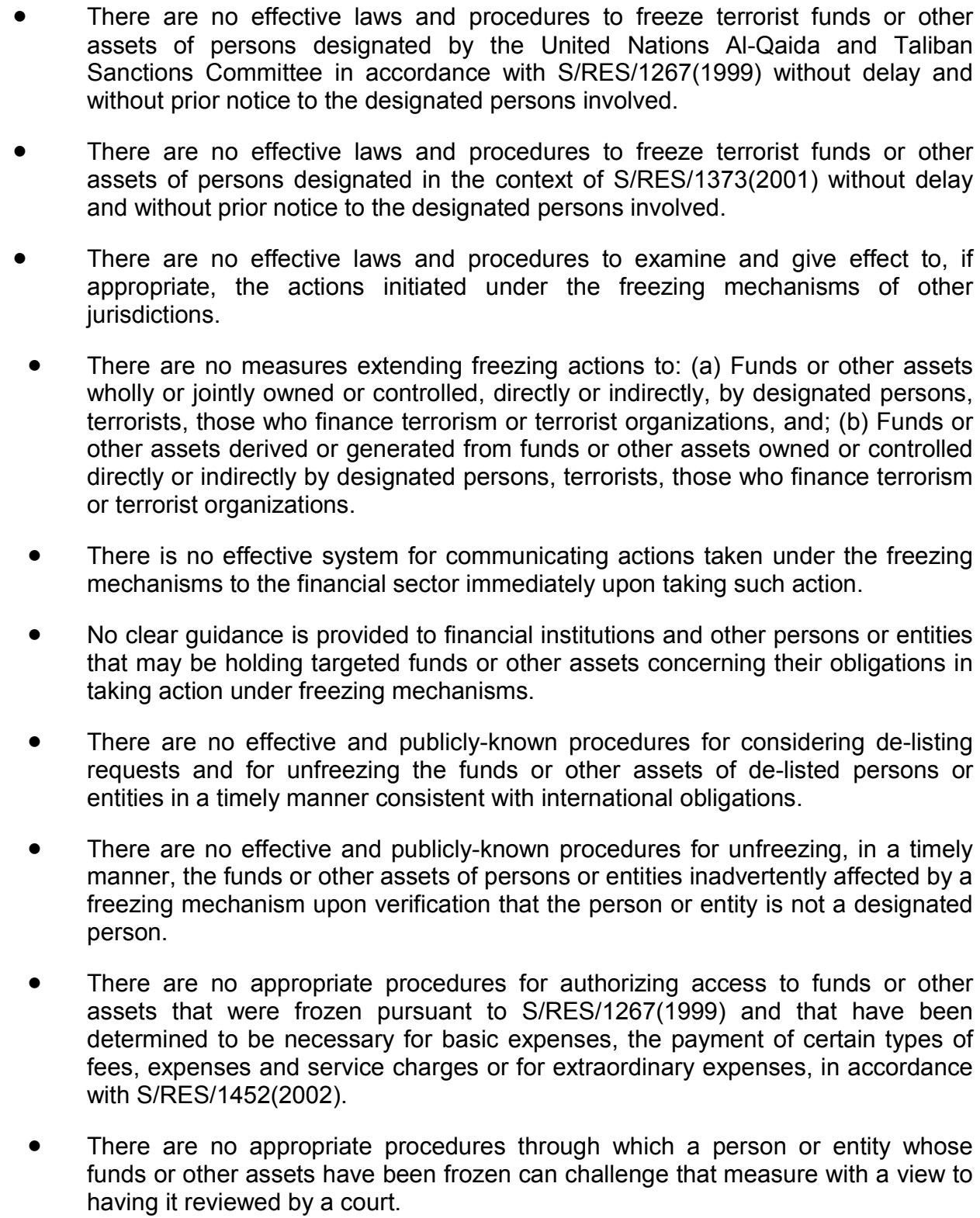 \\
\hline
\end{tabular}




\subsubsection{Description and Analysis FIU}

\section{Legal Framework}

349. In January 2004, as part of an integrated strategy to prevent and combat money laundering and terrorist financing, financial sector laws were amended to expressly designate the Ministry of Finance and Public Credit (SHCP) as the competent authority to:

- $\quad$ Receive, through the supervisory bodies, from financial institutions, reports on transactions that may be related to the crimes of money laundering or terrorist financing and request, through the corresponding supervisory bodies additional information or documentation in connection therewith;

- Obtain additional information, through the supervisory bodies, from other reporting entities, such as those engaged in the business of foreign exchange dealing, money services businesses and certain finance companies (Multiple Activities Financial Corporations known by the Spanish acronym "SOFOMES") on the same matter. And

- Disseminate such information to the competent authorities, among other attributions.

350. The aforementioned package of financial reforms also expanded the powers of the SHCP to adopt the applicable administrative measures to prevent and counter financing of terrorist organizations and their members, with the purpose of implementing the international standards developed since 2001 in this area, and complying with the resolutions of the United Nations Security Council.

351. In this context, through a decree published in the Mexican Federal Official Gazette in May 2004 and for the purpose of optimizing the systems to detect, prevent, and combat money laundering and terrorist financing, Article 15 of the Internal Regulations of SHCP ("Internal Regulations") was amended to broaden the attributions of the SHCP to deal with money laundering and terrorist financing issues. As a result, the Mexican Financial Intelligence Unit (FIU) was created, which allowed the consolidation of the existing powers in the matter of money laundering into a single administrative unit and the express conferral of new powers to it, including the following:

- $\quad$ Preventing and detecting acts or transactions related with terrorist financing.

- $\quad$ Requesting additional information from bound subjects on financial operations.

- Negotiating and entering into national and international agreements on information exchange.

- Fostering compliance with the regulations in effect in coordination with the respective supervisory bodies.

- $\quad$ Filing a criminal complaint before the Attorney General's Office regarding terrorist activity financing offenses. And

- Providing information to law enforcement authorities that would be relevant to the investigation or prosecution of terrorist activity financing offenses.

352. The FIU is an independent administrative unit formally within the structure of the Office of the Minister of Finance and Public Credit, in accordance with a Resolution published in the Gazette in November 2004. Its attributions are set forth under Article 15 of the Internal Regulations. The FIU is the unit in charge of exercising the powers of the SHCP to prevent, detect and deter money laundering and terrorist financing activities. 
353. In July 2006, Article 15 of the Internal Regulations was further amended for the purpose of strengthening the powers of the FIU in the matter of economic and strategic analysis, preparation of statistics and security policies for the information it holds.

\section{Establishment of FIU as National Centre (c. 26.1)}

354. The FIU is the national central body that receives and analyzes transaction reports and other information related to money laundering and terrorist financing, prepares intelligence analyses, and disseminate information to the authorities in charge of investigating and prosecuting such crimes. By virtue of Article 2, Section C, Subsection III of the Internal Regulations, in connection with Article 15, Section VI of the Internal Regulations, the FIU is responsible for receiving, analyzing, and disseminating the information contained in the transaction reports and in the declarations referred to under Article 9 of the Customs Law (declarations of cash ins, cash outs and receivables).

355. According to Article 15, sections VII and XXXI of the Internal Regulations, the FIU also has the authority to request additional information from reporting entities and to inform both the reporting entities and the corresponding supervisory bodies on the usefulness and quality of reports it receives.

356. Article 15 Sections X, XII, XII, XIV, and XV of the Internal Regulations, authorizes the FIU to receive, process, analyze, and disseminate within the scope of its powers and as an attribution of the SHCP, the evidence, certificates, reports, documentation, and information on the conducts that could favor, provide assistance, or aid to or otherwise cooperate with the perpetration of the crimes of terrorism and terrorist financing, or of transactions with resources from illegal origin, integrating the corresponding files, as well as to provide and require from the competent national authorities the necessary information and documentation for the performance of their duties.

Guidelines to Financial Institutions on Reporting STR (c. 26.2)

357. The obligation of presenting suspicious transaction reports (STRs) to the SHCP is established by the following legal provisions:

1. Article 115, Section II of the Credit Institutions Law.

2. Article 212, Section II of the Securities Market Law.

3. Articles 95, Section II and 95 Bis, Section II of the General Law of Credit Organizations and Auxiliary Activities.

4. Article 108 Bis, Section II of the Retirement Savings Systems Law.

5. Article 91, Section II of the Investment Companies Law.

6. Article 140, Section II of the Insurance Institutions and Companies General Law.

7. Article 112, Section II of the Federal Law of Bonding Institutions. And

8. Article 124, Section II of the Popular Savings and Loans Law.

358. According to the above provisions, the SHCP has the competence to determine the characteristics that the actions, transactions, and services must meet to be reported, taking into consideration the amounts, frequency, and nature thereof, the monetary and financial instruments used for such purposes and the business and banking practices followed in the places where they are 
carried out. It also has the competence to prescribe the reporting forms, in addition to the timeframes within which the reports must be transmitted to the FIU and the systems through which the information must be transmitted.

359. These legal provisions were the legal basis for the issuing of the General Dispositions that were published in the Official Gazette of the Federation in May 2004, two of which (regarding credit institutions and popular savings and loans entities) were repealed and once again issued in November 2006.

360. These dispositions stipulate that transaction reports must be prepared and presented taking into account the forms provided for therein.

361. In December 2004, a resolutionwas issued which establishes the official format to be used to report relevant, unusual, and suspicious transactions and provides instructions on how to complete it. The resolution was subsequently amended in May 2005.

362. The FIU is the competent authority to issue guidance and typologies on AML/CFT cases and to inform reporting entities on the usefulness of their reports (Article 15, Fractions VI and XXIV, of the Internal Regulations). Moreover, for the purposes of improving the quality of reporting and to assist reporting entities with tools to detect suspicious or unusual activities, the FIU developed a guide on unusual and suspicious transactions, which was distributed in October 2005 to the corresponding supervisory bodies so that they could, in turn, inform reporting entities.

363. The principal means by which the SHCP, through the FIU, has provided the guidance are:

1. The issuance of a best practices paper in May 2006 based on analyses of filed reports. Among other things, this paper identifies the main flaws detected in filed reports and provides guidance to assist entities in fulfilling their reporting obligations.

2. Meetings and discussions with the reporting entities, in seminars organized with their respective associations.

3. Bilateral meetings and discussions with individual reporting entities.

364. With respect to procedures that should be followed when reporting - in addition to the processes laid down in the AML/CFT general provisions applicable to each type of reporting entity all reporting entities submit their reports through electronic means to the corresponding supervisory body. Each of the supervisory bodies in turn establishes the terms under which reports should be submitted, specifying the systems to be used (e.g. reports filed through the National Banking and Securities Commission are transmitted through a system the "Interinstitutional System for the Transfer of Information" that is subject to a series of criteria issued by that Commission). When reports are received they are vetted to ensure that they have been properly completed (i.e. all the fields have been filled correctly) and the results are communicated back to the reporting entity and, as appropriate, along with guidance for correctly completing the forms.

365. Because the systems that have been established for receiving reports are part of the general systems through which reporting entities send all other information required by applicable regulation, the supervisory bodies have issued a number of rules and criteria that the entities must follow when submitting such information.

366. Separately, the FIU launched an initiative with the Association of Mexican Banks to identify the main deficiencies found in the suspicious transaction reports filed by banks between May 2004 and December 2005. Following as the main problems identified: insufficient description of operations 
and reasons for suspicion; the use of abbreviations and cut phrases, and ambiguity in the identification data. The FIU has also held a number of meetings with representatives of the National Banking and Securities Commission, the Federal Attorney General's Office, and banks to discuss reporting problems and jointly develop best practices to improve the quality of reports. The best practices document has been adopted by the majority of banks and some currency exchange firms. The authorities intend to expand its application to other financial institutions.

367. The best practices paper that was issued in May 2006 has been adopted by the majority of banks and some currency exchange firms. The authorities intend to extend its application to other financial institutions.

368. The FIU is authorized to design, in coordination with the competent administrative agencies of the Ministry SHCP (these are the supervisors for the purposes of money laundering and terrorist financing) the official forms for the filing of transaction reports.

369. Designated Non-Financial Businesses and Professions (DNFBPs) are not required to report suspicious transactions to SHCP and therefore no guidance has been issued for these sectors.

Access to Information on Timely Basis by FIU (c. 26.3)

369. In 2006, the FIU concluded memoranda of understanding (MOU) with supervisory bodies to strengthen support and collaboration among the financial authorities involved in AML/CFT, within the scope of authority of each agency, as well as to enhance compliance by reporting entities with their obligations. In particular, the FIU signed MOUs with the National Banking and Securities Commission, the National Insurance and Bonds Commission, and the National Retirement Savings System Commission The FIU also initiated discussions with the Tax Administration Service (SAT) with a view to concluding a similar arrangement. Negotiations are in the final stage.

370. For the purpose of providing the FIU with information that is useful for the performance of its duties, negotiations to obtain access to databases of different agencies and offices of the federal public administration were also concluded in 2006 with the Ministry of the Economy, in order to access the Database of the Public Registry of Commerce, and with the National Immigration Institute, to access the Integrated System for Immigration Operation.

371. The FIU also has direct access to the main tax and customs databases managed by the competent authorities. In addition, the FIU's database is fed by other tax data, such as Format 35, which contains the declarations submitted by every taxpayer to the SAT on cash receipt for any sale, lease, or donation which exceed Mex $\$ 100,000$ (aprox. US\$9,500). Customs declarations of transborder transportation of cash exceeding US\$10,000, as well as information on the confiscation of undeclared cash amounts are also sent on a frequent basis to the FIU through a physical memory device. The FIU has direct access to some private databases.

372. Access to some information is not online, such that information is sometimes only available by request to the source agency and transmitted on CDs. To guarantee the security of information, the FIU has adopted certain security measures, such as encryption of data and transportation by specially designated personnel.

373. In sum, the FIU has remote direct access to the main tax and customs databases, although there are limitations since some information is only available at the end of certain periods (mainly quarterly) and must be physically trasmitted on memory storage devices. It also has access to the Public Commerce Registry and private databases commonly used by financial institutions. 
374. The FIU does not have direct access to information contained in some databases of law enforcement authorities, in particular to criminal information records which, due to secrecy provisions, can only be accessed by the FIU in those cases being investigated by PGR or by the police with which the FIU collaborates. This limitation of access can affect the FIU's capability to produce useful information to assist investigations. On the other hand, according to legal requirement under Article 400 bis of the Federal Penal Code, PGR grants to the FIU access to the criminal case information in order to allow the FIU to prepare criminal complaint regarding money laundering cases involving the financial system. Furthermore, the FIU has access to relevant criminal statistical information handled by PGR which gathers all intelligence information in PGR. As a result of this, the FIU has conducted some strategic analysis that combines the information of its own database with criminal statistics to develop risk maps and other general risk-related information.

375. In this regard, the FIU has signed two MOUs with the Federal Attorney General dated June 2004 and October 2005, to regulate the interaction between both government agencies and set the foundations upon which they will cooperate in the performance of their duties. In addition, with respect to intelligence reports filed by the FIU, the working protocol developed since 2007, under which FIU analysts meet on a regular basis with PGR prosecutors that coordinate the investigation of cases raised by such reports, allows FIU analysts to get information from the prosecutors that is needed to obtain more financial information on targets under investigation or associates detected as a result of that.

\section{Additional Information from Reporting Parties (c. 26.4)}

376. In accordance with the provisions under Article 15, Sections VII and VIII of the Internal Regulations, the FIU can request and obtain from reporting entities and other administrative units of the SHCP information and documentation related to actions, transactions, and services that could be linked to the crimes of money laundering and terrorist financing. This must be done through the reporting entities' corresponding supervisory body. The reporting entities are in turn obliged to provide to the FIU, through the appropriate supervisory body, any additional information and documentation it may require relative to transaction reports.

377. According to these provisions, as well as to those issued by the supervisory authorities, providing this information does not imply in any way a violation of the confidentiality duties provided under the relevant financial sector laws.

Dissemination of Information (c. 26.5)

378. According to Article 15, Fraction XII, of the Internal Regulations, the FIU is authorized to provide to competent national authorities such information and documentation needed to carry out their duties. In this context, the FIU disseminates intelligence information to the competent authority in charge of coordinating criminal investigations and prosecuting federal crimes, namely the Office of the Federal Attorney General (PGR) and to the competent authority in charge of investigating tax fraud, namely the SAT, according to Articles 15-f, Fraction VI and 15-h, Fraction VII of the Internal Regulations. This dissemination is conducted in a proactive manner, through the transmission of intelligence reports and making complaints based on the analysis of transaction reports and other available information. The FIU also disseminates information on a reactive basis by attending to requests for information from the Federal Attorney General's Office or by judicial authorities.

379. The FIU prepares intelligence reports and collaborates with authorities in charge of investigating and prosecuting money laundering and terrorist financing. The FIU sends intelligence reports to the SAT in situations where $i$ ) there are not sufficient elements to conclude that the activities in question are related to money laundering or terrorist financing ii) but where they may be related to tax violations. As a result of its direct access to tax information, the FIU is able to detect 
mismatches between income declared for tax purposes and the financial activities and assets of a person which may be an indication of a tax violation. On the other hand, in situations where there are sufficient elements to conclude that the activities in question are related to money laundering or terrorist financing, the FIU sends its reports solely to the Attorney Gneral's Office whether or not they are also thought to involve tax violations.

380. Data provided by the FIU shows that during the period 2004-2007, there was a significant decline in the number of FIU reports sent to PGR for investigation and a relatively small increase in the number of inquiries initiated by the PGR from such reports, with the exception of 2007 when the number of inquiries increased sharply to 41 (or 59.4 percent) of reports provided by the FIU. This could indicate an improvement in the quality of FIU reports as confirmed by the FIU, and/or an increased focus by the PGR on ML cases reported by the FIU. The following table illustrates:

Number of Intelligence Reports sent by the FIU to the General Attorney's Office and to the Tax Administration Service

\begin{tabular}{|c|c|c|c|c|}
\hline & 2004 & 2005 & 2006 & 2007 \\
\hline IR Sent to the General Attorney's Office & 194 & 158 & 104 & 69 \\
\hline IR Sent to the Tax Administration Service & 332 & 512 & 1977 & 1478 \\
\hline
\end{tabular}

381. The FIU authorities argue that the decrease in the amount of proactive reports sent to PGR results from the fact that such reports are now focused on quality rather than quantity. The FIU has indeed corrected a number of deficiencies in its processes to achieve this improvement. For example, there are quality checks to avoid sending reports to PGR with a weak analysis, or where the "unusualness" or relevance is not well supported. Reports are also checked for data accuracy, including with respect to the names of persons involved (particularly in those based on journalistic articles). The FIU is also filtering the volume of reports that are only related with tax matters.

382. In practice, the FIU receives feedback from law enforcement authorities, particularly the Federal Attorney General's Office and the Tax Administration Service, through statistics on the utilization of reports transmitted to these agencies, such as the number of preliminary inquiries, tax fraud cases and indictments resulting from such reports. However, this kind of feedback does not directly provide information on the quality and usefulness of FIU reports to investigations and prosecutions.

383. The FIU is authorized to denounce to the Federal Attorney General such activities that may favor, provide assistance or aid to or otherwise cooperate with the perpetration of the crimes of terrorism and terrorist financing, or of transactions with resources from illegal origin, and obtain the evidentiary elements of the case. It is also authorized to assist the competent authorities, representing SHCP, in criminal proceedings relative to such crimes and, within the scope of its competence, follow up on and control proceedings originated from the accusations made by SHCP, as well as of those in which it may have any interest.

384. Article 15, Section XI of the Internal Regulations authorizes the FIU, in coordination with the SAT, to carry out any necessary control or audit actions. In this respect, it submits intelligence reports to the SAT when it identifies the perpetration of fiscal felonies or misdemeanors as a result of its analysis. 
Operational Independence (c. 26.6)

385. The FIU reports directly to the Office of the Minister of Finance and Public Credit, in accordance with a Resolution published in the Mexican Federal Official Gazette in November 2004. The Minister of Finance and Public Credit appoints the Director of the FIU. Article 15 of the Internal Regulations defines its powers and duties as a central, independent and autonomous authority to receive, process, and disseminate the financial information relative to the crimes of money laundering and terrorist financing.

386. The above-mentioned legal provision ensures that only the FIU can undertake the actions contemplated in the Internal Regulations without the participation of any other area of the Ministry. In addition, the information managed by the FIU cannot be made available to any other agency or department of the Ministry, except for those areas that have legal competence to receive such information, i.e. tax and customs authorities.

387. In the structure of the SHCP, the FIU is attached only to the minister, in accordance with the "Agreement by which administrative units of the SHCP are attached structurally," (as published in the Official Gazette of the Federation in November 2004). Thus, as an individual unit that is not part of any other area of the SHCP, the FIU, as a separate budgetary unit, can determine its own budget, and has power to directly request to and obtain from the SHCP administrative support to perform its duties, according to Article 15, Fraction XXXII of the Internal Regulations, which confers to the FIU the same powers granted to the under-secretariats of SHCP.

388. This legal provision ensures the autonomy and independence of the FIU.

Protection of Information Held by FIU (c. 26.7)

389. The vast majority of transaction reports are submitted to the FIU by electronic means and in encrypted form. The FIU, in coordination with the General Coordination Office of Information Security and Quality of the SHCP, has implemented meticulous security measures to protect the information it manages. Some reporting entities, such as for money remitters, foreign exchange centers, and some SOFOMES, submit their STRs through the SAT, whose database the FIU does not have direct access to. This can affect negatively the security of the information.

390. Similarly, in May 2004, a plan was developed to update the information technology of the FIU, for the purpose of strengthening and giving more security and reliability to the financial and economic statistical analysis processes. Among the relevant measures implemented was the implementation of a local intranet for exclusive use by FIU personnel, INTRAUIF, without outside connection, thereby affording control over intentional or fortuitous leakage of information received from reporting entities, intelligence reports produced for competent authorities and other sensitive information.

391. Additionally, the FIU signs confidentiality agreements with its personne. Article 10 of the National Security Law provides that: "Prior to its admission, personnel of National Security institutions will agree with the hiring institution to maintain the secrecy and confidentiality of the information they may have knowledge of during or due to their performance." In case of violation of this duty, the employee is subject to administrative and criminal sanctions.

392. The FIU has also developed its own security policies which are mandatory and must be observed by all employees. The purposes of the policies are to guarantee the integrity and secrecy of the information that the FIU manages, establish additional measures with respect to the security of the personnel and the facilities of FIU, and set out penalties for any failure to comply with the policies. Those policies deal with management and storage of sensitive information, rules for communication 
among employees of the FIU, and between them and outsiders, access to the FIU building, and physical security of the FIU office.

393. In the international context, the FIU formulates and attends to information requests with foreign FIUs exclusively through the secure network provided by the Egmont Group of Financial Intelligence Units. Similarly, the Memoranda of Understanding for the exchange of financial intelligence information signed with foreign counterparts contain provisions relative to confidentiality and protection of information, as well as restrictions or conditions for the dissemination thereof.

Publication of Annual Reports (c. 26.8)

394. Taking into account that the FIU was established in 2004, it published, in May of 2006 its only report, entitled "Memoir 2004-2005", which addresses the most important activities and results of the FIU as of the date of its creation until December 2005. The Memoir was distributed to reporting entities and national and international authorities with which the FIU interacts in the performance of its duties.

395. The Memoir contains statistics on reports received and outcomes and includes as an appendix a report on typologies, including 10 cases of money laundering based on reception and analysis of 77 disclosures made to PGR, as well as the translation into Spanish of typologies sanitized by the Egmont Group. That report was distributed in 2005 to all supervisory authorities for dissemination to their respective reporting entities. Similar reports will be issued by the FIU on a biennial basis. The next report is expected to be released in early September 2008.

396. The typologies developed by the FIU are available on its website and were included in the database of CICAD/OAS. In addition, in 2006 the FIU disseminated to all of the reporting entities and the supervisory authorities the typologies report of the FATF on money laundering in insurance and remittance markets.

397. For budgetary purposes, according to Articles 6 and 8 of the law of planning, the FIU is also required to issue an annual report on its activities and results for each fiscal year. This report is sent to the Cabinet of the President of the Republic to be included in the Executive Branch's Report to the Congress, which is public and contains information similar to that of a biennial report (e.g. main activities and statistics).

Membership of Egmont Group (c. 26.9)

398. The General Adjunct Office for the Investigation of Transactions (DGAIO), the former institutional structure of the Mexican FIU, was admitted into the Egmont Group in 1998. The current Mexican FIU, which was restructured in May 2004, maintained its participation in the Group and has appropriated all the obligations assumed by its predecessor.

399. Having been a member of the Egmont Group since 1998, the Mexican FIU was considered by the group as fully in accordance with the definition of an FIU. The Mexican FIU has also been participanting in the main Egmont Group events and activities, especially in the activities of the working groups. 
Egmont Principles of Exchange of Information Among FIUs (c. 26.10)

400. The FIU's interactions with its foreign counterparts reflect the Egmont Group's Statement of Purpose and its Principles for Information Exchange. Therefore, it conducts its relations with foreign counterparts based on reciprocity and mutual trust, acknowledges the importance of creating a global communications network among FIUs, and promotes international cooperation and the commitment to combat money laundering and terrorist financing at the international level.

401. The FIU is authorized to exchange information with its foreign counterparts, in accordance with the powers conferred under Article 15, Section XXIII of the Internal Regulations and observes, in its relations with other FIUs, the principles and best practices for the exchange of information issued by the Egmont Group.

402. he legal provisions that govern information exchanges with foreign counterparts are the MOUs in the area of cooperation for the exchange of financial intelligence information relating to money laundering and terrorist financing. The FIU is authorized to sign this kind of agreement as provided under Article 15, section XX of the Internal Regulations.

403. To the date of the mission, the FIU has concluded 25 memoranda of understanding with FIU members of the Egmont Group such as: Andorra, Netherlands Antilles, Aruba, Bolivia, Brazil, Canada, Chile, China, Colombia, Korea, El Salvador, Spain, the United States of America, Guatemala, Honduras, Indonesia, Israel, Paraguay, Peru, Portugal, Dominican Republic, Russia, Singapore, Sweden, and Ukraine. It is currently conducting negotiations to sign new MOUs with Argentina, Australia, Bahamas, Philippines, Holland, Italy, Cayman Islands, Japan, Malaysia, Poland, and France.

404. The FIU is also re-negotiating MOUs with Colombia and Canada to include a clause for the exchange of information relating to terrorist financing. Besides these two MOUs and one with Bolivia, all other MOUs include a provision regarding of exchange of information relating to terrorist financing.

405. The memorandum format utilized by the FIU to initiate negotiations with other agencies is substantially based on the model memorandum suggested by the Egmont Group, based on the principles of information exchange and best practices. In accordance with the terms of the best practices issued by the Egmont Group, the FIU exchanges information even in the absence of a memorandum of understanding on cooperation.

406. Additionally, the following international agreements relative to information exchange have been concluded:

- $\quad$ Financial Information Exchange Agreement between the Government of the Mexican United States and the Government of the United States of America with respect to Currency Transactions carried out through Financial Institutions to Combat Illicit Activities.

- Mutual Cooperation Agreement between the Government of the United Mexican States and the Government of the Republic of France for the Exchange of Information on Financial Transactions carried out through Financial Institutions to Prevent and Combat Illicit Origin or Money Laundering Transactions.

- Mutual Cooperation Agreement between the Government of the United Mexican States and the Kingdom of Spain for the Exchange of Information on Financial Transactions carried out through Financial Institutions to Prevent and Combat Illicit Origin or Money Laundering Transactions. 
- Mutual Cooperation Agreement between the Government of the United Mexican States and the Government of the Republic of Guatemala for the Exchange of Information on Financial Transactions carried out through Financial Institutions to Prevent, Detect and Combat Illicit Origin or Money Laundering Transactions. And

- Mutual Cooperation Agreement between the Government of the United Mexican States and the Republic of Panama for the Exchange of Information on Financial Transactions carried out through Financial Institutions to Prevent, Detect and Combat Illicit Origin or Money Laundering Transactions. Adequacy of Resources to FIU (c. 30.1)

407. In 2004, the year that the FIU was created, it was allocated a budget of Mex $\$ 500,000$. In 2005 , the budget was increased to Mex $\$ 2,549,300$. Additionally, that year, new offices were renovated for the FIU, which provided a better technological and security environment. Mex $\$ 2,000,000$ were allocated for the renovations which included the replacement of computer equipment, renewal of office equipment, security mechanisms in the facilities and for the information held by the FIU. In 2006, the budget assigned to FIU increased to Mex\$3,415,300 and in 2007, to Mex $\$ 5,221,300$.

408. The FIU was created due to the reorganization of duties within the SHCP. With its creation in May 2004, the FIU could include as its new staff complement, in addition to the personnel from DGAIO, its predecessor, officers from the Federal Tax Attorney General's Office, which was the area in charge of preparing accusations and following-up on criminal proceedings at the time the FIU did not exist, and officer from the Banking and Savings Unit, which was the competent normative and regulatory authority in the field of money laundering, among others.

409. To exercise its duties, the FIU has one General Director and five General Adjunct Directors, which have specialized functions in the efforts to prevent money laundering and terrorist financing:

- $\quad$ Financial Analysis 1 and 2: In accordance with the provisions under Article 15-D of the Internal Regulations, they must participate, within the scope of their competence, in the design of official forms to present reports, receive and analyze the information contained in the transactions reports and in customs declarations and obtain information directly from public or private databases for the integration of intelligence analyses.

- $\quad$ Legal Proceedings: Pursuant to Article 15-F of the Internal Regulations, its duties include receiving, processing and analyzing, within the FIU's scope of competence, the evidence, confirmations, reports, documents, and information on conducts related with the crimes of terrorism and terrorist financing, or of transactions with resources from illicit origin, integrating the corresponding files; denouncing to the Federal Attorney General the conducts related with such crimes, and assisting the competent authorities in representation of the SHCP in the respective criminal proceedings.

- $\quad$ Policy and National and International Relations: Its duties include participating in the development and analysis of preliminary projects of bills, decrees and dispositions for the prevention, detection and combating of money laundering and terrorist financing, as well as acting as liaison, within the scope of its competence, between administrative units and administrative agencies of the SHCP and the different government agencies and entities of the Federal Public Administration or other countries and international organizations. Other duties include negotiating, executing, and implementing agreements with such agencies, entities, countries or organizations. Article 15-A of the Internal Regulations of SHCP details its power and duties. 
- $\quad$ Economic and Statistical Analysis: In July 2006, Article 15-H Bis was incorporated into the Internal Regulations of the SHCP for the purpose of defining the powers and duties of this General Adjunct Director's Office in charge of proposing economic and statistical models to support the financial analysis work and rules that allow the classification and grouping, by risk level, of the information that the FIU obtains. It also concentrates statistical information and fosters security policies.

410. The FIU has initiated a new process of restructuring for the purpose of strengthening its capacities. As a result, it has more recently incorporated into its organizational structure two General Adjunct Directors' Offices: one for Technological Solutions and another one that serves as an interface with the Ministry of Public Security. These General Adjunct Directors' Offices are operational, although their integration is not yet formally reflected in the Internal Regulations. In addition, as part of the restructuring process, the SHCP authorized an increase in FIU personnel to a total of 123 persons and relocation to a larger facility. It is expected that the new offices and staff for the FIU will be in place by the first quarter of 2009.

411. The staff of the FIU currently consists of 51 officers, 41 of which perform substantive duties, and 10 administrative support work. Of the 41 officers in charge of substantive duties, 22 are financial intelligence analysts. The FIU has strived for an interdisciplinary executive structure aimed at taking advantage of specialization by areas and, at the same time, allowing for interaction between its separate components and the exchange of experience among all staff.

412. The size of FIU, on one hand, facilitates knowing the staff individually, and the identification and close monitoring of training requirements, as well as the safeguarding of the confidentiality of information they may have knowledge of in the performance of their duties. On the other hand the large volume of STRs and other reports received by the FIU also means that individual staff are overloaded with work. With the restructuring project of the FIU, which will be negotiated with the Ministry of Planning in 2008, there are plans to more than double the staff of the FIU to strengthen, first and foremost, the areas of technological support and financial analysis.

\section{Integrity of FIU Authorities (c. 30.2)}

413. Pursuant to the provisions under Article 6, Section II of the National Security Law, national security entities are any institutions and authorities that, as a result of their powers and duties, directly or indirectly participate in the tasks of national security; that is, in the prevention of and combat against threats to national security, including any financing of terrorist actions and organizations.

414. In this regard, the FIU has competence to establish measures and procedures to prevent and detect actions or operations that may favor, provide assistance or aid to, or otherwise cooperate with the perpetration of the crimes of terrorism, terrorist financing, or that may otherwise configure the execution of transactions with resources from illicit origin. For this reason, the FIU is considered a national security institution and, therefore, is excluded from the application of the Law of Professional Career Service in the Federal Public Administration.

415. The above was formalized through the execution of the Collaboration Guidelines between agencies and entities of the Federal Public Administration, which, due to the nature of their powers and duties, participate in the field of national security. The FIU signed such Guidelines in November 2006. 
ORGANIZATIONAL CHART

FIU MEXICO

TOTAL STAFF: 51
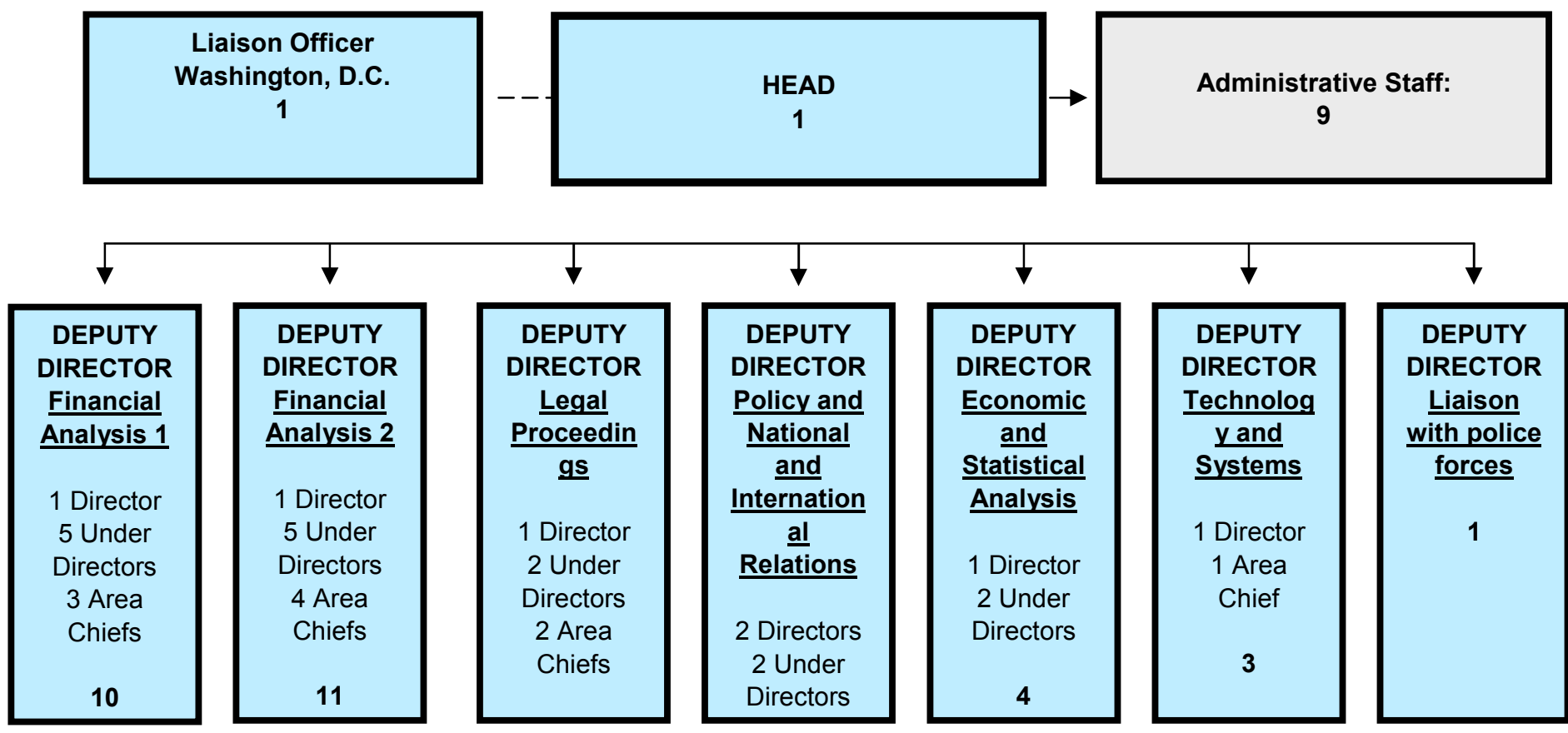

\begin{tabular}{|c|}
\hline DEPUTY \\
DIRECTOR \\
Legal \\
Proceedin \\
\hline$\underline{\text { gs }}$ \\
1 Director \\
2 Under \\
Directors \\
2 Area \\
Chiefs \\
\end{tabular}

\begin{tabular}{|c|}
\hline DEPUTY \\
DIRECTOR \\
Policy and \\
$\frac{\text { National }}{\text { and }}$ \\
$\frac{\text { Internation }}{\underline{\text { al }}}$ \\
$\frac{\text { Relations }}{2 \text { Directors }}$ \\
2 Under \\
Directors
\end{tabular}

\begin{tabular}{|c|}
\hline DEPUTY \\
DIRECTOR \\
$\frac{\text { Economic }}{\text { and }}$ \\
$\frac{\text { Statistical }}{\text { Analysis }}$ \\
1 Director \\
2 Under \\
Directors \\
4 \\
\hline
\end{tabular}

\begin{tabular}{|c|}
\hline DEPUTY \\
DIRECTOR \\
Technolog \\
\hline$\underline{y \text { and }}$ \\
Systems \\
1 Director \\
1 Area \\
Chief \\
3 \\
\end{tabular}

DEPUTY

DIRECTOR

Liaison

with police

forces 
416. It has not yet been decided whether a personnel professionalization service will be developed for national security entities. Therefore, at the moment, the FIU is excluded from professionalization policies applicable to the rest of SHCP, and it has not been able to implement an ad hoc professionalization mechanism that guarantees integrated preparation and development of FIU officers, focusing on quality and ethical values that also contribute, as required under Article 10 of the National Security Law, to safeguarding the confidentiality and security of the information managed by the FIU.

417. Notwithstanding this, the FIU has implemented measures for the selection of personnel that begin with the identification of profiles, evaluation of positions and organizational structures, that is, identifying the mission of the position depending on the powers and duties conferred to the FIU, considering the working environment, level of education, experience, and the areas of knowledge required, as well as the managerial and technical requirements of the position.

418. The FIU reviews an applicant's résumé and evaluates such applicant's qualifications against the criteria identified for a position. It also conducts interviews and verifies the candidate's background and references.

419. Once the candidate is selected, and with the support of the Management Sub-Office for the Evaluation of the Reliability of the Evaluation General Management of the Tax Administration Service, psychological, integrity and reliability tests are undertaken, which will determine whether the person will be hired.

420. Officers affiliated with the FIU sign a confidentiality agreement, as required under Article 10 of the National Security Law through which they agree to maintain secrecy and confidentiality with respect to the information they may have knowledge of during or as a result of the performance of their duties. There have been no sanctions applied to any FIU employee for failure to comply with these requirements; however any such failure would be subject to administrative and criminal proceedings.

421. The integrity and reliability tests are valid for two years. Therefore, a second round of evaluations has been carried out for personnel that have worked in the FIU for a longer time.

Training for FIU Staff (c. 30.3)

422. All staff of the FIU has been trained - both internally and internationally Likewise, the FIU has organized, in collaboration with international organizations, seminars and training courses for reporting entities and national authorities involved in the prevention of and combat against money laundering and terrorist financing. The FIU has offered training courses for its personnel on diverse topics related to their individual areas of responsibility. In the period between 2004 and 2008, the FIU personnel has taken part either as mentor or as partipant in 67 training events, including seminars, training courses, workshops, internally and internationally, totalling 244 persons trained, both from the FIU itself and from other Mexican agencies.

Statistics (applying R.32 to FIU):

423. The statistics provided by the Mexican FIU are comprehensive as indicated in the tables below.

\section{Number of Unusual, Relevant and Concerning transactions reports received by the FIU}

424. The AML/CFT General Provisions require reporting entities to submit to the FIU the following types of transaction reports: 
- Unusual Transaction Report - any transaction, activity, behavior or conduct that does not coincide with a customer's known or declared background or activity or with such customer's habitual transactional behavior considering the amount, frequency, type or nature thereof, without there being a reasonable justification for such behavior, or otherwise, any other transaction with respect to which financial institutions, for any other reason, consider that the resources could be destined to favor, provide assistance, aid or cooperation of any kind to perpetrate the crimes of terrorism, terrorist financing or money laundering.

- $\quad$ Relevant (or currency) Transaction Report - a transaction carried out with monetary instruments for an amount equal to or greater than the equivalent in national currency to US $\$ 10,000$.

- $\quad$ Concerning (or worrisome) Transaction Report - any transaction, activity, conduct or behavior of the directors, officers, employees and agents or representatives of financial institutions whose characteristics could contradict or jeopardize the application of the provisions under financial laws or AML/CFT General Provisions or which, for any other reason, causes any concern for financial institutions.

- $\quad$ 24-Hour Report - any unusual transaction which has sufficient elements to raise a suspicion that the resources could be destined to favor the perpetration of the crimes of terrorism, terrorist financing and money laundering.

\begin{tabular}{|l|r|r|r|r|}
\hline & \multicolumn{1}{|c|}{$\mathbf{2 0 0 4}$} & \multicolumn{1}{|c|}{$\mathbf{2 0 0 5}$} & \multicolumn{1}{c|}{$\mathbf{2 0 0 6}$} & $\mathbf{2 0 0 7}$ \\
\hline Unusual transaction reports received by the FIU & 29902 & 63674 & 56659 & $38400^{20}$ \\
\hline Relevant transaction reports received by the FIU & 3107880 & 5063403 & 5615371 & 6105523 \\
\hline Concerning transaction reports received by the FIU & 179 & 86 & 190 & $250^{21}$ \\
\hline
\end{tabular}

Source: the Mexican FIU.

425. The above statistics indicate an increase of 113 percent in the number of unusual transaction reports received by the FIU between 2004 and 2005. The number of reports decreased slightly in 2006, by 11 percent in relation to 2005 , and considerably in 2007 , by 32 percent in relation to 2006 . With respect to relevant (currency) transactions, there have been yearly increases in the number of reports between 2004 and 2007, with an increase of 63 percent alone between 2004and 2005.

426. In contrast, the number of concerning transaction reports received by the FIU was significantly lower in 2005, when compared to the previous or the following year. The figures in 2005 represent a mere 48 percent of the 2004 ones and 45 percent of those observed in 2006. This also seems to be inconsistent with the increase in the number of the other types of report in 2005.

\footnotetext{
${ }^{20}$ From the total of 128,995 unusual transaction reports received in $2007,90,595$ were excluded due to the fact that those reports were sent by the same financial institution and, since its origin, have not had sufficient elements of being related to money laundering or terrorist financing.

${ }^{21}$ From the total of 650 concerning transactions reports received in 2007,400 were excluded due to the fact that they were duplicated because it concerned a single operation done by the same group of persons.
} 
Number of unusual transaction reports related to terrorist financing received by the FIU

\begin{tabular}{|l|c|c|c|c|c|c|}
\hline & $\mathbf{2 0 0 3}$ & $\mathbf{2 0 0 4}$ & $\mathbf{2 0 0 5}$ & $\mathbf{2 0 0 6}$ & $\mathbf{2 0 0 7}$ & $\mathbf{2 0 0 8}$ \\
\hline $\begin{array}{l}\text { Unusual transaction reports regarding the UN and } \\
\text { OFAC lists of terrorists received by the FIU }\end{array}$ & 34 & 18 & 382 & 134 & 182 & $41^{22}$ \\
\hline
\end{tabular}

Source: the Mexican FIU.

427. It should be noted that the FIU generally receives the UN and OFAC lists from the Ministry of Foreign Affairs and makes a preliminary analysis before making a cross-check with unusual transactions reports.

Number of criminal complaints made by the FIU to the General Attorney's Office

\begin{tabular}{|l|r|r|r|r|}
\hline & $\mathbf{2 0 0 4}$ & $\mathbf{2 0 0 5}$ & $\mathbf{2 0 0 6}$ & $\mathbf{2 0 0 7}$ \\
\hline Proactive complaints & 1 & 43 & 37 & 14 \\
\hline Reactive complaints & 63 & 17 & 16 & 11 \\
\hline
\end{tabular}

Source: the Mexican FIU.

Number of Intelligence Reports sent by the FIU to the General Attorney's Office and to the Tax Administration Service

\begin{tabular}{|l|r|r|r|r|}
\hline & 2004 & 2005 & 2006 & 2007 \\
\hline IR Sent to the General Attorney's Office & 194 & 158 & 104 & 69 \\
\hline IR Sent to the Tax Administration Service & 332 & 512 & 1977 & 1478 \\
\hline
\end{tabular}

Source: the Mexican FIU.

428. The FIU sends intelligence reports to the General Attorney's Office when there are serious indications of money laundering and terrorist financing and to the SAT in situations where there are not sufficient elements to conclude that the activities in question are related to money laundering or terrorist financing but where they may be related to tax violations.

38. Number of answers sent by the FIU to requests made by the General Attorney's Office

\begin{tabular}{|c|c|c|c|}
\hline $\mathbf{2 0 0 4}$ & $\mathbf{2 0 0 5}$ & $\mathbf{2 0 0 6}$ & $\mathbf{2 0 0 7}$ \\
\hline 59 & 140 & 96 & 131 \\
\hline
\end{tabular}

Exchange of information between the Mexican FIU and foreign FIU

\begin{tabular}{|l|l|l|l|l|}
\hline & 2004 & 2005 & 2006 & 2007 \\
\hline
\end{tabular}

${ }^{22}$ Unusual transactions reports received by the FIU by January 16, 2008. 


\begin{tabular}{|l|c|c|c|c|}
\hline & $\mathbf{2 0 0 4}$ & $\mathbf{2 0 0 5}$ & $\mathbf{2 0 0 6}$ & $\mathbf{2 0 0 7}$ \\
\hline Requests made by the Mexican FIU & 4 & 17 & 22 & 30 \\
\hline Answers to foreign FIU & 23 & 57 & 70 & 72 \\
\hline
\end{tabular}

Source: the Mexican FIU.

429. There is no information on requests denied by either the Mexican FIU or its foreign counterparts.

Number of unusual and relevant transaction reports included in the intelligence reports and the denouncements made by the FIU to the General Attorney's Office and to the Tax Administration Service

\begin{tabular}{|c|c|c|c|}
\hline & $\begin{array}{l}\text { General Attorney's } \\
\text { Office (proactive) }\end{array}$ & $\begin{array}{l}\text { General } \\
\text { Attorney's } \\
\text { Office } \\
\text { (reactive) }\end{array}$ & $\begin{array}{l}\text { Tax } \\
\text { Administratio } \\
\text { n Service }\end{array}$ \\
\hline Period & Jan-Apr/2007 & Jan-Apr/2007 & $\begin{array}{c}\text { Jan- } \\
\text { Dec/2007 }\end{array}$ \\
\hline $\begin{array}{l}\text { Number } \\
\text { reports } \\
\text { analyzed }\end{array}$ & 54 & 77 & 11 \\
\hline $\begin{array}{l}\text { Number } \\
\text { persons } \\
\text { (natural } \\
\text { legal) }\end{array}$ & 205 & 446 & 11 \\
\hline $\begin{array}{l}\text { Numberof } \\
\text { Unusual } \\
\text { Transactions } \\
\text { Reports } \\
\text { included }\end{array}$ & 542 & 83 & 8 \\
\hline $\begin{array}{l}\text { Number of } \\
\text { Relevant } \\
\text { Transactions } \\
\text { Reports } \\
\text { included }\end{array}$ & 6963 & 4042 & 12327 \\
\hline $\begin{array}{l}\text { Total amount } \\
\text { involved (USD) }\end{array}$ & USD 354679648.69 & $\begin{array}{r}\text { USD } 174245 \\
944.28\end{array}$ & $\begin{array}{r}\text { USD } 262023 \\
175.60\end{array}$ \\
\hline $\begin{array}{l}\text { Amount per } \\
\text { intelligence } \\
\text { report (USD) }\end{array}$ & USD 6568141.64 & $\begin{array}{r}\text { USD } 2262 \\
934.34\end{array}$ & $\begin{array}{r}\text { USD } 23820 \\
288.69\end{array}$ \\
\hline
\end{tabular}

\subsubsection{Recommendations and Comments}

430. Taking into account the legal framework, the Mexican FIU is duly established under the scope of the Ministry of Finance and Public Credit (SHCP) and is in accordance with the Egmont Group's definition of an FIU by having legal compentence to receive, analyze, and disseminate information related to money laundering and terrorist financing.

431. The reporting obligations are established by rules issued by SHCP and the reporting entities make the reports to the FIU through their respective supervisory bodies. The FIU has access to financial, administrative, tax and customs information, most of it on an online basis. However, the FIU has no access 
to criminal information which therefore denies it access an important source of information to feed its analysis. The FIU should consider developing a secure mechanism to access some of this information, as well as negotiating with law enforcement agencies to obtain access to criminal information.

432. The FIU has been confronted for some time with technological problems in receiving on-line STRs from exchange centers, money services business and SOFOMES, which are required to report to the FIU through their supervisor, the SAT. Thus, there is an urgent need for the SAT to address this deficiency which denies the FIU timely and secure access to information from some of the most vulnerable sectors in Mexico.

433. The FIU should consider developing a mechanism which would allow it to evaluate the effectiveness of the AML/CFT regime, notably the added value of intelligence reports to investigations and prosecutions. It should, in particular, consider establishing a permanent feedback mechanism which would allow it to evaluate the quality and usefulness of intelligence reports sent to the Attorney General's Office and the SAT.

434. Although the FIU has not expressed any significant concerns in terms of its budget and staff, the volume of reports it receives is considerably high relative to the number of analysts available to work on them. Moreover, the number of disseminations to the Attorney General's Office is low in absolute terms. This would suggest a need to increase staff, in particular, analytical staff. As part of a restructuring project for the FIU, a proposal for a further increase in resources, notably a more than doubling of staff, has already been presented to the Cabinet of the Minister of Finance and Public Credit, although there is no specific timetable for the approval of this project.

435. The FIU should also consider evaluating its case selection procedures to ensure that they are effective and that there are no misperceptions by the analysts in terms of selecting cases of suspicions of money laudering, terrorist financing, or tax violations.

\section{Specific Recommendations}

- $\quad$ Urgently address the technical problems that have prevented the FIU from receiving STRs filed by certain sectors through the SAT.

- $\quad$ Seek to increase the FIU's access to criminal information beyond that obtained in the course of its participation in investigations.

- $\quad$ Establish with the Attorney General's Office and the SAT a mechanism to evaluate the efficiency of the reporting and analysis system, and the quality of intelligence reports and usefulness to investigations and prosecutions.

- As planned, increase the level of staff and other resources in light of the current and expected future volume of STRs, and other responsibilities assigned to the FIU.

- $\quad$ Periodically review the process for selecting "tax-related" STRs for referral to the SAT to ensure that ML/FT associated with this and other criminal activities are adequately considered by the FIU.

\subsubsection{Compliance with Recommendation 26}

\begin{tabular}{|c|c|cc|}
\hline & Rating & \multicolumn{2}{c|}{ Summary of factors relevant to s.2.5 underlying overall rating } \\
\hline R.26 & LC $^{23}$ & $\bullet \quad$ Does not have full, timely and secure access to STRs from exchange centers, \\
\hline
\end{tabular}

${ }^{23}$ Rating change from PC to LC agreed by FATF Plenary. 


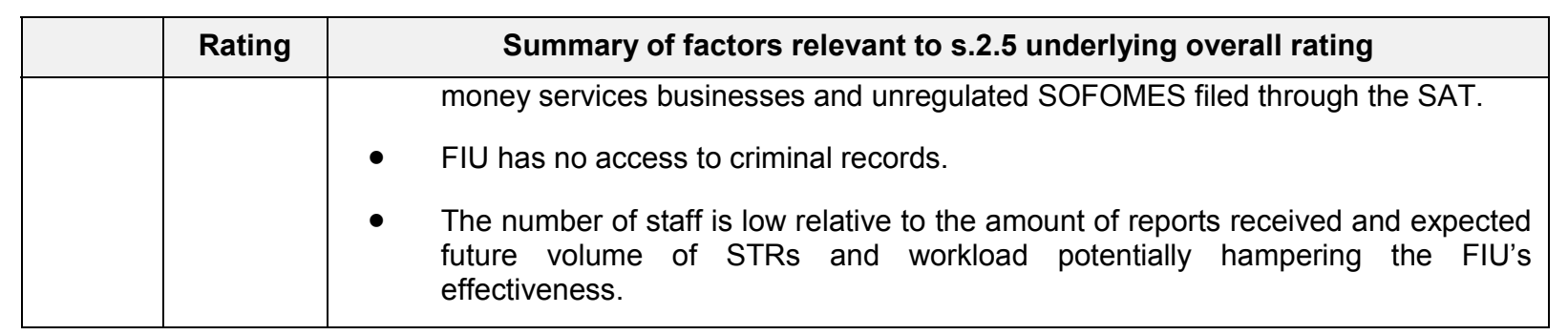

2.6 Law enforcement, prosecution and other competent authorities - the framework for the investigation and prosecution of offenses, and for confiscation and freezing (R.27, \& 28)

\subsubsection{Description and Analysis}

436. The procedures for the investigation and prosecution of money laundering and terrorist financing offenses are governed at the Federel level by the Federal Code of Penal Procedure (Código Federal de Procedimientos Penales or CFPP), which applies to all offenses in Federal jurisdiction. Each State has its own Code of Special Procedures and its own Penal Code. The Federal Law to Combat Organized Crime (LFDO) also contains procedural provisions applicable to the investigation and prosecution of offenses committed by organized crime.

437. Article 1 of the CFPP states, inter alia, that: "This Code comprises the following procedures: I. The procedure in respect of investigation prior to a matter being placed before the courts, which establishes the measures legally required in order for PGR to determine whether or not a criminal charge is to be laid ...,". Article 2 of the CFPP states that: "It shall be the responsibility of PGR to conduct a prior investigation and, if appropriate, to lay a criminal charge to be prosecuted before the courts. In the prior investigation, PGR shall have the following functions: I. To receive reports or accusations presented orally or in writing with regard to deeds that may constitute an offense; II. To perform and to order the carrying out of all actions necessary to establish evidence of the corpus delicti and probable authorship of the offense by the accused, and to determine reparation for harm done; III. To ask the competent court to authorize such precautionary measures consisting of bonding, seizure, or confiscation as may be necessary for purposes of prior investigation, as well as any search warrants that may apply; IV. To arrange for the apprehension or detention of suspects where applicable, etc."

438. Title II of the CFPP in Chapter I lays down the formal requirements for launching the preliminary inquiries (Articles 113 to 122), Chapter II establishes special rules for carrying out actions and preparing formal records for preliminary inquiries (Articles 123 to $133 \mathrm{bis}$ ), and Chapter III establishes provisions for laying charges and prosecuting them before the courts once sufficient evidence has been gathered to establish the nature of the offense and its probable authorship by the accused (Articles 134 to $135 \mathrm{bis}$ ).

439. In addition, Article 136 of the CFPP establishes that the PGR has the following powers in criminal cases: "I. To promote the initiation of penal proceedings; II. To request authorization for summons to appear at preparatory proceedings and for apprehension warrants, where appropriate; III. To seek the precautionary seizure of assets for purposes of reparation for harm done; IV. To provide evidence indicating that an offense has been committed and that the accused is its probable author; V. To seek the application of the corresponding penalties; and VI. In general, to facilitate the smooth running of proceedings in every way possible." Lastly, the CFPP provides that the Judicial Branch has responsibility for deciding the matter (Articles 305 to 360), either while the proceeding is under way (Articles 298 to 304, "Dismissal of charges") or after PGR has finished presenting its case (Articles 291 to 297), finding the accused either not guilty (Articles 94 to 102 and 348) or guilty. 
2. Article 3 of the Federal Law to Combat Organized Crime [Ley Federal Contra la Delincuencia Organizada] grants investigative and prosecutorial powers to PGR, and gives the federal courts competence to hear cases involving offenses committed by organized crime.

\section{Designation of Authorities ML/FT Investigations (c. 27.1)}

3. Under Articles 21 and 102 of the Mexican Constitution, as amended last June, the investigation of federal offenses is the responsibility of PGR and police forces which, for that purpose, operate under its authority and direct control. The imposition of penalties is the inherent and sole responsibility of the Judicial Branch. The Constitution states that the PGR is headed by the Attorney General, who is appointed by the President subject to ratification by the Senate.

4. The Organic Law of the Office of the Attorney General [Ley Orgánica de la Procuraduria General de la República] (LOPGR), which was published on December 27, 2002, establishes the organizational structure of the Office of the Attorney General, which forms part of the federal Executive Branch with responsibility for matters assigned to PGR and the Attorney General under applicable legislation. Article 2 of the LOPGR establishes that the Attorney General is the head of PGR and Article 4 sets out the PGR's main duties and responsibilities which includes the investigation and prosecution of offenses under federal law. The exercise of this responsibility consists of the following:

\section{A. In the preliminary inquiry:}

(a) To receive reports or accusations concerning acts of commission or omission that may constitute an offense.

(b) To investigate offenses under federal law as well as civil-court offenses over which it exercises its power of assumption, pursuant to the applicable provisions, with the assistance of the auxiliary bodies referred to in Article 20 of this law and other authorities of the federal government, of the Federal District, and of the states, under the terms of the applicable provisions and any cooperation agreements and other instruments that may be established for that purpose.

(c) To perform all actions necessary to establish evidence of the corpus delicti and the probable authorship of the offense by the accused, and to determine reparation for harm and damage done.

(d) To order the apprehension of, or, if applicable, to detain, those considered likely to be responsible for committing offenses, pursuant to Article 16 of the national Constitution.

(e) To seize assets in accordance with the applicable provisions.

(f) To restore the victim provisionally to the exercise of his or her rights, pursuant to the Federal Code of Penal Procedure and other applicable provisions.

(g) To release suspects provisionally, pursuant to Article 20, section A, item I, and final paragraph, of the national Constitution. 
(h) To petition the appropriate court for search warrants and such precautionary measures consisting of bonding, seizure, or confiscation of assets as may be necessary for purposes of prior investigation, and, where appropriate, for the proper execution of the judgment handed down.

(i) In those cases permitted by law, the Ministry of Public Prosecutions shall seek to reconcile conflicting interests by proposing solutions aimed at achieving compromise.

(j) To determine where it lacks competence to deal with a matter and to forward the matter to the appropriate authority, as well as the accumulation of prior investigations, if applicable.

(k) To identify exceptional situations with regards to a preliminary inquiry, in accordance with the applicable provisions.

(1) To determine that penal action is not to be undertaken, in the following cases:

1. When the deeds of which it has learned do not constitute an offense.

2. When, after all actions necessary have been carried out and all evidence has been examined, it is not possible to confirm either the corpus delicti or the probable authorship of the offense by the accused.

3. When the possibility of pursuing penal action has been extinguished, in accordance with the applicable provisions.

4. If the actions carried out reveal the existence of clear grounds for the exclusion of the offense, in accordance with the applicable provisions.

5. If it is impossible to demonstrate the existence of deeds constituting an offense, owing to an insuperable material obstacle. And

6. In such other cases as may be determined pursuant to the applicable provisions.

\section{B. Before the courts:}

(a) To pursue penal action before the competent court for federal offenses where there have been reports or accusations, where evidence of the corpus delicti has been established, and where the probable authorship of the offense by the accused has been established, and to request apprehension warrants or summonses to appear, as applicable.

(b) To petition the court for search warrants, precautionary measures such as bonding, seizure, or preventive confiscation of assets, letters rogatory, or the posting of guarantees for purposes of reparation for harm and damage done, unless such guarantees have previously been posted by the accused.

(c) To make persons apprehended or detained available to the court within the time limits laid down by law. 
(d) To bring evidence forward and to carry out the necessary actions to demonstrate the existence of the offense, the circumstances in which it was committed, and specific information in respect of the accused, criminal liability, the existence of harm and damage, and determination of the corresponding amount for purposes of reparation.

(e) To draw conclusions as provided for by law and to request the imposition of appropriate penalties and security measures and the payment of reparation in respect of harm and damage, or, if applicable, to lay forth grounds for the exclusion of the offense or for the extinguishing of penal action.

(f) To challenge court decisions, in the terms provided for by law.

(g) In general, to pursue activities to facilitate proceedings going forward, and to carry out such other duties and responsibilities as may be set forth in the applicable provisions.

5. The organizational structure of the Office of the Attorney General and the federal Ministry of Public Prosecutions as well as their duties and responsibilities, are established in Article 11 of the Organic Law. The structure sets out both a specialization system and a decentralization system by region and by function as follows:

\section{A. Specialization system:}

(a) The Office of the Attorney General shall have administrative units specializing in the investigation and prosecution of specific types of offenses, having regard to the ways in which organized crime manifests itself and the nature, complexity, and incidence of federal offenses.

(b) The specialized administrative units shall act throughout the nation's territory in coordination with the decentralized bodies and units.

(c) Depending on their hierarchical, functional, and budgetary level, the specialized administrative units may be structured with directorates, divisions, and other subordinate units in accordance with the applicable provisions.

\section{B. Decentralization system:}

(a) The Office of the Attorney General shall have decentralized units called delegations [delegaciones] in the States and Federal District. Each delegation shall be headed by a Delegate [Delegado], who shall be the hierarchical superior in charge of officials of the federal Ministry of Public Prosecutions, the federal investigative police and its experts, and such other personnel as may be assigned to the delegation.

(b) The headquarters of each delegation shall be established on the basis of the incidence of offenses, population density, the geographical characteristics of the states and Federal District, and proper workload distribution. 
(c) The Office of the Attorney General may have administrative units responsible for coordinating, supervising, and evaluating the delegations. If that is the case, the Attorney General shall issue a directive establishing the number of such administrative units and the number of delegations assigned to each.

(d) The delegations of the Office of the Attorney General shall have subdelegations [subdelegaciones] and agency offices [agencias] of the federal Ministry of Public Prosecutions which shall operate in geographical districts determined by the Attorney General by means of a directive, as well as regional offices [jefaturas regionales] and other administrative units established in accordance with the applicable provisions.

(e) The delegations shall handle matters concerning preliminary inquiries, pursuit of penal action, exceptional situations, lack of competence, accumulation, nonpursuit of penal action, oversight of proceedings, action for protection of a guaranteed right, crime prevention, community services, administrative services, and so forth, in accordance with the powers granted to them by the implementing regulations established under this law, and by the Attorney General by means of a directive.

(f) In those places where no permanent agency office exists, the delegations shall make arrangements to take care of the matters for which the federal Ministry of Public Prosecutions is responsible.

(g) The Attorney General shall establish the regulations necessary to assure the coordination and smooth functioning of the delegations with the central offices and specialized units, so that the federal Ministry of Public Prosecutions has coherent reporting lines and acts as a single entity.

(h) An information system shall be put in place to enable the unit responsible, as determined in the implementing regulations established under this law, to be made aware of legislation passed by states or the Federal District in timely fashion so that, where applicable, the Attorney General will be able to pursue the action referred to in Article 105, section II, item (c), of the national Constitution, and participate where appropriate in disputes referred to in section I of that article.

6. On June 25, 2003, implementing regulations were established pursuant to the Organic Law of the Office of the Attorney General. Article 2 of those regulations refers to the specialized units competent to deal with different types of offenses. The responsible unit for investigating ML and FT offenses, among others, is the Office of the Deputy Attorney General for the Investigation of Organized Crime [Subprocuraduría de Investigación Especializada en Delincuencia Organizada] (SIEDO). This Office has six specialized units that report to it as follows:

- $\quad$ Special Unit for the Investigation of Health Offenses [Unidad Especializada en Investigación de Delitos contra la Salud].

- $\quad$ Special Unit for the Investigation of Terrorism and Weapons Stockpiling and Trafficking [Unidad Especializada en Investigación de Terrorismo, Acopio y Tráfico de Armas]. 
- $\quad$ Special Unit for the Investigation of Operations Involving Resources of Unlawful Origin and Counterfeiting of Currency [Unidad Especializada en Investigación de Operaciones con Recursos de Procedencia Ilícita y de Falsificación o Alteración de Moneda].

- Special Unit for the Investigation of Abductions [Unidad Especializada en Investigación de Secuestros].

- $\quad$ Special Unit for the Investigation of Trafficking in Minors, Undocumented Persons, and Human Organs [Unidad Especializada en Investigación de Tráfico de Menores, Indocumentados y Órganos].

- $\quad$ Special Unit for the Investigation of Assault and Vehicle Theft [Unidad Especializada en Investigación de Asalto y Robo de Vehículos].

7. Article 27 of the regulations provides that each of the six specialized units shall be headed by an official having the following functions:

a. To discharge the duties and responsibilities set forth in Article 4 of the organic law in respect of the offenses falling within the unit's sphere of competence, in coordination with the administrative units and other competent bodies.

b. To be apprised of matters being dealt with by the delegations which pertain to offenses falling within the unit's sphere of competence, in accordance with the applicable rules and institutional policies, or as decided by the Attorney General or the corresponding Deputy Attorney General.

c. To exercise the power of assumption to investigate and prosecute civil-court offenses having a connection to federal offenses falling within the unit's sphere of competence.

d. To forward to the delegations, through the Directorate General for Oversight of Prior Investigations [Dirección General de Control de Averiguaciones Previas], the unsworn statements of accused persons pertaining to offenses falling within the unit's sphere of competence so that they may be followed up in accordance with the applicable rules and institutional policies, or as decided by the Attorney General or the corresponding Deputy Attorney General.

e. To issue directives with respect to exceptional situations, lack of competence, accumulation, and separation of prior investigations under the unit's responsibility.

f. To establish coordination mechanisms with the administrative units responsible for the oversight and follow-up of prior investigations and federal penal proceedings, to assure the smooth functioning of penal action and facilitate proceedings to be conducted before the courts.

g. To undertake coordination with the delegations in the investigations and activities carried on by the unit within each delegation's geographical area of responsibility in regard to offenses falling within the unit's sphere of competence, in accordance with the applicable rules and institutional policies, or as decided by the Attorney General or the corresponding Deputy Attorney General, and to provide advice and support to the delegations.

h. In coordination with the competent administrative units of the Office of the Attorney General, to propose policies, strategies, and lines of action to combat offenses falling within the unit's sphere of competence. 
i. In coordination with the competent administrative units of the Office of the Attorney General, to participate in international agencies or groups responsible for or involved in investigating or combating offenses falling within the unit's sphere of competence.

j. To provide the competent administrative units of the Office of the Attorney General with information and statistical data on the offenses falling within the unit's sphere of competence.

k. To exercise direct authority and control over the personnel assigned to the unit.

1. Such other functions as may be established under other applicable provisions or by decision of the Attorney General.

8. Article 28 of the regulations establishes the competence of the six specialized organized crime units to deal with matters in their respective areas. The Special Unit for the Investigation of Terrorism and Weapons Stockpiling and Trafficking is concerned with the offense referred to in Article 2 of the Federal Law to Combat Organized Crime, with reference to the following offenses:

(a) Terrorism, as referred to in Article 139, paragraph 1, of the Federal Penal Code.

(b) Weapons stockpiling and trafficking, as referred to in Articles 83 bis and 84 of the Federal Law on Firearms and Explosives [Ley Federal de Armas de Fuego y Explosivos].

9. The Special Unit for the Investigation of Operations Involving Resources of Unlawful Origin and Counterfeiting of Currency (UEIORPIFAM) is concerned with the offense referred to in Article 2 of the Federal Law to Combat Organized Crime, with reference to the following offenses:

(a) Operations involving resources of unlawful origin, as referred to in Article 400 bis of the Federal Penal Code.

(b) Counterfeiting of Currency, as referred to in Articles 234, 236, and 237 of the Federal Penal Code.

10. The six specialized units referred to in this article are apprised of investigations dealing with offenses falling within their spheres of competence even if such offenses were not committed by members of organized crime. In such cases, the units are not authorized to apply the provisions of the Federal Law to Combat Organized Crime. Notwithstanding the foregoing, the specialized units may be apprised of other unlawful acts relating to the offenses referred to in the foregoing paragraphs pursuant to guidelines issued by the Attorney General.

11. The foregoing is consistent with the provision contained in Article 8 of the Federal Law to Combat Organized Crime, which reads as follows: "The Office of the Attorney General shall have a specialized unit to investigate and prosecute offenses committed by members of organized crime, which unit shall be made up of officials of the Federal Ministry of Public Prosecutions, aided by officials of the Federal Judicial Police and experts. The specialized unit shall include a technical supervisory body which shall verify the authenticity of findings from intercepted private communications; it shall establish guidelines regarding the characteristics of the apparatus, equipment, and systems to be authorized, and the safekeeping, retention, maintenance, and use thereof. 
12. The implementing regulations issued under the Organic Law of the Office of the Attorney General shall establish the profiles and requirements that must be met by the civil servants named to the specialized unit, to assure a high level of professionalism in keeping with the duties and responsibilities they are asked to discharge under this law. Mention of the federal Ministry of Public Prosecutions in the present law shall be understood to refer to staff members of the specialized unit established pursuant to this article. Where necessary, the head of the specialized unit may request the assistance of other units of the federal public administration or of the states or Federal District."

13. The Special Unit for the Investigation of Operations Involving Resources of Unlawful Origin and Counterfeiting of Currency and the Special Unit for the Investigation of Terrorism and Weapons Stockpiling and Trafficking within the Office of the Deputy Attorney General for the Investigation of Organized Crime (SIEDO) are the units legally empowered to investigate and prosecute money laundering and terrorism offenses respectively, including terrorist financing. These are the agencies that deal with the ML and FT based on reports from the FIU and from the investigation of other predicate or operational offenses conducted at airports and in border areas. The paragraphs that follow describe sources of reports received by the SIEDO.

14. Complaints from the FIU. These are legal communications based on the authority granted to the FIU pursuant to Article 15 and Article $15 \mathrm{H}$, section II, of the Internal Regulations of the Ministry of Finance [Secretaría de Hacienda y Crédito Público] (SHCP), which, in the view of FIU analysts, may constitute evidence of the offense of an operation involving resources of unlawful origin.

- Intelligence reports from the FIU. Information based on intelligence reports concerning unusual or significant operations provided by Mexican financial institutions.

- $\quad$ Tips from the general public. These may be received in writing, by telephone, or via the Internet, and may be made directly to the offices of the SIEDO, to the unit's telephone numbers, or through the AFI by mail. It is noted that many of these tips received may be motivated by personal enmity or reflect grievances between the person reporting the tip and the person named in it, which calls for caution in dealing with them and for obtaining full information until the allegations can be corroborated.

- Reports from the Mexican customs authority.

- $\quad$ Reports from the Federal Preventive Police [Policía Federal Preventiva] (PFP).

- $\quad$ Reports from the Mexican army. These are reports of suspicious circumstances involving cross-border money as detected by army detachments at airports, maritime customs facilities, and other ports of entry, or any other situations detected by the Mexican army anywhere in the nation's territory in the course of its surveillance and protection activities.

- $\quad$ Reports from other countries' authorities. These are reports from other countries from which legal assistance is requested for investigating deeds suspected of constituting offenses, committed either by nationals of those other countries or by Mexicans, and on occasion the seizure of the proceeds of such offenses.

15. The Federal Preventive Police provides the general public with a timely and reliable information through the National Center for Public Outreach [Centro Nacional de Atención Ciudadana] (CNAC) with respect to complaints against civil servants working in the organization and reports and concerns relating to federal offenses (trafficking in drugs, weapons, or persons; abduction, robbery, or assault on the highways; child sexual abuse; money laundering; etc.). The objectives of the CNAC include the following:

- To encourage active participation by the general public.

- To establish effective communications mechanisms. 
- To broaden the range of options for collaborating with the Federal Preventive Police.

\section{Police Forces}

16. As indicated above, the Office of the Deputy Attorney General for the Investigation of Organized Crime (SIEDO) is the agency responsible for handling reports concerning, among other things, the offenses of money laundering, terrorism, and terrorism financing, and for investigating and prosecuting those offenses. It particular, it is responsible for investigating offenses under the Federal Law to Combat Organized Crime, and for ordering the carrying out of all actions necessary to establish evidence of the offense and the probable authorship of the offense by those accused. To carry out these functions, the SIEDO has at its disposal officials from the Federal Ministry of Public Prosecutions and federal investigation officials. The Federal Investigation Agency [Agencia Federal de Investigación] (AFI) acts under the authority of the Federal Ministry of Public Prosecutions and assists it in its investigative work.

17. The interviews conducted at the Office of the Attorney General and the Secretariat of Public Safety [Secretaria de Seguridad Pública] (SSA) revealed that while the AFI still reports to PGR for administrative purposes, a reorganization is currently under way aimed at merging the AFI with the Federal Preventive Police [Policia Federal Preventiva] (PFF), which reports to the Ministry of Public Safety. The objective is to create a combined Federal Police Force [Policia Federal] operating under a unified mandate for the Under-Secretary for Strategy and Police Intelligence [Subsecretario de Estrategia e Inteligencia Policia]. This would not mean that PGR would no longer be aided by this police force. To the contrary, the officials interviewed during the on-site visit indicated that the reorganization would strengthen the investigation and prosecution of offenses as the various functions performed by the two police forces would no longer be divided among them, and the two forces would work together without unnecessarily duplicating efforts and obstructing their mutual work.

18. At the same time, since July 2008 a small working group was established with permanent representatives from the PFP, PGR and the FIU to investigate relevant ML cases and provide all information in possession of each agency that may be linked to such cases. The authorities expect positive outcomes in the medium term from the work of the working group. With respect to all ML cases, it should be noted however that the reorganization has not generated any positive outcomes yet. The adjustments derived from the reorganization process have thus far actually obstructed the investigative process, as the repeated and frequent changes in the members of investigative teams have generated delays in the conduct of investigations, particularly in those cases detected by the FIU. Moreover, the authorities have not produced a final model for restructuring the body of investigators that should follow up cases under PGR's coordination.

19. Chapter III of the Organic Law of the Office of the Attorney General, in Article 20 et seq., makes specific reference to those rendering assistance to PGR; and the Federal Code of Penal Procedure, in Title VI, Chapter IV, Articles 220 to 239, describes expert evidence as it relates to the courts. The PGR's AML Unit also has a working group charged with preparing expert opinions in the areas of accounting and finance.

\section{The Federal Judicial Branch}

20. The Federal Judicial Branch [Poder Judicial] consists of the Supreme Court [Suprema Corte de Justicia de la Nación], which is responsible for the definitive interpretation of the national Constitution and issues rulings on specific cases, and the Federal Council of the Judiciary [Consejo de la Judicatura Federal], which has a regulatory and administrative role. The structure of the Judicial Branch is horizontal, unlike the pyramid structure of PGR, whose head (the Attorney General) has the power to issue general or specific directives to his personnel. 
21. For decisions on matters brought before the Federal Judicial Branch by PGR, the courts are organized into several levels of jurisdiction [instancias]. The first level is the Federal District Court [Juzgado de Distrito Federal], the second one is the Unitary Court [Tribunal Unitario], the third is Collegial [Tribunal Colegiado], and finally, on an exceptional basis, comes the Supreme Court. The Federal Judicial Branch does not have courts that specialize in specific offenses. Rather, all courts are competent to hear cases involving federal offenses of every kind.

\section{Ability to Postpone / Waive Arrest of Suspects or Seizure of Property (c. 27.2)}

22. There are no legislative or other measures in place that permit the competent authorities investigating ML cases to postpone or waive the arrest of suspected persons for the purpose of identifying persons involved in such activities or for evidence gathering. During the mission, it was made clear that no specific consideration had been given to the adoption of any legislative or other measure that would make it possible to postpone or waive the arrest of suspected persons and/or the seizure of money for the purpose of identifying persons involved in such activities or for evidence gathering. On the other hand, Mexican law does establish procedures for seizing money or gathering evidence, as discussed under Recommendation 3.

\section{Additional Element - Ability to Use Special Investigative Techniques (c. 27.3)}

23. The Federal Law to Combat Organized Crime provides for some of the so-called "special investigative techniques". In particular, Article 11 sets forth: "In the preliminary inquiries conducted with respect to offenses referred to in this law, the investigation shall also include a gathering of information concerning organizational structures, means of operation, and scopes of action. For such purposes, the Attorney General may authorize the infiltration of agents. In such cases, not only the natural persons belonging to the organization but also the legal entities that they use to achieve their criminal ends shall be investigated."

24. In addition, Articles 16, 34, and 35 of this law establishes provisions governing the interception of private communications, the protection of witnesses, and the benefits that may be granted to a member of organized crime who provides effective assistance in the investigation and prosecution of other members.

25. Under the Federal Law to Combat Organized Crime, the Attorney General or the head of the SIEDO is required to submit a written request to the competent judge in order to intercept private communications, and to cite the grounds supporting the belief that a member of organized crime is participating in the offense under investigation (Article 16).

26. Article 34 refers to the protection and assistance that the Office of the Attorney General must give witnesses and other participants in connection with offenses investigated under the law, as appropriate. Provisions are also established with respect to persons who repent of their actions, subject to certain limitations (Article 35). The law does not include any provision allowing the authorities to use the so-called "controlled delivery" technique in connection with any offense.

27. It should be noted that, on March 30, 2005, the Federal Executive Branch submitted to the House of Representatives [Cámara de Diputados] a proposal for a decree to overhaul and expand upon several provisions of the Federal Law to Combat Organized Crime, the Federal Penal Code, the Federal Code of Penal Procedure, and the Organic Law of the Federal Judicial Branch [Ley Orgánica del Poder Judicial de la Federación] which, among other things, deals with the special investigative techniques of "controlled delivery" and "undercover operations". 
Additional Element - Use of Special Investigative Techniques for ML/FT Techniques (c. 27.4)

28. Special investigative techniques may only be applied in the context of investigations concerning organized crime (i.e. within the framework of the Federal Law to Combat Organized Crime). Articles 1 and 2 of the Federal Law to Combat Organized Crime establish that money laundering and the financing of terrorism are offenses likely to be committed by organized crime. Accordingly it is possible to apply special investigative techniques to money laundering and terrorist financing investigations.

29. In accordance with information provided by PGR's AML Unit, there are currently twelve investigations where under cover agents are being used (three of which were initiated in 2004 and the remaining nine in 2007).

Additional Element - Specialized Investigation Groups \& Conducting Multi-National Cooperative Investigations (c. 27.5)

30. Outside of PGR, there are no permanent or temporary groups specialized in investigating the proceeds of crime. As discussed earlier in the analysis of Recommendation 3 and Special

Recommendation III, only PGR has the power to investigate and prosecute offenses, and to request the seizure of the instruments, objects, and proceeds thereof, and forfeitures may only take place only as a result of a court decision. PGR has an AML Unit and a Counter Terrorist Unit specialized in the investigations of money laundering and terrorist financing cases respectively. While these units are understaffed and lack the necessary resources to fulfil their mandate, they do have specialists in financial investigations.

31. There is a strong level of cooperation between Mexican law enforcement agencies and law enforcement agencies in other countries. Mexico cooperates with the competent authorities in other countries through mutual legal assistance requests, which may be provided on the basis of agreements and treaties, or international reciprocity (see Recommendations 36 and 38). In addition, Mexican law enforcement authorities provide international cooperation to their foreign counterparts.

Additional Elements - Review of ML \& FT Trends by Law Enforcement Authorities (c. 27.6)

32. While the authorities involved in the national system to prevent and combat money laundering and the financing of terrorism share experiences in the context of training courses and seminars, there is no formally established forum where they can periodically share information or review methods, techniques, and trends on a regular, interagency basis. Personnel from PGR and the FIU do meet regularly for the purpose of jointly analyzing specific cases. However, these meetings do not involve reviews of methods, techniques or trends.

Ability to Compel Production of and Searches for Documents and Information (c. 28.1)

33. PGR has broad powers to compel the production of or to seize and obtain transaction records, identification data obtained through the CDD process, account files and business correspondence, and other records, documents, or information held or maintained by financial institutions and other businesses or persons, all within the framework of due process. Article 180 of the Federal Code of Penal Procedures (CFPP) grants PGR broad powers to establish evidence of the corpus delicti and the probable authorship of the offense by the accused. It can request documents and financial information so as to track the objects and proceeds of the offense through the National Banking and Securities Commission [Comisión Nacional Bancaria y de Valores], the National Insurance Commission [Comisión Nacional de Seguros y Fianzas], the National Retirement Savings Commission [Comisión Nacional del Sistema de Ahorro para el Retiro], 
and the Tax Administration Service [Servicio de Administración Tributaria] in their respective areas of competence.

34. Article 2 of the CFPP empowers PGR to carry out the necessary activities to conduct a preliminary investigation and, if appropriate, to lay a criminal charge, with the assistance of the security forces. Notwithstanding the foregoing (beyond PGR's broad powers to compel government offices or the private sector to produce any kind of information within the framework of a preliminary inquiry) any entry into or search of premises must first be authorized pursuant to a search warrant issued by the competent judicial authority (see Articles 61 to 70 of the CFPP). Similarly, an arrest warrant must be obtained from the competent judicial authority in order to arrest any person being accused, other than in a case where a person committing an unlawful act is arrested in flagrante delicto (see Article 123 of the CFPP).

35. In keeping with the foregoing, Article 9 of the Federal Law to Combat Organized Crime establishes that requests for information or documents relating to the banking and financial system must be made through the corresponding national board, while those relating to tax matters must be made through the Ministry of Finance. In addition, Article 117 of the Law of Credit Institutions [Ley de Instituciones de Crédito] provides that the Office of the Attorney General may request financial information through the National Banking and Securities Commission or pursuant to a court order.

36. To investigate an offense, the PGR must gather together the fullest possible information to document the commission of the offense being investigated. In the particular case of money laundering and counterfeiting, this requires the following:

(a) Obtaining information on the suspects' finances and net worth from the national commissions that regulate Mexico's financial system including:

- The National Banking and Securities Commission.

- The National Insurance Commission.

- The National Retirement Savings Commission.

- $\quad$ The Tax Administration Service.

- The Bank of Mexico [Banco de México].

- $\quad$ The Financial Intelligence Unit.

- The Registry of Property and Commerce [Registro Público de la Propiedad y el Comercio], the Land Registry [Catastro], and the Motor Vehicle Registry [Registro Vehicular] in the states and the Federal District where the suspects operate.

(b) Obtaining information on the suspects' criminal background for purposes of identifying any prior underlying predicate offense generating resources, through contacts with the following:

- $\quad$ The various specialized units making up the SIEDO.

- The delegations of the Office of the Attorney General in the states and the Federal District where the suspects have been found to operate, and the offices of the state Attorneys General.

- The Directorate General of Crime Prevention and Social Rehabilitation [Dirección General de Prevención y Readaptación Social].

- $\quad$ The Directorate General for Convicted Persons [Dirección General de Sentenciados].

- The National Center for Planning, Analysis, and Information to Combat Crime [Centro Nacional de Planeación, Análisis e Información para el Combate a la Delincuencia] (CENAPI). 
37. Information also needs to be obtained on the suspects' lifestyle and day-to-day activities. For such purposes, the police forces (the AFI and the PFP) are instructed to locate their physical whereabouts and find information on their family relationships, friendships, residences, vehicles, employment, habits, and means of communication.

38. In order for the information gathered to be properly used as evidence of the corpus delicti, it must be analyzed by expert personnel consisting principally of accounting experts, document analysis experts, criminology experts, photography experts, vehicle identification experts, and property appraisal experts.

\section{Power to Take Witnesses' Statement (c. 28.2)}

39. PGR has the power to take witnesses' statements for use in investigations. In addition, Article 180, paragraph 1, of the Federal Code of Penal Procedures grants the Ministry broad powers to establish evidence of the corpus delicti and the probable authorship of the offense by the accused. Witnesses may give statements as part of the preliminary inquiries conducted by PGR, or at the public oral hearings after proceedings have commenced and the court that is to hear the case has been chosen.

40. Title VI, Chapter V, of the CFPP, concerning evidence, contains provisions relating to witnesses in Articles 240 to 257. Certain exceptions apply regarding witnesses who give testimony: the guardian, ward, or spouse of the accused, or any relative by consanguinity or affinity vertically without restriction or horizontally up to the fourth degree inclusive, or any person linked to the accused through love, respect, endearment, or close friendship, may not be compelled to make a statement; but should such persons wish to do so that fact shall be recorded and their statement shall be taken.

41. Similarly, the following persons are not required to give statements concerning information which they have received, of which they are aware of, or which is in their possession: attorneys, technical consultants, and notaries, with respect to matters in which they have been involved and with respect to which they possess information considered confidential by reason of the practice of their profession; ministers of any religious affiliation, with respect to confessions they have received in the practice of their ministry; journalists, with respect to names or recordings, telephone records, notes, documentary or digital archives, or anything else that might directly or indirectly lead to the identification of individuals who, by reason of the practice of their profession, may have provided them with confidential information as the basis for any publication or news story; civil servants or other individuals engaged in any other employment, post, or occupation for which the law recognizes their duty to maintain professional confidentiality; and physicians, surgeons, medical specialists, and clinical psychologists, with respect to information they possess about the health of their patients, by reason of the practice of their profession.

42. With regards to statements by accused persons, Article 207 of the Federal Code of Penal Procedures provides as follows: "A confession is a voluntary statement by a person who has attained the full age of 18 years and is in full use of his or her mental faculties, made to the Ministry of Public Prosecutions or to the court or tribunal hearing a case, concerning offenses committed by that person which is the subject of the charge, given in accordance with the formalities indicated in Article 20 of the national Constitution. A confession shall be admitted at any stage in the proceeding prior to the handing down of a final irrevocable judgment."

43. An accused person has the constitutional right to refuse to make a statement; but should the accused not make use of that right, he or she may make a statement to the prosecutor or to the judge. 

(c. 30.1)

44. The Office of the Attorney General (PGR) includes an Office of the Deputy Attorney General for the Investigation of Organized Crime (SIEDO), which consists of six specialized units. The Special Unit for the Investigation of Operations Involving Resources of Unlawful Origin and Counterfeiting of Currency (the AML Unit) is in changed of prosecuting ML cases and the Special Unit for the Investigation of Terrorism and Weapons Stockpiling and Trafficking is in charge of prosecuting terrorist offenses (the Counter-Terrorist Unit). The AML Unit has a Head of the Unit, a coordinator, 6 prosecutors, 39 agents from the Public Ministry, 3 accountants, 1 business expert and 9 administrative staff. The CounterTerrorist Unit has one Head of the Unit, 5 prosecutors, 12 agents from the Public Ministry and 5 administrative staff.

45. The human and material resources assigned to SIEDO and its units are not sufficient to address the critical situation that Mexico is facing in its fight against crime, and particularly organized crime. Recognizing this shortcoming, the Federal Government already made a commitment to strengthen the SIEDO with financial resources, training, expert services, infrastructure and equipment in the recently approved National Agreement for the Security, Justice and Legality.

46. The Specialized Unit of the Ministry of Public Safety, which includes the Federal Security Police (PFP) and has administrative control over the Federal Investigation Agency (AFI) insofar as money laundering is concerned, consists of approximately 76 people. In addition, these two police forces have 34 police stations distributed throughout the states. Both the PFP and the AFI are understaffed, and lack the necessary resources to address the challenges that the current Mexican reality is presenting. Recognizing these shortcomings, the Federal Government has already made the commitment to reassign resources within the budget to strengthen the security systems and make them more efficient in the recently approved National Agreement for Security, Justice and Legality.

Integrity of Competent Authorities (c. 30.2)

47. The Office of the Attorney General includes the Federal Prosecutors Career Service [Servicio de Carrera de Procuración de Justicia Federal], which is governed by the Organic Law of the Office of the Attorney General and the Federal Prosecutors Career Service Regulations [Reglamento del Servicio de Carrera de Procuración de Justicia Federal]. Officials of the Federal Ministry of Public Prosecutions assigned to the SIEDO are required to meet the requirements laid down in Chapter V of the Organic Law of the Office of the Attorney General with regards to the Federal Prosecutors Career Service, covering recruitment, career path, and separation from service. There is one exception, in that officials of the federal Ministry of Public Prosecutions may be named by special appointment. In that case, only the provisions concerning participation in a recruitment competition are waived: officials so named must meet all other requirements and, if they are successful in the competitions and evaluations they undergo, they may be included in the career service.

48. Evaluation processes are governed by the provisions contained in Chapter VI of the Organic Law of the Office of the Attorney General, entitled "Civil servant evaluation processes." These comprise initial, ongoing, periodic, and mandatory evaluation processes, examinations as to assets and net worth and the social environment, and psychometric, psychological, and toxicological tests. A check is also made as to whether they have any background linking them to illegal activities before their entry into the service.

49. In addition, to work in the SIEDO in any of the staff categories of PGR, they must meet the requirements indicated in the profile corresponding to the category in question. Profiles for officials of PGR list specific aptitudes and skills with particular reference to the ability to design and implement 
administrative, legal, and penal procedures, typing skills, computer literacy, drafting ability, and ability to express concepts orally and in writing. Officials of PGR must hold a licentiate's professional degree in law [Título de Licenciado en Derecho] and the corresponding professional registration [Cédula Profesional], and must have taken and passed the initial training course.

50. An official's psychological makeup is rated on the basis of intellectual ability, capacity for judgment, emotional stability, adherence to standards and values, attitude toward authority figures, ability to manage anger in interpersonal relations, adaptability, ability to work under pressure, drive and initiative, and creativity, with a middle-level score required after averaging these factors. In addition, a high score is required on the factors of discretion, trustworthiness, handling of information, and confidentiality. Officials are required to be in good health to ensure that they can perform their work properly, and for that purpose they are required to undergo a medical examination and answer a series of questions.

51. An official's career path covers requirements and procedures for further training, specialization, incentives and recognition, changes in assignment, professional development, security assessments, performance appraisals, promotions, and disciplinary actions. The essential performance competencies required are professional dedication, a commitment to achieving results, openness to change, an ability to learn, and objectivity. Desirable though not critical qualities are verbal skills, a sense of social responsibility, a desire to serve the needs of society, technical expertise, the ability to work as a member of a team, negotiating skills, and the ability to resolve conflicts. Officials must have basic knowledge about the conduct of prior investigations and about penal law, procedural law, human rights, constitutional law, actions for protection of a guaranteed right, criminology and criminal behavior, drafting, ethics, computing, and federal law in the area of penal procedure.

52. Separation from the Federal Prosecutors Career Service may be either regular or special. Regular separation encompasses resignation, permanent disability, retirement, and death, while special separation covers situations of failure to meet recruitment or service requirements, and dismissal.

53. The entity responsible for regulating, developing, and assessing the Federal Prosecutors Career Service is the Professional Board [Consejo de Profesionalización] governed by the Organic Law of the Office of the Attorney General, through the Council's ancillary bodies, the operation of which is subject to the Federal Prosecutors Career Service Regulations. Chapter VIII of the Organic Law of the PGR sets out the duty of responsibility and accountability of officers of the federal Ministry of Public Prosecutions. Chapter IX of the Organic Law of the PGR covers disciplinary action that may be taken against officials of the federal Ministry of Public Prosecutions should they fail in their duty of responsibility and accountability, or fail to fulfill obligations established in the Organic Law of the PGR. Disciplinary action may consist of public or private reprimand, suspension, or dismissal. It is the responsibility of the ancillary body of the Professional Board to administer procedures for separation from service and dismissal.

54. The federal police forces are required to assist PGR effectively in investigating and prosecuting offenses relating to money laundering and financing of terrorism, with strict observance of due legal process and respect for human rights. The skills required lie in the areas of leadership, communications, teamwork, strategic vision, experience in pursuing an investigation and with investigation methodologies, familiarity with channels of communication at the executive and management levels in government and private-sector entities, specialized training, a knowledge of analytical, field investigation, and intelligence procedures, and means and mechanisms for verifying that these requirements are met. For this purpose, prior assessments are conducted as to psychological makeup and general knowledge, as well as an examination of the social environment, a polygraph test, and toxicological and medical tests.

55. Thus, PGR has a Federal Prosecutors Career Service covering officials of PGR and of the AFI, as well as professional experts and technical specialists. An official's career path covers, among other things, 
requirements and procedures for further training, specialization, incentives and recognition, security assessments, performance appraisals, promotions, and disciplinary actions. The career service is governed by the principles of due legal process, efficiency, professionalism, honor, loyalty, impartiality, and respect for human rights. The theoretical and practical content of training, development, and specialization programs encourages officials of the federal Ministry of Public Prosecutions and those who assist them to carry out their duties based on these principles, and to promote effective learning and the full utilization of the knowledge and skills necessary to discharge the responsibilities of the service.

56. The Office of the Attorney General also has a Code of Conduct [Código de Conducto] which upholds the principles of due legal process, objectivity and impartiality, professionalism, efficiency, honor, loyalty, transparency, respect for human dignity, institutional solidarity, and accuracy. The Organic Law of the Office of the Attorney General establishes the obligation of officials of PGR to uphold the principles of due legal process, efficiency, professionalism, honor, loyalty, impartiality, and respect for human rights in the performance of their duties. It also indicates the kinds of conduct for which they may be held responsible or accountable and the disciplinary action that may be imposed should they fail to fulfill their obligations, which may take the form of public or private reprimand, suspension, or dismissal. Similarly, the Organic Law includes the procedure for imposing administrative penalties for failure to fulfill the obligations required of officials of PGR, irrespective of whether the official's conduct constitutes an offense that may cause a prior investigation to be undertaken and lead ultimately to criminal penalties being imposed, all with a view to safeguarding PGR as an institution.

\section{Training for Competent Authorities (c. 30.3)}

57. Officials of the Ministry of Public Prosecutions assigned to the SIEDO receive specialized training and development courses in the areas of organized crime, health offenses, terrorism, weapons stockpiling and trafficking, trafficking in minors, undocumented persons, and human organs, assault and vehicle theft, tax and financial offenses, and money laundering to ensure that they can carry out their duties as effectively as possible.

58. Since 2004, a total of 252 staff members have been trained by the SIEDO (see the detailed table contained in the annex). The total number of staff members trained by the AFI during the same period is 1,091 .

Additional Element (Rec 30) - Special Training for Judges (c. 30.4)

59. The interviews conducted with various officials from the Judicial Branch, revealed a high degree of knowledge on penal matters in general among judges and courts. However, assessors were left with the impression that more training and awareness raising needs to be provided to judges and courts concerning ML and FT offenses, and seizures, freezing and confiscation of property that is the proceeds of crime or is to be used to finance terrorism.

\section{Statistics (applying R.32)}

60. Post-mission statistics provided by the authorities show that during 2004-2007, the AML Unit initiated a total of 560 preliminary inquiries (Averiguaciones Previas) for ML cases. Of these, 449 did not specify a predicate offense, 65 were connected with drug-related offenses, 39 related to fraud related offenses, and 7 to offenses committed by advisors, officials or employees of credit institutions derived from Article 113 of the LIC.

61. During the same period, the AML Unit issued 149 indictments for ML in the context of 132 judicial proceedings. However, only 2 of these indictments were connected to FIU reports, which 
supports the view (expressed in the analysis of Recommendations 1 and 2) that FIU-generated reports are not being exploited by PGR's AML Unit to their maximum potential.

62. At the judicial level, the statistics also reflect a low level of effectiveness. Notwithstanding the 149 indictments for ML issued by PGR, there were only 30 judicial decisions in ML cases, 25 of which were convictions and 5 were acquittals. These figures may be reflecting a lack of capacity at the judicial level and/or weaknesses in the evidence used by PGR to support its accusations.

\subsubsection{Recommendations and Comments}

63. The fight against crime, and particularly organized crime, in Mexico has created an enormous challenge for the State. The number of homicides and kidnappings has increased significantly with respect to previous years and the levels of violence are plaguing the population. To tackle these problems, the authorities have articulated a comprehensive strategy that includes all of the relevant private and public sector stakeholders. These efforts also include the development of a national strategy for combating money laundering and the financing of terrorism, which is still in progress.

64. In developing the AML/CFT strategy, the authorities highlight the importance of effective interinstitutional cooperation and coordination. It is key that all players in the system act together, in a coordinated fashion, swiftly and effectively, whether they work in preventing or punishing crime. This should include setting up working guidelines with clear targets and precise timelines so as to stay focused on the problem.

65. Legal instruments are an important factor in fighting crime. A weakness identified in Mexico is that the relevant substantive and procedural provisions are scattered over a number of different legal texts, making interpretation difficult when the time comes to apply the provisions in specific cases. Every State has its own legal texts applicable to these types of offenses, which cover not only procedural law (state Codes of Penal Procedure) but also substantive law (state Penal Codes). This could potentially lead to conflicts of jurisdiction and areas of competence in applying the law, and also to difficulties in maintaining uniformity of criteria and ensuring the system's overall effectiveness.

66. Because the federal courts exercise their right of assumption to hear these cases, no actual problems of competence have arisen in practice. However, the reason behind this may also be that the regular courts do not have the adequate resources and/or are not sufficiently specialized to deal with such cases.

67. An analysis of the ML cases that reached a judicial ruling reveals that the majority of them relate to procedures conducted at the airports involving the physical cross-border transportation of foreign currency, or the seizures of cash or other property under search warrants or as a result of "fishing expeditions" conducted by the PFP or other security forces. These procedures usually turn up weapons, drugs, or cash and hence give rise to the various legal mechanisms that initiate penal action. However, a very important component is missing in them, which is to pursue the investigation further and not only to look into assets and net worth but also to conduct fieldwork, in an effort to identify the underlying foundations of the offense, or find the ultimate intended recipient of the merchandise, and thus reach the apex of the criminal organization.

68. For these purposes it would be helpful for the Mexican security forces to be able to apply special techniques of investigation, particularly "controlled deliveries" In the context of ML investigations. In addition, the legal provisions governing witness protection programs, or the possibility of postponing or waiving the arrest of suspects, should also be strengthened. Similarly, it is recommended that the special investigative techniques be extended to all underlying or predicate offenses listed in the FATF glossary, 
rather than being restricted to those identified in the Federal Law to Combat Organized Crime; and it is further recommended that the use of these tools be extended to cases where, in principle, the requirement of three or more people organizing themselves or associating with one another is not met.

69. It should be noted that, in recognition of some of these problems, on March 30, 2005, the federal Executive Branch set out an initiative which proposes to overhaul and expand upon several provisions of the Federal Law to Combat Organized Crime, the Federal Penal Code, the Federal Code of Penal Procedures, and the Organic Law of the Federal Judicial Branch. Among its more noteworthy provisions are measures to institute special investigative techniques such as controlled delivery and undercover operations, to establish a formal definition of an "informant," to legalize for purposes of evidence the use of recordings of communications made by one of the participants without judicial authorization, and the establishment of a national program to protect witnesses and undercover agents. Assessors recommend that these measures be approved and put in practice as soon as possible.

70. With regards to overall the effectiveness of the system, it must be pointed out that apart from the low number of ML convictions in general, there have been no ML convictions resulting from complex financial investigations or derived from FIU intelligence reports received by PGR. In effect, there are only two indictments connected with FIU intelligence reports. As noted in the assessment of effectiveness of Recommendations 1 and 2, the authorities believe that most cases reported by the FIU to PGR have not resulted in indictments because no evidence on criminal activity (as founded indicia) was found from the related criminal investigation. The authorities believe that the substance of the problem is mostly related with structural weaknesses at the criminal investigation level and they highlight the fact that the level of effectiveness in the investigation of all other crimes is very low in general.

71. Assessors agree with the authorities that the low level of effectiveness in the investigation of ML offenses is connected with multiple causes but primarily linked with structural problems at the law enforcement level. Most notably, (i) the reorganization in the federal forces of investigators (AFI and PFP) and their relationship with prosecutors (e.g., frequent changes in teams that lost track of the progress made in a criminal case); (ii) the inappropriate resources allocated to SIEDO; and (iii) a structure and process for case management by SIEDO further back in relation to the sharp rise in the number and diversity of cases assigned to SIEDO. The SIEDO has an immense day-to-day workload in trying to cope with the offenses committed in its area of responsibility, and it dedicates all of its energies to urgent cases that need immediate action with little attention being assigned to reports received from the FIU.

72. It is also striking to note the absence of convictions for corruption offenses, given that corruption is one of the underlying offenses most commonly prosecuted in Latin America as a predicate offense for money laundering. Consequently, agencies responsible for regulating the public administration such as the Ministry of the Civil Service [Secretaría de la Función Pública] should be involved in this effort not only for the purpose of exchanging information but also for drafting and coordinating joint strategies to combat and dismantle corruption.

73. Assessors also consider that more work needs to be done at the judicial level in terms of strengthening the capacity of judges to adjudicate financial crimes. There is generally a low level of specialization among judges and limited training is provided to them in the areas of AML/CFT. While more specialization would be desirable, in the meantime, Mexico should conduct more awareness-raising among judges and ensure that they receive adequate training to handle financial crimes in general and ML and TF cases in particular. The training should also be focused on financial and accounting aspects of $\mathrm{ML} / \mathrm{TF}$ investigations. While there appears to be a solid background knowledge of criminal law and criminal procedures, there seems to be a lack of training among prosecutors and judges on financial and accounting aspects of prosecuting and adjudicating financial crimes. It would also be helpful to conduct 
such training courses with the joint participation of all relevant institutions of the AML/CFT system, as a way to contribute to enhancing inter-institutional cooperation and reduce the disparities in interpretations.

74. It has also been noted that there is a very significant lack of training for other officials of PGR and officials of other agencies who have not been assigned to the specialized units, and particularly all other participants in the federal system who are situated in other states. Training activities have been concentrated in the federal district and a few other cities but the majority of the country has been marginalized from access to adequate training. A comprehensive nationwide training program should therefore be developed.

75. Insofar as human resources are concerned, the SIEDO's staffing levels are inadequate despite the fact that the country is now facing, as mentioned earlier, a highly complex situation in its fight against organized crime. It must also be taken into account that PGR officials must often transfer to other states. In addition, more police officers are needed, assigned to the 34 police stations established in the various states, to provide support to other government agencies. Moreover, additional staff are needed within the PGR to work exclusively on following up on the files established as a result of seizures of foreign currency being transported across the country's borders, as mentioned earlier, and additional technical resources are needed to investigate assets and net worth.

\subsubsection{Compliance with Recommendations $27 \& 28$}

\begin{tabular}{|c|c|c|}
\hline & Rating & Summary of factors relevant to s.2.6 underlying overall rating \\
\hline R.27 & PC & $\begin{array}{l}\text { - ML offenses are not being properly investigated by PGR, insufficient focus on ML } \\
\text { investigations committed through the financial system, and underutilization of } \\
\text { financial intelligence reports from the FIU/financial sector. } \\
\text { - The insufficiency of resources allocated to PGR's SIEDO and its specialized units } \\
\text { is affecting Mexico's capacity to conduct investigations and prosecutions of ML } \\
\text { offenses in an effective manner. } \\
\text { - Mexico does not have laws or other measures, nor considered such laws or } \\
\text { measures, that would allow competent authorities to postpone or waive the arrest } \\
\text { of suspected persons and/or the seizure of money for the purpose of identifying } \\
\text { persons involved in such activities. } \\
\text { The reorganization of the federal forces of investigation over the past year has } \\
\text { created coordination difficulties between these forces and prosecutors, thereby } \\
\text { affecting the effective investigation and prosecution of ML offenses. }\end{array}$ \\
\hline R.28 & LC & $\begin{array}{l}\text { - The reorganization of federal forces of investigation have created difficulties in the } \\
\text { coordination between such forces and prosecutors, thereby affecting the capacity } \\
\text { of competent authorities to exercise document production, search and seizure } \\
\text { powers in an effective manner. } \\
\text { - The insufficiency of resources allocated to PGR's SIEDO and its specialized units } \\
\text { is affecting their capacity to implement their investigative powers in an effective } \\
\text { manner. }\end{array}$ \\
\hline
\end{tabular}




\subsection{Cross Border Declaration or Disclosure (SR.IX)}

\subsubsection{Description and Analysis}

\section{Legal Framework}

76. Article 1 of the Customs Law, which regulates the entry to and exit from Mexico of all kinds of merchandise, covers all persons (including legal persons) that import or export such merchandise, whether they are the owners, holders, recipients, senders, representatives, customs brokers, and any other person involved in the introduction, removal, custody, storage, management or holding of merchandise. The General Customs Administration of the Tax Administration Service (SAT) is the central authority on customs matters, according to Article 11 of the Internal Regulations of the SAT.

77. Article 9 of the Customs Law establishes a declaration system in connection with the trans-border movement of currency and bearer negotiable instruments. The system applies to the import and export of cash, national or foreign checks, payment orders or any other receivables or any combination thereof, exceeding the equivalent of US\$10,000.00 in the relevant currency or currencies. The declarations must be made in the official forms approved by the SAT.

78. Any party who retains the services of international transportation companies for the custody and transportation of securities, as well as of courier service companies for the importation or exportation of any amount of cash or any of the instruments mentioned in the preceding paragraph, or a combination thereof, is required to declare to such companies the amounts to be transported, when the total thereof, in the relevant currency or currencies, exceeds the equivalent to US\$10,000. In turn, these companies are required to declare to the customs authorities the amounts that the parties to whom they provide such services have declared in the official forms.

79. If a person enters the country without declaring that he/she is carrying any amount exceeding the US $\$ 10,000$ equivalency threshold but less than US\$30,000, (involving cash, national or foreign checks, payment orders, or any other receivable instrument or any combination thereof), the customs authority will prepare a detailed record, pursuant to Articles 46 and 152 of the Customs Law and will ascertain the fine to be imposed for the offense. This fine can range from 20 percent to 40 percent of the amount that exceeds the US $\$ 10,000$ threshold.

80. Pursuant to Articles 184, Section VIII and 185 of the Customs Law, any person who fails to make the required declaration is liable to a fine under Article 105 of the Federal Tax Code, if the amount omitted exceeds the equivalent of US\$30,000. In that case, the person can be charged with a felony comparable to smuggling and the amounts not declared can be seized until the person proves that such funds originate from lawful sources. The Federal Attorney General's Office (PGR), in accordance with its attributions, is responsible for of requesting and obtaining additional information from the person who failed to make the required declaration. It is not an offense to make a false declaration under the circumstances described in this and the preceding paragraph.

81. The General Customs Administration is not authorized to investigate ML and/or TF. It has, however, implemented measures to prevent, inhibit, detect, and sanction all activities related to the smuggling of currency. It is the PGR that investigates ML or FT.

82. Customs declaration forms filled out by individuals and companies are sent to the FIU for intelligence analysis and up to 2005, this information was captured by the FIU and included in its database. Currently, the FIU has remote access to the Customs Administration's database with respect to declarations of amounts greater than the equivalent of US\$10,000 for the period 2006-2007. 
83. Mexico has adopted a mandatory declaration system, which requires all persons to declare to the General Customs Administration the importation and export of money or bearer negotiable instruments that exceed the equivalent of US\$10,000 in any currency (Article 9 of the Customs Law). Under Article 9, persons who use the services of international securities custody and transportation companies are also required to declare such transactions that exceed the US\$10,000 threshold. These companies also have to make their own declarations to the Customs Administration. In addition, the law also covers courier service companies that transport cash, national or foreign checks, payment orders, or any other receivable instrument, in excess of the equivalent US\$10,000 in any currency.

84. Article 9 of the Customs Law also requires persons (individuals and legal entities) to declare, upon entering or leaving the country, the transportation of cash, national or foreign checks, payment orders, or any other bearer negotiable instrument or any combination thereof, exceeding the equivalent of US\$10,000. These declarations are to be made using one of the two official forms-"Declaration for Passengers from Abroad" and "Money Declaration for Exiting Passengers." Such declarations must be handed over at the customs entrance or exit, as applicable. Additionally, a person engaged in import-export business must also declare the importation or export of cash or other bearer negotiable instruments, in accordance with the first paragraph of Article 9 of the Customs Law in an annex to the corresponding customs form. As noted earlier, it is not an offense to make a false declaration.

85. The FIU and Customs officers have been conducting a joint review of customs declaration forms for purposes of redesigning and improving the format and to obtain additional details with respect to the declared cash and monetary instruments. The review is also intended to identify deficiencies and loopholes in the system, and to implement the necessary controls.

\section{Request Information on Origin and Use of Currency (c. IX.2)}

86. It is not an offense to make a false declaration but only failure to declare which is dealt with as follows. When a person fails to make the required declaration (US\$10,000 equivalent) in violation of Article 9 of the Customs Law, the Customs Authority will prepare a detailed record of the facts (General Rule on Foreign Commerce number 2.12.18, in correlation with Articles 46 and 152 of the Customs Law.) The Customs Authority must include in the record the amount of cash, national or foreign checks, payment orders or any other receivable instruments or combination thereof, and include data that allows the identification of the offender. This can include a copy of his/her identification. The application of the sanctions (General Rule on Foreign Commerce number 2.12.18, pursuant to Articles 46 and 152 of the Customs Law) does not exempt the offender from the obligation to complete the declaration form. Any return of money that was not declared can only be made after the person has paid the corresponding fine and has made the required declaration.

87. Failure to make a declaration in an amount of less than the equivalent of US\$30,000 will be sanctioned by a fine in accordance with Articles 184, Sections VIII, XV and XVI and 185, section VII of the Customs Law. When the undeclared amount exceeds US\$30,000, the offender is handed over to the PGR to be charged for smuggling. In this regard, the PGR has authority to conduct the necessary investigations in connection with the origin and use of the cash or negotiable instruments that were not declared. Article 105 of the Federal Tax Code also imposes penalties for smuggling in connection with failure to declare cash and monetary instruments in excess of the equivalent of US $\$ 30,000$. It states that:

88. "Article 105.- The same penalties imposed on the felony of smuggling will be imposed to. Any person who fails to declare to customs, at the point of entry to or exit from the country, that he is carrying amounts in cash, national or foreign checks, payment orders or any other receivable instrument or any 
combination thereof, in excess of the equivalent to thirty thousand US dollars in the relevant currency or currencies, will be penalized with imprisonment from three months to six years. If a competent authority renders a convicting sentence with respect to the perpetration of the felony referred in this paragraph, the excess of the abovementioned threshold amount will become property of the federal tax authorities, except if the felon evidences the lawful origin of such resources."

89. Based on the foregoing, the PGR can initiate an investigation pursuant to its powers under Article 180 of the Federal Criminal Procedures Code.

Restraint of Currency (c. IX.3)

90. Pursuant to Chapter II, Article 11, Section XII of the Internal Regulations of the Tax Administration Service, the General Customs Administration has the power to "order and carry out preventive attachment to secure the fiscal interest when there is danger that the obligated party may flee or that a sale or concealment of assets or any other maneuver tending to evade compliance with fiscal obligations may be carried out, as well as of the cash amounts or national or foreign checks, money orders or any other receivable instrument or combination thereof, in excess of the amounts indicated under the legal provisions, when such amounts are not declared to the customs authorities upon entering or exiting national territory, in accordance with customs legislation, and to release the attached assets as may be appropriate." In case there is a suspicion of activities related with money laundering or terrorist financing, the corresponding judicial authorities (PGR) will be informed, which will conduct the necessary investigations to determine the lawful origin of the assets. This would not explicitly apply to false declarations under SR IX.3 (b) as it is not an offense to make a false declaration.

Retention of Information of Currency and Identification Data by Authorities when appropriate (c. IX.4)

91. According to the provisions under the General Rule on Foreign Commerce number 2.12.18, pursuant to Articles 46 and 152 of the Customs Law, the Customs Authority will prepare a detailed record describing the facts, including the amount of cash, national or foreign checks, payment orders, or any other receivable instruments or a combination thereof, as well as data on the identification of the offender, which may include a copy of his/her identification. This would not explicitly apply to false declarations under SR IX.4 (b) as it is not an offense to make a false declaration.

Access of Information to FIU (c. IX.5)

92. The FIU has access to information on all the parties who declare any amounts in excess of the US\$10,000 threshold, as well as information relative to the transportation of securities. It has access through the following: $i$ ) information received from Customs offices in Mexico; ii) information received from the Central Administration of Customs Investigation unit; or iii) through the FIU's remote access to the automated Customs Authority's database. No statistics were provided on the number of consultations made by the FIU or the number of declarations received and analyzed by the FIU.

\section{Domestic Cooperation between Customs, Immigration and Related Authorities (c. IX.6)}

93. Pursuant to Article 3, Paragraph two of the Customs Law “...federal and state public officers and employees, within the scope of their respective competence, must assist customs authorities in the performance of their duties when such authorities require it, and will be required to inform the authorities of any suspected or alleged violations to this Law that they may have knowledge of as well as to hand over the merchandise that is the subject matter thereof, if it is in their power. The customs, immigration, health, communications, marine and other authorities will carry out their duties in a coordinated fashion and will collaborate reciprocally in the performance thereof." In addition, the Article 11, section XVI of the Internal 
Regulations of the Tax Administration Service allows the General Customs Administration to maintain constant communication with other administrative authorities of the Tax Administration Service and The Ministry of Finance and Public Credit, with the federal depends and entities of the Public Federal Administration, and other federal entities in accordance with customs legislation. This coordination is focused on putting in place security measures at airports, maritime customs, other ports of entry and border area.

94. To accomplish what is established in Article 3, Paragraph two of the Customs Law, the General Customs Administration works together with immigration, health, security, judicial, fiscal and other authorities to prevent and detect illicit transactions that violate the laws and other legal provisions relative to the illegal entry or exit of merchandise through Mexican Customs, including illegal smuggling of foreign cash. In particular, their respective activities/contributions include:

- Immigration: control of the entry and exit of foreigners.

- $\quad$ Security: provides support to customs authorities when they require it, and are authorized to conduct surveillance and inspection activities outside of the customs zone.

- FIU: provides information on individuals or corporate entities that enter or exit Mexican territory.

- $\quad$ Customs: control of the entry and exit of merchandise.

95. The Customs Authority is supported by an adequate legal framework that lays the foundation for effective coordination with the above-mentioned authorities. With respect to implementation, there are no statistics or any other information to assess the effectiveness of these coordination arrangements.

International Cooperation between Competent Authorities relating to Cross-border Physical Transportation of Currency (c. IX.7)

96. The ability of the Customs Authority to provide assistance and cooperation in customs matters is provided by Article 3, Paragraph 3 of the Customs Law, which states that: "Customs authorities will collaborate with foreign authorities in the cases and in the terms provided under law and under the International Treaties to which Mexico is a party ...". In addition, Article 11, Section IX of the Internal Regulations of the Tax Administration Service allows the General Customs Administration to maintain constant communication with customs authorities of other countries to obtain and provide information and documentation related with international customs matters. This relationship is established in several bilateral and multilateral customs agreements on information exchange, customs services, and mutual assistance and cooperation.

97. Mexico has adopted several multilateral agreements of the World Trade Organization (WTO) and World Customs Organization (WCO). In addition, it has signed several international treaties and assistance agreements with foreign customs services.

98. The customs authorities of other countries with which Mexico has signed a treaty or agreement can request from the General Customs Administration the information they require on the cases in which the transportation of foreign currency has been declared, as well as information relative to failures to declare amounts in excess of the equivalent of US\$10,000, under the terms provided of the agreements. However, since no statistics on the number of information requests made and received by the General Customs Administration were provided, it is difficult to verify the effectiveness of international cooperation measures. The authorities did provide an unsigned copy of a Bilateral Strategic Plan dated 13 August 2007, for bilateral cooperation between the Mexican Customs Authority and their customs and 
immigration counterparts in the USA. This Plan includes elements for cooperation in several areas including cash smuggling and organized crime.

99. It was ascertained that the priorities addressed by the General Customs Administration in terms of international cooperation have been those which aim at strengthening the integrity of customs personnel, the automation of all customs dispatch processes, the coordination of daily operations, as well as infrastructure projects in the common border to promote the expansion of the exclusive FAST/Express lanes programs, strengthening the actions relative to law enforcement to combat smuggling, customs fraud and related felonies jointly and more efficiently; increasing cooperation on security matters, especially in the case of merchandise cargoes that, due to their nature, require special controls and establishing programs to resume commercial/customs activities in cases of emergencies or disasters. In this context, there is no specific strategy to address terrorist financing issues.

Sanctions for Making False Declarations/Disclosures (applying c. 17.1-17.4 in R.17, c. IX.8

100. It is not an offense to make a false declaration. As mentioned previously, if a person enters the country without declaring that he/she is carrying any amount exceeding the US $\$ 10,000$ equivalency threshold but less than US\$30,000, (involving cash, national or foreign checks, payment orders, or any other receivable instrument or any combination thereof), the customs authority will prepare a detailed record, pursuant to Articles 46 and 152 of the Customs Law and will ascertain the fine to be imposed for the offense. This fine can range from 20 percent to 40 percent of the amount that exceeds the US\$10,000 threshold. This provision also applies to individuals and entities that fail to declare such amounts to securities custody or transportation companies and courier companies, as well as to such companies themselves when they also fail to make the necessary declarations (Articles 184 and 185 of the Customs Law.)

101. If the offender pays the fine, the money will be returned to such violator and no further enforcement action will be taken. Failure to pay the fine would result in the undeclared excess (over the threshold) preventively seized (incautación), with basis on Articles 144, Section XXX of the Customs Law and 41, Section II of the Federal Tax Code.

102. If the amount not declared exceeds US\$30,000, it would be treated as a smuggling offense in terms of Article 105 of the Federal Tax Code. In this case, the customs authority would seize the money and hand it over to the PGR which is responsible for investigating the lawful origin thereof. This conduct can be penalized with imprisonment from three months to six years. If the offender is found guilty, the seized money is handed over to the Federal Tax Authorities, unless the offender can show evidence of its lawful origin.

Sanctions for Cross-border Physical Transportation of Currency for Purposes of ML or TF (applying $c$. 17.1-17.4 in R.17, c. IX.9) and Confiscation of Currency Related to ML/FT (applying c. 3.1-3.6 in R.3, c. IX.10)

103. (Please see discussion in the previous paragraphs.) The rules and procedures applied to the confiscation of currency related to money laundering and terrorist financing are also applied to persons who carry out cross-border transportation of currency and bearer negotiable instruments, with the particularity that if any failure to declare amounts in excess of the US\$10,000 threshold is detected, customs authorities have the power to preventively seize (incautación) the currency, pursuant to the abovementioned customs legislation. The PGR still has the duty to determining the source of the money and if applicable, any connection with money laundering or terrorist activities. 
104. The rules and procedures do not foresee any action to retain, seize, or confiscate currency of a person who presents a true declaration of an amount in excess of the US\$10,000 threshold, even if the authorities suspect that the currency is related to money laundering or terrorist financing. However, in case there is a suspicion of activities related with money laundering or terrorist financing, the PGR is to be informed and the latter will conduct the necessary investigations to determine the lawful origin of the assets.

\section{Confiscation of Currency Pursuant to UN SCRs (applying c. III.1-III.10 in SR III, c. IX.11)}

105. The deficiencies in the process for freezing terrorist assets described under SR.III impact on Mexico's capacity to freeze assets in relation to persons who are carrying out a physical cross-border transportation of currency or bearer negotiable instruments that are related to terrorist financing (please see criteria III.1 to III.10). The Mexican Customs Authority also has the power to seize the currency when any failure to declare any amount in excess of US\$10,000 is detected, although the PGR is entrusted with determining the source of the money and, if applicable, any connection with criminal activities. In such cases the Customs Authority does not have any power to freeze the accounts or assets of terrorists. As mentioned above, the rules and procedures do not foresee any action to retain, seize, or confiscate currency of a person who presents a true declaration of an excess of US $\$ 10,000$ even if the authorities suspect that the currency is related to terrorist financing.

\section{Notification of Foreign Agency of Unusual Movement of Precious Metal and Stones (c. IX.12)}

106. Pursuant to Article 3 of the Customs Law, customs authorities have exclusive competency over matters relative to the importation and export of merchandise into national territory, including gold, precious metals, and precious stones. The function of the General Customs Administration is supplemented with the provisions of Article 10, Section XI of the Internal Regulations of the Tax Administration Service, which empowers the General Customs Administration to "carry out other oversight actions to verify compliance with the legal provisions that regulate and impose taxes on the entry and exit of merchandise to and from national territory and the means of transportation, customs dispatch and the facts or actions deriving therefrom or from such entry and exit."

107. The exchange of sensitive information with other countries is based on agreements and arrangements, particularly those executed with countries that form part of the World Customs Organization (WCO). In cases in which unusual foreign trade transactions are detected, support is requested from the countries of origin and/or destination to verify the information provided by the importers related with the suspicious transaction. If any country requests information from Mexican Customs related with any foreign trade transaction in which the addressee or origin is related with a Mexican taxpayer, the General Customs Administration, through the Customs Investigation Central Administration, conducts the necessary investigations, the results of which are sent to the petitioning country. These procedures are applied in the context of the agreements and arrangements previously established with other customs systems in the world.

108. No statistics on the exchange of information were provided to enable an assessment of effectiveness.

Safeguards for Proper Use of Information (c. IX.13)

109. Mexican Customs Authority is responsible for preserving and safeguarding the information of the abovementioned declarations of for amounts exceeding the US\$10,000 threshold. It also enables them to share such information with the FIU and other competent authorities. 
110. The information on the amounts that exceed US $\$ 10,000.00$ is processed by Customs officers in the Currency Declaration Processing System (SICADED), which may only be accessed by persons authorized by the computer department (after registration and justification of use), which is also in charge of implementing control measures to avoid unauthorized any information disclosure.

111. SICADED has been integrated to the FIU's database, which the personnel of the PGR can access on the basis of the Memorandum of Understanding signed by both agencies.

\section{Additional Element - Implementation of SR.IX Best Practices (c. IX.14)}

112. The General Customs Administration has implemented entry and exit surveillance operations in several airports of the country to detect undeclared currency in high risk flights with important results. In addition, it uses X-ray equipment installed in the principal inspection points, as well as dogs trained to detect money, drugs, and weapons. Moreover, through its intelligence areas, it has developed risk profiles of persons and companies subject to investigation, in addition to determining the principal currencytrafficking routes inside and outside the country. In this context, it works jointly with police and immigration authorities in order to detect suspicious or illicit transactions prior to or during the entry into Mexico

\section{Additional Element - Computerization of Database and Accessible to Competent Authorities (c. IX.15)}

113. The General Customs Administration has a registry of the persons who declare any excess currency upon entering or leaving the country, which is kept by the SICADED, implemented in September 2006, which contains all the information on the passengers who have declared any amount over US $\$ 10,000$. In addition, a similar system is in the process of being implemented, which will allow the computerization of information relative to the transportation of securities and courier service companies.

114. The areas that carry out intelligence analysis, including the Financial Intelligence Unit, have remote access to this computer system, and they are also informed through the monthly reports prepared by customs authorities themselves. PGR and other law enforcement agencies access this information through the database.

\subsubsection{Recommendations and Comments}

- $\quad$ The authorities should enact legislation, as planned, to make false declarations an offense.

- $\quad$ The Customs Authority, the FIU, and other law enforcement agencies should improve the coordination to work more closely and permanently to investigate cases of cross-border transportation of currency or bearer negotiable instruments in order to determine its country of origin, bearing in mind that such currency may be the proceeds of criminal conduct committed in the said country.

- $\quad$ These agencies should also consider improving the institutional structure and the personnel capacities to deal with the identification of money possibly linked to terrorist financing activities, persons, or organizations.

- $\quad$ The Customs should establish mechanisms, such as statistics, to evaluate more appropriately the effectiveness of the measures in place to comply with this Recommendation.

- $\quad$ The FIU should be more involved and if possible take control of the investigation with respect to cash seized at the ports of entry and where appropriate initiate money laundering intelligence investigation. 


\subsubsection{Compliance with Special Recommendation IX}

\begin{tabular}{|c|c|c|}
\hline & Rating & Summary of factors relevant to $\mathbf{s . 2 . 7}$ underlying overall rating \\
\hline SR.IX & PC & $\begin{array}{l}\text { - It is not an offense to make false declarations. } \\
\text { - Cases of cross-border transportation of cash or other bearer negotiable } \\
\text { instruments are not being thoroughly investigated. } \\
\text { - Customs, Immigration, ONDCP and other competent authorities do not } \\
\text { coordinate domestically on issues related to the implementation of Special } \\
\text { Recommendation IX. } \\
\text { - Customs capability to identify money related to terrorist financing activities is } \\
\text { limited. } \\
\text { There is no specific procedure by the Customs to deal with cross-border } \\
\text { transportation of money related to terrorist financing. }\end{array}$ \\
\hline
\end{tabular}

\section{3. PREVENTIVE MEASURES - FINANCIAL INSTITUTIONS}

\subsection{Risk of money laundering or terrorist financing}

115. Mexico has not conducted a systemic review of ML and FT risks affecting financial institutions that could serve as a basis for applying enhanced and/or reduced measures in its financial system. Nonetheless, the authorities indicate that they are aware of the main sources of risks facing the financial sector, particularly those arising from drug trafficking and related criminal activities which are key priorities for the authorities. Terrorism financing risk is not considered to be a significant threat that would require special control measures in the financial sector.

116. All of the main financial activities covered by the FATF Recommendations that are conducted in Mexico are subject to AML/CFT requirements, but the scope of application to some of these activities vary as discussed below. There are also lending operations against automobile titles (cash for titles) that are conducted outside the mainstream lending institutions and are not subject to the AML/CFT requirements. These lending activities are considered by the authorities to be more related to pawning operations and are not supervised. There are no statistics available on the volume of such activities. This issue is discussed in Section 7 of this report.

117. The AML/CFT regulations also allow FIs to apply risk sensitive approaches to compliance with the CDD requirements. These are summarized below with reference to the applicable sections of the regulations, and in more detail under Recommendation 5:

- $\quad$ Chapter III: (Know Your Client Policy): Each of the AML/CFT regulations allows FIs to take risk into account in applying CDD and requires them to classify customers from low to high risk, with intermediate ratings allowed. They also require FIs to classify particular categories of customers as high risk such as PEPs and nonresident high-net worth clients.

- Chapter II: Customer Identification Policy: Each of the regulations allows FIs to apply a simplified identification regime to 26 categories of financial institutions (both domestic and foreign) and to governmental dependencies or entities.

- $\quad$ DCG 124 Title II: Applicable to Type 2, 3 and 4 Popular Savings and Loan Institutions: These entities are classified by the size of their assets and are progressively larger than Type 1 institutions. 
For these entities, know your customer policies and other AML/CFT requirements are more rigorous than for the smaller Type 1 institutions.

118. The regulatory and AML/CFT regime in Mexico also applies differing requirements to certain financial sectors including with respect to licensing and supervision. Some of the main differences are discussed below:

- $\quad$ Currency Exchange and Money Remittance Sectors (Casas de Cambio): Licensing is required for legal entities that engage in currency exchange business with the public in a professional and habitual manner, including such transactions effected through the funds and remittance transfers. Customer identification and related AML/CFT regulatory requirements (DCG 95) only apply (DCG 95) for transactions that equal or exceed the equivalent of US $\$ 10,000$ No licensing is required when foreign currency business (centros cambiarios) involves a more limited range of transactions in the purchase and sale of monetary instruments (as listed in Article 81-A of the General Law on Auxiliary Credit Organizations and Activities) that do not exceed the equivalent of US $\$ 10,000$ per customer per day. They are not allowed to settle such transactions through the transfer or remittance of funds.

- $\quad$ Foreign currency transactions connected to operations and services conducted by businesses located in border areas and free zones, as well as firms that regularly conduct business with foreigners (e.g., hotels), shall not be considered habitual and professional and are not required to be licensed. At the time of the mission, there were only 24 licensed currency exchange/remittance firms (expected to decline further due in large measure to the closure or threat of closure of correspondent accounts in the United States and actions taken by the Mexican authorities for breaches of the AML/CFT requirements). These entities are authorized by the SHCP (Secretaria de Hacienda y Credito Publico) and are supervised by the CNBV (Comision Nacional Bancaria y de Valores) including for AML/CFT.

- The currency exchange businesses (centros cambiarios) described above are not required to be licensed but are subject to the AML/CFT laws and regulations. The AML/CFT regulations only require customer identification and related AML/CFT requirements when transactions are equal or exceed US $\$ 3,000$. They are required to provide notification (registration) of their activities to the SAT (the tax authority "Secretaria de Administracion Tributaria") and are subject to SAT's supervision for AML/CFT purposes. A significant portion of these businesses have not given notice of their operations and AML/CFT oversight is still developing. There are an estimated 4,380 currency exchange businesses. More than 1,300 operations are estimated to be operating without notification to the SAT. The SAT has limited staff capacity to supervise these entities.

- $\quad$ Registered money remittance business (Transmisores de Dinero). Persons engaging in money remittance business are not required to be licensed. They are, however, subject to AML/CFT requirements under the AML/CFT laws and regulations but only with respect to transactions that equal or exceed US\$3,000. It is estimated that there are about 882 registered money remittance firms that meet this category. These are also subject to AML/CFT supervision by the SAT.

- $\quad$ SOFOMES (multipurpose financial (lending) institutions which are replacing the limited purpose institutions "SOFOLES"): As part of a deregulation program, there are both regulated and nonregulted SOFOMES. SOFOMES that are part of a financial group require licensing and supervision by the banking regulator $(\mathrm{CNBV})$. Those that are not do not require licensing and supervision by the CNBV but are subject to the AML/CFT laws. At the time of the mission AML/CFT regulations had not been issued. The SAT has been designated as the supervisor of unregulated SOFOMES for the purpose of compliance with the AML/CFT requirements. At the time of the mission, there were an estimated 634 unlicensed SOFOMES and about 13 regulated SOFOMES. 
119. With respect to popular savings and loans, Registered foreign exchange and money remittance firms, no formal sectoral review of ML/TF risks has been conducted/provided to justify the limited scope of application of the supervisory and AML/CFT framework. The main justification, as implied by the legal regime, is the relative size of transactions and assets. With respect to the simplified CDD regime allowed for financial institutions listed in Annex 1 of each of AML/CFT regulations, no formal risk review and justification was also conducted / provided. These issues are discussed further in Recommendation 5 below.

\subsection{Customer due diligence, including enhanced or reduced measures (R.5 to 8)}

\subsubsection{Description and Analysis}

\section{Legal and Institutional Framework}

\section{Financial Institutions Covered Subject to the Mexican AML/CFT Framework}

120. For purposes of this assessment, the following categories of financial institutions (FIs) are subject to the AML/CFT regime of Mexico and are authorized to conduct financial activities covered under FATF. As mentioned above, cash for titles lending operations, considered pawning by the authorities, are not covered by Mexico's AML/CFT legal and supervisory regime.

\begin{tabular}{|c|c|c|c|c|}
\hline \multirow{2}{*}{ Type of Financial Institution } & \multicolumn{3}{|c|}{ No. of Institutions } & \multirow{3}{*}{$\begin{array}{c}\text { Supervisor } \\
\text { (Prudential and AML/CFT) } \\
\mathrm{CNBV}^{24}\end{array}$} \\
\hline & 2005 & 2006 & 2007 & \\
\hline $\begin{array}{l}\text { Commercial Banks/ Multiple } \\
\text { Banking Institutions }\end{array}$ & 29 & 31 & 40 & \\
\hline $\begin{array}{l}\text { Savings and Loans Entities } \\
\text { ("Popular") }\end{array}$ & 3 & 18 & 48 & CNBV \\
\hline Stock Brokerage Firms & 29 & 31 & 32 & CNBV \\
\hline Investment Companies Sector ${ }^{25}$ & 54 & 52 & 52 & CNBV \\
\hline $\begin{array}{l}\text { Retirement Funds Management } \\
\text { Companies (Afores) }\end{array}$ & 16 & 21 & 21 & $\begin{array}{l}\text { CONSAR }^{26} \\
\text { CNBV }\end{array}$ \\
\hline $\begin{array}{lll}\text { Insurance } & \text { Companies and } \\
\text { Institutions } & & \\
\end{array}$ & 86 & 91 & 95 & $\mathrm{CNSF}^{28}$ \\
\hline Development Banks & 6 & 6 & 6 & CNBV \\
\hline $\begin{array}{lcl}\text { Limited } & \text { Purpose } & \text { Financial } \\
\text { Companies } & \text { (SOFOLES) } & \end{array}$ & 57 & 55 & 39 & CNBV \\
\hline Bonding Companies & 13 & 14 & 14 & CNSF \\
\hline
\end{tabular}

\footnotetext{
${ }^{24}$ National Banking and Securities Commission.

${ }^{25}$ Mutual Fund Operations and Mutual Fund Share Distributors.

${ }^{26}$ National Commission for the Retirement Savings System.

${ }^{27}$ This figure does not include insurance brokers and agents which total some 44944 as of January 2008.

${ }^{28}$ National Insurance and Bonding Commission.
} 


\begin{tabular}{|c|c|c|c|c|}
\hline \multirow{2}{*}{ Type of Financial Institution } & \multicolumn{3}{|c|}{ No. of Institutions } & \multirow{2}{*}{$\begin{array}{c}\text { Supervisor } \\
\text { (Prudential and AML/CFT) }\end{array}$} \\
\hline & 2005 & 2006 & 2007 & \\
\hline Credit Unions & 176 & 165 & 155 & CNBV \\
\hline Financial Leasing Companies & 28 & 23 & 10 & CNBV \\
\hline Financial Factoring Companies & 15 & 12 & 3 & CNBV \\
\hline Foreign Exchange Houses & 24 & 24 & 24 & CNBV \\
\hline $\begin{array}{r}\text { Foreign Exchange Centers (centros } \\
\text { cambiarios Est. total is } 3157 \text { of } \\
\text { which } 2212 \text { have been registered.) } \\
\text { (Est. Jan. 2008) }\end{array}$ & 1054 & 1482 & $2212^{29}$ & $\mathrm{SAT}^{30}$ \\
\hline Money Remitters & 342 & 514 & 857 & SAT \\
\hline $\begin{array}{l}\text { Multiple } \begin{array}{c}\text { Purpose } \\
\text { Companies }\end{array} \text { (SOFOMES) as at Jan. } \\
08\end{array}$ & NA & NA & 634 & $\mathrm{SAT}^{31}$ \\
\hline Total & & & & \\
\hline
\end{tabular}

Institutional Framework (See Recommendations. 23 and 29 for a more detailed description of the enabling AML/CFT legislation for the financial sector.)

121. The Ministry of Finance and Public Credit (SHCP-Secretaría de Hacienda y Crédito Público) is responsible for the implementation of the AML/CFT regime in the financial sector, with overall responsibility for the regulation and supervision of compliance with AML/CFT requirements. Its functions are performed through the following administrative bodies and agencies (órganos desconcentrados ${ }^{32}$ ):

- $\quad$ Banking, Securities and Savings Unit of the SHCP (UBVA-Unidad de Banca, Valores y Ahorro).

- Insurance, Pensions and Social Security Unit of the SHCP (USPSS-Unidad de Seguros, Pensiones y Seguridad Social).

- $\quad$ Development Bank Unit of the SHCP (UBD - Unidad de Banca de Desarrollo).

\begin{abstract}
${ }^{29}$ The SAT estimates that there are some 4,380 unlicensed centros cambiarios of which 3,069 had given the required notice (registered) of their activities. Post mission the authorities indicated that the total estimated number of centros cambiarios was 3157 and that 2212 have been registered. These estimates are based on the total number of registered operations, and the proportion of centros that have not registered identified during onsite inspections. The sample of entities supervised so far, however, may not be representative of the entire population of centros cambiarios (and money remitters). Industry representatives (Associacion de Centros Cambiarios y Transmisores de Dinero), estimates that there are some unlicensed 7569 centros cambiarios and money remitters but no information was provided to substantiate this estimate.
\end{abstract}

${ }^{30}$ Tax Administration Service

${ }^{31}$ SOFOMES which are not part of a regulated financial group will be supervised by the SAT for AML/CFT purposes when new AML/CFT regulations are issued under the provisions of Article 95 Bis of the General Auxiliary Credit Activities and Organizations Law. No date for their implementation was given to the mission. Those that form part of a financial group will continue to be authorized and supervised, including for AML/CFT by the relevant supervisory body.

${ }^{32}$ These agencies are operationally autonomous from the government. 
- $\quad$ Financial Intelligence Unit of the SHCP (FIU) - (Unidad de Inteligencia Financiera).

- National Banking and Securities Commission (CNBV-Comisión Nacional Bancaria y de Valores).

- Insurance and Bonding Commission (CNSF-Comisión Nacional de Seguros y Fianzas).

- $\quad$ Retirement Savings System National Commission (CONSAR-Comisión Nacional del Sistema de Ahorro para el Retiro).

- $\quad$ Tax Administration Service (SAT - Servicio de Administración Tributaria).

\section{Legal Framework}

122. The duties and powers of the above Secretary of the SHCP and its administrative units are established under the Organic Law for Public Federal Administration, the internal regulations of the SHCP. The duties and powers of the administrative agencies (the Commissions and the SAT) are established under the various laws and regulations under which they operate.

123. Article 89 of the Mexican Political Constitution empowers the President to issue decrees for, inter alia, the modification of the Internal Regulations of the SHCP in accordance with the provisions of Article 13 of the Organic Law for Public Federal Administration (for the issue of Presidential decrees, regulations, etc.). Article 31 of the said law authorizes the SHCP to plan, coordinate, evaluate, and supervise the financial system (subparagraphs VII and VIII). Pursuant to such powers, Article 60 XXXIV of the Internal Regulations of the SHCP authorizes the Secretary of the SHCP to issue regulations/rules of a general nature for matters under its jurisdiction ("Reglas de carácter general" hereinafter "DCGsdisposiciones de carácter general" or "regulations").

124. By Presidential Decree of December 2007, the Internal Regulations of the SHCP were amended to include in Article 27 the duty of the SHCP through its administrative units e.g., the Banking, Securities and Savings Unit (Unidad de Banca, Valores y Ahoro) to establish requirements for the prevention and detection of money laundering and terrorism finance as defined in the Federal Penal Code. Pursuant to such legal powers, the various financial regulatory laws (issued by the Congress) require the SHCP to issue $\mathrm{AML} / \mathrm{CFT}$ regulations (DCGs) as described in the ensuing paragraphs.

125. These regulations are enforceable and sanctionable under the various regulatory laws under which they are issued. The linkages between the laws and regulations are clear, as well as the applicability of sanctions. The various regulatory authorities have applied sanctions for noncompliance and there has not been uncertainty or challenge with respect to their enforceability. For a detailed discussion of the enabling legislation for these regulations and their enforceability under the financial laws and the DCGs themselves, please refer to Recommendations 17 and 29 of this report.

126. Before issuing such regulations, the SHCP consults with the main administrative bodies including the FIU as well as the CNBV, CONSAR, CNSF, or SAT, as the case may be. Several AML/CFT DCGs were issued by the SHCP in 1997, 2001, 2004, and 2006.

127. Before 2004, these regulations only covered money laundering (ML) preventive measures under Article. 400 of the Federal Penal Code and did not extend to the financing of terrorism (FT). In January 2004, the various financial laws were amended to allow the SHCP to issue AML/CFT regulations (DCGs) that include certain CFT measures pursuant to Article 139 of the Federal Criminal Code. In June 2007, the Federal Penal Code was amended to criminalize FT and international terrorism (Articles. 139 and 148 Bis.). Subsequent to these amendments, regulations were issued in May 2004 for the following 
categories of entities: $i$ ) banks and credit institutions; ii) limited purpose financial entities (SOFOLEs); iii) popular savings and loans entities; $i v$ ) foreign exchange firms (both licensed and registered, ${ }^{33}$ ) $v$ ) credit unions, leasing, factoring companies, and general deposit warehouses; vi) fund administration companies (mutual fund administration and share distribution companies, and retirement funds management); vii) stock brokerage firms; viii) insurance companies; ix) bonding companies; and $x$ ) money remittance firms (registered with the SAT).

128. On November 2006, new regulations for banks and SOFOLES (DCG 115) and for Popular Savings and Loans (DCG 124) were issued to strengthen certain AML/CFT measures, including the expansion of risk-based CDD provisions. All of the applicable regulations are listed below:

(Issued revised DCGs November 2006)

- Banks (including development banks) and SOFOLES ): DCG referred Article 115 of the Ley de Instituciones de Crédito (Credit Institutions Law) applicable to banking and SOFOLES.

- Popular Savings and Loans: DCG referred under Article 124 of the Ley de Ahorro and Crédito Popular (Popular Savings and Loans Law).

(Issued May 2004)

- $\quad$ Stock brokers: DCG referred under Article 52 Bis 4 of the Ley del Mercado de Valores (Securities Market Law).

- $\quad$ Retirement fund administrators, mutual fund operators and share distributors: DCG referred under Articles 108 Bis of the Ley de los Sistemas de Ahorro para el Retiro (Retirement Savings Systems Law) and 91 of the Ley de Sociedades de Inversión (Investment Companies Law).

- Insurance companies DCG referred under Article 140 of the Ley General de Instituciones and Sociedades Mutualistas de Seguros (Insurance Institutions and Companies General Law).

- Bonding companies DCG referred under Article 112 of the Ley Federal de Instituciones de Fianzas (Bonding Institutions Federal Law).

- $\quad$ Foreign exchange firms (Casas de Cambio): DCG referred under Article 95 of the Ley General de Organizaciones and Actividades Auxiliares del Crédito (General Law of Credit Organizations and Auxiliary Activities).

- Foreign exchange centers (Centros Cambiarios): DCG referred under Article 95 Bis of the Article 81-A of Ley General de Organizaciones and Actividades Auxiliares del Crédito.

- Money remitters: DCG referred under Article 95 Bis of the Ley General de Organizaciones and Actividades Auxiliares del Crédito. And

\footnotetext{
33 There are two categories of foreign exchange firms $i$ ) licensed which conduct foreign exchange transactions without limitation including those involving funds transfer and remittance, and ii) unlicensed and registered (with the Tax authorities (SAT)) that conduct more limited foreign exchange business in amounts below the equivalent of US $\$ 10,000$ per customer per day not involving transactions effected through funds transfers or remittances. The CNBV is responsible for AML/CFT supervision of licensed foreign exchange firms (casas de cambio) and the SAT is responsible for AML/CFT supervision of registered exchange centers (centros cambiarios) and money remittance firms (transmisores de dinero).
} 
- Credit unions, factoring companies, leasing companies and general deposit warehouses: DCG referred to under Article 95 of the Ley General de Organizaciones and Actividades Auxiliares del Crédito.

129. In this report, DCGs will henceforth be referred by the article in the law that governs the AML/CFT requirements for such institutions, e.g., DCG 115 for credit institutions.

130. The SHCP also issues "Oficios" which are administrative interpretive documents under the various regulations (DCGs: "Disposiciones de Carácter General") to interpret the content and scope of the regulations, in consultation with the various supervisory Commissions and the SAT. With respect to DCG 115, it has issued two such Oficios: UBA/094/2005 and UBA/200/2005 concerning the definition of PEPs and ultimate beneficiaries. Because these Oficios are issued pursuant to the powers of interpretation granted to the SHCP in the DCGs and the various financial regulatory laws, and are drafted in a manner that imposes obligations (e.g., "shall..."), they are considered other enforceable means (OEMs). They would be enforceable and sanctionable through the regulations (DCGs) and laws with respect to the requirements they address.

131. All of the DCGs have the same basic structure but vary in details and scope, depending on the groups of institutions. They are organized by chapters as follows:

\begin{tabular}{|c|c|}
\hline Chapter 1: & Objectives and Definitions \\
\hline Chapter II: & Customer Identification Policy \\
\hline Chapter III: & Know Your Customer Policy \\
\hline Chapter IV: & $\begin{array}{l}\text { Large Currency Transaction Reports (CTRs: transactions equal to or greater than } \\
\text { equivalent of US } \$ 10,000)\end{array}$ \\
\hline Chapter V: & Reports of Unusual/Suspicious Transactions (STRs: suspicious transaction reports) \\
\hline Chapter VI: & $\begin{array}{l}\text { Reports of Worrisome Transactions (STRs involving officials, employees or } \\
\text { agents of an FI) }\end{array}$ \\
\hline Chapter VII: & Internal Structures \\
\hline Chapter VIII: & Training and Dissemination \\
\hline Chapter IX: & Automated Systems \\
\hline Chapter X: & Confidentiality \\
\hline Chapter XI: & Other Obligations \\
\hline Chapter XII: & General Provisions \\
\hline
\end{tabular}

132. The insurance regulations (DCG 140) apply to all classes of insurance policies, not only to life and investment linked policies. This goes beyond the FATF requirements and reflects a more conservative approach. The insurance law (Article 140 Ley General de Instituciones y Sociedades Mutualistas de Seguros) establishes the general AML/CFT obligations on both insurance companies and insurance agents, including the duty to report suspicious activities. Insurers and their agents are required to comply with the AML/CFT requirements established in the law in accordance with regulations issued by the SHCP. The principal AML/CFT regulations were issued under DCG 140 but these do not include an explicit obligation of agents to report suspicion of ML/TF in all cases to the compliance officer, as exists under Regulation 14 and required under Article 140 of the insurance law. They do impose requirements for agents to observe certain CDD measures (DCG 140 imposes other customer identification requirements on agents (e.g. Reg. $4,6,16$, and 18) which are elaborated under Recommendation. 5 below) to enable the insurance companies to comply with their own CDD and other AML/CFT obligations, including the duty to report to the compliance officer of the insurance company which attempted suspicious transactions (Regulation 15). Insurance companies are required to supervise compliance with the applicable AML/CFT obligations by their agents (Reg. 36). Notwithstanding the lack of an explicit obligation of agents to report suspicion of 
$\mathrm{ML} / \mathrm{TF}$ in all cases to the compliance officer, the authorities are legally empowered to interpret such regulations. They assert that the the legal and regulatory provisions impose on agents an obligation to report their suspicion to the compliance officer of the respective insurance company and failure to do so would be subject to corresponding sanctions.

133. As mentioned above, a key limitation is the absence of an explicit provision in the regulations that contemplates all provisions of Article 140 of the insurance law on AML/CFT for agents to report unusual/suspicious activities in all cases even if to the compliance officer of their insurance companies. This issue should also be reviewed in light of the regulations issued by the SHCP of March 14, 2004 and May 18, 2005 where the SHCP/FIU establishes the reporting format and requirements for suspicious and large transactions only apply to insurance companies as contained in Regulations 19, 20, and 22 of DCG 140. These three provisions only seem to apply to insurance companies and not to agents. Consequently, there is a need for clarification in the application of the AML/CFT requirements for agents, and if necessary, establish clear linkages, among the provisions of Article 140 of the insurance law, the AML/CFT regulations under DCG 140, and the March 2004 and May 2005 regulations for reporting suspicious activities.

134. A regulatory gap exists with respect to the unregulated SOFOMES (multipurpose financial institutions that are not part of a financial group). They are covered, along with centros cambiarios and money remitters, under the General Law of Auxiliary Organizations and Activities for purposes of AML/CFT. The SAT will be the supervisor for AML/CFT purposes but implementing AML/CFT regulations have not been issued as yet. (They are expected to be issued during the last quarter of 2008). These entities no longer require a license to operate, hence, fit and proper controls would not apply to them. They are not allowed to accept deposits from the public but they can raise funds through a number of sources such as the sale of commercial paper, borrowings, and equity from private and public sources. Over the past year, the growth of this sector has been around 850 percent totaling 376 institutions in February 2008.

135. As indicated in footnote 24, statistics the authorities provided by the authorities indicate that there are approximately 4380 centros cambiarios and money remitters, of which 3069 have given the required notice to the SAT about their activities. According to the SAT, approximately 40 percent (post mission the authorities indicated that this figure is 81 percent ) have been subject to AML/CFT supervision. It is not known exactly how many of these operations may be in existence in Mexico, and how many may be carrying on significant volumes of business, e.g., above the legal US $\$ 10,000$ threshold, or the US\$15,000 threshold for occasional transactions established for FATF Recommendation 5.2(v).

\section{Prohibition of Anonymous Accounts (c. 5.1)}

\section{Banks and SOFOLES (reg. 9 of DCG 115) and Popular savings and loans (Regulation 6 of}

DCG 124) explicitly prohibit maintaining anonymous accounts or accounts in fictitious names. These regulations state that entities shall not establish or maintain anonymous accounts or accounts under fictitious names. Accounts cannot be opened or transactions executed until customers have been identified in accordance with the regulations.

137. The 2006 regulations (Regulation 4 of DCG 115 and DCG 124) also allow for numbered and coded accounts, but are subject to the CDD requirements established in the regulations. While not explicitly stated, the identification records for such accounts would be available to the appropriate internal staff such as the compliance officer and internal auditor, as well as to supervisors and other competent authorities. (See discussion under Recommendation 15 for internal controls). The regulators believe that such accounts are not generally used. A few FIs confirmed that they maintain such accounts particularly for high net worth clients. The mission did not observe any indications of noncompliance with the 
prohibition against anonymous or fictitious accounts in Mexico or outside of Mexico. The AML/CFT regulatory requirements, including this prohibition, would also extend to foreign branches and subsidiaries.

138. The DCGs (2004) for the rest of the FIs do not contain explicit prohibitions against the use of anonymous or fictitious name accounts. However, the customer identification and record-keeping requirements contained in the regulations, if strictly implemented, would effectively preclude the use of anonymous accounts, even though this would not necessarily preclude maintaining such accounts in fictitious names. For clarity and consistency in implementation, the introduction of similar prohibitions as contained in DCGs 115 and 124 would be useful. There are plans to make these changes as part of a regulatory reform process that is under consideration by the authorities.

When is CDD required (c. 5.2)

\section{(a) Establishing business relations}

139. Chapter 2 (customer identification policy) and Chapter 3 (know-your-customer policy) establish relatively comprehensive CDD requirements for FIs that broadly cover both occasional transactions (though not explicitly in all of the 2004 regulations as discussed below) and business relationships. The 2006 regulations for credit institutions (DCG 115) explicitly distinguish between transactions with occasional customers ("usuarios") and commercial relations with customers. These are discussed further below.

140. Banks and SOFOLES (DCG 115): As mentioned above, the regulations under Chapter II and Chapter III establish the requirement to conduct customer identification and CDD for business relationships. In these regulations, a clear distinction is made between business relationships and occasional customers or "usuarios."

141. Stock brokers (casas de bolsa) (DCG 52 bis 4): Regulation 4 states that stock brokers (who are also authorized to conduct currency exchange (casa de cambio) business) are required to identify their clients and conduct CDD "prior to opening of accounts or executing contracts of any type, and when carrying out Operations referred to in article 82 of the Ley General de Organizaciones y Actividades Auxiliares del Credito (the latter refers to currency exchange business), in amounts equal to or exceeding the equivalent in local currency of US $\$ 10,000 \ldots$.. The authorities indicate that the US $\$ 10,000$ threshold does not apply to business relationships, but should only apply to occasional transactions in the context of their foreign currency businesses. This would be consistent with the regulations for casas de cambio (Regulation 4 DCG 95) which has a similar customer identification threshold. As worded, however, it can be misinterpreted that the threshold applies to both brokerage and currency exchange business, and not only to the latter. Minor change in wording of this requirement could emphasize that the threshold applies only to occasional transactions relating to their currency exchange business to foster consistent implementation by FIs.

142. No distinction is made as to whether this requirement applies to business relationships as well as to occasional one-off transactions. While the threshold requirement may be appropriate for occasional transactions, it would not meet the requirement for the establishment of business relationships, even with respect to currency exchange business.

143. Retirement Fund Administrators and Fund Operators and Distributors (DCG 108 Bis and 91, respectively): Regulation 4 Chapter II: This regulation requires customer identification for the opening of all accounts and transactions. Fund operators and distributors are required to identify their clients at the time they open investment accounts, whether they be individuals or institutional investors. Some exceptions apply for retirement fund administrators who need to identify their clients when they make 
deposits (voluntary/complementary contributions) to their retirement accounts at teller windows. This is acceptable as most deposits to their accounts are made directly by their employers.

144. Insurance Companies (includes mutual insurance companies) (DCG 140): Regulation 4, I and II. These provisions require insurance companies to open customer identification files prior to the completion of any contract, where they shall record identification information for individuals and legal entities. They are also required to request customers to present documentation (verification) in support of the information recorded in the identification files, but the timing varies depending on the amount of the contract (See EC5.3, EC5.13 and EC5.14 below); For policies with annual or single premium of less than the equivalent of US $\$ 10,000$, individuals should present such documentation for verification and included in the identification files no later than the time a claim is made. In addition, FIs shall require such individuals to present documentation when incremental payments for annual or single premium policies reach or exceed the equivalent of US\$10,000. When the annual or single premium is equal to or exceeds the US\$10,000 threshold, presentation of documents is required not later than the time a policy is delivered to the customer. Please see discussion of these thresholds under EC 5.9, EC 5.13 and EC 5.14 with respect to simplified CDD and deferment of identification verification.

145. For legal entities, customer identification files shall be established, and identification documentation requested, prior to the completion of contracts as for individuals in the preceding paragraphs. However, presentation of identification information for verification should be conducted no later than the date when the policy is delivered (which, according to the CNSF, is usually when the contract has been "perfected"), with respect to single or annual premium policies that are less than the equivalent of US\$10,000. In practice, information on the clients is obtained before the policy is delivered. Please see discussion of these thresholds under EC 5.9, EC 5.13 and EC 5.14 with respect to simplified $\mathrm{CDD}$ and deferment of identification verification. Discussions with industry representatives indicate that they generally follow the regulatory requirements in practice for both individual and legal entities.

146. Licensed Casas de Cambio) (DCG 95): The regulations are more geared for CDD for occasional transactions and there are no clear requirements for these entities to conduct CDD when they establish business relationships, as exist under e.g., DCG 115 for banks. Regulation 3 requires casas de cambio to establish policies and procedures for customer identification while Regulation 4 only requires them to identify their clients prior to carrying out transactions equal to or in excess of the equivalent of US $\$ 10,000$. This threshold would be appropriate for occasional transactions but not for business relationships. Some casas de cambio informed that they maintain long term business relationships with clients for whom they provide a variety of services, such as payment for imports. Consequently, there should be an explicit CDD obligation for the establishment of business relationships without thresholds, and not only for occasional transactions. (Also see discussion for stock brokers above under c5.2 with respe $t$ to foreign currency transactions by brokers.)

147. Currency Exchange Centers (Centros Cambiarios) (DCG 81-A) and money remitters (DCG 95 Bis): Some of these firms and persons are believed to maintain business relationships with clients and also engage in transactions with occasional users. Similar to the previous paragraph for casas de cambio, the regulations do not adequately provide for CDD when business relationships are established. They are generally designed for CDD with respect to occasional transactions that equal or exceed a regulatory threshold of US $\$ 3,000$.

148. All other FIs: The regulations do not explicitly distinguish in the definitions between business relationships and occasional transactions. In practice and in the absence of specific identification thresholds, FIs would conduct CDD before establishing business relationships as the definition of client can be interpreted broadly enough as to cover both types of business. 


\section{(b) Carrying out occasional transactions above USD/EUR 15,000 including linked transactions (see discussion above under (a)}

149. Banks and SOFOLES (DCG 115): The CDD requirements apply generally regardless of the amounts involved with one exception. There is a CDD requirement for occasional transactions conducted in cash (See Chapter II, Regulation 18) equal or greater than the equivalent of US $\$ 3,000$, which is below the FATF threshold of US\$10,000 for non-wire transactions. For such transactions, credit institutions are required to obtain customer identification information for both natural and legal persons. There is no requirement to group linked transactions below this amount, but which in total equal or exceed the US\$10,000 threshold for occasional customers. There is a requirement in Regulation 46 to implement automated monitoring systems to detect structuring linked monetary transactions over a specified period of time for purposes of reporting large monetary transactions. However, because this requirement applies to account relationships, it is clearly not intended for occasional or one-off transactions. Broadly similar provisions apply to other FI below.

150. Popular savings and loans (DCG 124): No provisions are made for CDD with respect to occasional transactions. All customers must be identified regardless of whether they conduct occasional transactions or conduct business relationships. Large FIs covered by these regulations (Regulation 54 for Type 2, 3, and 4 entities) are also required to implement monitoring systems to detect structuring of transactions for purposes of reporting large monetary transactions. As under DCG 115, this requirement is not strictly for occasional transactions or clients as it applies to business account relationships.

151. Licensed Casas de Cambio) (DCG 95): CDD is required when these FIs engage in transactions equal to or exceeding the equivalent of US $\$ 10,000$ which is consistent with Recommendation 5.2 (b). However, for CDD purposes, there are no explicit provisions that would require FIs to consolidate multiple-linked transactions below this threshold that add up to US $\$ 10,000$ over a reasonable period of time. There is also a requirement under the provisions for establishment of automated systems in Chap. IX of the regulations for casas de cambio to have automated systems to detect and monitor structured monetary transactions carried out by the same customer in structured or multiple amounts within five days totaling or exceed the equivalent, in Mexican pesos, of US\$10,000. Nonetheless, it appears that the main purpose of this requirement is to enable ("para efectos") FIs to comply with the reporting obligations for large transactions under Regulation 17.

152. Currency Exchange Centers (Centros Cambiarios) (DCG 81-A) and money remitters (DCG 95 Bis): Chapter II Regulation 4 requires these firms and persons to identify and conduct CDD on their clients when they engage in transactions equal to or in excess of the equivalent of US $\$ 3,000$. The monitoring mechanism required for structured monetary transactions by a client is broadly similar to those for casas de cambio except that it does not include the reference to compliance with large transaction reporting. Currency exchange centers are legally prohibited from carrying out transactions in excess of the equivalent of US\$10,000.

153. Stock brokers (DCG 52 bis 4): Stock brokers are required to conduct CDD when they engage in currency exchange transactions equal to or in excess of the equivalent of US\$10,000. For CDD purposes, there are no explicit provisions require FIs to consolidate multiple-linked transactions below this threshold that add up to US\$ 10000 over a reasonable period of time. There is such a requirement under the provisions for the establishment of automated systems in Chapter IX of the regulations. (See discussions under casas de cambio above applying to transactions with a single client).

154. All Other FIs: The other regulations apply generally to all transactions irrespective of the amount, and to business relationships which in practice would be the norm. 
155. Banks and SOFOLES (DCG 115) and Popular savings and loans (DCG 124): All of these entities are authorized to conduct wire transfers. Chapter II Regulation 16 of DCG 115 applies to occasional customers requiring these FIs to conduct CDD when they conduct wire transfers, regardless of the amount.

156. Other FIs: Tere are no explicit requirements or thresholds for occasional wire transfers as discussed under (b) above, and centros cambiarios are legally prohibited from carrying on wire transfer business.

\section{(d) Suspicion of ML or TF}

157. All FIs: There is no explicit CDD requirement when there is suspicion of money laundering or terrorist financing. However, the regulations require FIs to strengthen the monitoring of transactions when there are indications that the client is acting for another person, where there are doubts about previouslyobtained identification, or where there are concerns about the conduct of transactions. These are all factors that FIs should take into account when determining whether to file a suspicious transaction report. (See e.g., DCG 115 Regulation 31 and 36).

\section{(e) Doubts about the veracity or adequacy of previously obtained identification}

158. All FIs. The regulations require FIs (e.g. DCG 115 Chapter II Regulation 21) to update customer documentation when, inter alia, there are doubts about the veracity of client information. In addition, the regulations (e.g., DCG 115 Chap. II reg. 4) also state that when identification documents presented by a client show erasures or alterations, or in some cases are false, FIs should obtain other forms of identification, or request two bankers or commercial references and two personal references. Such references shall include the names, address, and phone number of the referees, which shall be verified before an account is opened or a transaction completed.

159. The requirements described under sections (d) and (e) above should more clearly require the need to conduct CDD when there is suspicion or doubt as to previously-obtained information. In addition, it should be consistent with the need to refuse a transaction or business relationship or terminate an existing relationship when CDD cannot be completed as discussed under c5.14 and c5.16 below. In these circumstances and consistent with the Interpretative Note to Recommendation 5, regulatory guidance is required to avoid tipping off the client in the course of conducting CDD when there is suspicion. (See also the provisions in the regulations similar to DCG 115 Chapter III Regulation 27 for the procedures to be followed with respect to attempted suspicious transactions.)

160. In practice, there appear to be differences in the interpretation of the regulatory requirement with respect to the conduct of CDD for regular and occasional customers. Some FIs seem to take a more conservative approach and require identification, if not full CDD, of all clients whether relational or occasional.

Identification measures and verification sources (c. 5.3)

161. All the regulations impose relatively strict customer identification requirements on a broad range of categories of clients, including for individuals, legal persons and beneficiaries, and include specific provisions for nationals and foreigners. These requirements are mainly contained in Chapters II and III of the regulations that impose the need for policies and procedures for the customer identification (Chapter I) 
and "know your customer" (Chapter II), that include a requirement to implement criteria and procedures for verifying and updating such information.

162. All the regulations, (particularly DCG 115 for banks and other credit institutions and DCG 124 for popular savings and loans) impose obligations on FIs to apply risk-based approaches to customer identification and due diligence. These are discussed in more detail under c.5.8 and c.5.9 below.

163. Banks and SOFOLES (DCG 115) and Popular savings and loans (DCG 124): Chapter II, Regulations 3 and 4, outline the main customer identification and verification requirements for the following categories of clients that include recording details and keeping copies of the documents. FIs are required to open a customer identification file before opening an account or conducting a transaction which must include, at a minimum, the following:

For physical persons (Mexican nationals)

- Name, address, date of birth, occupation, business or profession, telephone, email, and if available, a national identification number (CURP), and/or federal tax identification number (RFC), and the number for the Advanced Electronic Signature.

- $\quad$ Presentation and copy (see DCG 115 Regulation 3) of: original personal identification document issued by an official body with photograph and signature and if relevant the address. A number of alternative official documents can be presented but it is considered by the industry that voter registration cards (which most citizens have) and passports are the most reliable.

- National identification card (CURP), and/or when available the taxpayer identification card and the Advanced Electronic Signature.

- $\quad$ Proof of address when the address given for opening the account is not the same as in the identification document, or when the identification document does not show address. To this effect, the customer may present supporting documentation such as recent utility bills or statements. The CNBV may approve other documents for this purpose.

- When the client is acting for another under a power of attorney, the original copy of the power of attorney should be requested or a certified copy thereof, as well as the identification and proof of address of the agent.

\section{Legal persons (Mexican)}

- $\quad$ Company name, line of business, tax ID number, if available Advanced Electronic Signature, address, telephone number, email, date and country of incorporation, names of administrators, general manager or legal representative as applicable, who can bind the entity with respect to the FI.

- Presentation and copy of: official or certified copy of the registered articles of incorporation, tax identification card or Advanced Electronic Signature, proof of address, official or certified copy of the power of attorney, and personal identification of the legal representative.

- $\quad$ For recently-formed entities not yet registered in the Public Commerce Register, the FI shall request a legally signed document declaring that the registration will be done and undertaken to provide the necessary documentation at that time. 


\section{Physical persons (foreigners)}

- Original passport and document showing their legal status in Mexico, full names, date of birth, nationality, address in country of origin, address in Mexico if known, tax identification number and Advanced Electronic Signature, if available.

\section{Legal persons (foreign)}

- Legal or apostil copy of their constitution, and a certified document of identity of their legal representative. When the latter is a foreigner, the documents in the previous bullet should be presented.

More basic requirements apply for financial entities (including foreign), government agencies and entities listed in Appendix 1: subject to "simplified" due diligence regime. See c5.9)

- $\quad$ Company name, activity or corporate purpose, federal tax identification number, Advanced Electronic Signature, address, phone, email, name of administrators, director, general manager or agent (as applicable) who can bind the entity.

- Official or certified copy of the power to bind the entity, certificate of designation as a financial institution (Article 90 of Financial Institutions Law), personal identification of the legal representative.

Funds providers ${ }^{34}$

- Physical persons: Broadly similar as for Mexican nationals, except for occupation or profession, activity of line of business, telephone number, and email.

- Legal persons: More limited requirements than for other legal entities and does not include line of business or corporate purpose, contact details as well as details of administrators and legal representatives.

\section{Beneficiaries}

- Ultimate Beneficiaries ("propietarios reales"): Similar identification requirements as for individuals and legal entities above. (See c5.5 below.)

- For beneficiaries that inherit the rights to an account or transaction in the event of death, at least: full name, address, and date of birth. Standard identification documentation is required at the time that they exercise their rights.

\section{Joint-owners and authorized third parties}

- Similar requirements as for other clients, as applicable.

\footnotetext{
${ }^{34}$ Funds providers ("provedores de recursos") are third parties that deposit funds into an account without being the beneficiaries of the account or transactions, except for employers and government agencies with respect to employment contracts and social programs, respectively.
} 
164. FIs are required to retain copies of customer identification documents after comparing them with their originals, as well as any other applicable information such as client interviews. Before establishing a business relationship with a client, FIs must conduct a personal interview with the customer or his legal representative, and a record kept of such interview.

165. When identification documents show that they have been erased or altered, the FIs should obtain other forms of identification or request bankers and personal references which will be verified with the issuers of such references. Once the customer identification file has been completed, it can be used by the FI for all other accounts and transactions of the customer to avoid having to repeat identification procedures. With regards to financial groups, the customer identification file may be prepared and retained by any member of the group, subject to certain conditions as discussed in Recommendation 10.

166. The identification requirements outlined above apply to all types of accounts including numbered and coded accounts. Such accounts are known to be used in the financial sector (e.g., banks).

167. Other FIs (2004 DCGs): The customer identification and verification requirements for the other FIs are broadly similar but more limited than those for banks and other credit institutions described above. They must compile a customer identification file, prior to the opening of accounts or entering into contracts of any type. Two main differences are as follows:

168. DCG 95 applicable to casas de cambio which require these entities to identify customers prior to carrying out foreign exchange transactions in amounts equal to or higher than the Mexican peso equivalent of US\$10,000 (See c5.2 above). For other FIs (stock brokers, operators, and administrators of investment companies and auxiliary organizations of credit), the customer identification and verification requirements establish the obligation of identifying their customers prior to the opening of an account or entering into any type of contracts.

169. DCG 140 Regulations 4, I and II: for insurance companies. (See EC 5.2 above for Insurance Companies). These provisions require insurance companies to request customers to present documentation in support of the information recorded in the identification files but the timing varies depending on the amount of the contract. (See EC5.9, EC5.13 and EC5.14 below.) For policies with annual or single premium of less than the equivalent of US\$10,000, individuals should present such documentation for verification and included in the identification files no later than the time a claim is made. In addition, insurance companies shall require such individuals to present documentation when incremental payments for annual or single premium policies reach or exceed the equivalent of US\$10,000. For legal entities, customer identification files shall be established, and identification documentation requested, prior to the completion of contracts as for individuals in the preceding paragraphs. However, presentation of identification information for verification is not required until the date when the policy is delivered (which according to the CNSF generally occurs when the contract is perfected), with respect to single or annual premium policies that are less than US\$10,000. In practice, information on the clients is obtained at the time the policy is being negotiated.

170. Except for the above, all FIs are required to obtain the following identification information, before establishing a business relationship or conducting a transaction:

\section{Physical persons (Mexican nationals)}

- $\quad$ Full name, home address; date of birth; nationality; occupation or profession; activity or line of business; phone(s); e-mail address, if applicable; national identification number (CURP) and/or the taxpayer's identification number if available. 
- $\quad$ FIs must also obtain copies of the following documents: original copy of personal identification document issued by the competent authorities that is current and bears the photograph, home address, and signature of the holder.

- $\quad$ Acceptable identification documents include voter's registration cards, passports, professional license, and military service identification cards. Other documents that may be considered include, inter alia, drivers licence, tax identification cards, and other officially issued identification by federal and state authorities. The most widely accepted and available identification document is the voter's registration card.

- $\quad$ Proof of address is required when the home address listed on the account or contract does not coincide with the address on the identification document, when the customer does not provide a home address. In such cases, the customer must submit e.g., copies of recent utility bills, property tax receipts or, bank statements of account.

- When the client is acting for another under a power of attorney, the original copy of the power of attorney should be requested or a certified copy thereof, as well as the identification and proof of address of the agent.

\section{Legal entities: Mexican}

- $\quad$ Corporate or business name; line of business, activity or corporate purpose; taxpayers' number; business address; phones; e-mail address, if applicable; date incorporated; nationality, and name of administrator, director, general manager or legal representative who can bind the entity.

- The following documents must be obtained: official copy or certified copy of the articles of incorporation; tax identification card; proof of address; official copy or certified copy of the power of attorney of the legal representative or representatives; and the identification documentation for the representatives.

- For newly-formed companies that have not yet been registered in the Public Commerce Register, the FI shall request a legally-signed document declaring that the registration will be done and undertaken to provide the necessary documentation at that time.

\section{Individuals: Foreigners}

- Original passport and document showing their legal status in Mexico, full names, date of birth, nationality, address in country of origin, and address while in Mexico, if known.

\section{Legal entities: Foreign}

- (Same as for banks and credit institutions above.)

Financial Entities (including foreign), government agencies and entities listed in Appendix 1: subject to the simplified due diligence regime. See c5.9)

- (Same as for banks and credit institutions above except that, as drafted, the provision to apply simplified measures is unqualified by the need to establish lower risk, and appears to be mandatory.) 


\section{Beneficiaries with survival rights upon the death of the client}

- Identification information is required for beneficiaries that includes the same data and documents as for the principal customers in Chap. II Regulation 4, when they exercise their rights as beneficiaries. This would include full name, home address, and date of birth. (See e.g., Regulation 4 I of DCG 52 bis, DCG 108, DCG 140, DCG 112, and DCG 95 bis).

171. Ultimate/final beneficiaries that acquire rights or benefits under an account, contract or transaction, including those that exercise effective control over a legal person or arrangement including beneficiaries of a trust, mandate or similar arrangement.

- $\quad$ FIs should comply with the identification requirements as for Mexican nationals and legal entities under Paragraph I and II of Regulation 4. It is unclear whether this provision applies only to foreign beneficiaries as these paragraphs only relate to Mexican nationals and legal entities. The following is required.

- Legal commercial entities: information on the corporate structure and controlling shareholders.

- Partnerships and nonprofit organizations: the name, the partners, associates or their equivalent.

- Trusts, mandates or commissions or similar legal arrangement: Regulation 6 in some of the 2004 regulations states that when the identity of trust beneficiaries, mandates, principals, shareholders or partners is indeterminate, the same data and documents indicated in Regulation 4 must be requested. This provision is not well drafted and seems incomplete. It should be reviewed/revised to clearly state that the identification required under Regulation 4 should be obtained when the indeterminate parties become known. The text will be clarified in the context of an ongoing review and reform of the regulations.

\section{Joint-owners and authorized third parties}

- (Similar requirements as for other clients, as applicable.)

172. All the regulations contain a provision, under Chapter XI: Other Obligations, that, where a FI has doubts about the accuracy of a customer's taxpayer identification card and/or the serial number of the Advanced Electronic Signature, they will verify the authenticity of the information contained in these, in accordance with the procedures established by the Secretaria (SHCP) for such purposes. This provision should be reviewed as it may adversely affect compliance with c.5.15 and c.5.16 below that require refusal or termination of a transaction or business relationship when proper CDD cannot be completed.

173. Regulation 4 of the 2004 regulations states that when there are indications or there is certainty that identification documents presented by customers are false or show erasures or alterations, FIs must obtain other means of identification, or ("o bien") request two banking or commercial references, and two personal references, including name, address and telephone, which will be verified before opening an account or executing a contract. This provision is not well drafted and if strictly applied can result in customer identification requirements that are less reliable and reducing the requirements to commercial and personal references, even when identification first presented is false or show alterations. Suspect identification information should generally require enhanced CDD, refusal and/or filing a suspicious report with the FIU. Note that chapter V of all the Regulations lists the presentation of false information as a possible basis for filing a suspicious activity report. This provision, as drafted, can significantly reduce the rather comprehensive identification documentary requirements established previously in these regulations. The authorities maintain that this was not the intention of the regulations but the drafting should be reviewed and revised in the context of the ongoing the current review and reform of the regulations. 
174. In practice, most FIs appear to identify their clients, irrespective of the type of customer and amount of transactions involved. The most common and reliable form of identification used is the Voters Identification Card and most persons above voting age have one. The Electronic Tax Number and passports also seems to be used due to their reliability, when available.

\section{Identification of Legal Persons or Other Arrangements (c. 5.4)}

175. See customer identification requirements for legal entities above. The regulations require identification and verification of any person acting on behalf of a legal person, [including the name of the company, line of business, corporate identification numbers, contact details, country of incorporation, names of administrators, general manager or legal representative as applicable, who can bind the entity with respect to the FI.] In the case of trusts, powers of attorney, agency or other similar arrangements, the identification requirements described under c.5.3 concerning the parties to such arrangements must be observed, mutatis mutandis. This includes identification of settlors, beneficiaries, principals, and agents. See c.5.5.2 below.

176. FIs must verify the legal status of a legal person or arrangement by obtaining a copy of incorporation and registration documents including an official or certified copy of the registered articles of incorporation. The regulations also require certified copy of the instrument (e.g. power of attorney) that provides the authority to the legal representative, as well as the identification of such person. As mentioned under 5.3 above, verification of incorporation documents can be delayed in cases of newly-incorporated entities, subject to certain undertakings.

177. In Mexico, only financial institutions (e.g. credit, insurance, SOFOMES and other specified entities) are allowed to act as trustees, hence the incidence of FIs providing services to trusts/trustees would be much limited than in other jurisdictions. However, from discussions with industry representatives, it is not standard practice across the sectors for FIs to explicitly request the applicants for business to state in the application documents the capacity under which they are acting, which assist FIs determine when an applicant for business is acting on behalf of others, e.g., as trustee for beneficiaries of a trust established either in Mexico or under the laws of another jurisdiction.

\section{Identification of Beneficial Owners (c. 5.5; $5.5 .1 \& 5.5 .2)$}

178. (See description under c5.3 and c5.4 with respect to identification requirements legal persons.) The regulations have broadly similar requirements therefore, in the interest of brevity the following description is largely based on DCG 115.

179. Regulation 31 states that when there are indications or certainty that a customer is acting for and on behalf of another person, the FI, to the extent possible, shall identify the beneficial owner without prejudice to the duty of confidentiality that the beneficiary may have with third parties by virtue of a contract or agreement ("contractual o convencional"). However, as mentioned under c5.4 above, it is not standard practice across the sectors for FIs to explicitly request the applicants for business to state in the application documents the capacity under which they are acting (see c5.4 above).

180. Regulation 4 VI and VIII, Regulation 11, Regulation 31, and Regulation 32 of the regulations require FIs to identify the beneficial owners of accounts and transactions. In particular, Regulation 32 requires FIs to establish identification procedures to identify beneficial owners ("propietarios reales") pursuant to the requirements established under Regulation 4 with respect to individuals and legal persons and arrangements, as appropriate. Beneficial owners should be identified in the following cases: 
- Commercial legal entities classified as high risk. FIs are required to determine corporate structure and controlling shareholders. To this end, FIs are required to obtain corporate information including company name, country of incorporation, address, on corporate purpose and capital stock of the legal entities that make up the business group or, where appropriate, the business groups that make up the conglomerate, as defined under Mexican law. These requirements are limited and they should extend to all types of legal entities.

- Nonprofit organizations or partnerships classified as high-risk. FIs should identify the partners, associates, or their equivalent. In this regard, FIs must adopt measures to identify the person or persons who have control of or have decision-making power over the administration of such entities. In the case groups of such entities, FIs shall identify the persons that have ultimate control of the legal entities, and control of voting power in general meetings, those that have the power to name the majority of members of the board of directors or equivalent body, or through any other means, control the legal entity, irrespective of the percentage of the equity which they hold in the company or association.

- $\quad$ Trusts, mandates and any other similar legal arrangement. When the identity of the beneficiaries and other parties to such arrangements is indeterminate, the identification requirements under Regulation 4 for individuals and legal entities shall apply when they exercise their rights before the FI. (See discussion under EC5.3 on the requirement for identification of "indeterminate" parties to trust and other legal arrangement.) This provision is not well drafted and seems incomplete. It should be reviewed/revised to clearly state that the identification required under Regulation 4 should be obtained when the indeterminate parties become known. The text will be clarified in the context of an ongoing review and reform of the regulations.

181. The above requirements do not apply to the identification of legal persons whose shares or negotiable instruments representing such shares are listed on the stock exchange.

182. Some provisions in the regulations should be reviewed for consistency of application across all the financial sectors. For instance, the 2004 regulations could be clarified to indicate that the identification requirements for ultimate beneficiaries should apply to both Mexican and foreign beneficiaries as provided for in the 2006 regulations.

\section{Information on Purpose and Nature of Business Relationship (c. 5.6)}

183. There is no direct explicit obligation in any of the regulations to obtain information on the purpose and intended nature of business relationships. However, the various regulations do contain some but insufficient elements for obtaining such information as described below:

184. Banks and SOFOLES (DCG 115), and Popular savings and loans (DCG 124): Regulations 23 and 24 of DCG 115 require FIs to establish the transaction profile of a client. Such profile is to be based on client information available to the institution including the amount, number, type, nature, and frequency of the transactions that such customers normally conduct; origin and destination of funds; on the knowledge of the employee or officer of the institution with respect to its portfolio of customers, and on other factors and criteria determined by the FIs themselves. Regulation 25 requires FIs to, for new or existing customers who have been classified as high risk, obtain from such customers identification questionnaires that allow for collection of more information on the origin of funds and on the activities and transactions that they conduct or intend to carry out.

185. DCG 124 contains similar requirements in Chapter III Regulation 17 to establish client transaction profiles. However, the requirement in Regulation 44 (as in DCG 115 above) to obtain identification questionnaires for high-risk clients with respect to the origin of funds, activities, and 
transactions that they conduct or intend to conduct, only applies to the larger Type 2, 3, and 4 savings and loans. ${ }^{35}$ Consideration should be given to applying this requirement to the smaller Type 1 entities where similar high-risk clients are identified.

186. Other FIs: Similar to DCG 115 and 124 above, the other regulations require FIs (e.g., DCG 52 Bis-4 Regulation 18) to establish client transaction profiles that shall be based on information that the client provides to the institution including in relation to the amount, number, type, nature, and frequency of the transactions that such clients normally conduct; origin and destination of funds; knowledge of the employee or officer of the institution with respect to its portfolio of customers, and on other factors and criteria determined by the FIs themselves.

Ongoing Due Diligence on Business Relationship (c. 5.7; 5.7.1 \& 5.7.2)

187. The regulations contain a number of provisions, sometimes indirect, that as a whole meet the ongoing due diligence requirements of c.5.7 with respect to the monitoring of customer transactions and updating of information. FIs are required to update customer information, including the monitoring of transaction profiles, on the basis of ML and FT risks. Some of the key provisions are described below, seriatim.

188. Banks and SOFOLES (DCG 115) and Popular savings and loans (DCG 124): These two regulations contain broadly similar requirements.

- $\quad$ Regulation 3: FIs should have customer identification policies that, inter alia, require procedures to update customer information.

- Regulation 5: In the case of concentration/master accounts, FIs should closely monitor transactions.

- $\quad$ Regulation 19: FIs should establish mechanisms to monitor cash transactions above a certain threshold (USD 3 000).

- $\quad$ Regulation 20: FIs should establish more strict monitoring mechanisms with respect to customers whose line of business or activity is related to industrial, commercial, or service sectors that involve large amounts of US\$ cash.

- $\quad$ Regulation 21: For customers classified as high risk, including PEPs, FIs must establish mechanisms to update customer identification files at least once a year.

- $\quad$ Regulation 23: KYC policies must include, at a minimum, procedures to establish customer transaction profiles and to develop systems to monitor client transactions in order to detect inconsistencies with such transactions.

- $\quad$ Regulation 31. Monitoring of customer transactions should be strengthened when there are concerns that a person is acting for another or there are doubts about information provided by a client.

\footnotetext{
${ }^{35}$ Type 1: Assets under 7,000,000 Investment Units (UDIS) Type 2: Assets between 7,000,000 and 50,000,000 Investment Units (UDIS)". Type 3: Assets between 50,000,000 and 280,000,000 Investment Units (UDIS). Type 4: Assets over 280,000,000 Investment Units (UDIS)". The value of UDIS as published in the Federal Official Gazette on June 25, 2003. [Value of an UDI on June 25, 2003=

US\$3,272,020 Mexican pesos-US\$0.3110. Value of a UDI up to March 7, 2008 is US\$3.9674 Mexican pesos US\$ 0.3639].
} 
- $\quad$ Regulation 46: FIs should have automated systems to, inter alia, detect and monitor small structured monetary transactions below the CTR threshold (US\$10,000).

189. Other FIs: The requirements for other FIs to conduct ongoing CDD on business relationships are generally similarly but less detailed than under DCG 115 and DCG 124. The requirements can vary according to the nature of each entity. The requirements for stock brokers under DCG 52 Bis-4 are described below as an example.

- $\quad$ Regulation 3: Customer identification policies should have procedures that include updating of customer information.

- $\quad$ Regulation 11: FIs should have measures to update information and documentation contained in customer files in order to maintain current such information during the course of a business relationship, especially when significant changes to a client's transaction profile is identified, or when there is doubt about previously-obtained information.

- $\quad$ Regulation 13: FIs should more closely monitor customer transactions in cases of higher risk.

- $\quad$ Regulation 18: KYC policies should include procedures to update and monitor customer identification.

- $\quad$ Regulation 31: FIs should have automated systems to detect and monitor transactions for purposes of identifying structuring below US\$10,000.

190. In practice, ongoing CDD appeared to concentrate mostly on monitoring of account activity to detect large and suspicious activities, in line with the requirements in Chapter IX to maintain automated systems.

\section{Risk-Enhanced Due Diligence for Higher-Risk Customers (c. 5.8)}

191. All of the regulations covering the various sectors contain risk-sensitive approaches that allow for enhanced and simplified CDD but no guidelines have been issued to aid FIs in their CDD regulatory compliance. In particular, under Chapter III of the regulations (e.g., Regulations 25 and 26 of DCG 115 and Title II Chapter II of DCG 124), FIs are required to classify customers and transactions in accordance with the degree of ML and TG risks. The main provisions for enhanced CDD are:

192. Banks and SOFOLES (DCG 115): FIs should conduct enhanced CDD for higher-risk categories of customers, business relationships, and transactions in the following cases:

- Regulation 20: Enhanced monitoring of transactions involving sectors that deal in large sums of U.S. dollars.

- $\quad$ Regulation 21: FIs should have risk-based procedures that require, for high-risk clients, conducting a visit to the customer's address, in order to corroborate the information and identification documents provided. The results of such visits must be recorded in the customer's identification file. In addition, for such high-risk customers and PEPs, FIs should establish measures to update the identification files at least once per year.

- $\quad$ Regulation 25: KYC policy should be based on the degree of transaction risk presented by clients. Customers should be classified as either high risk or low risk with institutions having discretion to apply intermediate risk ratings. For higher-risk customers, more information and stricter monitoring is required, and a warning system implemented to detect changes in customer transactions. Also, for higher-risk clients, FIs should use client questionnaires to obtain more information on source of funds, their activities, and transactions that they conduct or plan to conduct. FIs must require 
identification questionnaires for existing and new customers classified as high risk that allow for the collection of more information on the origin of funds and on the activities and transactions that customers conduct or intend to carry out.

- $\quad$ To establish the degree of risk, (including for classifying customers as PEPs) FIs should have internal procedures that take into account, among others, the customers' background, activity or line of business, source of funds, place of residence, and other criteria established by the FIs.

- Regulation 26: FIs must classify the transactions conducted by customers in accordance with the degree of ML and FT risks. High-risk transactions include, among others, those which are conducted with foreign PEPs and high-net worth nonresident customers in the private banking or similar unit of FIs. With regard to the aforementioned customers, FIs must ascertain and record the reasons why they have chosen to open an account in Mexico.

- $\quad$ For transactions that have been classified as high risk, FIs must adopt reasonable measures to determine the origin of funds of individuals, and must obtain identification information specified in Chapter II of the regulation, regarding the spouse and dependents of the customer, as well as on entities where he has equity interests. In the case of legal entities, information must be obtained on the corporate structure and principal shareholders.

- With regards to PEPs, FIs must develop mechanisms to establish the degree of risk in transactions conducted with Mexican PEPs. To this end, they must ascertain whether the transaction profile is reasonably consistent with the customer's functions, position/seniority, and level of responsibility.

- $\quad$ Regulation 27: FIs must obtain management approval and inform the Compliance Officer when opening high-risk accounts.

- $\quad$ Regulation 39: The Compliance Committee (“Comite de Comunicacion y Control”) must be informed of the execution of contracts or the opening of accounts that might generate a high degree of risk.

\section{Popular savings and loans (DCG 124)}

193. Applicable to all institutions: Type 1, 2, 3, and 4 savings and loans ${ }^{36}$ :

- $\quad$ Title I Regulations 3 through 42 of DCG 124 establish the basic CDD and other AML/CFT requirements for the four types of savings and loans institutions differentiating them by size as well as their scope of permissible activities. Type 1 savings and loans institutions are authorized to conduct a narrow range of activities while Type 4, a much broader range similar to those of banks. Consequently, more risk-based requirements are established for Types 2, 3, and 4 institutions under Title II of the regulations, as follows:

- $\quad$ Regulation 17: KYC policies should include provisions that allow an institution to modify its CDD procedures in accordance with the degree of risk with respect the larger institutions, i.e. Type 2, 3, and 4.

- Regulation 18: Type 1 institutions should, in the case of transactions equal or above the equivalent of US\$10,000 (CTR), enhance monitoring of such transactions taking into account knowledge of

\footnotetext{
${ }^{36}$ Type 1: Assets under 7000000 Investment Units (UDIS); Type 2: Assets between 7,000,000 and 50,000,000 Investment Units (UDIS)"; Type 3: Assets between 50000000 and 280,000,000 Investment Units (UDIS). Type 4: Assets over 280,000,000 Investment Units (UDIS)".
} 
the customer and other relevant circumstances. Such FIs shall also visit the customer at his address to verify the identification documents.

194. For Type 2, 3, and 4 savings and loans, additional CDD and other AML/CFT measures are imposed by the regulations, including more risk-based elements than for Type 1 . These are as follows.

- $\quad$ Regulation 44: KYC policies should be based on customer transaction risk requiring more information and closer scrutiny of transactions when higher risk is involved. FIs should classify customers (and transactions (Regulation 45)) in accordance with their risk profile using at least two ratings: low risk and high risk, applying intermediate ratings as appropriate. FIs should elaborate internal criteria to ascertain the degree of risk and if the client is a PEP. High-risk customers may require a visit to their address to verify CDD information. For such high-risk customers, FIs should also update identification information at least annually.

- $\quad$ Regulation 45: In addition to the above, FIs shall classify transactions with PEPs (including Mexican PEPs) as high risk, as well as those with nonresident customers. For such transactions FIs should take additional measures including establishing source of funds (but not source of wealth), as well as information on spouse and dependents, associated legal entities. In case of customers that are legal persons, information on the principal shareholders and corporate structure should be obtained.

- $\quad$ Regulation 47: Transactions or accounts for high-risk customers should be approved by management and brought to the attention of the compliance officer. (See Recommendation 6 for additional discussion on the CDD requirements on PEPs.)

- $\quad$ Regulation 50, III: FIs should establish a Compliance Committee ("Comite de Comunicacion y Control") which shall, inter alia, be aware of the opening of accounts or transactions that are high risk.

195. Other FIs: Similar provisions are contained in Chaps. III and VII regarding the KYC policy requirements of the other regulations which, for example in the case of DCG 52, Bis 4, require the following:

- $\quad$ Regulation 11: Regarding customers classified as high risk, as well as PEPs, FIs shall implement measures to update the identification files at least once a year.

- $\quad$ Regulation 13: KYC policies must be based on the degree of transaction risk requiring more information for higher-risk transactions, and enhance monitoring. FIs should rank customers as either low or high risk but can apply intermediate risk levels as appropriate.

- $\quad$ To assign the degree of risk and to determine whether a customer is a PEP (both foreign and Mexican), FIs should establish criteria that take into account, inter alia, the customer's background, profession, activity or line of business, the source of funds, etc. This should include procedures to rank transactions conducted by Mexican PEPs in accordance with the degree of risk. Early warning monitoring systems should be developed to monitor customer transaction activity.

- Regulation 14: For high-risk transactions, FIs should take reasonable measures to ascertain the origin of the resources and try to obtain identification data for the customer's spouse and dependents, as well as for associated legal entities, including with respect to the principal shareholders and corporate structure.

- $\quad$ Foreign PEPs and nonresident clients shall be classified as high risk.

- Regulation 15: The opening of high-risk accounts and contracts must be approved by management and brought to the attention of the Compliance Officer. 
- $\quad$ Regulation 24: FIs should establish a Compliance Committee which shall, inter alia, be aware of high-risk transactions and develop and disseminate (while not specified, it is intended that dissemination be made to staff of the institution) criteria for the classification of clients in accordance to risk. In addition, under Regulation 27, the Compliance Officer shall inform the Compliance Committee of new high-risk accounts or transactions.

\section{Risk-Application of Simplified/Reduced CDD Measures when appropriate (c. 5.9)}

196. See discussions for enhanced CDD in c.5.2, c.5.3 and c.5.8 above, and in particular, Chapter II reg. 4 IV of all of the DCGs with respect to simplified identification for customers including those listed in Annex 1 to the regulations. The risk-based elements are discussed in more detail below.

Banks and SOFOLES (DCG 115):

- $\quad$ Regulation 4 IV: In the case of FIs and government of Mexico companies, agencies and entities listed in Appendix 1 (simplified CDD regime) of DCG 115 including local and foreign financial institutions (located in countries that apply AML/CFT measures and which are supervised for compliance), Government of Mexico (implicit) federal, state and municipal dependencies and entities, entities listed in the stock exchange, and securities depositories. For these clients, the FIs may apply "simplified" customer identification measures and obtain the following minimum information: company name; activity or corporate purpose; federal taxpayer identification number (RFC); serial number of the Advanced Electronic Signature, when available; address; telephone number(s); e-mail address; and, as appropriate, name of the administrator(s), director, general manager or agent, who, with their signature(s), can bind the legal entity.

- Additionally, it will be necessary to present as appropriate, the following minimum information: the official or certified copy of the instrument establishing the powers of legal representative(s), issued by notary public; for financial institutions the certificate of designation as such issued under the Financial Institutions Law by a competent officer, as well as his personal identification in accordance with the regulatory requirement for individuals. FIs may apply the simplified measures described in the preceding paragraph, provided that the companies, agencies or entities in question have been classified as low-risk customers.

- $\quad$ Regulation 4 (for both DCG 115 and 124) When the identification documents presented by customers show erasures or alterations, FIs must obtain other means of identification OR request two banking or business references and two personal references, including name, address and telephone, which will be verified with the reference before opening an account or executing a contract. This provision if strictly applied can, in effect, result in reduced CDD for such customers by substituting commercial and personal references for the more reliable identification documents required in the preceding provisions of Regulation 4 . While it may not be the intention of this provision, as drafted but if strictly implemented, can effectively reduce the $\mathrm{CDD} /$ identification requirements in circumstances where lower risk does not apply but which may present higher risk.

- $\quad$ Regulation 12: Simplified ID is allowed for savings accounts for customers that receive salary payments from their employers, and for nonchecking accounts used by government for assistance payments to certain sectors of society.

- $\quad$ See Regulation 25 above under c5.8.

Popular savings and loans (DCG 124)

197. Applicable to all institutions: Type 1, 2, 3, and 4 savings and loans: Title I of the regulations 
- Regulation 4, IV: Simplified CDD is allowed for entities listed in Annex I broadly similar to the provisions in DCG 115 for credit institutions as described above. This regulation provides FIs the discretion to apply simplified identification of the listed customers. It does not include the clause in DCG 115 that FIs may apply the simplified measures only when they have classified such clients as low-risk.

- $\quad$ Regulation 4 When the identification documents presented by customers show erasures or alterations. See discussion above for DCG 115.

- $\quad$ Regulation 8: In the case of savings accounts, debit cards and demand deposits, FIs are only required to record the applicable identification information specified in Paragraph I, II or III of Regulation 4. This would exclude identification of ultimate beneficiaries and authorized third parties under pars. VI, VII and VIII of this regulation. Regulation 8 further states that FIs should also obtain other data presented by the client or shareholder ("socio") or their representatives in accordance with the mentioned provisions ("fracciones mencionadas"). These provisions are very confusing. On the one hand, they limit the application of identification to Paragraphs I, II or III, and on the other provides a general data requirement pertaining to those presented by the client or shareholder. It should be revised and the authorities indicate that it will be done in the context of the current review and reform of the regulations.

- $\quad$ Regulation 12: In the case of deposits made in savings accounts or through other means for payroll payments, the opening of which is made upon request of a customer for its employees.

198. Other FIs including Insurance companies: (See discussion for Regulation 4, DCG 115 and 124 above for EC 5.9 with respect to reduced identification verification requirements when documentation is or appears to be false or altered. DCG 115 and DCG 124 do not include references to false documentation.)

199. With regard to insurance entities (Regulations 4 I and II of DCG 140), the regulations only require verification of identity of individuals, including nonbeneficiary policy holders, at the time a claim is made when the policy is less than the equivalent of US\$10,000, or no later than when the policy is delivered when the amount equals or exceeds this amount. For legal entities verification or presentation of documentation is required no later than when a policy is delivered when the policy amount does not exceed this amount. These provisions, particularly for individuals, are inherently based on a presumption of (lower) risk for policies below this threshold. Consequently, the postponement of verification/presentation of identity documents and integration in the customer file would effectively constitute a reduction in CDD, considering that verification is a key component of the CDD process (EC5.3). The US\$10,000 threshold is also well in excess of the US\$1,000/2,500 thresholds given in the examples for life insurance policies under EC5.9, particularly with respect to individual clients. This would be related, but in addition to, EC5.13 and EC5.14 that would allow the postponement of identification and verification of beneficiaries to a policy, but where the general rule is to complete identification and verification at the beginning of a relationship or transaction, and only allow postponement in specified circumstances where $i$ ) this occurs as soon as reasonably practical $i$ ), it is essential no to interrupt the normal course of business and iii) ML risk is effectively managed. There is nothing in Regulation 4 of DCG 140 that in any way relates to these sub-criteria. On the contrary, the inclusion of a US\$10,000 equivalency threshold is more connected to a perception of lower risk for certain policies.

200. With respect to simplified CDD for FIs and government entities listed in Appendix 1, FIs have a mandatory obligation to apply simplified customer identification measures ("aplicaran medidas simplificadas") for such customers. This varies from the other regulations which allow discretion in applying simplified CDD, and in the case of credit institutions (DCG 115) such simplified measures are only allowed if an FI has classified any of these customers as low risk. 
201. There are no adequate guidelines or definitions with respect to the categories (e.g., banks, casas de cambio, money remitters, etc.) of foreign FIs that would be captured under Annex 1, and no guidelines or other instrument has been provided with respect to the adequacy of the AML/CFT regimes in specific countries where they are located. Regulation 4 of all of the DCGs allow for simplified identification of legal entities that are listed in Annex 1, including Mexican and foreign FIs, federal, state and municipal entities, and public companies listed in the Mexican stock exchange. With respect to foreign FIs, simplified identification is allowed only with respect to entities that are incorporated ("constituidas") in countries or territories that apply measures to prevent, detect, and combat transactions originating from illicit sources and terrorism financing. Such FIs must also be subject to AML/CFT oversight and supervision in their home countries. Note that these foreign FIs do not refer to their Mexican subsidiaries constituted locally, and that branches of foreign entities are not allowed in Mexico (see Table on pages 28-29). Additional guidelines or provisions are required to help FIs ascertain cases where all entities listed in the Annex meet or do not meet the basis for a simplified regime, particularly with respect to foreign FIs.

\section{Risk-Simplified/Reduced CDD Measures Not to Apply when Suspicions of ML/TF or other high-risk scenarios exist (c. 5.11)}

202. There are no explicit provisions in the regulations disallowing simplified CDD when there is suspicion of ML or FT. DCG 115 (Regulation 4) applicable to banks, SOFOLES and other credit institutions requires FIs to apply simplified identification only to those FIs and other entities listed in Annex 1 (see c.5.10 above) that have been classified as "low" risk, implying that they should not be applied in cases of suspicion of ML or FT, or where there is higher risk. None of the other DCGs contain similar provisions limiting the simplified application to low-risk clients. It is recommended that all the regulations have wording similar to those for DCG 115 Reg. 4 IV, mutatis mutandis. The authorities indicate that it will be done in the context of the current review and reform of the regulations. In the case of DCG 124 for popular savings and loans, the ability to apply simplified identification is discretionary and hence the risk-based approach allowed would require enhanced CDD for clients classified as high risk. However, this would only apply to Type 2, 3 and 4 FIs under Title II Regulation 44.

203. With respect to all the other FIs, Regulation 4 of the DCGs, as worded, imposes a mandatory obligation to apply simplified identification ("aplicaran medidas simplificadas") to those clients listed in Annex 1. Consequently, there seems to be a drafting contradiction with the application of risk sensitive (enhanced) CDD allowed under Chapter III of the regulations. In practice, there are categories of entities listed in Annex, both local and foreign, that could present higher risk scenarios such as local unregulated SOFOMES (the list includes "Sociedades Financieras de Objeto Limitado" and "Sociedades Financieras de Objeto Múltiple"). The list also include foreign financial institutions ("entidades financieras del exterior") the scope of which has not been defined and can include a broader category of FIs including e.g., foreign based bureau de change and money remittance business.

204. As discussed above, Regulation 4 of the DCGs seems to allow for reduced identification requirements in circumstances where documentation appears to be false and/or altered. As discussed above, such circumstances would generally present higher risk as indicated under Chapter $\mathrm{V}$ for suspicious activities.

\section{Risk-Based Application of CDD to be Consistent with Guidelines (c. 5.12)}

205. Apart for the risk-based provisions in the regulations (e.g. PEPs and non-residents), no guidelines have been issued by the authorities that would assist FIs in ascertaining the degree of risk in customer relationships and transactions e.g., clients, economic sectors, products, services, geographic locations (both 
in Mexico and overseas), etc. Guidelines have been issued by the FIU for purposes of filing unusual/suspicious transactions but these are not adequate for this purpose. Nonetheless, from discussions with FIs it is evident that they have identified certain sectors in Mexico as high risk, including cash intensive businesses, centros cambiarios, casas de cambio, principal drug trafficking locations, PEPs, etc.

\section{Timing of Verification of Identity - General Rule (c. 5.13)}

206. Under Regulation 4 (and Regulation 5 other than DCG 115 and DCG 124) of the regulations, all FIs are required to set up a customer identification file before any account is opened or any type of transaction is executed. Some exceptions apply, as discussed under c.5.14 below, with respect to the presentation of documents to verify such identification. Similar provisions are contained in DCG 115 and DCG 124 that prohibit anonymous and fictitious accounts, requiring full compliance with customer identification before opening accounts or conducting transactions.

Timing of Verification of Identity - Treatment of Exceptional Circumstances (c.5.14 \& 5.14.1)

40. See discussions under c.5.2. c5.3, c5.9 and c.5.13 above.

207. All FIs: In the case of legal persons that have been recently formed and which have not as yet been registered in the Public Commercial Register, Regulation 4 allows FIs to request a certified document signed by a legally authorized representative declaring that registration will be carried out, at which time the relevant identification information will be submitted to the FI.

208. Beneficiaries: In the case of the death of a customer, identification of the surviving beneficiary will be obtained at the time the beneficiary presents himself to claim his rights.

209. Insurance companies DCG 140: Regulation 4 allows institutions to obtain and maintain customer identification documents after executing the insurance policies in the following circumstances:

210. For Mexican individuals, presentation of customer identification documents can be made:

- No later than the date on which a claim is submitted when the annual premium or single premium does not exceed the equivalent in national currency to US\$10,000. In these cases, identification should be obtained and filed at the time when lower incremental payments reach the equivalent of US\$10,000.

- $\quad$ No later than the date on which an insurance policy is delivered, when the amount of the annual premium or single premium is does not exceed the equivalent in national currency to US\$10,000.

211. For legal entities (Mexican), presentation of customer identification documents can be made:

- $\quad$ No later than the date on which an insurance policy is delivered, when the amount of the annual premium or single premium is equal to or more than the equivalent in national currency to US $\$ 10,000$.

212. These verification requirements with respect to individuals are not consistent with the FATF Recommendations as the delay in verification of identity should be limited to the identification of beneficiaries under insurance policies at or before payout under the policy, and not with respect to all of the contracting parties/policyholders. (See discussion under EC 5.9 above on the applicable threshold. In practice, industry representatives state that they obtain, but not necessarily place on file, information on the underlying contracting parties/policyholders at the time a policy is issued. It is not certain, however, how the regulatory requirements are observed in practice when agents and other intermediaries are involved, 
such as when banks sell policies on behalf of an insurance affiliate. (These are referred to by the industry as "bancassurance" business).

213. There are no requirements for FIs to adopt risk management systems to mitigate risks related to the deferment of customer identification verification under any of the circumstances above.

\section{Failure to Complete CDD before commencing the Business Relationship (c. 5.15)}

214. See c.5.13 above. Under Regulation 4 and Regulation 5 (other than DCG 115 and DCG 124), all FIs are required to set up a customer identification file before any account is opened or any type of contract is executed. Some exceptions apply, as discussed under c.5.14 above. Similar provisions are contained in DCG 115 and DCG 124 that prohibit anonymous and fictitious accounts, requiring full compliance with customer identification before opening accounts or conducting transactions.

215. There is no requirement to consider filing a suspicious transaction report when CDD cannot be completed. Regulation 4 of the DCGs contains provisions that effectively allow FIs to apply alternative forms but reduced customer identification measures (e.g. commercial and personal references) in circumstances where there are indications or certainty that identification documents presented by customers are false (other than DCG 115 and DCG 124), and/or show erasures or alterations. (see. c.5.9 and c.5.11 above.) Consideration should be given to requiring FIs to file STRs in such cases where warranted pursuant to the provisions of Chapter $\mathrm{V}$ of the regulations and also to make them consistent with the regulatory provisions discussed in the next paragraph.

\section{Failure to Complete CDD after commencing the Business Relationship (c. 5.16)}

216. FIs are not required to terminate a business relationship when they are unable to comply with some of the CDD requirements in the regulations. The regulations allow that, where doubts arise with regard to identification information or documents provided by the customer, or regarding the conduct of transactions, FIs should strengthen monitoring of transactions and, where appropriate, these shall be submitted to the Compliance Committee for their consideration as to whether a STR should be filed with the FIU. (DCG 115 Regulation 31, DCG 124 Regulation 19, DCG 52 Bis-4 Regulation 17, etc.). (See preceding paragraph.) In addition, under Chapter XI of the regulations: Other Obligations, where an FI has doubts about the accuracy of a customer's taxpayer identification card and/or the serial number of the Advanced Electronic Signature, they should verify the authenticity of the information contained by other means. These provisions should be reviewed as failure to properly identify a customer may be grounds for refusing to conduct a transaction, open an account, or terminate a business relationship as the case may be (also see previous paragraph).

\section{Existing Customers - CDD Requirements (c. 5.17)}

217. FIs were required to regularize the customers' identification records for accounts that were opened or transactions executed before the AML/CFT regulations (DCGs) were issued and became effective in May 2004. Such regularization must be carried out on a risk basis, mainly considering the average balances of each account or agreement, as well as any relevant and unusual transactions. In addition, they must adopt measures to update the information and documentation contained in the customers' identification records especially when significant changes in customer transactions are detected, and in case of doubt over the accuracy of information.

218. Similar provisions were provided in the new regulations issued in 2006 (DCG 115 and DCG 124) which required regularization by January 1, 2007. From discussions with the authorities and FIs, it seems that these requirements have been generally complied with. For banks, Oficios UBA/094/2005 and 
UBA/200/2005, the SHCP (Secretaria) allowed regularization of accounts based on size and risk, limiting regularization to large accounts only (equal or more than Mex\$30,000 and in some cases the equivalent of US\$10,000), and suspicious accounts.

Existing Anonymous-account Customers - CDD Requirements (c. 5.18)

219. Although anonymous accounts are prohibited in Mexico, the requirements under c.5.17 would also apply to numbered and coded accounts where these are relevant, e.g., in the banking sector.

Foreign PEPs - Requirement to Identify (c. 6.1)

220. All of the regulations require FIs to have systems in place to identify and conduct enhanced CDD on PEPs. These regulations define a PEP as follows:

"an individual who acts or has acted in a prominent public capacity in a foreign country or in Mexico. It includes, among others, heads of state and government, political leaders, high-level governmental, judicial or military officials, senior executives of state-owned corporations and officials or important members of political parties.

The category of Politically Exposed Persons includes spouses of these and persons with whom they are related by consanguinity or within the second degree of affinity, as well as legal entities with which Politically Exposed Persons maintain asset or equity ties". (In DCG 108 the last line reads as "close associates of the Politically Exposed Person".) This definition is in line with the essential criteria and even goes beyond it by including domestic PEPS (additional element).

221. The procedures to be used by FIs to identify PEPs should take into account, inter alia, the customer's history, profession, activity or line of business, origin of funds, place of residence and other circumstances determined by the FI.

222. Banks and SOFOLES (DCG 115) and Popular Savings and Loan (DCG 124 Type 2, 3 and 4 entities only): The authorities are required to and have issued to FIs an illustrative list of public positions that are to be considered to be Mexican PEPs. FIs must issue their own lists of positions of PEPs based on this list. For the purposes of regulations, persons considered to be Mexican PEPs due to their position continue to be considered as such for one year after leaving the position for which they were so classified. Without prejudice to the foregoing, in the event that a person no longer meets the requirements to be considered a PEP during the year immediately prior to the date on which that person intends to begin a new business relationship with any FI, the FI must classify the person as such during the year following that in which the account has been opened or the contract executed.

223. Through Oficios UBA/094/2005 and UBA/200/2005, the SHCP (Secretaria de Hacienda y Credit Publico) further defined and expanded the various positions of PEPs in Mexico that should be considered by banks in complying with the requirements. Similar Oficios have not been issued for other sectors. In addition, many FIs have subscribed with private firms that provide them with updated lists of PEPs in Mexico and other countries.

224. Pursuant to its powers under the regulations, the SHCP issued an initial list of positions of PEPs in accordance with article 110 of the Mexican Political Constitution, which includes, among others: members of the House of Representatives, senators, justices of the Supreme Court, advisors of the Federal Judicature, dispatch secretaries, chiefs of administrative departments, the head of the government of the Federal District, attorney generals and district attorneys, circuit court magistrates and district court judges, 
and directors general or their equivalents of decentralized agencies, companies controlled by the state, other similar companies, associations and public trusts as well as state governors, among others. This list was issued to provide certain examples, without limitation, and serve as a basis for FIs to develop their own lists, adding other public officers they deem pertinent.

225. During 2006, the Federal Electoral Institute sent to the FIU the lists of candidates to the Senate and the House of Representatives (of all political parties, including representatives and senators elected through the principle of relative majority and proportional representation), which were channeled to the supervising bodies to enable them to determine any unusual activity in the accounts of such persons, and to report to the FIU any suspicious transactions. No reports were received from the FIs through the supervisory authorities with respect to any of the persons on the lists.

226. Other FIs: In order to determine whether a customer is a PEP, FIs are required to develop internal criteria taking into account, inter alia, the customer's history, profession, activity or line of business, origin of funds, place of residence and other circumstances determined by the FI itself. In such cases, FIs shall establish measures to update the customer identification files at least once per year.

227. Foreign PEPs must also be treated as high risk customers. (See e.g., DCG 52 Bis-4 reg. 14).

Foreign PEPs - Risk Management (c. 6.2; 6.2.1)

228. Banks and SOFOLES (DCG 115) and Popular Savings and Loan (DCG 124 Type 2, 3 and 4 entities only): For high risk customers, including PEPs, the regulations require FIs to obtain senior management approval upon opening accounts or conducting transactions, and to inform the compliance officer of such accounts and transactions. If prior to or after establishing a business relationship, an FI determines that a prospective or existing customer is a PEP (high risk customers), the FI must obtain management approval to establish or continue the commercial relationship. (See DCG 115 reg. 27 and 28 and DCG 124 reg. 47 and 48).

229. Other FIs: The regulations with respect to the other FIs contain only limited provisions for senior management approval for new and existing PEP relationships. They require FIs to obtain high level management approval ("nivel directivo") for all high risk accounts which implicitly covers PEPs but only with respect to the opening of accounts or the execution of contracts. They do not require senior management approval for the continuation of a PEP relationship if a customer/beneficiary subsequently becomes or is identified as a PEP. The regulations could be expanded/clarified indicating that such approval is explicitly required in all cases as under DCG 115 and DCG 124 above. This modification will be included in the context of the current review and reform of the regulations.

Foreign PEPs - Requirement to Determine Source of Wealth and Funds (c. 6.3)

230. Banks and SOFOLES (DCG 115) and Popular Savings and Loan (DCG 124 Type 2, 3 and 4 entities only): (e.g. Regs. 2526 of DCG 115) The procedures to be used by FIs to identify PEPs should take into account, inter alia, the customer's history, profession, activity or line of business, origin of funds, place of residence and other circumstances determined by the FI. Although source of wealth is not explicitly mentioned, it could be broadly interpreted from the other CDD elements to be taken account, particularly from the origin of funds. To assist FIs in implementing this requirement in a consistent manner, it would be useful to clarify in the regulations that the scope of information required ("origen de recursos") includes both source of funds (e.g. from a loan, sale of assets, inheritance, etc.) and source of wealth ("patrimonio") which would be the sum total of property owned and/or net worth. 
231. Other FIs: See c.6.1 and c.6.4. As above, it would be useful to clarify that the scope of "origen de recursos" applies to both origin of funds and of wealth".

Foreign PEPs - Ongoing Monitoring (c. 6.4)

232. Banks and SOFOLES (DCG 115) and Popular Savings and Loan (DCG 124 Type 2, 3 and 4 entities only): Reg. 21 requires FIs to establish procedures to update, at least once a year, the identification files of PEPs. Reg. 26 further requires FIs to classify foreign PEPs as high risk customers, and to ascertain and record the reasons why they have chosen to open an account in Mexico. FIs must develop mechanisms to establish the degree of risk in transactions with Mexican PEPs and to monitor account activity to determine for consistency with the customer's profile. While the specific monitoring requirement Reg. 26 only refers to Mexican PEPs, Reg.25 (e.g. DCG 115) requires FIs to apply stricter supervision of transactions with all higher risk clients, not only PEPs. This would implicitly cover foreign PEPs.

233. Other FIs: Chap. II: FIs must implement measures to update PEP identification files at least once a year, and to identify PEPs (Chap. III). They must establish internal criteria to identify PEPs which must include, inter alia, the customer's background, profession, activity or line of business, the source of funds and other circumstances determined by the FI. There is also a general requirement to apply stricter monitoring of transactions with higher risk clients, not only PEPs (Reg. 11). In addition, FIs must also develop procedures to establish the degree of risk involved in operations carried out with Mexican PEPs, to determine whether the transactions are consistent with their profile. There is also a provision that requires FIs to establish an early warning system to detect changes in their transaction patterns but it is not clear whether it applies to both foreign and Mexican PEPs. The drafting of the applicable provisions should be reviewed to remove any potential confusion and redundancy.

234. In practice, all FIs met by the mission appeared to be well sensitized to the need to identify PEPs, and to apply enhanced CDD with respect to such relationships. They appeared to be more focused, however, on monitoring business conducted with domestic PEPs, fairly reflecting their concerns about local circumstances.

Domestic PEPs - Requirements (Additional Element c. 6.5)

235. All FIs: The enhanced CDD for PEPs extends to Mexican PEPs. See c.6.1-c.6.4 above.

Domestic PEPs - Ratification of the Merida Convention (Additional Element c. 6.6)

236. Mexico has ratified the United Nations Convention against Corruption, approved by the General Assembly on October 31, 2003, "the Merida Convention" for which it was a leading proponent.

\section{Cross Border Correspondent Accounts and Similar Relationships - introduction}

237. The regulations for banks and SOFOLES (DCG 115), Fund administrator and operators (DCG 108) and Stock brokers (DCG 52 Bis-4) include provisions for establishing correspondent accounts and similar relationships. In practice, this requirement would mainly apply to banks in Mexico. Only few indicated that they provide correspondent account facilities for overseas institutions, mainly for their affiliates.

238. With respect to fund administrators and operators (DCG 108) and stock brokers (DCG 52 Bis-4), there are no other requirements in the regulations for FIs to implement enhanced procedures with respect to their correspondent relationships. From discussions with the financial sector, the mission was not aware 
that such business relationships were a regular practice in this sector. Nonetheless, the regulatory requirements are as follows:

- (Fund administration and distribution companies DCG 108 reg. 14) and (Stock brokers DCG 52

Bis-4 reg. 16): FIs must strictly observe KYC policies with respect to correspondent accounts opened by overseas FIs established in countries or territories advised by the SHCP where they do not or insufficiently apply AML/CFT measures. FIs must refrain from carrying out correspondent transactions with institutions or other financial intermediaries that have no physical presence in any jurisdiction whatsoever.

Requirement to Obtain Information on Respondent Institution (c. 7.1)

239. Banks (DCG 115 Reg. 29, Reg. 30): FIs must obtain from their foreign counterparts a document in which they affirm their compliance with obligations similar to those established in this regulation, with respect to the identification and knowledge of customers. FIs must also obtain information to enable them to determine the business activity of their respondent/counterparts and to evaluate the AML/CFT controls that are in effect to ascertain whether they comply with international AML/CFT standards. Where appropriate, FIs should ensure that their counterparts are supervised by a competent authority, verify that they have good reputation, and determine whether they have been subject to investigations or sanctions (while not explicitly stated, this would include both regulatory and non-regulatory action) due to noncompliance with applicable laws and regulations.

240. Fund administration and distribution companies DCG 108 reg. 14) and (Stock brokers DCG 52 Bis-4 reg. 16): No similar provisions are in place for these entities particularly with respect to similar business relationships with overseas entities.

Assessment of AML/CFT Controls in Respondent Institution (c. 7.2)

241. Banks (DCG 115): See c.7.1 above.

242. Fund administration and distribution companies DCG 108 reg. 14) and (Stock brokers DCG 52 Bis-4 reg. 16): No similar provisions are in place for these entities.

Approval of Establishing Correspondent Relationships (c. 7.3)

243. Banks (DCG 115): Reg. 29: FIs must, before establishing correspondent bank relationships/services with foreign counterparts, obtain senior management ("nivel directivo") approval. In practice, such approval is granted by senior management in Mexico, and in the case of foreign banks, from their head offices abroad.

Documentation of AML/CFT Responsibilities for Each Institution (c. 7.4)

244. Banks and SOFOLES (DCG 115 reg. 29): FIs must document the AML/CFT measures and procedures that their counterparts observe, in accordance with their national laws and regulations. This includes a document or certificate that sets out their responsibilities to comply with AML/CFT requirements similar to those of Mexico. In addition, they shall document the AML/CFT measures and procedures that their counterparts overseas will observe in accordance with their national requirements.

245. Fund administration and distribution companies DCG 108 reg. 14) and (Stock brokers DCG 52 Bis-4 reg. 16): No similar provisions are in place for these entities. 
Payable-Through Accounts (c. 7.5)

246. There are no provisions for this type of correspondent account in the regulations. The FIs (and the authorities) indicated that they do not provide such services, and the mission did not observe any indications of their use.

Misuse of New Technology for ML/FT (c. 8.1)

247. As the level of banking access and the internationalization of the financial sector in Mexico increases, the sophistication of financial products and services, and the technology used, is increasing. These could raise the potential for misuse for ML and FT purposes. Nonetherless, there are no explicit or direct requirements in the regulations for FIs to have policies in place and measures to prevent misuse of technological developments in ML or FT schemes. For nonbanking entities, particularly centros cambiarios, the authorities believe that the low level of sophistication of this sector and the basic procedures involved the delivery of services may not justify such measures. The mission partly agrees with this position but the lack of information on the scope and scale of their activities is not fully known.

\section{Risk of Non-Face to Face Business Relationships (c. 8.2 \& 8.2.1)}

248. The regulations have broad requirements for FIs (Chap. II) to formulate and implement KYC policies which would include customer identification and due diligence as prescribed under Reg. 4 of the DCGs. The regulations require FIs to implement risk-based CDD policies which should mitigate risks arising from non-face-to-face transactions and new technologies. Stricter requirements (and guidelines under Rec. 25) are required, however, e.g., with respect the use of technologies such as debit and prepaid cards where value can be added electronically without face-to-face contact, after an account has been opened.

249. Banks and SOFOLES (DCG 115): Reg. 6: Before establishing or beginning a commercial relationship, FIs must conduct a personal interview with the customer or customer's legal representative, and the information obtained through this interview must be recorded in writing. Reg. 15 states that when transactions are carried out through electronic or optical means, or using any other form of technology, FIs must establish the customer identification file prior to the transaction in accordance with the regulations. This shall include procedures for conducting a personal interview with customer. As mentioned above, this would, if strictly implemented, help mitigate risks arising from such transaction and clients but a "specific" requirement is established under FATF EC 8.2 and 8.2.1.

250. Similar provisions are established for other FIs that require the conduct of a personal interview with their clients.

\subsubsection{Recommendations and Comments}

\section{General Recommendations}

- $\quad$ Review all of regulations (DCGs issued in 2004 and 2006) for purposes of simplifying the structure, enhancing clarity and consistency.

- Upgrade the DCG's issued in 2004 in line with the 2006 regulations, paying due regard to sectorspecific needs.

- $\quad$ Review the scope of coverage of the AML/CFT requirements for life insurance and bonding agents in the regulations, to ensure that they include explicit obligations consistent in scope with the 
AML/CFT provisions in the applicable laws (e.g. Art. 140 of the insurance law), including with respect to reporting of suspicious transactions to the compliance officer. (See Rec. 13)

- $\quad$ Issue CDD (and other AML/CFT) regulations for unregulated SOFOMES subject to the Law for Auxiliary Credit Organizations and Activities, consistent with those for regulated entities.

- $\quad$ (See Section 7) Review the significance of lending activities by cash for (automobile) titles operations and consider applying AML/CFT requirements if justified.

EC 5.1

- $\quad$ For consistency with the 2006 regulations, consider including an explicit the prohibition against maintaining anonymous or fictitious name accounts in all the other regulations (DCGs).

- $\quad$ Limit the use of numbered and coded accounts to specified institutions and circumstances, and include in all the DCGs provisions similar to those in DCG 115 and DCG 124 that require full customer identification requirements for such accounts.

EC 5.2

- To enhance clarity and aid consistency in implementation, in DCG 52 (stock brokers), specify that the US $\$ 10,000$ customer identification threshold only applies to occasional foreign currency business transactions.

- $\quad$ Casas de cambio, and when applicable centros cambiarios, that maintain establish business relationships should be required to identify and conduct CDD regardless of the amount.

- $\quad$ Provide in all the regulations clear requirements that distinguish CDD for the establishment of business relationships and for the conduct of occasional customers, taking into account the need for reasonable thresholds for occasional transactions across all sectors.

- $\quad$ Expand the CDD requirements for occasional transactions to cover all types of transactions, taking into account the US $\$ 1,000$ FATF threshold for wire transfers under under SRVI.

- $\quad$ Consider an explicit CDD provision requiring the summing up of linked transactions below the US\$10,000 (US\$15,000 under FATF c5.2(b)) threshold for occasional transactions similar to the provisions similar to those under Chaps. V and IX of the regulations.

- $\quad$ CDD for cash transactions (e.g., DCG 115 Regs. 19 and 20) should include non-U.S. dollar currencies.

- $\quad$ Require CDD for all transactions or activities when there is suspicion including where warranted where there is doubt about the veracity or adequacy of customer information, (See also c5.15 and c5.16 below on the requirement to refuse and discontinue transactions and business relationships.)

\section{EC5.3 (See also EC5.14)}

- $\quad$ Require verification/presentation of identification documents for non-beneficiary parties to an insurance policy (e.g ,. policyholder) at time a business relationship is established, or a policy is contracted, and limit postponement of such verification/presentation to beneficiaries only.

- $\quad$ Revise Reg. 4 of all of the regulations to clarify/ensure that the provisions for alternative identification and verification measures do not reduce CDD in cases where identification documentation shows erasures, alterations and/or are false, as the case may be. 


\section{EC 5.4 and EC 5.5}

- Clarify in the 2004 regulations that the identification requirements for ultimate beneficiaries applies to both Mexican and foreign beneficiaries as in the 2006 regulations.

- $\quad$ Explicitly require FIs to ascertain/request applicants for business to state in the application documents the capacity under which they are acting, not only when there are "indications" that they are acting on behalf of others.

\section{EC 5.6}

- Require all FIs to obtain information on the purpose and intended nature of business relationships, irrespective of the level of the degree of customer risk, and the size of the financial institution (re: Type 1 Popular Savings and Loans institutions).

\section{EC 5.8}

- $\quad$ Streamline/expand the requirement for (enhanced) risk-based KYC implementation in all the regulations beyond transaction-related risks to cover the full range elements necessary to establish customer profiles e.g., additional client categories, economic activity, geography, etc. See EC 5.9 and EC 5.12 below.

\section{EC 5.9}

- $\quad$ Review the adequacy of list of customers subject to the mandatory simplified CDD regime for clients in Annex 1 of the regulations, including with respect to clients that are foreign financial institution, and require a low risk classification before applying simplified CDD as provided in DCG 115.

- $\quad$ DCG 124 Reg. 8. The drafting provisions for simplified due diligence for savings accounts, debit cards, and demand deposits seems unjustified and should be reconsidered.

- DCG 140: Review the customer identification verification requirements for insurance companies with respect to the US\$10,000 equivalency threshold to avoid reducing the CDD requirements.

\section{EC 5.12}

- $\quad$ Provide more adequate guidelines to assist FIs in complying with the risk-based CDD provisions of the regulations.

\section{EC 5.14}

- Impose a reasonable period of time within which verification of identification should be completed for recently formed legal entities, including strict risk mitigating requirements such as prohibiting financial transactions.

- Amend the regulations for insurance entities (DCG 140) to limit the deferral of verification/presentation of identification documents to beneficiaries only. 


\section{EC 5.15 and EC 5.16}

- $\quad$ Requiring FIs to refuse opening an account or conduct a transaction when the required identification documents cannot be obtained or properly verified including e.g., when they are believed to have been altered and/or are false.

- $\quad$ Explicitly require FIs to terminate a business relationship when proper CDD cannot be completed.

\section{EC 6.2}

- $\quad$ As planned, extend/clarify the enhanced CDD provisions for PEPs, including a requirement to obtain senior management approval for the continuation of existing PEP accounts, similar to those contained in DCG 115 and DCG 124 to all the other FIs, including to Type 1 Popular Savings and Loan entities.

\section{EC 6.3}

- Expand/clarify the scope of the requirement to obtain information on "origen de recursos" to include both origin of funds and source of wealth.

\section{$\operatorname{Rec} 7$}

- $\quad$ Extend the enhanced CDD, approval and information requirements to Fund administration and distribution companies in DCG 108 and Stock brokers (DCG 52 Bis-4) as exists for banking entities.

\section{EC 7.4}

- $\quad$ For fund and securities entities, require that the respective AML/CFT responsibilities for the correspondent and respondent institutions be established, (e.g. the CDD obligations for the Mexican correspondents and their cross-border respondent institutions).

\section{EC 8.1 and EC 8.2}

- $\quad$ Establish a basic requirement in all the applicable regulations for FIs to implement policies and procedures to prevent misuse of technological developments for ML and FT purposes.

- $\quad$ Expand the CDD risk management requirements in Chap. III of all the regulations to include such ML and FT risks arising from the non-face-to-face business and transactions, and technological developments.

\subsubsection{Compliance with Recommendations 5 to 8}

\begin{tabular}{|c|c|cl|}
\hline & Rating & \multicolumn{1}{c|}{ Summary of factors underlying rating } \\
\hline R.5 & PC & $\bullet$ & No CDD (AML/CFT) regulations and supervision as yet for unregulated SOFOMES. \\
& & $\bullet \begin{array}{l}\text { Inadequate implementation of CDD requirements esp. oversight requirements } \\
\text { imposed on insurance companies for business conducted through agents. }\end{array}$ \\
& - $\begin{array}{l}\text { Need to qualify the use of numbered and coded accounts in accordance with c5.1. } \\
\end{array}$ & $\begin{array}{l}\text { Significant legal and capacity deficiencies in implementing CDD requirements for } \\
\text { centros cambiarios and money remitters. }\end{array}$ \\
\hline
\end{tabular}




\begin{tabular}{|c|c|c|}
\hline & Rating & Summary of factors underlying rating \\
\hline & & $\begin{array}{l}\text { - Inadequate CDD threshold (USD } 10 \text { O00) for business relationships for casas de } \\
\text { cambio and insurance companies. } \\
\text { - No distinction in all cases between CDD requirements for business relationships and } \\
\text { all types of occasional transactions, including a direct requirement for aggregating } \\
\text { linked occasional transactions. } \\
\text { - No explicit requirement to conduct CDD in all cases where there is suspicion of } \\
\text { ML/FT or doubt about the adequacy of customer information. } \\
\text { - Inadequate provisions in all the regulations with respect to CDD requirements when } \\
\text { there are indications and/or certainty of false, erased or altered identification } \\
\text { documents. } \\
\text { - Weak identification verification requirements for non-beneficiary insurance } \\
\text { policyholders. } \\
\text { Insufficient requirements in the } 2004 \text { regulations for the identification of foreign } \\
\text { beneficiaries. } \\
\text { - No direct explicit requirement for Fls to ascertain/request that applicants for business } \\
\text { to state whether they are acting on behalf of others. } \\
\text { - No general requirement for obtaining information on the purpose and nature of } \\
\text { business relationships. } \\
\text { - } \text { Insufficient justification and guidelines for risk-based CDD, including with respect to } \\
\text { simplified CDD for customers listed in the Annex of the regulations. } \\
\text { insurance policies are too broad. } \\
\text { respect to newly-formed companies. } \\
\text { existing business relationships when CDD cannot be completed and file a STR. } \\
\text { Provions to defer verification of identification of customers associated with } \\
\text { - }\end{array}$ \\
\hline R.6 & LC & $\begin{array}{l}\text { - No explicit requirement in some regulations to obtain senior management approval } \\
\text { for existing PEP accounts and relationships. } \\
\text { - Need to define the scope of "origen de recursos" to include source of wealth for } \\
\text { PEPs in addition to source of funds. }\end{array}$ \\
\hline R.7 & LC & $\begin{array}{l}\text { - Inadequate CDD requirements for correspondent relationships for the mutual fund } \\
\text { and securities firms, including the need to establish their AML/CFT responsibilities } \\
\text { and that of their respondents. }\end{array}$ \\
\hline R.8 & PC & $\begin{array}{l}\text { - No specific requirements to implement measures to prevent misuse of technological } \\
\text { developments. } \\
\text { - No specific risk mitigating CDD requirements for transactions that do not require } \\
\text { face-to-face contact. }\end{array}$ \\
\hline
\end{tabular}




\subsection{Third Parties and Introduced Business (R.9)}

\subsubsection{Description and Analysis}

\section{Legal Framework}

251. FIs are responsible for conducting their own CDD. However, the financial regulatory laws and regulations allow for such interview to be conducted by third-parties under specified circumstances such by affiliates of a financial group and intermediaries (brokers and agents) for insurance and bonding companies. (e.g. for loans granted by financial groups, third-parties can conduct the initial interview with the customer (Art. 46 Bis 1 and 46 Bis 2 of the Ley de Instituciones de Crédito (Credit Institutions Law). FIs are, however, ultimately responsible for complying with the law and reliance can only be placed on domestic intermediaries. (See c9.4 below).

252. The insurance and bonding industry also allow for certain activities to be performed through intermediaries (e.g. other financial institutions) including through insurance agents (Art. 23 of the Ley General de Instituciones y Sociedades Mutualistas de Seguros (Insurance Institutions and Companies General Law), and Art. 87 of the Ley Federal de Instituciones de Fianzas (Federal Bonding Institutions Law) and their regulations. The AML/CFT regulations (DCG 140) apply mainly to insurance companies and their agents. The agents are required to obtain CDD information and documentation on behalf of FIs to enable them to comply with their AML/CFT requirements. Similar arrangements are allowed for bancassurance business where insurance policies are sold by an affiliate member of a financial group such as through a bank or an insurance company.

253. The insurance/bonding and money remittance sectors are the most relevant for purposes of this Recommendation and are discussed in more detail below.

\section{Requirement to Immediately Obtain Certain CDD elements from Third Parties (c. 9.1)}

254. See c.9.2 below: There is no direct requirement for FIs to immediately obtain from other FIs customer CDD and identification information (not necessarily copies of documentation) when they rely on them for CDD. However, the AML/CFT regulations require that where there is reliance for CDD between members of financial groups, it should be governed by formal agreements that include provisions that allow for such information to be obtained on demand and upon opening an account. When insurance companies (DCG 149 Reg. 4) and bonding companies (DCG 112) rely on their intermediaries (agents) for $\mathrm{CDD}$, the regulations require that the insurance agents (not the insurers and bonding companies) collect all the customer information and documentation required under regulations and provide it to the insurance companies for inclusion in their customer files. There is no explicit requirement for such information to be "immediately" provided by the agents or requested by the insurer, as required under c.9.1.

255. Money Remitters (DCG 95 Bis): Reg. 4 requires money remitters that pay remittances to the beneficiary customer ("Transmisores de Dinero Pagadores" or paying money remitters) to obtain identification information and documentation for the beneficiary/recipient customers, and to provide such information to the remitting firm ("Transmisores de Dinero Dispersores") that originated the transaction. This regulation also requires the latter to establish customer identification files (including information on the remitting and receiving/beneficiary customer) prior to carrying out transactions equal to or greater than US $\$ 3,000$. There is no explicit requirement for the remitting firm to immediately obtain such information from the paying agents. 
256. Banks and SOFOLES (DCG 115): Reg. 8: With regard to financial groups, the customer identification file may be prepared and retained by any of the institutions within the group, provided that the following conditions are satisfied:

- The institution that prepares and retains the customer identification file has an explicit authorization from the client to provide the information and documents pertaining to its identification to any of the institutions that make up the financial group.

- The institutions that make up the financial group execute an agreement expressly stipulating that: (a) they may exchange the information and documents pertaining to the identification of the customer, with the purpose of establishing a new commercial relationship with said customer; (b) the institution that prepares the file will make it available to the other institutions so that they may examine it and/or provide it to the authority responsible for its inspection and oversight, when required, and (c) in the event that any of the institutions separates from the financial group, it must establish its own customer identification files.

257. Insurance institutions (DCG 140): Similar provisions are provided for insurance entities as for credit institutions. Reg. 9 states that, with regard to financial groups, the customer identification file may be prepared and retained by any of the institutions within the group, provided that the following conditions are satisfied:

- The client has given an explicit authorization to allow the institution that prepares and retains the customer identification file to provide identification data and documents pertaining to any of the institutions that make up the financial group.

- The entities that make up the financial group agree to do so in writing.

- That the following are expressly contained in the agreement: (a) to share with the entities that make up the group the they may exchange the data and documents pertaining to the identification of the customer and /or to make the customer file available to the other institutions for their review and to make it available to the insurance commission (CNSF) responsible for inspection and supervision when required; (b) the members of the financial group can request the customer identification data and documents or the customer file solely to establish business relationships with the client and once established, for purposes of (a) above; and (c) in the event that one of the entities separates from the financial group, it must establish its own customer identification files.

258. Reg. 4 of DCG 140 also requires insurance agents to obtain all the customer identification information and documentation required by the regulations and to provide it to the insurance companies to enable them to comply with the requirement to establish customer files.

259. All other FIs except Popular Savings and Loans (DCG 124) and Centros Cambiarios (DCG 81-A): Chap. II (see regs. 8 or 9) contains provisions similar to those above that allow customer identification files to be maintained by one member of a financial group. This requirement is not believed to be applicable to centros cambiarios as they are not known to form part of regulated financial groups. In any event, c9.2 requires that information be made available on request, not that files be maintained by a member of a group.

Regulation and Supervision of Third Party (c.9.3) (applying R. 23, 24 \& 29, c. 9.3)

260. Except for money remittance firms and to a lesser extent insurance agents the arrangements described below, mainly apply to other FIs regulated and supervised in Mexico. For remittance firms, the 
paying remittance firm ("Transmisor de Dinero Pagador") is not subject to the full scope of AML/CFT regulations but are required to contribute/collaborate with the remitting firms ("Transmisor de Dinero Dispersor") to enable them to comply with the CDD obligations. Paying firms are required to observe the identification and KYC politics established by the remitting firms (DCG 95 BIS - XV), including for reporting unusual/suspicious transactions. In addition, while the SAT (tax authorities) has the legal mandate to supervise remitting firms (dispersores) for AML/CFT, they are not subject to licensing requirements and a significant part of the sector has not as yet been registered and/or supervised. The SAT requires such firms to submit to it a copy of their AML/CFT procedures. The SAT does not require the paying firms (pagadores) to maintain and submit such documentation.

261. The SAT indicates that it has focused its efforts in supervising the remitting firms (dispersores) because the transaction records are maintained at their headquarters. In accordance to the regulations for money remitters, supervision powers of the SAT are implemented through onsite inspections of remitting firms (dispersores). Hence, as part of its onsite inspections of this sector, the SAT requires all the information necessary to test compliance with the regulations, including information on the paying firms. This is not, however, what the Recommendations require. EC9.3 requires that the remittance firms (dispersores) satisfy themselves that the entities being relied on (the paying firms) for CDD have measures in place to comply with CDD requirements (see e.g., the requirements under DCG 95 Bis, Reg. 15 ), and that they are effectively regulated and supervised for AML/CFT. The authorities may consider implementing a system that requires the main remittance firms (dispersores) to implement oversight mechanisms of their agents (pagadores) to ensure that they are effectively complying with the applicable CDD requirements. This will complement the SAT's supervisory activities and would be necessary due to the potentially large number of paying agents that would otherwise be unsupervised.

262. Insurance companies rely on their agents for a significant proportion of their business and CDD. The regulations (DCG 140) impose more limited and sometimes indirect AML/CFT obligations on agents largely designed to assist the companies with their own compliance with the applicable regulations. These are: $i$ ) Reg. 4: agents should collect CDD information and documents required by this regulation and to provide it to the insurance companies to enable them to include it in their customer identification files. ii) Reg. 6: insurance agents should require from beneficiaries CDD information required under Reg. 4. iii) Reg. 15: insurance agents, when they are certain or have indications that an attempted transaction may be connected with ML or FT, shall accept the transaction and immediately inform the compliance officer of the insurance company. iv) Reg. 16: when insurance agents believe that a client is acting for another, they shall take steps to identify the real owner or beneficiary. v) Reg. 18: insurance agents shall observe the CDD policies, procedures and other measures established by the insurance companies in accordance with the regulations. vi) Reg. 26 VIII: indirectly, the insurance companies/compliance officer shall establish the training programs for agents. vii) Reg. 28 and 29: insurance companies and agents established as legal entities shall develop and implement training programs, and the insurance companies shall record participation of agents in such programs. Insurance agents that are legal entities shall ensure that persons with direct contact with the public or administration of funds are trained before undertaking such tasks.

263. In addition, Reg. 36 requires insurance companies to monitor their agents for compliance with the regulatory provisions applicable to them, as well as with the CDD policies and procedures established by them. In practice, insurance companies have not generally complied with this requirement even with respect to agents organized as legal entities. Also, the relatively large number of insurance agents (more than 44000 as of January 2008) would make effective supervision by the regulators a daunting task. Consequently, the focus should be on enhanced supervision and enforcement by the CNSF on insurers to ensure that they are monitoring compliance by their agents. This would provide a more realistic and effective framework for compliance. (See Rec. 23 below.) 
Adequacy of Application of FATF Recommendations (c. 9.4)

264. Not applicable. Reliance is only allowed with respect to domestic intermediaries.

Ultimate Responsibility for CDD (c. 9.5)

265. Subject to the foregoing, all FIs are ultimately responsible for conducting their own customer identification and verification as contained in the various regulations (Reg. 4) and in the policy requirements in Chap. III. Only DCG 115 for credit institutions has an explicit requirement in Reg. 6 which states that when extending loans or credit, institutions may allow third parties to conduct the interviews of clients but such institutions will be responsible at all times for compliance with the customer identification obligations established in the regulations.

\subsubsection{Recommendations and Comments}

\section{EC 9.3}

- $\quad$ Explicitly require in the regulations, (esp. for money remitters and insurance companies, that FIs immediately obtain CDD information from parties that conduct CDD on their behalf.

- $\quad$ Enforce the requirement for insurance companies to monitor compliance by their agents of their AML/CFT regulatory obligations.

- $\quad$ Consider implementing a system that requires remitting firms (dispersor) to monitor paying agents' (pagador) operations (on whom reliance is placed for certain CDD elements) and compliance with the regulations.

- Other: For consistency with Art. 140 of the insurance law (and similarly for bonding companies), review the suspicious reporting requirements in DCG 140 and in the regulations issued by the SHCP-FIU that establishes the reporting procedures and format.

- $\quad$ Compliance with Recommendation 9

\begin{tabular}{|c|c|ll|}
\hline & Rating & \multicolumn{1}{c|}{ Summary of factors underlying rating } \\
\hline R.9 & PC & $\bullet$ & $\begin{array}{l}\text { Lack of a requirement for Fls to "immediately" obtain CDD information from third } \\
\text { parties. } \\
\end{array}$ \\
& $\begin{array}{l}\text { Inadequate supervision/monitoring of insurance intermediaries for compliance with } \\
\text { AML/CFT obligations. } \\
\text { Inadequate supervision/monitoring of paying agents (on whom reliance is placed) } \\
\text { by remittance firms for compliance with AML/CFT obligations. }\end{array}$ \\
\hline
\end{tabular}

\subsection{Financial Institution Secrecy or Confidentiality (R.4)}

266. Summary: Financial secrecy does not constitute an obstacle for the effective implementation of the FATF recommendations. Competent administrative, law enforcement, prosecutorial and judicial authorities are allowed to obtain any information and documentation kept by FIs and other entities subject to AML/CFT requirements. An apparent limitation could exist in the arrangements where the prosecution (PGR) must channel all requests for information from reporting institutions through the respective supervisory agency. However, the procedure currently in place is working effectively, has not been challenged, and has significantly reduced response times and improved cooperation between PGR and CNBV. Judges (unlike prosecutors and law enforcement authorities) have direct access to information from financial institutions, but in practice they have preferred to request it through the CNBV. 


\subsubsection{Description and Analysis}

\section{Legal Framework}

267. The confidential nature of customer information kept by reporting institutions, the exceptions to that confidentiality and the authorities that are empowered to obtain confidential information, are described in very similar terms in each of the general laws that govern every type of financial institution. These provisions are mainly contained in the following and related articles: Arts. 117 Credit Institutions Law (LIC); Art. 34 Popular Savings and Loan Law; Art. 46 Insurance Institutions and Mutual Societies Law; Art. 192 Securities Market Law; Art. 67 Retirement Savings Systems Law; Art. 55 Investment Companies Law; Art. 46 and 126 Bonding Institutions Law; Art. 95 and 95 Bis General Law of Organizations and Auxiliary Activities of Credit applicable to factoring, licensed casas de cambio, registeredcentros cambiarios, registeredmoney remitters and unregulated multi-purpose financial institutions (SOFOMES).

\section{Inhibition of Implementation of FATF Recommendations (c. 4.1)}

268. Financial secrecy does not constitute an obstacle for the effective implementation of the FATF recommendations, in particular for compliance with the AML/CFT obligations contained in the respective regulatory laws, as well as in the underlying AML/CFT regulations. Competent administrative, law enforcement and judicial authorities are allowed to obtain any information and documentation kept by FIs subject to AML/CFT requirements. By virtue of article 117 of the LIC (and all other similar provisions for the other types of financial institutions), the disclosure of information protected by banking secrecy to the authorities expressly authorized under law does not imply a transgression of any legal confidentiality obligation or constitute a violation of restrictions to disclose information set forth under any contracts.

Banking Secrecy obligations (c.4.1)

269. The confidentiality provisions of Art. 117 , of the LIC, which is replicated in the other sectoral laws, state that:

"The information and documents related to the operations and services referred to in Article 46 of this Law [which lists all the authorized activities], will be confidential. Credit institutions ... shall not in any case give notice or information of the deposits, operations or services ... but to the depositor, debtor, holder, beneficiary, grantor of a trust, trustee, constituent [comitente o mandante], to their legal representatives or to whom they have granted power to dispose of the account or to intervene in the operation or service."

[Note: for purposes of brevity, only the Credit Institutions Law is cited herein. No substantial difference, in law or in practice, was found in the treatment of confidentiality duties by other reporting institutions].

270. The AML/CFT provisions under Art. 115 of the Credit Institutions Law lift the confidentiality provisions established under Art. 117. In particular, it states that compliance with the AML/CFT legal provisions does not constitute a breach of confidentiality. Furthermore, Chap. X of DCG 115 (AML/CFT regulation issued under the Credit Institutions Law) states that the provision of information and reports by officers, employees, representatives, etc. of FIs would not constitute a breach of confidentiality imposed by law or contract, and would not attract liability. All of the AML/CFT provisions in the other financial laws listed above, and their related AML/CFT regulations contain similar gateway provisions. (Chap. X of the AML/CFT regulations. See Rec. 5 below for a detailed description of each one of these laws and regulations and the FIs to which they apply.) 
Access by competent authorities (c.4.1)

271. Art. 117 of the LIC (and its mirror provisions in the laws for other sectors) empowers competent authorities to obtain confidential information and documentation held by reporting institutions.

272. Among the listed authorities empowered to obtain bank-secret information are:

- Judicial authorities.

- $\quad$ The Federal Attorney General or his delegate (PGR), and the general attorneys or deputies of the Federal District and the States.

- The federal tax authorities, for fiscal purposes.

- $\quad$ The Ministry of Finance and Public Credit (SHCP), for the exercise of its competence with respect to the AML/CFT preventive system, which includes the various Supervisory Bodies (Commissions under the SHCP) as well as the FIU.

- The Secretariat for Public Service, when investigating or auditing the net worth of public federal officials.

273. The CNBV and the other supervisors under the umbrella of the SHCP can request and obtain any information deemed necessary for their duties:

"The abovementioned does not affect credit institutions' obligation to provide the National Banking and Securities Commission, all sort of information and documents that, in exercise of its inspection and supervision functions, requests to them regarding the operations that they undertake and the services rendered, nor the obligation of providing information requested by the Bank of Mexico, the Institute for the Bank Savings Protection and the Financial Services Users Protection and Defense Commission, according to the applicable legal provisions" (LIC, Art. 117, paragraph 6).

274. In addition, the AML/CFT provisions under Art. 115 of the LIC (and similar provisions under the other financial laws) empower the SHCP, through the relevant supervisory agency (e.g. CNBV for banks) to request and obtain information and documentation from FIs with respect to any AML/CFT matter covered under Art. 115. It can also request additional information from any other person for such purpose, and is authorized to provide information to the competent authorities. Broadly similar powers are provided to the SHCP and supervisory agencies in the applicable AML/CFT regulations (re: Chaps. X, XI, and XII), to enable them to discharge their obligations under the law (see section Rec. 10 below on record keeping).

\section{Role of the Supervisory Agencies that intermediate the requests for information}

275. A peculiar feature of the Mexican system is that all the authorities allowed to have access to information protected by banking secrecy (except judges in limited cases) are prevented from requesting the information directly from financial institutions. Instead, they must send their requests to the appropriate supervisory agency (in practice the CNBV is most commonly used), which in turn sends out requests to the supervised institutions, collects the responses and forwards them to the requesting authority (Article 180 of the Federal Code of Criminal Procedures. A similar procedure is foreseen in article 9 of the Federal Law against Organized Crime).

276. When the request is made by judges they have the option of sending their requests directly to the financial institution if they have enough information to identify the person or account that is being investigated. Likewise, prosecutors have the option of requesting a judge to issue a court order directly to 
the financial institution if they can provide enough identification details of the suspect. In practice, judges and prosecutors have preferred to channel their requests thorough the CNBV because the mechanism in place is reportedly more expeditious and because financial institutions know that they can be subject to administrative sanctions when they do not respond within the time indicated by the CNBV.

"The credit institutions shall answer the requirements formulated by the National Banking and Securities Commission as a result from the indicated authority's requests in this article, within the term that the same Commission determines. The Commission shall sanction the credit institutions that do not deliver within the established terms and conditions, according to Articles 108 to 110 of this law." (Article 117 LIC, paragraph 9).

277. The current arrangements were put in place to overcome perceived abuses from law enforcement officials who obtained and misused information about persons that were not linked to any criminal investigation, which constituted a violation of banking secrecy. The procedure was also introduced to avoid what was considered an overwhelming number of requests to financial institutions, coming from multiple sources and without meeting minimal standards otr adequately identifying the subject or the account. Financial institutions were reluctant to respond to requests like that, it was argued, because that could imply a breach of their banking secrecy duties.

278. According to PGR officials the system has improved markedly in the last two years and a response now may take as low as three to five business days when they clearly identify the person prior to sending the request through the CNBV. Even when the identification data is limited, the entire process of obtaining information from financial institutions does not take more than one month, down from up to six months a couple of years ago.

\section{Sharing of confidential information with other local and foreign authorities (c.4.1)}

279. There are no limitations to the ability of competent authorities to obtain information from other national authorities as long as the information requested is within their scope of competence. Among other examples, article 97 of the Law of Credit Institutions allows various supervisors and economic authorities to share information among them:

“... To facilitate the fulfillment of their functions, the Ministry of Finance, the Bank of Mexico, the $C N B V$, the Commission for the Protection of Users of Financial Services and the Institute for the Protection of Banking Savings, shall be able to request and share the information that they obtain..."

280. In addition, the AML/CFT provisions under Art. 115 of the LIC applicable to banks and other specified credit institutions states that the SHCP, through the CNBV, can require FIs and other persons to provide it with any information and documentation. It can further provide the information it receives to other "competent authorities". Similar provisions are contained in the AML/CFT provisions of the various financial regulatory laws.

281. Based on article 4, paragraph XXIV of the Law of the CNBV, the Commission is empowered to sign Memoranda of Understanding with foreign regulatory and supervisory organizations, including for the exchange of information protected by secrecy provisions and all the information obtained from the performance of its surveillance powers. Article 9 of the same Law complements this legal provision stating that CNBV would provide legal assistance to its foreign counterparts regarding confidential information provided that an agreement (MOU) between both authorities (CNBV and requesting authority) has been signed and as long as the reciprocity principle prevails in such agreement. 
282. In addition, Art. 117 Bis of the LIC allows the CNBV to provide overseas financial authorities with information concerning operations and services under the AML/CFT provisions of Art. 117 and under Art. 46 (permissible activities for FIs covered by the LIC.).

“Artículo 117 Bis.- La Comisión Nacional Bancaria y de Valores estará facultada para proporcionar a autoridades financieras del exterior, información sobre las operaciones y servicios previstos en el artículo 117, así como en la fracción XV del artículo 46 de esta Ley, que reciba de las instituciones de crédito, siempre que tenga suscritos con dichas autoridades acuerdos de intercambio de información en los que se contemple el principio de reciprocidad, debiendo en todo caso abstenerse de proporcionar la información cuando a su juicio ésta pueda ser usada para fines distintos a los de la supervisión financiera, o bien, por causas de orden público, seguridad nacional o por cualquier otra causa prevista en

los acuerdos respectivos.

283. Other supervisory agencies are not generally allowed to exchange information with foreign counterparts. The CONSAR and SAT are not expressly empowered to exchange information with foreign counterparts regarding AML/CFT. They are, however, allowed to share information with foreign counterparts on non-AML/CFT supervisory issues in accordance with the following legal provisions: In the case of SAT, Art. 7 para. VI, VIII and IX; Tax Administration Service Law; Arts. 9, para. XX and 20, and para. LI, LII and LIII of the Internal Regulations of the Tax Administration Service. With regards to the CNSF, Art. 108, para. VIII Bis of the LGISMS enables it to subscribe international agreements for the Exchange of information with foreign counterparts. No statistics were provided as to the number of such agreements which have been signed and implemented by the CNSF.

Sharing of confidential information between financial institutions to fulfill R.7, R.9 and SR. VII (c.4.1)

284. A new provision was introduced in the LIC that establishes the possibility of exchanging information between credit institutions for the purpose of preventing operations with illegal proceeds. No similar provision exists for the other sectors:

"Article 115 Bis.- Credit institutions will be able to exchange information in the terms prescribed in the implementing regulations of article 115 of this law, with the purpose of strengthening the measures to prevent and detect acts, omissions $u$ operations that could [facilitate] the commission of [ML and FT]. Compliance with their obligations and the exchange of information referred to in this article will not imply any transgression whatsoever against what is established in article 117 of this law [obligation of confidentiality]".

285. The law that introduced this new provision was issued in February 1 of 2008 immediately after finalization of the assessment mission, and the regulations necessary to operationalize the exchange of information among credit institutions have not been issued. It is therefore not possible to assess the effectiveness of the new provision.

286. Notwithstanding the absence of an explicit legal authorization to exchange customer information among financial institutions, banking secrecy in Mexico does not prevent financial institutions to exchange the information that is necessary to fulfill FATF recommendations 7, 9 and VII. With the regulatory regime currently in place, the interested person (the customer) can waive his confidentiality privilege on a case by case or general manner. In practice, financial institutions (particularly those that are members of a financial group) which have a need for such waivers include them in their standard contracts. In particularly, Reg. 4 of Chap. II of the various AML/CFT regulations allows sharing of information between members of a financial group subject to the express authorization of the client. This provision 
mainly relates to the maintenance of customer identification records held by one member of a financial group.

287. The three cases highlighted in the assessment methodology where a financial institution might potentially find it difficult to exchange necessary customer information due to banking secrecy, are mentioned below, together with the solution that is applicable (and in most cases applied) in the Mexican context:

- $\quad$ Payable-through accounts (PTA): Correspondent institutions in Mexico are obliged to apply article 5 of the Regulations for Credit institutions, which tells them to demand from their respondent counterpart that sufficient customer data and documents be kept and made available upon request. Therefore, banking secrecy could not be invoked. On the other hand, respondent institutions from México would have to ask their customers to sign an authorization as a regular part of the initial contract with him. It is noted that the supervisory authorities and the financial institutions met during the mission (esp. banks) indicated that it is not the practice in Mexico to provide PTA accounts for foreign institutions, and very few regular correspondent accounts are maintained. (See Rec. 7 above.)

- The introduction of customers by a third party: AML/CFT regulations do not allow transferring the CDD responsibility to a third party, which makes this situation null in the Mexican context. Within the same financial group, a customer's CDD data may be shared with his prior consent, but each institution is required to maintain the customer's information before initiating a new relationship with him. Also, there must be an agreement between the group's entities for allowing speedy access to copies of the documentation whenever it is needed.

- $\quad$ The transferring of customer information which must accompany a wire transfer: banking secrecy does not prevent the ordering institution to send the identification details of its client, as this is considered by Mexican institutions as an integral element of the remittance service.

288. In all these cases the Mexican regulations require that the financial institution providing the service remains responsible for performing the identification and CDD requirements. Should an institution find an impediment to obtain or disclose the necessary information, it would have to suspend that service until it gets proper authorization from its clients and counterparts.

\section{Fiduciary Secrecy}

289. Article 118 of the Credit Institutions Law was repealed on December $30^{\text {th }} 2005$, thereby eliminating an obstacle which administrative, judicial and law enforcement authorities (except the CNBV) had to obtain information about trusts. Access to trust-related information is now governed by the same provisions that are applicable to any other type of financial information.

\section{Professional Secrecy}

290. In general, it is a crime to disclose confidential information, or information that has been acquired as a result of one's employment or position, if such disclosure causes harm to the interested party and it is made without his consent and without a legitimate reason. The penalty for this ranges from 30 to 200 days of community service (article 210 of the Federal Criminal Code). If the secret revealed is of an industrial nature, or if the disclosing person is a public official or someone who provides professional or technical services, the penalty will range from one to five years, fines and suspension of professional practice for up to one year (article 211).

291. A duty of professional secrecy is also recognized in the Federal Code of Penal Procedure. Lawyers, notaries and other professionals such that they cannot be obliged to testify in Court if the laws 
governing their respective profession impose a duty of confidentiality. Article 243 Bis of the Federal Code of Penal Procedure provides that:

"The following persons will not be obligated to make a declaration on the information they receive, have knowledge of or have in their power:

I. Lawyers, technical consultants and notaries public, with respect to matters in which they have been involved, when the information they have must be reserved to practice their profession;...IV. Persons or public officers who perform any other job, position, work or profession by reason of which the law acknowledges the duty to maintain confidentiality or professional secrecy".

292. Professional secrecy in Mexico does not appear to inhibit the implementation of the FATF recommendations. In order for any professional privilege to be exercised in a criminal procedure, it has to be explicitly recognized by the legislator. Inference from doctrinal or customary sources would not suffice. Moreover, there is an obligation applicable to all people, including professionals, to denounce the commission of any crime of which they have knowledge (article 117 of the Federal Code of Penal Procedure). Finally, law enforcement and judicial authorities have alternative means to obtain the necessary information for their investigations, such as the use of search warrants [cateo] prescribed in article 63 of the Code of Penal Procedures, and the legal resources analyzed under section 2.6 of this report.

\subsubsection{Recommendations and Comments}

293. The CONSAR and SAT should be expressly empowered to exchange information with foreign counterparts regarding AML/CFT. The authorities indicate that they are taking steps to put in place mechanisms for the CONSAR to exchange information with such counterparts through the PRG with which it is authorized to share information by virtue of Article 113 of its governing law.

294. To avoid the potential risk of unduly vetting the requests for information sent by PGR and other investigative agencies, the Supervisory agencies that intermediate these requests should formally (preferably within MOUs) establish, in consultation with the investigating authorities, the basic criteria that they will use in reviewing whether or not a request for information can be forwarded to the financial institutions. Care should be taken to avoid instituting unreasonable burdens on investigatory authorities when they motivate and justify their information requests to the CNBV. Similarly, it is important to mitigate the risk of over-burdening financial institutions with "fishing-expedition" types of requests for information.

295. Specific recommendation:

- The CONSAR and SAT should be expressly empowered to exchange information with foreign counterparts regarding AML/CFT.

\subsubsection{Compliance with Recommendation 4}

\begin{tabular}{|l|l|l|}
\hline & Rating & Summary of factors underlying rating \\
\hline R.4 & C & \\
\hline
\end{tabular}




\subsection{Record keeping and wire transfer rules (R.10 \& SR.VII)}

\subsubsection{Description and Analysis}

296. Summary: All the sector-specific regulations impose the obligation to keep record of the transactions performed and the contracts signed, for a minimum period of ten years after the execution of the transaction. These records must allow the reconstruction of individual transactions, and there are explicit obligations to respond in a timely manner to requests from competent authorities. The AML/CFT regulations do not mention keeping of all business correspondence and account files, but this is required from all businesses by the Code of Commerce.

297. With respect to wire transfers, accurate and meaningful information is collected and sent by ordering institutions in Mexico, but this is subject to a threshold that is higher than the one recommended by FATF. Intermediary institutions and registered money remitters are not regulated for purposes of SR.VII.

Legal Framework

298. Credit institutions: Art. 115, paragraph $5 \mathrm{c}$ and 6) of the Credit Institutions Law (LIC), and its corresponding regulations issued by the Ministry of Finance (Art. 53 of said Regulations) establish the principal recordkeeping requirements for these FIs. The legal and regulatory provisions for credit institutions are replicated in the laws and regulations for all other reporting sectors under the following legal provisions:

- $\quad$ Popular savings and loans: Regulations referred under Art. 124 of the Popular Savings and Loans Law (Art. 38).

- $\quad$ Foreign exchange firms: Regulations applicable to auxiliaries of credit organizations and Foreign exchange firms referred under Art. 95 of the Ley General de Organizaciones y Actividades Auxiliares del Crédito (articles 35, 36 and 38).

- $\quad$ Money remitters: Regulations referred under article 95 Bis of the Ley General de Organizaciones y Actividades Auxiliares del Crédito applicable to money remitters (article 33).

- $\quad$ Securities. Regulations referred under article 52 Bis 4 of the Securities Market Law (article 38).

- Bonding institutions: Regulations referred under article 112 of the Ley Federal de Instituciones de Fianzas (Federal Bonding Institutions Law), article 37.

- Insurance: Regulations referred under article 140 of the Ley General de Instituciones and Sociedades Mutualistas de Seguros (article 38).

- Investment Companies: Article 36 of the regulations referred under articles 108 Bis of the Ley de los Sistemas de Ahorro para el Retiro (Retirement Savings Systems Law) and 91 of the Ley de Sociedades de Inversión (Investment Companies Law).

299. Articles 33 and 38 of the Code of commerce, which apply to all businesses in Mexico including financial institutions, complement the aforementioned regulations.

Record-Keeping \& Reconstruction of Transaction Records (c. $10.1 \& 10.1 .1)$

300. Art. 115 (para. 3) of the LIC (which is repeated in the laws of the other sectors) imposes a general obligation on FIs to establish, in the manner determined via regulations by the SHCP, "measures 
and procedures to detect and prevent [the crimes of ML and FT]". Implicitly this would cover the recordkeeping requirements as contained in both the laws and underlying regulations.

301. Paragraph 6 of the same article requires FIs to keep, for at least ten years, the information and documentation referred to in clause (c) above.

302. The AML/CFT regulations further elaborate the recordkeeping requirements including maintaining of all necessary records of the customer identification file, and those of any transaction ("operation"), for a period of ten years following its execution, even if the account has been terminated for any reason. Operations/transactions are very broadly defined in each of the regulations either by specific reference to the applicable laws and/or to include assets, liabilities, services and those similar or connected to these operations whether singular or plural. This obligation is applicable to both domestic and international transactions.

303. The regulations for credit institutions (DCG 115) and for popular savings and loans (DCG 124) require that the records must be sufficient to allow the reconstruction of every individual transaction. e.g., Art. 53 of DCG 115 requires that "The copies of the reports foreseen in these regulations, and the records of the operations undertaken, must allow their reconstruction and must be kept for a period of at least ten years after they conclude."Article 33 of the Code of Commerce also requires that any person (including legal persons) dedicated to commercial activities ("comerciante") to keep an accounting system that allows, among other things, "to identify individual operations and their characteristics, and to connect the individual operations with the original documents that support them". Article 38 further requires that the person "maintains properly filed for a period of at least 10 years, the original documents of all operations in a manner that allows to link the documents with the corresponding operations and with the records made of them".

304. FIs shall also comply with the criteria established by the supervisory agencies with respect to microfilming, taping, conservation and destruction of documents. The above regulations contain all the basic elements of criterion 10.1 and 10.1.1. Compliance with these record keeping obligations, in conjunction with the general rules on microfilming and preservation of the integrity of the information by other means (art. 49 Code of Commerce), make the records sufficient to reconstruct individual transactions that could serve as evidence in prosecutions. The information received from PGR officials did not suggest any difficulties in obtaining the necessary information and using the records from financial institutions to trace a transaction and use it for prosecution and as evidence in court.

305. Based on actual evidence of implementation by financial institutions and supervisory procedures of the CNBV, the mission was also satisfied that the obligation to keep records covers all "operations" as broadly defined in the regulations. However, it would be useful that all of the regulations (e.g. Art. 115 (see bullet (b) above) relating to "contracts" be reviewed to reflect the broader scope of recordkeeping contained in the umbrella requirement (e.g. under paragraphs 3 of Art. 115 of DCG 115), and in the definition of "operations" in the regulations. Bullet (c) above and paragraphs 6 of Art. 115 should also be similarly broadened. While there is a general obligation in the law requiring FIs to establish measures and procedures to prevent and detect ML and FT in accordance to the regulations, which allows regulators to issue detailed regulations on record keeping, other paragraphs of the same laws could be construed as reducing the scope of the record keeping obligation. In fact, Paragragraphs 5 and 6 Art. 115 of the LIC (and similarly in the other regulations) only refer to the authority of the SHCP to issue regulations with respect to customer identification files and transactions that are reported as suspicious. Nothing is said in the sector specific laws about keeping records of other types of information or documentation, such as transactions that are never flagged for internal review. These are only included in the regulations. 
306. With respect to identification data, all regulations clearly state that "The data and documents that integrate the identification files of customers and users, shall be kept during all the time that the account or contract is current, and after that for a period of at least ten years".

307. Articles 47 to 50 of the Code of Commerce more generally require to preserve for 10 years all business correspondence sent and received. Article 33 cited above also requires that the records be sufficient "to identify individual operations and their characteristics, and to connect the individual operations with the original documents that support them".

308. All the elements of assessment criterion c.10.2 are found across different parts of the Mexican legislation. However, it would be useful to make specific reference in the financial regulations to the requirement to keep records of business correspondence and other types of files, and not only records of the customer identification files and his transactions as is currently the case.

\section{Availability of Records in timely manner (c. 10.3)}

309. As explained in section 3.4 of this report, on the subject of banking secrecy (R.4), competent authorities have unlimited access to the information contained in the records of financial institutions, with the only caveat that all requests for information must be channeled through the respective supervisory agency (most commonly the CNBV) ${ }^{37}$. With respect to timing of the responses, several legal provisions require financial institutions to ensure that all requests for information from competent authorities must be complied "within the terms and by the means established by them" [by the requesting authority in each request]. For example:

"“"The credit institutions shall answer the requirements formulated by the National Banking and Securities Commission as a result from the indicated authority's requests in this article, within the term that the same Commission determines. The Commission shall sanction the credit institutions that do not deliver within the established terms and conditions, according to Articles 108 to 110 of this law." (Article 117 LIC, paragraph 9).

310. In practice, according to prosecutors, their experience under the current system has been positive for the last couple of years in terms of the breath of the information available and the timeliness of it.

Obtain Originator Information for Wire Transfers (applying c. $5.2 \& 5.3$ in R.5, c.VII.1)

311. The same CDD requirements explained in section 3.2 serve for purposes of identifying customers according to criterion VII.1 of the methodology. However, it should be noted that the threshold for identification of occasional customers is US\$3,000, and it does not include the obligation to accumulate lower transactions from a single customer over a period of time. In principle, financial institutions could accept occasional customers for wire transfer services, and only those customers who reach US\$3,000 in a single transfer would be identified. In that case the threshold would not be in accordance with FATF Special Recommendation VII, which allows countries to set a threshold of no more than US $\$ 1,000$ on wire transfers before triggering the regular CDD procedures.

\footnotetext{
${ }^{37}$ Only the judges (not the PGR or the law enforcement) have the option of requesting information directly from financial institutions.
} 
Inclusion of Originator Information in Cross-Border Wire Transfers (c. VII.2)

312. The regulations for credit institutions and for popular savings and loans make reference to the data that must be included in wire transfers (for other financial institutions it would most likely be inapplicable, except for money remitters who are not regulated on this mater as discussed in section 3.11). When credit institutions act as ordering institutions on any funds transfer, they are required to transmit the originator's information and keep the data for future reference by the authorities, in accordance to the FATF requirement: In fact, article 16 of the Regulations for Credit Institutions (and 13 of the Regulations for Popular Savings and Loans) stipulate the following

"the institutions that act as ordering institution on behalf of their clients or users, will be obliged to transmit the following: I. In case of international transfers, at least the commercial name or name of the person (last name, mother's maiden name, domicile and, if applicable, the number of the respective bank account and, if not a customer, the number of the unique identifier number assigned by the financial institution)"

313. The issue of batch transfers is not addressed in the regulations.

Inclusion of Originator Information in Domestic Wire Transfers (c. VII.3)

314. Art 16 of the Regulations for Credit Institutions requires from ordering institutions to collect and insert only the following information in the transfer: "(...) II. In case of domestic transfers, the account number of the client or the unique identifier assigned by the ordering institution." The other information remains with the financial institution, who must "maintain it readily available to the Ministry of Finance and the Commission, in order to submit it in the time that they stipulate" In the assessors' opinion, this procedure satisfies the requirement of the second option under criterion VII.3.

Information transmitted with the transfer (c.VII.4)

315. There are no provisions with respect to wire transfers when Mexican institutions act as intermediaries in the payment chain.

Transfers lacking Originator Information (c. VII.5)

316. Article 36-XI of the Regulations for credit institutions states that, in order to determine if a transaction is unusual, institutions should have regard to factors such as "when an electronic transfer is received without complete information". Article 46 of the same regulation obliges credit institutions to have automated systems that must be capable, among other functions, of "classifying the operations according to the criteria established by each institution, in order to detect operations possibly unusual".

317. These two provisions, however, do not require institutions to adopt risk based procedures specifically for identifying and handling wire transfers that are not accompanied by complete originator information, as is required in c.VII.5. They do not indicate either how to proceed if such transactions are detected.

Monitoring compliance and imposition of sanctions (c. VII.6 and c. VII.7)

318. Supervision of compliance with these requirements is undertaken by the CNBV as part of its regular visits to credit institutions (for details please refer to section 3.10). In addition, credit institutions are required to file monthly and individualized reports of those wire transfers of US $\$ 3,000$ or above which are linked to the same customer and reach the amount of US\$10,000 in one month. 
319. Article 58 of the Regulations provides that the CNBV will oversee that the institutions comply, including their branches, subsidiaries, agents or offices, both domestically and abroad. The CNBV will also impose "the sanctions for non-compliance of the mentioned obligations". The sanctions applicable in this case would be applied in accordance with par. 10 of article 115 of LIC, which stipulates a fine of up to 100,000 days of minimum salary (approximately US\$505,673). According to article 59, even the presentation of incomplete information, illegible or erroneous, will be considered a failure to comply.'

Additional elements: elimination of thresholds SR VII (c. VII.8 and c. VII.9)

320. Not applied.

\subsubsection{Recommendations and Comments}

- $\quad$ R.10: Consider reviewing the law(s) to more explicitly provide for a broader recordkeeping requirements consistent with the underlying regulations and avoid the potential for restrictive interpretations of the authority of the Regulators to regulate all aspects of recordkeeping.

- $\quad$ R.10: Consider clarifying the record keeping obligations contained in financial regulations to more clearly include all forms of account files and business correspondence (these are only required by the Code of Commerce).

- $\quad$ SR.VII: The authorities should lower the threshold for CDD on occasional wire transfers from US $\$ 3,000$ to US $\$ 1,000$ or lower.

- $\quad$ SR.VII: The intermediary institutions in a wire transfer should be obliged to keep accurate and meaningful information thorough the transfer chain.

- $\quad$ SR.VII: Batch wire transfers should be regulated to require that the batch file in which the individual transfers are grouped, contain full originator information that is traceable by the authorities of the foreign recipient institution.

- $\quad$ SR.VII: To the extent that money remitters conduct wire transfers, they should be subject to the same obligations as credit institutions for this service.

- $\quad$ SR.VII: Require institutions to adopt risk-based procedures for identifying and handling wire transfers that are not accompanied by complete originator information.

\subsubsection{Compliance with Recommendation 10 and Special Recommendation VII}

\begin{tabular}{|c|c|c|}
\hline & Rating & Summary of factors underlying rating \\
\hline R.10 & C & \\
\hline SR.VII & PC & $\begin{array}{l}\text { - } \quad \text { CDD threshold of US } \$ 3,000 \text { exceeds FATF limit. } \\
\text { - } \quad \text { No regulation of batch transfers } \\
\text { - } \quad \text { No regulation of the information that must be kept by intermediary institutions } \\
\text { (regs. only cover the originator and beneficiary financial institutions). } \\
\text { - } \quad \text { No requirement to adopt risk-based procedures for identifying and handling } \\
\text { transfers with incomplete originator information. } \\
\text { - } \quad \text { Money remitters are not subject wire transfer regulations. }\end{array}$ \\
\hline
\end{tabular}




\subsection{Monitoring of Transactions and Relationships (R.11 \& 21)}

\subsubsection{Description and Analysis}

321. Summary: All reporting institutions in Mexico are required to monitor their customers' transactions, identify those that are unusual because they fall outside the customer's profile, analyze the background and purpose of said transactions and determine whether or not there is a reasonable explanation for them. Detailed criteria were given by the regulators for the detection of unusual transactions, and most institutions seem to have the necessary internal control mechanisms to comply with them (automation being greater in the banking sector). However, too often, the examples of potentially unusual transactions listed in the regulations are being used by institutions as the sole triggering factor for the filing of reports with the FIU, without performing an adequate analysis of "the background and purpose" of each transaction.

\section{Legal Framework}

322. The different AML/CFT Regulations for each category of reporting institution address in almost identical manner the obligation to monitor transactions and relationships. The key provisions from the regulation for credit institutions (replicated in the other sectoral regulations), which are substantially replicated for all other sectors, are: articles 23 (policies), 24 (profiling and alerts), 25 (high risk customers), 26 (high risk operations); 36 (examination and decision to report), 46 (automated alerts). A separate note is made at the end of this section to highlight differences of implementation of the monitoring requirements of money exchanges and remitters which are, otherwise, formally very similar to those of licensed financial institutions described next.

Special Attention to Complex, Unusual Large Transactions (c. 11.1)

323. Articles 23 and 24 of the regulations for credit institutions establish a clear obligation to determine the expected transactional behavior of customers and to detect any transactions that fall outside their profile. This obligation applies with respect to all customers:

“Article 23: Each institution's know-your-customer policy must include, at a minimum:

I. Procedures by which the institution will track the operations undertaken by its customers.

II. Procedures for adequately ascertaining the transactional profile of the customer

III. The hypotheses in which the operations differ from the transactional profile

$I V$. Measures for the identification of unusual operations

$V$. Considerations to adapt, as needed, the degree of risk previously assigned to the customer.

"Article 24: ... [the transactional profile] shall be incorporated to the system of alerts referred to in article 25, with the objective of detecting inconsistencies between the information given by the customer and the frequency, type or nature of his transactions".

324. There is also a requirement of enhanced monitoring of high-risk customers (article 25).

"Article 25: ... when the degree of [customer] risk is higher, more information must be requested from him, in addition to conducting a stricter supervision of his transactional behavior. For these purposes, the entities must have a system of alerts that allows them to verify and detect changes in the transactional behavior of said customers." 
325. In addition, enhanced attention is required for high-risk transactions, and article 26 mentions some types of operations that must be considered as inherently generating a higher-risk. These are transactions with PEPs, private banking services to non-residents and any other operation classified as high-risk by the institution's internal procedures.

"Article 26: The entities must classify the operations of their customers according the their level of risk. There shall be considered as high risk, among others, the transactions undertaken with PEPs, and the transactions of customers that do not reside in Mexico and which correspond to the affluent segment known as 'private banking'...

"For operations classified as high risk, the institutions shall adopt reasonable measures to know the origin of the funds, and shall try to obtain the data ... about his/her spouse, dependents, companies or associations economically related,...",

326. Article 46 complements the previous obligations with the requirement to have an automated system that must be capable of "contributing the tracking and analyzing the possible unusual operations..., considering at least the information initially provided by the customer, the historical records of his operations, his transactional behavior, the average balances and any other parameter that may contribute to the analysis of these type of operations".

327. Article 23 of the regulations for credit institutions provides a list of 13 "circumstances that should be considered for purposes of determining if an operation is unusual". This list is only a minimum requirement and it is not meant to substitute the institution's own determination of unusual transactions. However, the list confusingly mixes elements of unusualness (or red flags), with examples of transactions that would necessarily have to be reported as suspicious.

328. Among the normal "red-flags" that should prompt further analysis but not necessarily be reported are the appearance of structuring of transactions, the lack of sufficient information in a wire transfer, and transactions involving tax-preferential countries (from a list separately informed by the authorities). Conversely, other situations also included in this provision appear to warrant an immediate report to the authorities, such as the following:

- When the customer or user attempts to bribe or intimidate the personnel of the financial institution in order to complete a suspicious transaction;

- When the customer blatantly tries to evade the parameters that the institution uses detect transactions that must be reported.

329. This confusion may have led some institutions to adopt the practice- as described by some of them - of reporting all transactions that contain any of the listed behaviors or characteristics, without due regard to their possible legitimate explanation or otherwise. Another factor that appears to have exacerbated this practice in the past, according to practitioners- is the apparent tick-box approach of supervisors whenever they find this kind of transaction. As it will be explained in section 3.7, the FIU is engaged in an effort to improve the quality of reports and to reduce defensive reporting. Also, as discussed under section 3.10, supervisory practices have evolved towards a more specialized and substantial approach, and many of the financial institutions met by the mission acknowledged this positive change.

Examination of Complex \& Unusual Transactions (c. 11.2)

330. According to article 36, paragraph 2 of the regulation(s), "The institutions must examine the background and purpose of the operations that are presented to the Committee in order to classify them as 
Unusual Operations or not, establishing in writing the results of this evaluation which shall be available to the Secretariat [Ministry of Finance] and the Commission [CNBV], at least for ten years from the time when the transactions took place".

331. Note that the concept of "Unusual operation" in this context, means an operation that must be reviewed to decide whether to report it to the FIU. It encompasses any unusual transaction that cannot be reasonably explained after careful analysis, as well as the transactions that are suspected of being related with the commission of money laundering or terrorism (please refer to section 3.7 for further details on suspicious transactions reporting). In practice, many FIs document "red flag" transactions that are not forwarded to their committee.

332. The committee referred to above is the "communications and control committee" that all institutions must have, which is responsible among other matters, for issuing the know your customer and customer due diligence policies and approving the training programs on prevention, detection and reporting of transactions. FIs with less than 25 employees, Type I popular savings and loans (the smallest in asset size), Registered currency exchanges centers ("centros cambiarios") and money remitters are exempted from the obligation to have this Committee, but not from the obligation to have an independent compliance officer (more details on internal controls in section 3.8).

\section{Record-Keeping of Findings of Examination (c. 11.3)}

333. Article 36 cited above clearly requires to document in writing the findings with respect to the unusual transaction and the decision to report or not, and it states that all related documentation must be kept for ten years from the time when the transaction took place. The financial institutions interviewed did not indicate any concern or difficulty in complying with this requirement. Also, law enforcement and judicial authorities generally expressed satisfaction with the comprehensiveness and availability of records from financial institutions. Finally, samples of these records are routinely reviewed by the CNBV and the other supervisory authorities in order to determine if unusual transactions are being properly examined and reported.

\section{Registered money remitters and currency exchange centers ("centros cambiarios") - implementation of R.11}

334. Money remitters (Transmisores de Dinero, TD) and currency exchange centers (CC) that only engage in operations below US $\$ 10,000$ do not have to be licensed. However, they have to be registered with the SAT and, for transactions above US $\$ 3,000$ comply with AML/CFT identification and reporting requirements very similar to the ones described here for all other financial institutions. Given the high degree of informality and the lesser sophistication of this sector, the monitoring of transactions has been almost exclusively focused on the control of unique or structured transactions starting at US $\$ 3,000$. Based on the mission's interviews and results of SAT's supervisory actions it is possible to say that these businesses are paying little attention to the profile of customers and the different risks involved in their activity. Aiming to address this problem the SAT has prepared a transactional matrix in Excel which will be given to all CC and TD for free. The matrix will help the industry identify the unusual patterns of transactions of their clients, and therefore facilitate the detection and monitoring of transactions that could merit additional review.

\section{Special Attention to Countries Not Sufficiently Applying FATF Recommendations (c. 21.1 \& 21.1.1)}

335. One of the factors indicated in the regulations among those that should prompt a further review of the transaction by the institution is precisely: 
Article 36-X:“ ".. When the operation that the client or user wants to do involves countries or jurisdictions where: a) Mexican legislation considers that they apply preferential tax regimes; or b) that in the view of the international organizations of which Mexico is a member, do not have measures to prevent, detect and combat operations with funds of illicit proceed, or funds for terrorism or its financing, or when their application of those measures is weak.

With this purpose, the Secretariat will provide the institutions with the lists that contain the names of said countries and jurisdiction".

336. The Ministry of Finance established a confidential channel of communication, which is used for the distribution to regulated financial entities of notices containing the lists of designated persons or countries involved in terrorist financing activities, as well any countries of concern.

337. According to Article 30 of the AML/CFT regulation for credit institutions ${ }^{38}$, financial institutions must strictly apply their customer due diligence policy in the case of correspondent accounts with financial institutions from abroad, when such accounts are located in countries or territories where measures for preventing money laundering and terrorist financing are not implemented or are insufficiently applied.

338. In connection with the foregoing, the Ministry will provide to entities and persons subject to the AML/CFT regime with the lists of the countries and jurisdictions that, according to Mexican law, apply preferential tax regimes or that, in the judgment of the international organizations of which Mexico is a party, do not have sufficient measures to prevent, detect and combat transactions with resources from illegal origin or terrorist financing or where such measures are insufficiently applied.

Examinations of Transactions with no Apparent Economic or Visible Lawful Purpose from Countries Not Sufficiently Applying FATF Recommendations (c. 21.2)

339. The consequence of flagging out a potentially unusual transaction in application of article 36 as quoted, is that the institutions are required to examine that transaction in more depth and make a determination as to whether there is a reasonable and legitimate explanation or, otherwise, whether an "unusual transaction report" must be filed with the FIU (same as for criterion 11.2)

\section{Ability to Apply Counter Measures with Regard to Countries Not Sufficiently Applying FATF Recommendations (c. 21.3)}

340. These countries are already foreseen in the regulations as deserving more stringent monitoring requirements (article 36) although the authorities do not have much flexibility to expand or reduce the corresponding list of countries. If countries are specifically named by an international organization as insufficiently applying the FATF recommendations, then they are included in Mexico's list. In opinion of the assessors, this is similar to the first of the examples given in the assessment methodology -albeit the mildest of them- of how to address the issue of non-cooperating countries by way of imposing additional CDD requirements. There are no legal mechanisms allowing the authorities to impose more specific counter measures with regard to these countries, and the authorities cannot include a country of concern that has not been previously named by an international organization.

\footnotetext{
${ }^{38}$ Similarly drafted for the other relevant sectors.
} 


\subsubsection{Recommendations and Comments}

- $\quad$ R.11: Review the list of potentially suspicious transactions given in the regulations and clarify their correct use as triggers of additional review of the transaction, and not of a mandatory report to the FIU. Also provide additional guidance to reporting institutions in this area.

- $\quad$ R. 21: Consider allowing the regulators to impose a broader range of countermeasures and to address the potential of countries of concern to Mexico before these are identified by an international organization.

\subsubsection{Compliance with Recommendations $11 \& 21$}

\begin{tabular}{|l|l|c|c|}
\hline & Rating & Summary of factors underlying rating \\
\hline R.11 & LC & $\begin{array}{l}\text { Many reporting institutions are using the list of possible alerts provided in the } \\
\text { regulations as triggers of reports, without sufficiently analyzing the background } \\
\text { and purpose of such transactions. }\end{array}$ \\
- & $\begin{array}{l}\text { The monitoring of transactions by money exchanges (centros cambiarios) and } \\
\text { money remitters (transmisores de dinero) has been almost exclusively focused } \\
\text { on the control of unique or structured transactions starting at US } \$ 3,000 .\end{array}$ \\
\hline R.21 & LC & $\begin{array}{l}\text { Mexico can impose countermeasures only with respect to countries previously } \\
\text { identified by an international organization, and not to countries of specific } \\
\text { concern to Mexican authorities. }\end{array}$ \\
\hline
\end{tabular}

3.7 Suspicious Transaction Reports and Other Reporting (R.13-14, 19, 25 \& SR.IV)

\subsubsection{Description and Analysis ${ }^{39}$}

341. Summary: Mexico has a comprehensive legal and regulatory framework for the reporting of transactions to the FIU which includes the filing of reports for any suspicion of money laundering and, more generally, for any unusual transaction that is not justified. Both actual and attempted transactions must be reported and there are other types of reports based on objective monetary thresholds. There is also a clear obligation to report transactions suspected of being related to domestic terrorism or its financing, but the obligation does not extent to the financing of international acts of terrorism, except when persons involved in the transaction are terrorists included in official lists by international organizations or foreign countries. Most sectors are actively reporting, although additional efforts and guidance are needed to reduce the number of so called "defensive" reports, and to enhance their quality. Finally, a technical glitch has prevented the FIU from receiving the reports filed by registered money exchanges centers and remitters, and by the bonding companies, thereby creating an important deficiency in the reporting system.

\section{Legal Framework}

342. Similar to other aspects of the AML/CFT preventive system, the rules for reporting suspicious transactions and other types of transactions are identical for all financial institutions, but they are contained in separate laws and regulations for each type of activity or group. The principal reporting obligation is contained in the various financial laws governing the various financial institutions. These are implemented by AML/CFT regulations issued under each of the applicable laws. Citations, when needed, will be mainly

39 The description of the system for reporting suspicious transactions in section 3.7 is integrally linked with the description of the FIU in section 2.5 and the two texts need not be duplicative. Ideally, the topic should be comprehensively described and analyzed in one of the two sections, and referenced or summarized in the other. 
drawn from the regulations for credit institutions, that is, those applicable to FIs covered under the Law of Credit Institutions (LIC), Art. 115.

343. The key regulations for suspicious activity reporting are contained in Chapters V and VI of the AML/CFT regulations. Chapter V relate to the main duty to report suspicious operations (under Mexican law, these are referred to as "unusual") to the FIU. Chapter VI deal with a special type of suspicious transactions, activities or conduct involving employees, officials and other insiders of FIs. These are referred to as "Worrisome" (Preocupantes) Operations. The key legal and regulatory provisions for suspicious transaction reporting under Chapter $\mathrm{V}$ are listed below for ease of reference:

344. Law of Credit Institutions (article 115) and its regulations (especially Regs. 27, 35, 36 and 60).

- $\quad$ Securities Market Law, article 212, and its regulations (especially Reg. 21).

- $\quad$ Law of Credit Organizations and Auxiliary Activities, articles 95 and 95Bis, and its regulations: Reg. 18 (for auxiliary credit organizations and licensed casas de cambio); Regs. 12, 17, 18, 19 and 20 (for money remitters); Regs. 11, 15, 16, 17 and 18 (for money exchange centers).

- $\quad$ Retirement Savings Systems Law, article 108 Bis, and its regulations (especially Reg. 19).

- Investment Companies Law, article 91, section II and its regulations (especially Reg. 19).

- Insurance Institutions and Companies General Law, article 140, and its regulations (especially Reg. 15, paragraph 2).

- $\quad$ Federal Bonding Institutions Law, article 112, and its regulations (especially Reg. 14, second paragraph).

- $\quad$ Popular Savings and Loans Law, article 124, and its regulations (especially Reg. 25).

Requirement to Make STRs on ML and TF to FIU (c. 13.1 \& IV.1)

345. The financial laws establish similar reporting obligations for FIs which are elaborated in sectorspecific regulations. For instance, Art.115 of the Law of Credit Institutions requires FIs to "I. establish mechanisms and procedures to prevent and detect acts, omissions or operations that could facilitate... the commission of ... [terrorism and its financing, international terrorism and its financing and money laundering]" and to "II. Present reports to the Ministry of Finance, through the CNBV ${ }^{40}$, about: a) the acts, operations and services of their clients which could be related to the above paragraph; and b) all acts... undertaken by [officers or staff of the institution] that could fall in the aforementioned hypothesis or which could contravene or prejudice the adequate application of those provisions". The FIU is the entity within the Ministry of Finance that is charged with handling the STRs, according to internal regulations of said Ministry.

346. The legal statutes cited above indicate that the reporting obligations are to be implemented "as prescribed in general regulations to be issued by the Ministry of Finance, in consultation with [the respective sectoral supervisory agency]" (article 115, par. 3 of the Law of Credit Institutions, reproduced for all other sectoral laws). In the assessors' opinion, the Mexican statues establish a clear obligation to report suspicious transactions under procedures established by the underlying regulations. The requirements under the regulations are described in more detail below.

347. Mexican regulations make it mandatory to submit the following categories of reports:

${ }^{40}$ This procedure will be further discussed below. 
a) Unusual operations reports:

- $\quad$ Reg. 2, XIII of the regulations for credit institutions defines this category as follows: "Unusual Operation is any operation, activity, conduct or behavior that does not match the customer's background, or his known or declared activity, or does not correlate with his usual pattern of transactions vis a vis the amount, frequency, type or nature of the transaction being considered, if there is no reasonable justification for said behavior, or otherwise a transaction in which the institution believes, for any other reason, that the funds could be directed to facilitate, help, aid or cooperate in any way with the commission of the crime prescribed in article 139 of the Federal Penal Code [terrorism], or a crime that could be included in any of the hypothesis of article 400Bis of said Code [money laundering]".

- $\quad$ "It shall also be deemed to be an unusual operation the one undertaken by a user [as opposed to a regular customer] when the funds could be thought to be directed to facilitate committing the crimes mentioned in the preceding paragraph, and the institution has enough elements to file a report".

- $\quad b$ ) Concerning (or worrisome) operations reports:

- $\quad$ Reg. 2 XIV defines these operations as any "the operation, activity, conduct or behavior" of an employee, official or other insider of the institution who seems suspicious, even if he does not engage in transactions with the institution, such as when the employee displays a lavish lifestyle not corresponding to his income (article 2, numeral XIV); This is a specific type of suspicious activity not explicitly contemplated by FATF Rec.13 but which is designed to draw special attention to the risk of ML/FT through illicit activities aided and abetted by staff of FIs. It also likely responds to country-specific circumstances. According to FIU officials, these types of reports have contributed to the investigation of potential ML cases that may have otherwise gone undetected.

- c) 24-hour reports:

- Reg. 27 refers to the situation when institutions have either "indications or certainty... that upon attempting to conduct a transaction with funds that could originate from illicit activities in the terms of article 400 Bis [money laundering] or that the funds could be intended to facilitate, assist...in any form the commission of [domestic terrorism]". These reports are for cases where the degree of suspicion is high requiring almost immediate reporting to the FIU. This obligation is equivalent to what FATF 13 refers to as having "reasonable grounds to suspect". It is established in article 27 of the regulations for credit institutions and repeated in the regulations of all other sectors.

- $\quad$ Timing of reports-30 days:

- $\quad$ Reg. 35 of DCG 115 (and similarly for the others) requires FIs to file the STRs within 30 calendar days, counting from the moment when the transaction is detected. This time period would allow FIs ample time to analyze transactions and avoid unduly delaying analysis and the decision to report. In principle, it should also allow for the preparation of well researched and substantiated reports, leading to high quality STRs for the FIU. In particular, Reg. 35 states: "The institutions must submit to the Ministry, through the CNBV, their reports of unusual operations no later than 30 calendar days from the moment when the operation is detected by the system, model or employee of the institution, whatever occurs first, using the official template that the Ministry shall issue, by electronic means, and in accordance with the terms and conditions that the Ministry establishes". Reg. 36 further provides a list of circumstances that should be considered in deciding if an operation is suspicious (unusual). The results of the analysis of each case should be documented, retained for a minimum 10 years, and made available to SHCP/FIU and the CNBV. 
348. The scope of the obligation to report is broad and satisfies the FATF requirement with respect to objective and subjective tests: $i$ ) where institutions have reasonable grounds to suspect of certain crimes (objective test); and ii) when they suspect that a crime may be committed (subjective test). The scope of the obligation even includes a third category of transactions that are both unusual and unjustified, regardless of any suspicion.

349. In practice, there has been an overwhelming number of STRs, many of which are irrelevant and of low quality. The authorities acknowledge that there is a need to improve the reporting practices of FIs and are taking steps to reduce the number and improve the quality of reports. (See Rec. 26). The following charts show a very high number of STRs filed since 2004, which peaked in 2005 before declining over the last two years indicating efforts to reduce the number of reports. [Note: all the statistics provided in this section were provided by the FIU]

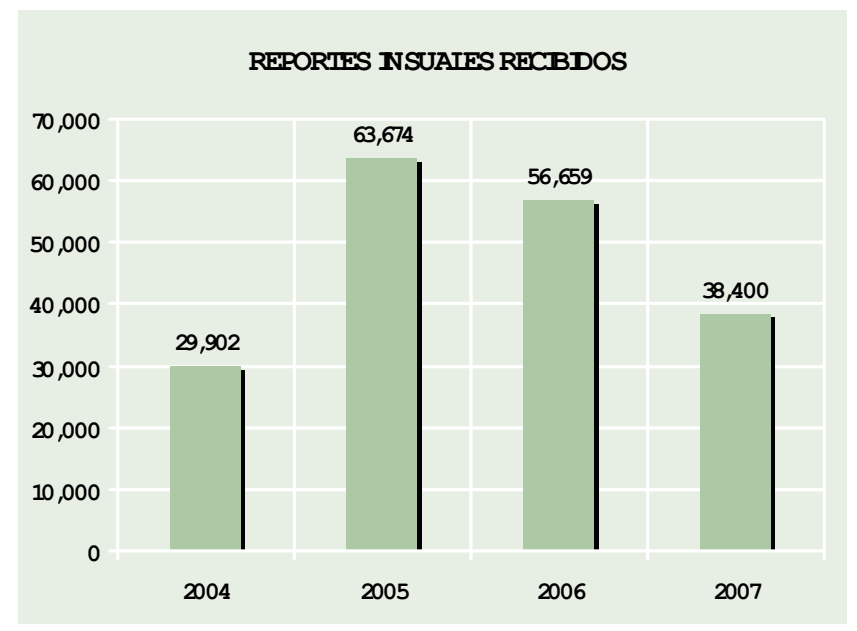

350. The following break down of STRs in 2005 shows the source of such reports by region. The data is highly correlated with high crime regions such as Mexico City and border areas with the United States. 


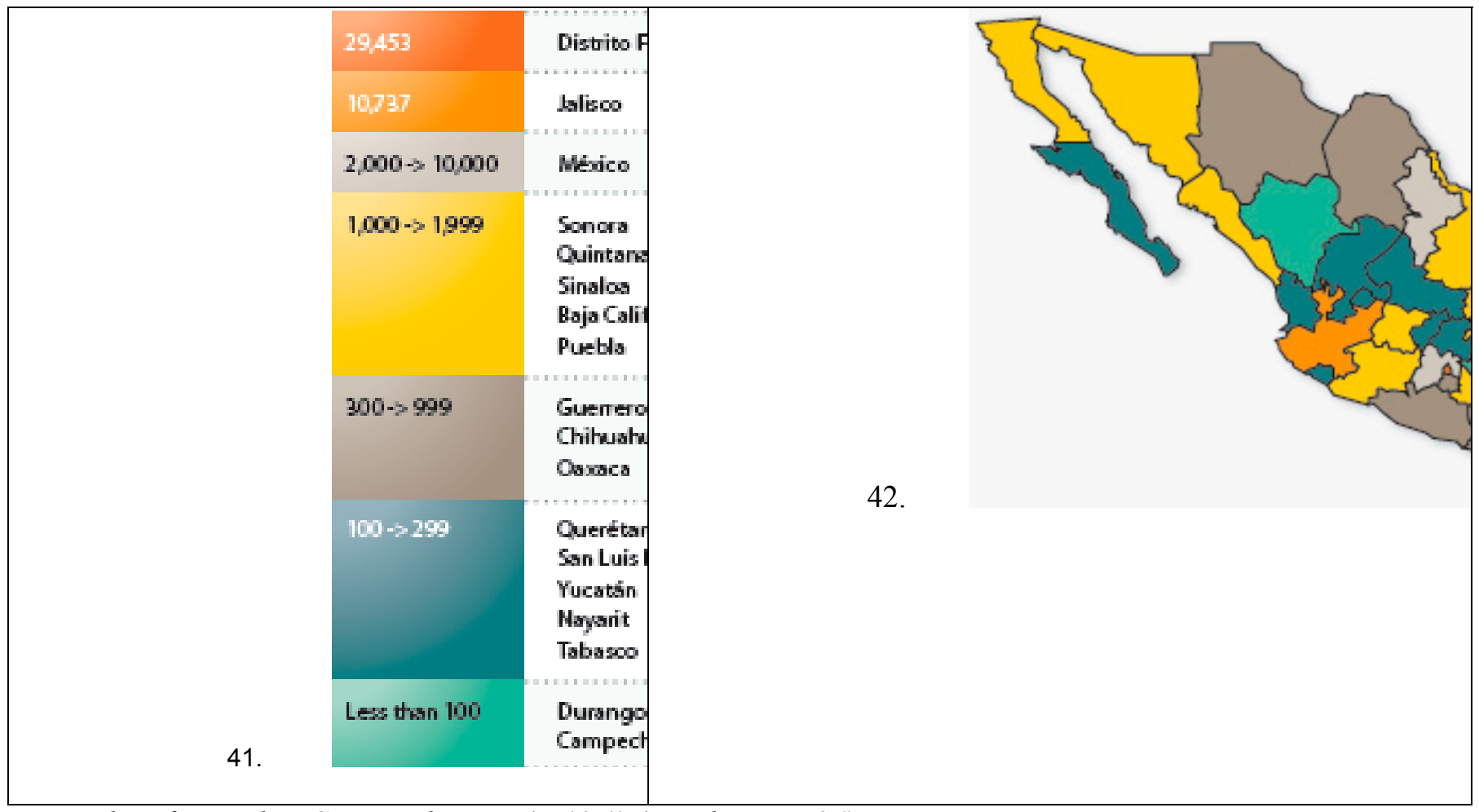

Procedure for sending STRs to the FIU (c. 13.1) (see also Rec. 26)

351. The reports of unusual and suspicious operations are sent to the FIU technically mainly through the competent supervisory agencies. Both the FIU and the Supervisory agencies are part of the SHCP. The FIU has entered into MOUs with each of these agencies which provide, inter alia, that:

- $\quad$ FIs file their STRs electronically through the CNBV, the Insurance Commission and the SAT, respectively. For this, the CNBV uses the same secure gateway that supports all other communications with its supervised institutions. The SAT, in contrast, receives reports from money remitters and currency exchanges via a secure Website in which the reporting businesses are previously registered and given an access code.

- The electronic system automatically verifies that the basic technical requirements are complied with (like filling out all necessary fields in the lay-out) and responds with a confirmation or it rejects the report, as appropriate. Staff of the supervisory agencies do not have access to the information contained in the reports except through their routine supervisory processes.

- $\quad$ Once filed, the STRs are immediately and electronically forwarded to the FIU in encrypted form.

352. The following table contains a break out of STRs by type of institution. 


\begin{tabular}{|c|c|c|c|c|c|}
\hline \multicolumn{6}{|c|}{ REYPORTES DE OPERACIONES INUSUAIES RECBDOS POR TIPO DE INSTIIUCÓN FNANCIERA } \\
\hline TPO DE NSTIIUCDN & 2004 & 2005 & 2006 & $2007 *$ & Total \\
\hline ADM N ITIRADORAS DE FONDOS PARA EL REITRO & 245 & 5 & a[ & 102 & 405 \\
\hline AIMACENES GENERAIES DE DEPOSIO & a & 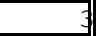 & & & 7 \\
\hline ARRENDADORAS FNANCERAS & d] & (]. & 14 . & & 22 \\
\hline BANCA DE DESARROIIO & 3,464 & 22,228 & 4,515 & 453 & 30,660 \\
\hline BANCA MUITIPIE & 17,325 & 29,06 & 31,993 & 19,999 & 98,373 \\
\hline CASAS DE BOISA & 27 . & 179 & 460 & 22 & 1,082 \\
\hline CASAS DE CAMBD & $7,436[$ & 9,013 & 15,400 & 11,06 & 42,916 \\
\hline CENTROS CAMBARDS & ] & 0 & a & a. & 0 \\
\hline FM PRESAS DE FACTORA.E FNANCERO & d. & 6. & a & & 6 \\
\hline ENTDADES DE AHORRO Y CREDIIO POPUIAR & ] & a & a & 1] & 11. \\
\hline NSTIIUCDNES DE FANZAS & ] & ] & 10 & 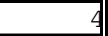 & 28 \\
\hline NSTIUCDNES Y SOCFDADESMUTUALISTAS DE SEGUROS & 159 & 504 & 65 & 2,272 & 3,532 \\
\hline SOCFDADES DISIRBU DORAS DE ACCDNES DE SOCFDADES DE IVERSDN & ] & a. & 260 & 27 & 537 \\
\hline SOCEDADES FNANCERAS DE OBETO LIM IIADO & $1,048[$ & 1,096 & 1,65 & 1,16 & 4,961 \\
\hline SOCFDADES OPERADORAS DE SOCFEADES DE NVERSDN & d. & 179 & 31] & 31. & 805 \\
\hline TRANSM BORES DE DNERO & ]. & a. & a. & a. & $\underline{0}$ \\
\hline UN DNES DE CREDIO & ] & 1,33 & 1,363 & 2,590 & 5,289 \\
\hline TOTAIES & 29,902 & 63,674 & 56,659 & 38,400 & 188,635 \\
\hline
\end{tabular}

353. In line with their market significance, multi-banking institutions file a large majority of the STRs (58 percent), followed by licensed money remitters (28 percent ). However, the lack of reports from registered money remitters and money exchanges (those that are subject to supervision by the SAT) in a country with such influx of migrant remittances, are indications of a significant gap in the system. The mission was informed that these two sectors are actively filing their STRs with the SAT, but a software problem between the SAT and the FIU prevented the FIU from being able to decode the information received from the SAT. This, however, does alone not explain the nil reports since 2004, nor the delay in resolving the transmission problem. There is, therefore, an urgent need for all stakeholders involved to take prompt and decisive action to resolve this serious deficiency.

354. There are no explanations for the lack of reports from certain sectors, e.g., popular savings.STRs Related to Terrorism and its Financing (c. 13.2)

355. Reg. 27 of DCG 115 for credit institutions, which is replicated for the other sectors, imposes the obligation to file a report within 24 hours "if the institution has indication or certainty that ... the funds ..... could be directed to facilitate ... [domestic terrorism]. In addition, institutions must report as unusual, in the same period [of 24 hours], any operations conducted with the persons referred to in the last paragraph of Reg. 60. This Reg. requires the SHCP to disseminate the lists of people identified by international organizations or by other countries "as being related with terrorism or its financing, or related with other illegal activities". The following table (this is a count of reports that contain the words terror, UN or OFAC in the description) provides an indirect indication of implementation of this requirement through the number of reports filed that have some link to the UN and OFAC lists. So far there has not been a single match with the lists of the UN Security Council Resolutions in the Mexican financial system: 


\begin{tabular}{|c|c|c|c|c|c|c|c|}
\hline \multicolumn{8}{|c|}{$\begin{array}{l}\text { Reportes de operaciones inusuales recibidos } \\
\text { donde en los campos "razón de inusualidad" ylo } \\
\text { "descripción de la operación se refiere a: }\end{array}$} \\
\hline Concepto & 2003 & 2004 & 2005 & 2006 & 2007 & 2008 & Total \\
\hline OFAC & 21 & 16 & 355 & 120 & 164 & 41 & 717 \\
\hline TERROR & 10 & 1 & 21 & 8 & 8 & 0 & 48 \\
\hline ONU & 3 & & 5 & 4 & 6 & & 18 \\
\hline OFAC + TERROR & & 1 & & & 4 & & 5 \\
\hline OFAC + ONU & & & 1 & 2 & & & 3 \\
\hline Total & 34 & 18 & 382 & 134 & 182 & 41 & 791 \\
\hline
\end{tabular}

356. The above provisions create a direct obligation to report any transaction that is suspected of being related to domestic terrorism or its financing but remain silent with respect to the financing of international terrorism, except with respect to internationally recognized lists of terrorists (probably because the regulations were issued before the enactment of the terrorist financing offense). This does not satisfy the requirement of FATF 13 to report the financing of any acts of terrorism, either domestically or internationally.

357. A broader obligation to report the suspicion of TF that included its international component could be considered included in the very broad definition of unusual operations as prescribed in Mexican regulations. This approach is allowed under the FATF Methodology for SR. IV, where the footnote indicates that "systems based on the reporting of unusual transactions (rather than suspicious transactions), are equally satisfactory". Arguably, any system that effectively identifies "unusual operations" should be capable of flagging funds of legitimate origin when they are directed or used in a manner that is inconsistent with the customer's profile, and this would capture instances of both local and international operations. However, the assessors could not be persuaded of the effective implementation of this requirement for the detection of terrorist financing operations, because there seems to be an absence of reports generated in this way and a very low level of awareness among most practitioners about the risks for being misused for terrorist financing purposes. More guidance and outreach, and a review of the regulations, are necessary to make full use of the existing preventive system for purposes of detecting the financing of international terrorism.

\section{Reporting of Attempted Transactions (c. 13.3, first part)}

358. The obligation to report attempted transactions is not explicitly established in the regulations. The authorities explained that attempted transactions are implicit in the definition of unusual transactions, as it includes not only actual transactions but also any "activity, conduct or behavior that does not match the customer's background, or his known or declared activity, or does not correlate with his usual pattern of transactions". The FIU has received STRs occasionally based on attempted transactions. However, some large financial institutions interviewed informed that they report attempted transactions as a matter of good practice, but this is not required.

359. It should be noted that Reg. 27 DCG 115 refers to the attempt to carry out a transaction ("al pretenderse realizar una operación..."). However, the subsequent obligation to report is tied only to the 
transactions that are undertaken by the financial institution ("deberán, al aceptar la operación, dar aviso...").

Reg. 27 DCG 115: "Whenever the entities have indications or certainty that, upon attempting to conduct a transaction, the funds could originate from illicit activities in the terms of article 400 Bis [money laundering] or the funds could be intended to facilitate, assist...in any form the commission of [domestic terrorism], the entities shall, when accepting the transaction, immediately inform the compliance officer who shall in turn file a suspicious activity report with the FIU within 24 hours."

\section{No Reporting Threshold for STRs (c. 13.3, second part)}

360. Consistent with the standard, there are no thresholds contained in the law or regulations that would limit the range of suspicious transactions to be reported. However, the existing guidelines or "best practices" jointly prepared by the FIU and the Bankers' Association in May 2006, in an effort to reduce the excessive number of low quality reports, indicate that unusual operations that do not meet certain monetary thresholds, do not need to be reported to the FIU unless there is "reasonable indicia" of any criminal activity. The stated objective of the guidelines is, then, that transactions of little value should not be reported if they are only "unusual and unexplained", even though the regulations require a report in these cases. Only the really "suspicious" transactions should.

361. This apparent distinction is subsequently blurred in the Guidelines when they indicate that an example of "reasonable indicia of criminal activity" (which should be reported regardless of the amount) is "when the characteristics of the transaction or transactions do not correspond to the usual behavior of the person who conducts them". Such example would effectively make it mandatory to report all unusual transactions, therefore worsening the over-reporting problem.

362. In opinion of the assessors, this attempt to raise the benchmark of suspicion by establishing a vague threshold via guidelines has the unintended effect of adding confusion to the reporting obligation and not addressing the potential underlying causes for the excessive number and low quality of STRs. Also, since the guidelines are an attempt at reducing the scope of the regulatory requirement, they may generate legal risks for financial institutions which will not be complying with regulations under the expectation of regulatory forbearance or the understanding that the Supervisory authorities will not enforce compliance with that aspect of the regulations. If the authorities consider that the STR obligation is too broad, a more sensible approach would be to review the regulatory framework, at the same time that they undertake the other measures that the FIU is taking, like its efforts to provide better feedback.

363. Having pointed out the implementation difficulties of the guidelines, it is important to note that they do not necessarily affect compliance with the FATF standard because all "suspicious" transactions must still be reported regardless of their amount.

364. For reference, the following table shows the [very high] amounts of the thresholds established in the guidelines, and their approximate equivalent in U.S. dollars: 


\begin{tabular}{|l|c|c|c|c|}
\hline \multirow{2}{*}{ Sector } & \multicolumn{2}{|c|}{ SCENARIO 1 } & \multicolumn{2}{c|}{ SCENARIO 2 } \\
\cline { 2 - 5 } & Total amount & $\begin{array}{c}\text { Aggregated } \\
\text { during }\end{array}$ & $\begin{array}{c}\text { Transaction } \\
\text { amount }\end{array}$ & $\begin{array}{c}\text { Aggregated } \\
\text { during }\end{array}$ \\
\hline Individuals & $\begin{array}{c}\text { Over 1 MP } \\
\text { (USD 100 000) }\end{array}$ & $\begin{array}{c}\text { Month immediately } \\
\text { preceding }\end{array}$ & $\begin{array}{c}\text { Over 5 MP } \\
\text { (USD 500 000) }\end{array}$ & $\begin{array}{c}\text { Three preceding } \\
\text { months }\end{array}$ \\
\hline $\begin{array}{l}\text { Companies (except } \\
\text { corporate sector } \\
\text { and government) }\end{array}$ & $\begin{array}{c}\text { Over 2 MP } \\
\text { (USD 200 000) }\end{array}$ & $\begin{array}{c}\text { Month immediately } \\
\text { preceding }\end{array}$ & $\begin{array}{c}\text { Over 10 MP } \\
\text { (USD 1 000 000) }\end{array}$ & $\begin{array}{c}\text { Three preceding } \\
\text { months }\end{array}$ \\
\hline $\begin{array}{l}\text { Corporate sector } \\
\text { and government }\end{array}$ & $\begin{array}{c}\text { Over 5 MP } \\
\text { (USD 500 000) }\end{array}$ & $\begin{array}{c}\text { Month immediately } \\
\text { preceding }\end{array}$ & $\begin{array}{c}\text { Over 30 MP } \\
\text { (USD 300 000) }\end{array}$ & $\begin{array}{c}\text { Three preceding } \\
\text { months }\end{array}$ \\
\hline
\end{tabular}

365. According to the FIU, a recent study of a sample of reports whose quality was assessed indicates that they have started to see improvements in the quality and relevance of STRs. Another indication of improvement in the quality of STRs is the following chart, which compares the number of STRs (lighter color) vs. the number of individuals associated with those STRs (darker bars, corresponding to "expedientes únicos" or single files that consolidate all the STRs per person in only one investigation). Note that the total number of STRs has decreased while the number of persons investigated increased.

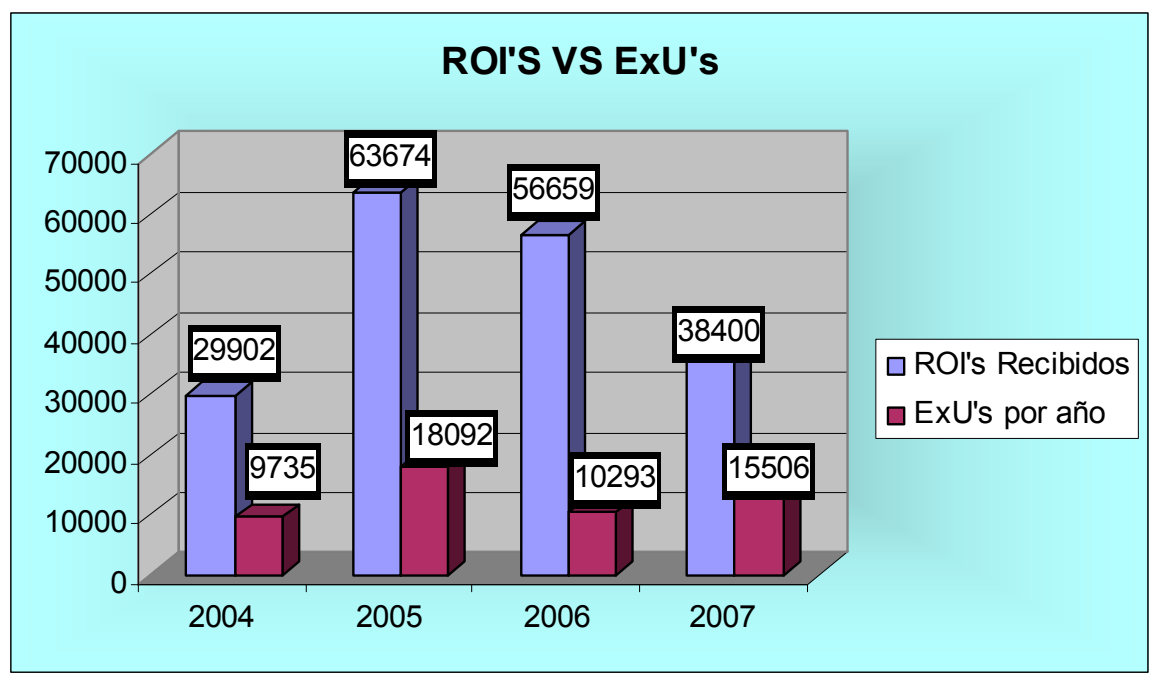

Making of ML and TF STRs Regardless of Possible Involvement of Tax Matters (c. 13.4, c. IV.2)

366. Under Mexican law, if tax matters are believed to explain the unusualness of a transaction, that transaction would still have to be reported because tax evasion is criminalized and thus a predicate offense for money laundering, given the all-crimes approach to the criminalization of money laundering. Financial institutions interviewed also expressed the opinion that it would normally be too risky not to report a transaction with the excuse that it looks only like a tax scheme, because these transaction can be used to 
disguise money laundering. Finally, the statistics available to the mission confirmed that the majority of the STRs disseminated by the FIU are disseminated to the tax authorities because the preliminary analysis at the FIU indicates that the matter is more likely to involve fiscal fraud or tax evasion, than other predicate crimes (please refer to R.26 for an analysis of the implications of this situation in the effectiveness and resources of the FIU).

367. The following chart provides further indirect evidence that financial institutions do not refrain from reporting operations just because they seem to be tax related. Note the large number of cases forwarded by the FIU to the tax authority (SAT) as soon as they determine that the case is tax-related, compared to the more elaborated cases of ML sent to PGR. It is important to mention that since the year 2007 the law allows the parallel prosecution of money laundering and tax fraud offenses derived from the same wrongful act. Prior to that, this was considered double jeopardy so the authorities were forced to give priority to one of the two offenses]:

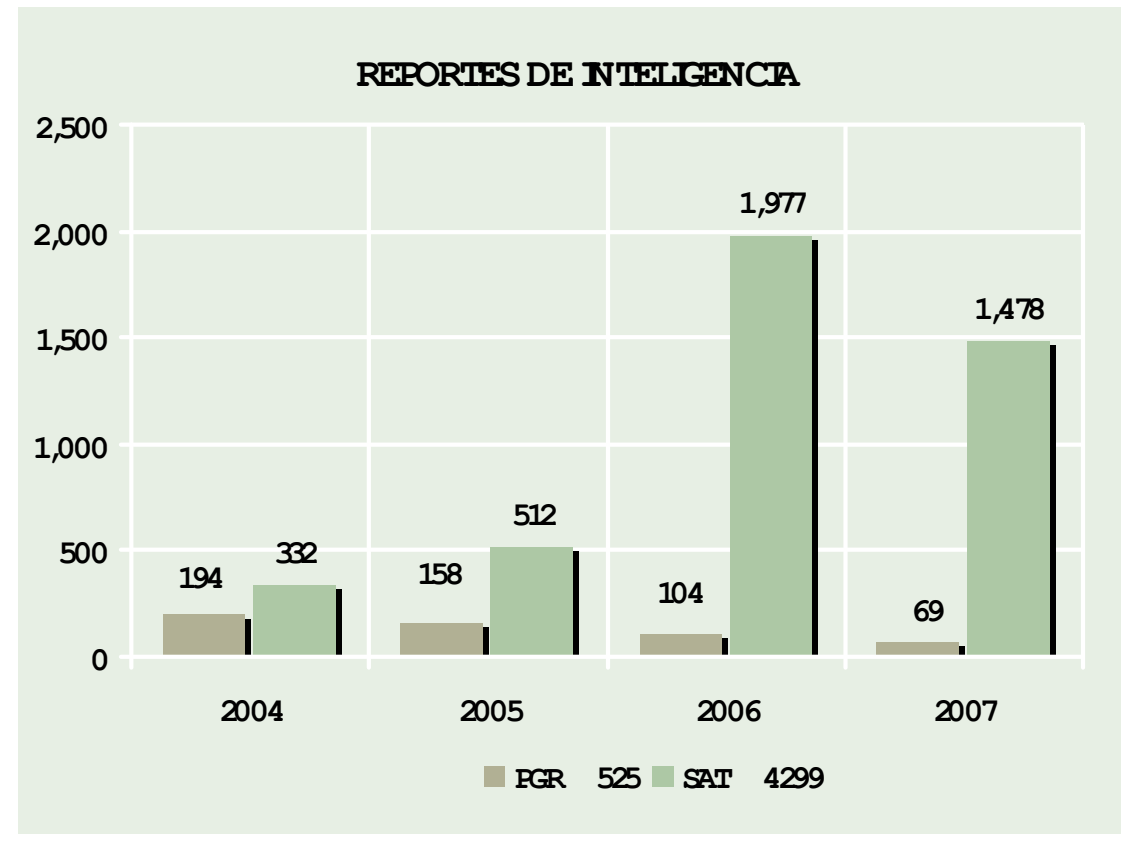

Additional Element - Reporting of All Criminal Acts (c. 13.5)

368. The reporting obligation in Mexico includes all criminal activity. This is because offense of money laundering in the Penal Code refers to any "illicit activity" and not a list of predicate crimes. In turn, the different financial regulations require FIs to detect and report the operations that are suspected of being related to the activities referred to in the Penal Code. Moreover, as explained earlier, financial institutions are also required to report any unusual operations that cannot be reasonably explained, even when no crime is suspected. 
369. According to article 115, paragraph 8 of the Law of Credit Institutions, "compliance with the obligations prescribed in this article [including STR reporting] will not constitute a violation whatsoever of the provisions of article 117 [confidentiality] ... of this Law". The regulations (article 47 in the case of credit institutions) reiterate this principle and complement it by specifying that the protection applies to the institution, the members of its board of directors or managers, the committee, the compliance officer, the executive officers, other officers, and any employees and agents or representatives of the financial institutions. $^{41}$

370. The legal protection granted in the above terms seems adequate ad the mission did not find any practical limitations or concerns from reporting institutions. Additionally, when the FIU transmits a case to law enforcement authorities it does what is in its hands to avoid giving hints about the identity of the institution(s) that filed the related STRs.

\section{Prohibition Against Tipping-Off (c. 14.2)}

371. Article 115 paragraph 11, of the Credit Institutions Law (which is replicated in the regulations for all other reporting entities) stipulates: "The members of the board of directors, executive officers, other officers, employees, agents or representatives, managers and statutory examiners of financial institutions, as may correspond, must abstain from disclosing any information on the reports and any other documentation or information to persons or authorities other than those expressly authorized to require, receive or maintain such information or documentation under the relevant legal or regulatory provisions."

372. Article 47 of the regulations states that "The members of the board of directors or managers, the committee, the compliance officer, the executive officers, other officers, and any employees and agents or representatives of financial institutions shall maintain absolute confidentiality with information relative to the reports ... and it is strictly prohibited to alert or give notice to the customers or users about their inclusion in such reports." The breach of these duties will be penalized in terms of the applicable laws.

\section{Additional Element - Confidentiality of Reporting Staff (c. 14.3)}

373. Financial legislation expressly prohibits staff of the FIU and the supervisory bodies from disclosing any information in connection with transaction reports relative to the crimes of money laundering, terrorism or terrorist financing. Also, as a matter of policy, the FIU does not include copies of STRs in its intelligence reports to the PGR, nor information that could easily lead to the identification of the person who filed the report. In fact, the cases forwarded to PGR are usually the result of many STRs (10 on average).

374. Public officers must abstain from disclosing any information on such reports and other documentation and information to any persons or authorities other than those expressly authorized to require, receive and maintain such information and documentation under the relevant legal or regulatory provisions (i.e,. Article 115, section II of the Credit Institutions Law).

\footnotetext{
${ }^{41}$ These provisions are mirrored by the regulations for all the other financial institutions listed under "Legal Framework" at the beginning of this section.
} 
375. All the sectoral regulations require the filing of currency transaction reports called "relevant transaction reports" with the FIU. These are defined in article $2 \mathrm{XV}$ of the Credit regulations as "transactions carried out with monetary instruments in an amount equal to or in excess of the equivalent to US\$10,000". The same threshold applies to the other types of institutions, except for foreign exchange centers and money remitters which is US\$3,000. These obligations are established in the following provisions:

- $\quad$ AML/CFT General Provisions referred under article 115 of the Credit Institutions Law: Provisions Eighteenth, Nineteenth, Twentieth and Thirty-fourth.

- AML/CFT General Provisions referred under article 124 of the Popular Savings and Loans Law: Provision Twenty-second.

- $\quad$ AML/CFT General Provisions referred under article 95 of the General Law of Credit Organizations and Auxiliary Activities applicable to auxiliary credit organizations and foreign exchange firms (casas de cambio), money remitters, and to foreign exchange centers (centros cambiarios).

- $\quad$ AML/CFT General Provisions referred under article 52 Bis 4 of the Securities Market Law: Provision Twentieth.

- AML/CFT General Provisions referred under article 112 of the Federal Bonding Institutions Law: Provisions Second, section VIII and Eighteenth.

- $\quad$ AML/CFT General Provisions referred under article 140 of the Insurance Institutions and Companies General Law: Provisions Second, section VIII and Nineteenth.

- $\quad$ AML/CFT General Provisions referred under articles 108 Bis of the Retirement Savings Systems Law and 91 of the Investment Companies Law: Provision Twenty-ninth, sections II and IV.

376. "Monetary instruments" are defined as bills and coins of the Mexican currency or the legal currency of any other country, travellers' checks and coins minted in platinum, gold and silver.

377. Financial institutions must submit relevant transactions reports to the Financial Intelligence Unit each quarter through electronic means, in the terms and specifications indicated by the SHCP (i.e. article 34 of regulations for credit institutions). The next table shows the overall number of CTRs ("relevant transactions") received by the FIU since 2004: 


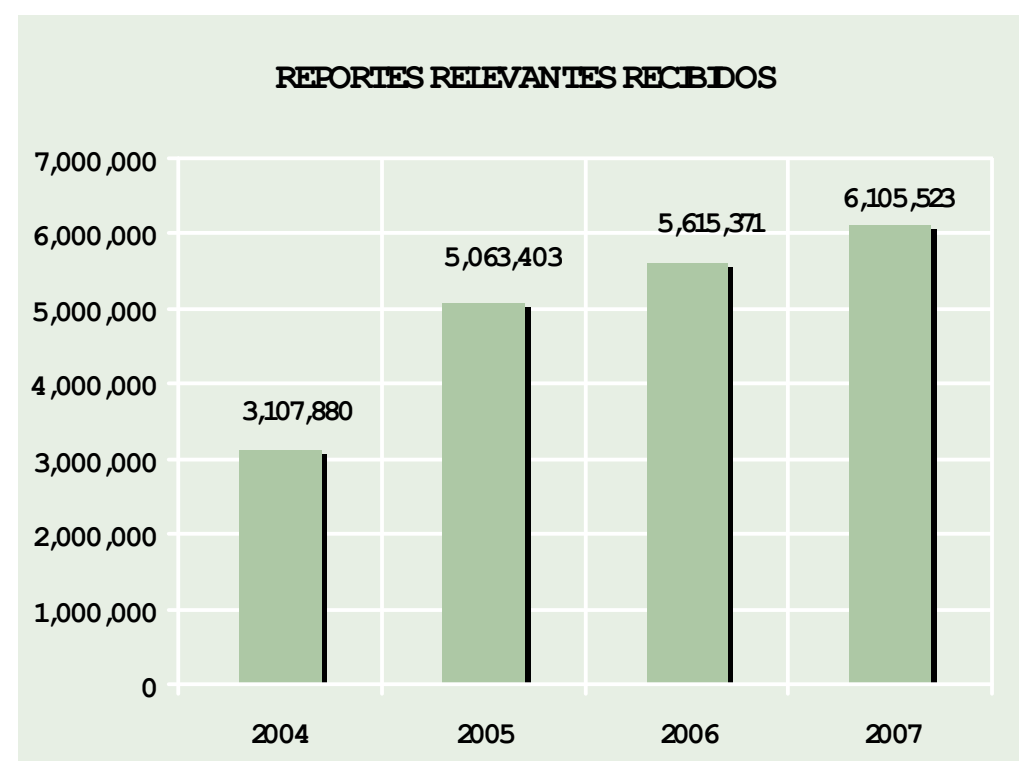

378. The regulations applicable to credit institutions (article 18) further contemplate that in carrying out individual transactions of occasional users (as opposed to regular customers) in cash in an amount equal to or in excess of the equivalent in national currency to US $\$ 3,000$, bound subjects must obtain the following information (this regime for occasional users is only applicable to credit institutions, whose regulations were more recently updated):

- Individuals: name, nationality, identification number and type, home address, date of birth, Population Registration Code and/or Federal Taxpayers' Registry, if available, or serial number of the Advanced Electronic Signature, when available, in accordance with applicable provisions.

- $\quad$ Legal persons: business or corporate name, Federal Taxpayers' Registry or serial number of the Advanced Electronic Signature, when available, address and nationality.

379. In addition, credit institutions must establish mechanisms to monitor such cash transactions (article 19). For this purpose, "they must create a registry of the customers and users that carry out such transactions with the objective of identifying them, knowing their transactional behavior and having more information to issue the relevant reports, when appropriate". They must maintain all this information at the disposal of the FIU and the relevant supervisory body. Not surprisingly, the next table shows that multibanking institutions are the most intensive filers of CTRs in Mexico, followed by the regulated casas de cambio (licensed by the SHCP). On the other hand, the lack of CTR reports received from the less formal exchange businesses ("centros cambiarios") in 2007 is puzzling, and is indicative of serious compliance and technical limitations reflected in other sections of this report: 
REPORIES DE OPERACONES RETEVANTES RECBDOS POR TIPO DE NSIIIUCDN EMANCERA

\begin{tabular}{|c|c|c|c|c|c|}
\hline TIPO DE NSTIIUCON & 2004 & 2005 & 2006 & 2007 & Total \\
\hline ADM N ISTRADORAS DE FONDOS PARA ELRETRO & 1,078 & 551 & 456 & 472 & 2,563 \\
\hline AIMACENES GENERAIES DE DEPOSHO & 0 & 1,226 & 0 & 0 & 1,226 \\
\hline ARRENDADORAS FNANCERAS & 0 & 16 & 39 & 13 & 64 \\
\hline BANCA DE DESARROLIO & 26,595 & 22,959 & 28,376 & 53,306 & 131,236 \\
\hline BANCA MULIIPE & $2,932,428$ & $4,635,443$ & $5,240,500$ & $5,780,425$ & $18,588,796$ \\
\hline CASAS DE BOISA & 32,018 & 47,699 & 14,786 & 6,533 & 101,035 \\
\hline CASAS DE CAMBD & 91,091 & 263,187 & 232,481 & 171,217 & 757,976 \\
\hline CENTROS CAMBARROS & 0 & 1,308 & 1,156 & 0 & 2,465 \\
\hline FM PRESAS DE FACTORA_E FINANCFRO & 0 & 8 & 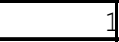 & 3 & 12 \\
\hline ENTIDADES DE AHORRO Y CREDIIO POPUIAR & 0 & 0 & 116 & 547 & 663 \\
\hline NSTIIIUCDNNES DE FANZAS & 1,559 & 1,586 & & 6 & 3,156 \\
\hline NSTIIUCDNES Y SOCEDADESMUTUALISTAS DE SEGUROS & 3,300 & 6,695 & 4,484 & 5,714 & 20,194 \\
\hline SOCEEDADES DISTRBUDORAS DE ACCDNES DE SOCEDADES DE NVERSDN & 0 & 2,927 & 6,469 & 5,882 & 15,272 \\
\hline SOCEDADES FNANCERAS DE OBETO LM IIADO & 19,811 & 42,149 & 43,463 & 47,034 & 152,450 \\
\hline SOCIEDADES OPERADORAS DE SOCEDADES DE INVERSDN & 0 & 8,987 & 9,764 & 11,872 & 30,623 \\
\hline TRANSM BORES DE DNERO & 0 & 462 & & 0 & 462 \\
\hline UN DNES DE CREDIO & 0 & 28,202 & 33,278 & 22,499 & 83,978 \\
\hline TOTAL & $3,107,880$ & $5,063,403$ & $5,615,371$ & $6,105,523$ & $19,892,177$ \\
\hline
\end{tabular}

Fuente: Unidad de Inteligencia Financiera

380. These institutions must establish internal senior approval mechanisms for cash transactions in US dollars, carried out by individuals in amounts over US\$10,000, as well as for those carried out by legal persons in amounts over US\$50,000.

381. According to regulations' article 20, the credit institutions "must establish more rigorous monitoring mechanisms with regard to customers or users whose business activity is related to the industrial, commercial or services sectors that involve the management of large amounts of cash in U.S. dollars". On the other hand, the threshold that triggers such enhanced monitoring is increased to US\$100,000 in one calendar month.

382. The customers and users registry referred to in article 19 must contain:

- $\quad$ For individuals: name, nationality, identification number and type, home address, occupation or profession, business activity or type of business, date of birth, Population Registration Code and/or Federal Taxpayers' Registry, if available, or serial number of the Advanced Electronic Signature, when available, in accordance with applicable provisions.

- $\quad$ For legal persons: business or corporate name, business activity or corporate purpose, Federal Taxpayers' Registry or serial number of the Advanced Electronic Signature, when available, and address.

- Date and amount of each one of the transactions carried out.

- Detail of the amounts operated by each customer and user, in the different states of the Republic. Additional Element - Computerized Database for Currency Transactions Above a Threshold and Access by Competent Authorities (c. 19.2)

383. The information sent by financial institutions is integrated into the FIU's database, used in the analysis of cases and available for use by the PGR upon request. The FIU has strict measures to supervise and execute the use and exploitation of the information contained therein, in accordance with the regulatory provisions and guidelines established by the General Coordination Office of Information Security and Quality. 
384. The FIU issued guidelines that establish security policies. Such guidelines apply in general and are mandatory for all personnel. The purposes of such guidelines are to guarantee the integrity and secrecy of the information that the FIU manages and to establish additional measures with respect to the security of FIU personnel and the FIU's physical facilities, as well as to define the imposition of penalties in case of breach of such policies.

385. During the assessors' visit to the facilities of the FIU, a reasonable number of security measures were evident.

Guidelines and Feedback for Financial Institutions with respect to STR and other reporting (c. 25.1 and c. 25.2) [Note: guidelines with respect other aspects of compliance are analyzed in Section 3.10]

386. The Financial Intelligence Unit is the authority in charge of issuing guidelines for bound subjects relative to compliance with their reporting obligations, as provided for under article 15, section XXIV of the Internal Regulations of SHCP. It has been only recently that the FIU started strengthening its capacity to engage in a more strategic analysis of the statistical and other information available. It is expected that in the medium term it will be able to generate typologies and other types of guidance stemming from this information and more attuned to the specific realities of the Mexican system and its criminality patterns. However, other forms of guidelines and feedback have taken place, as follows.

387. As a result of actions undertaken by the authorities and private sector representatives, a best practices document was issued in 2006 which identified ways to improve the quality of all reports submitted by the various financial institutions, through the National Banking Commission (CNBV), to the Financial Intelligence Unit (FIU). Prior to that, the Memoir of the FIU for the period 2004-2005 had included an Appendix on Typologies and another which contained an extensive list of potentially suspicious operations which could be taken in consideration by financial institutions as part of their monitoring processes. These alerts were broken down according to the different sectors affected (i.e. banking, securities, etc).

388. On the other hand, the FIU holds meetings with reporting institutions, either in groups or bilaterally, to discuss ways to improve the effectiveness of their reporting system and the quality of their reports. in 2007 the FIU conducted individual meetings with representatives from 9 banks (sometimes more than once), 2 exchange houses, 1 securities firm, 1insurance company, ad 1 development bank.

389. Another form of guidance provided to reporting institutions is in the form of response to individual requests from financial institutions or from their associations, with regard to the application of the regulations. This is the competence of the respective regulatory office of the Ministry of Finance and not the supervisory agencies (i.e. the Banking and Savings Unit of the Ministry, in terms of article 27 of the Internal Regulations of SHCP, and the Securities, Insurance and Pensions Unit pursuant to article 32 of such Internal Regulations). When providing this type of guidance these units within the Ministry must consult the prior opinion of the FIU and the sectoral supervisory agency.

390. Some feedback is given to reporting institutions in the form of automated acknowledgment of receipt of reports. Also, the Memoir 2004-2005 included some statistics about the number of reports received and cases forwarded for prosecution. Information about the actual use that the FIU or other authorities make of a specific STR is legally not available to the reporting institution. However, the FIU has provided general feedback during training courses to the banking sector and other financial sectors 
391. More recently, the FIU has implemented a system by which the quality of a small sample of the STRs is evaluated by its analysts, and the result of such evaluations will be privately and periodically shared with each financial institution, starting around mid-2008. This evaluation is based on a set of qualitative and quantitative criteria already discussed with the financial sector. So far, there is no mechanism in place to provide reporting institutions with more opportune and relevant feedback about their reports.

\section{Additional comments on the effectiveness of the reporting system}

392. The quality of STRs, as a result of efforts from the authorities and the private sector, has reportedly improved since early 2007 . However, both the authorities and many financial institutions informed that there is still a long way to go to maximize the value and usage of reports. The most common flaws identified by supervisors during last years inspections to the monitoring and reporting systems of credit institutions, were the following, according to information received from the CNBV:

393. Supervisory findings with respect to reporting suspicious operations:

- $\quad$ Systems are poorly callibrated and generate excessive number of alerts that do should not be considered unusual.

- Inadequate analysis of the alerts generated by automatized systems.

- Deficiencies in the completion of the STR template, especially in the description, the reasons why the institutions report the transaction, and the identification of the accounts and persons involved.

- Transactional profiles not being assigned to new customers, and profiles inadequately determined, which limits the usefulness of automated detection systems.

394. Supervisory findings with respect to the obligation to haveing automated systems.

- Lack of systems that consolidate the different accounts and transactions of one customer.

- No automatization of the internal reports that must flow from the concerned employee to the compliance unit, in a secure and auditable manner.

- Deficient detection of structured operations (fractioned below the reporting threshold), due to insuficient information about the customers and users who conduct operations at the teller.

395. These findings have not yet resulted in the application of sanctions by the CNBV, but the institutions have been instructed to ammend the deficiencies. According to the CNBV, sanctions may be forthcoming if after subsequent inspection visits an institution has not taken appropriate actions.

\subsubsection{Recommendations and Comments}

- $\quad$ Swift action and resources need to be committed to guarantee that the reports from currency exchanges centers and money remitters, and from bonding companies are available to the FIU and the investigative authorities.

- Revise the regulatory provisions that trigger the filing of STRs, and not only the guidelines, as one of the measures to reduce over-reporting.

- $\quad$ All AML/CFT sector-specific regulations should be revised to explicitly incorporate the obligation to use the preventive mechanisms to detect and report the financing of terrorism, including in relation to the recently created offense of international terrorism. 
- $\quad$ Authorities should provide more guidance to reporting institutions on how to detect terrorist financing operations, and promote awareness of the risks of being misused by foreign terrorist organizations to channel their funds.

- $\quad$ The FIU should start providing more regular feedback to reporting institutions based in the objective parameters already defined. Also, it should inform institutions about money laundering techniques specific to the Mexican reality, resulting from the strategic analysis of the information available to the FIU and law enforcement authorities.

- $\quad$ The Supervisory agencies should continue their efforts to carry out risk-focused inspections and encourage financial institutions to fine-tune their automated systems in order to reduce excessive alerts that overwhelm their internal control systems and create a defensive reporting culture.

- The obligation to report attempted transactions in all cases should be explicitly established in the regulations.

\subsubsection{Compliance with Recommendations 13, 14, 19 and 25 (criteria 25.2), and Special Recommendation IV}

\begin{tabular}{|c|c|c|}
\hline & Rating & Summary of factors underlying rating \\
\hline R.13 & PC & $\begin{array}{l}\text { - The reports filed by some sectors are not being transmitted to the FIU, nor utilized in } \\
\text { any form (Bonding companies and the registered money transmitters and currency } \\
\text { exchanges). } \\
\text { - There is no clear obligation to report the suspicion of the financing of international } \\
\text { acts of terrorism (only of terrorist acts committed locally). } \\
\text { - Excessively broad definition of suspicion in the regulations generates defensive } \\
\text { reporting, and the guidance issued to address this issue is not legally adequate to } \\
\text { limit the scope of said regulations. } \\
\text { - The obligation to report attempted transactions in all cases is not explicitly } \\
\text { established in regulations, and not consistently implemented by financial institutions. }\end{array}$ \\
\hline R.14 & C & \\
\hline R.19 & C & \\
\hline R.25 & LC & $\begin{array}{l}\text { - The recently increased strategic analysis capability of the FIU has not yielded } \\
\text { significant information that could be used by reporting institutions to recalibrate their } \\
\text { preventive mechanisms, and the FIU has not published Mexico-specific typologies } \\
\text { since } 2005 \text {. } \\
\text { FIU provides occasional feedback on STR quality to institutions of concern, but there } \\
\text { is no mechanism in place to provide reporting institutions with more opportune and } \\
\text { relevant feedback about their reports, other than an automatic acknowledgment of } \\
\text { receipt of their STRs. The project to rate the quality of STRs still has not reached a } \\
\text { representative sample of reports. }\end{array}$ \\
\hline SR.IV & PC & $\begin{array}{l}\text { - No clear obligation to report suspicions of financing of international acts of terrorism } \\
\text { (only of terrorist acts committed locally). } \\
\text { - The obligation to report attempted transactions in all cases is not explicitly } \\
\text { established in regulations, and not consistently implemented by financial institutions. }\end{array}$ \\
\hline
\end{tabular}




\subsubsection{Description and Analysis}

\section{Legal Framework}

396. Chaps. II and III of all of the regulations require FIs to have customer identification and "know your customer policies". These generally include following basic elements (e.g., DCG 115 Regs. 3, and 21 and 22 , respectively):

397. Chap. II Reg. 3 Customer Identification: FIs must prepare and implement a customer identification policy, which will include, at a minimum, the identification provisions established for such purposes in this Chap. as well as the criteria, measures and procedures that are required for their compliance, including those regarding verification and updating of information provided by customers. In the preparation of this policy, guidelines for the identification of occasional customers must be included and observed.

398. Chap. III Reg. 22 and 23 Know Your Customer: Institutions must prepare and comply with a "Know Your Customer" policy which will include, at a minimum, the guidelines established in the regulations, as well as the criteria, measures and procedures required for their implementation. The policy must include, at a minimum: $i$ ) procedures for the FI to monitor transactions conducted by their customers; ii) procedures for understanding of the transaction profile of the customer; iii) identification of cases where transactions are inconsistent with the transaction/customer profile; $i v$ ) measures for the identification of possible suspicious ("unusual") transactions; and $v$ ) the basis for, where appropriate, modifying the degree of transaction/customer risk previously determined.

399. For the other regulations, similar provisions as above are contained except that they generally do not distinguish between regular and occasional customers. Because these provisions refer to policies for compliance with the various DCGs, they implicitly cover CDD, recordkeeping, detection and reporting of unusual and suspicious activities, all of which are covered in the regulations.

400. Title II Chap. I and II of DCG 124 for Popular Savings and Loans include an additional KYC policy requirement for the larger Type 2, 3 and 4 entities. These set out additional requirements for riskbased approaches to such policies and procedures, reflecting the increased size, scope and sophistication of the larger entities.

401. While the level of compliance can vary across sectors and institutions in scope and content, in practice most FIs covered by the regulations appear to have established formal AML/CFT policies and procedures.

\section{Establish and Maintain Internal Controls to Prevent ML and TF (c. 15.1, 15.1.1 \& 15.1.2)}

402. See Legal Framework above on the requirement to establish AML/CFT policies and procedures. Chap. VII and VIII of the regulations requires FIs to consult with staff, e.g., internal auditors and compliance officers in the elaboration of AML/CFT policies and procedures, including the approval of the same for, inter alia, adherence with the applicable regulations. FIs are also required to have systems to disseminate AML/CFT regulations and their amendments.

403. Chap. VII of the regulations requires FIs to implement internal structures that focus almost exclusively on the establishment of a compliance function within institutions. In particular, it requires FIs to have a compliance committee, comprised of senior executives. Where an FI has less than 25 staff, the 
compliance officer (discussed below) is responsible for the functions of the committee. The functions of the committee are summarized below:

- $\quad$ Submit the AML/CFT policies to the audit committee for approval.

- $\quad$ Receive the results and implement recommendations of internal auditing on their review of AML/CFT.

- Be aware of high risk customers and transactions through the Compliance Officer.

- $\quad$ Establish and disseminate criteria for classification of customers based on degree of risk.

- Disseminate to appropriate staff officially recognized lists issued by international agencies or authorities from other countries of persons linked to terrorism or terrorist financing, or to other illegal activities, and the list of PEPs.

- $\quad$ Consider and decide whether suspicious transaction reports should be sent to the FIU.

- $\quad$ Approve AML/CFT training programs.

- Inform the relevant section of the FIs of inappropriate conduct or compliance of/by directors, officers, employees or agents so that the corresponding disciplinary measures may be carried out.

- $\quad$ Resolve all other matters submitted to its consideration pertaining to the application of these provisions.

404. The committee must also appoint a senior executive among its members as the compliance officer (e.g. DCG 115 Reg. 42) who has primary responsibility for the line oversight for the compliance functions. There are no legal restrictions on access to information by the compliance officer and internal audit in the regulations and none apparently exist in practice. However, it would be desirable to have specific provisions in the regulations that emphasize the ability to access in a timely manner all necessary information to perform their functions, notably with respect to numbered and coded accounts.

405. The compliance officer may also be designated by the Board (consejo de administracion o directivo) of an FI, as appropriate, and shall be a person who is independent of the business units of the FI. Such person shall not be the internal auditor.

Independent Audit of Internal Controls to Prevent ML and TF (c. 15.2)

406. With the exception of DCG 115 (see description in the following paragraph), the AML/CFT regulations do not explicitly require an independent audit function, whether internal or external, to test compliance with the AML/CFT requirements. However, an internal audit requirement is implicitly albeit indirectly addressed in Chap. VII e.g., where it states that the compliance committee shall submit AML/CFT policies to an audit committee and where such auditor shall participate in the compliance committee meetings without vote. The lack of an explicit requirement to have an independent and well resourced audit function in the regulations is a key deficiency.

407. DCG 115 Chap. XI requires banks and SOFOLES to have internal control measures in place that include inspection by the internal auditor, or by an independent external auditor, to evaluate the level of compliance with the regulations, and to report on its findings yearly. These reports must be submitted to the management office and the compliance committee to review the operational effectiveness of the measures implemented, and to monitor corrective action programs. They must be retained for at least five years, and submitted to the CNBV within 60 calendar days following the close of the fiscal year to which the audit corresponds, through the electronic means specified by the CNBV. 
Ongoing Employee Training on AML/CFT Matters (c. 15.3)

408. See 15.1 above referring to Chap. VIII of the regulations which deals solely with the need for FIs to have staff training and communication programs. Also see c. 15.4 below. Chap. VIII of the regulations requires FIs to have training and employee dissemination programs that must include, at a minimum, courses given at least once per year, which must be specially focused on officers and employees who work in the areas of customer service or funds management. These courses must cover, inter alia, customer identification and "Know your Customer" policies; occasional customer identification policies (DCG 115 only), as well as criteria, measures and procedures developed by the institution for the compliance with these provisions.

409. Chap. VIII also requires FIs to disseminate information to staff on techniques, methods and trends for the prevention, detection and reporting of unusual and suspicious transactions.

410. Institutions must issue participation certificates to the officers and employees that attend training courses. These participants will be tested on the knowledge acquired, and measures will be taken with respect to those that fail to achieve satisfactory results. Officers and employees that will work in customer service or funds management areas must receive related training before assuming the position or upon beginning work.

411. In practice, many FIs have ongoing training programs for their staff, including e-learning on $\mathrm{AML} / \mathrm{CFT}$. On average, employees can get between 3 to 10 hours of training every year.

Employee Screening Procedures (c. 15.4)

\section{Banks and SOFOLES (DCG 115), Popular savings and loans (DCG 124) and Fund}

administrators (DCG 108): Chap. XI of these regulations requires FIs to adopt staff selection procedures to ensure that personnel have the necessary technical ability and experience, as well as to endeavour to hire staff of good integrity.

413. Other FIs: Chap. XI requires FIs, through their personnel selection procedures, to ensure that their staff has sufficient technical capacity, experience and honorability to perform their activities. With regard to officers and employees who work in the customer service and funds management areas, FIs must ensure that they receive adequate training to make them aware and help them to comply with AML/CFT regulations, before or upon their admission to the institution. It is considered that there is a lack of integrity where persons have been sentenced for offenses against property, those divested of the right to engage in commerce or hold a job, position or commission in the Mexican civil service or financial system.

414. In practice, many FIs conduct "socio-economic" reviews of their employees to ensure that they are of integrity and honesty.

415. The CNBV and other Commissions have also issued rules and requirements for employment in the financial sector of Mexico. These rules require FIs to verify that members of the board, technical committees, general manager, auditors and other officials to have technical capacity, and integrity.

Additional Element - Independence of Compliance Officer (c. 15.5)

416. The compliance officer is a member of the committee (composed of senior management) and reports to it. Such persons must not be engaged actively in the business units of FIs and cannot be the internal auditor. The designation of the officer and any changes thereof is to be communicated to the 
respective supervisory authorities. In smaller entities, the compliance officer may be designated by the Board to which it would report.

Application of AML/CFT Measures to Foreign Branches \& Subsidiaries (c. 22.1, 22.1.1 \& 22.1.2)

417. In all the regulations, (except DCG 124 for Popular Savings and Loans where it is not applicable), Chap. XI requires FIs to use best efforts to apply Mexican AML/CFT measures in their foreign branches and subsidiaries. To the extent possible, FIs must ensure that these measures are applied, as appropriate, in their offices, branches, agencies and affiliates located abroad, especially in those located in countries where AML/CFT regimes are nonexistent or insufficient. See also c.22.2 below.)

Requirement to Inform Home Country Supervisor if Foreign Branches \& Subsidiaries are Unable Implement AML/CFT Measures (c. 22.2)

418. When it is impossible to apply the AML/CFT provisions in their overseas operations, FIs must inform the SHCP, the supervisory Commissions, in writing within 20 business days. In those cases where regulations of the country where offices, branches, agencies and affiliates of an FI are located have stricter AML/CFT requirements, those requirements must be observed, and the overseas operations shall inform their Mexican head office.

Additional Element - Consistency of CDD Measures at Group Level (c. 22.3)

419. There are no requirements for banks, securities and insurance entities to apply consistent CDD measures for customers that conduct business with multiple branches and subsidiaries worldwide. Nor are there provisions for such FIs to group such clients for CDD and other AML/CFT purposes.

\subsubsection{Recommendations and Comments}

\section{EC 15.2}

- $\quad$ As in DCG 115, all of the other regulations should include an explicit requirement to have a wellresourced and independent audit function.

Compliance with Recommendations 15 \& 22

\begin{tabular}{|c|c|c|}
\hline & Rating & \multicolumn{2}{c|}{ Summary of factors underlying rating } \\
\hline R.15 & LC & $\bullet \begin{array}{l}\text { No explicit requirement in all the AML/CFT regulations to have a well } \\
\text { resourced and independent audit function. }\end{array}$ \\
\hline R.22 & C & \\
\hline
\end{tabular}

\subsection{Shell Banks (R.18)}

\subsubsection{Description and Analysis}

Legal Framework: (See Rec. 23.3 below for a more detailed description of the legal framework for authorizing banking entities.)

420. The LIC provides legal framework for licensing of bank in Mexico which effectively prohibits the establishment of shell banks. The licensing authority for banks is the SHCP (transfer of such authority 
to the CNBV is in process) which covers both the initial licensing as well as changes in ownership or controlling interests in existing banks. The licensing regime established LIC requires the authorities to consider whether, inter alia, the structure of a bank will hinder effective supervision, the major shareholders are fit and proper, and whether the ownership and control structure is transparent. The licensing requirements also apply to the establishment of subsidiaries of foreign financial institutions (see Article 45 of the LIC.)

\section{Prohibition of Establishment Shell Banks (c. 18.1)}

421. Mexican licensing regime (LIC) is comprehensive and strict, and effectively precludes the establishment of shell banks. Art. 8 through 27 of the LIC require banks to have a physical presence as well as mind and management in the Mexico. It states that banks operating in Mexico must have their legal domicile, management and control within Mexico. In practice, all do so.

Prohibition of Correspondent Banking with Shell Banks (c. 18.2)

422. Banks, SOFOLES and other credit institutions DCG 115 (Reg. 33); Fund administrator and distributors (Reg. 14) DCG 108; and Sock brokers (Reg. 16) DCG 52 Bis-4. These regulations require FIs to abstain from conducting correspondent banking transactions with financial institutions or intermediaries that do not have a physical presence in any jurisdiction. Since the absence of a physical presence is a key definitional element for shell banks, this prohibition would effectively preclude these FIs from conducting correspondent banking relationships with shell banks. Consistent with c18.1 above, FIs and the supervisory authorities are aware of the need for mind and management as a necessary element for the physical presence test described above. In addition, these regulations also require FIs to conduct strict CDD on correspondent accounts opened for overseas FIs domiciled in countries with no, or that do not adequately apply, AML/CFT measures. This requirement would also provide FIs the opportunity to detect the possible existence of shell banks which would then be refused correspondent accounts. The mission did not identify any case where FIs provided correspondent accounts to shell banks.

Requirement to Satisfy Respondent Financial Institutions Prohibit of Use of Accounts by Shell Banks (c. 18.3)

423. See c.18.1 and c.18.2 above. There are no explicit requirements for FIs to satisfy themselves that their respondent institutions in foreign countries do no permit their accounts to be used by shell banks. In practice, however, it seems that very few banks provide correspondent accounts to overseas FIs.

\subsubsection{Recommendations and Comments}

- $\quad$ Explicitly require FIs to satisfy themselves that their respondent institutions in foreign countries do no permit their accounts to be used by shell banks.

\subsubsection{Compliance with Recommendation 18}

\begin{tabular}{|c|c|c|c|}
\hline & Rating & \multicolumn{1}{c|}{ Summary of factors underlying rating } \\
\hline R.18 & LC & $\bullet \quad \begin{array}{l}\text { No requirement for Fls to satisfy themselves that their foreign respondents do not } \\
\text { permit their accounts to be used by shell banks. }\end{array}$ \\
\hline
\end{tabular}




\section{A. 3.10 The Supervisory and Oversight System - Competent Authorities and SROs. Role, Functions, Duties, and Powers (Including Sanctions) (R. 17, 23, 25 \& 29)}

\subsubsection{Description and Analysis}

Legal Framework

\section{Regulatory Authorities}

424. The SHCP (Secretaría de Hacienda y Crédito Publico) is the overall regulatory authority for AML/CFT. These powers are conferred by Art. 31 para. VII and VIII of the Organic Law of the Federal Public Administration which authorizes it, inter alia, to regulate and supervise the financial system. This authority is further elaborated and exercised through the powers conferred by the various financial regulatory laws, its three operating units, and the various supervisory Commission and agencies. The SHCP operates through three Administrative Units: the Banking, Securities and Savings Unit (UBVA, Unidad de Banca, Valores y Ahorro), the Insurance, Pensions and Social Security Unit (USPSS, Spanish acronym for Unidad de Seguros, Pensiones y Seguridad Social), and the Development Banking Unit (UBD, Spanish acronym for Unidad de Banca de Desarrollo). Supervision is conducted by the various supervisory Commissions and agencies listed below.

425. The SHCP has powers to: (a) issue AML/CFT regulations (Dispocisiones de Caracter General) that establish measures and procedures for the subject entities to preventing and detecting ML and FT activities; (b) to participate in the preparation of laws or decrees, and other legal instruments with respect to ML and FT; and (c) to respond to inquiries made by financial entities in connection with the application of the AML/CFT regulations, in consultation with the FIU and the relevant supervising agencies. (See e.g., Art. 31 of the Ley Organica de la Administracion Publica Federal, Art. 115 of the Ley de Instituciones de Credito, and Chap. II of the AML/CFT regulations such as reg. 55 of DCG 115).

426. The AML/CFT regulations require FIs to comply with requirements to prevent, detect and report suspicious activities established in the various financial laws and AML/CFT regulations. The supervisory agencies are responsible for overseeing compliance with these requirements. The applicable financial regulatory laws provide the supervisors with comprehensive powers of supervision and inspection, including sanctioning powers for non-compliance with the AML/CFT requirements. The specific provisions and references in the laws and regulations that provide the enabling powers to the supervisory agencies are discussed below under c.23.2, Rec. 19 and Rec. 17.

\section{Supervisory Authorities}

427. There are four supervisory agencies (órganos desconcentrados) under the SHCP responsible for AML/CFT supervision:

- $\quad$ National Banking and Securities Commission (CNBV)

- $\quad$ National Insurance and Bonds Commission (CNSF)

- $\quad$ National Retirement Savings System Commission (CONSAR)

- $\quad$ Tax Administration Service (SAT)

428. The SHCP has issued AML/CFT regulations, (Disposiciones de Caracter General or DCGs) which are supervised and enforced by the supervisory agencies. These are listed below, along with the applicable financial regulatory laws and their supervisory agencies (in brackets). 
429. Financial laws and the AML/CFT DCGs issued under each

(Revised DCGs Nov. 2006)

- Banks, SOFOLES and Other Credit institutions (banks, SOFOLES, and others credit institutions): DCG referred article 115 of the Ley de Instituciones de Crédito (Credit Institutions Law) applicable to banking and credit institutions; (CNBV).

- Popular Savings and Loans: DCG referred under article 124 of the Ley de Ahorro and Crédito Popular (Popular Savings and Loans Law). (CNBV).

- $\quad$ (Other DCGs May 2004).

- Stock brokers: DCG referred under article 52 Bis 4 of the Ley del Mercado de Valores (Securities Market Law); (CNBV).

- Mutual/Investment Fund Companies and Operators: DCG referred to under article 91 of the Ley de Sociedades de Inversión (Investment Companies Law).

- $\quad$ Retirement fund administrators: DCG referred under articles 108 Bis of the Ley de los Sistemas de Ahorro para el Retiro (Retirement Savings Systems Law) (CONSAR).

- Insurance companies DCG referred under article 140 of the Ley General de Instituciones and Sociedades Mutualistas de Seguros (Insurance Institutions and Companies General Law); (CNSF) .

- Bonding companies DCG referred under article 112 of the Ley Federal de Instituciones de Fianzas (Bonding Institutions Federal Law); (CNSF).

- $\quad$ Licensed foreign exchange firms (Casas de Cambio): DCG referred under article 95 of the Ley General de Organizaciones and Actividades Auxiliares del Crédito (General Law of Credit Organizations and Auxiliary Activities); (CNBV).

- $\quad$ Registered foreign exchange firms (Centros Cambiarios): DCG referred under article 95 Bis of the Art. 81-A of Ley General de Organizaciones and Actividades Auxiliares del Crédito; (SAT).

- $\quad$ Registered money remittance firms: DCG referred under article 95 Bis of the Ley General de Organizaciones and Actividades Auxiliares del Crédito; (SAT).

- Credit unions, factoring companies, leasing companies and general deposit warehouses: DCG referred to under article 95 of the Ley General de Organizaciones and Actividades Auxiliares del Crédito. (CNBV).

Regulation and Supervision of Financial Institutions (c. 23.1)

430. Most financial sector activities as defined in the FATF Recommendations are supervised for AML/CFT in Mexico. The four supervisory authorities list above (CNBV, CNSF, CONSAR and SAT) have been granted AML/CFT supervisory responsibility pursuant to the regulatory laws and the AML/CFT regulations. (See 23.2 below.) In terms of total assets in the financial system, approximately 80 percent is accounted for by banks, retirement and mutual funds which are supervised for AML/CFT. Other sectors are supervised for AML/CFT but their significance, at least by asset size, is lower.

431. Notwithstanding, there are some financial activities in Mexico covered under the FATF Recommendations that are not effectively supervised for AML/CFT, which can pose risks to the rest of the financial sector. (See section 3.1: Risk of money laundering or terrorist financing for a more detailed discussion on risk.) These are discussed below. 


\section{Registered currency exchange centers (Centros Cambiarios) and registered money}

remitters: These activities are subject to the AML/CFT regulations established under DCG 81-A and DCG 95 Bis of Ley General de Organizaciones and Actividades Auxiliares del Crédito. They are subject to the supervision of the SAT. Estimates vary as to the total number of foreign exchange firms and money remittance firms that require registration but the authorities estimate that both sectors amount to about 4 380. The industry association (Associacion de Centros Cambiarios y Transmisores de Dinero), however, believes that there are significantly more in operation (See Rec. 5) The authorities are of the view that a significant proportion of these are small "mom and pop" operations. About 3069 have given statutory notice to the SAT as to their activities and only 89 ( 80 centros cambiarios and nine money remitters) are members of the sector's Association. (By contrast, there are only 23 licensed casas de cambio and about four licensed money remitters.) Of the 3069 registered, at the time of the mission the SAT had visited about 1734 money remittance and foreign exchange firms, and sanctioned about 567 for non-compliance with AML/CFT and registration requirements.

433. Supervision of this sector poses a significant challenge for the authorities. The sheer number of firms/persons engaged in this sector, the increasing number of unregulated SOFOMES ${ }^{42}$, and the limited supervisory staff in the SAT, make effective supervision a significant challenge. A contributing factor to the growth in this sector may revolve around the legal definition and sharp differences in equity requirements between licensed and unlicensed (registered) currency exchange centers. (Art. 81-A of the General Law of Organizations and Auxiliary Activities of Credit (Ley General de Organizaciones y Actividades Auxiliares del Crédito.) Persons who engage in remittance and foreign exchange business in amounts of less than the equivalent of US\$10,000 per day per customer are not required to be authorized. This threshold does not appear to adequately differentiate between the retail and wholesale nature of the less formal foreign currency and remittance market in Mexico. Market participants state that the average retail transaction is about USD 250 to USD 350. It is suspected that there are an unknown number of unregistered and unsupervised money remitters and currency exchange centers that may be conducting business at or above the USD 10000 threshold enhancing the degree of ML and FT risks, and posing a challenge for enforcement. Nevertheless, the SAT endeavours to conduct surveillance and inspection activities aimed at detection such operators with a view to informing the CNBV since such operations would require licensing.

434. As part of its supervision, the SAT AML/CFT unit tries to identify registered centros cambiarios and money remittance that are transacting in amounts above the legal limit. The SAT reports such cases to the CNVB because such operations may constitute a violation of the General Law of Auxiliary Credit Organizations and Activities. These cases have being submitted to the General Attorney's Office (PGR) for investigation. While this may serve as a stopgap measure, resolving this problem may require, inter alia, an increase in supervisory resources for the SAT, legal reform and policy solutions, including a reassessment of the legal threshold that distinguishes between the licensed from the registered operators, and practical enforcement mechanisms. It may also require the creation of a specific framework for regulating wire transfers for money remitters. Balancing the need for effective AML/CFT supervision of this sector, while allowing operators to continue to serve the legitimate needs of their customers and communities, will require a review of existing policy and prudent resource management.

\footnotetext{
${ }^{42}$ SOFOMES are mostly unregulated multi-purpose lending institutions that are subject to AML/CFT requirements under the Law for Auxiliary Credit Organizations and Activities but for which no AM/CFT regulations have been issued as yet. They must include "enr" or "entidad no regulada" in their titles to indicate their unregulated status. They have been unregulated since 2006, and have until 2013 to convert from regulated SOFOLES (limited purpose lending institutions) or liquidate if they are not part of a financial group. Regulated SOFOMES are those that form part of a financial group and will continue to be subject to the AML/CFT regulations applicable to credit institutions.
} 
435. Unregulated SOFOMES ("entidad no regulada") are covered under Art. 87-B and 95 Bis of the Ley General de Organizaciones and Actividades Auxiliares del Crédito for AML/CFT purposes of AML/CFT. The remaining SOFOLES are limited purpose financial institutions that can lend for specifically authorized sectors such as mortgages (the biggest share), auto loans, agriculture, consumers, etc. and can also engage in leasing and factoring operations. According to the authorities, some casas de cambio (foreign exchange firms) have converted to SOFOMES. They are not permitted to accept deposits from the public and fund their operations from the sale of commercial paper, borrowing and equity.

436. As part of Government policy, SOFOLES are being deregulated since July 2006. They have until 2013 to either convert to unregulated SOFOMES (multiple purpose financial institutions) or be liquidated. Those that are part of a financial group through equity participation will continue to be supervised for AML/CFT by the CNBV under DCG 115, but will no longer require licensing. The unregulated SOFOMES will be supervised for AML/CFT by the SAT for AML/CFT compliance but as of the time of the mission, AML/CFT regulations (DCGs) had not been issued by the SHCP as yet.

437. As of January 2008, there were 424 SOFOMES in Mexico of which 634 are unregulated. This represents an increase from 41 unregulated entities operating in January 2007, or 850 percent . In contrast, there were only 13 regulated (part of financial groups) SOFOMES in January 2008, compared to 2 in January 2007. In total they accounting for less than 4 percent of financial system assets (September 2007 estimates). The mission did not obtain estimates for total assets held by the unregulated SOFOMES. However, statistics provided to the mission show that their minimum paid up capital can range from as low as the equivalent of US\$100 to US\$1.4 billion.

438. The authorities do not believe that this sector represents a high degree of ML and FT risks as it not authorized to take deposits, but no formal review of such risk has been undertaken. However, on current growth levels and trends, the unregulated nature of the sector, and the uncertainty of their asset size, the potential of for ML and FT risk can increase. In addition, the absence (since mid-2006) of AML/CFT regulations for unregulated SOFOMES is a concern, as well as the limited budget and staff of the SAT to undertake effective ongoing supervision when these regulations are implemented. As indicated earlier, the SAT is also responsible for the supervision of registered foreign exchange centers (centros cambiarios) and money remitters which the SAT estimates total more than 4,380.

439. Insurance agents and brokers ("apoderados de personas morales") (These intermediaries will be referred hereinafter generally as "agents"): The AML/CFT regulations for insurance companies (DCG 140) and for bonding entities (DCG 112) impose more limited obligations for agents. Please refer to Recs. 5, 13 and SR IV for a description of the scope of coverage of agents in the AML/CFT regulations, including the duty in the 2004 and 2005 regulations issued by the SHCP/FIU establishing the procedures and format for reporting suspicious and large transactions. The DCG 140 regulations address the duty to report suspicious activity in the case of attempted transactions and subsequently realized transactions to compliance officers of insurance companies. In addition, both regulations covering the Commission's duty to supervise for compliance (reg. 51 DCG 140 for insurance and reg. 50 DCG 112 for bonding) should extend to supervising AML/CFT compliance by agents, particularly the large corporate agents. In practice, the duty imposed by the regulations on insurance companies' to oversee compliance by their agents with respect to their AML/CFT obligations should be more rigorously enforced. In this regard, consideration could be given to exercising oversight of agents also through the internal audit and compliance arrangements of these FIs. 
Designation of Competent Authority (c. 23.2)

440. As indicated under c.23.1, Mexico has four main supervisory agencies responsible for AML/CFT supervision. Among them, these agencies cover all of the financial activities covered by the AML regulations as follows:

- National Banking and Securities Commission (CNBV): banks and SOFOLES, factoring, leasing, credit unions, deposit warehouses, securities brokers, mutual fund operators and distributors, casas de cambio.

- $\quad$ National Insurance and Bonds Commission (CNSF): insurance and bonding institutions but as discussed in Rec. 5 and under c23.2 above, there is indirect but reasonable coverage for agents in the AML/CFT regulations).

- National Retirement Savings System Commission (CONSAR): retirement fund administrators.

- Tax Administration Service (SAT): foreign exchange centers (centros cambiarios), money remitters (and when AML/CFT regulations are issued unregulated SOFOMES).

441. Financial laws and AML/CFT regulations (DCGs) establish the power of the supervisory authorities to supervise and impose penalties for non-compliance. All of the regulations require the three Commissions and the SAT (e.g,., reg. 58 of DCG 115 for credit institutions) to supervise compliance by FIs with their AML/CFT obligations. The regulations require the supervisors to review compliance with the applicable provisions with respect to their local branches, subsidiaries, affiliates, agencies and offices, as well as their overseas operations.

442. The supervisory programs of these bodies cover both offsite and onsite activities, and include AML and CFT elements. As expected, the main focus of activities has been on AML in view of the relative importance of ML risk in the Mexican system, especially from drug trafficking and organized crime related offenses. A summary of these programs, and of the results obtained to date, follows.

443. With the exception of the SAT, the supervisory agencies have developed an impressive capacity to supervise for AML/CFT with respect to those sectors assigned to them. These agencies have a cadre of well trained, dedicated professional staff that facilitates supervision and enforcement of compliance with AML/CFT requirements. A summary of the AML/CFT supervisory program for the main supervisory agencies follows.

45. CNBV: The CNBV is responsible for the supervision of the following number of entities:

\begin{tabular}{|l|c|}
\hline \multicolumn{1}{|c|}{ Financial Institution } & Number \\
\hline Banking Institutions & 40 \\
\hline Popular Savings and Loans & 48 \\
\hline Credit Unions & 155 \\
\hline Development Banks & 6 \\
\hline $\begin{array}{l}\text { SOFOLES (Sociedades Financieras de } \\
\text { Objeto Limitado) }\end{array}$ & 39 \\
\hline Casas de Cambio & 24 \\
\hline Securities Brokers & 32 \\
\hline
\end{tabular}




\begin{tabular}{|l|c|}
\hline \multicolumn{1}{|c|}{ Financial Institution } & Number \\
\hline Mutual/investment Fund Operatiors & 44 \\
\hline Mutual/investment Fund Distributors & 8 \\
\hline Leasing Entities & 10 \\
\hline Factoring Entities & 3 \\
\hline General Deposit Warehouses & 20 \\
\hline Total & 429 \\
\hline
\end{tabular}

444. The supervision of FIs is organized along functional lines under various Vice Presidencies. There are units that specialize in the supervision of the various sectors, including consolidated supervision of financial groups. AML/CFT supervision falls under the general oversight of these Vice Presidencies who oversee both prudential and AML/CFT supervision. Two structural arrangements for supervision by the CNBV are shown on the charts in the following page.

445. The CNBV has been conducting AML/CFT supervision as part of its prudential and other oversight activities. In the past, AML/CFT supervision has generally been conducted through onsite inspections but in April 2007, a specialized AML/CFT unit (DGPOI: Dirección General de Prevención de Operaciones Ilícitas) was established. It is expected that the functions of this unit will improve the efficiency of AML/CFT supervision and help to develop more specialization in this area. The DGPOI has started to participate in general integrated inspections. It can and has also conducted separate focused inspections, independent of the prudential areas. It will also be engaged in special examinations for AML/CFT cases, as required. The CNBV has developed comprehensive and detailed procedures for the conduct of both offsite and onsite supervision. With respect to AML/CFT, these are largely focused on the review for compliance with the various requirements established in the regulations (DCGs). 


\section{STRUCTURE OF SUPERVISION OF THE CNBV}

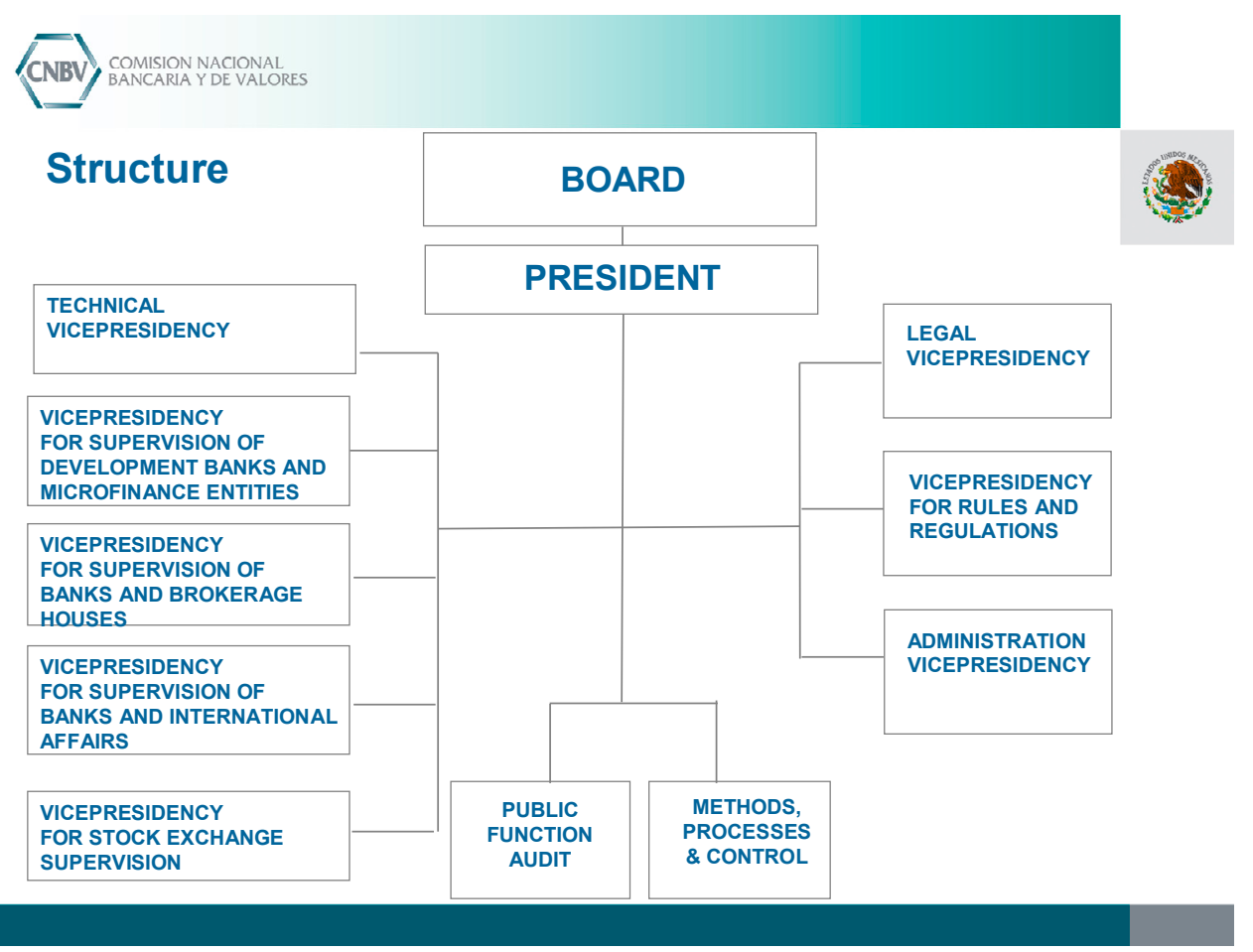

CNBV COMISION NACIONAL
BANCARIA Y DE VALORES

\section{Structure}

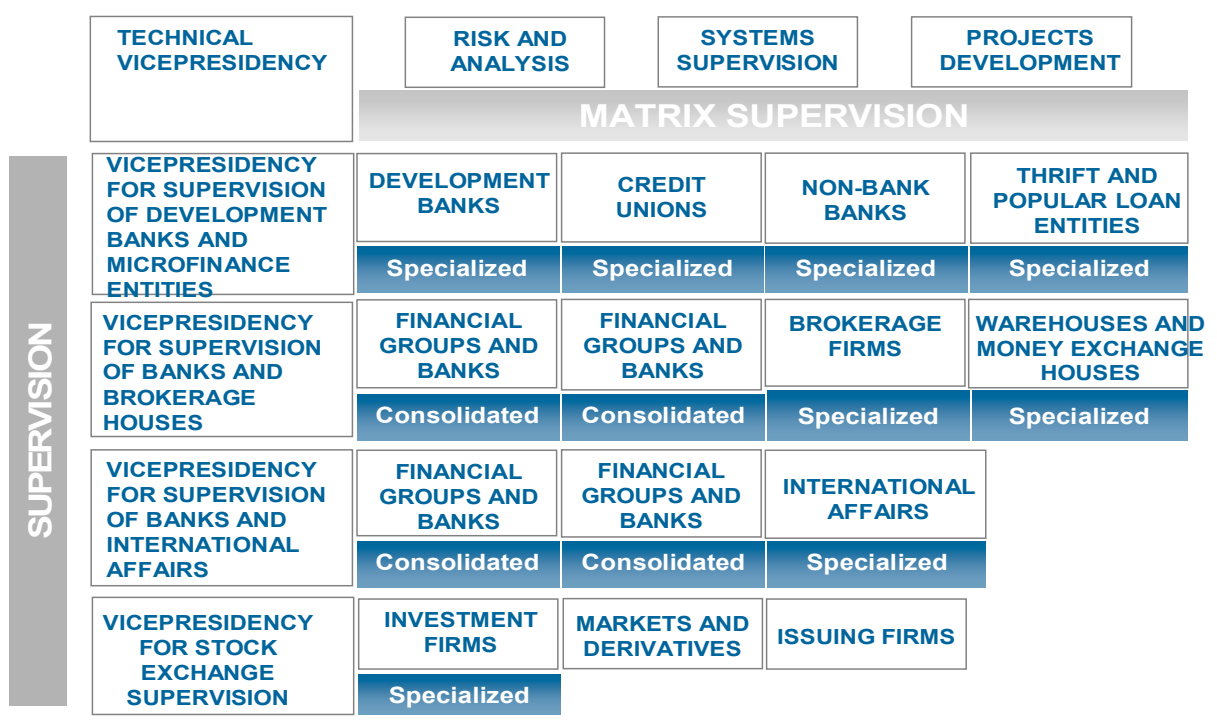

\section{Off-site Supervision}

446. Off-site supervision largely consists of periodic assessment of the financial information received from each supervised entity, compliance with legal requirements, and follow-up from previous 
examinations. The main objective is to ascertain the overall financial condition of an FI. To this end, the CNBV analyzes quarterly financial reports, internal reports, and other information received from institutions. The CNBV also reviews any changes in the management and control structure of FIs, which may be relevant to AML/CFT supervision. When necessary, it can institute corrective action and initiate sanctioning procedures.

447. Off-site AML/CFT supervision mainly relates to the receipt and review of information required by the AML/CFT regulations such as CTRs, policies and procedures manuals, and the establishment and appointment of the compliance committee and compliance officer, respectively. As for prudential supervision, the CNBV also follows up on findings from previous examinations for corrective action. Offsite review of these and any other related issues may give rise to enforcement procedures for noncompliance.

448. The CNBV has also introduced a risk-based approach to its supervisory processes that involves identifying the inherent risks in FIs' activities and the various risk mitigants. The result of this offsite analysis is used for examination planning purposes, and includes AML/CFT elements. A brief description of this process follows.
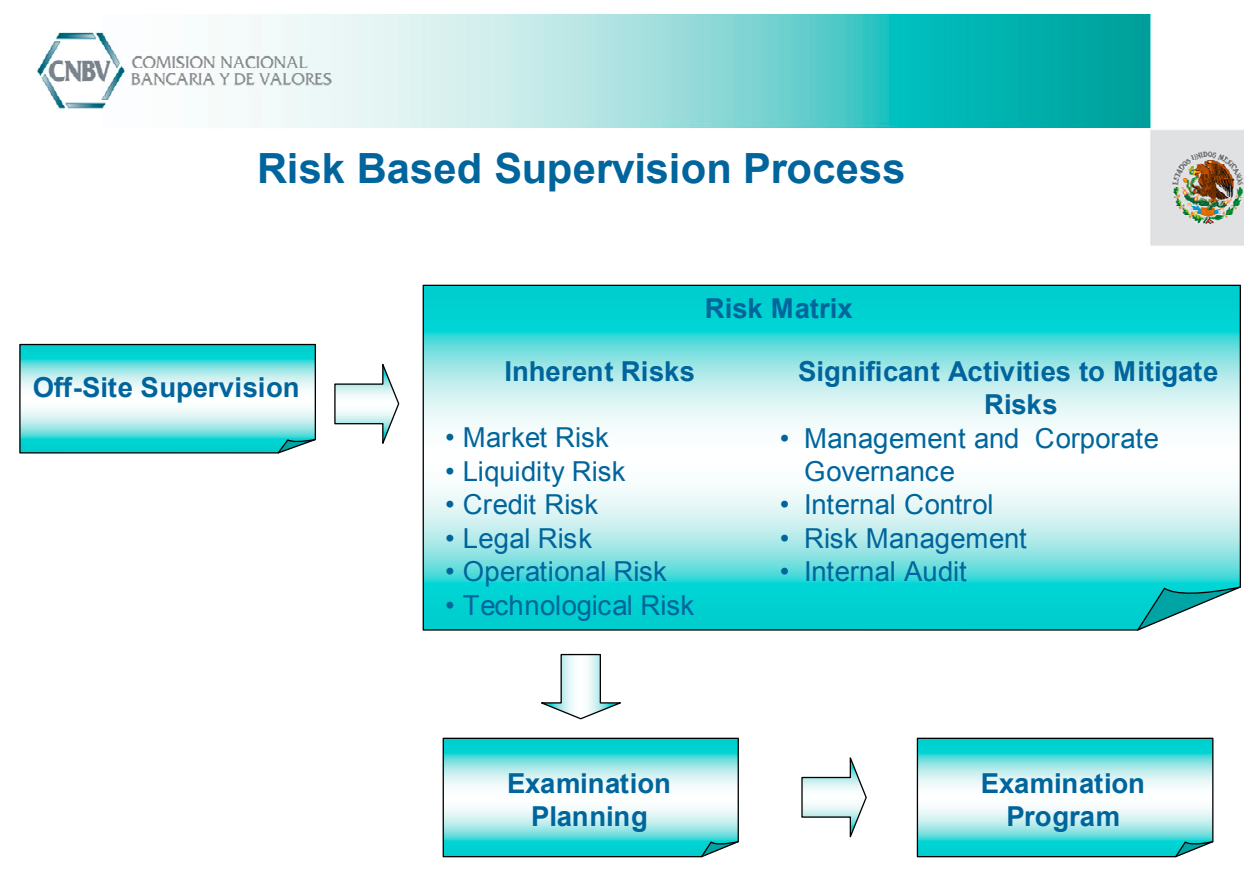

449. ML and FT risks, along with reputational risk, are considered to be part of a number of the inherent risks, especially legal, operational, and market risk. With respect to risk mitigation factors, $\mathrm{AML} / \mathrm{CFT}$ is largely captured under internal controls. While this is appropriate, increased emphasis could be placed on management and corporate governance, as this factor has a significant influence on the culture of compliance, which are necessary preconditions for effective application of AML/CFT controls. It would also focus attention on compliance by top management with the legal obligation imposed by the AML/CFT regulations, which could have a direct impact on legal risk.

450. Offsite risk-based AML/CFT supervision could be enhanced with input and analysis relating to the inherent ML and FT risks faced by institutions. To this end, the CNBV should consider analyzing inherent risks arising from the various: commercial sectors, clients, products, services, channels of 
distribution, and geographic locations. Such analysis would complement those emanating from other sources of information such as levels and trends in financial statements and from the FIU statistics on reporting quality and trends. The DGPOI should participate closely in the development and integration of these risk elements into the off-site risk-based supervisory framework, e.g., the MACROS+ROP system.

451. Increased emphasis on offsite supervision would also be required if the authorities, as planned, refocus prevention mechanisms in the financial sector by placing more reliance on self-regulatory mechanism, including "third party" reviews such as from external auditors. The CNBV also has the authority to contract outside auditors and professionals to conduct reviews or investigations to complement its supervisory process when required.

\section{On-site Examination}

452. General on site examinations are conducted every one or two years, depending on the sector and risk, and regularly include AML/CFT elements. Two types of examination procedures can be applied: general ("integral") and simplified (limited scope), depending on risk. AML/CFT examinations are conducted as part of the integrated prudential supervision conducted by regular examiners and/or the specialized DGPOI. In addition, on-site examinations are also conducted with respect to IT systems that include a review of systems for identifying large, unusual, and suspicious activities. These reviews may be conducted separately or in conjunction with prudential and AML/CFT inspections.

453. Since 2007, the DGPOI has participated in general onsite examinations with the prudential supervisors which have provided a basis for a more integrated approach to supervision of compliance with the AML/CFT regulatory requirements. The DGPOI can also conduct separate examinations focused on particular areas of interest including the conduct of supervisory investigations. The general process for examinations generally involves planning based on input from the off-site process, an on-site visit to the FIs, report writing and communication of findings, corrective action, and sanctions where necessary. AML/CFT elements are captured by this process.

454. While the CNBV has developed risk-based process for prudential supervision, the focus on onsite examinations has to date largely been on legal compliance. These largely cover: internal controls, compliance functions, policies procedures, and tools for analyzing the quality and submission of large and suspicious activity reports, review of client files for KYC compliance, and training. With the establishment of the DGPOI in 2007, the CNBV conducted inspections that focused on FIs operating in higher risk sectors (e.g., banking, securities, and casas de cambio). Some of these FIs were selected on the basis of qualitative and quantitative criteria including inter alia, the types of operations, clients, and geographic sectors they operate in. Supervisors can also target an FI for special inspection as a result of any information or concerns relating to ML or FT, in which case only AML/CFT elements are reviewed.

455. It is important to note, however, that AML/CFT supervision seems to be more rigorous for the banking, securities and foreign exchange sectors, largely reflecting the degree of risk. In this context, FIs that deal in cash have attracted increased supervisory attention due to their vulnerability to ML at the placement staged (stock brokers are also authorized to deal in foreign currency trading business).

456. Since the formation of the DGPOI in April 2007, it has participated in 25 onsite examinations for AML/CFT, including nine banks, seven securities firms, and nine casas de cambio. The average number of AML/CFT inspectors per examinations is between five and eight. Where the DGPOI does not participate, the prudential supervisors assign between one and two inspectors for each examination for AML/CFT. Additional statistics on the number of examinations that included AML/CFT elements follow: 


\begin{tabular}{|l|c|c|c|c|}
\hline \multicolumn{1}{|c|}{ Financial Institution } & & \multicolumn{3}{c|}{ Number Onsite Examinations } \\
\hline Banking Institutions & Total Number* & $\mathbf{2 0 0 5}$ & $\mathbf{2 0 0 6}$ & $\mathbf{2 0 0 7}$ \\
\hline Popular Savings and Loans & 40 & 17 & 23 & 31 \\
\hline Credit Unions & 48 & NA & NA & NA \\
\hline Development Banks & 155 & 0 & 29 & 4 \\
\hline SOFOLES & 6 & 1 & 2 & 27 \\
\hline Casas de Cambio & 39 & 16 & 25 & 13 \\
\hline Securities Brokerage Houses & 24 & 11 & 11 & 22 \\
\hline Mutual/Investment Funds Operators & 32 & 21 & 23 & 12 \\
\hline Mutual/Investment Funds Distributors & 44 & 8 & 10 & 1 \\
\hline Leasing Institutions & 8 & 1 & 2 & 5 \\
\hline Factoring Institutions & 10 & 7 & 13 & 3 \\
\hline General Deposit Warehouses & 3 & 4 & 6 & 10 \\
\hline Total & 20 & 9 & 9 & $\mathbf{1 5 7}$ \\
\hline
\end{tabular}

*No. of institutions subject to supervision as of September 2007.

457. It is noted that the single largest number of financial institutions are credit unions at 163 . While large in number, these are very small member owned entities that have accounted for less than 0.5 percent of system assets at least over the past three years.

458. Based on the examination findings, the focus was largely on the review of the AML/CFT requirements. Generally, there appears to be a relatively high and increasing compliance rate among banks and stock brokers but less so in the other sectors, especially SOFOLES, factoring and deposit warehouses. The range in compliance ratings can also vary widely in some sectors. Of concern will be compliance by the SOFOMES under the new unregulated regime after new AML/CFT regulations are issued to cover them under the SAT's supervision.

\begin{tabular}{|c|c|c|c|}
\hline \multirow[b]{2}{*}{ Financial Institution } & \multicolumn{3}{|c|}{ Global Compliance Rating (\%) } \\
\hline & 2005 & 2006 & 2007 \\
\hline Instituciones de Crédito & $\begin{array}{l}\text { Range: } 42.4-100 \\
\text { Avg: } 79.7 \%\end{array}$ & $\begin{array}{l}\text { Range: } 82.1-100 \\
\text { Avg: } 93.4 \%\end{array}$ & $\begin{array}{l}\text { Range: } 63.8-100 \\
\text { Avg: } 90.7 \%\end{array}$ \\
\hline Instituciones de Banca de Desarrollo & $\begin{array}{l}\text { Range: } 62.5- \\
62.5 \\
\text { Avg: } 62.5\end{array}$ & $\begin{array}{l}\text { Range: } 75.7-92 \\
\text { Avg: } 83.9 \%\end{array}$ & $\begin{array}{l}\text { Range: } 60.4- \\
91.6 \\
\text { Avg: } 75.1 \%\end{array}$ \\
\hline $\begin{array}{l}\text { Sociedades Financieras de Objeto } \\
\text { Limitado }\end{array}$ & $\begin{array}{l}\text { Range: } 61.4- \\
99.3 \\
\text { Avg: } 88.3 \%\end{array}$ & $\begin{array}{l}\text { Range: } 80.3-99.1 \\
\text { Avg: } 91.1 \%\end{array}$ & $\begin{array}{l}\text { Range: } 62.7- \\
100 \\
\text { Avg: } 92.1 \%\end{array}$ \\
\hline Casas de Cambio & $\begin{array}{l}\text { Range: } 64.4- \\
98.8 \\
\text { Avg: } 85.1 \%\end{array}$ & $\begin{array}{l}\text { Range: } 81.3-99.9 \\
\text { Avg: } 91.4 \%\end{array}$ & $\begin{array}{l}\text { Range: } 64.4- \\
98.8 \\
\text { Avg: } 85.6 \%\end{array}$ \\
\hline
\end{tabular}




\begin{tabular}{|c|c|c|c|}
\hline \multirow[b]{2}{*}{ Financial Institution } & \multicolumn{3}{|c|}{ Global Compliance Rating (\%) } \\
\hline & 2005 & 2006 & 2007 \\
\hline Almacenes Generales de Depósito & NA & $\begin{array}{l}\text { Range: } 65.1-70.3 \\
\text { Avg: } 67.7 \%\end{array}$ & $\begin{array}{l}\text { Range: } 74.6- \\
100 \\
\text { Avg: } 85.7 \%\end{array}$ \\
\hline Empresas de Factoraje Financiero & NA & $\begin{array}{l}\text { Range: } 62.9-86.3 \\
\text { Avg: } 70.3 \%\end{array}$ & $\begin{array}{l}\text { Range: } 74.3- \\
89.2 \\
\text { Avg: } 81 \%\end{array}$ \\
\hline Uniones de Crédito & NA & NA & $\begin{array}{l}\text { Range: } 5.4-85 \\
\text { Avg: } 69.7\end{array}$ \\
\hline Arrendadoras Financieras & NA & $\begin{array}{l}\text { Range: } 66.4-87 \\
\text { Avg: } 77.9 \%\end{array}$ & $\begin{array}{l}\text { Range: } 79.3- \\
92.8 \\
\text { Avg: } 87.7 \%\end{array}$ \\
\hline Casas de Bolsa & $\begin{array}{l}\text { Range: } 89.9- \\
99.9 \\
\text { Avg: } 97.8 \%\end{array}$ & $\begin{array}{l}\text { Range: } 91.4-100 \\
\text { Avg: } 96.7 \%\end{array}$ & $\begin{array}{l}\text { Range: } 91.1- \\
100 \\
\text { Avg: } 97.0 \%\end{array}$ \\
\hline Entidades de Ahorro y Crédito Popular & NA & NA & NA \\
\hline $\begin{array}{l}\text { Sociedades Operadoras de Sociedades } \\
\text { de Inversión }\end{array}$ & NA & NA & $\begin{array}{l}\text { Range: } 60.4- \\
100 \\
\text { Avg: } 88.7 \%\end{array}$ \\
\hline $\begin{array}{l}\text { Sociedades Distribuidoras de } \\
\text { Sociedades de Inversión }\end{array}$ & NA & NA & NA \\
\hline Total & & & \\
\hline
\end{tabular}

459. With regards to supervisory resources, the CNBV has assigned a reasonable number of supervisors that are available to conduct AML/CFT inspections. The number of staff and budgetary allocations to the various supervisory units are as follows:

\begin{tabular}{|l|c|c|}
\hline \multicolumn{1}{|c|}{ Departments } & Staff & Annual Budget (MXN) \\
\hline $\begin{array}{l}\text { Dirección General de Supervisión de } \\
\text { Instituciones Financieras A }\end{array}$ & 49 & 37183168.19 \\
\hline $\begin{array}{l}\text { Dirección General de Supervisión de } \\
\text { Instituciones Financieras B }\end{array}$ & 51 & 38679269.84 \\
\hline $\begin{array}{l}\text { Dirección General de Supervisión de } \\
\text { Instituciones Financieras C }\end{array}$ & 50 & 40917790.49 \\
\hline $\begin{array}{l}\text { Dirección General de Supervisión de } \\
\text { Instituciones Financieras D }\end{array}$ & 52 & 33406008.79 \\
\hline $\begin{array}{l}\text { Dirección General de Supervisión de } \\
\text { Instituciones } \\
\text { Especializadas A }\end{array}$ & 43 & 32731839.66 \\
\hline $\begin{array}{l}\text { Dirección General de Supervisión de } \\
\text { Instituciones } \\
\text { Especializadas B }\end{array}$ & 38 & 27899644.04 \\
\hline $\begin{array}{l}\text { Dirección General de Supervisión de } \\
\text { Instituciones } \\
\text { Especializadas C }\end{array}$ & 39 & \\
\hline
\end{tabular}




\begin{tabular}{|l|c|c|}
\hline \multicolumn{1}{|c|}{ Departments } & \multicolumn{1}{|c|}{ Staff } & Annual Budget (MXN) \\
\hline $\begin{array}{l}\text { Dirección General de Supervisión de } \\
\text { Entidades de Ahorro y Crédito } \\
\text { Popular }\end{array}$ & 36 & 22465347.83 \\
\hline $\begin{array}{l}\text { Dirección General de Supervisión de } \\
\text { Banca de Desarrollo y Entidades de } \\
\text { Fomento }\end{array}$ & 50 & 40319514.05 \\
\hline $\begin{array}{l}\text { Dirección General de Supervisión de } \\
\text { Sistemas Informáticos de } \\
\text { Instituciones Financieras }\end{array}$ & 52 & 32792290.90 \\
\hline $\begin{array}{l}\text { Dirección General de Intermediarios } \\
\text { Bursátiles }\end{array}$ & 62 & 47775266.20 \\
\hline $\begin{array}{l}\text { Dirección General de Sociedades de } \\
\text { Inversión }\end{array}$ & 46 & 36928959.97 \\
\hline $\begin{array}{l}\text { Dirección General de Prevención de } \\
\text { Operaciones llícitas }\end{array}$ & 42 & 24913230.00 \\
\hline $\begin{array}{l}\text { Dirección General de Atención a } \\
\text { Autoridades }\end{array}$ & 46 & 30503887.64 \\
\hline $\begin{array}{l}\text { Dirección General de Delitos y } \\
\text { Sanciones }\end{array}$ & 45 & 319232.05 \\
\hline
\end{tabular}

460. The CNBV also complements its supervisory program through cooperation agreements with overseas supervisors. Through these arrangements, overseas supervisors have participated in on-site visits of Mexican-licensed entities and CNBV staff has also participated in similar visits abroad. Visits by foreign supervisors to their Mexican subsidiaries ${ }^{43}$ covering AML/CFT topics were: 2005: 1; 2006: 2; and 2007: nil. Other visits by foreign supervisors that touched on AML/CFT issues were: 2005: 5; 2006: 8; and 2007: 7. Overseas visits by the CNBV that covered AML/CFT issues were as follows ${ }^{44}: 2007: 2$.

\section{CNSF}

461. The CNSF is responsible for the supervision of some 95 insurance (life insurance premiums make up about 40.3 percent of the total), 14 bonding companies and 46697 insurance and bonding agents. Of these agents, 16,786 are provisional agents, i.e. they are quasi-employees working with entities under a training program. Of the rest, 25,919 are individuals, 278 are agents organized as legal entities, and 3931 are brokers (apoderados de persona moral). Brokers represent agents that are organized as legal entities and 61 quasi-employee/agents.

\footnotetext{
${ }^{43}$ The CNBV states that home supervisors are continuously updated through meetings and conference calls of supervisory developments at the CNBV.

${ }^{44}$ When several Mexican financial institutions were purchased by international groups at the beginning of the decade, they tended to gradually close the international networks of the acquired institutions. The international expansion of Mexican financial institutions is a relatively recent phenomenon. It is only during the course of the past few months that foreign subsidiaries and branches have become fully integrated with their Mexican head offices and they have reached a relative importance that warrants on-site inspection work.
} 


\section{Off-site supervision}

462. Off-site AML/CFT activities include the authorization process for fit and proper requirements of insurance and bonding companies, and agents. The CNSF also reviews regulatory reports it receives from these entities, including their AML/CFT policies and procedures manuals, reports on training programs, CTR and STR reports, and the functions of the compliance committee and compliance officer. The CNSF also reviews the work of third parties and sources, such as from external auditors, for any AML/CFT issues they might raise. The results of such reviews can give rise to supervisory action on their part.

\section{On-site Examinations}

463. The CNSF is responsible for the supervision of some 95 insurance (life insurance premiums make up about 40.3 percent of the total), 14 bonding companies and 46,697 insurance and bonding agents. Of these agents, 16786 are provisional agents, i.e., they are quasi-employees working with entities under a training program. Of the rest, 25,919 are individuals, 278 are agents organized as legal entities, and 3,931 are brokers (apoderados de persona moral). Brokers represent agents that are organized as legal entities and 61 quasi-employee/agents.

464. AML/CFT supervision is less developed for the insurance sector than for the banking and securities sectors. The CNSF has largely concentrated its supervision of insurance and bonding companies as it does not have the capacity to supervise, on an ongoing basis, all of the licensed agents. In addition, because the AML/CFT regulations apply to both life (and investment) and nonlife business, the scope of supervision for AML/CFT is much wider.

465. The CNSF is still developing its inspection procedures for AML/CFT but much remains to be done. Over the 3.75 years (Jan. 2004-Sept. 2007), the CNSF has conducted 102 on-site inspections (2004: 26; 2005:36; 2006: $32,{ }^{45}$ and 2007: $8^{46}$ ) that focused a review of the AML/CFT regulatory requirements. Of these, 10 were specifically for AML/CFT purposes. Up to March 2007, the CNSF had imposed a total of 44 sanctions, which mainly related to non-compliance with the CTR ("Operaciones Relevantes") reporting requirement.

466. Going forward, the CNSF has proposed the creation of a Specialized Oversight Department specifically to supervise AML/CFT issues, to be ascribed to its General Financial Oversight Department. This arrangement will mirror the functions of the DGPOI established in 2007 within the CNBV. This proposed department shall consist of two sub-departments and seven offices. Budgetary allocations have been made for 2008 for the establishment of this new department. No information was provided to the mission as to the underlying reasons or risks, and the specific focus of supervision of this proposed unit with respect to AML/CFT.

\section{CONSAR}

467. CONSAR is responsible for supervising 18 pension fund administrators (Afores). It focuses supervision for AML/CFT on those administrators that manage funds that receive voluntary and complementary sub-account contributions, as there is a higher potential that these funds may originate

\footnotetext{
${ }^{45}$ During 2006, specialized inspections for AML were initiated

${ }^{46}$ Included are two specialized AML visits to insurance and bonding agents, four to insurance companies, and two to bonding entities.
} 
from illicit sources. Less than 1 percent of administered funds originate from these additional contributions. During the period January 2006 to November 2007, the total amount of voluntary contributions in the sector amounted to the equivalent of about US\$125 million. During this same period, however, 315 STRs were filed with the FIU, including a very significant outlier.

\section{Off-site Supervision}

468. The main focus of CONSAR's AML/CFT supervision is on off-site processes. It has access to the database of all account holders as part of its oversight arrangements which provides it with the opportunity to develop programs to identify unusual activity in the accounts. From the results of this review, it can target fund administrators for on-site inspection and has in the recent past used such information for planning and conducting on-site inspections. In summary, the principal review areas include:

- $\quad$ Oversight of reporting obligations. All CTRs and SARs filed by Afores to the FIU are transmitted electronically through the CONSAR's system.

- $\quad$ Review of periodic reports filed under the AML/CFT regulations relating to KYC policies and procedures manuals, activities of the Compliance Committee and Compliance Officer arrangements, training programs, etc.

- Information with respect to updates on the functions of the compliance committee, compliance officer and $\mathrm{KYC}$ policies and procedures manuals.

\section{On-site Examinations}

469. On-site inspections are only carried out when reporting of suspicious transactions raise certain red flags, or when the offsite process detects other areas of possible weakness. The onsite review process is based on an inspection manual that is structured to reflect the requirements established under the $\mathrm{AML} / \mathrm{CFT}$ regulations. In recent past, it has conducted one special AML/CFT examination as a result of its offsite monitoring activities.

470. The mission was satisfied that, in light of the inherently lower level of exposure of retirement funds to ML and FT (re: authorities' views and FATF Recommendation 5.9 examples), coupled with the comprehensive access to and monitoring of customer information from offsite, the emphasis on offsite supervisory processes seems appropriate for the time being.

\section{SAT}

471. The SAT is responsible for the supervision of foreign currency exchange centers (centros cambiaros) and money remitters. Persons and entities that do not transact in amounts equivalent to US $\$ 10,000$ or above, per client per day do not require licensing and are not subject to supervision except for AML/CFT by the SAT. There are about 2,212 registered centros cambiarios and 857 registered money remitters. Estimates vary as to the number of unregistered operators from about 2,400 to 4,380, and it is unknown how many of these engage in significant volumes and amounts. Registration is by means of filing of an official form (Aviso RC) through which registrants give notice to the SAT that they are engaged in these activities. This information includes, inter alia, particulars of shareholders and designation of a compliance officer. Upon filing of the Aviso RC, SAT grants to the foreign exchange center or money remitter a registration number to identify it. While registration SAT is compulsory, the SAT does not has legal authority to revoke such registration.

472. The SAT is also responsible under the law to supervise SOFOMES for AML/CFT compliance, but has not commenced supervision because the regulations have not been issued. As indicated earlier, 
SOFOMES are unregulated multiple purpose lending entities and there are some 634 unregulated SOFOMES, an increase from 41 that were operating in January 2007. On current trends, this number is likely to increase sharply in the coming years further stretching the the staff capacity and budget of the SAT for AML/CFT supervision. In comparison to centros cambiarios and money remitters, the risk inherent in the activities of SOFOMES may not be as high due to the fact that they are not allowed to accept deposits from the public. However, there are still inherent risks in raising funds, e.g., through private placements of commercial paper and equity investments, and their operations may be larger and more complex as they can now lend to multiple sectors.

473. The SAT only has six persons in its AML/CFT unit and has access to about 52 more inspectors from SAT's local branches that can carry out onsite inspections. In spite of staffing limitations, in the past three years (2005-07) it has sent 1110 supervisory letters and has initiated and conducted about 800 onsite visits. During this period it applied 583 fines totaling about US\$300,000, or an average of about US\$600 per fine.

474. The SAT applies an on-site visit program that based on the review of key elements largely based on the regulations, including: duty to give notice to the SAT of their activities, KYC policies and customer identification files, compliance function, training, monitoring systems, branch network, and regulatory reporting requirements (CRTs and SARs). The results of 482 visits show that compliance in general is weak with scores ranging from 13 percent to 59 percent .

Fit and Proper Criteria and Prevention of Criminals from Controlling Institutions (c. $23.3 \&$ 23.3.1)

\section{General}

475. The Mexican financial system is overseen by multiple regulators. The SHCP sets regulatory policy for the financial system, particularly the granting and revoking of bank licenses, and control over ownership and investments in FIs. The CNBV is the supervisor and regulator for banks, ${ }^{47}$ other credit institutions, and securities markets, including mutual funds. The Central Bank of Mexico (Banco de Mexico) has regulatory responsibilities with respect to, inter alia, foreign exchange, payment systems and financial products and services. The CONSAR oversees Afores (retirement fund administrators) and the CNSF oversees insurance and bonding companies. The institutional framework also includes the Mexican Association of Securities Intermediaries (AMIB), which administers qualification examinations for employees of brokers, investment advisors, including employees of banks engaged in the sale of securities. The professionalism of these agencies is well recognized in the markets.

476. All regulated financial intermediaries require authorization from the SHCP to operate in Mexico. These entities are subject to strict licensing requirements including the vetting of owners, directors and officers for technical competence, solvency, and integrity. According to SHCP staff, rigorous checks are conducted for banks, securities, and insurance entities including criminal background checks with the PGR and other sources.

\footnotetext{
${ }^{47}$ Post mission, on February 1, 2008, the powers previsiously ascribed to the Secretaría de Hacienda y Credito Publico in relation to the regulation commercial banking institutions, were transferred to the National Banking and Securities Commission by publication in the Official Gazette, (Article 9, transitorio). This will take full effect in 120 days from publication.
} 
477. There are thousands of registered foreign exchange centers/money remitters (estimates of up to 4 380) and SOFOMES (634) ${ }^{48}$ can operate without authorization. Such institutions are only required to file notice of their activities with the SAT (the Tax Administration Service) which is authorized to supervise them for AML/CFT purposes. There are no effective mechanisms for screening prospective and existing owners and controllers of these entities for fit and proper purposes, raising the risk that they may infiltrated by criminal elements. There is also requirement for these firms to provide an annual update with respect to the branches they operate, but this would be inadequate for fit and proper purposes. The authorities believe that a significant proportion of these firms are small "mom and pop" operations, but this does not necessarily mitigate ML/TF risks.

478. The notice referred to above contains information on the following: business or corporate name; name of the owner or, if applicable; the principal shareholders; addresses of all its business premises; names of the managers or agents; copy of the Taxpayers Identification Card; and a description of the activities they conduct. The notice must be presented within the 15 business days following the date of commencement of operations, and the SAT must be informed of any changes to the foregoing information within 15 business days. The SAT has insufficient resources to enforce the registration/notification requirement, and conducting more thorough vetting of operations for fit and proper would not be effective in light of existing resources. As mentioned before, there are an estimated 4,380 of these operators and the SAT only has six persons in its AML/CFT unit, plus access to about 52 additional inspectors. This situation raises significant risks of ML and FT, not only within these sectors, but to the rest of the financial system. This deficiency will become more manifested with the increase in unregulated SOFOMES as they are assigned to the SAT for AML/CFT supervision.

\section{$C N B V$}

479. The licensing authority for deposit taking, most credit institutions and securities firms rests with the SHCP. However, the CNBV with the new Securities Market Law of December 2005 licenses intermediaries in the securities sector, and is awaiting a revision of the Law of Credit Institutions (LIC) to transfer the licensing process for banks to the CNBV in the near future. (Post mission, the applicable legal amendment was published in the Official Gazette on February 1, 2008, to take effect in 120 days from publication. This reform will mandate that all license applications be reviewed by the CNBV's Board of Directors. Changes in ownership or controlling interests in existing banks must now be approved by the SHCP. The CNBV does not have formal authority regarding changes in ownership or controlling interests for banks. The SHCP currently approves significant changes in ownership and investment in FIs in consultation with the CNBV. This process is expected to change with the transfer of authority to the CNBV. The views of the CNBV have historically been taken into account by the SHCP.

480. Under the LIC, the SHCP has discretionary powers to reject applications. For licensing purposes, the CNBV gives its opinion as to whether the resulting structure will hinder effective supervision. It also gives opinion on the suitability of major shareholders, transparency of ownership structure, and source of paid-in capital. A fit and proper test for the proposed directors, as stated in Articles 23 and 24 of the LIC, is carried out before a license is granted. For these purposes, an investigation on the proposed shareholders background is carried out involving local and foreign financial authorities. These articles also require that the members of the board and senior management of a bank have a broad knowledge of financial and management matters, and meet solvency and integrity requirements. A general operating plan is required

\footnotetext{
${ }^{48}$ See Recommendation 5 for a discussion on the deregulation of SOFOLES (limited purpose financial entities). Those that are members of a financial group will continue to be regulated and supervised for prudential and AML/CFT purposes but will not require a license. The remaining SOFOLES will convert to SOFOMES (multiple purpose financial entities) by 2013 or liquidate.
} 
by the LIC that impose requirements for policies and internal controls before an authorization is granted. The licensing requirements also apply to the establishment of subsidiaries of foreign financial institutions under Article 45 of the LIC.

481. At present, the SHCP's approval is required when a person (legal and natural) seeks to acquire more than 5 percent of the equity capital of another bank (Article 17 of the LIC). The SHCP will take into consideration the opinions of the CNBV and the Banco de Mexico. In addition, any person who wishes to purchase or sell equities representing more than 2 percent of the paid-in capital of a bank must notify such purchase or sale to the SHCP within the following three working days after the transaction takes place.

\section{CNSF}

482. Article 5 of the Insurance Institutions Law requires the prior authorization of the SHCP to incorporate and operate as an insurance company. The licensing process of the CNSF for insurance entities is generally similar to that for FIs supervised by the CNBV described above with respect to fit and proper requirements for owners, directors and officers of insurance companies. In addition, Article 3 of the Insurance Institutions Law grants the authority to the CNSF to license insurance agents and brokers ("apoderados"). The CNSF is also authorized to suspend authorization for up to two years or to revoke it.

\section{CONSAR}

483. Afores require the authorization of the CONSAR under the provisions of Article 19 of the Ley de los Sistemas de Ahoro para el Retiro (Retirement Savings Systems Law), in consultation with the SHCP. Most of the retirement fund administrators (Afores) are affiliated with a licensed financial group that have been authorized by the SHCP and supervised by the CNBV. In this regard, the ultimate owners, directors, officials, and other controllers would have undergone fit and proper screening by the SHCP and the CNBV.

\section{Application of Prudential Regulations to AML/CFT (c. 23.4)}

484. Banks, securities firms, and insurance companies are all subject to prudential supervision by the $\mathrm{CNBV}$ and the CNSF. These FIs are required to have internal control and recordkeeping requirements that are appropriate to their operations and risks, and to have internal audit programs to test and review the adequacy of the internal control regime. In addition, they are required to have annual external audit programs. A number of the large FIs are listed in the Mexican stock exchange which would require them to abide by strict accounting, auditing, and disclosure requirements.

485. There are a number of financial groups operating in the Mexican financial system that include banks securities and investment firms. In this regard, these groups are subject to consolidated accounting and supervision, and where they are members of overseas parent companies, they are subject to consolidated cross-border supervision. In practice, overseas regulators have conducted onsite visits of their Mexican affiliates that included AML/CFT elements.

486. There is a least one Mexican bank that has expanded fairly rapidly in recent years in a number of other countries but which has not as yet been subject to comprehensive ongoing consolidated supervision by the Mexican home supervisor.

Licensing or Registration of Value Transfer/Exchange Services (c. 23.5)

487. As discussed in c.23.1 and c.23.3 above, only foreign exchange firms (casas de cambio) that carry out transactions equal to or exceeding the equivalent of US $\$ 10,000$ per client per day are required to 
be licensed. These entities are also authorized to engage in money remittance business. Foreign exchange centers that carry out transactions below the equivalent of US $\$ 10,000$ per client per day are not required to be licensed but only need to register and file a notice with the SAT providing information as to their operations. This arrangement was established many years ago with the apparent intention of differentiating between retail and wholesale operations. And probably contributed to there being only 24 casas de cambio (soon to reduce to 21 or less) and an estimated 4,380 unregulated operators ( $(3,157$ centros cambiarios and 1,223 money remitters). Of these, only about 3,069 have been registered. (See discussion in footnote 24 under Recommendation 5 with respect to these estimates.)

488. Casas de cambio are authorized by the SHCP under Article 81 of the Ley de Organizaciones y Actividades Auxiliares del Credito. Neither Article 81, 82, 83 et seq. of this law provides for the provision of corporate, personal data and business plans before authorization nor information to establish the integrity and criminal background of the persons owning or controlling these entities. In addition, the Dispocision de Caracter General of September 29, 2004, that established more detailed requirements for the authorization of casas de cambio including detailed personal data and background information of key and controlling persons including of officers, directors and large shareholders. It also requires, inter alia, proposed shareholders to provide two financial references from banks or stock brokers ("bancaria y/o bursatil"). The DCG also requires copies of the AML/CFT policies for customer identification and KYC consistent with the provisions of Article 95 of the Law.

489. It is worth noting also that pursuant to Article 87 of this Law, the SHCP, in consultation with the $\mathrm{CNBV}$, can revoke the license of a casa de cambio for various reasons including for contravention of laws and regulations that apply to it which can include the AML/CFT requirements.

490. Foreign exchange centers (centros cambiarios) and money remitters are required to give notice to the SAT of their activities within 15 days following the date of the startup of activities. They are also required to file an updated notice each September, and to provide information as to the branches they operate. The SAT does not have an express legal authority to de-register foreign exchange centers (centros cambiarios) and money remitters after they have filed notice of their activities.

\section{Monitoring and Supervision of Value Transfer/Exchange Services (c. 23.6)}

491. See c.23.2 above. Only licensed casas de cambio are subject to supervision by the CNBV and money remitters by the SAT. The latter has undertaken supervision of these entities in the past for AML/CFT and has identified them for priority attention due to the perceived high risk for ML in their operations. Recently, the authorities closed down one casa de cambio as a result of an ML investigation.

492. Registered foreign exchange centers and money remitters are supervised by the SAT for AML/CFT purposes. In spite of staff limitations, the SAT has conducted an impressive number of onsite visits (SAT indicated that it has conducted 800 on-site visits) to these firms to review their AML/CFT compliance arrangements. These reviews included, inter alia, compliance with the annual notice requirements, KYC and customer identification policies and files, large transaction records (US\$3,000), reporting of suspicious transactions, compliance function including the designation of a compliance officer, training, and monitoring systems. The SAT applies a rating system for ten key areas of supervision. The mission was provided with the results of such site inspections and the ratings results. That said, there remains a significant number of operators that have not registered and are therefore outside the reach of the SAT. Nevertheless, the SAT has expended effort to increase awareness and promote registration.

Licensing and AML/CFT Supervision of other Financial Institutions (c. 23.7)

493. See c.23.3 above. 
Guidelines for Financial Institutions (c. 25.1)

494. No specific AML/CFT guidelines have been issued by any of the regulatory or supervisory authorities dealing with ML/FT techniques and methods, etc. ${ }^{49}$ They have, however, participated with the FIU in the development and dissemination of industry best practices for reporting suspicious activities in order to reduce the practice of overreporting.

495. The CNBV, in coordination with other supervisory authorities, also participates in courses or workshops where it presents its supervision processes, as well as its expectations with respect to effective compliance with the AML/CFT requirements. Special workshops have been given to train FIs on the use of the Inter-Institutional Information Transference System (SITI) implemented by the CNBV for CTR and STR reporting.

496. The industry could benefit from more guidance on non-cash money laundering techniques and schemes, particularly in the structuring and integration stages of ML. This would help FIs expand their focus beyond cash transactions that seems to be the general practiced. With the internationalization of the Mexican financial system, this is necessary especially for cross-border business.

\section{Power for Supervisors to Monitor AML/CFT Requirement (c. 29.1)}

497. All of the supervisory agencies in charge of monitoring and enforcing AML/CFT compliance have adequate powers under the various financial supervisory laws and regulations For example for the $\mathrm{CNBV}$, these powers are established in its organic law and its internal regulations [e.g., Chapters I and II of the Ley de la Comision de Bancaria y de Valores (Law of the CNBV), Article 115 of the Ley de Instituciones de Credito (Credit Institutions Law)]. The CNBV also has its Supervision Regulations ("Reglamento de Supervision, 2005) that provides it with broad powers of supervision and oversight over the FIs under its jurisdiction. (These would cover supervision of compliance with the AML/CFT regulations.)

498. For the CNSF, similar provisions are contained in its internal regulations (e.g., Reglamento de Inspeccion y Vigilancia (regulation for supervision and monitoring) and its Internal Regulation (Reglamento Interior 1998, Title I, Chapter IV). All of the AML/CFT regulations (DCGs) also have provisions for the supervisory agencies to monitor for compliance with these regulations (e.g., Regulation 58 of DCG 115 for banks and SOFOLES.) The specific supervisory powers to monitor for compliance with the AML/CFT regulatory requirements, including sanctioning powers, are granted under the financial regulatory laws. These laws establish the obligation for FIs to comply with AML/CFT obligations, in accordance with the regulations issued under each. The supervisory agencies, in turn, use their traditional supervisory powers to conduct ongoing supervision and onsite inspections for purposes of reviewing compliance with the AML/CFT regulations, either in conjunction with their prudential functions or independently. Pursuant to these powers, all of the supervisory agencies that conduct AML/CFT supervision (CNBV, CNSF, CONSAR, and SAT) have in practice conducted supervision for AML/CFT, including onsite inspections and the application of sanctions. In so doing, they have unrestricted access to

\footnotetext{
${ }^{49}$ While these are not guidelines for purposes of FATF Rec. 25.1, the SHCP, through its administrative units (e.g. Insurance, Securities and Pensions Unit, and the Bank and Savings Unit), has authority to interpret AML/CFT regulations (DCGs) for administrative purposes. Based on this authority, it issues criteria and consult with industry stakeholders before issuing interpretive documents through Official Notices (Oficios). Prior to the issue of such Oficios, the administrative units consult with the relevant supervisory Commissions and Financial Intelligence Unit. While not strictly feedback, the Banks and Savings Unit has issued two Oficios in 2005 dealing with PEPs and beneficial owners.
} 
documents and other information required for the proper discharge of their supervision duties. As far as the mission is aware, none of these agencies has been challenged with respect to the exercise of such powers.

$C N B V$

499. The CNBV is empowered under Articles 2 through 9, Section I of the National Banking and Securities Commission Law (Ley de la Comisión Nacional Bancaria y de Valores) to supervise, enforce, and sanction financial institutions within the scope of its competency. Furthermore, the various financial regulatory laws, for purposes of AML/CFT provide as follows:

- Banks and SOFOLES): Article 115 of the Credit Institutions Law: This law authorizes the SHCP, through the CNBV, inter alia, to receive and obtain from FIs any information and documentation in relation to the requirements of the regulations issued thereunder. (See Recommendation 17 below on sanction under this law.) AML/CFT regulations (DCG 115 Regulation 55) further state that the $\mathrm{CNBV}$, in the exercise of the supervisory powers conferred upon it by the Law and other regulations, is mandated to ensure that FIs, including, as the case may be, their offices, branches, agencies and affiliates, both in Mexico and abroad, comply with their AML/CFT obligations, and will impose sanctions for failure to comply with such obligations in accordance with the Law. In addition, the CNBV may request, at any time, information or documentation necessary to exercise its powers.

- $\quad$ All other FI under the supervision of the CNBV are subject to supervision and sanction provisions that are broadly similar to those that apply to banks. The sanctioning provisions for securities brokers are contained under Article 392 section I subsection $n$ ) of the new Securities Market Law 2007. It is noted, however, that the sanctions provided under this article refers to sanctions against persons who fail to maintain documentation or information within ("dentro") the established timeframe which are referred to in Articles 212 fraccion III, last paragraph, .... of this law. Note: For clarity and consistency it would be useful to review the drafting of these sections/provisions as follows: the term "dentro" in Article 392 for purposes of the recordkeeping provisions could imply that documentation is to be maintained within a certain period of time, and not for ("por") the minimum established period.

CONSAR

- $\quad$ Retirement fund administrators. DCG referred under Article108 Bis of the Retirement Savings Systems Law. Similar provisions as above (see Recommendation 17 below for sanctions under this law).

- $\quad$ AML/CFT regulations (DCG 108 39, Regulation 41): These contain provisions similar to those supervised by the CNBV above.

CNSF

- Insurance companies. DCG referred under article 140 of the Insurance Institutions and Companies General Law and Bonding companies DCG referred under Article 112 of the Bonding Institutions Federal Law. Similar provisions as above (see. Recommendation 17 below for sanctions under this law).

- $\quad$ AML/CFT regulations (DCG 10839 Regulation 41): These contain provisions similar to those supervised by the CNBV above.

- $\quad$ SAT. 
- $\quad$ Foreign exchange firms (Centros Cambiarios) and money remittance firms: DCG referred under Article 95, Bis of the Article 81-A of General Law of Credit Organizations and Auxiliary Activities. Similar to the provisions for licensed Casas de Cambio above (see Recommendation 17 below for sanctions under this law).

- $\quad$ AML/CFT regulations (DCG 81-A Bis Regulation 33 and DCG 95 Bis Regulation 35): These contain provisions similar to those supervised by the CNBV above.

Authority to conduct AML/CFT Inspections by Supervisors (c. 29.2)

500. All of the supervisory agencies above have adequate powers to conduct inspections for compliance including mandatory access to books, records and other information to enable them to properly discharge their duties. (See discussion for banks and other credit institutions above under c.29.1.)

Power for Supervisors to Compel Production of Records (c. $29.3 \&$ 29.3.1)

501. See c.29.2 above.

Powers of Enforcement \& Sanction (c. 29.4)

502. All of the financial regulatory laws above provide for adequate sanctioning powers to each of the supervisory authorities for violations with the AML/CFT legal and regulatory requirements. Such powers to sanction extend to directors and officers of FIs. See Recommendation 17 below.

Availability of Effective, Proportionate \& Dissuasive Sanctions (c. 17.1)

503. The AML/CFT laws and regulations provide for a range of administrative sanctions to be applied to FIs for failure to comply with the AML/CFT laws and requirements applicable to them. Each of the supervisory agencies responsible for supervising compliance is authorized to apply these sanctions under procedures established by each of the governing laws. The financial regulators can apply both fines and also apply administrative sanctions that include barring individuals from participating in the financial system as owners, officers, and employees. The following table provides brief descriptions of the fines that can be applied under the various laws to the FIs as well as to their directors, managers, officers, staff and authorized persons, including insurance agents, and to any other natural or legal person that in anyway cause the FIs to breach their obligations.

504. The range of fines provides flexibility to apply sanctions but may not be proportionate and dissuasive for very large institutions and financial groups (high end of the range is approximately US\$500,000). For small-and medium-sized entities, e.g., in the foreign exchange and money remittance sectors, the lower end of the range may be appropriate. To illustrate, actual fines applied, e.g., by the CNBV over the past five years, however, show that in 2007 the average fine was about the equivalent of US\$2,200 per sanction and the highest average was in 2004 when the average fine was about US $\$ 8,000$. For larger FIs, these fines would not appear to be dissuasive. In 2002, a fine of about US\$473,000 was imposed but this is still pending collection.

\section{SANCTIONS APPLIED BY THE SUPERVISORY COMMISSIONS AND THE SAT FOR VIOLATIONS OF AML/CFT LAWS AND REGULATIONS}

505. Daily minimum salary in Mexican pesos (Mex\$) is, for 2007, US\$50.57 and for 2008, US\$52.59, which is about US\$5.00. Therefore, the fines range from 200 to $100,000 \mathrm{dms}$ or equivalent of US\$1,000 toUS $\$ 500,000$. 


\begin{tabular}{|c|c|c|c|}
\hline LAWS & $\begin{array}{l}\text { REGULATED } \\
\text { INSTITUTIONS }\end{array}$ & $\begin{array}{l}\text { LEGAL } \\
\text { PROVISIONS } \\
\text { (Art.) }\end{array}$ & $\begin{array}{l}\text { TYPE OF ADMINISTRATIVE } \\
\text { SANCTION }\end{array}$ \\
\hline \multicolumn{4}{|c|}{ CNBV } \\
\hline $\begin{array}{l}\text { Credit Institutions Law } \\
\text { (Ley de Instituciones de } \\
\text { Crédito) }\end{array}$ & $\begin{array}{l}\text {-Commercial banks } \\
\text {-Development banks } \\
\text {-SOFOLES }\end{array}$ & 115 & $\begin{array}{l}\text { Fine up to } 100000 \text { days of minimum daily } \\
\text { salary. } \\
\text { (100 } 000 \text { días de salario mínimo general } \\
\text { diario vigente en el Distrito Federal.) }\end{array}$ \\
\hline \multirow[t]{2}{*}{$\begin{array}{l}\text { Securities Market Law } \\
\text { (Ley del Mercado de } \\
\text { Valores) }\end{array}$} & $\begin{array}{l}\text {-Stock brokers (Casas de } \\
\text { Bolsa) }\end{array}$ & $\begin{array}{l}\text { 392, fracción I, } \\
\text { inciso } \mathrm{n} \text { ) }\end{array}$ & $\begin{array}{l}\text { Fine between } 200 \text { to } 10000 \text { minimum daily } \\
\text { salary. } \\
\text { As noted above, these fines apply narrowly } \\
\text { to failure to comply with the ten year } \\
\text { recordkeeping and reporting requirements } \\
\text { under Article } 212 \text { of the Law and } \\
\text { regulations. }\end{array}$ \\
\hline & & 392, fracción VII & $\begin{array}{l}\text { Fine between } 200 \text { to } 100000 \text { minimum } \\
\text { daily salary for breaches of the AML/CFT } \\
\text { regulations for which there are no other } \\
\text { sanctions applied in the Law. }\end{array}$ \\
\hline $\begin{array}{l}\text { Investment Companies Law } \\
\text { (Ley de Sociedades de } \\
\text { Inversión) }\end{array}$ & $\begin{array}{l}\text {-Mutual fund operators } \\
\text {-Mutual fund share } \\
\text { distributors }\end{array}$ & 91 & Fine up to 100,000 minimum daily salary. \\
\hline $\begin{array}{l}\text { General Law of Auxiliary } \\
\text { Credit Organizations and } \\
\text { Activities } \\
\text { (Ley General de Org. y Act. } \\
\text { Aux. del Crédito) }\end{array}$ & $\begin{array}{l}\text {-Credit unions } \\
\text {-Leasing companies } \\
\text {-Factoring companies } \\
\text {-General deposit } \\
\text { warehouses } \\
\text {-Casas de cambio. }\end{array}$ & 95 & Fine up to 100000 minimum daily salary. \\
\hline $\begin{array}{l}\text { Law of Popular Savings and } \\
\text { Loans } \\
\text { (Ley de Ahorro y Crédito } \\
\text { Popular) }\end{array}$ & $\begin{array}{l}\text {-Popular Savings and } \\
\text { Loans }\end{array}$ & 130, fracción XVI & $\begin{array}{l}\text { Fine between } 1000 \text { and } 5000 \text { minimum } \\
\text { daily salary. }\end{array}$ \\
\hline \multicolumn{4}{|c|}{ CNSF } \\
\hline $\begin{array}{l}\text { Insurance Institutions and } \\
\text { Mutual Societies Law }\end{array}$ & $\begin{array}{l}\text {-Insurance entities and } \\
\text { agents. }\end{array}$ & 138 and 140 & Fine up to 100000 minimum daily salary. \\
\hline $\begin{array}{l}\text { Federal Law for Bonding } \\
\text { Institutions }\end{array}$ & $\begin{array}{l}\text {-Bonding institutions and } \\
\text { agents }\end{array}$ & 110 an $\mathrm{d} 120$ & Fine up to 100000 minimum daily salary. \\
\hline \multicolumn{4}{|c|}{ CONSAR } \\
\hline $\begin{array}{l}\text { Law on Retirement Savings } \\
\text { System }\end{array}$ & $\begin{array}{l}\text {-Retirement fund } \\
\text { administrators }\end{array}$ & 100 and 108 bis & $\begin{array}{l}\text { Fine from } 2,000 \text { to } 20,000 \text { minimum daily } \\
\text { salary }\end{array}$ \\
\hline \multicolumn{4}{|c|}{ SAT } \\
\hline $\begin{array}{l}\text { General Law of Auxiliary } \\
\text { Credit Organizations and }\end{array}$ & $\begin{array}{l}\text { - Foreign exchange firms } \\
\text { (centros cambiarios) }\end{array}$ & $81-A$ & Fine up to 100,000 minimum daily salary. \\
\hline
\end{tabular}




\begin{tabular}{|l|l|c|c|}
\hline \multicolumn{1}{|c|}{ LAWS } & \multicolumn{1}{|c|}{$\begin{array}{c}\text { REGULATED } \\
\text { INSTITUTIONS }\end{array}$} & $\begin{array}{c}\text { LEGAL } \\
\text { PROVISIONS } \\
\text { (Art.) }\end{array}$ & $\begin{array}{c}\text { TYPE OF ADMINISTRATIVE } \\
\text { SANCTION }\end{array}$ \\
\hline Activities & - Money remitters & 95 Bis & $\begin{array}{l}\text { The SAT can impose fines of up to } \\
100000 \text { minimum daily salary. The } \\
\text { authorities plan to soon issue legal } \\
\text { provision clarifying the basis for applying } \\
\text { such sanctions. }\end{array}$ \\
\hline
\end{tabular}

\section{$C N B V$}

506. Sanctions applied for AML/CFT to date by the CNBV have consisted of fines only, as indicated in the following table (in Mexican pesos). The CNBV is currently in process of revoking the license of a casa de cambio for suspected ML offenses. It is also considering the imposition of additional administrative sanctions against persons involved in this case on the basis of breaches of the AML/CFT laws and/or regulations.

\section{CNSF}

507. According to the CNSF, up to December 2007, it had applied 67 sanctions for noncompliance, mainly due to breaches of the CTR reporting requirement. The following tables illustrate:

\section{CNSF}

\begin{tabular}{|r|r|r|}
\hline \multicolumn{1}{|c|}{ Year } & No. of Sanctions & \multicolumn{1}{c|}{$\begin{array}{c}\text { Amount } \\
\text { (millions of pesos) }\end{array}$} \\
\hline 2005 & 24 & US $\$ 1.6$ \\
\hline 2006 & 32 & US $\$ 6.4$ \\
\hline 2007 & 11 & US $\$ 3.1$ \\
\hline
\end{tabular}

CONSAR

\begin{tabular}{|c|c|c|}
\hline Year & No. of Sanctions & $\begin{array}{c}\text { Amount } \\
\text { (millions of pesos) }\end{array}$ \\
\hline 2005 & 8 & US\$0.67 \\
\hline 2006 & 1 & US $\$ 0.044$ \\
\hline 2007 & 4 & US $\$ 0.40$ \\
\hline
\end{tabular}




\begin{tabular}{|c|c|c|c|c|c|c|c|c|}
\hline Year & $\begin{array}{l}\text { ISSUED OFICIAL COMMUNICATION TO } \\
\text { SUMMON } \\
\text { (GIVE NOTICE TO THE PARTIE"S CONCERN) }\end{array}$ & $\begin{array}{l}\text { PENDING TO } \\
\text { GIVE NOTICE } \\
\text { OR SUMMON }\end{array}$ & $\begin{array}{l}\text { INAPLICABLE, } \\
\text { CANCELLED } \\
\text { AND/OR } \\
\text { DROPPED }\end{array}$ & $\begin{array}{l}\text { OFFICIAL } \\
\text { COMMUNICATIONS } \\
\text { WITH NO EFFECT }\end{array}$ & NO. FINES & $\begin{array}{l}\text { TOTAL } \\
\text { USD }\end{array}$ & FINES PAID & $\begin{array}{l}\text { PAYMENTS DUE } \\
\text { (In process of } \\
\text { collection) } \\
\text { USD }\end{array}$ \\
\hline 2002 & 1 & 0 & 0 & 0 & 1 & 4730370.12 & - & 4730370.12 \\
\hline 2003 & 16 & 0 & 2 & 0 & 6 & 2807500.80 & 80085.00 & 2727415.80 \\
\hline 2004 & 83 & 0 & 3 & 3 & 70 & 5622284.70 & 2181968.76 & 3440315.94 \\
\hline 2005 & 283 & 0 & 32 & 18 & 108 & 3344657.60 & 1926032.60 & 1418625.00 \\
\hline 2006 & 264 & 0 & 17 & 5 & 39 & 957194.80 & 258236.50 & 698958.30 \\
\hline 2007 & 39 & 2 & 4 & 0 & 14 & 319979.50 & 134010.50 & 185969.00 \\
\hline TOTAL & 686 & 2 & 58 & 26 & 238 & 1781987.52 & 4580333.36 & 13201654.16 \\
\hline
\end{tabular}


$S A T$

508. The SAT has also applied a fairly large number of sanctions but in smaller amounts. Fines imposed over the past three years are as follows, in Mexican pesos (Mex\$):

\begin{tabular}{|l|c|c|c|r|r|r|}
\hline \multirow{2}{*}{ Types of Activities } & \multicolumn{2}{|c|}{2005} & \multicolumn{2}{c|}{2006} & \multicolumn{2}{c|}{2007} \\
\cline { 2 - 7 } & No. & $\begin{array}{c}\text { Amount } \\
\text { (Mex\$) }\end{array}$ & No. & Amount (Mex\$) & No. & Amount (Mex\$) \\
\hline $\begin{array}{l}\text { Registered money } \\
\text { remitters only }\end{array}$ & 29 & 152511.00 & 28 & 147252.00 & 8 & 42072.00 \\
\hline $\begin{array}{l}\text { Registered foreign } \\
\text { exchange centers } \\
\text { only }\end{array}$ & 171 & 899289.00 & 326 & 1714434.00 & 15 & 78885.00 \\
\hline $\begin{array}{l}\text { Registered foreign } \\
\text { Exchange centres/ } \\
\text { Money remitters }\end{array}$ & 3 & 15777.00 & 3 & 15777.00 & 0 & 0 \\
\hline
\end{tabular}

509. The average amount of fine applied to date is about the equivalent of US\$525. Of these fines, 65 were applied to money remitters, 512 to centros cambiarios, and six to other unregistered operators. While these fines may be proportional and dissuasive for small operators, they would be too low for those that engage in large volume of transactions and amounts. The mission is not aware about the size of operations to which these fines were applied. Post mission, the authorities informed that in September 2008, the SAT issued administrative rules to impose fines in amounts higher than those previously being applied. These rules will now take in account the severity and the repeated nature of violations.

\section{Designation of Authority to Impose Sanctions (c. 17.2)}

510. See c.17.1 above. The three supervisory Commissions and the SAT apply these sanctions under the applicable laws.

\section{Ability to Sanction Directors \& Senior Management of Financial Institutions (c. 17.3)}

511. See c.17.1 above. The sanctions under the applicable laws can be imposed on the FIs as well as their directors, officers, employees, agents and authorized representatives.

\section{Range of Sanctions - Scope and Proportionality (c. 17.4)}

512. In the Mexican context, the range of sanctions available provide sufficient flexibility to apply proportional sanctions but even at the high end may not be sufficient to dissuade very large FIs . As noted above, the authorities have the power to impose fines as well as restrict, suspend, and revoke licenses, except for unregulated centros cambiarios, money remitters and SOFOMES where no license is issued, but are instead registered. While not contemplated by this Recommendation, a process of deregistration of these entities would be a useful complement to the authorities' sanctioning powers. 
Adequacy of Resources for Competent Authorities (c. 30.1)

513. The CNBV, CNSF, CONSAR and SAT are agencies under the SHCP classified under Mexican law as "Organos desconcentrados" pursuant to Article 17 of the Organizational Law of the Federal Public Administration. In effect, they are administrative agencies separate from the centralized public administration but hierarchically subordinated to the SHCP. They operate with a fair degree of operational and technical autonomy, and are authorized to resolve issues for which the have legal and regulatory competence, including the supervision and enforcement of the AML/CFT laws and regulations under their jurisdiction. With respect to the CNBV, the SHCP is in process of transferring additional powers to it that would involve licensing of banks (and other entities) under its jurisdiction. This process is expected to be completed within 120 from the date of publication of the legal amendments (published in the Official Gazette on February 1, 2008).

514. The CNBV, CONSAR, and CNSF seem to have adequate resources to perform their AML/CFT functions, but which need to be reviewed in the following areas.

515. CNBV: The specialized AML/CFT unit (DGPOI) will likely need upgrading in staff numbers to better enable it to support all of the other supervisory units, particularly onsite inspections, while at the same time conducting its own specialized visits. In addition, a future increase in cases developed by the FIU and the PRG, as expected, will likely lead for more requests for assistance, which could strain resources for routine supervisory activities. This will require careful resource management on the part of the CNBV to ensure that its core AML/CFT supervisory functions are not adversely affected.

516. CNSF: Because the AML/CFT regulations cover all aspects of the insurance sector, (line and nonlife) the CNSF conducts comprehensive AML/CFT supervision of FIs. This may have resource implications and is apparently stretching existing staff resources. As indicated above, its Board has approved and made budgetary provisions for the establishment of a dedicated AML/CFT department but detail staffing arrangements are still be to decided. This increase in resources would allow the CNSF to better supervise and refocus attention on higher risk activities, e.g., life/investment business and on oversight by entities of their agents and brokers.

517. CONSAR: The specialized and limited scope of business conducted by Afores (retirement funds) and the technological capacity of the CONSAR to monitor sector activity from an offsite basis does not justify increasing resources for AML/CFT. Consequently, the existing capacity of the CONSAR appears to be adequate.

518. SAT: Under current industry conditions, the SAT does not have sufficient budget and staff resources to adequately oversee all of the registered and unregistered centros cambiarios and money remitters. The addition of unregulated SOFOMES to its supervision will only compound the challenge. Consequently, the adequacy of the SAT's future resources will largely depend on the future policy and legal response to the risks posed by these unlicensed sectors.

Integrity of Competent Authorities (c. 30.2)

519. The supervisory and regulatory authorities have an impressive cadre of staff that is involved in AML/CFT issues. They exhibited a high degree of professionalism and technical competence in the areas for which they are responsible. As these authorities embark on the implementation of more riskbased approaches to their work, it may be useful to obtain more specialized training and tools in this area, particularly with respect to enhancing offsite supervision for purposes of risk identification and monitoring in the financial system. 
520. The financial regulatory laws contain strict confidentiality provisions with respect to the use of information that public officials, including the SHCP and its supervisory authorities, obtain from FIs in the course of their respective duties as permitted by law. This requirement applies even after they leave their posts. Failure to observe such confidentiality shall be grounds for administrative, civil or penal sanctions. (e.g., See Article 117 of the LIC for credit intermediaries.)

521. With respect to the integrity of supervisory staff, they are subject to the technical and fitness requirements established under the Regulations for the Law on Professional Career Service in Public Administration. These regulations establish the recruitment requirements and processes to be observed for public officials (including supervisors) In particular, Article 4 of these regulations establish the basic requirements for professional public sector careers that include provisions for, inter alia, honesty, observance of laws, impartiality, quality of service, competence, and training.

Training for Competent Authorities (c. 30.3)

522. The supervisory authorities, particularly the CNBV, have provided their staff the opportunity to participate in a number of training events in Mexico and abroad. Since 2007, staff of the CNBV participated in about $60 \mathrm{AML} / \mathrm{CFT}$ related courses or workshops, either as instructors (10 events) or participants (50 events). About 250 staff of the CNBV attended as participants.

Statistics (applying R.32)

523. All of the supervisory Commissions and the SAT responsible for monitoring of compliance and sanctions have very detailed statistics that are relevant and fairly accurate. The mission was impressed by the extent of statistics available, and the relevance to their work and to the mission. It facilitated significantly the assessment of implementation.

524. Of particular note are the statistics on the number of AML/CFT examinations and the results obtained, especially by CNBV and SAT.

\subsubsection{Recommendations and Comments}

\section{EC 23.1 and EC 23.2}

- $\quad$ Review and reconsider the current licensing policy and threshold for the money exchange and remittance sectors, with a view to regularizing and reducing ML and FT risks particularly in the unlicensed categories. The aim would be to limit the extent to which the unregulated sector may be engaging in high value and high volume transactions.

- $\quad$ Bring all unregulated SOFOMES under effective AML/CFT regulation and supervision by an agency that has the capacity and resources to do so. A key focus of such regulation and supervision should be on fit and proper tests for top management, owners, and controllers of such entities.

$C N B V$

- $\quad$ Strengthen AML/CFT supervision through the incorporation of additional risk elements into the offsite planning process and system. 
- $\quad$ Enhance existing procedures for supervising client acceptance and monitoring by FIs of high risk clients, particularly with respect to cash intensive and unregulated financial intermediaries.

- $\quad$ Enhance oversight of local FIs (e.g., banks) that have operations abroad, and increase the use of supervisory MoUs to facilitate cross-border consolidated supervision.

CNSF

- $\quad$ Enhance the supervision of the channels of distribution for insurance and bonding entities, including oversight of agents' AML/CFT compliance by such companies. Also clarify in the applicable regulatory provisions that the CNSF will supervise (not only sanction) for compliance with their AML/CFT obligations.

- $\quad$ Review the contracting arrangements between insurance and bonding companies and their agents and consider requiring that they include explicit compliance with the AML/CFT obligations to support effective implementation of the regulatory requirements.

- $\quad$ Enforce the obligation for insurance and bonding companies to provide (enhanced) AML/CFT training for their agents and brokers, prioritizing those that accept cash from customers and suspicious activity detection and reporting.

$S A T$

- $\quad$ Develop a system, in close collaboration with other stakeholders (e.g., CNBV, CNSF, the FIU and the industry Association) to better target major high risk operations for registration and onsite inspections.

- $\quad$ Consider the adequacy of its staffing resources particularly in light of the increased responsibility for SOFOMES, and the large number of foreign exchange centers and money remitters subject to its supervision.

EC 23.3 See EC 23.2 above.

EC 23.5 and EC 23.6

- $\quad$ Enforce the registration requirement and implement more effective measures in the unregulated sectors (centros cambiarios and money remitters) to prohibit unregistered operators from accessing the regulated financial sector.

EC 25.1

- The supervisory authorities, in conjunction with the FIU and other authorities as necessary, should issue industry specific guidelines for implementing the AML/CFT requirements, particularly with respect to new ML and FT risks, ML/FT techniques and methods in the structuring and laying stages of money laundering. This would aid in the implementation of the risk-based CDD requirements established in the regulations.

EC 17.1

- In view of the relatively low average size of fines applied to date, review proportionality and dissuasive nature of fines and consider additional use of other non-monetary measures. 
EC 17.4

- $\quad$ Consider applying/including non-monetary sanctions for breaches with the AML/CFT requirements for the unlicensed entities (e.g., centros cambiarios, money remitters, and SOFOMES) that would include a process for de-registration.

EC $30.1,30.3$ and 30.3

- $\quad$ Enhanced training for risk-based supervision including for offsite surveillance of ML and FT risks.

- Increase the focus on, and provide specialized training to inspections staff, for the review of controls in FIs designed to detect noncash money laundering, particularly during the structuring stages.

- Increase the staff of the DGPOI to enable it to better support all of the CNBV's supervisory units and other outside authorities such as the FIU and the PGR.

- $\quad$ Need to increase staff for the SAT for the supervision of money exchange centers, money remitters, and SOFOMES.

\subsubsection{Compliance with Recommendations 17, 23, 25 \& 29}

\begin{tabular}{|c|c|c|}
\hline & Rating & Summary of Factors Underlying Rating \\
\hline R.17 & PC & $\begin{array}{l}\text { - Sanctions not sufficiently proportionate and dissuasive. On average, relatively low fines } \\
\text { applied and insufficient use of nonmonetary sanctions. }\end{array}$ \\
\hline R.23 & PC & $\begin{array}{l}\text { - Insufficient supervision, largely due to inadequate budgetary and human resources, of } \\
\text { the unregulated foreign exchange centers and money remittance sector. } \\
\text { - No AML/CFT regulation and supervision for unlicensed SOFOMES. } \\
\text { - Inadequate oversight mechanisms for intermediaries (channels of distribution) in the } \\
\text { insurance and bonding sectors, and on cash acceptance practices. } \\
\text { - Insufficient use of offsite supervisory capacity for planning and conducting onsite } \\
\text { inspections, consistent with the risk-based provisions in the regulations and prudential } \\
\text { supervision. }\end{array}$ \\
\hline R.25 & & $\begin{array}{l}\text { Section-specific rating would be: NC } \\
\text { - Need for more current guidelines on new ML and FT techniques and methods including } \\
\text { for new technologies. } \\
\text { - Need for industry-specific guidelines on ML and FT risks in the Mexican market to } \\
\text { support risk-based compliance. }\end{array}$ \\
\hline R.29 & C & \\
\hline
\end{tabular}




\subsection{Money or Value Transfer Services (SR.VI) ${ }^{50}$}

525. Summary: Money transmission businesses are required to be registered and are generally subject to AML/CFT requirements very similar to those imposed on credit institutions. The Law designates the SHCP as the regulatory body for money remittance business, and it assigns responsibility to the SAT (the tax authority), inter alia, to supervise compliance and impose sanctions. The SAT is empowered to obtain information and documentation from these reporting institutions for purposes of carrying out its functions. However, the resources available to the SAT for overseeing compliance with the regulations are very low relative to the number of registered institutions, and additional efforts are needed to obtain a better indication of the size of the industry and where the main risks lie.

\subsubsection{Description and Analysis}

\section{Legal Framework}

526. The General Law of Organizations and Auxiliary Credit Activities (Ley General de Organizaciones y Actividades Auxiliares del Crédito) (the Law) defines two categories of entities that can provide money transfer services: registered money transfer businesses ("transmisores de dinero") under the authority of the SAT, and licensed exchange houses ("casas de cambio") under the authority of the CNBV.

527. (i) Article 95 Bis of the Law requires money transmission businesses to be registered and it establishes their principal AML/CFT requirements, which are generally similar to those of other FIs described earlier in this report.

528. In addition, (ii) Article 81 requires a licence from the SHCP for anyone wishing to carry on business of currency purchase, sale and exchange business with the public in Mexico, in a regular and professional manner and in amounts of USD 10000 or higher per customer, per day. However, if such business is settled through the transfer or transmission of funds, the licensing requirement applies regardless of any monetary thresholds. These businesses must be organized as corporations/limited companies known as "casas de cambio".

Scope of application of AML/CFT regulations to Money Remitters

529. The Law defines money remitters consistent with the FATF definition and the Interpretative Note to SR VI, Article 95 Bis, paragraph 2 of the Law defines them as:

"For purposes of these provisions, money transmitter is the person" that, customarily and for consideration, commission, benefit or profit, receives in national territory rights or resources in national or foreign currency, directly in its offices or through cable, facsimile, courier services, electronic means or electronic transfers of funds, to transfer them abroad,

\footnotetext{
${ }^{50}$ Note: This section should be read in conjunction with the findings elsewhere in the report, particularly with respect to CDD, monitoring of transactions, filing of reports, internal controls, and supervision of money or value transfer services.

${ }^{51}$ In Mexico, as is usually the case in countries of a civil legal tradition, the concept of "person" encompasses both physical (sometimes called natural) persons and legal persons.
} 
or to another place within national territory or to deliver them in the same place in which it receives them to a designated beneficiary, in accordance with the instructions of the sender."

530. The AML/CFT regulations (DCG 95 Bis) of May 2004 distinguish between two categories of money transmitters: dispersers and payors. Only the dispersers are subject to the full scope of the $\mathrm{AML} / \mathrm{CFT}$ regulations, whereas the payors are treated, for purposes of AML/CFT requirements, as agents of the disperser remitters. These two intermediaries are further defined in the regulations as:

a) "Disperser money transmitters" (transmisores de dinero dispersores): "the person that, having received through any means in national territory rights or resources in national or foreign currency, delivers them to another person with which it has a contractual relationship, in order for such person to deliver them to the designated beneficiary." Disperser transmitters in Mexico are authorized to deliver the payment either in person at their offices or at the domicile of the recipient, by depositing the payment in the recipient's bank account, or by means of a payor money transmitter (Regulation 4).

b) "Payor money transmitters" (transmisores de dinero pagadores): "the person that, having established a contractual relationship with the 'disperser money transmitter' receives from such party, through any means, the rights or resources for the designated beneficiary."

531. The only AML/CFT obligations applicable to the payor transmitters are to identify customers, to comply with the disperser's CDD policies where applicable, to conduct due diligence on employees and to train them. No other requirements are established for the payors in the regulations. In particular, the following regulations apply to payors:

Regulation 4 "The payor money transmitters, in their operations, shall obtain all the information and documentation referred to in this article [for customer identification] and provide it to the disperser money transmitters so that they can complete their corresponding customer identification files."

Regulation 15: "The payor money transmitters must observe the policies of identification and knowledge of the customer elaborated by the disperser money transmitters, as well as the criteria, methods and procedures that the dispersers establish in accordance with these regulations."

Regulation 24: "The money transmitters [without distinction] must keep evidence of ... [training provided to employees]."

Regulation 31: "The money transmitters [without distinction] must adopt procedures for the selection of employees to assure that they have the necessary technical capacity, experience and honorability, to conduct their functions...."

532. The above requirements do not directly contemplate all the aspects of an AML/CFT preventive system, but they create the obligation for payor money transmitters to follow the procedures established by the disperser transmitters in order to enable the latter to comply with their more comprehensive requirements. The regulations could be enhanced if the disperser transmitters were explicitly held responsible and accountable for the implementation of AML/CFT controls 
throughout all the stages of the money remittance operation, regardless of who performs the final payment. In this respect, payor transmitters would be the same as an agent acting on behalf of a disperser and indistinguishable from the disperser in terms of compliance with AML/CFT requirements.

533. The regulations contain, however, a few factors that help strengthen the AML/CFT regime in the remittance chain. Regulation 23 requires the disperser transmitters to include in the contract with the payor agents the obligation for the latter to implement the training and dissemination requirements established in the regulations, and to make non-compliance a basis for revoking the contract. Regulation 5 partly repeats Regulation 23 requiring the disperser transmitters to include in their contracts with the paying agents the obligation on the latter to (a) develop training and dissemination programs, (b) keep a record of participation in training by its staff, and (c) ensure and record that persons who will deal with clients or manage resources are trained on the subject before assuming their responsibilities. Noncompliance with these contractual obligations on the part of agents would be a basis for revocation.

534. In addition, Regulation 21 requires disperser transmitters to ascertain that their payor agents, their (dispersers) staff, officials, etc, are not engaging in conduct that could result in breaches of the regulations by the disperser transmitters.

535. Regulation 32 appears to limit the application of the mitigating requirements described in the preceding paragraph as it only requires dispersers, to the extent possible, to try ("procurarán") to ensure that the regulations are applied by transmitters with whom they have contractual regulations (payors) with respect to the delivery of rights or funds to the designated beneficiaries [of remittances].

536. The rest of this section of the report contains the detailed description and analysis of the AML/CFT regulations that apply to disperser transmitters, unless noted otherwise. For practical purposes, all references to "the Regulations" made in this section will refer to the Regulations (DCG 95 bis) for money transmitters.

\section{Designation of Registration Authority (c. VI.1); list of agents (c. VI.4)}

537. Article 95 Bis of the Law gives the Ministry of Finance the power to regulate all money transmitters for AML/CFT purposes only. It also designates the SAT as the supervisor for compliance (including through onsite visits to the agents' premises), and for enforcement/sanctions. The law and regulations empower the SHCP through the SAT to obtain the information and documentation from these reporting institutions (both dispersers and payors) that is necessary to carry out its functions.

538. Regulation 38 requires disperser money transmitters to register with the SAT. The registration requirement consists of a duty to file information using an official form where they inform the SAT that the activities that they conduct fall under Article 95 Bis of the Law. There is no requirement to maintain a list of their payors or agents. It could not be ascertained whether in practice they maintain such lists but the SAT indicated that they can obtain such information on agents in the course of their on-site inspections of remitters. (As not all money remitters have registered and been supervised, the SAT itself does not have a complete list/information of the actual number of money remitters, and hence information on their agents.)

539. The data required for registration with the SAT under Regulation 38 includes:

- $\quad$ Name or commercial name of the money transmitter. 
- $\quad$ Name of the owner or principal shareholders, when applicable.

- Domicile of its offices, locals, establishments or branches (does not include the payor/agents).

- $\quad$ Name of the administrators (management).

- $\quad$ Copy of their tax identification document [cédula de identificación fiscal].

- $\quad$ The activities that they perform which fall under article 95 Bis of the Law.

540. This notice must be presented within the first 15 business days after the transmitter starts conducting the activities referred to in article 95 Bis of the Law. Disperser money transmitters must also notify any modification of the aforementioned information, and whenever they cease to perform [remittance activities] within 15 days. This information must be updated at least once a year ...". Failure to register would constitute a violation of the regulations (Regulation 36) and subject to sanctions as provided under Article 95 Bis of the Law which includes a fine of up to 100,000 minimum daily salaries (about USD 500 000). These sanctions can also apply to members of the board and staff of remitters.

541. The SAT reported that 857 disperser money transmitters had filed the required notice, out of an estimated total of 1,223 that are in operation. The SAT has arrived at this total based on an extrapolation from the fact that 42.7 percent of 472 remittance businesses that were visited from 2005 to 2007, operated without registration. Based on 857 disperser money transmitters registered, the total number of money transmitters in the country is estimated as $857 \times 1.427=1223$.

\begin{tabular}{|c|c|c|c|}
\hline & $\begin{array}{l}\text { Total en operación } \\
\text { (estimado incluyendo } \\
\text { informales) }\end{array}$ & $\begin{array}{l}\text { Registrados } \\
\text { ("formales") }\end{array}$ & \begin{tabular}{|c|}
$\begin{array}{c}\text { Supervisados y } \\
\text { vigilados hasta el } \\
2007 \\
\end{array}$ \\
\end{tabular} \\
\hline Transmisores de Dinero & 1223 & 857 & 472 \\
\hline Centros Cambiarios & 3157 & 2212 & 1262 \\
\hline \multirow[t]{2}{*}{$\begin{array}{l}\text { CCTD No registrados o } \\
\text { Eventuales }\end{array}$} & & & 176 \\
\hline & 4380 & 3069 & 1910 \\
\hline
\end{tabular}

542. The large quantities of dollar bank notes circulating in Mexico indicate that there is a large un-banked segment of remittance providers which operate through alternative means, most likely through cash couriers, and which go undetected by the SAT officials during their field inspections. The U.S.-Mexico border is one of the most active in the world in terms of physical movement of persons and money between two countries, and many of those persons are known to operate as cash couriers. The extent of the informal value transfer sector poses significant challenges to implementation of effective AML/CFT controls, including through the formal financial sector that provide services to such operators. The CNBV tries to identify unregistered operations through its own supervision of, e.g., banks, and informs the SAT of any activities identified.

543. Details on supervisory and enforcement actions taken by the SAT, including with respect to unregistered transmitters, as well as the resources available for this function, are provided below in the context of criterion VI.5 (sanctions).

Preventive requirements for money remitters (c. VI.2 first part): Applying R.5-9 (CDD), R.10 and SR.VII (record keeping and wire transfers), R.15 and 22 (internal controls).

544. $\quad$ R.5 applied to remittances (CDD): Article 95 Bis of the Law contains the general $\mathrm{AML} / \mathrm{CFT}$ requirements for money transfer services, in the same terms as those contained in the law 
of credit institutions. In turn, the regulations contain similar requirements to those of the regulations applicable to credit institutions, most notably the following: identification of customers prior to conducting any transaction, verification via a detailed list of acceptable documents, measures to identify the beneficial owner, and obligation to update the information regularly.

545. The only significant difference with respect to the identification requirements applicable to other financial institutions is that the obligation to identify remittance customers is triggered only when the amount of the transaction is equal to, or above US $\$ 3,000$ (Article 4 of the regulations). FATF R.5 allows countries not to impose CDD requirements for occasional transactions that are below the designated threshold of US $\$ 10,000 /$ EUR 15,000. Considering that the transactions performed by money remitters should generally be of an occasional nature, the Mexican threshold of US $\$ 3,000$ is in accordance with the FATF recommendations. It is not known, however, the extent to which remitters maintain long-term business relationships with customers that would require CDD irrespective of thresholds.

546. Par. IV of Reg. 18 of the AML/CFT regulations (DCG 95-Bis) requires money remitters to, for purposes of determining whether an operation is suspicious, take into account structuring of small transactions conducted by a single person that total or exceed the equivalent of US $\$ 3,000$ during a period of five days. In addition, under Chapter IX of the regulations, remitters are required to have systems in place to detect this type of structuring of transactions (more details below in the analysis of R.11 as applied to money remitters). However, without an explicit requirement to aggregate such transactions for purposes of conducting CDD, it would be rather difficult in practice for money remitters to know their clients and implement these requirements.

547. R.6 applied to remittances (PEPs): The regulations for money remitters (Regulation 2-IX and Regulation 8) address the issue of CDD for politically exposed persons similar to the requirements for other financial institutions. Therefore, the more detailed analysis made in Section 3.2 of the report is also applicable here. The following conclusions should be reiterated: a) the definition of PEPs satisfies the FATF standard and it also includes national PEPs; $b$ ) to determine if someone is a PEP, disperser transmitters must have internal procedures that take into account among others, the customers' background, activity or line of business, source of funds and place of residence; c) for customers classified as high risk, including PEPs, disperser money transmitters must establish mechanisms to update customer identification files at least once a year (Article 8); and d) the Ministry of Finance further defined and expanded the categories of PEPs, but this was only applicable to banks. No guidance has been issued for money remitters.

548. R.7 applied to remittances (cross-border correspondents): The regulations do not include any requirement in this respect and the business of money remitters in Mexico do not indicate that they maintain correspondent relationships for banks and other FIs located abroad.

\section{R.8 and 9 applied to remittances (intermediaries, non face-to-face and new}

technologies): There is no specific reference in the regulations to non face-to-face transactions, including when conducting transactions with a customer for the first time. However, the regulations stipulate that the money transmitter must always complete the identification file of the customer "prior to conducting any operations for an amount equal to or higher than US\$3,000" (Article 4, also re-stated in article 5). More specifically, Regulation 7 prescribes that the customers' identification file must be completed prior to conducting "operations through electronic or optical means or through any other technology." Therefore, it is clear that even if a service is provided remotely, the institution must first gather and verify all the documentation that supports that customer's identity, domicile and other data. The regulations contain very detailed indication of the type of documents that are acceptable for identification purposes, and require that "money 
transmitters must keep in the customer's file a copy of all the documents mentioned in this disposition, prior comparison with the originals by the disperser transmitters themselves, or by the payor transmitters."

550. In addition, article 4 prescribes that "The payor money transmitters, in their operations, shall obtain all the information and documentation referred to in this article and give it to the disperser money transmitters so that they can complete their corresponding customer identification files" (first paragraph after numeral IV). There is no requirement for either the disperser transmitter, or the payor agent, to immediately obtain/provide CDD information (to the disperser transmitter), as required under EC 9.1.

551. When another person acts on behalf of the customer the money transmitters must obtain the original power of attorney or a certified copy of it, with clear indication of the faculties conferred. They must also obtain the identification and supporting documentation of the representative, in addition to the identification of the customer (Regulation 4, I, c), Paragraph 4).

552. R.10 applied to remittances (record keeping): Similarly to the requirements for all other financial institutions, money remitters in Mexico are required to keep records of customer identification documents, transactions, and reports for a minimum of 10 years, but not of all account files or business correspondence. The only difference with the requirements for credit institutions is that the regulations do not indicate that the records must allow the reconstruction of the transactions. "The copies of the reports foreseen in these dispositions, and the records of the operations undertaken must be kept for a period of at least ten years after they conclude."

"The data and documents that integrate the identification files of customers and users, shall be kept during all the time that the account or contract is current, and after that for a period of at least ten years."

"With this purpose, the institutions shall comply with the criteria contained in the Code of Commerce with respect to with respect to microfilming, taping, conservation and destruction of documents."

553. SR.VII applied to remittances (wire transfers): The regulations do not include any reference to the issue of wire transfers. Money remitters are not required to include the originator's information on any funds transfer when they act as ordering institution, nor to keep that information throughout the chain when they act as intermediaries, or to detect and possibly report wire transfers that lack sufficient originator information.

554. This weakness of the Mexican regulations is compounded by the absence of a requirement to identify and maintain customer identification information for occasional transactions (and possibly for business relationships) with respect to transactions below US\$3,000. This would not be in compliance with the FATF CDD (c.5.2 c) and SR.VII that establish a threshold of US\$1,000 for wire transfers.

555. R.15 and 22 applied to remittances (internal controls \& branches): With respect to internal controls the AML/CFT regulations for money remitters, similar to those for other financial institutions, focus almost exclusively on the establishment of a compliance function within institutions. In particular, Regulations 21 and 22 require managers of disperser transmitters to designate one or more persons responsible for overseeing compliance with AML/CFT obligations. The appointment of these "compliance officers" must be notified to the SAT. Given the smaller size of money transmitters relative to other institutions, the compliance officers of these entities also 
perform the functions of the "Compliance Committee" that is required for credit and other types of financial institutions. There are no provisions with respect to the hierarchical level that this officer should have, let alone about its independence. The regulations do not explicitly or implicitly mention any internal and external auditing functions either.

556. The following are the main functions that the regulations assign to the compliance officer of money transmitters:

- $\quad$ Determine the CDD policies and procedures of the money transmitter.

- $\quad$ To know and evaluate the weaknesses of internal controls and adopt corrective measures.

- $\quad$ To know when a payor money remitter or its employees incur in conducts that breach their AML/CFT obligations under their contract or the regulations.

- $\quad$ Establish the criteria for the classification of customers according to risk.

- $\quad$ Approve the training programs for employees.

- Disseminate the international lists of terrorists among the employees and approve the training programs.

- $\quad$ Decide which operations must be reported to the FIU as suspicious.

- Inform of conducts of employees that violate their AML/CFT obligations.

557. The regulations also impose an obligation to have strict procedures for the selection of prospective employees, to guarantee that they are honorable and possess the necessary technical capacity. For this purpose, "there shall be deemed not honorable the persons sentenced for patrimonial crimes, or those judicially incapacitated to exercise commerce or to take employment or position in the public sector or in the Mexican financial system" (Regulation 31).

558. With respect to branches abroad, Regulation 32 of the regulations stipulates that "to the extent possible, dispersor money remitters will pursue the implementation of these regulations in all their offices, branches, agencies, subsidiaries, locals or establishments located abroad, especially those in countries where there are no or insufficiently applied measures to prevent, detect and combat operations with resources of illicit origin." This is basically the same provision created for credit institutions and, according to information received from industry practitioners, very few Mexican money remitters have branches abroad. They mainly operate as respondent institutions for foreign banks.

559. Finally, it is worth mentioning that the SAT is authorized to require that money transmitters modify their internal policies and procedures to prevent ML and FT.

Reporting obligations for money remitters (c. VI.2, second part): Applying R.4 (secrecy), R.11 (monitoring), R.13 (STR), R.14 (tipping off and legal protection) and R.21 (attention to some countries)

560. Except for the threshold of US\$3,000, all the other comments on preventive requirements explained in previous sections apply to money transmitters. In brief these are:

561. R.4: There are no secrecy or confidentiality provisions that could limit the ability of competent authorities to obtain information from money transmitters (Articles 27, 28, and 29). Article 36 adds that the SAT, when exercising its supervisory authority, "shall be able to require at any time 
the information or documentation deemed necessary. " On the other hand, access to information by the judicial authorities cannot be restricted on reasons of confidentiality (please refer to Section 3.4).

562. R.11: Disperser money transmitters are required to monitor all transactions, regardless of the amount, in order to detect, analyze and report those that should be sent to the FIU. Article 26 of the regulations creates the obligation to have a system in place, preferably automated, to perform the following functions, among others:

- “...III. Classify the operations ... to detect possible unusual operations;

- $\quad$ IV. Detect and monitor the operations of a single customer ... in one or several amounts which could total US\$3,000 over a period of five business days.

- V. Contribute to the monitoring and analysis of potentially unusual operations ... access to the historical records of transactions from each customer, ... average of transactions ...

- Group together in a consolidated database the different operations per customer..."

563. $\underline{\text { R.13: }}$ : The same types of suspicious transaction reports explained in section 3.7 are contemplated in the regulations for money transmitters, using the same definitions, timeframes and guidelines. The reports must be filed for suspicions of either ML or TF (Reg. 12), the amount of the transaction being irrelevant. Regulation 12 requires FIs to report attempted transactions when they have indications or certainty that an attempted transaction may be associated with ML or FT. However, these are to be reported only if the FI accepts the transaction. The possible involvement of tax reasons does not preclude the filing of an STR. Money remitters must report their suspicions to the FIU through their supervisory authority which is the SAT.

564. However, as noted in Section 3.7, at the time of the visit the STRs filed by money remitters were not being transmitted to the FIU due to a technical problem in the communication between the systems of the FIU and those of the SAT. This is a serious weakness in implementing SR.VI. The authorities were optimistic that they would be able to resolve the issue during 2008 .

565. R.14: Regulation 28 of the Regulations establishes strict confidenciality and prohibits to tip off the customer or third parties about an STR. Complementary, Regulation 28 gives legal protection to the reporting institution and persons by stating that "compliance with the obligation of money transmitters... to send to [the FIU] the reports and information herein prescribed, will not constitute violation of the restrictions of disclosure imposed by contract or law..."

566. R.21: Regulation 13 establishes an obligation to apply more strictly the CDD procedures when the funds "proceed from, or go to countries or territories where there are no or insufficiently applied measures to prevent, detect and combat ...."

Monitoring (c. VI.3), Supervision (c. VI.2 applying R.23 and R.29) and Sanctions for money remitters (c. VI.5 applying R.17)

567. The regulatory powers of the Ministry of Finance through the SAT are adequate. Article 95 Bis of the Law states that "The [currency exchanges] and money transmitters shall be obliged to comply (...), in the terms that the Ministry of Finance will determine by general regulations, prior consultation with the Tax Administration Service, SAT..." "Likewise, the Ministry of Finance, ... will establish the general orientation of the procedures and criteria that must be complied by the [currency exchanges] and the money transmitters, with respect to: ... [identification, CDD record keeping, training, etc.]" 
568. With respect to supervision and sanctions, the powers of SAT are generally adequate from a formal standpoint. In this respect, the Regulations provide that "The SAT ... will oversee that the disperser money transmitters, including their offices, branches, agencies, subsidiaries, locals or establishments, both in national territory and abroad, comply with the obligations established in the present Dispositions, with their own policies to know the customer, ... and it will impose the corresponding sanctions... " (Reg. 36 of the AML/CFT Regulations).

569. Article 95 Bis of the Law, paragraph 9 states that "The violation of the dispositions of this article [which lays out the basis of all preventive requirements for money remitters] will be sanctioned by the Tax Administration Service with fines up to 100,000 days of the official daily minimum salary in force in the Federal District [Mex\$5,229,000 pesos as of December 2007, or approximately US $\$ 482,000$ on the last day of the mission when the exchange rate was approximately 10.83].”

570. However, the powers of the SAT to supervise for AML/CFT do not extend to payor money remitters. Moreover, the resources assigned to the relevant Unit of the SAT have so far been insufficient for the task at hand. However, the SAT has recently hired 52 new employees and indicated to the mission that they are dedicated exclusively to AML/CFT oversight of money transmiters and remitters. They are in the process of being trained and expect to start conducting inspections in 2008.

\section{Additional Element - Applying Best Practices Paper for SR VI (c. VI.6)}

571. The Mexican authorities have yet to establish a clear strategy to estimate the number of money transmitters operating and to systematicaly identify and bring into compliance those that operate unregistered. However, the following measures from the best practices paper for SR.VI correspond to actions taken by the authorities:

- $\quad$ MVT services are required to be registered with the SAT and a clear procedure for such registration exists.

- $\quad$ MVT are required to submit details of the address from which they operate, and notify the authorities of any change.

- $\quad$ Identify MVT that are not registered, by several means such as: a) following leads provided by the FIU as a result of STRs that are under analysis; b) visiting all the MVT that operate within a predetermined area and determining whether they are registered or not. For those not registered, the SAT sends letters raising awareness of their several obligations and alerting them of the consequence of not complying.

- $\quad$ The SAT makes publicly available its responses to questions from the industry about the interpretation of applicable laws and regulations (outreach and guidance).

- $\quad$ MVT are subject to CDD, record keeping, and suspicious reporting requirements.

- $\quad$ Compliance monitoring: the SAT attempts to identify informal practitioners, it has the legal authority to check on registered and unregistered entities without warning and it is empowered to impose fines for noncompliance. 


\subsubsection{Recommendations and Comments}

- $\quad$ Issue regulations that require money transmitters to include CDD information on all wire transfers sent and received, or at least on those equal or higher than USD 1000 , in accordance to SR. VII and its interpretative note.

- $\quad$ Include account files and business correspondence as part of the data for which money remitters must keep proper records, and require that these records must allow the reconstruction of the transactions.

- $\quad$ Require an explicit CDD for occasional transactions that in aggregate equal or exceed the established CDD threshold, which would also support implementation of the suspicious activity monitoring and reporting requirements.

- Insert an explicit requirement in the regulations for Disperser Transmitters to maintain a list of the agents and Payor Transmitters with whom they operate.

- $\quad$ Require in the AML/CFT regulations that the contracts between Disperser and Payor Transmitters incorporate all the obligations of the former with respect to customer identification, timeframes for forwarding documentation, monitoring of transactions and sending of unusual/suspicious activity reports, etc.

- $\quad$ Require in the AML/CFT regulations that the contract between Disperser and Payor Transmitters allows the former to audit the Payor's compliance with its AML/CFT obligations.

- $\quad$ The regulations should be amended to make the disperser transmitters accountable for any failure of their Payor transmitters to satisfy the applicable CDD, monitoring and reporting requirements. Also require that CDD information obtained by the payor/agent is immediately obtained by the disperser.

- $\quad$ The SAT should be explicitly empowered to inspect, instruct, and sanction as appropriate all the payor transmitters, and not only the disperser transmitters.

- Maintain efforts to train staff of the SAT and to dedicate a significant number of them to the inspection of AML/CFT.

- $\quad$ Educate the public about the characteristics that they should expect and demand from reputable money remitters, including evidence of registration with the SAT and minimum customer identification requirements.

- $\quad$ There should be a more concerted and well-resourced effort from the SAT and other stakeholders to estimate the number and significance of MVT, identify those who operate informally and determine the areas of greater priority to prevent risks of ML and FT.

\subsubsection{Compliance with Special Recommendation VI}

\begin{tabular}{|c|c|c|c|}
\hline & Rating & \multicolumn{1}{c|}{ Summary of actors underlying rating } \\
\hline SR.VI & PC & $\begin{array}{l}\text { Large volumes of cash are brought from abroad by informal and unregistered couriers } \\
\text { and there has not been a systematic effort to estimate the number of MVT and to identify } \\
\text { those that operate informally. }\end{array}$ \\
& $\begin{array}{l}\text { The obligation for money remitters to consider, for purposes of ascertaining suspicion, } \\
\text { small structured transactions that in aggregate equal or exceed the USD } 3 \text { 000 } \\
\text { threshold, does not constitute an explicit requirement to undertake CDD. }\end{array}$ \\
& -\begin{tabular}{l} 
Insufficient supervisory actions and resources relative to the large number of providers \\
\hline
\end{tabular}
\end{tabular}




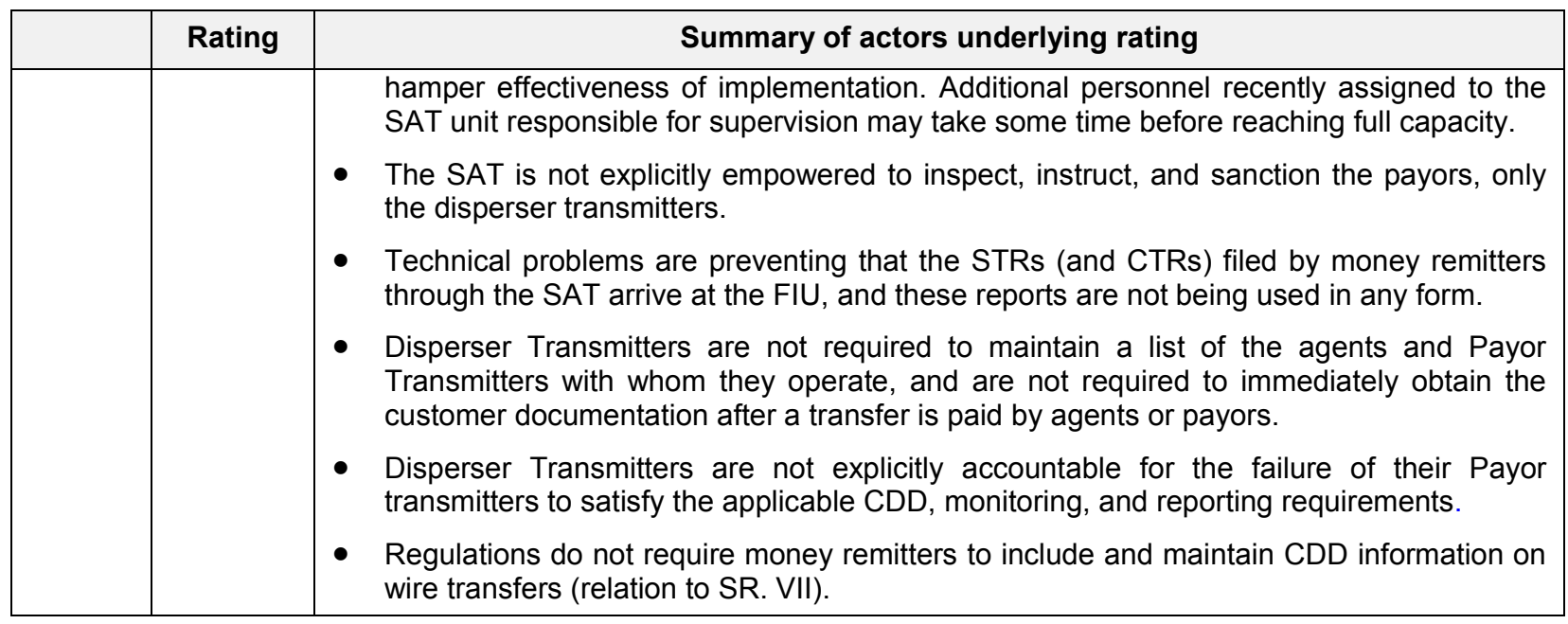

\section{4. PREVENTIVE MEASURES - DESIGNATED NON-FINANCIAL BUSINESSES AND PROFESSIONS}

\subsection{Customer Due Diligence and Record-keeping (R.12)}

\subsubsection{Description and Analysis}

572. No AML/CFT preventive regime applicable to DNFBP exists in Mexico. National authorities are reportedly in the process of analyzing each sector, its risks, vulnerabilities, existing regulatory bodies, effectiveness of the regulations, and possibilities of making their current controls and activities compatible with new AML/CFT preventive measures. However, the mission was not provided with any evidence of such analysis.

573. All the types of DNFBPs exist in Mexico. It should be clarified, however, that according to the law, and in practice, trust services are only provided by credit institutions. The table provided under "Overview of DNFBP Sector" in the introduction of this report, summarizes the available data with respect to DNFBPs.

574. To date, in connection with DNFBPs, the only reporting requirement that exists is an obligation to report cash transactions to the SAT for amounts in excess of the equivalent in national currency to US\$10,000, as provided under the Income Tax Law. The FIU has access to this information. This is an obligation for all tax payers and, therefore applicable to real estate agents, dealers in precious metals and precious stones, independent professionals such as lawyers, notaries, commercial notaries and accountants, trust and company service providers (which are only banks) and non-profit organizations, as long as they are subject to the tax law. This requirement was established recently and no statistics were provided about its usage so far.

575. There is no legal definition of casinos in Mexico. The law prohibits all games of chance except those explicitly listed in the Gaming Law of 1947. The activities that are typical of casinos, including slot machines are prohibited, in principle, except during regional fairs (please see details under Section 1.4 at the introduction of this report). Considering that this is the only "designated nonfinancial business" which is fairly regulated for reasons of gaming policy in Mexico (not for AML/CFT purposes), the following paragraphs summarize those regulations to the extent that they can have AML/CFT implications. 
576. Some of the general requirements imposed on temporary casinos resemble typical AML/CFT measures (regulations issued in September 2004 implementing the Law of Games and Drawings of 1947). Specifically, the regulations provide for the vetting of casino operators, and an obligation to keep "a registry for the purpose of determining the users whose bets, in light of the amount of such bets, raise the suspicion that transactions with illicit resources are being conducted." The permits issued under the most recent legislation (which does not cover many of the existing permits) mandate permit holders to inform the authorities (not necessarily the FIU) of any behavior or practice of the users that is likely to constitute felonies related with organized crime or transactions with illicit resources. The mission was not informed of any instances in which this reporting provisions were used.

577. Mexican laws prohibit games of chance, betting games and drawings unless the Ministry of Interior (Secretaría de Gobernación) has issued a permit for such purposes. The activities that are most similar to casinos, among those that can receive permits, are Remote Betting Centers ${ }^{52}$ and Number Drawing Halls ${ }^{53}$ (commonly known as Foreign Books and Bingos), as well as racetracks (greyhounds or horses) and squash or front-tennis, also known as live entertainment.

578. Not all events of this nature are subject to receive an authorization. It is necessary for the establishments of the principal permit holders to keep an accurate registry for the purpose of determining the users whose bets, in light of the amount of such bets, raise the suspicion that transactions with illicit resources are being conducted. The legislation in effect, the provisions of which are set forth in the most recent permits issued, obligates permit holders to inform the authorities of any behavior or practice of the users that is likely to constitute felonies related with organized crime or transactions with illicit resources.

579. The Regulations of the Ley Federal de Juegos y Sorteos authorize permit holders to receive bets via the Internet, through the telephone or electronically and obligates them to establish a control system, which must be in writing and contain the description of the rules and procedures that ensure the inviolability and prevent the manipulation of the betting system. Such control must have at least: a) the account number and identity of the bettor, and b) the date, time and number of the transaction, the amount betted, and the selection requested.

580. For purposes of this assessment, it is important to clarify that these unauthorized gaming halls, which basically offer slot machine games, are not covered by the requirements of FATF R. 12 and 16. The inadequate enforcement of the prohibition of slot machines is therefore not relevant here. However, the authorities' concern about inherent ML risks should be addressed in accordance to

\footnotetext{
${ }^{52}$ Remote Betting Centers, also known as foreign books, are establishments authorized by the Ministry of the Interior to obtain and operate exchange of bets in events, sports competitions, and games permitted under the Ley Federal de Juegos y Sorteos, carried out abroad or in national territory, transmitted in real time and simultaneously in video and audio, as well as the practice of number drawing indicated under Section IV, Article 124 of the Regulations of the Ley Federal de Juegos y Sorteos.

${ }^{53}$ These are establishments where it is possible to practice number drawings, which are carried out by selling to the public certain cards pre-printed on paper or electronic means with numbers selected at random. The mechanics of such drawings must be carried out in such a way that the participant indicates the numbers that are obtained by picking numbered balls at random and which are communicated to the attendees through an electronic board or other appropriate means, so that the winners of the drawing are the first persons who complete their card with the numbers published on the board.
} 
FATF R.20 to the extent that many of these establishments are not clearly illegal, due to existing legal loopholes, even though they have no received a permit from the competent authority.

Legal Framework

581. There are no AML/CFT-specific or other regulations imposing the type of CDD, record keeping and monitoring requirements of the FATF Recommendations for DNFBPs.

582. CDD Measures for DNFBPs in Set Circumstances (Applying c. 5.1-5.18 in R. 5 to DNFBP) (c. 12.1): Not applied.

583. CDD Measures for DNFBPs in Set Circumstances (Applying Criteria under R. 6 \& 8-11 to DNFBP) (c.12.2): Not applied.

\subsubsection{Recommendations and Comments}

584. DNFBPs should be subject to AML/CFT obligations for identification of customers, record keeping and monitoring of transactions as required by Recommendation 12 of the FATF.

\subsubsection{Compliance with Recommendation 12}

\begin{tabular}{|c|c|c|}
\hline & Rating & Summary of factors relevant to s.4.1 underlying overall rating \\
\hline R.12 & NC & $\begin{array}{l}\text { - No AML/CFT regulations exist for any category of DNFBP, except trust services which } \\
\text { only specified financial institutions can provide. }\end{array}$ \\
\hline
\end{tabular}

\subsection{Suspicious Transaction Reporting (R.16)}

\subsubsection{Description and Analysis}

\section{Legal Framework}

585. DNFBPs are not subject to any AML/CFT reporting or internal control requirement. The only requirement that exists is an obligation to report cash transactions to the SAT for amounts in excess of the equivalent in national currency to US $\$ 10,000$, as provided under several articles of the Income Tax Law: Article 86, paragraph XIX; Article 97, paragraph VI; Article 133, paragraph VII; Article 145, paragraph V; Article 154-Ter. This is an obligation for all taxpayers and, therefore applicable to real estate agents, dealers in precious metals and precious stones, independent professionals such as lawyers, notaries, commercial notaries and accountants, trust and company service providers (which are only banks) and non-profit organizations, as long as they are subject to the tax law. The following requirements/obligations are not applied to DNFBPs in Mexico:

- $\quad$ Requirement to file STRs on ML and TF to FIU (applying c. 13.1 \& IV.1 to DNFBPs).

- $\quad$ STRs Related to Terrorism and its Financing (applying c. 13.2 to DNFBPs).

- $\quad$ No Reporting Threshold for STRs (applying c. 13.3 \& IV.2 to DNFBPs).

- $\quad$ Making of ML and TF STRs Regardless of Possible Involvement of Fiscal Matters (applying c. 13.4 and c. IV.2 to DNFBPs).

- $\quad$ Additional Element-Reporting of All Criminal Acts (applying c. 13.5 to DNFBPs). 
- $\quad$ Protection for Making STRs (applying c. 14.1 to DNFBPs).

- $\quad$ Prohibition Against Tipping-Off (applying c. 14.2 to DNFBPs).

- $\quad$ Additional Element - Confidentiality of Reporting Staff (applying c. 14.3 to DNFBPs).

- $\quad$ Establish and Maintain Internal Controls to Prevent ML and TF (applying c. 15.1, 15.1.1 \& 15.1.2 to DNFBPs).

- Independent Audit of Internal Controls to Prevent ML and TF (applying c. 15.2 to DNFBPs).

- $\quad$ Ongoing Employee Training on AML/CFT Matters (applying c. 15.3 to DNFBPs).

- $\quad$ Employee Screening Procedures (applying c. 15.4 to DNFBPs).

- $\quad$ Additional Element - Independence of Compliance Officer (applying c. 15.5 to DNFBPs).

- $\quad$ Special Attention to Countries Not Sufficiently Applying FATF Recommendations (c. 21.1 \& 21.1.1).

- $\quad$ Examinations of Transactions with no Apparent Economic or Visible Lawful Purpose from Countries Not Sufficiently Applying FATF Recommendations (c. 21.2).

- $\quad$ Ability to Apply Counter Measures with Regard to Countries Not Sufficiently Applying FATF Recommendations (c. 21.3).

\subsubsection{Recommendations and Comments}

586. DNFBPs should be subject to an obligation to file reports of suspicious transactions and maintain internal controls for AML/CFT purposes, in the terms of the FATF Recommendation 16.

\subsubsection{Compliance with Recommendation 16}

\begin{tabular}{|c|c|c|}
\hline & Rating & \multicolumn{1}{c|}{ Summary of factors relevant to s.4.2 underlying overall rating } \\
\hline R.16 & NC & $\bullet \begin{array}{l}\text { No AML/CFT regulations exist for any category of DNFBP, except trust service providers } \\
\text { which are designated financial institutions. }\end{array}$ \\
\hline
\end{tabular}

\subsection{Regulation, Supervision, and Monitoring (R.24-25)}

\subsubsection{Description and Analysis}

587. Legal Framework: Non existent.

588. Regulation and Supervision of Casinos (c. 24.1, 24.1.1, 24.1.2 \& 24.1.3): Not applied.

589. Monitoring Systems for Other DNFBPs (c. $24.2 \&$ 24.2.1): Not applied.

590. Guidelines for DNFBPs ( applying c. 25.1): Not applied.

\subsubsection{Recommendations and Comments}

591. DNFBPs should be subject to a risk-sensitive regulatory framework for AML/CFT, there should be one or several authorities responsible for overseeing compliance with it and for providing guidance to reporting institutions. 


\subsubsection{Compliance with Recommendations $24 \& 25$ (criteria 25.1, DNFBP)}

\begin{tabular}{|c|c|l|}
\hline R.24 & Rating & \multicolumn{1}{|c|}{ Summary of factors relevant to s.4.3 underlying overall rating } \\
\hline R.25 & $\begin{array}{l}\text { No AML/CFT regulations and supervisory framework exist for any category of } \\
\text { DNFBP, except for trust service providers which are designated financial institutions. }\end{array}$ \\
\hline & $\begin{array}{l}\text { DNFBP: NC } \\
\text { No AML/CFT framework and guidelines for DNFBPs. }\end{array}$ \\
\hline
\end{tabular}

\subsection{Other Non-Financial Businesses and Professions-Modern-Secure Transaction Techniques (R.20)}

592. The authorities did not provide any information about measures taken to encourage the development and use of modern and secure techniques for conducting financial transactions that are less vulnerable to money laundering. Neither have they considered the need to impose CDD and/or reporting obligations to other businesses or activities that could generate a significant risk of ML or FT in the Mexican context. An example of such businesses that could be considered, as mentioned at the beginning of this report, are the unlicensed slot-machine halls that the authorities are concerned about, and the potentially significant lending operations by pawn shops (e.g., "cash for automobile titles) mentioned under section 3 above. At least those who are able to obtain a judicial protection (recurso de amparo) preventing the authorities from shuting them down, should be required to identify their clients, monitor transactions and report suspicions to the FIU. According to the authorities' own observations, these businesses are perceived as legitimate by the community and by the financial institutions in the geographic areas where they operate, and that makes them an ideal channel for ML.

\subsubsection{Description and Analysis}

593. Legal Framework: Not available.

594. Other Vulnerable DNFBPs (applying R. 5, 6, 8-11, 13-15, 17 \&21 c. 20.1): Not available.

595. Modernization of Conduct of Financial Transactions (c. 20.2): Not available.

\subsubsection{Recommendations and Comments}

- Mexico should consider applying Recommendations 5, 6, 8-11, 13-15, 17 and 21 to nonfinancial businesses and professions (other than DNFBP) that are at risk of being misused for ML and FT.

- $\quad$ Mexico should take measures to encourage the development and use of modern and secure techniques for conducting financial transactions that are less vulnerable to ML.

\subsubsection{Compliance with Recommendation 20}

\begin{tabular}{|c|c|c|}
\hline & Rating & Summary of factors underlying rating \\
\hline R.20 & NC & $\begin{array}{l}\text { - No consideration has been given to applying the FATF recommendations to other } \\
\text { high-risk businesses and professions. } \\
\text { - No evidence of measures taken to encourage the development and use of modern }\end{array}$ \\
\hline
\end{tabular}




\section{5. LEGAL PERSONS AND ARRANGEMENTS \& NON-PROFIT ORGANIZATIONS}

\subsection{Legal Persons - Access to Beneficial Ownership and Control Information (R.33)}

\subsubsection{Description and Analysis}

596. Legal Framework: Mexico has a Federal Public Registry of Commerce (the Registry) governed by the Commercial Code, the Regulations of the Public Registry of Commerce, the relevant commercial and business laws (such as the Law of Commercial Companies, the Law of Credit Institutions, etc.) and supplementary by the Federal Civil Code.

597. Pursuant to Article 18 of the Commercial Code, the Registry registers commercial acts and acts related with merchants that require registration under applicable legislation. The operations of the Registry are handled by the Secretariat of Commerce. At the state level and in the Federal District, these operations are handled by the authorities in charge of the public registries of property in accordance with applicable coordination agreements. Registration is optional for individual merchants and mandatory for commercial companies and vessels.

598. There is an electronic file for every registered commercial company or merchant. The files are identified by a progresive number assigned automatically by the system. The files are created when a constitutive act is registered for the first time (such as the establishment of a company, the registration of a merchant, the registration of the bylaws of a foreign company, the powers of attorney for natural persons, and the changes of domicile for companies). The files contain information such as the name of the company or merchant, the type of commercial operations conducted, the date in which its operations began, the domicile, the public deeds for the establishment of commercial companies, the amendments thereof, and the public deeds of termination, dissolution and spinoffs, the minute of the first board meeting, the powers of attorney and the revoked powers of attorney, the capital increases, the issuances of shares, among others. The pubic deeds for the establishment of commercial companies would typically record ownersip and control details at the time of incorporation.

599. Applications for registrations may be filed in person or electronically through the internet (the later for Notary Publics and Registered Commercial Agents only). The SIGER registers commercial acts by order of arrival. It takes approximately 10 days to register acts filed in person and two days for those filed electronically.

600. There is an electronic file for every registered commercial company or merchant. The files are identified by a sequential number assigned automatically by the system. The files are created when a constitutive act is registered for the first time (such as the establishment of a company, the registration of a merchant, the registration of the bylaws of a foreign company, the powers of attorney for natural persons, and the changes of domicile for companies). The files contain information such as the name of the company or merchant, the type of commercial operations conducted, the date in which its operations began, the domicile, the public deeds for the establishment of commercial companies, the amendments thereof, and the public deeds of termination, dissolution and spinoffs, the minute of the first board meeting, the powers of attorney and the revoked powers of attorney, the capital increases, the issuances of shares, among others. The pubic deeds for the establishment of 
commercial companies would typically record ownership and control details at the time of incorporation.

601. Foreign companies applying for registration in the Registry must previously provide evidence of their incorporation pursuant to the laws of their home country and of their authorization to conduct commercial activities, which is granted by the Secretariat of Commerce.

602. The absence of registration of an act that requires mandatory registration causes the act to be valid only among the parties that celebrated it and to have no effects vis á vis third parties. The documents filed will only generate legal effects vis a vis third parties as of the date of their registration. Any third party may consult the data bases and request certifications.

603. In accordance with the Law of Commercial Companies, the transfers of ownership rights in commercial companies (such as shares in corporations) do not require mandatory registration in the Registry. In the case of corporations, for instance, the company will only acknowledge as shareholders those which are registered as such in the company's Share Ledger. To this effect, upon request of a shareholder, the company must register in such share ledger all transfers of shares. The corresponding share certificates may be endorsed on behalf of the buyer, or they may be cancelled and new share certificates may be issued.

604. It should be noted that registration in the share ledger is not a mandatory requirement. The law simply implies that to be recognized as a shareholder and to enjoy the corresponding rights thereof, the shareholder must be registered. However, while unusual, there may be a gap in time between the moment in which a shareholder purchases its shares and the actual registration of the transfer in the stock ledger. Accordingly, information recorded in a stock ledger may not necessarily be accurate and current at all times. It should also be noted that there is no requirement to register beneficial ownership information in the stock ledger or anywhere else in the corporation either.

605. If there is foreign participation in the company's capital stock, notice must be given to the National Registry of Foreign Investments. In limited cases, an approval from the National Commission on Foreign Investments may also be required.

606. In summary, the Registry records and provides information as to $i$ ) the constituting documents of a company; ii) the different classes of shares; iii) the rights attaching to the shares; and iv) the amount paid up on the issued shares and the identity and percentage of ownership interests of the shareholder, but only with respect to the fixed portion of the capital stock. In addition, applicable laws provide that any amendments to the bylaws, the granting and revoking of general powers of attorney, some liens, and bankruptcy proceedings, must be registered before the Registry.

607. However, the transfer of shares, the capital increases and decreases in the variable portion of the capital stock, and the appointment and removal of officers and directors do not require mandatory registration at the Registry. The concept of "good standing" of the company does not exist in Mexico. There is no public record that may provide information as to the statement of accounts, the agreements between shareholders, or the existence of a security interest affecting the shares.

608. Measures to Prevent Unlawful Use of Legal Persons (c. 33.1): Mexico has not taken any concrete measures to prevent the unlawful use of legal persons in relation to money laundering and terrorist financing. Commercial and corporate laws do not require adequate transparency concerning the ownership, beneficial ownership or control of legal persons. 
609. The Registry is a system of central registration which records ownership and control details when a constitutive act, such as the establishment of a company, is registered for the first time. However, given that transfers of ownership rights do not require mandatory registration, the Registry does not keep the changes in ownership, and control information up to date.

610. Access to Information on Beneficial Owners of Legal Persons (c. 33.2): The Registry has no legal powers to compel a legal person to provide information or to register an act that does not require mandatory registration under applicable laws. As a result, upon a request from a third party (whether a private person or a public institution) concerning information regarding a legal person, the Registry would only be capable of furnishing the information that it holds in its files. In this regard, since transfers of ownership rights do not require mandatory registration, the Registry may not be holding, and may therefore not be able to provide in all cases, adequate, accurate and current information on the ownership, beneficial ownership or control of the legal person in question.

611. On the law enforcement side, the Attorney General's Office may use all of the investigative powers conferred to it by the CFPP and other relevant laws for the conduct of preliminary inquiries (see comments to Recommendations 27 and 28) to compel a legal person to provide information on its ownership structure. However, since transfers of ownership rights do not require mandatory registrations (not even in the company's registries), and since there is no requirement for owners of legal persons to register beneficial ownership and control information in the Registry, nor anywhere in a legal person's records, the requested legal person may not be in a position to provide adequate, accurate, and current information on ownership, beneficial ownership or control, in which case the relevant information would have to be sought from the actual owners.

612. In light of these circumstances, one must conclude that competent authorities in Mexico may not be able to obtain or have access in a timely fashion to adequate, accurate, and current information on beneficial ownership and control of legal persons.

613. Prevention of Misuse of Bearer Shares (c. 33.3): Legal persons are not able to issue bearer shares in Mexico. Pursuant to articles 111, 124 and 125 of the Law of Commercial Companies, and transitory articles second, third and fourth of the decree that amends such law, published in the Official Gazette of the Federation on December $30^{\text {th }}$, 1982, shares in Mexico must always be nominative.

614. However, Mexico does not preclude a foreign shareholder of a Mexican corporation from being itself a corporation incorporated in a jurisdiction that does allow the issuance of bearer shares. Since there are no requirements for shareholders of Mexican corporations to register beneficial ownership and control information in the Registry, nor anywhere in the legal person's records, competent authorities may not be able to abstain or have access in a timely fashion to adequate, accurate, and current information on the beneficial ownership and control of legal persons whose foreign shareholders have issued bearer shares.

615. Additional Element-Access to Information on Beneficial Owners of Legal Persons by Financial Institutions) (c. 33.4): Mexico has not established any specific measures to facilitate access by financial institutions to beneficial ownership and control information, so as to allow them to more easily verify the customer identification data. As discussed in detail in the analysis of

Recommendation 5, financial legislation (DGC 115) provides that credit institutions must establish procedures to identify the effective or beneficial owners, understood to be: "The person that through another person or by any act or mechanism obtains the benefits derived from an account, contract or operation and that ultimately exercises the rights of use, benefit, or disposition of resources as the true owner of such resources. It also comprises those persons that exercise control of a legal person, as 
well as the beneficiaries of a "fideicomiso", the brokers of a broakerage agreement and the agents of an agency agreement". For such purposes, the credit institution shall request the identification documents and data required for national or foreign individuals or entities, as the case may be.

In this regard, when dealing with commercial legal persons classified as high-risk, credit institutions (DCG 115) must also know the legal person's corporate structure and its controlling shareholders, requiring information relative to the name, nationality, address, corporate purpose, and capital of the business entities that integrate the business group or of the business groups that integrate the consortium. When dealing with civil legal persons or associations classified as high-risk, credit institutions must identify the partners, the associates and the persons who control or have decisionmaking authority in the management of such kinds of organizations, companies or associations. When dealing with members of groups, credit institutions must identify the parties that ultimately control the legal person through any means, whether by controlling the general meeting or having the power to appoint the majority of the members of the board of directors or equivalent body, regardless of the percentage of ownership interests that they may hold. However, as explained above, since there is no requirement for owners of legal persons to register beneficial ownership and control information in the Registry, nor anywhere in a legal person's records, the requested legal person (and by extension financial institution) may not be in a position to provide adequate, accurate, and current information on ownership, beneficial ownership or control, in which case the relevant information would have to be sought from the actual owners where these are known. These shortcomings may also make it difficult for credit institutions to verify customer identification data.

\subsubsection{Recommendations and Comments}

616. In order to fully comply with Recommendation 33, Mexico should implement the following measures.

- $\quad$ Take adequate measures to prevent the unlawful use of legal persons in relation to money laundering and terrorist financing by ensuring that their commercial, corporate, and other laws require adequate transparency concerning beneficial ownership and control of legal persons. One possibility would be to amend the applicable laws to make it a mandatory requirement to file beneficial ownership and control details (and any changes thereto) with the Registry. As complement to this, the law could also make it a mandatory requirement for legal persons to record and keep in their books adequate, accurate and current information on their beneficial ownership and control. The Registry should also have the legal powers to compel a legal person to produce such information and to sanction any failures to comply with such requests.

- $\quad$ Take appropriate measures to ensure that foreign shareholders of Mexican companies that in their jurisdictions are able to issue bearer shares do not misuse this ability for money laundering purposes. In this regard, it would also be convenient to make it a mandatory requirement for such type of foreign shareholders to file beneficial ownership and control information (and any changes thereto) with the Registry. The law should also require legal persons with such type of foreign shareholders to record and keep in their books adequate, accurate, and current information on the beneficial ownership and control of their foreign shareholders. Likewise, the Registry should also have the legal powers to compel a foreign shareholder of a Mexican legal person to produce such information and to sanction any failures to comply with such requests. Compliance with Recommendation 33.

617. Specific recommendations:

- $\quad$ Mexico should take measures to prevent the use of legal persons in relation to ML/TF. 
- $\quad$ The Registry should ensure that it is able to obtain or have access to adequate, accurate, and current beneficial ownership and control information.

- $\quad$ Mexico should take appropriate measures to ensure that legal persons using bearer shares are not misused for ML.

- $\quad$ Mexico should put in place measures to facilitate access by financial institutions to beneficial ownership and control information, so as to allow them to more easily verify the customer identification data.

\subsubsection{Compliance with Recommendations 33}

\begin{tabular}{|c|c|ll|}
\hline & Rating & \multicolumn{1}{c|}{ Summary of factors underlying rating } \\
\hline R.33 & NC & $\bullet \begin{array}{l}\text { Mexico has not taken measures to prevent the use of legal persons in relation to } \\
\text { ML/TF. }\end{array}$ \\
& $\begin{array}{l}\text { The Registry may not be able to obtain or have access to adequate, accurate, and } \\
\text { current beneficial ownership and control information. }\end{array}$ \\
& $\begin{array}{l}\text { Mexico has not taken appropriate measures to ensure that legal persons using } \\
\text { bearer shares are not misused for ML. }\end{array}$ \\
\hline
\end{tabular}

\subsection{Legal Arrangements - Access to Beneficial Ownership and Control Information (R.34)}

\subsubsection{Description and Analysis}

618. Legal Framework: Under Mexican law, only individuals or legal entities are entitled to own property. However, there are also other legal arrangements that can be established to segregate certain rights or obligations, including property rights over assets. Such arrangements are: "fideicomisos" (an arrangement with similar legal effects as those produced by trusts) and "associations in participation" (i.e. joint ventures)

619. Fideicomisos are regulated under Articles 381 to 407 of the General Law of Credit Instruments and Transactions (Ley General de Títulos y Operaciones de Crédito). In accordance with article 381 of such Law, under a fideicomiso, the "fideicomitente" (i.e., the grantor) transfers to a fiduciary institution (equivalent to a trustee in a trust) - which can only be a financial institution explicitly authorized by law to carry out that business (mainly banks) - property or title of one or more goods or rights that are destined for legal and determined purposes, and may be established for the benefit of a third party named "fideicomisario" (equivalent to a "cestui que trust"). Fideicomisos are not legal entities and are not required to register in any public registry."

620. As mentioned above, only designated licensed financial institutions can act as trustees in Mexico. Under no circumstances can the creator of a fideicomiso, or any other entity, serve in this capacity. Traditionally, only Mexican banks were authorized to serve as trustees. Recently, however, insurance companies have also been offering this service.

621. Strict fiduciary secrecy requirements under Article 117 of the Credit Institutions Law state as a general rule that, with the exception of information requested by the CNBV for its supervisory functions, the infringement of fiduciary secrecy, even to authorities or courts in cases or claims that do not involve the creator, the trustee, or beneficiary as a party or defendant in such cases, would expose the credit institution to civil liability for the damage and detriment caused. The courts in such cases may request information from the credit institution directly or through the CNBV. 
622. Apart from the exception to fiduciary secrecy provided in the case of information requested by the CNBV for the conduct of its supervisory functions, or the courts in the above mentioned cases, Article 117 also sets forth that fiduciary secrecy will not apply (and information must therefore be provided) when a credit institution receives a request to provide information on fideicomisos from certain specified authorities, such as: the Attorney General (to prove the corpus of a crime and the possible liability of the offender); the authorities of the SHCP (for fiscal purposes), and the FIU (for the conduct of its functions), among others. Such requests must be well founded and channelled through the CNBV. The CNBV may sanction the credit institution that does not provide the requested information in due course. The CNBV may also exchange information on fideicomisos with counterparts in other countries, provided that an agreement exists among them and that the principle of reciprocity is respected. Pursuant to Article 97 of the Law on Credit Institutions, the exchange of information on fideicomisos among the SHCP, the CNBV, the Bank of Mexico, the National Commission for the Protection and Defense of Financial Services' Users and the Institute for the Protection of Bank Savings will not imply a violation of fiduciary secrecy either. The authorities were unable to provide statistics on the amount of requests received by the CNBV or the amounts of sanctions applied to credit institutions, if any.

623. Measures to Prevent Unlawful Use of Legal Arrangements (c. 34.1): The Mexican system has relied on fiduciary service providers to obtain, verify, and retain records of the details of the fideicomiso. Since only credit institutions may act as trustees, the provision of fiduciary services will also be covered by all of the KYC requirements applicable to credit institutions. As discussed in detail in the analysis of Recommendation 5, financial legislation (DCG 115) provides that credit institutions must establish procedures to identify the effective or beneficial owners,. understood to be: "The person that through another person or by any act or mechanism obtains the benefits derived from an account, contract or operation and that ultimately exercises the rights of use, benefit, or disposition of resources as the true owner of such resources. It also comprises those persons that exercise control of a legal person, as well as the beneficiaries of a "fideicomiso", the brokers of a broakerage agreement and the agents of an agency agreement". For such purposes, the credit institution shall request the identification documents and data required for national or foreign individuals or entities, as the case may be.

624. With regard to fideicomisos, brokerage, or agency agreements, when the identity of the beneficiaries, principals, or commissioners is undertermined, the credit institution shall request the identification documents and data required for national or foreign individuals or entities, as the case may be, whenever any of the parties exercises its rights at the credit institution Credit institutions acting as trustees must also record and keep the details of every transaction performed through the fideicomiso.

625. Access to Information on Beneficial Owners of Legal Arrangements (c. 34.2): Pursuant to the provisions of article 117 of the Law on Credit Institutions (described above), competent authorities may be able to obtain or have access in a timely fashion to adequate, accurate and current information on the beneficial ownership and control of fideicomisos held by a credit institution, and in particular, the creator, the trustee and the beneficiaries of express fideicomisos. However, the authorities were unable to provide statistics on the amount of requests received by the CNBV from other competent authorities, or the amounts of sanctions applied to credit institutions for failing to provide this type of information, if any. As a result, it was not possible to assess the effectiveness of implementation of this measure.

626. Additional Element-Access to Information on Beneficial Owners of Legal Arrangements by Financial Institutions)(c. 34.3): Mexico has not established any specific measures to facilitate access by financial institutions to beneficial ownership and control information, so as to allow them to 
more easily verify the customer identification data. Moreover, the lack of adequate transparency concerning the beneficial ownership and control of legal persons in general (described under Recommendation 33), may also impact on the credit institution's capacity to easily verify identification data in connection with a "fideicomiso" or other legal arrangements.

\subsubsection{Recommendations and Comments}

627. In order to fully comply with recommendation 34, Mexico should:

- $\quad$ Mexico should address the shortcomings identified under Rec. 33 as they may impact on a credit institution's capacity to easily verify identification data in connection with a "fideicomiso" or other legal arrangements.

- Maintain comprehensive statistics on the amounts of requests received by the CNBV or the amount of related sanctions applied to credit institutions.

\subsubsection{Compliance with Recommendations 34}

\begin{tabular}{|c|c|cc|}
\hline & Rating & \multicolumn{1}{c|}{ Summary of factors underlying rating } \\
\hline R.34 & LC & - $\begin{array}{l}\text { No statistics on the number of requests for beneficial ownership information or } \\
\text { the amount of sanctions applied to conclude that the measures are effective. }\end{array}$ \\
\hline
\end{tabular}

\subsection{Non-Profit Organizations (SR.VIII)}

\subsubsection{Description and Analysis}

628. Legal Framework: The third section of article 27 of Mexico's Constitution is the legal basis for non-profit organizations (NPOs) in Mexico. It recognizes the existence of private charitable institutions, whose purpose is to aid the needy, perform scientific research, promote education, and provide reciprocal assistance to the associates or any other lawful purpose. Article 2687 of the Código Civil Federal (Federal Civil Code) expressly indicates that charitable associations shall be governed by the corresponding special laws.

629. Private assistance institutions are governed as such since 1943. The majority of States in Mexico have their own legislation in connection with private assistance institutions. In general terms, these laws define private assistance institutions as "non-profit entities with individual legal status and capital, which perform social assistance actions with private property without designating the beneficiaries individually."

630. In accordance with the Ley de Instituciones de Asistencia Privada para el Distrito Federal and other equivalent laws in the States of Mexico, private assistance institutions are classified into foundations and associations.

631. Foundations are entities formed with private assets contributed through inter-vivos acts or testamentary disposition, to be used to perform actions for the benefit of society, while associations are legal entities whose members contribute periodic fees or procure donations to support the institution without prejudice that members may also agree to contribute personal services.

632. Under Article 56, the Ley de Asistencia Social considers the creation of a Directorio Nacional de Instituciones de Asistencia Social (National Directory of Social Assistance Institutions) 
to promote the assistance services and support that public and private institutions provide and information on their location within national territory. This Directory will include the social assistance institutions registered through the Sistemas para el Desarrollo Integral de la Familia (Integral Family Development Systems) of the States or the Federal District, and the Private Assistance Boards or similar organizations.

633. The Servicio de Administración Tributaria (Tax Administration Service-SAT) is the original possessor of NPO information, which is essentially collected on tax regulation grounds; however, said information has been recently shared with the Financial Intelligence Unit (UIF) to exploit it for AML/CFT purposes. The SAT and FIU are identifying appropriate means to make use of the information already available, along with analysing suitable approaches to move toward NPOs and to complete an overall review of the sector and its risks regarding ML/FT.

634. The SAT holds a registry on the NPOs that are authorized to issue tax deductible receipts and operate throughout the country, classified by federative location, as provided by Article 22, fraction XXV of its Internal Bylaws. The registry lists those NPOs that are currently operating along with those that have already been revoked or cancelled. The lists of NPOs that are authorized to receive tax deductible receipts and of NPOs that had their licenses revoked are published in the Federal Official Gazzette and in the SAT's internet site.

635. The Centro Mexicano de la Filantropia (Mexican Philanthropy Center), manages as well a registry with all NPOs operating in Mexico, including those authorized by SAT, others not authorized to issue tax deductible receipts that operate anyway and those already revoked or cancelled. The total inventory exceeds 10,000 , from which 5,121 are authorized by SAT, while 5,484 are not authorized or revoked. From the universe of authorized NPOs, 171 were established according to international agreements, for that reason they are allowed to receive funds from abroad.

636. Below is a table with the number of authorized NPOs the SAT allowed to issue taxdeductible receipts in 2006 (by category or sector) and a graphic that distinguishes them by geographic distribution.

\begin{tabular}{|l|r|}
\hline \multicolumn{1}{|c|}{ Category } & Total \\
\hline Aid & 3704 \\
\hline Education & 735 \\
\hline Scientific or technological investigation & 161 \\
\hline Cultural & 317 \\
\hline Scholarship & 100 \\
\hline Ecology related & 87 \\
\hline Reproduction of protected and endangered species & 10 \\
\hline Economic support to other NPOs & 241 \\
\hline Public services or works & 48 \\
\hline Private libraries of public access & 9 \\
\hline Private museums of public access & 27 \\
\hline Total & $\mathbf{5 4 3 9}$ \\
\hline Authorized to issue tax deductible receipts in accordance with International & 623 \\
\hline
\end{tabular}




\section{DISTRIBUTION OF AUTHORIZED NPOs IN THE MEXICAN REPUBLIC}

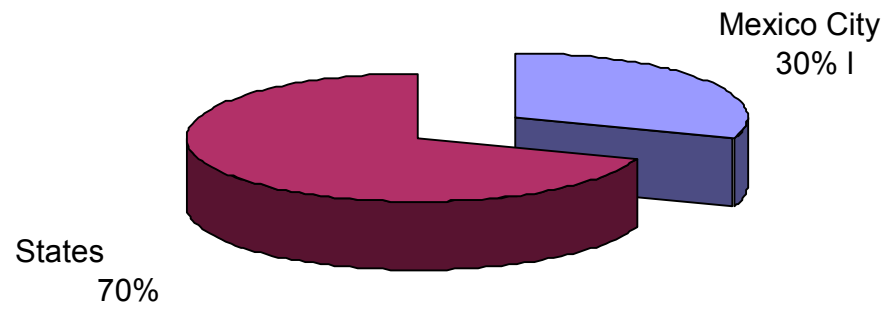

637. Review of Adequacy of Laws \& Regulations of NPOs (c. VIII.1): Mexico has not conducted a review of the adequacy of domestic laws and regulations that relate to nonprofit organizations, nor has it used available sources of information to undertake domestic reviews of, nor has the capacity to obtain timely information on the activities, size and other relevant features of its non-profit sectors for the purpose of identifying the features and types of NPOs that are at risk of being misused for terrorist financing by virtue of their activities or characteristics.

638. Towards the end of the year 2006, the Financial Intelligence Unit (FIU) began a strategic study on NPOs from the list of NPOs authorized and not authorized to issue tax deductible receipts prepared by the Centro Mexicano para la Filantropía (Mexican Philanthropy Center) (more than 10,000 records). The general and specific data of NPOs, their partners, managers, and directors were cross-checked with the information contained in the FIU's database with the following results:

639. Legal Persons (NPO): It was determined that 2,415 persons had been reported by different reporting entities (STRs and CTRs), of which only 63 had suspicious transactions reports (STRs). The FIU focused on analyzing the financial information on this last universe. This analysis resulted in five intelligence reports to the SAT or to PGR and the reservation of two cases (while there are elements of suspicion, these are insufficient to justify an intelligence report. Accordingly, such cases will be subject to stricter monitoring).

640. Individuals (directors, founders, partners, managers): It was determined that 565 persons had been reported by different reporting entities (STRs and CTRs), of which only 44 had unusual transactions reports (STR). The FIU focused on analyzing the financial information on this last universe. This analysis resulted in three intelligence reports to the SAT or PGR, and three additional ones which are still in under analysis.

641. The NPOs with higher intrinsic risks are those that receive funds from abroad. However, it is important to point out that NPOs are not authorized to transfer funds or carry out cross-border movements of cash, for which they would necessarily have to act through existing financial intermediaries, which are subject to AML/CFT regulatory provisions. 
642. Outreach to the NPO Sector to Protect it from Terrorist Financing Abuse (c. VIII.2): Mexico has not undertaken outreach to the NPO sector with a view to protecting the sector from terrorist financing abuse. However, the authorities point out that there are plans to implement an outreach program in the following months.

643. While no specific outreach has been conducted aimed at raising awareness about the risks of terrorist abuse, for tax purposes, Mexican legislation demands transparency in the management of NPOs and the rendering of accounts. For example, it requires periodic publication of the NPO's financial statements, the annual presentation of a simplified opinion and the annual tax returns detailing the income obtained and expenses incurred. Additionally, NPOs are required to keep their accounting in a simplified form and in the case of donations of assets, they must also maintain records of such assets that allow identifying the donors, the assets received and delivered and, if applicable, the assets destroyed that were not delivered to the beneficiaries, as well as records of any voluntary recovery of fees.

644. NPOs are also required to provide (on or before February 15 of each year) to the local tax administration of their domicile, information on the persons to which they may have made donations in the immediately preceding calendar year. With regards to publicity, NPOs that are authorized to issue tax deductible receipts are required to maintain at the disposal of the public in general for consultation: documentation relative to the authorization, use and application of the donations received and any document relative to compliance with tax obligations corresponding to the past three years.

645. Additionally, they must inform the SAT of the cash, national or foreign currency and silver and gold pieces that they receive as donations in excess of the amount of one hundred thousand pesos, on or the $17^{\text {th }}$ day of the month immediately after the month on which the donation was made.

646. Supervision or Monitoring of NPOs that Account for Significant Share of the Sector's Resources or International Activities (c. VIII.3): NPOs that are authorized to issue tax deductible receipts are supervised by the SAT's Administración General de Auditoria Fiscal Federal (General Administration of the Federal Tax Auditor) and Administración General de Grandes Contribuyentes (General Administration of Large Taxpayers) for tax purposes and in Federal jurisdictions. In its capacity as supervisor, the SAT may order and conduct on-site visits, audits, inspections, verifications, and any other act provided by law to monitor compliace with tax and customs legislation. Moreover, the SAT must report to the FIU any affair that it identifies in the exercise of its functions that is or could be related with FT or ML. It should be highlighted that this only covers NPOs that are authorized to issue tax deductible receipts (i.e., not all NPOs) and that it is only conducted for tax purposes. This is therefore a weakness in the system.

647. Supervision is also complemented by the work of registered CPAs that issue opinions on the NPO's financial statements.

648. Information maintained by NPOs and availability to the public thereof (c. VIII.3.1): NPOs authorized to receive tax deductible donations must keep available for the general public's consultation: $i$ ) documentation relative to the authorization; ii) documentation relative to the use and application of the donations received, and iii) documentation relative to compliance with tax obligations corresponding to the past three years. It should be highlighted that this only covers NPOs that are authorized to issue tax deductible receipts (i.e,. not all NPOs) and that it is only conducted for tax purposes. This is therefore a weakness in the system. 
649. Additionally, NPOs authorized to receive tax deductible donations abroad must prepare and keep available for the general public (for a period of three years): $i$ ) a statement of financial position, and ii) a list of the managers and employees that received income from the authorized NPO for an amount in excess of Mex\$264,077 (amount which is updated biannually) as payment of salaries, fees, compensations or any other item. It should be highlighted that this only covers NPOs that are authorized to issue tax deductible receipts (not all NPOs) and that it is only conducted for tax purposes. This is therefore a weakness in the system.

650. Measures in place to sanction violations of oversight rules by NPOs (c. VIII.3.2): The SAT is empowered to sanction violations of oversight measures or rules by NPOs or persons acting on behalf of NPOs.

651. Regardless of other administrative or criminal sanctions, the SAT may apply the revocation of the authorization to receive tax deductible donations. The SAT publishes in its website the list of NPOs that suffered a revocation of this authorization.

652. The SAT may also apply fines of up to 10,160 pesos (or the termination of the authorization), for violations of the obligations to carry out adequate accounting. In enforcing its tax collection powers, the SAT is also entitled to attach assets (including bank accounts) and obligations, auction them, sell them or adjudicate them in favor of the State.

653. The application of these sanctions does not preclude parallel civil, administrative, or criminal proceedings where appropriate.

654. Licensing or registration of NPOs and availability of this information (c. VIII.3.3): The SAT holds a registry of NPOs authorized to issue tax deductible receipts. Theregistry is classified by federative location and lists NPOs that are currently operating along with those that have already been revoked or cancelled.

655. The Centro Mexicano de la Filantropia (Mexican Philanthropy Center), manages as well a registry with all NPOs operating in Mexico, including those authorized by SAT, others not authorized to issue tax deductible receipts that operate anyway and those already revoked or cancelled. The total inventory exceeds 10,000, from which 5,121 are authorized by SAT, while 5,484 are not authorized or had their authorization revoked. From the universe of authorized NPOs, 171 were established according to international agreements, for that reason they are allowed to receive funds from abroad. The Center's registry is publicly available.

656. Maintenance of records by NPOs, and availability to appropriate authorities (c. VIII. 3.4): NPO's authorized to receive tax deductible donations are subject to the following obligations:

a) Inform of any change of tax address, name, termination, liquidation or dissolution of the NPOs to the administrating authority that granted the authorization to receive tax deductible donations. Such notice must be submitted within 10 days after the relevant event took place with a copy of the notice that they may have presented to the tax authorities. They must also notify any change in the purpose or end thereof or in any other requirement that may have been considered to grant such authorization.

Likewise, NPO's must report to the SAT the termination or invalidity their authorization and relevant registration, or any other document that may have served to evidence the 
purpose of the NPO. Moreover, in these cases, a new authorization or acknowledgment, registration, agreement or document must be filed.

In case of failure to comply with the foregoing obligations, the SAT will revoke the respective authorization, regardless of other applicable sanctions.

b) For purposes of maintaining the authorization to receive tax-deductible donations, they must also submit once a year a sworn statement confirming that they continue to comply with all tax requirements and obligations.

c) Issue receipts for the donations that they receive-in cash or kind-that contain, among other requirements: $i$ ) the name, tax address and Federal Taxpayers' Registration Code of the NPO or recipient; $i$ i) the place and date of issuance; iii) the name and address of the donor and, if applicable, the tax address and Federal Taxpayers' Registration Code; $i v$ ) the amount and description of the assets donated or the amount of the donation; $v$ ) the express indication that they cover a donation and that the recipient agrees to use the donated assets to achieve its purposes.

d) Submit annual tax returns, through which they inform the SAT of the income obtained and expenses incurred.

e) Provide on or before February 15 of each year to the local tax administration of their domicile information on the persons to which they may have made donations in the immediately preceding calendar year. They must also report transactions conducted with "related parties", specifying the type of transaction, the date and the amount.

f) Publicity requirements: Keep available for the general public's consultation: $i$ ) documentation relative to the authorization; ii) documentation relative to the use and application of the donations received; iii) documentation relative to compliance with tax obligations corresponding to the last three years.

g) Carry out activities whose primary intent is to achieve the main purpose of the NPO; they may not participate in political campaigns or be involved in propaganda activities or activities intended to influence legislation.

h) Use the donations and the proceeds thereof only and exclusively to achieve the purposes of the NPOs. NPOs may not under any circumstance use more than 5 percent of the donations they receive to cover their administrative expenses.

i) Maintain their accounting in a simplified form. In the case of donations of assets, they must also maintain records of such assets that allow identifying the donors, the assets received and delivered and, if applicable, the assets destroyed that were not delivered to the beneficiaries, as well as records of the voluntary recovery fees they obtain from the assets received as a donation.

657. Additionally, NPOs authorized to receive deductible donations abroad, regardless of whether they are assistance or charitable institutions authorized under applicable laws, must also comply with the following obligations: $i$ ) prepare and keep available for the public and for a period of 
three years: a statement of financial position, a list of the managers and employees that received income from the authorized NPO, for an amount in excess of Mex $\$ 264,077$ (amount which is updated biannually) as payment of salaries, fees, compensations, or any other item; ii) with regard to the structure of their income: receive a substantial part from the Federation, Federal District, States or Municipalities, from donations or activities related with its purpose, and not receive excessive amounts or income from leases, interest, dividends, and royalties or from activities unrelated with their purpose.

658. It should be highlighted that these obligations only cover NPOs that are authorized to issue tax deductible receipts (not all NPOs) and that it is only conducted for tax purposes. This is therefore a weakness in the system.

659. Measures to ensure effective investigation and gathering of information (c. VIII.4): The SAT has appropriate databases that ensure that they can effectively investigate and gather information on NPOs, such as: $i$ ) the declarations on transactions with third parties; ii) the transactions with clients and suppliers; iii) the system of tax receipts; iv) the system of transactions conducted with Notary Publics; v) the notice of granted donations; vi) the reports of unusual transactions provided to the FIU, and vii) any additional monthly or annual tax statement.

660. The publicity and reporting obligations referred to above, and that NPOs authorized to receive tax deductible receipts are bound to comply with, also contributes to collect relevant information to ensure that competent authorities can effectively investigate and gather information. It should be highlighted however that this only applies to NPOs supervised by the SAT (, not all NPOs). The assessment team has received no information with respect to all other NPOs.

661. Domestic cooperation, coordination and information sharing on NPOs (c. VIII.4.1): The SAT has no restrictions to allow access to its databases to the FIU. Article 69 of the Federal Fiscal Code expressly provides that tax secret shall not be applicable in the case of investigations conducted by the FIU in the context of Article 400 Bis of the CPF (money laundering offense). It should be highlighted, however, that this only applies to NPOs supervised by the SAT (, not all NPOs). The assessment team has received no information with respect to all other NPOs.

662. Access to information on administration and management of NPOs during investigations (c. VIII.4.2): Although Article 69 of the Federal Fiscal Code exempts the application of tax secrecy when information must be provided to the FIU or to judicial authorities conducting criminal procedures, the provision does not make a specific reference to the PGR, which is the organism in charge of leading criminal investigations. As a result, and while PGR could ultimately obtain through the FIU all of the relevant information that the SAT may hold on NPOs (particuarly those that are authorized to issue tax deductible receipts), it is unclear whether PGR may have direct access to it as well. It should be highlighted however that this only applies to NPOs supervised by the SAT (i.e., not all NPOs). The assessment team has received no information with respect to all other NPOs.

663. Sharing of information, preventative actions and investigative expertise and capability, with respect to NPOs suspected of being exploited for terrorist financing purposes (c. VIII.4.3): The SAT is bound to report to the FIU any affairs that come to its knowledge in the exercise of its functions and that could be related with FT or ML. As a result, should the SAT detect a suspicion or have reasonable grounds to suspect that a particular NPO is being exploited for terrorist financing purposes, or is a front organization for terrorist fundraising, it should report the suspicion to the FIU. It should be highlighted however that this only applies to NPOs supervised by the SAT (i.e., not all NPOs). The assessment team has received no information with respect to all other NPOs. 
664. Mexico has not developped the expertise and capabilities to investigate and examine those NPOs that are suspected of either being exploited or actively supporting terrorist activity or terrorist organizations.

665. Mexico does not have the mechanisms in place to allow prompt investigative or preventive action against such NPOs.

666. Responding to international requests regarding NPOs - points of contacts and procedures (c. VIII.5): The appropriate point of contact to respond to international requests for information regarding particular NPOs that are suspected of terrorist financing or other forms of terrorist support is the FIU. Please refer to comments under Recommendation 30 for a description of the FIU's procedures for the international exchange of information.

\subsubsection{Recommendations and Comments}

667. In order to fully comply with Special Recommendation VIII, Mexico should implement the following measures:

- $\quad$ Review the adequacy of domestic laws and regulations that relate to NPOs; use all available sources of information to undertake domestic reviews of or have the capacity to obtain timely information on the activities, size and other relevant features of their NPO sectors for the purpose of identifying the features and types of NPOs that are at risk of being misused for terrorist financing by virtue of their activities or characteristics; and conduct periodic reassessments by reviewing new information on the sector's potential vulnerabilities to terrorist activities.

- $\quad$ Undertake outreach to the NPO sector with a view to protecting the sector from terrorist financing abuse. This outreach should include raising awareness in the NPO sector about the risks of terrorist abuse and the available measures to protect against such abuse.

- $\quad$ Promote effective supervision or monitoring of those NPOs (other than NPO's authorized to issue tax deductible receipts) which account for: $i$ ) a significant portion of the financial resources under control of the sector; and ii) a substantial share of the sector's international activities.

- $\quad$ Require all NPOs (other than NPOs authorized to receive donations abroad) to maintain information on: $i$ ) the purpose and objectives of their stated activities; and ii) the identity of person(s) who own, control or direct their activities, including senior officers, board members and trustees. This information should be publicly available either directly from the NPO or through appropriate authorities.

- Implement appropriate measures to sanction violations of oversight measures or rules by NPOs or persons acting on behalf of NPOs (other than NPOs authorized to issue tax deductible receipts). The application of such sanctions should not preclude parallel civil, administrative, or criminal proceedings with respect to NPOs or persons acting on their behalf where appropriate.

- $\quad$ Require all NPO's to be licenced (other than NPOs authorized to issue tax deductible receipts).

- Require all NPOs (other than NPO's authorized to issue tax deductible receipts) to maintain, for a period of at least five years, and make available to appropriate authorities, records of domestic and international transactions that are sufficiently detailed to verify that funds have been spent in a manner consistent with the purpose and objectives of the organization. 
- $\quad$ Ensure effective domestic cooperation, coordination and information sharing among all levels of appropriate authorities or organizations that hold relevant information on NPOs of optential terrorist financing concern (other than NPOs authorized to issue tax deductible receipts).

- $\quad$ Ensure full access to information on the administration and management of a particular NPO may be obtained during the course of an investigation (other than NPOs authorized to issue tax deductible receipts).

- $\quad$ Develop and implement mechanisms for the prompt sharing of information among all relevant authorities in order to take preventative or investigative action when there is a suspicion or reasonable grounds to suspect that a particular NPO is being exploited for terrorist financing purposes or is a front organization for terrorist fundraising (other than NPOs authorized to issue tax deductible receipts).

- $\quad$ Develop the investigative expertise and capabilities to examine those NPOs that are suspected of either being exploited by or actively supporting terrorist activity or terrorist organizations.

- Develop mechanisms to allow for prompt investigative or preventive action against such NPOs.

\subsubsection{Compliance with Special Recommendation VIII}

\begin{tabular}{|c|c|c|}
\hline & Rating & Summary of factors underlying rating \\
\hline SR.VIII & PC & $\begin{array}{l}\text { - The relevant reviews of the domestic non-profit sector have not been conducted. } \\
\text { - No outreach to the NPO sector has been undertaken with a view to protecting the } \\
\text { - Mector from TF abuse. } \\
\text { cover a limited number of NPOs, which are those authorized by the SAT to issue } \\
\text { tax deductible receipts. } \\
\text { - No steps have been taken to promote effective supervision or monitoring of } \\
\text { relevant NPOs. } \\
\text { - Not all NPOs are required to maintain relevant purpose and control information } \\
\text { - } \text { - Noty those authorized to issue tax deductible receipts). } \\
\text { rules (only those authorized to issue tax deductible receipts). } \\
\text { - Not all NPOs are required to be licenced (only those authorized to issue tax } \\
\text { - deductible receipts). } \\
\text { - Not all NPOs are required to maintain detailed records of transactions to verify } \\
\text { that funds have been spent consistent with purpose and objectives (only those } \\
\text { authorized to issue tax deductible receipts). } \\
\text { - There is no effective domestic cooperation, coordination and information sharing } \\
\text { among all levels of appropriate authorities or organizations that hold relevant } \\
\text { information on NPOs of potential terrorist financing concern (other than NPOs } \\
\text { authorized to issue tax deductible receipts). } \\
\text { - There are no mechanisms to ensure that full access to information on the } \\
\text { idministration and management of a particular NPO may be obtained during the } \\
\text { receipts). } \\
\text { exploited for terrorist financing purposes or is a front organization for terrorist }\end{array}$ \\
\hline
\end{tabular}




\begin{tabular}{|l|l|l|}
\hline & Rating & \multicolumn{1}{c|}{ Summary of factors underlying rating } \\
\hline & $\begin{array}{l}\text { fundraising (other than NPOs authorized to issue tax deductible receipts). } \\
\text { - There is no investigative expertise and capabilities to examine those NPOs that } \\
\text { are suspected of either being exploited by or actively supporting terrorist activity or } \\
\text { terrorist organizations. } \\
\text { There are no mechanisms to allow for prompt investigative or preventive action } \\
\text { against such NPOs. }\end{array}$ \\
\hline
\end{tabular}

\section{6. NATIONAL AND INTERNATIONAL CO-OPERATION}

\subsection{National Co-Operation and Coordination (R.31)}

\subsubsection{Description and Analysis}

668. The national authorities involved in the AML/CFT preventive regime are the following:

\section{Financial authorities}

- $\quad$ Regulatory administrative units of the Ministry of Finance and Public Credit (SHCP), including the Banking, Securities and Savings Unit, and the Insurance, Pensions and Social Security Unit.

- $\quad$ Administrative agencies of SHCP that serve as supervisory bodies for the purposes of money laundering and terrorist financing: National Banking and Securities Commission, National Insurance and Bonds Commission, Retirement Savings System National Commission and the Tax Administration Service (SAT).

- $\quad$ Financial Intelligence Unit.

- $\quad$ General Customs Administration of SAT.

- $\quad$ Asset Disposal and Management Service of the SHCP.

\section{Administration of Justice Authorities}

- $\quad$ Federal Attorney General and Federal Preventive Police of the Ministry of Public Security.

\section{Other agencies of the Federal Public Administration}

- $\quad$ Ministry of Foreign Affairs and the Ministry of the Interior.

Mechanisms for Domestic Cooperation and Coordination in AML/CFT (c. 31.1):

\section{Supervisory Cooperation}

669. There are no legal impediments for cooperation among the various supervisory bodies and other domestic authorities in Mexico (see Recommendation 4 on secrecy and confidentiality provisions). In practice, as was evident prior to and during the mission, the cooperation arrangements appeared to be very efficient and effective. 
670. In accordance with article 15, sections I and II of the Internal Regulations of the SHCPwhich include all of the financial authorities listed above - can coordinate their activities for the development of draft laws and decrees. They can also participate in the presentation of reports to the SHCP on various matters, e.g., approvals of financial products and services offered by financial institutions to their clients, particularly those that may be vulnerable to ML and FT.

671. Article 31, XX of the Federal Public Administration Organic Law also provides the legal basis for the SHCP to enter into collaboration agreements with Federal, State, Municipal and Federal District authorities on matters within its jurisdiction and national public security. This would include AML/CFT related issues. Underpinning supervisory cooperation are formal AML/CFT bilateral cooperation arrangements (Collaboration Agreements) signed by each of the following supervisory bodies, in representation of the SHCP. The FIU signed these agreements with the following agencies on the following dates:

- $\quad$ March 2006: National Banking and Securities Commission (CNBV - Spanish acronym for Comisión Nacional Bancaria y de Valores).

- $\quad$ May 2006: National Insurance and Bonds Commission (CNSF - Spanish acronym for Comisión Nacional de Seguros y Fianzas).

- $\quad$ November 2006: Retirement Savings System National Commission (CONSAR - Spanish acronym for Comisión Nacional de Sistemas de Ahorro para el Retiro).

672. Collaboration agreements have also been signed with the following:

- June 2006: Ministry of the Economy (SE-Spanish acronym for Secretaría de Economía).

- $\quad$ December 2006: Ministry of the Interior (SEGOB - Spanish acronym for Secretaría de Gobernación).

- $\quad$ August 2006: National Immigration Institute (INM-Spanish acronym for Instituto Nacional de Migración).

673. The cooperation agreements between the supervisory agencies and the FIU generally provide, inter alia, for the coordination of activities for the sharing, security, and transmission of information (including suspicious transactions). The sharing of such information is intended to improve the quality and timeliness of reports sent to the FIU by financial institutions, and enables the supervisory agencies to focus their inspection and supervisory activities on specific areas of ML/FT concern. The agreements with the other government agencies mainly allow for access by the FIU to their information and databases to support the FIU's intelligence functions.

674. At the time of the mission, the FIU was in discussions with the Tax Administration Service (SAT: Secretaria de Administracion Tributaria ${ }^{54}$ ) and the Ministry of Foreign Affairs (Secretaria de Relaciones Exteriores) to enter into similar cooperation agreements to allow access to the FIU to their information databases. Notwithstanding the absence of such agreement, the SAT can cooperate and share information with the FIU mainly through the administrative units of the SHCP. (Article 7 of the Tax Administration Law and a new Regulation (Article 3) that came into effect in December 2007, that gives effect to the Law).

\footnotetext{
${ }^{54}$ The SAT is the supervisor of unlicensed centros cambiarios, money remitters, and the unregulated SOFOMES.
} 


\section{Cooperation between $C N B V$ and $P G R$}

675. As explained under R.4 in Section 3.4 of the report, the investigative authorities that are authorized to obtain information protected by banking secrecy must send their requests through the appropriate supervisory agency (in practice the CNBV is most commonly used), which in turn sends out requests to the supervised institutions, collects the responses and forwards them to the requesting authority. The procedure currently in place is working effectively, has not been challenged, and has significantly reduced response times and improved cooperation between PGR and CNBV.

676. PGR officials would prefer having direct access to banking information in special cases. However, in their opinion, which was shared by supervisors and financial institutions alike, the procedure is working well in practice and response times have improved significantly in recent years. When the request contains precise information about the investigated person, such as names, identification numbers, account numbers and address, financial institutions are able to respond in a matter of three to five business days. In other cases, where PGR needs to find out if a person has conducted a financial transaction at any of the reporting institutions, the response can take longer. Also, when the CNBV or the financial institutions find homonyms, PGR is asked to provide additional identification data so that the person can be singled-out, in order to protect the privacy of third persons not involved in the investigation. Even then, according to the authorities, most of the times the entire process only takes between 15 days and one month to process, down from up to six months a couple of years ago.

677. This mechanism has also benefited from improved relationships and communication between the PGR and the CNBV, and from the the increasing experience being gained from the specialization of personnel both at the PGR and the CNBV. Both institutions have designated a special unit or department to centralize the request, receipt and dissemination of information.

678. Although the current procedure is working efficiently, it is not established under a formal arrangement or memorandum between the PGR and CNBV that would firmly establish this positive relationship going forward. Much depends on the personal relationships that currently exit. Care should be taken to avoid instituting an unreasonable burden on the investigatory authorities when they motivate and justify their information requests to the CNBV. Similarly, care should be taken to avoid over-burdening financial institutions with requests for information, particularly of the "fishing expedition" type.

\section{Cooperation Between PGR and the FIU}

679. Cooperation between the between PGR and the FIU has been enhanced since 2007 and is currently working effectively. At the operational level, the enhanced collaboration entails a joint preparation of cases that in practice no longer require the filing of proactive reports by the FIU. This has resulted in a substantial number of indictments with no link to proactive reports but with a significant contribution from the FIU. The requirement for the PGR to obtain a formal complaint from the SHCP before bringing a case involving the financial institutions to court, does not currently appear to represent an practical obstacle to the effective cooperation between PGR and the FIU. It is the view of PGR that the requirement has ultimately contributed to closer working relationship with the FIU and that it has allowed them to convey to them a clearer idea of what PGR expects from the FIU's to provide them with respect to cases referred. The FIU also shares the view that closer collaboration with PGR has improved their interaction as well as PGR's understanding of the FIU's role and outputs. 
680. Nevertheless, assessors recommend the removal of the requirement for the PGR to obtain a formal complaint from the SHCP before bringing a case involving the financial sector to court. In addition, the working relationships between PGR and the FIU (please refer to analysis under Recommendations 1 and 2) should continue to be enhanced, including through more formal institutionalized mechanisms, e.g., formal establishment of joint working groups including for the development and implementation of AML/CFT policies and strategies.

681. There are two memoranda of understanding between the PRG and the SHCP through the FIU, dated June 2004 and October 2005, respectively. The purpose of the first memorandum is to establish a framework for the FIU to provide to the PGR with financial intelligence reports in accordance with the applicable laws and regulations. Such reports are to enable the PGR to undertake ML investigations. The MOU also contain provisions on the confidentiality and control of such intelligence reports, as well as the rules to request the consent from the competent authorities for proper use thereof during an investigation.

682. The second MOU deals with the authorization of the personnel of the SIEDO (Organized Crime Special Investigation Agency) of the PRG to access the FIU's databases. It also establishes commitments for the administration of legal complaints reveived by the PGR (e.g., from the SHCP) for purposes of investigation and prosecution of ML.

683. The FIU also works in coordination with the Ministry of Foreign Affairs, when, within the scope of its competence, dealing with international lists of terrorists.

\section{Relations between Security Forces and the PGR}

684. As discussed under R. 27, while the AFI still reports to PGR for administrative purposes, a reorganization is currently under way aimed at merging the AFI with the Federal Preventive Police [Policia Federal Preventiva] (PFF), which reports to the Ministry of Public Safety. The objective is to create a combined Federal Police Force [Policia Federal] operating under a unified mandate for the Under-Secretary for Strategy and Police Intelligence [Subsecretario de Estrategia e Inteligencia Policia]. However, the reorganization has so far created frictions between the police forces and prosecutors and this has obstructed the investigative process. The repeated and frequent changes in the police staff of investigative teams have generated delays in the conduct of investigations, particularly in those cases detected by the FIU.

\section{Relations between the Judiciary and the PGR}

685. As indicated in the analysis of Recommendations 27 and 28, Mexico does not have any effective joint cooperation or coordination mechanisms between the PGR and the Judiciary to implement joint policies and conduct activities aimed at fighting organized crime. Nor is there a discussion forum between these entities to analyze and address current serious problems or to build consensus on criminal policy.

686. In addition, although they are inherently autonomous organizations, there is often a significant divergence of opinion on issues, particularly on how specific cases are resolved, and this adversely impacts on the effectiveness of the criminal prosecution system. These differences are more likely to be evident at the time the final verdict is issued, and less during criminal proceedings in lower criminal courts. 
Additional Element - Mechanisms for Consultation Between Competent Authorities and Regulated Institutions (c. 31.2)

687. The SHCP and its supervisory commissions, within their respective competences, can and do consult with the industry associations with respect to AML/CFT matters. The principal industry groups are as follows:

- $\quad$ Asociación De Bancos De México (banking association).

- $\quad$ Asociación Mexicana De Casas De Cambio (association of licensed foreign exchange houses).

- Asociación Nacional De Centros Cambiarios y Transmisores de Dinero (unlicensed/registered association of foreign exchange centers and money remitters).

- $\quad$ Asociación Mexicana de Instituciones de Seguros (association of insurance companies).

- $\quad$ Asociación Mexicana de Intermediarios Bursátiles (association of securities intermediaries).

- $\quad$ Asociación Mexicana de Entidades Fianancieras Especializadas (association of especializad financial institutions e.g., factoring, leasing and Sofoles).

688. A concrete example of this consultation involved the issue of Circulars (Oficios) defining the scope and application for CDD purposes under the regulations with respect to politically exposed persons (PEPs) and beneficial owners.

Statistics (applying R.32)

GENERAL DIRECTORATE FOR THE PREVENTION OF ILLICIT OPERATIONS

SUMMARY OF OFFICIAL COMMUNICATIONS REQUESTING INFORMATION

AND FREEZING OF ACCOUNTS (as of August 13, 2008)

\begin{tabular}{|c|c|c|c|c|c|}
\hline \multicolumn{6}{|c|}{2006} \\
\hline \multirow[b]{2}{*}{$\begin{array}{l}\text { REQUIRING } \\
\text { AUTHORITY }\end{array}$} & \multirow[b]{2}{*}{ RECEIVED } & \multicolumn{3}{|c|}{ ATTENDED } & \multirow[b]{2}{*}{ PENDING } \\
\hline & & $\begin{array}{c}\text { OFFICIAL } \\
\text { COMMUNICATIONS }\end{array}$ & $\begin{array}{l}\text { PERCENTAGE } \\
\text { ATTENDED }\end{array}$ & $\begin{array}{l}\text { AVERAGE } \\
\text { BUSINESS } \\
\text { DAYS }\end{array}$ & \\
\hline $\begin{array}{l}\text { PGR } \\
\text { UEIORPIFAM } \\
\text { (1) }\end{array}$ & 82 & 82 & 100.00 & 73 & \\
\hline UIF (2) & 84 & 84 & 100.00 & 26 & \\
\hline TOTAL & 166 & 166 & 100.00 & & 0 \\
\hline
\end{tabular}

(1) INCLUDES 16 REQUESTS ADDRESSED TO THE FINANCIAL SYSTEM

(2) REQUESTS ADDRESSED TO BANKS, SECURITIES FIRMS, LICENSED CURRENCY EXCHANGE HOUSES AND MUTUAL FUNDS 
GENERAL DIRECTORATE FOR THE PREVENTION OF ILLICIT OPERATIONS

SUMMARY OF OFFICIAL COMMUNICATIONS REQUESTING INFORMATION

AND FREEZING OF ACCOUNTS (as of August 13, 2008)

\begin{tabular}{|c|c|c|c|c|c|}
\hline \multicolumn{6}{|c|}{2007} \\
\hline \multirow[b]{2}{*}{$\begin{array}{l}\text { REQUIRING } \\
\text { AUTHORITY }\end{array}$} & \multirow[b]{2}{*}{ RECEIVED } & \multicolumn{3}{|c|}{ ATTENDED } & \multirow[b]{2}{*}{ PENDING } \\
\hline & & $\begin{array}{c}\text { OFFICIAL } \\
\text { COMMUNICATIONS }\end{array}$ & $\begin{array}{l}\text { PERCENTAGE } \\
\text { ATTENDED }\end{array}$ & $\begin{array}{l}\text { AVERAGE } \\
\text { BUSINESS } \\
\text { DAYS }\end{array}$ & \\
\hline $\begin{array}{l}\text { PGR } \\
\text { UEIORPIFAM } \\
\text { (1) }\end{array}$ & 105 & 105 & 100.00 & 120 & \\
\hline UIF (2) & 665 & 663 & 99.70 & 78 & 2 \\
\hline TOTAL & 770 & 768 & 99.85 & & 2 \\
\hline
\end{tabular}

(1) INCLUDES 48 REQUESTS ADDRESSED TO THE FINANCIAL SYSTEM

(2) REQUESTS ADDRESSED TO BANKS, SECURITIES FIRMS, LICENSED CURRENCY EXCHANGE HOUSES AND MUTUAL FUNDS

\begin{tabular}{|c|c|c|c|c|c|}
\hline \multicolumn{6}{|c|}{2008} \\
\hline \multirow[b]{2}{*}{$\begin{array}{l}\text { REQUIRING } \\
\text { AUTHORITY }\end{array}$} & \multirow[b]{2}{*}{ RECEIVED } & \multicolumn{3}{|c|}{ ATTENDED } & \multirow[b]{2}{*}{ PENDING } \\
\hline & & $\begin{array}{c}\text { OFFICIAL } \\
\text { COMMUNICATIONS }\end{array}$ & $\begin{array}{l}\text { PERCENTAGE } \\
\text { ATTENDED }\end{array}$ & $\begin{array}{l}\text { AVERAGE } \\
\text { BUSINESS } \\
\text { DAYS }\end{array}$ & \\
\hline $\begin{array}{l}\text { PGR } \\
\text { UEIORPIFAM } \\
\text { (1) }\end{array}$ & 97 & 48 & 49.48 & 47 & 49 \\
\hline UIF (2) & 720 & 395 & 54.86 & 58 & 325 \\
\hline TOTAL & 817 & 443 & 52.17 & & 374 \\
\hline
\end{tabular}

(1) INCLUDES 34 REQUESTS ADDRESSED TO THE FINANCIAL

SYSTEM

(2) REQUESTS ADDRESSED TO BANKS, SECURITIES FIRMS, LICENSED CURRENCY EXCHANGE HOUSES AND MUTUAL FUNDS

\subsubsection{Recommendations and Comments}

- $\quad$ Although the current arrangement, whereby the PGR must request information protected by banking secrecy, is working efficiently, it should be established under a formal arrangement 
between the PGR and financial supervisory authorities that would firmly establish this positive relationship going forward.

- $\quad$ The requirement for the PGR to obtain a formal complaint from the SHCP before bringing a case involving the financial sector to court should be removed.

- $\quad$ The working relationships between PGR and the FIU should continue to be improved, including through more formal institutionalized mechanisms, e.g., formal establishment of joint working groups including for the development and implementation of AML/CFT policies and strategies.

- The transition to a single federal police force should bne closely monitored to address current frictions between the AFI and PFF.

- Joint cooperation or coordination mechanisms should be established between the PGR and the Judiciary to implement joint policies and conduct activities aimed at fighting organized crime. A discussion forum should also be created to allow them to jointly analyze and address current serious problems and to build consensus on criminal policy.

\subsubsection{Compliance with Recommendation 31}

\begin{tabular}{|c|c|c|c|}
\hline & Rating & \multicolumn{1}{c|}{ Summary of factors underlying rating } \\
\hline R.31 & LC & - $\begin{array}{l}\text { The reorganization of the federal forces of investigation over the past year has } \\
\text { created transitional coordination and cooperation difficulties between these } \\
\text { forces and prosecutors. }\end{array}$ \\
$\begin{array}{l}\text { - } \\
\text { Absence of effective joint cooperation or coordination mechanisms between } \\
\text { the PGR and the Judiciary to implement joint policies and conduct activities } \\
\text { aimed at fighting organized crime. }\end{array}$ \\
\hline
\end{tabular}

6.2 The Conventions and UN Special Resolutions (R.35 \& SR.I)

\subsubsection{Description and Analysis}

Legal Framework

689. Ratification of AML Related UN Conventions (c. 35.1): Mexico signed the United Nations Convention against the Illegal Trafficking of Drugs and Pscichotropic Substances of 1988 (the Vienna Convention) on February 16, 1989 and ratified it on April 11, 1990.

690. Mexico signed the United Nations Convention against Transnational Organized Crime (the Palermo Convention) on December 13, 2000 and ratified it on March 4, 2003. Mexico is also a party to the three supplementary protocols: $i$ ) the Protocol to Prevent, Suppress and Punish Trafficking in Persons, especially Women and Children; ii) the Protocol Against the Smuggling of Migrants by Land, Sea and Air; and iii) the Protocol Against the Illicit Manufacturing of and Trafficking in Firearms, their Parts and Components and Ammunition.

691. Ratification of CFT Related UN Conventions (c. I.1): Mexico signed the International Convention for the Suppression of the Financing of Terrorism on September 7, 2000, and ratified it on January 20, 2003. Mexico has signed and ratified all of the treaties listed in the annex of the UN's Terrorist Financing Convention. 
692. Implementation of Vienna Convention (Articles 3-11, 15, 17 \& 19, c. 35.1): Mexico has adopted legislation to implement Article 3 of the Vienna Convention through Article 2 of the LFDO and Article 194 of the CPF. However, the ML offense does not cover the "concealment or disguise of the true nature, source, location, disposition, movement, or ownership of or rights with respect to property" nor the "possession or use of property without a specific purpose." Additional focus also needs to be placed in conducting investigations of ML offenses committed through the financial system.

693. Mexican legislation does not allow for appropriate use of controlled delivery as required by the Vienna Conventions (Article 7, Vienna Convention).

694. Implementation of SFT Convention (Articles 2-18, c. 35.1 \& c. I.1): Mexico has adopted legislation that partially implements Articles 2 and 4 of the SFT Convention through Article 2 of the LFDO, Articles 139 and 148 Bis of the CPF and Article 194 of the CFPP.

695. The TF offense is not fully consistent with Article 2 of the STF Convention. It only focuses on what is used for the act (and not on the intentions of the act) and it requires a showing (rather than a purpose) that the act generated alarm, fear, or terror to a population. In addition, the terrorist financing offenses under Mexican law are not consistent with article 2 of the SFT Convention as they do not extend the financing conduct to all of the acts that constitute offenses within the scope of, and as defined in the treaties listed in the annex of SFT Convention.

696. Mexico has not implemented measures to freeze without delay funds or other assets of terrorists, those who finance terrorism and terrorist organizations in accordance with UNSCRs relating to the prevention and suppression of FT.

697. Implementation of Palermo Convention (Articles 5-7, 10-16, 18-20, 24-27, 29-31 \& 34, c. 35.1): Mexico has adopted legislation to implement articles 5 through 7 of the Palermo Convention through article 2 of the LFDO, article $400 \mathrm{Bis}$ of the CPF and relevant administrative regulations. (See also discussion in the preceding paragraphs on concealment and disguise etc. with respect to the implementation of the Vienna Convention.)

698. Mexican legislation does not allow for appropriate use of controlled delivery as required by the Palermo Conventions (Article 20, Palermo Convention). Furthermore, under Mexican law, criminal liability does not extend to legal persons as required by the Palermo Convention (Article 10 of the Palermo Convention).

699. Implementation of UNSCRs relating to Prevention and Suppression of FT (c. I.2): Mexico has not fully implemented UNSCRs relating to the prevention and suppression of FT.

Additional Element - Ratification or Implementation of Other Relevant International Conventions (c. 35.2): Within the scope of the Inter-American Committee Against Terrorism (CICTE) of the Organization of American States (OAS), Mexico promoted the creation of the InterAmerican Convention against Terrorism. Mexico signed this convention on June 3, 2002 and ratified it on June 9, 2003. Mexico signed the United Nations Convention Against Corruption (the Merida Convention) on December 9, 2003 and ratified it on July 20, 2004.

\subsubsection{Recommendations and Comments}

700. In order to fully comply with Recommendation 35, Mexico should: 
- Amend Article 400 Bis of the CPF to incorporate the conduct of "conversion of property" into the money laundering offense.

- Amend Article 400 Bis of the CPF to incorporate the conduct of "concealment or disguise of the true nature, source, location, disposition, movement, or ownership of or rights with respect to property" as a primary conduct and not as a purpose.

- $\quad$ Amend Article 400 Bis of the CPF to incorporate the conduct of "possession or use of property" into the money laundering offense. The possession or use of property should be criminalized without a specific purpose.

- $\quad$ Amend the CPF to criminalize the "conspiracy to commit" the offense and make it applicable to the money laundering offense.

- $\quad$ Enact legislation to allow the use of the controlled delivery as a special technique of investigation.

701. In order to fully comply with Special Recommendation I, Mexico should:

- $\quad$ Amend the terrorist financing conduct in Section 148 Bis of the CPF to focus it on the intention of the act to cause death or serious bodily injury rather than on what is used to commit the act.

- $\quad$ Amend the terrorist financing conduct in Section 148 Bis of the CPF to require a purpose of generating alarm, fear or terror rather than a showing.

- $\quad$ Amend the CPF to extend the terrorist financing conducts to the financing of the acts that constitute an offense within the scope of, and as defined in the treaties listed in the annex of the SFT Convention.

- $\quad$ Enact effective laws and procedures to freeze without delay funds or other assets of terrorists, those who finance terrorism and terrorist organizations in accordance with UN SCRs relating to the prevention and suppression of FT.

- $\quad$ Adopt legislation making legal persons criminally liable for ML.

\subsubsection{Compliance with Recommendation 35 and Special Recommendation I}

\begin{tabular}{|c|c|ll|}
\hline & Rating & \multicolumn{1}{c|}{ Summary of factors underlying rating } \\
\hline R.35 & LC & $\begin{array}{l}\text { - Mexico has not fully implemented the Vienna and Palermo Conventions. } \\
\text { - Mexico has not fully implemented the Terrorist Financing Convention. }\end{array}$ \\
\hline SR.I & PC & $\begin{array}{l}\text { - The Terrorist Financing Convention has not been fully implemented. } \\
\text { United Nations Security Council Resolutions relating to the prevention and } \\
\text { suppression of FT are not being fully implemented. }\end{array}$ \\
\hline
\end{tabular}




\subsection{Mutual Legal Assistance (R.36-38, SR.V)}

\subsubsection{Description and Analysis}

702. Mexico does not have a law regulating mutual legal assistance. However, it can provide international legal assistance either through bilateral or multilateral agreements, or under the principle of international reciprocity, as applicable.

703. Mexico assigns a high degree of importance to international cooperation through legal assistance and extradition, both of which are considered key tools in the fight against crime. The Government has designated the Attorney General's Office (PGR) as the coordinating authority for this purpose. The PGR is houses a specialized unit, the General Directorate of Extraditions and Legal Assistance (DGEAJ), which, upon receiving a request for international legal assistance, is responsible for obtaining the requested information and to provide an immediate response.

704. Under the international agreements signed by Mexico, the requirements for processing requests for MLA are as follows:

- $\quad$ The requests must be submitted in writing.

- $\quad$ Mexico may begin to comply with the request immediately upon receiving it by fax, electronic mail, or other media, while the requesting country submits the signed original in writing with the appropriate formalities.

- If Mexico determines that an MLA request is urgent, the failure to submit the original request in writing shall not prevent the initiation of steps to process the request.

705. The MLA requests must include the following information:

- $\quad$ The name of the institution and of the competent authority responsible for the criminal proceedings that originate the request.

- The purpose of the MLA request and a description of the specific legal assistance requested.

- A description of the facts under investigation or criminal proceedings, the text of the legal provisions describing the conduct as a punishable offense and, when necessary, the extent of the damage caused.

- $\quad$ The basis for, and description of, any special proceedings that the Requesting Party may desire in executing the MLA request, provided that such proceedings do not violate the Mexico's legislation.

- The identification of the persons under investigation or subject to a judicial process.

- $\quad$ The location and description of the premises to be searched or inspected.

- The location and description of the goods to be secured or forfeited. And

- $\quad$ Any other information that may be useful to Mexico in complying with the request.

706. If Mexico believes that the information contained in an MLA request is insufficient to respond and provide such assistance, it may request additional information.

Procedure for International MLA Requests Made to Mexico (Passive) 
- The DGEAJ receives the official request from the competent authorities within Mexico to obtain information and documentation, and to carry out activities abroad.

- $\quad$ The request letter is forwarded to the Directorate of International Legal Assistance.

- The assistance request is forwarded to the Subdirectorate of Legal Assistance Requests Made by Mexico, comprising one deputy director, three agents of the Public Prosecutor's Office, four department heads, and one deputy coordinator of services.

- $\quad$ The Deputy Director of Legal Assistance Requests Made by Mexico forwards the international legal assistance request to the aforementioned personnel so that they can analyze the request to determine whether it complies with the requirements established in international mutual legal assistance treaties. If the request does not comply with these requirements, the requesting authority will be asked to correct any omissions so that the request can be processed.

- $\quad$ The request for assistance is sent to the corresponding foreign authority, in accordance with the applicable agreement.

- Records of the procedures carried out by the corresponding foreign authorities are sent to the DGEAJ.

- $\quad$ The documents are forwarded to the Directorate of Mutual Legal Assistance.

- The documents are submitted to the Subdirectorate of Legal Assistance made by Mexico.

- $\quad$ The Deputy Director of Legal Assistance Requests made by Mexico forwards the documents received to the staff of that directorate so that they can determine whether or not the points established in the request have been addressed.

- The staff responsible for processing the request submits the records of the steps taken to the requesting Mexican authority, thereby responding to the request.

\section{Procedure for International MLA Requests Made to Mexico (Passive)}

- $\quad$ The DGEAJ receives the official request for MLA from the coordinating authority of a foreign government requesting to obtain information, documentation, individual statements, and to carry out other activities in Mexico.

- $\quad$ The request letter is forwarded to the Directorate of International Legal Assistance at PGR.

- The assistance request is forwarded to the "Subdirectorate of Legal Assistance Requests Made to Mexico", comprising 1 deputy director, and 1 agent of the Public Prosecutor's Office.

- $\quad$ The Deputy Director of Legal Assistance Requests Made to Mexico forwards the request to the Public Prosecutor's Office so that it can analyze the request to determine whether it complies with the requirements established in international mutual legal assistance treaties. If the request does not comply with these requirements, the requesting authority will be asked to correct any omissions so that the request can be processed.

- If the staff of the Subdirectorate of Legal Assistance Requests Made to Mexico determines that the legal assistance request complies with the formalities established in the relevant international agreement, it sends the request for support to the corresponding Mexican authority for processing.

- $\quad$ Records of the procedures carried out by the corresponding Mexican authorities are sent to the DGEAJ. 
- $\quad$ The documents are forwarded to the Directorate of Mutual Legal Assistance.

- $\quad$ The documents are submitted to the Subdirectorate of Legal Assistance Made to Mexico.

- The Subdirectorate of Legal Assistance Requests Made to Mexico, in order to forward the response to the given foreign government, must take the necessary steps to certify the signature of the Mexican ministerial or judicial authority with the Interior Ministry, for certification, or with the Ministry of Foreign Affairs, for authentication, as applicable.

- Once authenticated or certified, the required information and documentation is sent to the requesting foreign authority, and the legal assistance request is thereby concluded.

707. The agreements on MLA in criminal matters currently in effect in Mexico are as follows:

\section{Multilateral agreements}

- United Nations Convention against Transnational Organized Crime, adopted at New York on November 15, 2000.

- United Nations Convention against Corruption, approved by the General Assembly on October 31, 2003.

- Inter-American Convention Against Terrorism, adopted at Bridgetown, Barbados on June 3, 2002.

- Inter-American Convention on Mutual Assistance in Criminal Matters, adopted in Nassau, Bahamas, on May 23, 1992.

- Inter-American Convention on Serving Criminal Sentences Abroad, adopted at Managua, Nicaragua, on June 9, 1993.

708. Mexico has signed bilateral agreements with the following states: Argentina, Australia, Canada, Colombia, Costa Rica, Cuba, Chile, China, Ecuador, El Salvador, the United States, France, Germany, Greece, Guatemala, Honduras, Korea, Nicaragua, Panama, Paraguay, Peru, Portugal, Spain, the United Kingdom, Uruguay, and Venezuela. It has also signed legal assistance agreements with Switzerland and Bolivia, which have yet to take effect, as the legislative bodies of these two countries have not yet approved them. It has also signed agreements with India, Russia, and Brazil that are pending approval by the Mexican Senate.

709. There is case law from the Supreme Court of Justice of the Nation, confirming the rule that "international agreements have precedence over federal laws and in respect of the federal constitution". As a result, the Mexican State is required to comply with the commitments and provisions established in international instruments, and these take precedence over secondary legal provisions. Assistance provided according to the principle of international reciprocity has been successful and includes the examples of Switzerland and Brazil.

710. In urgent cases where a country requests that Mexico use precautionary (preventive) measures, these may be processed upon receipt of MLA request, provided that sufficient information has been provided to determine that the conditions under which precautionary measures may be ordered have been met. These measures will be canceled if the Requesting Party does not formalize the request within the period established according to the type of assistance granted for this purpose.

711. If Mexico is asked to use precautionary measures, including the production of records by each financial institution, the freezing of accounts, people or property searches, attachment and 
obtaining of evidence for use in money laundering investigations and prosecution, the country must have the required legislation in place to allow the Mexican authorities to act effectively.

\subsubsection{Widest Possible Range of Mutual Assistance (c. 36.1)}

712. Mexico can provide comprehensive assistance because it is able to carry out the following processes:

- $\quad$ Compile declarations from witnesses, suspects, or accused parties.

- $\quad$ Locate individuals.

- Voluntarily transfer an individual for the purposes of carrying out a proceeding (witness or expert) in the requesting country.

- $\quad$ Obtain and submit documentation and information, including information on financial institutions.

- $\quad$ Secure and confiscate real or movable property.

- Conduct searches and inspections.

- Issue expert appraisals.

- Issue notifications.

713. It is worth noting that these proceedings are established in the agreements, and that cooperation can be provided under the same terms even when no agreement exists. However, the deficiencies in the money laundering and terrorist financing offenses (discussed under R. 1 and SR II respectively) may impact on Mexico's ability to provide MLA.

\subsubsection{Provision of Assistance in Timely, Constructive and Effective Manner (c. 36.1.1)}

714. The Office of the Attorney General of the Republic is the coordinating authority and is empowered to provide mutual legal assistance based on the elements mentioned above and on the signing of bilateral or multilateral agreements or treaties, or based on the principle of reciprocity.

715. Requests for legal assistance have been made reasonably quickly and have been effective and constructive.

\subsubsection{No Unreasonable or Unduly Restrictive Conditions on Mutual Assistance (c. 36.2)}

716. The Mexican State does not impose any unreasonable, disproportionate, or unduly restrictive conditions on compliance with mutual legal assistance requests.

\subsubsection{Efficiency of Processes (c. 36.3)}

717. The Office of the Attorney General of the Republic is committed to responding to mutual legal assistance requests effectively and efficiently. Generally, legal assistance requests are submitted directly by the coordinating authority of the requesting country to the Office of the Attorney General of the Republic. When no international agreement signed by the Mexican government exists, the international legal assistance request is sent via diplomatic pouch through the Ministry of Foreign Affairs, according to the principle of international reciprocity. 
718. Once the request has been reviewed and the requirements for international instruments on legal assistance fulfilled, the Office of the Attorney General of the Republic then requests the support of the different agencies of the federal public administration, the administrative units of the PGR, or of the state governments, so that they can provide the information and documentation required to respond to and carry out the proceedings requested by the requesting country, which may consist of financial information, the freezing of bank accounts, criminal and immigration history, people searches, conducting interrogations, and the voluntary transfer of individuals.

719. When the PGR receives the information relevant to the international legal assistance request, it then submits that information in accordance with the procedures established in each international treaty or agreement on legal assistance so that the information has legal force abroad (authentication or certification).

720. Certification (apostilla) is understood as the certification of the signatures of public servants in order to prove the validity and legitimacy of documents issued by the Mexican government. The procedure is followed by those countries party to the Convention Abolishing the Requirement of Legalization for Foreign Public Documents (Hague Convention). Legalization is understood as the declaration of authenticity of signatures appearing in an official document, as well as the legal status of the person or persons whose signatures appear in said document. The difference between the two concepts is that certification does not require the involvement of consular authorities in the requesting country and therefore streamlines the process.

\subsubsection{Provision of Assistance Regardless of Possible Involvement of Fiscal Matters (c. 36.4)}

721. Mexico responds to international legal assistance requests in fiscal matters as illicit fiscal activities are considered serious offenses under Mexican law.

\subsubsection{Provision of Assistance Regardless of Existence of Secrecy and Confidentiality Laws (c. 36.5)}

722. Bank secrecy and professional secrecy laws do exist in Mexico; nevertheless, it is possible to process international legal assistance requests and even deliver the financial information requested by the requesting country, for which purpose the representative of the Public Prosecutor's Office is empowered to request financial information or documentation from the National Banking and Securities Commission, as well as from institutions in the Mexican financial system, and the latter are obligated to provide such information.

723. Thus, Article 9 of the Federal Law Against Organized Crime establishes the procedure that must be followed in order to obtain this information:

724. “Requests to the Public Prosecutor's office, or the federal judicial authority, for information or documents relating to the banking or financial system shall be made by the National Banking and Securities Commission, the National Retirement Savings Plans Commission, and the National Insurance and Guarantee Commission, as applicable. Requests relating to fiscal matters shall be made through the Ministry of Finance and Public Credit."

725. In addition, Article 117 of the Law on Lending Institutions establishes that the Attorney General of the Republic or the public servant it empowers for such purpose may request financial information through the National Banking and Securities Commission or on orders of the judicial authorities. 
726. The Public Prosecutor's office requests financial information to monitor resources that may be illegally obtained and to conduct more comprehensive investigations.

\subsubsection{Availability of Powers of Competent Authorities (applying R.28, c. 36.6)}

727. The PGR, upon processing a request for mutual legal assistance in a criminal matter, requests the support of the units responsible for investigating crimes, which in this case is accomplished through the representative of the Public Prosecutor's Office or agents of state governments, which are empowered to request any type of information from the institutions in the Mexican financial system, for which provisions exist in the international agreements or that is related to federal crimes or state crimes.

728. In the case of money laundering or terrorism financing crimes, the National Banking and Securities Commission is responsible for delivering information and requests same from the financial institutions.

\subsubsection{Avoiding Conflicts of Jurisdiction (c. 36.7)}

729. Mexico does not accept continuing international jurisdiction and, at the same time, it respects the international sovereignty of its peers. However, it frames its criminal proceedings on the fight against impunity; thus, Articles 1 through 6 of the Federal Criminal Code establish the assumptions based on which Mexican criminal law is applied. Article 1 establishes that this Code shall be applied throughout the Republic for federal crimes, and Article 2 provides for the application of the Code to: (i) Crimes that are begun, planned, or committed abroad, when they have an effect in Mexican territory or are intended to have an impact thereon, and (ii) crimes committed in Mexican consulates or against the staff thereof, when such crimes have not been tried in the country in which they were committed.

730. According to the provisions of Article 3, continuing offenses ${ }^{55}$ (delitos continuos) committed abroad that continue to be committed in Mexico shall be prosecuted according to the laws of the latter, regardless of whether the offenders are Mexican or foreign nationals. The same rule shall apply to continued offenses (delitos continuados).

731. Crimes committed abroad in foreign territory by a Mexican national against Mexican or foreign nationals, or by a foreign national against a Mexican national, shall be tried in the Republic, in accordance with federal laws, if they meet the following requirements, as set forth in Article 4 of the CPF:

I.- $\quad$ The accused must be in the Republic.

II.- The criminal has not been tried in the country in which the crime was committed. And

III.- The offense of which they are accused is a crime in the country in which it was committed and in the Republic (principle of dual criminality).

732. In terms of Article 5 of the CPF, the following shall be considered as having been committed in the Republic:

55 A crime is con tinuing or permanent when the commission thereof is prolonged over time (Federal Crminal Code, Article 7 (II). 
I.- Crimes committed by Mexicans or foreigners at sea, on board national vessels.

II.- Crimes committed on a national warship that has been docked or that is at sea in the territorial waters of another nation. This extends to merchant ships, if the criminal has not been tried in the country where the port is located.

III.- Crimes committed on a foreign vessel docked at a national port or located in the territorial waters of the Republic, if public order is disturbed or if the offender or the victim are not crew members on such vessel. Otherwise, steps shall be taken in accordance with the right of reciprocity.

IV.- Crimes committed on board domestic or foreign aircraft located in the territory or in domestic or foreign airspace or territorial waters, in cases similar to those indicated for vessels in the preceding paragraphs. And

V.- Crimes committed in embassies and Mexican representative offices.

733. Finally, Article 6 of the CPF stipulates that when the crime committed is not provided for in the Code, but is established in a special law or in an international treaty subject to mandatory compliance by Mexico, the latter shall apply. When a matter appears to be regulated by various provisions, the special law shall take precedence over the general law.

Additional Element - Availability of Powers of Competent Authorities Required under R28 (c. 36.8)

734. The PGR is the authority responsible for coordinating the processing of international legal assistance requests in criminal matters. When the PGR handles this type of request, it works through the General Directorate of Extraditions and Legal Assistance, which is regulated by the Organic Law of the PGR and its Regulations, as well as by the contents of the treaties and the bilateral and multilateral international agreements signed by the Mexican government.

735. Where no agreement exists, assistance is requested via diplomatic means through the Ministry of Foreign Affairs, which in turn forwards the request to the PGR.

736. In the Ministry of Foreign Affairs, the General Directorate of Legal Affairs, through the International Legal Assistance Directorate, is the sole unit responsible for processing legal assistance and extradition requests.

737. In addition, coordination and cooperation between the General Directorate of Legal Affairs and other administrative units in the SRE ensure that requests are responded to and processed rapidly and consistently, in all areas that respond to an assistance request; in other words, in addition to the technical and legal aspects, requests can also involve, when necessary, addressing issues relating to international public law, human rights, or consular matters.

International Cooperation under SR V (applying c. 36.1-36.6 in R. 36, c. V.1)

738. Criteria 36.1-36.6 in R. 36 apply to the obligations under SR.V. However, the deficiencies in the terrorist financing offense described under SR.II could have an impact on Mexico's ability to provide MLA. 
Additional Element under SR V (applying c. 36.7 \& 36.8 in R.36, c. V.6)

739. Criteria 36.7 and 36.8 in R. 36 apply to the obligations under SR.V. However, the deficiencies in the terrorist financing offense described under SR.II could have an impact on Mexico's ability to provide MLA.

Dual Criminality and Mutual Assistance (c. $37.1 \& 37.2$ )

740. The principle of dual criminality stipulates that the act giving rise to the request for legal assistance or extradition should be classified as a crime in both the requesting and the requested country.

741. In the context of legal assistance in criminal matters, dual criminality in Mexico is not an essential element for processing requests, except in cases requiring the implementation of precautionary measures, such as attachment and forfeiture, among others.

742. Nevertheless, Mexican law does not require the crime originating the request for international legal assistance to be described in similar terms in both countries, nor does it require the elements of the crime to fully match. Rather, the laws of the two nations must contain provisions for punishing the offense in similar circumstances and for an applicable penalty of no less than one year of imprisonment.

International Cooperation under SR V (applying c. 37.1-37.2 in R. 37, c. V.2)

743. Criteria 37.1-37.2 in R. 37 apply to the obligations under SR.V. However, the deficiencies in the terrorist financing offense described under SR.II could have an impact on Mexico's ability to provide MLA.

Timeliness to Requests for Provisional Measures including Confiscation (c. 38.1)

744. Mexico may provide response to MLA requests by foreign countries related to the identification, seizure and forfeiture of laundered property from, proceeds from instrumentalities used in, or instrumentalities intended for use in, the commission of any ML, FT or other predicate offense. This type of MLA is usually provided in an effective and rapid manner. However, there are no appropriate laws and procedures to freeze terrorist funds or other assets at the request of a foreign country.

Property of Corresponding Value (c. 38.2)

745. The Mexican legal system does not provide for the forfeiture of property of equivalent value.

Coordination of Seizure and Confiscation Actions (c. 38.3)

746. Mexico has signed MLA agreements with the following countries: Australia, Canada, Colombia, Costa Rica, Cuba, Chile, China, Ecuador, El Salvador, France, Germany, Greece, Guatemala, Honduras, Korea, Nicaragua, Panama, Paraguay, Peru, Portugal, Spain, the United Kingdom, the United States, Uruguay, and Venezuela.

747. When a request for MLA is made, the attachment process is as follows: 
748. The Requesting Party shall notify the Requested Party of the reasons why it believes that the objects, products, or instruments of crimes are located in the territory of the latter. When the property has been located, the competent authority of the Requested Party shall, at the behest of the Requesting Party, order the attachment of same and shall take the necessary steps to avoid the concealment, alteration, impairment, destruction, transaction, transfer, or disposal of same, provided that such steps are permitted under national law.

749. If the request for legal assistance refers to the confiscation of the property, proceeds, or instruments of crimes, the competent authorities of the Requested Party may, if their national law allows:

a) Execute the forfeiture order issued by a competent authority of the Requesting Party.

b) Begin a proceeding to obtain a forfeiture order from the Requesting Party, in accordance with its national law.

750. In addition to these requirements, the MLA request must include the following: a copy of the forfeiture order, duly certified by the issuing authority of same; information on the evidence supporting the order; and an indication that a final judgment has been issued for the order, a requirement that the Requested Party may waive.

International Cooperation under SR V (applying c. 38.1-38.3 in R. 38, c. V.3)

751. The deficiencies in the process for freezing terrorist assets described under SR.III impact on Mexico's capacity to freeze, seize and confiscate terrorist assets at foreign request".

Asset Forfeiture Fund (c. 38.4)

752. The second paragraph of Article 40 of the Federal Criminal Code indicates that if the forfeited instruments or objects contain toxic or dangerous substances, they shall be destroyed on the order of the authority handling the case, under the terms established in the Federal Code of Criminal Procedure; however, said authority, if appropriate, may decide to retain such instruments or objects for teaching or research purposes.

753. Regarding the instruments of a crime, or the items motivating the crime or resulting therefrom, the competent authority shall determine their purpose, according to their usefulness: to raise funds (procuración), to dispense justice, or to not use same, as applicable, in accordance with the applicable provisions of the law.

754. In terms of resources obtained through the sale of confiscated goods, Article 182-R of the Federal Code of Criminal Procedure states:

755. "Resources obtained through the sale of goods forfeited in federal criminal proceedings, as referred to in Article 1(I) of the Federal Law on the Administration and Sale of Public-Sector Goods, as well as the sale of their fruits and products, shall be delivered, in accordance with the provisions of Article 89 of said Law, in equal parts, to the Federal Judiciary, the Office of the Attorney General of the Republic, and the Ministry of Health. The resources corresponding to the Ministry of Health shall be allocated to drug prevention and rehabilitation programs."

756. In this regard, Article 89 of the Federal Law on the Administration and Sale of Public Sector Goods stipulates that: "Resources obtained through the sale proceedings referred to in Article 38 of this Law, as well as the fruits generated by the goods administered by the SAE [Public Sector 
Assets Management and Disposal Service] shall be subject to a deduction of administrative and maintenance costs, costs associated with preserving said goods, and fees assessed by special commissioners who are not civil servants and who are responsible for such proceedings, as well as payments of resulting claims submitted by users or third parties, for hidden, tax, or other liabilities, nonexistent assets, matters under dispute, and other outlays similar to the aforementioned expenses and costs, and those as determined by the Revenue Law of the Federation or other applicable legislation.

757. The resources derived from sales, together with the fruits generated by the goods administered by the SAE, shall be deposited into a fund with two general subaccounts, one for the fruits of such goods, and another for the sale thereof. Each general subaccount shall have specific subaccounts corresponding to each good or group of goods delivered for administration or to each of the sales indicated in the preceding paragraph, therefore allowing the transfer of resources obtained from the general subaccount to the different subaccounts.

758. Resources in the specific subaccounts shall be delivered by the SAE, which has the right to receive same, in the periods of time agreed upon for such purpose with the transferring entity or with the Treasury of the Federation and in accordance with applicable legal provisions. Once said resources have been delivered, the SAE shall bear no responsibility whatsoever should any claims be made."

759. It is worth mentioning the important role of the SAE "Assets Management and Sale Service", the entity responsible for administering, selling, and determining the destination of attached goods. Its functions are specifically established in the Regulations of the Federal Law on the Administration and Sale of Public-Sector Goods and its statutes.

760. The SAE is not required to formulate plans for allocation of property, given that legal provisions are in place for the distribution of resources obtained as a result of the forfeiture of goods ordered by the Federal Judiciary.

Sharing of Confiscated Assets (c. 38.5)

761. Mexico envisages the possibility of sharing forfeited assets when so established in the treaties or agreements signed for this purpose.

762. An example of this type of agreement is that signed by the Office of the Attorney General of the Republic of the United Mexican States, the Ministry of Finance of the United Mexican States, the U.S. Department of Justice, and the U.S. Treasury Department on the sharing of forfeited assets.

763. It is worth noting that the decision to share forfeited goods is made at the discretion of the parties, in accordance with the aforementioned agreement, and must be executed in a manner consistent with the terms established in laws, policies, and internal guidelines and procedures, whether or not the transfer is appropriate and, if applicable, the amount to be shared in the context of the contribution made by the other government to the investigations, proceedings, or other actions resulting from the confiscation of such goods.

764. Another example is the Treaty on Mutual Legal Assistance in Criminal Matters between the United Mexican States and the Republic of Brazil, which contains a chapter devoted to the sharing of goods. This treaty has been signed by the States parties and is currently being approved by the Senate, in accordance with the exclusive powers conferred upon it by Article 76(I) of the Political Constitution of the United Mexican States 
Additional Element (R 38) - Recognition of Foreign Orders for a) Confiscation of assets from organizations principally criminal in nature; b) Civil forfeiture; and, c) Confiscation of Property which Reverses Burden of Proof (applying c. 3.7 in R.3, c. 38.6)

765. In the Mexican legal system, forfeiture is a penalty of an accesory nature imposed by the State against the particular offender and assumes the existence of some type of illegal conduct. Provisions for forfeiture exist in criminal, administrative, customs, and tax terms, but not in civil, commercial, or labor terms.

Additional Element under SR V (applying c. 38.4-38.6 in R. 38, c V.7)

46. Not applicable.

Statistics (applying R.32)

766. The number of active international legal assistance cases from 2004 to 2007 was 1,627; 45 of which were money laundering cases. Of the 1627 cases 434 cases were closed, and 22 of these were money laundering cases.

767. The number of passive international MLA cases from 2004 to 2007 was 404; 54 of which were money laundering cases. Of the $54 \mathrm{ML}$ cases, 41 were closed, and 11 are pending. The following chart illustrates the type of MLA requests received by Mexico in the 2004-2007 period: [See next page] 


\section{REQUESTS FOR INTERNATIONAL MLA}

\section{ACTIVE REQUESTS}

\section{(Requests made by Mexico to other countries)}

\section{$\underline{2004}$}

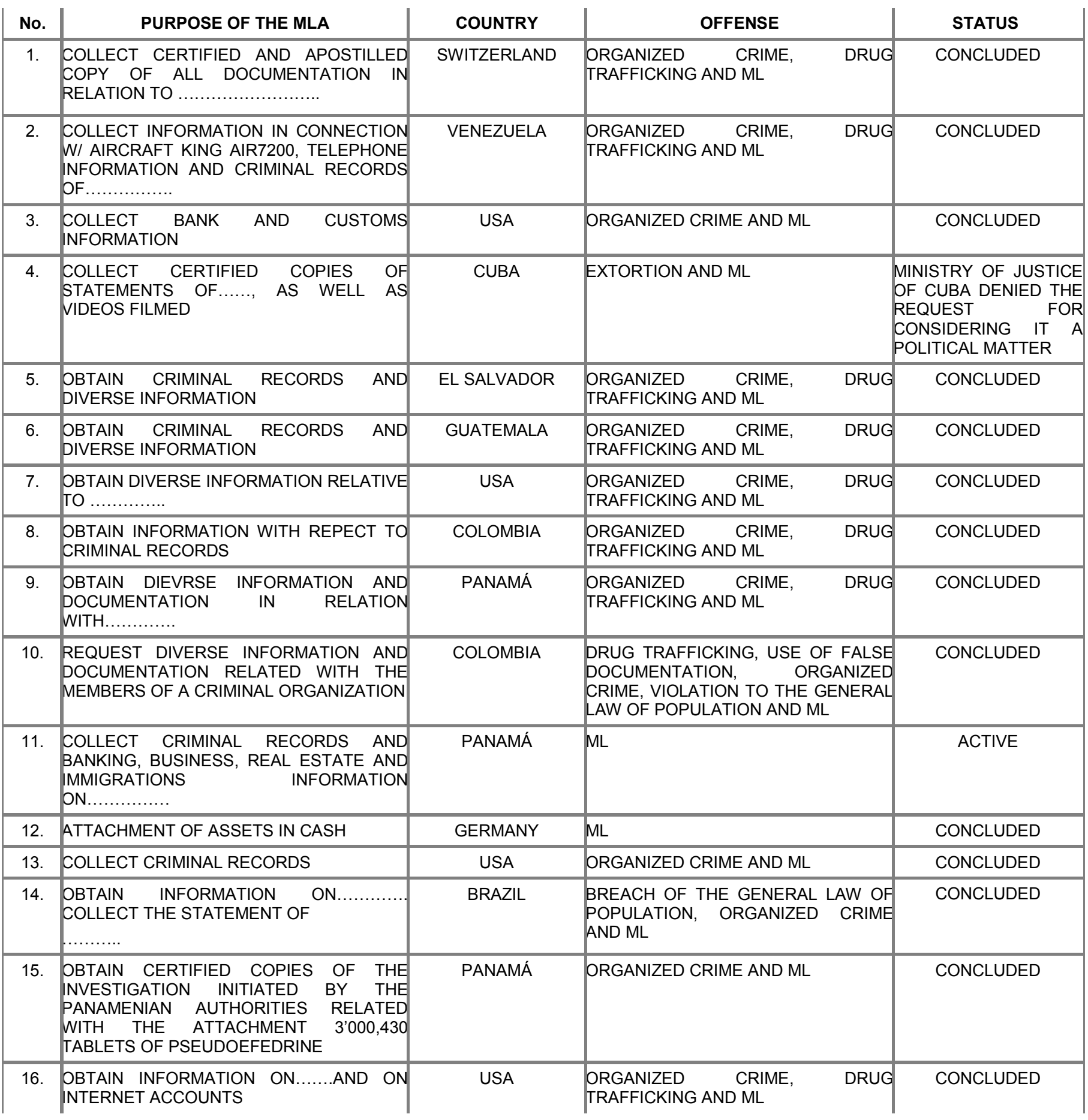


$\underline{2005}$

\begin{tabular}{|c|c|c|c|c|}
\hline No. & PURPOSE OF THE ASSISTANCE & COUNTRY & OFFENSE & STATUS \\
\hline 1. & $\begin{array}{l}\text { OBTAIN INFORMATION ON.........AND OF } \\
\text { INTERNET ACCOUNTS }\end{array}$ & USA & $\begin{array}{l}\text { ORGANIZED CRIME, } \\
\text { TRAFFICKING AND ML }\end{array}$ & ACTIVE \\
\hline 2. & OBTAIN DOCUMENTS & USA & $\begin{array}{l}\text { ORGANIZED CRIME, } \\
\text { TRAFFICKING AND ML }\end{array}$ & CONCLUDED \\
\hline 3. & COLLECT STATEMENT FROM ........... & USA & $\begin{array}{l}\text { ORGANIZED CRIME, } \\
\text { TRAFFICKING AND ML }\end{array}$ & CONCLUDED \\
\hline 4. & $\begin{array}{l}\text { OBTAIN CRIMINAL, FINANCIAL AND ENTRY } \\
\text { AND EXIT RECORDS }\end{array}$ & PANAMÁ & $\begin{array}{l}\text { ORGANIZED CRIME, } \\
\text { TRAFFICKING AND ML }\end{array}$ & CONCLUDED \\
\hline 5. & 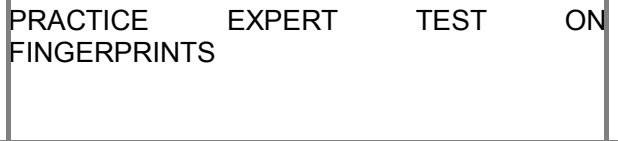 & COLOMBIA & $\begin{array}{l}\text { DRUG TRAFFICKING, USE OF FALSE } \\
\text { DOCUMENTATION, ORGANIZED CRIME, } \\
\text { ML AND BREACH OF THE GENERAL } \\
\text { LAW OF POPULATION }\end{array}$ & CONCLUDED \\
\hline 9. & $\begin{array}{l}\text { OBTAIN INFORMATION ON FINANCIAL } \\
\text { TRANSACTIONS OF ...... }\end{array}$ & SPAIN & ML & CONCLUDED \\
\hline
\end{tabular}


2006

\begin{tabular}{|c|c|c|c|c|c|}
\hline No. & PURPOSE OF THE ASSISTANCE & COUNTRY & OFFENSE & & STATUS \\
\hline 1. & 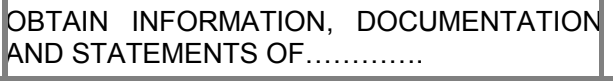 & COLOMBIA & ORGANIZED CRIME AND ML & & PENDING CLOSURE \\
\hline 2. & $\begin{array}{llrl}\text { COLLECT } & \text { STATEMENTS } & \text { OF } & \text { SIX } \\
\text { INDIVIDUALS } & \text { AND } & \text { INFORMATION } & \text { AND } \\
\text { DOCUMENTATION FROM A CRIMINAL CASE }\end{array}$ & USA & $\begin{array}{l}\text { ORGANIZED CRIME, } \\
\text { TRAFFICKING AND ML }\end{array}$ & DRUG & CONCLUDED \\
\hline 3. & ATTACHMENT OF USD299 450.00 & NICARAGUA & ML & & CONCLUDED \\
\hline 4. & $\begin{array}{lcr}\text { OBTAIN DIVERSE } & \text { INFORMATION } & \text { AND } \\
\text { DOCUMENTATION } & \text { RELATED } & \text { WITH } \\
\text { CRIMINAL RECORDS OF ...... } & \end{array}$ & EL SALVADOR & ML & & ACTIVE \\
\hline 5. & $\begin{array}{ll}\text { OBTAIN DIVERSE } & \text { INFORMATION, } \\
\text { DOCUMENTATION AND } & \text { STATEMENTS } \\
\text { RELATED WITH.......... } & \end{array}$ & USA & $\begin{array}{l}\text { DRUG TRAFFICKING, ML } \\
\text { CRIMINAL ASSOCIATION }\end{array}$ & AND & ACTIVE \\
\hline 6. & $\begin{array}{l}\text { COLLECT INFORMATION RELATED WITH } \\
\text { THE BANKRUPTCY OF THE COMPANY } \\
\text { "PUEBLO CORPORATION" }\end{array}$ & USA & ML & & ACTIVE \\
\hline 7. & $\begin{array}{l}\text { ATTACH DIVERSE ASSETS AND BANK } \\
\text { ACCOUNTS OF .......... }\end{array}$ & USA & ML & & ACTIVE \\
\hline 8. & REQUEST THE DETTACHMENT OF... & SWITZERLAND & $\begin{array}{l}\text { ORGANIZED } \quad \text { CRIME, } \\
\text { TRAFFICKING AND ML }\end{array}$ & DRUG & PENDING CLOSURE \\
\hline 9. & COLLECT CRIMINAL RECORDS & COLOMBIA & $\begin{array}{l}\text { ORGANIZED CRIME, } \\
\text { TRAFFICKING AND ML }\end{array}$ & DRUG & CONCLUDED \\
\hline 10. & $\begin{array}{lll}\text { COLLECT } & \text { FINANCIAL } & \text { INFORMATION, } \\
\text { DOCUMENTATION, CRIMINAL RECORDS } \\
\text { AND ENTRY AND } & \text { EXIT INFORMATION } \\
\text { OF...... } & & \end{array}$ & COLOMBIA & $\begin{array}{l}\text { ORGANIZED CRIME, } \\
\text { TRAFFICKING AND ML }\end{array}$ & DRUG & PENDING CLOSURE \\
\hline 11. & $\begin{array}{l}\text { OBTAIN INFORMATION ON CRIMINAL, } \\
\text { WORK AND IMMIGRATION RECORDS OF ..... }\end{array}$ & USA & ML & & ACTIVE \\
\hline
\end{tabular}

\begin{tabular}{|c|c|c|c|c|}
\hline \multicolumn{5}{|c|}{$\underline{2007}$} \\
\hline 6. & COLLECT CRIMINAL RECORDS & PANAMÁ & ORGANIZED CRIME AND ML & ACTIVE \\
\hline No. & NOTRERROSENOF THE ASSISTANCE & COUAARY & $\begin{array}{l}\text { ORGANIZED OFFENRSE, } \\
\text { TRAFFICKING AND ML }\end{array}$ & SIDATVS \\
\hline$\phi:$ & $\begin{array}{l}\text { 6OLLEE干 INFORAACRRMAPAN } \cdots \cdots \cdot \ldots \text { AND } \\
\text { DOCUMENTATION RELATED WITH } 9\end{array}$ & COtSAXBAIA & $\begin{array}{l}\text { ORGANIZEE CRINARANF ML DRUG } \\
\text { TRAFFICKING AND ML }\end{array}$ & COAETIMEED \\
\hline 9. & 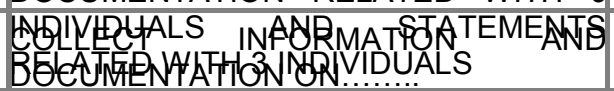 & GERMANY & DRUG TRAFFICKING AND ML & ACTIVE \\
\hline 2. & $\begin{array}{l}\text { COLLECT DOCUMENTATION } \\
\text { CRIMINAL ACTIVITIES OF ........ }\end{array}$ & USA & DRUG TRAFFICKING AND ML & ACTIVE \\
\hline 3. & OBTAIN DIVERSE INFORMATION ON & USA & DRUG TRAFFICKING AND ML & ACTIVE \\
\hline 4. & COLLECT STATEMENT FROM & USA & ML & ACTIVE \\
\hline 5. & $\begin{array}{l}\text { IMPLEMENT } \\
\text { ATTACHMENT OF } \\
\text { BANK ACCOUNTIVE } \\
\text { REALS ESTATE } \\
\text { OTHER ASSETS }\end{array}$ & USA & $\begin{array}{l}\text { DRUG TRAFFICKING, ML AND } \\
\text { CRIMINAL ASSOCIATION }\end{array}$ & ACTIVE \\
\hline
\end{tabular}




\section{PASSIVE REQUESTS}

\section{(Requests made to Mexico by other countries)}

With respect to the passive requests for ML, between 2004 and 2007 Mexico received a total of 404 requests, 54 of which were for ML. Of these, 41 were concluded and 11 are still pending

$\underline{2004}$

\begin{tabular}{|c|c|c|c|c|}
\hline No. & PURPOSE OF ASSISTANCE & COUNTRY & OFFENSE & STATUS \\
\hline 1 & 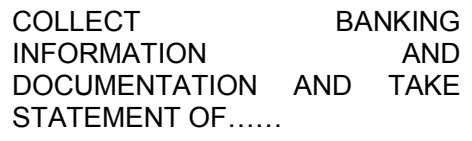 & USA & ML & CONCLUDED \\
\hline 2 & $\begin{array}{lrr}\text { COLLECT } & \text { BANKING } \\
\text { INFORMATION, } & \text { REAL } & \text { ESTATE } \\
\text { REGISTRIES } & \text { AND } & \text { TAX } \\
\text { DECLARATIONS OF } & \end{array}$ & USA & $\begin{array}{l}\text { ML AND DRUG } \\
\text { TRAFFICKING }\end{array}$ & CONCLUDED \\
\hline 3 & $\begin{array}{l}\text { COLLECT } \\
\text { DOCUMENTATION INFORMATION, } \\
\text { STATEMENTS }\end{array}$ & COLOMBIA & $\begin{array}{l}\text { ML AND ENRICHMENT OF } \\
\text { ASSETS }\end{array}$ & CONCLUDED \\
\hline 4 & $\begin{array}{l}\text { COLLECT } \\
\text { INFORMATION }\end{array}$ & USA & $\begin{array}{l}\text { ML AND CONCEALMENT } \\
\text { OF ASSETS }\end{array}$ & ACTIVE \\
\hline 5 & $\begin{array}{lr}\text { COLLECT } & \text { WITNESS } \\
\text { STATEMENTS, } & \text { BANKING } \\
\text { INFORMATION } & \\
\text { INFORMATION ON } \\
\text { VEHICLE }\end{array}$ & COLOMBIA & ML & CONCLUDED \\
\hline 6 & COLLECT CRIMINAL RECORDS & COLOMBIA & ML & CONCLUDED \\
\hline 7 & $\begin{array}{lrr}\text { COLLECT } & \text { BANKING } & \text { AND } \\
\text { CORPORATE } & \text { INFORMATION } \\
\text { AND STATEMENTS }\end{array}$ & PANAMA & ML & CONCLUDED \\
\hline 8 & 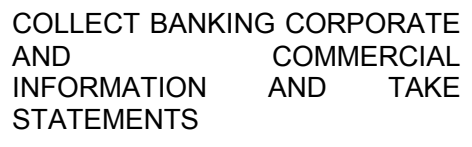 & COLOMBIA & ML & CONCLUDED \\
\hline 9 & $\begin{array}{l}\text { COLLECT } \quad \text { BANKING, } \\
\text { CORPORATE AND REAL ESTATE } \\
\text { INFORMATION }\end{array}$ & COLOMBIA & ML & CONCLUDED \\
\hline 10 & COLLECT STATEMENTS & USA & $\begin{array}{c}\text { ML, DRUG TRAFFICKING, } \\
\text { CORRUPTION AND BANK } \\
\text { FRAUD }\end{array}$ & CONCLUDED \\
\hline 11 & $\begin{array}{l}\text { COLLECT STATEMENTS FROM } \\
\text { LEGAL REPRESENTATIVES OF } \\
\text { TWO CORPORATIONS AND } \\
\text { CRIMINAL RECORDS }\end{array}$ & PANAMÁ & ML & CONCLUDED \\
\hline 12 & $\begin{array}{l}\text { COLLECT CERTIFIED COPIES OF } \\
\text { STATEMENTS FROM...... }\end{array}$ & UAS & $\begin{array}{l}\text { DRUG TRAFFICKING, ML. } \\
\text { ORGANIZED CRIME AND } \\
\text { MURDER }\end{array}$ & CONCLUDED \\
\hline 13 & $\begin{array}{l}\text { COLLECT BANKING AND } \\
\text { CORPORATE INFORMATION }\end{array}$ & COLOMBIA & ML & CONCLUDED \\
\hline 14 & $\begin{array}{l}\text { COLLECT } \\
\text { INFORMATION } \\
\text { RECORD } \\
\text { RE }\end{array}$ & COLOMBIA & $\begin{array}{l}\text { ML, ILLICIT ENRICHMENT } \\
\text { AND USE OF FALSE } \\
\text { DOCUMENTATION }\end{array}$ & CONCLUDED \\
\hline 15 & COLLECT CERTIFIED COPIES OF & ARGENTINA & ML & CONCLUDED \\
\hline
\end{tabular}


No. PURPOSE OF ASSISTANCE

JUDICIAL DECISIONS

17 COLLECT DOCUMENTATION, CRIMINAL RECORDS AND IMMIGRATION AND WORK INFORMATION

18

COLLECT STATEMENTS FROM.....

19 COLLECT STATEMENT FROM ....

20 COLLECT CRIMINAL RECORDS OF.....

21 CONDUCT SEVERAL ATTACHMENT AND FORFEITURE OF TWO AIRCRAFT

22 COLLECT INFORMATION AND TAX, CORPORATE AND REAL ESTATE DOCUMENTATION 23 COLLECT BANKING AND

24 COLECT INFORMATION ON THE EXISTANCE CORPORATION

25 COLECT BANKING INFORMATION AND CRIMINAL RECORDS

COLOMBIA DOCUMENTATION

28 COLLECT CRIMINAL RECORDS AND IMMIGRATION INFORMATION

COUNTRY

USA

COLOMBIA

COLOMBIA

COLOMBIA
OFFENSE

STATUS

COLOMBIA

$\mathrm{ML}$

CONCLUDED

$\mathrm{ML}$

CONCLUDED

$\mathrm{ML}$

ML

$\mathrm{ML}$

ML, FRAUD AND WIRE FRAUD

CONCLUDED

HONDURAS

COLOMBIA

\section{ML, FALSE STATEMENTS, KIDNAPPINGS AND EXTORTION}

$\mathrm{ML}$

$\mathrm{ML}$

$\mathrm{ML}$

$\mathrm{ML}$

$\mathrm{ML}$

ML

CONCLUDED

CONCLUDED

CONCLUDED

ACTIVE

CONCLUDED

ACTIVE

CONCLUDED

$\underline{2005}$

No. PURPOSE OF THE ASSISTANCE

1 COLLECT INFORMATION RELATED WITH AN AFI PROCEDURE IN THE FEDERAL DISTRICT

2 COLLECT BANKING INFORMATION

COLLECT INFORMATION

COLLECT CRIMINAL AND WORKRELATED RECORDS

5 INVESTIGATE THE EXISTANCE OF CRIMINAL RECORDS

6 COLLECT INFORMATION

7 COLLECT INFORMATION

8 COLLECT BANKING INFORMATION

9 COLLECT BANKING INFORMATION

10 COLLECT INFORMATION

\section{COUNTRY}

COLOMBIA

USA.

ARGENTINA

GUATEMALA

CHILE

PANAMÁ

SPAIN

USA

USA

COLOMBIA
OFFENSE

STATUS

ML AND FRAUD

CONCLUDED

CONCLUDED

CONCLUDED

CONCLUDED

CONCLUDED

ML

ACTIVE

$M L$

CONCLUDED

$M L$

CONCLUDED

ML

CONCLUDED

$M L$

ACTIVE 
11 COLLECT INFORMATION

COLOMBIA

$\mathrm{ML}$

ACTIVE

$\underline{2006}$

No. PURPOSE OF ASSISTANCE

COUNTRY

OFFENSE

STATUS

1 OBTAIN INFORMATION AND DOCUMENTATION ON....

2 OBTAIN INFORMATION AND DOCUMENTATION ON....

UK

DRUG TRAFFICKING AND ML

CONCLUDED

GUATEMALA

AND

ILLEGAL

ACTIVE

TRANSACTIONS

AND INVESTMENTS

3 COLLECT STATEMENT FROM....

USA

DRUG TRAFFICKING AND ML

CONCLUDED

4 COLECT DOCUMENTS AND

GUATEMALA

ML AND OTHERS

CONCLUDED CONDUCT INTERROGATIONS

GUATEMALA

ML AND OTHERS

CONCLUDED

GUATEMALA

ML

CONCLUDED

BRAZIL

ML

ACTIVE

$\underline{2007}$

\section{No. PURPOSE OF THE ASSISTANCE}

COUNTRY

OFFENSE

STATUS

1 OBTAIN DOCUMENTS

USA

BANK FRAUD, WIRE FRAUD, VIOLATION OF THE LAWS OF

ACTIVE THE JUSTICE DEPARTMENT

2 COLLECT INFORMATION

USA ML

ACTIVE

3 COLLECT CRIMINAL

AND GUATEMALA ML

ACTIVE

4 VERIFY EXISTANCE OF A BANK ACCOUNT

USA ML AND OTHERS

ACTIVE

5 OBTAIN INFORMATION ON A JUDICIAL PROCEDURE

USA DRUG TRAFFICKING AND ML

ACTIVE

6 COLLECT WITNESS STATEMENTS AND CRIMINAL RECORDS

7 COLLECT INFORMATION ON BANK ACCOUNTS

8 OBTAIN CRIMINAL RECORDS

USA

ACTIVE

GUATEMALA ML

ACTIVE

CHILE ML

ACTIVE

9 INTERVIEW WITNESS

USA ML

ACTIVE

\subsubsection{Recommendations and Comments}

768. Mexican legislation provides an internal legal system of mutual legal assistance in the absence of agreements, which is highly useful for facilitating international legal cooperation.

769. As indicated in the analysis of Special Recommendation III, consideration should be given to an expedited system and to establishing a system avoiding prolonged legal verification periods, thereby allowing the Public Prosecutor's Office to freeze assets, subject to approval by the judge hearing the case. 
770. Mexico is a party to the International Convention for the Suppression of the Financing of Terrorism of 1999, which expressly establishes that States Parties may not refuse a request for mutual legal assistance on the grounds of bank secrecy or fiscal secrecy when that request is made as part of an investigation or the prosecution of terrorist acts. These provisions should be included in the Extradition Law or in the laws on international legal cooperation issued in due course.

771. Specific recommendations:

- $\quad$ Appropriate laws and procedures should be implemented to freeze terrorist funds or other assets at the request of a foreign country.

- Introduce legal provisions for confiscating goods of equivalent value.

- $\quad$ Address the deficiencies in the money laundering and terrorist financing offenses described under R1. and SR.II as they can impact on Mexico's ability to provide MLA.

- $\quad$ Address the deficiencies in the process for freezing terrorist assets described under SR III as they impact on Mexico's capacity to freeze, seize and confiscate terrorist assets at foreign request.

\subsubsection{Compliance with Recommendations 36 to 38 and Special Recommendation V}

\begin{tabular}{|l|l|l|}
\hline R.36 & Rating & Summary of factors relevant to s.6.3 underlying overall rating \\
\hline R.37 & LC & $\begin{array}{l}\text { - The deficiencies in the money laundering and terrorist financing offenses may impact } \\
\text { on Mexico's ability to provide MLA. }\end{array}$ \\
\hline R.38 & PC & $\begin{array}{l}\text { The deficiencies in the money laundering and terrorist financing offenses may impact } \\
\text { on Mexico's ability to provide MLA. }\end{array}$ \\
\hline SR.V & PC & $\begin{array}{l}\text { There are no appropriate laws and procedures to freeze terrorist funds or other } \\
\text { assets at the request of a foreign country. }\end{array}$ \\
$\begin{array}{l}\text { Mexican law contains no provisions for confiscating goods of equivalent value. } \\
\text { - }\end{array}$ & $\begin{array}{l}\text { The deficiencies in the terrorist financing offense described under SR.II impact on } \\
\text { Mexico's ability to provide MLA. } \\
\text { The deficiencies in the process for freezing terrorist assets described under SR.III } \\
\text { impact on Mexico's capacity to freeze, seize and confiscate terrorist assets at foreign } \\
\text { request. }\end{array}$ \\
\hline
\end{tabular}

\subsection{Extradition (R.37, 39, SR.V)}

\subsubsection{Description and Analysis}

772. As in most countries, extradition in Mexico is a mixed responsibility. The Executive is responsible for the administrative aspects of extradition, through the Ministry of Foreign Affairs and the PGR, while the District Courts are responsible for its judicial aspects.

773. The processing of extradition requests is based on the provisions of the Political Constitution of the United Mexican States, and of the treaty applicable to the specific case. In the absence of a treaty, the provisions of the International Extradition Law shall apply, based on the general principles of the law and on international reciprocity. 
774. The extradition procedure in Mexico is as follows: once the formal request for extradition has been received and accepted, the Ministry of Foreign Affairs sends the corresponding document and file to the PGR so that it can request the competent District Court judge to issue an order to comply with the request and arrest the requested individual and, if applicable, seize documents, money, or other objects found in their possession that are related to the alleged crime or that could serve as evidence, if so requested by the requesting State.

775. Once the individual of the request has been arrested, he will be brought, without delay, before the appropriate District Court, which will advise him of the content of the extradition request and the supporting documents. The detainee will offer a defense, speaking on his own behalf or through his defense attorney, and will have up to three days to assert a defense.

776. The requested individual will have 20 days in which to assert his defense. This period may be extended by the judge if necessary with the prior approval of the Public Prosecutor's Office. In that same period of time, the Public Prosecutor's Office may submit the evidence it deems appropriate.

777. At the end of the three-day period granted to assert a defense, or before that time, if the necessary steps have been taken, the judge shall issue his opinion to the Ministry of Foreign Affairs within the following five days on the case and the evidence presented. If, within the established period for asserting a defense, the requested individual has not done so or expressly consented to his status, the judge will proceed to issue his opinion without any further proceedings being necessary.

778. The judge will submit his opinion and the corresponding file to the Ministry of Foreign Affairs so that the Minister can issue the final resolution. The person under arrest, meanwhile, will remain at the location in which he is available to this entity.

779. The Ministry of Foreign Affairs, based on the file and the judge's opinion, will rule whether to grant or reject the extradition request within the following 20 days.

780. If the ruling grants extradition, it may only be contested through an "amparo" proceeding. Once the 15-day period has elapsed without the person under arrest or his legal representative having filed a request for an "amparo" proceeding or if, as applicable, the request is denied, the Ministry of Foreign Affairs will inform the requesting State that its extradition request has been granted and will order the surrender of the individual to the requesting State. The requested individual shall be surrendered within no more than 60 days.

781. The procedure described is applicable to extradition requests based on an international legal instrument on extradition or, in the absence thereof, on the principle of international reciprocity.

782. In Mexico, extradition is established in the Constitution, Article 119(III) of which establishes that:

"Extraditions at the request of a foreign State shall be handled by the Federal Executive, with the participation of the judicial authority under the terms of this Constitution, the international agreements signed on this issue, and the applicable regulations. In such cases, the writ issued by the judge ordering compliance with the request shall be sufficient to detain the requested individual for up to 60 calendar days." 
783. International agreements and the International Extradition Law regulate the procedures and requirements for extradition of individuals in Mexico. By way of example, below are the corresponding articles of Mexico's International Extradition Law:

784. Articles 2 and 3 of the International Extradition Law establish the procedures to be followed to process and resolve any extradition request received, and indicate which entity is responsible for the processing of such requests.

785. The requirements for processing an extradition request are set forth in Article 10 of the aforementioned law:

786. "The United Mexican States will require, for processing the request, that the Requesting State undertake:

I. If appropriate, to grant reciprocity.

II. That crimes committed prior to the extradition, omitted from the complaint and not connected to those specified therein, will not be taken into consideration in the proceeding, not even as aggravating circumstances. The Requesting State is relieved of this commitment if the accused freely consents to be tried by [the Requesting State] or if, having remained in its territory more than two consecutive months while absolutely free to leave, he fails to do so.

III. That if the requested individual is extradited he will be brought before a competent court, established under law prior to the crime of which he is accused in the complaint, to be tried and sentenced in accordance with the formalities required by law.

IV. That his defense will be heard and he will be provided the legal resources in any event, even if he has been convicted in absentia.

V. That if the crime of which the subject of the request is accused is punishable, under its laws, by death or any of the punishments specified in Article 22 of the Constitution, only imprisonment or a less severe punishment established by those laws will be imposed, either directly or by substitution or commutation.

VI. That extradition of the same individual will not be granted to a third state, except in the cases specified in the second section of this article; and

VII. That the United Mexican States will be provided with a certified copy of the final judgment in the proceeding."

Dual Criminality and Mutual Assistance (c. $37.1 \& 37.2)$

47. See Recommendation 37

Money Laundering as Extraditable Offense (c. 39.1)

787. The crime of conducting operations using illegally obtained resources, known usually as money laundering, is an extraditable offense in Mexico. Extradition requests are processed in accordance with the provisions of international agreements signed with other countries or, in the absence thereof, pursuant to the provisions of the International Extradition Law. However, the deficiencies in the money laundering and terrorist financing offenses (discussed under R. 1 and SR II respectively) may impact on Mexico's ability to extradite.

788. There is no special procedure followed in Mexico for money laundering cases; the same procedure is followed in all cases for all extraditable offenses. 
Extradition of Nationals (c. 39.2)

789. In accordance with Article 14 of the International Extradition Law, no Mexican may be turned over to a foreign state unless under circumstances that are exceptional in the judgment of the Executive. The decision of whether or not to grant the extradition of nationals is made at the discretion of the Executive and must be duly substantiated and justified in accordance with the procedures established in the Law.

790. Some international agreements stipulate that if a national is not extradited, the national authorities shall investigate the offense. Example: Article 9 of the Extradition Treaty with the United States establishes that neither contracting party shall be bound to deliver up its own nationals, but if extradition is not granted, the Requested Party shall submit the case to its competent authorities for the purpose of prosecution, provided that Party has jurisdiction over the offense.

791. Similarly, Article 32 of the International Extradition Law states that: "If the requested individual is Mexican and extradition is denied for that sole reason, the Ministry of Foreign Affairs will notify the detainee and the Public Prosecutor's Office, making the detainee available to him and remitting the record to him so that the Public Prosecutor may transfer the case to the competent court, if appropriate."

Cooperation for Prosecution of Nationals (applying c. 39.2(b), c. 39.3)

792. Mexico has implemented a number of mechanisms to obtain evidence for the purposes of prosecuting any Mexican citizen who is to be tried under Article 4 of the CPF, which provides for the possibility of a domestic trial when the crime is committed abroad, or the extradition is not granted through the channels set up by the mutual legal assistance agreements in criminal matters that have been signed by Mexico, or under the principle of reciprocity, through which they can provide the widest range of assistance under international law.

793. Among other legal assistance mechanisms, Mexico has included provisions in recent agreements for handling cases using videoconferencing, an innovative mechanism that streamlines and assists with the administration of justice. This practice is established in the agreements on mutual assistance in criminal matters signed recently with Brazil and Spain.

Efficiency of Extradition Process (c. 39.4)

794. The national legal framework and applicable international instruments regulating extradition make it possible to extradite individuals presumed to be the perpetrators of the crime of money laundering. Based on the procedures established with each country, it is possible to present an individual involved in money laundering activities, provided that the requirements established in the corresponding international instrument are met. The International Extradition Law and applicable international instruments establish a strict process, as a result of which there are no unjustified delays in proceedings, and in which the procedures analyzed above are followed.

\section{Additional Element (R.39) - Existence of Simplified Procedures relating to Extradition (c. 39.5)}

795. Requests for the extradition of individuals must be submitted by diplomatic means, in accordance with national law. In terms of simplifying the extradition of individuals who agree to be extradited immediately to the requesting country, it is worth noting that most international extradition treaties signed by Mexico establish the possibility of holding a summary proceeding, provided that the requested individual has given his consent to it. 
796. The simplified extradition process is established in the international agreements signed by Mexico and in the International Extradition Law as follows:

797. Once the subject of the request has been arrested, he will be brought, without delay, before the appropriate District Court, which will advise him of the content of the extradition request and the supporting documents. The detainee will offer a defense, speaking on his own behalf or through his defense attorney, and will have up to three days to assert a defense.

798. If the requested individual fails to assert a defense or expressly consents to his status within the three-day period, the judge will proceed, without additional formalities and within three days, to issue his opinion on the case and the evidence presented.

Additional Element under SR V (applying c. 39.5 in R. 39, c V.8)

799. The deficiencies in the terrorist financing offense described under SR.II could impact on Mexico's ability to extradite.

Statistics (applying R.32)

\begin{tabular}{|c|c|c|}
\hline YEARS & $\begin{array}{c}\text { PERSONS } \\
\text { EXTRADITED BY } \\
\text { MEXICO }\end{array}$ & $\begin{array}{c}\text { PERSONS } \\
\text { EXTRADITED TO } \\
\text { MEXICO }\end{array}$ \\
\hline 2002 & 29 & 18 \\
\hline 2003 & 35 & 22 \\
\hline 2004 & 34 & 18 \\
\hline 2005 & 42 & 21 \\
\hline 2006 & 72 & 24 \\
\hline 2007 & 86 & 13 \\
\hline 2008 & 6 & 0 \\
\hline
\end{tabular}

\begin{tabular}{|c|c|c|c|c|c|}
\hline No. & NATIONALITY & OFFENSE & COUNTRY & STATUS & AMOUNT \\
\hline 1. & MEXICAN (ALL) & ML & USA & $\begin{array}{l}\text { US GOVT. DESISTED } \\
\text { AS A RESULT OF THE } \\
\text { DEATH OF PERSON } \\
\text { TO BE EXTRADITED }\end{array}$ & USD 3000000 \\
\hline 2. & MEXICAN & ML & FRANCE & $\begin{array}{c}\text { CONCLUDED. NEVER } \\
\text { RECEIEVD A } \\
\text { REQUESTED FOR } \\
\text { PROVISIONAL } \\
\text { ARREST }\end{array}$ & UNSPECIFIED \\
\hline 3. & US & $\begin{array}{c}\text { DRUG } \\
\text { TRAFFICKING } \\
\text { AND ML }\end{array}$ & USA & $\begin{array}{c}\text { DELIVERED ON } \\
7 / 25 / 2997\end{array}$ & UNSPECIFIED \\
\hline 4. & MEXICAN & ML & USA & $\begin{array}{c}\text { DELIVERED ON } \\
11 / 30 / 2006\end{array}$ & UNSPECIFIED \\
\hline
\end{tabular}




\begin{tabular}{|l|l|c|c|c|c|} 
& & & & \\
\hline 5. & MEXICAN & DRUG & USA & DELIVERED ON & UNSPECIFIED \\
TRAFFICKING & AND ML & & & \\
\hline
\end{tabular}




\begin{tabular}{|c|l|c|c|c|c|}
\hline No. & NATIONALITY & OFFENSE & COUNTRY & STATUS & AMOUNT \\
\hline 1. & MEXICAN & ML & USA & $\begin{array}{c}\text { DELIVERED ON } \\
1 / 19 / 2007\end{array}$ & UNSPECIFIED \\
\hline 2. & USA & $\begin{array}{c}\text { DRUG } \\
\text { TRAFFICKING } \\
\text { AND ML }\end{array}$ & USA & $\begin{array}{c}\text { DETENTION } \\
\text { ORDER PENDING } \\
\text { IMPLEMENTATION }\end{array}$ & UNSPECIFIED \\
\hline 3. & MEXICAN & $\begin{array}{c}\text { DRUG } \\
\text { TRAFFICKING } \\
\text { AND ML }\end{array}$ & USA & $\begin{array}{c}\text { DELIEVRED ON } \\
11 / 7 / 2007\end{array}$ & UNSPECIFIED \\
\hline 4. & USA & $\begin{array}{c}\text { DRUG } \\
\text { TRAFFICKING } \\
\text { AND ML }\end{array}$ & USA & $\begin{array}{c}\text { DELIVERED ON } \\
10 / 12 / 2006\end{array}$ & UNSPECIFIED \\
\hline 5. & CUBAN & ML & USA & $\begin{array}{c}\text { DELIVERED ON } \\
10 / 2 / 2006\end{array}$ & UNSPECIFIED \\
\hline 6. & RUMANIAN & ML & USA & $\begin{array}{c}\text { DELIVERED ON } \\
7 / 11 / 2006\end{array}$ & UNSPECIFIED \\
\hline
\end{tabular}

\begin{tabular}{|c|c|c|c|c|c|}
\hline No. & NACIONALIDAD & DELITO & PAÍs & STATUS & MONTO \\
\hline 1. & MEXICANA & $\begin{array}{c}\text { LAVADO DE } \\
\text { DINERO }\end{array}$ & EUA & $\begin{array}{c}\text { ENTREGADO EL } \\
19 / E N E . / 2007\end{array}$ & NO ESPECIFICADO \\
\hline 2. & ESTADOUNIDENSE & $\begin{array}{c}\text { CONTRA LA } \\
\text { SALUD Y } \\
\text { LAVADO DE } \\
\text { DINERO }\end{array}$ & EUA & $\begin{array}{c}\text { PENDIENTE DE } \\
\text { CUMPLIMENTAR } \\
\text { LA ORDEN DE } \\
\text { DETENCIÓN }\end{array}$ & NO ESPECÍFICADO \\
\hline 3. & MEXICANA & $\begin{array}{c}\text { CONTRA LA } \\
\text { SALUD Y } \\
\text { LAVADO DE } \\
\text { DINERO }\end{array}$ & EUA & $\begin{array}{c}\text { ENTREGADO EL } \\
\text { 07/NOV./2007 }\end{array}$ & NO ESPECIFICADO \\
\hline 4. & ESTADOUNIDENSE & $\begin{array}{c}\text { CONTRA LA } \\
\text { SALUD Y } \\
\text { LAVADO DE } \\
\text { DINERO }\end{array}$ & EUA & $\begin{array}{c}\text { ENTREGADO EL } \\
12 / O C T . / 2006\end{array}$ & NO ESPECIFICADO \\
\hline 5. & CUBANO & $\begin{array}{c}\text { LAVADO DE } \\
\text { DINERO }\end{array}$ & EUA & $\begin{array}{c}\text { ENTREGADO EL } \\
\text { 02/OCT./2006 }\end{array}$ & NO ESPECIFICADO \\
\hline 6. & RUMANA & $\begin{array}{c}\text { LAVADO DE } \\
\text { DINERO }\end{array}$ & EUA & $\begin{array}{c}\text { ENTREGADO EL } \\
11 / A G O . / 2006\end{array}$ \\
\hline
\end{tabular}




\begin{tabular}{|c|c|c|c|c|c|}
\hline No. & NATIONALITY & OFFENSE & COUNTRY & STATUS & AMOUNT \\
\hline 1. & MEXICAN & $\begin{array}{c}\text { DRUG } \\
\text { TRAFFICKING, ML } \\
\text { AND CRIMINAL } \\
\text { ASSOCIATION TO } \\
\text { COMMIT } \\
\text { HOMICIDE }\end{array}$ & USA & $\begin{array}{c}\text { DETENTION } \\
\text { ORDER PENDING } \\
\text { IMPLEMENTATION }\end{array}$ & UNSPECIFIED \\
\hline 2. & MEXICAN & $\begin{array}{c}\text { DRUG } \\
\text { TRAFFICKING, ML } \\
\text { AND CRIMINAL } \\
\text { ASSOCIATION }\end{array}$ & USA & $\begin{array}{c}\text { DETENTION } \\
\text { ORDER PENDING } \\
\text { IMPLEMENTATION }\end{array}$ & UNSPECIFIED \\
\hline 3. & MEXICAN & $\begin{array}{c}\text { DRUG } \\
\text { TRAFFICKING, ML } \\
\text { AND CRIMINAL } \\
\text { ASSOCIATION TO } \\
\text { COMMIT } \\
\text { HOMICIDE }\end{array}$ & USA & $\begin{array}{c}\text { DETENTION } \\
\text { ORDER PENDING } \\
\text { IMPLEMENTATION }\end{array}$ & UNSPECIFIED \\
\hline 4. & MEXICAN & $\begin{array}{c}\text { FORGERY OF } \\
\text { DOCUMENTATION } \\
\text { AND ML } \\
\end{array}$ & USA & $\begin{array}{c}\text { DELIVERED ON } \\
1 / 8 / 2008\end{array}$ & UNSPECIFIED \\
\hline 5. & MEXICAN & ML & USA & $\begin{array}{c}\text { DELIVERED ON } \\
11 / 13 / 2007\end{array}$ & USD 653570 \\
\hline 6. & MEXICAN & $\begin{array}{c}\text { DRUG } \\
\text { TRAFFICKING } \\
\text { AND ML }\end{array}$ & USA & $\begin{array}{c}\text { DELIVERED ON } \\
6 / 5 / 2007\end{array}$ & UNSPECIFIED \\
\hline 7. & ITALIAN & ML & USA & $\begin{array}{c}\text { DELIVERED ON } \\
5 / 4 / 2007\end{array}$ & UNSPECIFIED \\
\hline
\end{tabular}

\begin{tabular}{|c|l|c|c|c|c|}
\hline & NATIONALITY & OFFENSE & COUNTRY & STATUS & AMOUNT \\
\hline 1. & MEXICAN & ML & USA & $\begin{array}{c}\text { REQUEST FOR } \\
\text { PROVISIONAL } \\
\text { DETENTION FILED } \\
\text { ON 10/2/2007 }\end{array}$ & UNSPECIFIED \\
\hline 2. & MEXICAN & ML & USA & PENDING DELIVERY & UNSPECIFIED \\
\hline 3. & MEXICAN & ML & USA & $\begin{array}{c}\text { PENDING OPINION } \\
\text { OF DISTRICT } \\
\text { COURT }\end{array}$ & UNSPECIFIED \\
\hline 4. & MEXICAN & ML & USA & $\begin{array}{c}\text { PENDING OPINION } \\
\text { OF DISTRICT } \\
\text { COURT }\end{array}$ & UNSPECIFIED \\
\hline 5. & MEXICAN & ML & USA & $\begin{array}{c}\text { PENDING OPINION } \\
\text { OF DISTRICT } \\
\text { COURT }\end{array}$ & UNSPECIFIED \\
\hline
\end{tabular}




\begin{tabular}{|c|c|c|c|c|c|}
\hline & NATIONALITY & OFFENSE & COUNTRY & STATUS & AMOUNT \\
\hline 6. & MEXICAN & $\begin{array}{l}\text { DRUG TRAFFICKING, } \\
\text { ML AND CRIMINAL } \\
\text { ASSOCIATION }\end{array}$ & USA & $\begin{array}{l}\text { HAS AN "AMPARO" } \\
\text { AGAINST THE } \\
\text { EXTRADITION }\end{array}$ & UNSPECIFIED \\
\hline 7. & MEXICAN & $\begin{array}{l}\text { DRUG TRAFFICKING, } \\
\text { ML AND CRIMINAL } \\
\text { ASSOCIATION }\end{array}$ & USA & $\begin{array}{c}\text { DETENTION ORDER } \\
\text { PENDING } \\
\text { IMPLEMENATION }\end{array}$ & UNSPECIFIED \\
\hline 8. & MEXICAN & $\begin{array}{l}\text { DRUG TRAFFICKING, } \\
\text { ML AND CRIMINAL } \\
\text { ASSOCIATION }\end{array}$ & USA & $\begin{array}{c}\text { DETENTION ORDER } \\
\text { PENDING } \\
\text { IMPLEMENTATION }\end{array}$ & UNSPECIFIED \\
\hline 9. & MEXICAN & $\begin{array}{l}\text { DRUG TRAFFICKING, } \\
\text { ML AND CRIMINAL } \\
\text { ASSOCIATION }\end{array}$ & USA & $\begin{array}{c}\text { DETENTION ORDER } \\
\text { PENDING } \\
\text { IMPLEMENTATION }\end{array}$ & UNSPECIFIED \\
\hline
\end{tabular}

\begin{tabular}{|c|c|c|c|c|c|}
\hline No. & NATIONALITY & OFFENSE & COUNTRY & STATUS & AMOUNT \\
\hline 1. & MEXICAN & $\begin{array}{c}\text { ML, ORGANIZED } \\
\text { CRIME, DRUG } \\
\text { TRAFFICKING, } \\
\text { POSSESSION OF } \\
\text { FIREARMS } \\
\text { RESERVED TO THE } \\
\text { EXCLUSIVE USE BY } \\
\text { THE ARMY }\end{array}$ & USA & $\begin{array}{c}\text { PENDING THE US } \\
\text { GOVTS. FILING A } \\
\text { REQUEST FOR } \\
\text { PROVISIONAL } \\
\text { DETENTION }\end{array}$ & $\begin{array}{r}\text { USD } 205564753 \\
\text { EUR } 201460 \\
\text { CAD } 180 \\
\text { MXN } 14306520\end{array}$ \\
\hline
\end{tabular}

\section{Recommendations and Comments}

800. As the statistics reflect, there has been a significant increase in recent years of extraditions granted at foreign request. The General Directorate of Extraditions and Legal Assistance at PGR should be commended for its outstanding work in this area, particularly during the most recent period.

801. Nevertheless, assessors recommend that Mexico address the deficiencies of the ML and TF offense described under R. 1 and SR II respectively, which could impact on Mexico's ability to extradite.

\subsubsection{Compliance with Recommendations 37 \& 39, and Special Recommendation V}

\begin{tabular}{|c|c|cc|}
\hline R.39 & Rating & \multicolumn{1}{c|}{ Summary of factors relevant to s.6.4 underlying overall rating } \\
\hline R.37 & LC & - & $\begin{array}{l}\text { The deficiencies in the money laundering and terrorist financing offenses } \\
\text { may impact on Mexico's ability to extradite. }\end{array}$ \\
\hline SR.V & LC & $\begin{array}{l}\text { The deficiencies in the money laundering and terrorist financing offenses } \\
\text { may impact on Mexico's ability to extradite. }\end{array}$ \\
\hline
\end{tabular}


Mexico's ability to extradite.

\subsection{Other Forms of International Cooperation (R.40 \& SR.V)}

\subsubsection{Description and Analysis}

\section{Legal Framework}

802. Mexican authorities have the authority to collaborate with their foreign counterparts in their respective areas of competence. In the majority of cases, international cooperation may take place directly between authorities exercising similar responsibilities and functions.

\section{Widest Range of International Cooperation (c. 40.1)}

803. Administrative and law enforcement authorities concerned with combatting money laundering and terrorist financing in Mexico (including the FIU, the financial sector supervisors and the Attorney General's Office) are able to provide the widest range of international cooperation to their foreign counterparts.

804. It is important to state at the outset that no country has expressed concerns to the assessment team with regards to Mexico's level of international cooperation. To the contrary, one country in particular emphasized the significant improvements in international cooperation with Mexico in the AML/CFT area over the past year. Specifically, this country highlighted the constructive and positive developments in international cooperation at Mexico's FIU level and the impressive progress in international collaborative efforts with Mexico's Attorney General's Office.

805. The FIU is authorized under Article 15, sections XX, XXII and XXIII of the SHCP's internal regulations to exchange information and documentation with the competent authorities of the countries with which treaties or agreements, on the matters over which it is competent, have been executed. In this context, the FIU has negotiated and signed a Memoranda of Understanding on cooperation for the exchange of intelligence information in support of investigations related with the crimes of money laundering and terrorist financing. The FIU may also and has exchanged financial documentation and information with foreign analogous entities that form part of the Egmont Group of Financial Intelligence Units. Any information available to the FIU may be shared with foreign FIUs.

806. The FIU has the necessary powers to provide to its foreign counterparts the widest range of international cooperation, since the above mentioned Article 15 under Sections VII, VIII, X and XII authorizes it to:

a) Request and obtain from reporting entities, directly or through the corresponding competent authorities, information and documentation with respect to reports on transactions related with money laundering or terrorist financing and any additional information from other persons or sources that may be necessary to exercise its powers.

b) Request the administrative units of the SHCP and other competent national authorities to collaborate in the exercise of its powers and provide the necessary information and documentation, including access to databases. 
c) Receive, gather and analyze, within the scope of its competency, the evidence, confirmations, reports, documents and statements on the activities related with the crimes of money laundering, terrorism and terrorist financing.

d) Supervisory commissions are authorized to sign a Memoranda of Understanding on information exchange and provide the widest range of international cooperation to foreign supervisory authorities as well. For instance, the Banking and Securities Commission (CNBV) is empowered to provide legal assistance to its foreign counterparts regarding confidential information provided that an agreement (MOU) between both authorities (CNBV and requesting authority) has been signed and as long as the reciprocity principle prevails in such agreement.

807. The CNBV also has the power to authorize the performance of a visit by a foreign supervisor to its subsidiaries located in Mexico. Likewise, CNBV may carry out its surveillance and inspections activities abroad in order to supervise its foreign subsidiaries. In order for a foreign counterpart to perform a visit to its foreign subsidiary, it needs to have a MoU signed with CNBV, where the reciprocity principle prevails. Such visits shall be subject to Mexican legal provisions and to terms and conditions specified in the MoU signed.

808. CNBV has signed agreements for the exchange of information with all the home supervisors of financial entities doing business in Mexico, with the purpose to have an effective exchange of information and visits. During such visits, foreign authorities may have access to all the information needed to perform their supervisory powers, including all information and documents related to AML/CFT.

809. On the law enforcement side, mutual legal assistance instruments establish the procedures that Mexican law enforcement authorities must follow in order to comply with a legal assistance request from abroad.

Provision of Assistance in Timely, Constructive and Effective Manner (c. 40.1.1)

810. Mexico has the ability to provide assistance in a rapid, constructive and effective manner.

811. The Financial Intelligence Unit (FIU) as a member of the Egmont Group since 1998, in its relationships with foreign counterparts, follows the directives contained in the Statement of Purpose adopted in Madrid on June 24, 1997, the principles for information exchange for cases of money laundering and terrorist financing approved in The Hague on June 13, 2001 and the best practices agreed upon on November 15, 2004. In this sense, it formulates and handles information requests on the basis of mutual trust, based on reciprocity principles and on the agreements that may exist between the parties. It is authorized to exchange information spontaneously or at the request of a foreign FIU.

812. The FIU is connected to the private security network of the Egmont group, for which it can process information requests quickly, effectively, and securely.

813. Taking into consideration its scope of competence, CNBV has carried out a series of activities with the purpose to ensure that the requests for assistance are responded in a rapid, constructive, and effective manner. There is a process implemented at CNBV in order to provide answers to the requests for information and for the performance of on-site visits by overseas supervisors. Such process is certified under the international standard named: (ISO 9001:2000), with 
the purpose to ensure that all requests for information are answered on an expeditious basis. There also exists the continuous improvement of such process to enforce its compliance. With regards to implementation, the CNBV has been cooperating with foreign counterparts under the terms of MOUs entered with such authorities. Please refer to EC 40.2 below as well as the table on the supervisory MOUs entered by supervisors with foreign counterparts, and the statistics table under Rec. 32 below with respect to implementation of these arrangements.

814. Legal assistance among law enforcement authorities is provided in accordance with bilateral and multilateral agreements and treaties on such matter or in accordance with international reciprocity. Likewise, the process for provision of mutual legal assistance in a prompt manner has been certified by the standard ISO 9001:2000.

Clear and Effective Gateways for Exchange of Information (c. 40.2)

\section{Supervisory Cooperation}

815. The CNBV's International Mechanisms for cooperation: Memoranda of Understanding (MoUs) can be entered into with foreign regulatory and supervisory organizations, including the exchange of information protected by secrecy provisions, as well as information obtained from the performance of its surveillance powers. (Article 4, paragraph XXIV of the Law of the Comision Nacional Bancaria y de Valores, (CNBV). Article 9 of this Law allows the CNBV to provide legal assistance to its foreign counterparts regarding confidential information under these MoUs under conditions of reciprocity. MoUs may be either bilateral or multilateral, whether restricted to banking or securities, or both. The law allows for the CNBV to investigate and perform visits of inspection with respect to the persons individuals and legal entities who may be carrying unauthorized financial activities.

816. The abovementioned law also allows for reciprocal inspection visits by the CNBV and overseas supervisors. (Article, paragraph XVIII and Art. 5, Article 66 to 68 of the Surveillance Regulation of the CNBV and the MoUs). Such visits shall be subject to Mexican legal provisions and to terms and conditions specified in the MoU signed. During such visits, foreign authorities may have access to all the information needed to perform their supervisory powers, including all information and documents related to AML/CFT.

817. Banking Sector: The CNBV has entered into bilateral MoUs (memoranda of understanding) with financial authority counterparts in 10 countries, including: Argentina, Canada, Guatemala, Panama, Peru, Spain, The Netherlands, United States of America, and Venezuela. With respect to the United States, it has MoUs with five counterpart supervisors including the Board of Governors of the Federal Reserve System, the Office of the Comptroller of the Currency, the Office of Thrift Supervision (in process), the Federal Deposit Insurance Corporation (in process), and the New York State Banking Department.

818. Securities: With respect to securities supervision, the CNBV has also entered into bilateral MoUs with 12 countries including Argentina, Brazil, Chile, Colombia, Costa Rica, Ecuador, France, Panama, Paraguay, Portugal, Spain, and the United States (with the Commodity Future Trading Commission and the Securities Exchange Commission). As a member of IOSCO, the CNBV has also entered into a multilateral MoU that includes 40 signatory countries. No information was provided with respect to implementation of these arrangements.

819. Joint Banking and Securities: MoUs have been signed with six countries including Brazil, British Virgin Islands, El Salvador, Honduras, Switzerland, and Uruguay. 
820. The CNBV indicated that it has actively cooperated with some of these counterparts, particularly those from the United States. The CNBV has only conducted inspection visits of overseas Mexican financial institutions on two occasions in 2007. Foreign supervisors have participated in the inspections in Mexico only three times, once in 2005 and twice in 2006. There were 20 AML-specific visits by overseas supervisors since 2005. Most of these visits involved banks. No similar cooperation statistics was provided with respect to the insurance sector.

821. This level of cooperation is relatively low but may be due to the fact that internationalization of the Mexican banking system commenced within the last decade. Nonetheless, the CNBV informed the mission that it maintains regular informal contact by telephone with overseas supervisors to coordinate and discuss supervisory activities and issues, including for AML. The authorities also participate in regional and international supervisory conferences and events.

822. The CNBV has signed the following Bilateral Memoranda of Understanding (MoU):

\begin{tabular}{|c|c|}
\hline \multicolumn{2}{|r|}{ Bilateral MoU's in banking matters } \\
\hline Country & Authority \\
\hline Argentina & Central Bank of the Republic of Argentina \\
\hline Canada & Office of the Superintendent of Financial Institutions \\
\hline Spain & Bank of Spain \\
\hline United States of America & $\begin{array}{l}\text { Board of Governors of the Federal Reserve System } \\
\text { And the } \\
\text { The Office of the Comptroller of the Currency }\end{array}$ \\
\hline United States of America & New York State Banking Department \\
\hline Guatemala & Superintendence of Banks \\
\hline The Netherlands & De Netherlandsche Bank N.V. \\
\hline Panama & Superintendence of Banks \\
\hline Peru & Superintendence of Banks and Insurance \\
\hline United Kingdom & Financial Services Authority \\
\hline Venezuela & Superintendence of Banks and other Financial Institutions \\
\hline
\end{tabular}

\begin{tabular}{|l|l|}
\hline \multicolumn{2}{|c|}{ Bilateral MOU's on securities matters } \\
\hline Argentina & \multicolumn{1}{c|}{ Authority } \\
\hline Brazil & National Securities Commission of Argentina \\
\hline Chile & Comissão de Valores Mobiliários \\
\hline Colombia & Superintendence of Securities and Insurance \\
\hline Costa Rica & Superintendence of Securities \\
\hline Ecuador & National Commission of Securities \\
\hline Spain & Superintendence of Companies \\
\hline United States of America & Stock Market Commission \\
\hline
\end{tabular}




\begin{tabular}{|l|l|}
\hline \multicolumn{2}{|c|}{ Bilateral MOU's on securities matters } \\
\hline \multicolumn{1}{|c|}{ Country } & \multicolumn{1}{c|}{ Authority } \\
\hline United States of America & Securities and Exchange commission \\
\hline France & Commission des Opérations de Bourse \\
\hline Panama & National Securities Commission \\
\hline Paraguay & National Securities Commission \\
\hline Portugal & Comissão do Mercado de Valores Mobiliários \\
\hline
\end{tabular}

\begin{tabular}{|l|l|}
\hline \multicolumn{2}{|c|}{ Bilateral MOU's (Banking and securities matters) } \\
\hline Country & Authority \\
\hline Brazil & Central Bank of Brazil \\
\hline Honduras & National Banking and Insurance Commission \\
\hline El Salvador & Superintendence of Financial System \\
\hline British Virgin Islands & Financial Services Commission \\
\hline
\end{tabular}

823. The CNBV is a member of the International Organization of Securities Commissions (IOSCO) and a signatory of the Multilateral Memorandum of Understanding Concerning Consultation and Cooperation and the Exchange of Information (MoU). As a signatory of the MoU, CNBV may exchange all securities related information with all of the signatory countries: the following tables support the authorities' opinion about the improved cooperation between PGR and CNBV over the last few years.

INFORMATION REQUESTS ISSUED BY THE CNBV

2005

\begin{tabular}{|l|c|}
\hline \multicolumn{1}{|c|}{ Type of requests } & Number of requests \\
\hline Financial Regulatory Framework & 11 \\
\hline Confidential Information Requests & 22 \\
\hline Banking System & 1 \\
\hline TOTAL & 34 \\
\hline
\end{tabular}

2006

\begin{tabular}{|c|c|}
\hline \multicolumn{1}{|c|}{ Type of requests } & Number of requests \\
\hline Financial Regulatory Framework & 2 \\
\hline Confidential Information Requests & 7 \\
\hline TOTAL & 9 \\
\hline
\end{tabular}

2007

\begin{tabular}{|l|c|}
\hline \multicolumn{1}{|c|}{ Type of requests } & Number of requests \\
\hline Confidential Information Requests & 7 \\
\hline
\end{tabular}




\begin{tabular}{|c|c|}
\hline Financial Regulatory Framework & 24 \\
\hline TOTAL & 31 \\
\hline
\end{tabular}


INFORMATION REQUESTS RECEIVED BY THE CNBV

2005

\begin{tabular}{|l|c|}
\hline \multicolumn{1}{|c|}{ Type of requests } & Number of requests \\
\hline Financial Regulatory Framework & 63 \\
\hline Confidential Information Requests & 27 \\
\hline Banking System & 7 \\
\hline Economic Information & 2 \\
\hline \multicolumn{1}{|c|}{ TOTAL } & $\mathbf{9 9}$ \\
\hline
\end{tabular}

2006

\begin{tabular}{|c|c|}
\hline \multicolumn{1}{|c|}{ Type of requests } & Number of requests \\
\hline Financial Regulatory Framework & 36 \\
\hline Confidential Information Requests & 35 \\
\hline TOTAL & $\mathbf{7 1}$ \\
\hline
\end{tabular}

2007

\begin{tabular}{|l|c|}
\hline \multicolumn{1}{|c|}{ Type of requests } & Number of requests \\
\hline Financial Regulatory Framework & 41 \\
\hline Confidential Information Requests & 19 \\
\hline Banking System TOTAL & 3 \\
\hline \multicolumn{2}{|c|}{ T3 } \\
\hline
\end{tabular}

\section{FIU Cooperation}

824. There are clear and effective mechanisms at the FIU level to facilitate and allow for prompt and constructive exchanges of information directly between counterparts.

825. The Financial Intelligence Unit (FIU) is part of the Egmont Group since 1998 and, in its relationships with foreign counterparts, follows the directives and agreements adopted by the Group. In this sense, it executes the Memoranda of Understanding (MoU) with its foreign counterparts, for the purpose of facilitating mutual cooperation and financial information exchange to support investigations relative to money laundering and terrorist financing, which contemplate the principles for information exchange and best practices issued by the Egmont Group.

826. The FIU has executed MoUs in cooperation for intelligence information exchange with the following countries: Andorra, Aruba, Netherlands Antilles, Bolivia, Brazil, Chile, China, Canada, Korea, Colombia, El Salvador, Spain, the United States of America, Guatemala, Honduras, Indonesia, Israel, Paraguay, Peru, Portugal, Dominican Republic, Russia, Singapore, Sweden and Ukraine. It is currently conducting negotiations to sign new MoUs with: Argentina, Australia, Bahamas, the Philippines, Italy, Malaysia, Cayman Islands, Japan, the Netherlands, Poland, Romania, France and the United Kingdom. 
827. Additionally, Mutual Cooperation International Treaties for the exchange of information with respect to transactions carried out through financial institutions have been executed with the following countries: The United States of America, published in the Official Gazette of the Federation (DOF-Spanish acronym for Diario Oficial de la Federación) on March 29, 1995; France, published in the DOF on August 6, 1999; Spain, published in the DOF on February 11, 2000; Guatemala, signed on February 21, 2002, and Panama, signed on June 17, 2002.

828. It should be pointed out that the FIU has exchanged information with foreign counterparts that form part of the Egmont Group, even in the absence of an MoU.

\section{Spontaneous Exchange of Information (c. 40.3)}

829. Exchanges of information are possible: (a) both spontaneously and upon request, and (b) in relation to both money laundering and the underlying predicate offenses.

830. The Financial Intelligence Unit (FIU) formulates and handles information requests on the basis of mutual trust, based on reciprocity principles and on the agreements that may exist between the parties. It is authorized to exchange information spontaneously or at the request of a foreign FIU.

831. On the supervisory side, the CNBV can exchange information spontaneously and upon request. Based on bilateral and multilateral MoU's, the CNBV may exchange information spontaneously and upon request. In fact, these mechanisms envisage that whenever there is a situation or concern on one side, it can spontaneously communicate it to its counterpart, to ensure an efficient surveillance of the financial system and the possible application of an international enforcement action.

832. By virtue of the IOSCO MoUs (to which the CNBV has acceded), Mexico has agreed to "make all reasonable efforts to provide, without prior request, the other requesting authorities with any information that it considers is likely to be of assistance to those other authorities in securing compliance with laws and regulations applicable in their jurisdiction." The mission did not receive any adverse responses from the international community with respect to Mexico's inability or unwillingness to provide effective cooperation to its foreign supervisory counterparts.

833. The Federal Attorney General does not have any limitations with respect to the exchange of information relative to money laundering and basic predicate crimes pursuant to a request, provided the requirements set forth under the applicable agreements and treaties are met.

\section{Making Inquiries on Behalf of Foreign Counterparts (c. 40.4)}

834. Competent authorities are authorized to conduct inquiries on behalf of foreign counterparts.

835. Pursuant to the provisions under Article 15, Sections VII, VIII, X, and XII of the Internal Regulations of the SHCP, the Financial Intelligence Unit (UIF) can request and obtain from reporting entities, directly or through the competent authorities, information and documentation with respect to reports on transactions related with money laundering or terrorist financing and any additional information from other persons or sources that may be necessary to exercise its powers.

836. It may also require the administrative units of the SHCP and other competent national authorities to collaborate in the exercise of its powers and provide the necessary information and documentation, including access to databases, as well as receive, gather and analyze the evidence, confirmations, reports, documents, and statements on the activities related with the crimes of money 
laundering, terrorism, and terrorist financing. All of this information may be obtained pursuant to a request submitted by a foreign FIU for the purpose of assisting it in the performance of investigations.

837. With regards to the supervisory authorities, pursuant to article 4, paragraph XXV of the Law of the Comisión Nacional Bancaria y de Valores (CNBVL), the CNBV may provide information to foreign counterparts. For such purpose, it may perform visits, request information or even request the appearance of the alleged offenders as well as any other person who may contribute to the investigation.

838. Notwithstanding the above, and as mentioned in 40.1, foreign authorities may perform visits to their foreign subsidiaries in Mexico. The home supervisory authorities can have access to the procedures and policies regarding client identification by the foreign subsidiaries of banking entities, as well as to the files and account records of their clients, including information regarding AML/CFT, as long as the supervisory authorities previously sign an MoU for the exchange of information.

839. On the law enforcement side, the investigations requested in mutual legal assistance requests may be carried out through the channels and procedures provided under bilateral or multilateral treaties or agreements and with the intervention of the Ministry of Foreign Affairs.

FIU Authorized to Make Inquiries on Behalf of Foreign Counterparts (c. 40.4.1)

840. Pursuant to Article 15, Section XXIII of the Internal Regulations of the SHCP, the FIU may share with foreign counterparts all of the information contained in its databases, including information relative to unusual transactions reports.

841. In addition, it can request and obtain from reporting entities, directly or through their corresponding supervisor, additional information with respect to reports of transactions related with money laundering or terrorist financing and to require from the administrative units of the SHCP and other competent national authorities, any information and documentation that may be necessary for the exercise of its powers, including access to databases. In this regard, the FIU has also negotiated access to tax, immigration, and business databases. All of this information may be obtained pursuant to a request submitted by a foreign FIU for the purpose of assisting it in the performance of investigations.

842. As an administrative agency, however, the FIU does not have access to police or law enforcement databases.

Conducting of Investigations on Behalf of Foreign Counterparts (c. 40.5)

843. The Federal Attorney General's Office is the only authority that may conduct investigations on behalf of foreign counterparts. Investigations requested in mutual legal assistance requests are conducted through the channels and procedures provided for under bilateral or multilateral treaties or agreements and with the intervention of the Ministry of Foreign Affairs.

No Unreasonable or Unduly Restrictive Conditions on Exchange of Information (c. 40.6)

844. Exchanges of information are not made subject to disproportionate or unduly restrictive conditions. 
845. The Financial Intelligence Unit does not impose excessive or disproportionate conditions with regard to information exchange. It only restricts the exchange of information to the limits established within the scope of its competency and under applicable national legislation.

846. It would also limit the exchange of information with foreign counterparts for lack of reciprocity or if the exchange would jeopardize national sovereignty, security or politics, the public order and the essential interests of the Mexican State. In such case, it would promptly communicate its decision to not provide such information. It should be noted that up to now an exchange of information has never been denied for any of these reasons.

847. With regards to the supervisory authorities, pursuant to Article 4, Paragraphs XXIV and XXV and Article 9 of the CNBVL, the CNBV may exchange confidential information on financial matters to other foreign supervisors provided that an $\mathrm{MoU}$ has been signed with its counterpart and that the principle of reciprocity is respected.

848. The CNBV may not provide the financial confidential information to foreign homologous supervisors when it believes that such information will be used for purposes different than for supervisory purposes. Information exchanges may also de denied for reasons of public order, national security, or any other cause established in the MoU.

849. The Federal Attorney General does not impose excessive or restrictive conditions in rendering mutual legal assistance either and would only limit the exchange of information for lack of reciprocity.

850. The treaties on mutual legal assistance recently signed by Mexico contemplate the spontaneous transfer of information through Central Authorities, even if a request for legal assistance has not been submitted. This permits the exchange of information and evidence with respect to actions criminally punishable when any of the parties consider that this transfer, due to its nature, would allow another party to: $i$ ) submit a request for legal assistance; ii) initiate criminal proceedings; or, iii) facilitate the development of a criminal investigation that is underway.

\section{Provision of Assistance Regardless of Possible Involvement of Fiscal Matters (c. 40.7)}

851. Tax offenses could also be predicate offenses to money laundering in Mexico. Accordingly, the FIU would not reject a request for cooperation on the ground that the request is considered to involve fiscal matters.

852. On the supervisory side, information provided to foreign counterparts under a MoU is usually intended to be for supervisory purposes only. Accordingly, if a request for cooperation involves fiscal matters, the CNBV would typically provide the financial information for supervisory purposes only and leave the fiscally sensitive information aside. If the request for cooperation involves only fiscal matters, the CNBV would answer that it is not the competent authority to provide such information and would refer the requesting counterpart to the proper authority that could respond to its request.

853. The Federal Attorney General's Office does not consider tax matters as grounds to reject a request for assistance either. The rejection of mutual legal assistance requests is based solely on the restrictions set forth under applicable mutual legal assistance instruments. 
Provision of Assistance Regardless of Existence of Secrecy and Confidentiality Laws (c. 40.8)

854. Professional privilege or legal professional secrecy do not prohibit the provision of assistance. On December 30, 2005, a decree that amended Article 117 and repealed Article 118 of the Credit Institutions Law (LIC) relative to bank and fiduciary secrecy. These amendments standardized the conditions for the disclosure of information protected by secrecy. Article 117 of the LIC expressly includes exceptions to bank and fiduciary secrecy and requires financial institutions to provide information to the competent national authorities. Through these gateway mechanisms, the FIU and the Federal Attorney General's Office have the necessary powers and ability to cooperate with their international counterparts. Similar provisions are contained Article 358 of the Securities Market Law and Article 55 of the Investment Firms Law that allow the CNBV to provide assistance and exchange confidential information with its foreign counterparts.

855. Article 117 of the Credit Institutions Law expressly contemplates certain exceptions to bank and fiduciary secrets such as requests from:

- Judicial authorities, by virtue of a resolution rendered in judicial proceedings in which the holder, settlor, beneficiary, trustee, principal or agent, as applicable, is involved or is the defendant. Judicial authorities may submit their request directly to the financial institution or through the CNBV.

- $\quad$ The Office of the Federal Attorney General, the Offices of the District Attorneys of the States of the Republic and of the Federal District and the Military Justice Attorney General, to confirm the corpus delicti and the probable guilt of the suspect.

- $\quad$ The federal tax authorities, for fiscal purposes.

- $\quad$ The SHCP - through the Financial Intelligence Unit - for the purposes of investigations related with money laundering and terrorist financing.

- $\quad$ The Federal Treasurer, when the act of surveillance requires it, to request the account statements and any other information relative to the personal accounts of public officers, assistants and private parties related with the investigation at hand.

- $\quad$ The Auditoría Superior de la Federación (Federal Auditor General) in the exercise of its duties of review and control of the Cuenta Pública Federal (Federal Public Account) and with respect to personal accounts of public officers, assistants and private parties related with the investigation at hand.

- $\quad$ The Secretaría de la Función Pública (Ministry of Public Office) in the exercise of its duties of investigation or control to verify changes or increases in the assets of federal public officers.

- $\quad$ The Instituto Federal Electoral (Federal Electoral Institute).

856. Financial institutions must respond to the requirements that the CNBV may submit at the request of the above mentioned authorities, within the terms that the CNBV establishes for such purposes. In case of failure to comply, the CNBV may sanction the financial institution in accordance with Articles 108 to 110 of the Credit Institutions Law.

857. Accordingly, the FIU and the Federal Attorney General's Office have the capacity to provide international cooperation without the national provisions on bank and fiduciary secrecy representing an obstacle. 
858. Likewise the CNBV can provide confidential information to its foreign counterparts upon request, provided that there be a MoU and so long as the reciprocity principle prevails.

\section{Safeguards in Use of Exchanged Information (c. 40.9)}

859. The MoU template that the FIU proposes to its foreign counterparts provides that any information exchanged in accordance with the MoU will be strictly confidential and must receive the same treatment as reserved information and the same protection that the legislation of the requesting FIU grants to similar information originating from national sources. The confidentiality obligation will be in effect throughout the effective term of the $\mathrm{MoU}$ and for up to 12 additional years as of the date of its termination.

860. The national legislation on the protection of information is the Federal Law of Transparency and Access to Public Government Information (Ley Federal para la Transparencia y Accesoa la Informacion de Actos Publicos de Gobierno - LFTAIPG). The purposes of such Law are to provide transparency to public services through the dissemination of the information generated by federal authorities, improve the organization, classification and management of documents and favor the rendering of accounts so that citizens can evaluate the performance of authorities. Such Law is of mandatory observation for federal public officers. The general principle is that all government information is public with the exception of information classified as reserved because its dissemination may cause any of the following effects: $i$ ) compromise national security, public security or national defense; ii) impair the conduction of negotiations or of international relationships, including information that other states or international organizations deliver as confidential information to the Mexican State; iii) damage the financial, economic or monetary stability of the country; iv) endanger the life, security or health of any person, or $v$ ) cause serious damage to the activities of verification of compliance with laws, prevention or prosecution of crimes, administration of justice, tax collection, immigration control operations, and the procedural strategies in judicial or administrative procedures until resolutions are not final.

861. In addition, the following is considered reserved information: any information that by an express provision of law is considered confidential or reserved; industrial, trade, tax, bank and fiduciary secrets, or any other information considered as such by any legal provision; preliminary investigations; judicial records or the records of administrative proceedings followed in the form of a trial until they become final; procedures relative to the liability of public officers until a final jurisdictional or administrative resolution is rendered or a resolution containing the opinions, recommendations or points of view that form part of the deliberative process of public officers until the final decision is adopted.

862. Reserved information may remain classified as such up to a period of 12 years. When the reservation period or the causes that gave rise to the reservation conclude, the information will become public.

863. Pursuant to Article 18 of the same Law, information provided by private parties to authorities as confidential will be considered confidential information, including trade, industrial, tax, bank and fiduciary secrets, among others, and any personal information whose disclosure or marketing requires the consent of individuals.

864. The information that national authorities exchange with foreign counterparts on the prevention and combat against money laundering and terrorist financing is considered information related with national security, for which it is protected by confidentiality and secrecy duties, in terms of the National Security Law (Ley de Seguridad Nacional). 
865. Such law provides that each national security entity is responsible for the administration, protection, classification or declassification of and access to the information it generates or safeguards, in terms of the Ley de Seguridad Nacional and the LFTAIPG.

866. Pursuant to Article 51 of the Ley de Seguridad Nacional, in addition to the information that satisfies the criteria set forth under the LFTAIPG, the following is reserved information for national security reasons: information whose application implies the revelation of norms, procedures, methods, sources, technical specifications, technology or equipment useful for the generation of intelligence for national security, regardless of the nature or origin of the documents that contain it, or information that if revealed may be used to carry out or add to a threat.

867. Lastly, Articles 53 and 54 of the Ley de Seguridad Nacional provide that any public officer or any person having access to information relative to national security must sign a confidentiality promise, which they will keep at all times, even after they no longer hold the position by virtue of which they were granted access to such information.

868. The persons who for any reason participate in or have knowledge of intelligence products, sources, methods, measures or operations or records or information deriving from the actions contemplated under such law, must abstain from disclosing or disseminating them through any means and must adopt the necessary measures to avoid their publicity.

869. Likewise, all of the information collected and received by the CNBV as part of its supervisory functions is protected by many mechanisms and legal provisions, to ensure that it is only used for authorized purposes. The three main legal controls or safeguards to ensure the confidentiality of information received in this area are: $i$ ) the Financial Laws; the Federal Transparency and Access to Public Government Information Law; and the Public Officers' Administrative Responsibilities Federal Law.

870. With regards to financial laws, Article 115 of the Law of Credit Institutions, states that all public officers from the Ministry of Finance, the CNBV, banks, and financial institutions with a limited purpose, as well as their members of the board of directors, officers, employees, and legal representatives of such financial institutions supervised by the CNBV, are obliged to abstain from providing any information on the reports and any other documents and notices in regards to any detected acts, operations, or services related to money laundering or terrorist financing, except to the authorities expressly authorized for such purpose by law. Such authorities, according to Article 117 of CIL, would be: $i$ ) the judicial authority; ii) the Attorney General; iii) the Ministry of Finance; and iv) the FIU. Article 115 is replicated in other financial laws, which regulate other financial institutions supervised by the CNBV.

871. As to the Public Officers' Administrative Responsibilities Federal Law, its Article 8 sets forth that all public officers shall guard and look after the information and documents that they have access to due to their job, position or commission, and information and documents that they have under their responsibility as well as to prevent and avoid the use, subtraction, destruction, concealment or wrongful use of such information and documents.

872. Moreover, all bilateral MoU's signed by CNBV clearly include the following provision: "Information would be shared to the extent reasonable and subject to any relevant statutory provisions, including those restricting disclosure. Any confidential information received from another supervisor would be used only for lawful supervisory purposes. According to applicable national legislation, each supervisor would hold confidential all information received pursuant to this Memorandum (other than publicly available information) and would not disclose such information 
other than as necessary to carry out its lawful supervisory responsibilities. If the information provided will be used for another purpose, the supervisor that received the information will not disclose it to a third party without previously notifying to the supervisor that provided the information."

\section{Additional Element - Exchange of Information with Non-Counterparts (c. 40.10 \& c. 40.10.1)}

873. The exchange of information with authorities that are not counterparts is carried out indirectly through the national authority having the power to do so, in accordance with applicable national legislation.

874. For example, Article 15, Sections XVII and XXII of the Internal Regulations of the SHCP empowers the FIU to serve as liaison between the administrative units and the administrative agencies (órganos desconcentrados) of the SHCP and the different agencies and entities of the Federal Public Administration on the matters over which it is competent, as well as between the SCHP and the countries or international or intergovernmental organizations with which treaties or agreements on money laundering and terrorist financing have been executed.

875. Likewise, the CNBV provides assistance and information mainly and directly to its counterparts. Confidential information (with secrecy provisions) may only be provided to a foreign counterpart as long as there exist a MoU signed. The CNBV may provide information indirectly to foreign authorities, through an information request presented by their national counterparts, according to Articles 117 of CIL, 19 and 295 in the Stock Market Law, as well as 55 of Mutual Funds Law, and 34 of the Credit and Savings Law.

876. One of the requirements for the FIU to exchange information is that the requesting authorities indicate the purpose for which the information will be used. All bilateral MoU's provide that the requests for assistance shall contain the purpose for which the information is being sought. Such purpose must be related to the foreign counterpart's ability to perform its duties.

877. With regards to the supervisory authorities, it is also an international practice that the requesting authority provides some background information to the requested authority. This background information also allows for the exchange of information to take place in a way that permits the use of the information only for the authorized purposes.

\section{Additional Element - Provision of Information to FIU by Other Competent Authorities pursuant to request from Foreign FIU (c. 40.11)}

878. The FIU may obtain additional information from reporting entities through the corresponding supervisory bodies, whether through the Comisión Nacional Bancaria y de Valores (National Banking and Securities Commission), Comisión Nacional de Seguros y Fianzas (National Insurance and Bonds Commission), Comisión Nacional del Sistema de Ahorro para el Retiro (National Retirements Savings System Commission) and Servicio de Administración Tributaria (Tax Administration Service). In addition, it may obtain information generated by such supervisory bodies or other agencies of the federal public administration when it is related with activities or investigations on money laundering, terrorism, or terrorist financing. This information may be disclosed to its foreign counterparts, with the prior approval of the authorities that provided or developed it, except if the relevant information is part of the FIU's databases. 
International Cooperation under SR V (applying c. 40.1-40.9 in R. 40, c. V.5)

879. The answers provided for the criterions under Recommendation 40, also apply for the obligations under Special Recommendation V. However, the shortcomings in the terrorist financing offense described in SR.II may affect the implementation in terrorist financing cases.

Additional Element under SR V (applying c. 40.10-40.11 in R. 40, c. V.9)

880. The answers provided for the criterions under Recommendation 40, also apply for the obligations under Special Recommendation V. However, the shortcomings in the terrorist financing offense described in SR.II may affect the implementation in terrorist financing cases.

\section{Statistics (applying R.32)}

881. Financial Intelligence Unit: From May to December 2004, the FIU sent four information requests abroad and processed 23 requests from different countries. In 2005, 17 information requests were submitted to foreign FIUs and 57 requests from other countries were received and processed. In 2006, the FIU sent 22 information requests abroad and processed 62 requests from different countries. Up to October 2007, the FIU had sent 27 information requests abroad and received 65 requests from foreign FIUs.

882. CNBV: During 2005, 2006, and 2007, the CNBV received various requests of information from different countries, and required information to its foreign counterparts, according to the following tables:

INFORMATION REQUESTS ISSUED BY THE CNBV

2005

\begin{tabular}{|c|c|}
\hline Type of requests & Number of requests \\
\hline Financial Regulatory Framework & 11 \\
\hline Confidential Information Requests & 22 \\
\hline Banking System & 1 \\
\hline TOTAL & 34 \\
\hline
\end{tabular}

2006

\begin{tabular}{|l|c|}
\hline \multicolumn{1}{|c|}{ Type of requests } & Number of requests \\
\hline Financial Regulatory Framework & 2 \\
\hline Confidential Information Requests & 7 \\
\hline TOTAL & 9 \\
\hline
\end{tabular}

2007

\begin{tabular}{|l|c|}
\hline \multicolumn{1}{|c|}{ Type of requests } & Number of requests \\
\hline Confidential Information Requests & 7 \\
\hline Financial Regulatory Framework & 24 \\
\hline TOTAL & $\mathbf{3 1}$ \\
\hline
\end{tabular}


INFORMATION REQUESTS RECEIVED BY THE CNBV

2005

\begin{tabular}{|l|c|}
\hline \multicolumn{1}{|c|}{ Type of requests } & Number of requests \\
\hline Financial Regulatory Framework & 63 \\
\hline Confidential Information Requests & 27 \\
\hline Banking System & 7 \\
\hline Economic Information & 2 \\
\hline \multicolumn{1}{|c|}{ TOTAL } & $\mathbf{9 9}$ \\
\hline
\end{tabular}


2006

\begin{tabular}{|l|c|}
\hline \multicolumn{1}{|c|}{ Type of requests } & Number of requests \\
\hline Financial Regulatory Framework & 36 \\
\hline Confidential Information Requests & 35 \\
\hline TOTAL & 71 \\
\hline
\end{tabular}

2007

\begin{tabular}{|l|c|}
\hline \multicolumn{1}{|c|}{ Type of requests } & Number of requests \\
\hline Financial Regulatory Framework & 41 \\
\hline Confidential Information Requests & 19 \\
\hline Banking System TOTAL & 3 \\
\hline \multicolumn{2}{|c|}{ T3 } \\
\hline
\end{tabular}

\subsubsection{Recommendations and Comments}

- Mexico should address the deficiencies of the TF offense described under SR II, which could impact on the law enforcement authorities' ability to provide international cooperation.

\subsubsection{Compliance with Recommendation 40 and Special Recommendation $\mathrm{V}$}

\begin{tabular}{|c|c|cc|}
\hline & Rating & Summary of factors relative to s.6.5 underlying overall rating \\
\hline R.40 & C & & \\
\hline SR.V & LC & $\bullet \begin{array}{l}\text { The deficiencies in the terrorist financing offense described under SR.II impact } \\
\text { on the law enforcement authorities' ability to provide international cooperation. }\end{array}$ \\
\hline
\end{tabular}

\section{7. OTHER ISSUES}

\subsection{Resources and Statistics}

\begin{tabular}{|c|c|c|}
\hline & Rating & Summary of factors underlying rating \\
\hline R.30 & PC & $\begin{array}{l}\text { Supervisory: PC } \\
\text { - } \quad \text { EC } 30.1,30.3 \text { and } 30.3 \\
\text { - Insufficient training for risk-based supervision including for offsite surveillance of ML } \\
\text { and FT risks. } \\
\text { - Insufficient focus on, and provision of specialized training to inspections staff, for the } \\
\text { review of controls in Fls designed to detect non-cash suspicious transactions. } \\
\text { - Insufficient staff of the DGPOI to provide more adequate support to all of the CNBV's } \\
\text { supervisory units and other outside authorities such as the FIU and the PGR. } \\
\text { - Insufficient staff for the SAT for supervising money exchange centers, money } \\
\text { remitters, and SOFOMES. }\end{array}$ \\
\hline
\end{tabular}




\begin{tabular}{|l|l|l|}
\hline R.32 & $\begin{array}{l}\text { FIU: PC } \\
\text { Low number of staff relative to the amount of reports received and expected future } \\
\text { volume of STRs and workload, and there is no timetable for increasing resources for } \\
\text { the FIU, especially in the number of staff. }\end{array}$ \\
\hline LC & $\begin{array}{l}\text { Law Enforcement: PC } \\
\text { Insufficiency of resources allocated to PGR's SIEDO and its specialized units } \\
\text { hinders effectiveness in the conduct investigations and prosecutions. }\end{array}$ \\
$\begin{array}{l}\text { FIU (and Customs): LC } \\
\text { There is no information on requests denied by either the Mexican FIU or its foreign } \\
\text { counterparts. } \\
\text { No statistics were provided on the number of consultations made by the FIU or the } \\
\text { number of declarations received and analyzed by the FIU. } \\
\text { Customs: LC } \\
\text { No statistics or any other information to assess the effectiveness of domestic } \\
\text { coordination arrangements. } \\
\text { No statistics on the number of international information requests made and received } \\
\text { by the General Customs Administration were provided. } \\
\text { Law Enforcement: C }\end{array}$ \\
\hline
\end{tabular}

\subsection{Other relevant AML/CFT Measures or Issues}

50. None.

\subsection{General Framework for AML/CFT System (see also Section 1.1)}

883. With respect to the scope of coverage of financial institutions in the AML/CFT regime, the mission discussed with the authorities their views on the scale (number and size of operations) and scope (geographic coverage) of lending operations that are not covered by the AML/CFT laws and regulations. In particular, the mission enquired about lending operations against automobile titles (cash for titles) that are conducted outside the mainstream lending institutions and are not subject to the AML/CFT requirements. It was evident that such activities exist by virtue of prominent advertising boards in Mexico City. It is not known whether or not such operations are carried out in other parts of the country. These lending activities are considered by the authorities to be more related to pawning operations and are not supervised. However, as there are no statistics on the volume and scope of such activities, and the authorities have not formally investigated and justified the lack of application of the AML/CFT regime, a potential lacuna could exist should their operations more closely resemble other specialized lending operations as opposed to more traditional pawning business. There has been at least one publicized case in the region of similar operations associated with large scale fraud and related money laundering. (See C4T (Cash for Titles) Management, Inc., Charles Richard Homa, Michael Gause and numerous other related parties and entities in the case of SEC v. Homa, Gause et. al. (Case No. 99CV06895) Federal District Court for the Northern District of Illinois, Eastern Division, USA.).

884. The authorities should also consider conducting a review of ML and FT risks in business and professional sectors, other than DNFBPs (Rec. 20), and where justified apply the FATF Recommendations to such sectors. In addition, Mexico should also strongly encourage the 
development of more modern and secure systems for conducing financial transactions that would help to reduce reliance on cash and the informal economy.

Table 1. Ratings of Compliance with FATF Recommendations

\begin{tabular}{|c|c|c|}
\hline Forty Recommendations & Rating & Summary of factors underlying rating ${ }^{56}$ \\
\hline \multicolumn{3}{|l|}{ Legal systems } \\
\hline 1. $\mathrm{ML}$ offense & PC & $\begin{array}{l}\text { - ML offense does not cover the "concealment } \\
\text { or disguise of the true nature, source, } \\
\text { location, disposition, movement, or } \\
\text { ownership of or rights with respect to } \\
\text { property" nor the "possession or use of } \\
\text { property without a specific purpose". } \\
\text { ML offense is not being effectively } \\
\text { implemented, insufficient focus on ML } \\
\text { investigations committed through the } \\
\text { financial system, and underutilization of } \\
\text { financial intelligence reports from the FIU. }\end{array}$ \\
\hline $\begin{array}{l}\text { 2. ML offense-mental element and } \\
\text { corporate liability }\end{array}$ & LC & $\begin{array}{l}\text { The money laundering offense is not being } \\
\text { effectively implemented as is shown by the } \\
\text { very low number of convictions relative to } \\
\text { the significant threat of organized crime, the } \\
\text { low number of indictments, the volume of } \\
\text { intelligence reports of STRs and the size and } \\
\text { complexity of the financial system. }\end{array}$ \\
\hline $\begin{array}{l}\text { Confiscation and provisional } \\
\text { measures }\end{array}$ & LC & $\begin{array}{l}\text { - Legislation does not provide for the ability to } \\
\text { forfeit assets of equal or corresponding value. } \\
\text { There are no criminal laws/tools for } \\
\text { preventing or voiding contracts and actions } \\
\text { that diminish the ability to recover assets } \\
\text { subject to forfeiture. }\end{array}$ \\
\hline \multicolumn{3}{|l|}{ Preventive measures } \\
\hline $\begin{array}{l}\text { 4. Secrecy laws consistent with the } \\
\text { Recommendations }\end{array}$ & C & \\
\hline 5. Customer due diligence & PC & $\begin{array}{l}\text { - } \\
\text { so CDD (AML/CFT) regulations and } \\
\text { SOpervision as yet for unregulated } \\
\text { SOFOMES. } \\
\text { Inadequate implementation of CDD } \\
\text { requirements esp. oversight requirements } \\
\text { imposed on insurance companies for business }\end{array}$ \\
\hline
\end{tabular}

${ }^{56}$ These factors are only required to be set out when the rating is less than Compliant. 


\begin{tabular}{|c|c|c|}
\hline Forty Recommendations & Rating & Summary of factors underlying rating ${ }^{56}$ \\
\hline & & 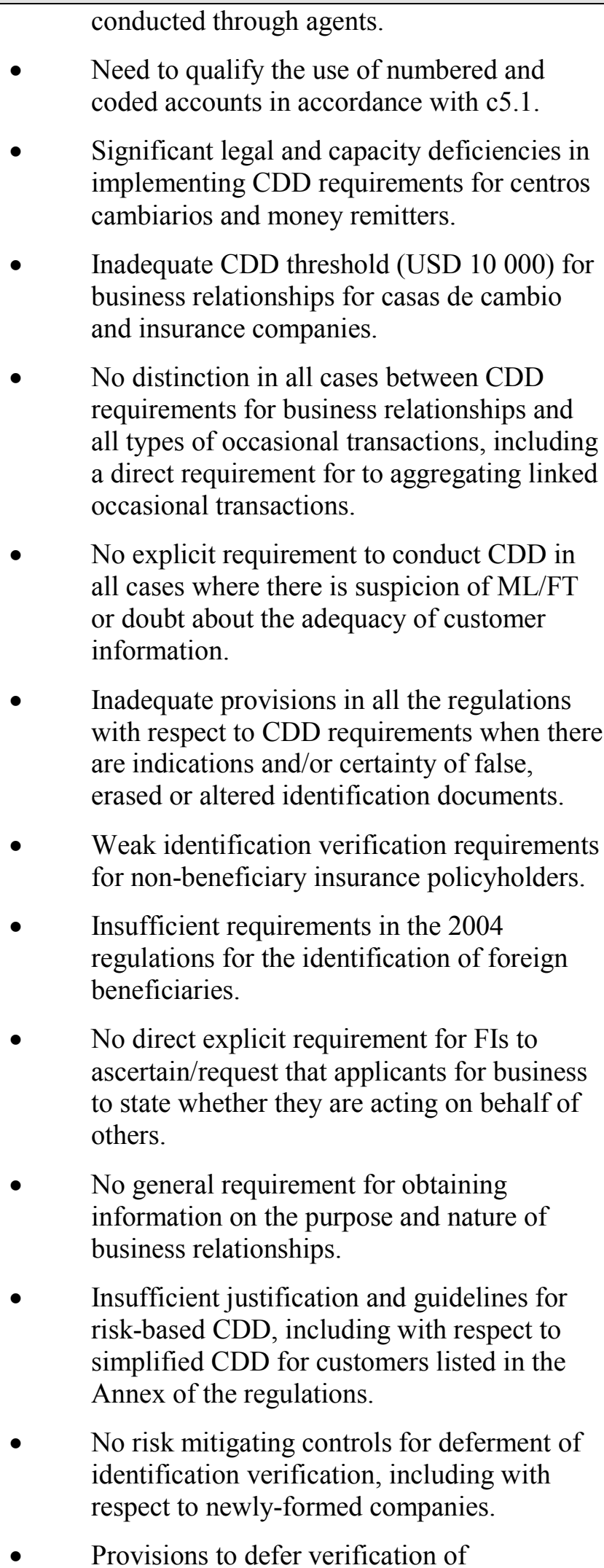 \\
\hline
\end{tabular}




\begin{tabular}{|c|c|c|}
\hline Forty Recommendations & Rating & Summary of factors underlying rating ${ }^{56}$ \\
\hline & & $\begin{array}{l}\text { identification of customers associated with } \\
\text { insurance policies are too broad. } \\
\text { No explicit provision to refuse to open an } \\
\text { account (e.g. when identification } \\
\text { documentation/verification is inadequate or } \\
\text { cannot be completed) and to terminate } \\
\text { existing business relationships when CDD } \\
\text { cannot be completed and file a STR. }\end{array}$ \\
\hline 6. Politically exposed persons & LC & $\begin{array}{l}\text { - No explicit requirement in some regulations } \\
\text { to obtain senior management approval for } \\
\text { existing PEP accounts and relationships. } \\
\text { Need to define the scope of "origen de } \\
\text { recursos" to include source of wealth for } \\
\text { PEPs in addition to source of funds. }\end{array}$ \\
\hline 7. Correspondent banking & LC & $\begin{array}{l}\text { Inadequate CDD requirements for } \\
\text { correspondent relationships for the mutual } \\
\text { fund and securities firms, including the need } \\
\text { to establish their AML/CFT responsibilities } \\
\text { and that of their respondents. }\end{array}$ \\
\hline $\begin{array}{l}\text { 8. New technologies \& non face-to- } \\
\text { face business }\end{array}$ & PC & $\begin{array}{l}\text { - } \\
\text { mo specific requirements to implement } \\
\text { developments. } \\
\text { No specific risk mitigating CDD } \\
\text { requirements for transactions that do not } \\
\text { require face-to-face contact. }\end{array}$ \\
\hline 9. Third parties and introducers & PC & $\begin{array}{l}\text { - Lack of a requirement for FIs to } \\
\text { "immediately" obtain CDD information from } \\
\text { third parties. } \\
\text { Inadequate supervision/monitoring of } \\
\text { insurance intermediaries for compliance with } \\
\text { AML/CFT obligations. } \\
\text { Inadequate supervision/monitoring of paying } \\
\text { agents (on whom reliance is placed) by } \\
\text { remittance firms for compliance with } \\
\text { AML/CFT obligations. }\end{array}$ \\
\hline 10. Record-keeping & C & \\
\hline 11. Unusual transactions & LC & $\begin{array}{l}\text { Many reporting institutions are using the list } \\
\text { of possible alerts provided in the regulations } \\
\text { as triggers of reports, without sufficiently } \\
\text { analyzing the background and purpose of } \\
\text { such transactions. } \\
\text { The monitoring of transactions by money } \\
\text { exchanges (centros cambiarios) and money }\end{array}$ \\
\hline
\end{tabular}




\begin{tabular}{|c|c|c|}
\hline Forty Recommendations & Rating & Summary of factors underlying rating ${ }^{56}$ \\
\hline & & $\begin{array}{l}\text { remitters (transmisores de dinero) has been } \\
\text { almost exclusively focused on the control of } \\
\text { unique or structured transactions starting at } \\
\text { US } \$ 3,000 \text {. }\end{array}$ \\
\hline 12. DNFBP-R.5, 6, 8-11 & NC & $\begin{array}{l}\text { No AML/CFT regulations exist for any } \\
\text { category of DNFBP, except trust services } \\
\text { which only specified financial institutions } \\
\text { can provide. }\end{array}$ \\
\hline 13. Suspicious transaction reporting & PC & $\begin{array}{l}\text { - The reports filed by some sectors are not } \\
\text { being transmitted to the FIU, nor utilized in } \\
\text { any form (Bonding companies and the } \\
\text { registered money transmitters and currency } \\
\text { exchanges). } \\
\text { There is no clear obligation to report the } \\
\text { suspicion of the financing of international } \\
\text { acts of terrorism (only of terrorist acts } \\
\text { committed locally). } \\
\text { Excessively broad definition of suspicion in } \\
\text { the regulations generates defensive reporting, } \\
\text { and the guidance issued to address this issue } \\
\text { is not legally adequate to limit the scope of } \\
\text { said regulations. } \\
\text { The obligation to report attempted } \\
\text { transactions is not explicitly established in } \\
\text { regulations, and not consistently } \\
\text { implemented by financial institutions. }\end{array}$ \\
\hline 14. Protection \& no tipping-off & C & \\
\hline 15. Internal controls, compliance \& audit & LC & $\begin{array}{l}\text { - No explicit requirement in all the AML/CFT regulations } \\
\text { to have a well resourced and independent audit } \\
\text { function. }\end{array}$ \\
\hline 16. DNFBP-R.13-15 \& 21 & NC & $\begin{array}{l}\text { - No AML/CFT regulations exist for any category of } \\
\text { DNFBP, except trust service providers which are } \\
\text { designated financial institutions. }\end{array}$ \\
\hline 17. Sanctions & PC & $\begin{array}{l}\text { - Sanctions not sufficiently proportionate and dissuasive. } \\
\text { On average, relatively low fines applied and insufficient } \\
\text { use of nonmonetary sanctions. }\end{array}$ \\
\hline 18. Shell banks & LC & $\begin{array}{l}\text { No requirement for Fls to satisfy themselves that their } \\
\text { foreign respondents do not permit their accounts to be } \\
\text { used by shell banks. }\end{array}$ \\
\hline 19. Other forms of reporting & C & \\
\hline $\begin{array}{l}\text { 20. Other NFBP \& secure transaction } \\
\text { techniques }\end{array}$ & NC & $\begin{array}{l}\text { - No consideration has been given to applying the FATF } \\
\text { recommendations to other high-risk businesses and } \\
\text { professions. }\end{array}$ \\
\hline
\end{tabular}




\begin{tabular}{|c|c|c|}
\hline Forty Recommendations & Rating & Summary of factors underlying rating ${ }^{56}$ \\
\hline & & $\begin{array}{l}\text { - No evidence of measures taken to encourage the } \\
\text { development and use of modern and secure techniques } \\
\text { for conducting financial transactions that are less } \\
\text { vulnerable to ML. }\end{array}$ \\
\hline $\begin{array}{l}\text { 21. Special attention for higher risk } \\
\text { countries }\end{array}$ & LC & $\begin{array}{l}\text { - Mexico can impose countermeasures only with respect } \\
\text { to countries previously identified by an international } \\
\text { organization, and not to countries of specific concern to } \\
\text { Mexican authorities. }\end{array}$ \\
\hline 22. Foreign branches $\&$ subsidiaries & C & \\
\hline $\begin{array}{l}\text { 23. Regulation, supervision and } \\
\text { monitoring }\end{array}$ & PC & $\begin{array}{l}\text { - Insufficient supervision, largely due to inadequate } \\
\text { budgetary and human resources, of the unregulated } \\
\text { foreign exchange centers and money remittance sector. } \\
\text { - No AML/CFT regulation and supervision for unlicensed } \\
\text { SOFOMES. } \\
\text { - Inadequate oversight mechanisms for intermediaries } \\
\text { (channels of distribution) in the insurance and bonding } \\
\text { sectors, and on cash acceptance practices. } \\
\text { - Insufficient use of offsite supervisory capacity for } \\
\text { planning and conducting onsite inspections, consistent } \\
\text { with the risk-based provisions in the regulations and } \\
\text { prudential supervision. } \\
\text { - Insufficient cross-border supervision including through } \\
\text { the use of supervisory MOUs. }\end{array}$ \\
\hline $\begin{array}{l}\text { 24. DNFBP_regulation, supervision } \\
\text { and monitoring }\end{array}$ & NC & $\begin{array}{l}\text { - No AML/CFT regulations and supervisory framework } \\
\text { exist for any category of DNFBP, except for trust } \\
\text { service providers which are designated financial } \\
\text { institutions. }\end{array}$ \\
\hline 25. Guidelines \& Feedback & PC & $\begin{array}{l}\text { Supervisory: NC } \\
\text { - Need for more current guidelines on new ML and FT } \\
\text { techniques and methods including for new technologies. } \\
\text { - Need for industry-specific guidelines on ML and FT } \\
\text { risks in the Mexican market to support risk-based } \\
\text { compliance. } \\
\text { - FIU: LC } \\
\text { - The recently increased strategic analysis capability of } \\
\text { the FIU has not yielded significant information that could } \\
\text { be used by reporting institutions to recalibrate their } \\
\text { preventive mechanisms, and the FIU has not published } \\
\text { Mexico-specific typologies since } 2005 \text {. } \\
\text { - FIU provides occasional feedback on STR quality to } \\
\text { institutions of concern, but there is no mechanism in } \\
\text { place to provide reporting institutions with more } \\
\text { opportune and relevant feedback about their reports, } \\
\text { other than an automatic acknowledgment of receipt of } \\
\text { their STRs. The project to rate the quality of STRs still } \\
\text { has not reached a representative sample of reports. }\end{array}$ \\
\hline
\end{tabular}




\begin{tabular}{|c|c|c|}
\hline \multirow[t]{2}{*}{ Forty Recommendations } & Rating & Summary of factors underlying rating ${ }^{56}$ \\
\hline & & $\begin{array}{l}\text { DNFBP: NC } \\
\text { - No AML/CFT framework and guidelines for DNFBPs. }\end{array}$ \\
\hline \multicolumn{3}{|l|}{ Institutional and other measures } \\
\hline 26. The FIU & LC & $\begin{array}{l}\text { Does not have full, timely and secure access } \\
\text { to STRs from exchange centers, money } \\
\text { services businesses and unregulated } \\
\text { SOFOMES filed through the SAT. } \\
\text { - } \quad \text { FIU has no access to criminal records. } \\
\text { The number of staff is low relative to the } \\
\text { amount of reports received and expected } \\
\text { future volume of STRs and workload } \\
\text { potentially hampering the FIU's } \\
\text { effectiveness. }\end{array}$ \\
\hline 27. Law enforcement authorities & PC & $\begin{array}{l}\text { - ML offenses are not being properly } \\
\text { investigated by PGR, insufficient focus on } \\
\text { ML investigations committed through the } \\
\text { financial system, and underutilization of } \\
\text { financial intelligence reports from the FIU. } \\
\text { - The insufficiency of resources allocated to } \\
\text { PGR's SIEDO and its specialized units is } \\
\text { affecting Mexico's capacity to conduct } \\
\text { investigations and prosecutions of ML } \\
\text { offenses in an effective manner. } \\
\text { Mexico does not have laws or other measures } \\
\text { that would allow competent authorities to } \\
\text { postpone or waive the arrest of suspected } \\
\text { persons and/or the seizure of money for the } \\
\text { purpose of identifying persons involved in } \\
\text { such activities. } \\
\text { The reorganization of the federal forces of } \\
\text { investigation over the past year has created } \\
\text { coordination difficulties between these forces } \\
\text { and prosecutors, thereby affecting the } \\
\text { effective investigation and prosecution of ML } \\
\text { offences. }\end{array}$ \\
\hline 28. Powers of competent authorities & LC & $\begin{array}{l}\text { The reorganization of federal forces of } \\
\text { investigation have created difficulties in the } \\
\text { coordination between such forces and } \\
\text { prosecutors, thereby affecting the capacity of } \\
\text { competent authorities to exercise document } \\
\text { production, search and seizure powers in an } \\
\text { effective manner. }\end{array}$ \\
\hline
\end{tabular}




\begin{tabular}{|c|c|c|}
\hline Forty Recommendations & \multirow[t]{2}{*}{ Rating } & Summary of factors underlying rating ${ }^{56}$ \\
\hline & & $\begin{array}{l}\text { The insufficiency of resources allocated to } \\
\text { PGR's SIEDO and its specialized units is } \\
\text { affecting their capacity to implement their } \\
\text { investigative powers in an effective manner. }\end{array}$ \\
\hline 29. Supervisors & C & \\
\hline 30. Resources, integrity, and training & PC & $\begin{array}{l}\text { - } \begin{array}{l}\text { - } \\
\text { EC } 30.1,30.3 \text { and } 30.3 \\
\text { Insufficient training for risk-based } \\
\text { supervision including for offsite surveillance } \\
\text { of ML and FT risks. } \\
\text { Insufficient focus on, and provision of } \\
\text { specialized training to inspections staff, for } \\
\text { the review of controls in FIs designed to } \\
\text { detect non-cash suspicious transactions. } \\
\text { Insufficient staff of the DGPOI to provide } \\
\text { more adequate support to all of the CNBV's } \\
\text { supervisory units and other outside } \\
\text { authorities such as the FIU and the PGR. } \\
\text { Insufficient staff for the SAT for supervising } \\
\text { money exchange centers, money remitters, } \\
\text { and SOFOMES. } \\
\text { FIU: PC } \\
\text { Low number of staff relative to the amount of } \\
\text { reports received and expected future volume } \\
\text { of STRs and workload, and there is no } \\
\text { timetable for increasing resources for the } \\
\text { FIU, especially in the number of staff. } \\
\text { Law Enforcement: PC } \\
\text { Insufficient resources allocated to PGR's } \\
\text { SIEDO and its specialized units hinder } \\
\text { effectiveness in the conduct investigations } \\
\text { and prosecutions. }\end{array} \\
\end{array}$ \\
\hline 31. National co-operation & LC & $\begin{array}{l}\text { - The reorganization of the federal forces of } \\
\text { investigation over the past year has created } \\
\text { transitional coordination and cooperation } \\
\text { difficulties between these forces and } \\
\text { prosecutors. } \\
\text { Absence of effective joint cooperation or } \\
\text { coordination mechanisms between the PGR } \\
\text { and the Judiciary to implement joint policies } \\
\text { and conduct activities aimed at fighting } \\
\text { organized crime. }\end{array}$ \\
\hline 32. Statistics & LC & Supervisory: C \\
\hline
\end{tabular}




\begin{tabular}{|c|c|c|}
\hline Forty Recommendations & Rating & Summary of factors underlying rating ${ }^{56}$ \\
\hline & & $\begin{array}{l}\text { FIU: LC } \\
\text { There is no information on requests denied } \\
\text { by either the Mexican FIU or its foreign } \\
\text { counterparts. } \\
\text { No statistics were provided on the number of } \\
\text { consultations made by the FIU or the number } \\
\text { of declarations received and analyzed by the } \\
\text { FIU. } \\
\text { Customs: LC } \\
\text { No statistics or any other information to } \\
\text { assess the effectiveness of domestic } \\
\text { coordination arrangements. } \\
\text { No statistics on the number of international } \\
\text { information requests made and received by } \\
\text { the General Customs Administration were } \\
\text { provided. }\end{array}$ \\
\hline 33. Legal persons-beneficial owners & NC & $\begin{array}{l}\text { Mexico has not taken measures to prevent the } \\
\text { use of legal persons in relation to ML/TF. } \\
\text { The Registry may not be able to obtain or } \\
\text { have access to adequate, accurate and current } \\
\text { beneficial ownership and control information. } \\
\text { Mexico has not taken appropriate measures to } \\
\text { ensure that legal persons using bearer shares } \\
\text { are not misused for ML. }\end{array}$ \\
\hline $\begin{array}{l}\text { 34. Legal arrangements - beneficial } \\
\text { owners }\end{array}$ & LC & $\begin{array}{l}\text { Lack of sufficient measures to ensure that } \\
\text { there is adequate, accurate and timely } \\
\text { information on the beneficial ownership and } \\
\text { control of legal arrangements in all cases. } \\
\text { No statistics on the number of requests for } \\
\text { beneficial ownership information or the } \\
\text { amount of sanctions applied to conclude that } \\
\text { the measures are effective. }\end{array}$ \\
\hline \multicolumn{3}{|l|}{ International Cooperation } \\
\hline 35. Conventions & LC & $\begin{array}{l}\text { - Mexico has not fully implemented the Vienna } \\
\text { and Palermo Conventions. } \\
\text { Mexico has not fully implemented the } \\
\text { Terrorist Financing Convention. }\end{array}$ \\
\hline 36. Mutual legal assistance (MLA) & LC & $\begin{array}{l}\text { The deficiencies in the money laundering and } \\
\text { terrorist financing offenses may impact on } \\
\text { Mexico's ability to provide MLA. }\end{array}$ \\
\hline
\end{tabular}




\begin{tabular}{|c|c|c|c|}
\hline \multicolumn{2}{|c|}{ Forty Recommendations } & Rating & Summary of factors underlying rating ${ }^{56}$ \\
\hline \multicolumn{2}{|c|}{ 37. Dual criminality } & LC & $\begin{array}{l}\text { - The deficiencies in the money laundering and } \\
\text { terrorist financing offenses may impact on } \\
\text { Mexico's ability to provide MLA and } \\
\text { extradite. }\end{array}$ \\
\hline \multicolumn{2}{|c|}{ 38. MLA on confiscation and freezing } & PC & $\begin{array}{l}\text { There are no appropriate laws and procedures } \\
\text { to freeze terrorist funds or other assets at the } \\
\text { request of a foreign country. } \\
\text { Mexican law contains no provisions for } \\
\text { confiscating goods of equivalent value. }\end{array}$ \\
\hline \multicolumn{2}{|c|}{ 39. Extradition } & LC & $\begin{array}{l}\text { The deficiencies in the money laundering and } \\
\text { terrorist financing offenses may impact on } \\
\text { Mexico's ability to extradite. }\end{array}$ \\
\hline \multicolumn{2}{|c|}{ 40. Other forms of co-operation } & C & \\
\hline \multicolumn{4}{|c|}{ Nine Special Recommendations } \\
\hline \multicolumn{2}{|c|}{ SR.I Implement UN instruments } & PC & $\begin{array}{l}\text { - The Terrorist Financing Convention has not } \\
\text { been fully implemented. } \\
\text { United Nations Security Council Resolutions } \\
\text { relating to the prevention and suppression of } \\
\text { FT are not being fully implemented. }\end{array}$ \\
\hline \multicolumn{2}{|c|}{ SR.II Criminalize terrorist financing } & PC & $\begin{array}{l}\text { - } \\
\text { Article } 2 \text { of the TF Convention. It only } \\
\text { focuses on what is used for the act (and not } \\
\text { on the intentions of the act) and it requires a } \\
\text { showing (rather than a purpose) that the act } \\
\text { generated alarm, fear, or terror to a } \\
\text { population. } \\
\text { While the TF offense covers the financing of } \\
\text { a significant number of terrorist acts, it does } \\
\text { not extend to the financing of the acts that } \\
\text { constitute an offense within the scope of, and } \\
\text { as defined in the treaties listed in the annex of } \\
\text { the TF Convention. } \\
\text { No TF investigations to date and therefore } \\
\text { cannot conclude that the measures are } \\
\text { effective. }\end{array}$ \\
\hline SR.III & $\begin{array}{l}\text { Freeze and } \\
\text { terrorist assets }\end{array}$ & NC & $\begin{array}{l}\text { There are no effective laws and procedures to } \\
\text { freeze terrorist funds or other assets of } \\
\text { persons designated by the United Nations Al- } \\
\text { Qaida and Taliban Sanctions Committee in } \\
\text { accordance with S/RES/1267(1999) without } \\
\text { delay and without prior notice to the } \\
\text { designated persons involved. }\end{array}$ \\
\hline
\end{tabular}




\begin{tabular}{|c|c|c|}
\hline Forty Recommendations & Rating & Summary of factors underlying rating ${ }^{56}$ \\
\hline & & 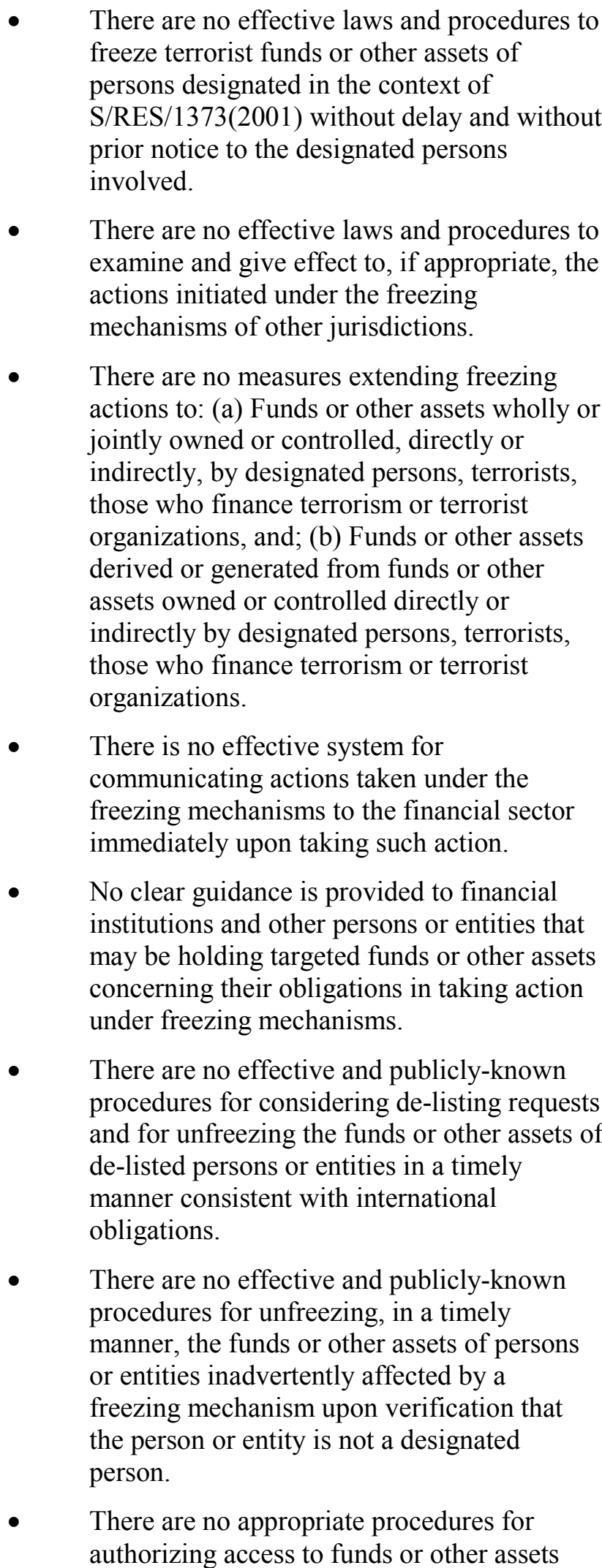 \\
\hline
\end{tabular}




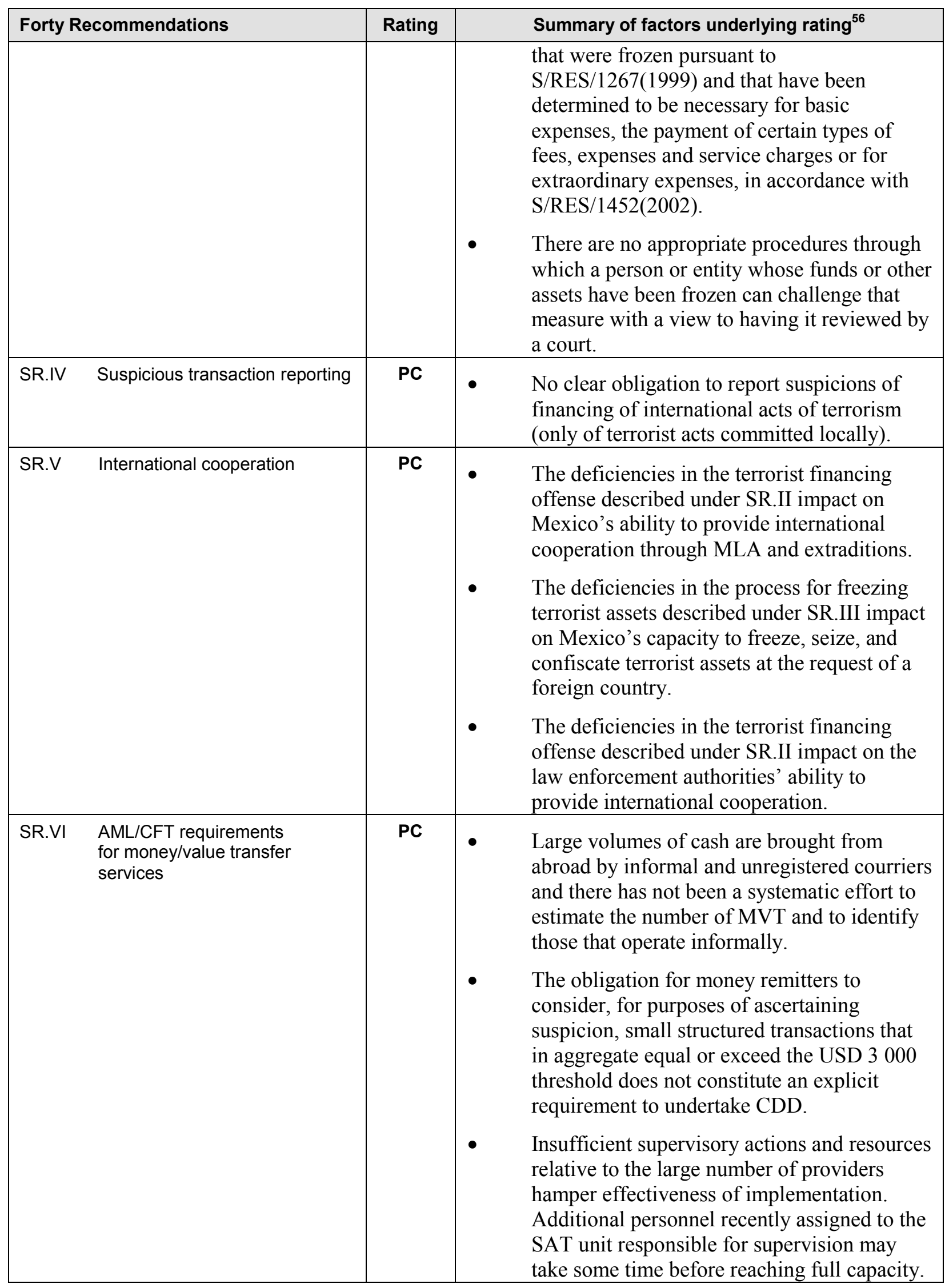




\begin{tabular}{|c|c|c|}
\hline \multirow[t]{2}{*}{ Forty Recommendations } & Rating & Summary of factors underlying rating ${ }^{56}$ \\
\hline & & $\begin{array}{l}\text { The SAT is not explicitly empowered to } \\
\text { inspect, instruct and sanction the payors, only } \\
\text { the disperser transmitters. } \\
\text { Technical problems are preventing that the } \\
\text { STRs (and CTRs) filed by money remitters } \\
\text { through the SAT arrive at the FIU, and these } \\
\text { reports are not being used in any form. } \\
\text { Disperser transmitters are not required to } \\
\text { maintain a list of the agents and payor } \\
\text { transmitters with whom they operate, and are } \\
\text { not required to immediately obtain the } \\
\text { customer documentation after a transfer is } \\
\text { paid by agents or payors. } \\
\text { Disperser transmitters are not explicitly } \\
\text { accountable for the failure of their Payor } \\
\text { transmitters to satisfy the applicable CDD, } \\
\text { monitoring and reporting requirements. } \\
\text { Regulations do not require money remitters } \\
\text { to include and maintain CDD information on } \\
\text { wire transfers (relation to SR. VII). }\end{array}$ \\
\hline SR.VII Wire transfer rules & PC & $\begin{array}{l}\text { - } \quad \text { CDD threshold of USD 3,000 exceeds FATF } \\
\text { limit. } \\
\text { - } \quad \text { No regulation of batch transfers. } \\
\text { No regulation of the information that must be } \\
\text { kept by intermediary institutions (regulations } \\
\text { only cover the originator and beneficiary } \\
\text { financial institutions). } \\
\text { No requirement to adopt risk-based } \\
\text { procedures for identifying and handling } \\
\text { transfers with incomplete originator } \\
\text { information. } \\
\text { Money remitters are not subject wire transfer } \\
\text { regulations. }\end{array}$ \\
\hline SR.VIII Nonprofit organizations & PC & $\begin{array}{l}\text { The relevant reviews of the domestic non- } \\
\text { profit sector have not been conducted. } \\
\text { No outreach to the NPO sector has been } \\
\text { undertaken with a view to protecting the } \\
\text { sector from TF abuse. } \\
\text { Most measures in place concerning NPOs are } \\
\text { only for tax purposes and only cover a } \\
\text { limited number of NPOs, which are those } \\
\text { authorized by the SAT to issue tax deductible }\end{array}$ \\
\hline
\end{tabular}




\begin{tabular}{|c|c|c|}
\hline Forty Recommendations & Rating & Summary of factors underlying rating ${ }^{56}$ \\
\hline & & $\begin{array}{l}\text { receipts. } \\
\text { No steps have been taken to promote } \\
\text { effective supervision or monitoring of } \\
\text { relevant NPOs. } \\
\text { Not all NPOs are required to maintain } \\
\text { relevant purpose and control information } \\
\text { (only those authorized to issue tax deductible } \\
\text { receipts). } \\
\text { Not all NPOs are subject to appropriate } \\
\text { sanctions for violations of oversight or rules } \\
\text { (only those authorized to issue tax deductible } \\
\text { receipts). } \\
\text { Not all NPOs are required to be licenced } \\
\text { (only those authorized to issue tax deductible } \\
\text { receipts). } \\
\text { Not all NPOs are required to maintain } \\
\text { detailed records of transactions to verify that } \\
\text { funds have been spent consistent with } \\
\text { purpose and objectives (only those authorized } \\
\text { to issue tax deductible receipts). } \\
\text { capabilities to examine those NPOs that are } \\
\text { There is no effective domestic co-operation, } \\
\text { co-ordination and information sharing among } \\
\text { all levels of appropriate authorities or } \\
\text { organizations that hold relevant information } \\
\text { on NPOs of potential terrorist financing } \\
\text { concern (other than NPOs authorized to issue } \\
\text { tax deductible receipts). } \\
\text { There are no mechanisms to ensure that full } \\
\text { access to information on the administration } \\
\text { and management of a particular NPO may be } \\
\text { obtained during the course of an investigation } \\
\text { investigative action when there is a suspicion } \\
\text { or reasonable grounds to suspect that a } \\
\text { particular NPO is being exploited for terrorist } \\
\text { financing purposes or is a front organization } \\
\text { deductible receipts). } \\
\text { - }\end{array}$ \\
\hline
\end{tabular}




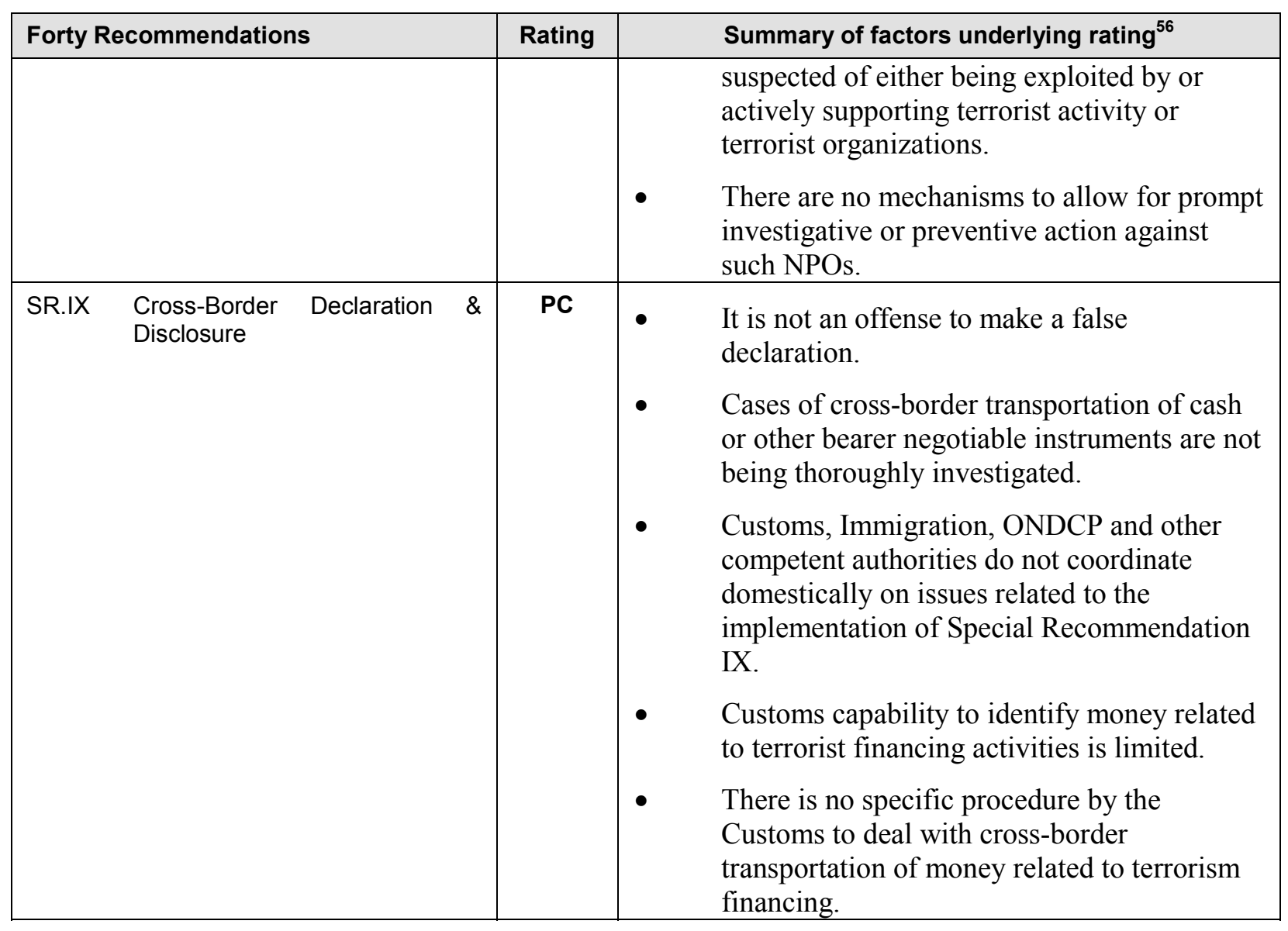


Table 2. Recommended Action Plan to Improve the AML/CFT System

\begin{tabular}{|c|c|}
\hline FATF 40+9 Recommendations & Recommended Action (in order of priority within each section) \\
\hline General & \\
\hline $\begin{array}{l}\text { 2. Legal System and Related } \\
\text { Institutional Measures }\end{array}$ & \\
\hline $\begin{array}{l}\text { Criminalization of Money Laundering } \\
\text { (R.1 and 2) }\end{array}$ & $\begin{array}{l}\text { - Amend Article } 400 \text { Bis of the CPF to incorporate the conduct of } \\
\text { "concealment or disguise of the true nature, source, location, } \\
\text { disposition, movement, or ownership of or rights with respect to } \\
\text { property" as a primary conduct and not as a purpose. } \\
\text { - Amend Article } 400 \text { Bis of the CPF to incorporate the conduct of } \\
\text { "possession or use of property" into the money laundering offense. The } \\
\text { possession or use of property should be criminalized without a specific } \\
\text { purpose. } \\
\text { - Reinforce coordination among all relevant actors involved in } \\
\text { investigating and prosecuting crime in Mexico and define clearer } \\
\text { protocols for the processes followed by each of them. } \\
\text { - Institutionalize the current practices of close collaboration among the } \\
\text { FIU and PGR authorities. } \\
\text { - Place additional focus in conducting investigations of money laundering } \\
\text { offeses committed through the financial system. } \\
\text { - Foster awareness among prosecutors to generate an interest in } \\
\text { pursuing criminal investigations involving the financial system. } \\
\text { - Develop adequate training programs to enhance the capacity of } \\
\text { prosecutors and judges to prosecute and adjudicate money laundering } \\
\text { cases involving the financial system. } \\
\text { - Consider the possibility of amending the CPF to make legal persons } \\
\text { criminally liable for money laundering offenses. } \\
\text { - Amend the CPF to eliminate the requirement for PGR to obtain a formal } \\
\text { complaint from the SHCP to bring cases to court when the conduct } \\
\text { involved was carried out using the services rendered by a financial } \\
\text { institution. }\end{array}$ \\
\hline $\begin{array}{l}\text { Criminalization of Terrorist Financing } \\
\text { (SR.II) }\end{array}$ & $\begin{array}{l}\text { - Amend the terrorist financing conduct in Section } 148 \text { Bis of the CPF to } \\
\text { focus it on the intention of the act to cause death or serious bodily injury } \\
\text { rather than on what is used to commit the act. } \\
\text { - Amend the terrorist financing conduct in Section } 148 \text { Bis of the CPF to } \\
\text { require a purpose of generating alarm, fear, or terror rather than a } \\
\text { showing. } \\
\text { - Extend the terrorist financing conduct in Section } 148 \text { Bis of the CPF to } \\
\text { the financing of the acts that constitute an offense within the scope of, } \\
\text { and as defined in, the treaties listed in the annex of the UN Terrorist } \\
\text { Financing Convention consistent with its obligations under SR.II. } \\
\text { - Mexico should conduct an assessment of terrorism and terrorist } \\
\text { financing threats and vulnerabilities, partially drawing from the findings } \\
\text { of this assessment, in order to estimate its exposure such risks. } \\
\text { - Adopt legislation making legal persons criminally liable for FT. }\end{array}$ \\
\hline $\begin{array}{l}\text { Confiscation, freezing, and seizing of } \\
\text { proceeds of crime (R.3) }\end{array}$ & $\begin{array}{l}\text { - Mexican criminal law provides a broad range of procedures and tools to } \\
\text { attach and forfeit property. However, Mexico should include in its } \\
\text { legislation the ability to forfeit property "for the equivalent or } \\
\text { corresponding value". }\end{array}$ \\
\hline
\end{tabular}




\begin{tabular}{|c|c|}
\hline FATF $40+9$ Recommendations & Recommended Action (in order of priority within each section) \\
\hline & $\begin{array}{l}\text { - Mexican legislation should also be amended to include specific } \\
\text { provisions for preventing or voiding (nullifying) contracts or other acts in } \\
\text { which the persons involved knew or should have known that as a result } \\
\text { of those acts the authorities' ability to recover property subject to } \\
\text { forfeiture would be impaired. }\end{array}$ \\
\hline $\begin{array}{l}\text { Freezing of funds used for terrorist } \\
\text { financing (SR.III) }\end{array}$ & 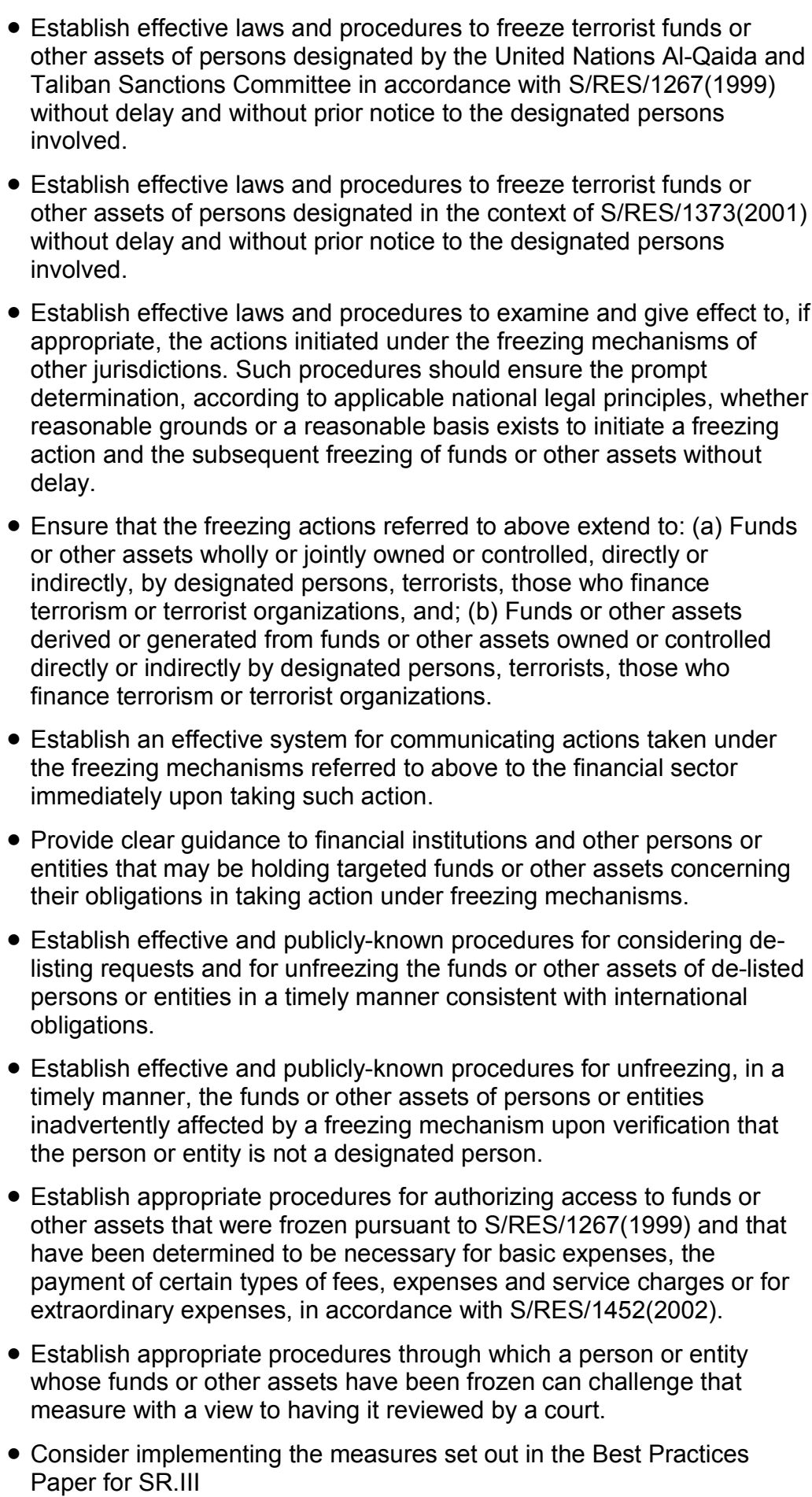 \\
\hline The Financial Intelligence Unit and its & - Urgently address the technical problems that have prevented the FIU \\
\hline
\end{tabular}




\begin{tabular}{|c|c|}
\hline FATF 40+9 Recommendations & Recommended Action (in order of priority within each section) \\
\hline functions (R.26) & $\begin{array}{l}\text { from receiving STRs filed by certain sectors through the SAT. } \\
\text { - Seek to increase the FIU's access to criminal information beyond that } \\
\text { obtained in the course of its participation in investigations. } \\
\text { - Establish with the Attorney General's Office and the SAT a mechanism } \\
\text { to evaluate the efficiency of the reporting and analysis system, and the } \\
\text { quality of intelligence reports and usefulness to investigations and } \\
\text { prosecutions. } \\
\text { - As planned, increase the level of staff and other resources in light of the } \\
\text { current and expected future volume of STRs, and other responsibilities } \\
\text { assigned to the FIU. } \\
\text { - Periodically review the process for selecting "tax-related" STRs for } \\
\text { referral to the SAT to ensure that ML/FT associated with this and other } \\
\text { criminal activities are adequately considered by the FIU. }\end{array}$ \\
\hline $\begin{array}{l}\text { Law enforcement, prosecution and } \\
\text { other competent authorities (R.27 and } \\
\text { 28) }\end{array}$ & $\begin{array}{l}\text { - In developing the AML/CFT strategy, highlight the importance of } \\
\text { effective inter-institutional cooperation and coordination and set up } \\
\text { working guidelines with clear targets and precise timelines. } \\
\text { - Provide Mexican security forces the ability to apply special techniques } \\
\text { of investigation, particularly "controlled deliveries" in the context of ML } \\
\text { investigations and extend them to all underlying or predicate offenses } \\
\text { listed in the FATF glossary. } \\
\text { - Allow for the possibility of postponing or waiving the arrest of suspects } \\
\text { and strengthen witness protection programs. } \\
\text { - Expand the scope of the Ministry of the Civil Service [Secretaría de la } \\
\text { Función Pública] to enable it to draft and coordinate joint strategies to } \\
\text { combat and dismantle corruption. } \\
\text { - Strengthen the capacity, awareness-raising and training for judges to } \\
\text { adjudicate financial crimes and ML and TF cases in particular. A } \\
\text { comprehensive nationwide training program should be developed. } \\
\text { - Increase staff and financial resources for the PGR's and for SIEDO in } \\
\text { particular. } \\
\text { - Improve PGR's capacity to investigate assets and net worth. }\end{array}$ \\
\hline $\begin{array}{l}\text { Cross Border Declaration or disclosure } \\
\text { (SR IX) }\end{array}$ & $\begin{array}{l}\text { - The authorities should enact legislation, as planned, to make false } \\
\text { declarations an offense. } \\
\text { - The Customs Authority, the FIU, and other law enforcement agencies } \\
\text { should improve the coordination to work more closely and permanently } \\
\text { to investigate cases of cross-border transportation of currency or bearer } \\
\text { negotiable instruments in order to determine its country of origin, } \\
\text { bearing in mind that such currency may be the proceeds of criminal } \\
\text { conduct committed in the said country. } \\
\text { - These agencies should also consider improving the institutional } \\
\text { structure and the personnel capacities to deal with the identification of } \\
\text { money possibly linked to terrorist financing activities, persons, or } \\
\text { organizations. } \\
\text { - The Customs should establish mechanisms, such as statistics, to } \\
\text { evaluate more appropriately the effectiveness of the measures in place } \\
\text { to comply with this Recommendation. } \\
\text { - The FIU should be more involved and if possible take control of the } \\
\text { investigation with respect to cash seized at the ports of entry and where } \\
\text { appropriate initiate money laundering intelligence investigation. }\end{array}$ \\
\hline Preventive Measures-Financial & \\
\hline
\end{tabular}




\begin{tabular}{|c|c|}
\hline FATF 40+9 Recommendations & Recommended Action (in order of priority within each section) \\
\hline Institutions & \\
\hline $\begin{array}{l}\text { Risk of money laundering or terrorist } \\
\text { financing }\end{array}$ & $\begin{array}{l}\text { - Conduct a systemic review of ML and FT risks in the financial sector to } \\
\text { aid compliance with the risk-based CDD requirements, including the } \\
\text { issue of related guidelines. }\end{array}$ \\
\hline $\begin{array}{l}\text { Customer due diligence, including } \\
\text { enhanced or reduced measures } \\
\text { (R.5-8) }\end{array}$ & 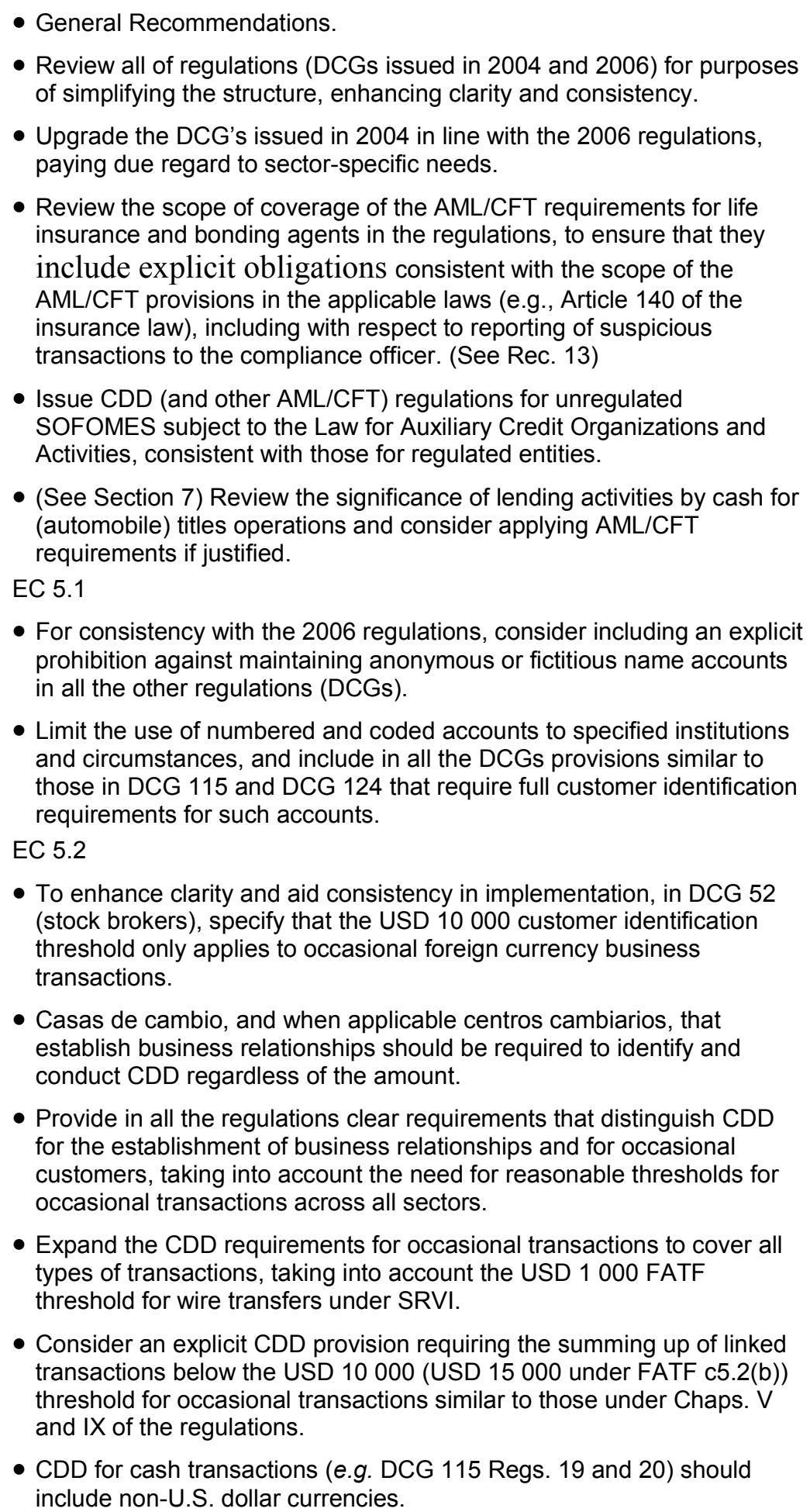 \\
\hline
\end{tabular}




\begin{tabular}{|c|c|}
\hline FATF 40+9 Recommendations & Recommended Action (in order of priority within each section) \\
\hline & 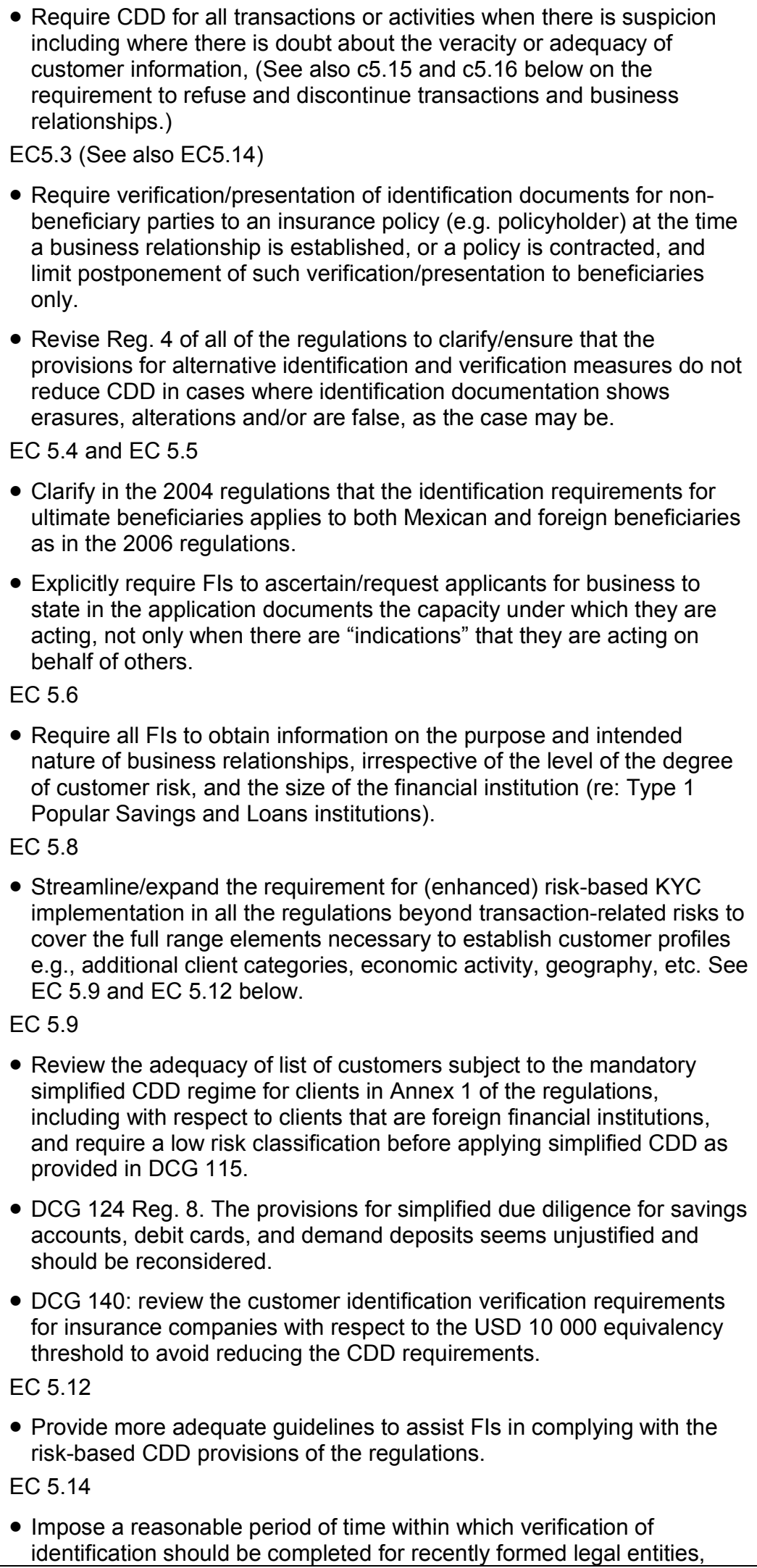 \\
\hline
\end{tabular}




\begin{tabular}{|c|c|}
\hline FATF $40+9$ Recommendations & Recommended Action (in order of priority within each section) \\
\hline & 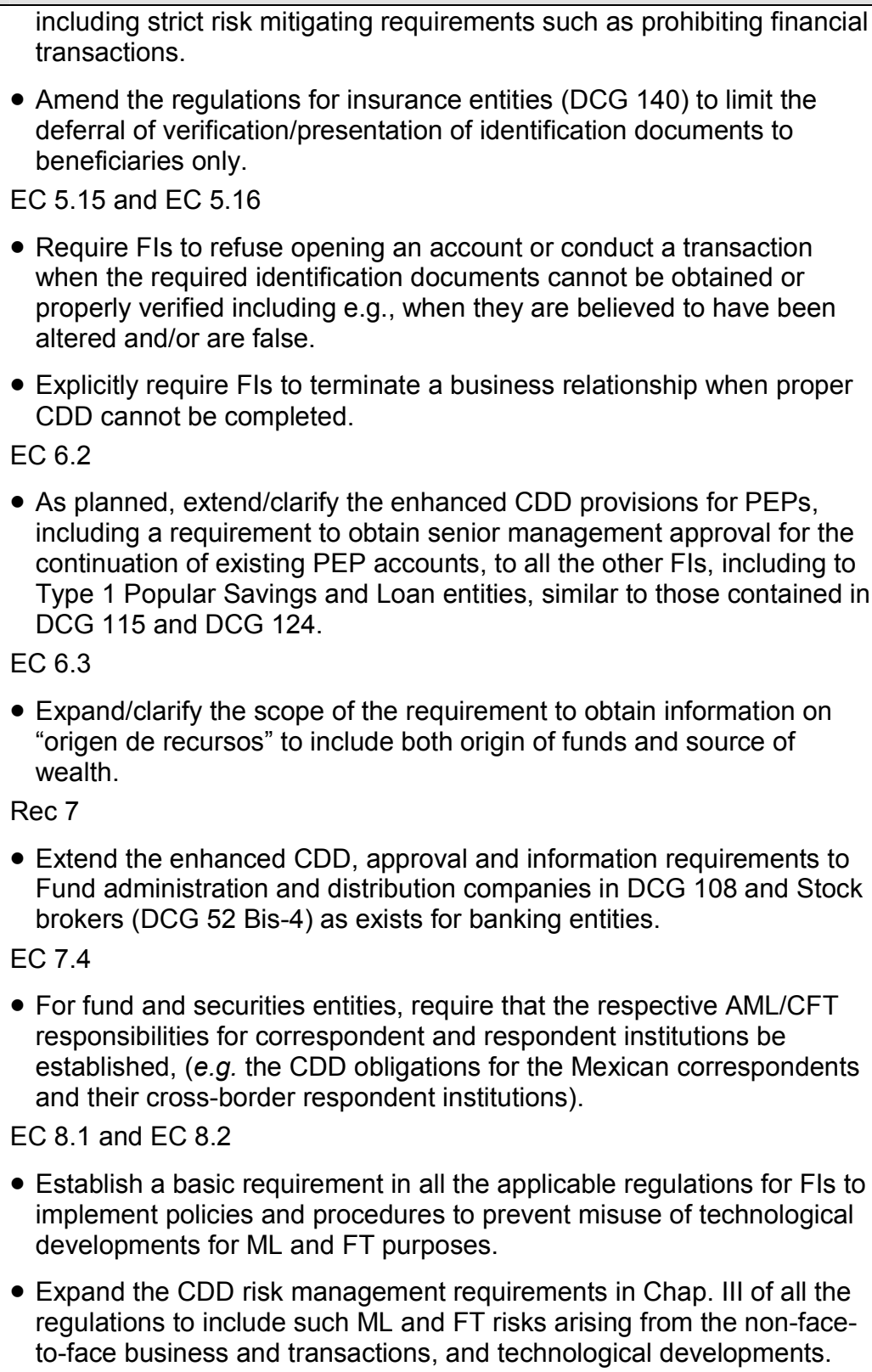 \\
\hline $\begin{array}{l}\text { Third parties and introduced business } \\
\text { (R.9) }\end{array}$ & $\begin{array}{l}\text { - Explicitly require in the regulations, (esp. for money remitters and } \\
\text { insurance companies), that Fls immediately obtain CDD information } \\
\text { from parties that conduct CDD on their behalf. } \\
\text { - Enforce the requirement for insurance companies to monitor } \\
\text { compliance by their agents with their AML/CFT regulatory obligations. } \\
\text { - Consider implementing a system that requires remitting firms } \\
\text { (dispersor) to monitor paying agents' (pagador) operations (on whom } \\
\text { reliance is placed for certain CDD elements) and compliance with the } \\
\text { regulations. } \\
\text { - Other: For consistency with Art. } 140 \text { of the insurance law (and similarly } \\
\text { for bonding companies), review the suspicious reporting requirements } \\
\text { in DCG } 140 \text { and in the regulations issued by the SHCP-FIU that } \\
\text { establishes the reporting procedures and format. }\end{array}$ \\
\hline
\end{tabular}




\begin{tabular}{|c|c|}
\hline FATF $40+9$ Recommendations & Recommended Action (in order of priority within each section) \\
\hline $\begin{array}{l}\text { Financial institution secrecy or } \\
\text { confidentiality (R.4) }\end{array}$ & $\begin{array}{l}\text { - The CONSAR and SAT should be expressly empowered to exchange } \\
\text { information with foreign counterparts regarding AML/CFT. }\end{array}$ \\
\hline $\begin{array}{l}\text { Record keeping and wire transfer rules } \\
\text { (R.10 \& SR.VII) }\end{array}$ & $\begin{array}{l}\text { - R.10: Consider reviewing the law(s) to more explicitly provide for } \\
\text { broader recordkeeping requirements consistent with the underlying } \\
\text { regulations and avoid the potential for restrictive interpretations of the } \\
\text { authority of the Regulators to regulate all aspects of recordkeeping. } \\
\text { - R.10: Consider clarifying the record keeping obligations contained in } \\
\text { financial regulations to more clearly include all forms of account files } \\
\text { and business correspondence (these are only required by the Code of } \\
\text { Commerce). } \\
\text { - SR.VII: The authorities should lower the threshold for CDD on } \\
\text { occasional wire transfers from USD } 3000 \text { to USD } 1000 \text { or lower. } \\
\text { - SR.VII: The intermediary institutions in a wire transfer should be obliged } \\
\text { to keep accurate and meaningful information throughout the transfer } \\
\text { chain. } \\
\text { - SR.VII: Batch wire transfers should be regulated to require that the } \\
\text { batch file in which the individual transfers are grouped, contains full } \\
\text { originator information that is traceable by the authorities of the foreign } \\
\text { recipient institution. } \\
\text { - SR.VII: To the extent that money remitters conduct wire transfers, they } \\
\text { should be subject to the same obligations as credit institutions for this } \\
\text { service. } \\
\text { - SR.VII: Require institutions to adopt risk-based procedures for } \\
\text { identifying and handling wire transfers that are not accompanied by } \\
\text { complete originator information. }\end{array}$ \\
\hline $\begin{array}{l}\text { Monitoring of transactions and } \\
\text { relationships }(\mathrm{R} .11 \& 21)\end{array}$ & $\begin{array}{l}\text { R.11: Review the list of potentially suspicious transactions given in the } \\
\text { regulations and clarify their correct use as triggers of additional review } \\
\text { of the transaction, and not of a mandatory report to the FIU. Also } \\
\text { provide additional guidance to reporting institutions in this area. } \\
\text { R. } 21 \text { : Consider allowing the regulators to impose a broader range of } \\
\text { countermeasures and to address the potential of countries of concern } \\
\text { to Mexico before these are identified by an international organization. }\end{array}$ \\
\hline $\begin{array}{l}\text { Suspicious transaction reports and } \\
\text { other reporting (R.13, 14, 19, 25, \& } \\
\text { SR.IV) }\end{array}$ & $\begin{array}{l}\text { - Swift action and resources need to be committed to guarantee that } \\
\text { reports from currency exchanges centers and money remitters, and } \\
\text { from bonding companies are available to the FIU and the investigative } \\
\text { authorities. } \\
\text { - Revise the regulatory provisions that trigger the filing of STRs, and not } \\
\text { only the guidelines, as one of the measures to reduce over-reporting. } \\
\text { - All AML/CFT sector-specific regulations should be revised to explicitly } \\
\text { incorporate the obligation to use preventive mechanisms to detect and } \\
\text { report the financing of terrorism, including in relation to the recently } \\
\text { created offense of international terrorism. } \\
\text { - Authorities should provide more guidance to reporting institutions on } \\
\text { how to detect terrorist financing operations, and promote awareness of } \\
\text { the risks of being misused by foreign terrorist organizations to channel } \\
\text { their funds. } \\
\text { - The FIU should start providing more regular feedback to reporting } \\
\text { institutions based in the objective parameters already defined. Also, it } \\
\text { should inform institutions about money laundering techniques specific } \\
\text { to the Mexican reality, resulting from the strategic analysis of the } \\
\text { information available to the FIU and law enforcement authorities. }\end{array}$ \\
\hline
\end{tabular}




\begin{tabular}{|c|c|}
\hline FATF 40+9 Recommendations & Recommended Action (in order of priority within each section) \\
\hline & $\begin{array}{l}\text { - The Supervisory agencies should continue their efforts to carry out risk- } \\
\text { focused inspections and encourage financial institutions to fine tune } \\
\text { their automated systems in order to reduce excessive alerts that } \\
\text { overwhelm their internal control systems and create a defensive } \\
\text { reporting culture. } \\
\text { - The obligation to report attempted transactions should be explicitly } \\
\text { established in the regulations. }\end{array}$ \\
\hline $\begin{array}{l}\text { Internal controls, compliance, audit and } \\
\text { foreign branches (R.15 \& 22) }\end{array}$ & $\begin{array}{l}\text { - As in DCG 115, all of the other regulations should include an explicit } \\
\text { requirement to have a well resourced and independent audit function. }\end{array}$ \\
\hline Shell banks (R.18) & $\begin{array}{l}\text { - Explicitly require Fls to satisfy themselves that their respondent } \\
\text { institutions in foreign countries do no permit their accounts to be used } \\
\text { by shell banks. }\end{array}$ \\
\hline $\begin{array}{l}\text { The supervisory and oversight system- } \\
\text { competent authorities and SROs } \\
\text { Role, functions, duties and powers } \\
\text { (including sanctions) (R.23, 29, } 17 \text { and } \\
\text { 25) }\end{array}$ & 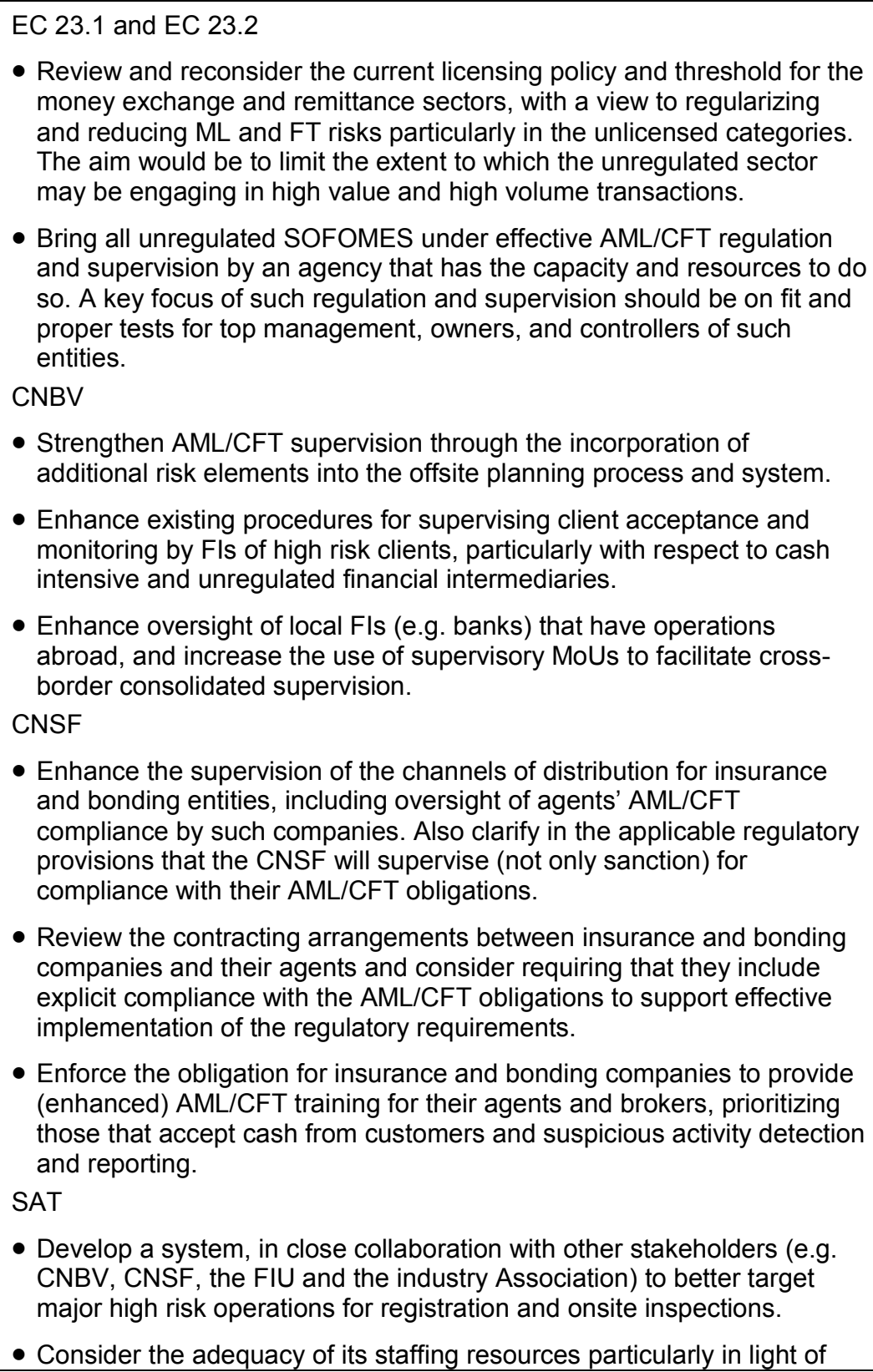 \\
\hline
\end{tabular}




\begin{tabular}{|c|c|}
\hline FATF $40+9$ Recommendations & Recommended Action (in order of priority within each section) \\
\hline & $\begin{array}{l}\text { the increased responsibility for SOFOMES, and the large number of } \\
\text { foreign exchange centers and money remitters subject to its } \\
\text { supervision. } \\
\text { EC } 23.3 \text { See EC } 23.2 \text { above. } \\
\text { EC } 23.5 \text { and EC } 23.6 \\
\text { - Enforce the registration requirement and implement more effective } \\
\text { measures in the unregulated sectors (centros cambiarios and money } \\
\text { remitters) to prohibit unregistered operators from accessing the } \\
\text { regulated financial sector. } \\
\text { EC } 25.1 \\
\text { - The supervisory authorities, in conjunction with the FIU and other } \\
\text { authorities as necessary, should issue industry-specific guidelines for } \\
\text { implementing the AML/CFT requirements, particularly with respect to } \\
\text { new ML and FT risks, ML/FT techniques and methods in the structuring } \\
\text { and laying stages of money laundering. This would aid in the } \\
\text { implementation of the risk-based CDD requirements established in the } \\
\text { regulations. } \\
\text { EC } 17.1 \\
\text { - In view of the relatively low average amount of fines applied to date, } \\
\text { review proportionality and dissuasive nature of fines and consider } \\
\text { additional use of non-monetary measures. } \\
\text { EC } 17.4 \\
\text { - Consider applying/including nonmonetary sanctions for breaches with } \\
\text { the AML/CFT requirements for the unlicensed entities (e.g. centros } \\
\text { cambiarios, money remitters, and SOFOMES) that would include a } \\
\text { process for de-registration. }\end{array}$ \\
\hline Money value transfer services (SR.VI) & $\begin{array}{l}\text { - Issue regulations that require money transmitters to include CDD } \\
\text { information on all wire transfers sent and received, or at least on those } \\
\text { equal or higher than USD } 1000 \text {, in accordance to SR. VII and its } \\
\text { interpretative note. } \\
\text { - Include account files and business correspondence as part of the data } \\
\text { for which money remitters must keep proper records, and require that } \\
\text { these records must allow the reconstruction of the transactions. } \\
\text { - Require an explicit CDD for occasional transactions that in aggregate } \\
\text { equal or exceed the established CDD threshold, which would also } \\
\text { support implementation of the suspicious activity monitoring and } \\
\text { reporting requirements. } \\
\text { - Insert an explicit requirement in the regulations for Disperser } \\
\text { Transmitters to maintain a list of the agents and Payor Transmitters } \\
\text { with whom they operate. } \\
\text { - Require in the AML/CFT regulations that the contracts between } \\
\text { Disperser and Payor Transmitters incorporate all the obligations of the } \\
\text { former with respect to customer identification, timeframes for forwarding } \\
\text { documentation, monitoring of transactions and sending of } \\
\text { unusual/suspicious activity reports, etc. } \\
\text { - Require in the AML/CFT regulations that the contract between } \\
\text { Disperser and Payor Transmitters allows the former to audit the Payor's } \\
\text { compliance with its AML/CFT obligations. } \\
\text { - The regulations should be amended to make the disperser transmitters } \\
\text { accountable for any failure of their Payor transmitters to satisfy the } \\
\text { applicable CDD, monitoring and reporting requirements. Also require } \\
\text { that CDD information obtained by the payor/agent is immediately }\end{array}$ \\
\hline
\end{tabular}




\begin{tabular}{|c|c|}
\hline FATF 40+9 Recommendations & Recommended Action (in order of priority within each section) \\
\hline & $\begin{array}{l}\text { obtained by the disperser. } \\
\text { - The SAT should be explicitly empowered to inspect, instruct, and } \\
\text { sanction as appropriate all the payor transmitters, and not only the } \\
\text { disperser transmitters. } \\
\text { - Maintain efforts to train staff of the SAT and to dedicate a significant } \\
\text { number of them to the inspection of AML/CFT. } \\
\text { - Educate the public about the characteristics that they should expect } \\
\text { and demand from reputable money remitters, including evidence of } \\
\text { registration with the SAT and minimum customer identification } \\
\text { requirements. } \\
\text { - There should be a more concerted and well-resourced effort from the } \\
\text { SAT and other stakeholders to estimate the number and significance of } \\
\text { MVT, identify those who operate informally and determine the areas of } \\
\text { greater priority to prevent risks of ML and FT. }\end{array}$ \\
\hline $\begin{array}{l}\text { 4. Preventive Measures }- \\
\text { Nonfinancial Businesses and } \\
\text { Professions }\end{array}$ & \\
\hline $\begin{array}{l}\text { Customer due diligence and record- } \\
\text { keeping (R.12) }\end{array}$ & $\begin{array}{l}\text { - DNFBPs should be subject to AML/CFT obligations for identification of } \\
\text { customers, recordkeeping and monitoring of transactions as required by } \\
\text { Recommendation } 12 \text { of the FATF. }\end{array}$ \\
\hline Suspicious transaction reporting (R.16) & $\begin{array}{l}\text { - DNFBPs should be subject to an obligation to file reports of suspicious } \\
\text { transactions and maintain internal controls for AML/CFT purposes, in } \\
\text { the terms of the FATF Recommendation } 16 \text {. }\end{array}$ \\
\hline $\begin{array}{l}\text { Regulation, supervision, monitoring, } \\
\text { and sanctions (R.17, 24, \& 25) }\end{array}$ & $\begin{array}{l}\text { - DNFBPs should be subject to a risk-sensitive regulatory framework for } \\
\text { AML/CFT, there should be one or several authorities responsible for } \\
\text { overseeing compliance with it, and for providing guidance to reporting } \\
\text { institutions. }\end{array}$ \\
\hline $\begin{array}{l}\text { Other designated non-financial } \\
\text { businesses and professions (R.20) }\end{array}$ & $\begin{array}{l}\text { Mexico should consider applying Recommendations } 5,6,8-11,13-15 \text {, } \\
17 \text { and } 21 \text { to non-financial businesses and professions (other than } \\
\text { DNFBP) that are at risk of being misused for ML and FT. } \\
\text { - Mexico should take measures to encourage the development and use } \\
\text { of modern and secure techniques for conducting financial transactions } \\
\text { that are less vulnerable to ML. }\end{array}$ \\
\hline 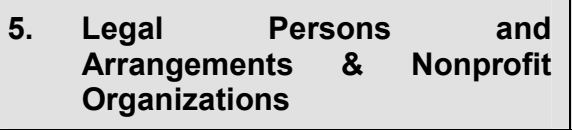 & \\
\hline $\begin{array}{l}\text { Legal Persons-Access to beneficial } \\
\text { ownership and control information } \\
\text { (R.33) }\end{array}$ & $\begin{array}{l}\text { - Mexico should take measures to prevent the use of legal persons in } \\
\text { relation to ML/TF. } \\
\text { - The Registry should ensure that it is able to obtain or have access to } \\
\text { adequate, accurate, and current beneficial ownership and control } \\
\text { information. } \\
\text { - Mexico should take appropriate measures to ensure that legal persons } \\
\text { using bearer shares are not misused for ML. } \\
\text { - Mexico should put in place measures to facilitate access by financial } \\
\text { institutions to beneficial ownership and control information, so as to } \\
\text { allow them to more easily verify the customer identification data. }\end{array}$ \\
\hline $\begin{array}{l}\text { Legal Arrangements-Access to } \\
\text { beneficial ownership and control }\end{array}$ & $\begin{array}{l}\text { - Mexico should address the shortcomings identified under Rec. } 33 \text { as } \\
\text { they may impact on a credit institutions' capacity to easily verify }\end{array}$ \\
\hline
\end{tabular}




\begin{tabular}{|c|c|}
\hline FATF $40+9$ Recommendations & Recommended Action (in order of priority within each section) \\
\hline information (R.34) & $\begin{array}{l}\text { identification data in connection with a "fideicomiso" or other legal } \\
\text { arrangements. } \\
\text { - Maintain comprehensive statistics on the amounts of requests received } \\
\text { by the CNBV or the amount of related sanctions applied to credit } \\
\text { institutions. }\end{array}$ \\
\hline Nonprofit organizations (SR.VIII) & 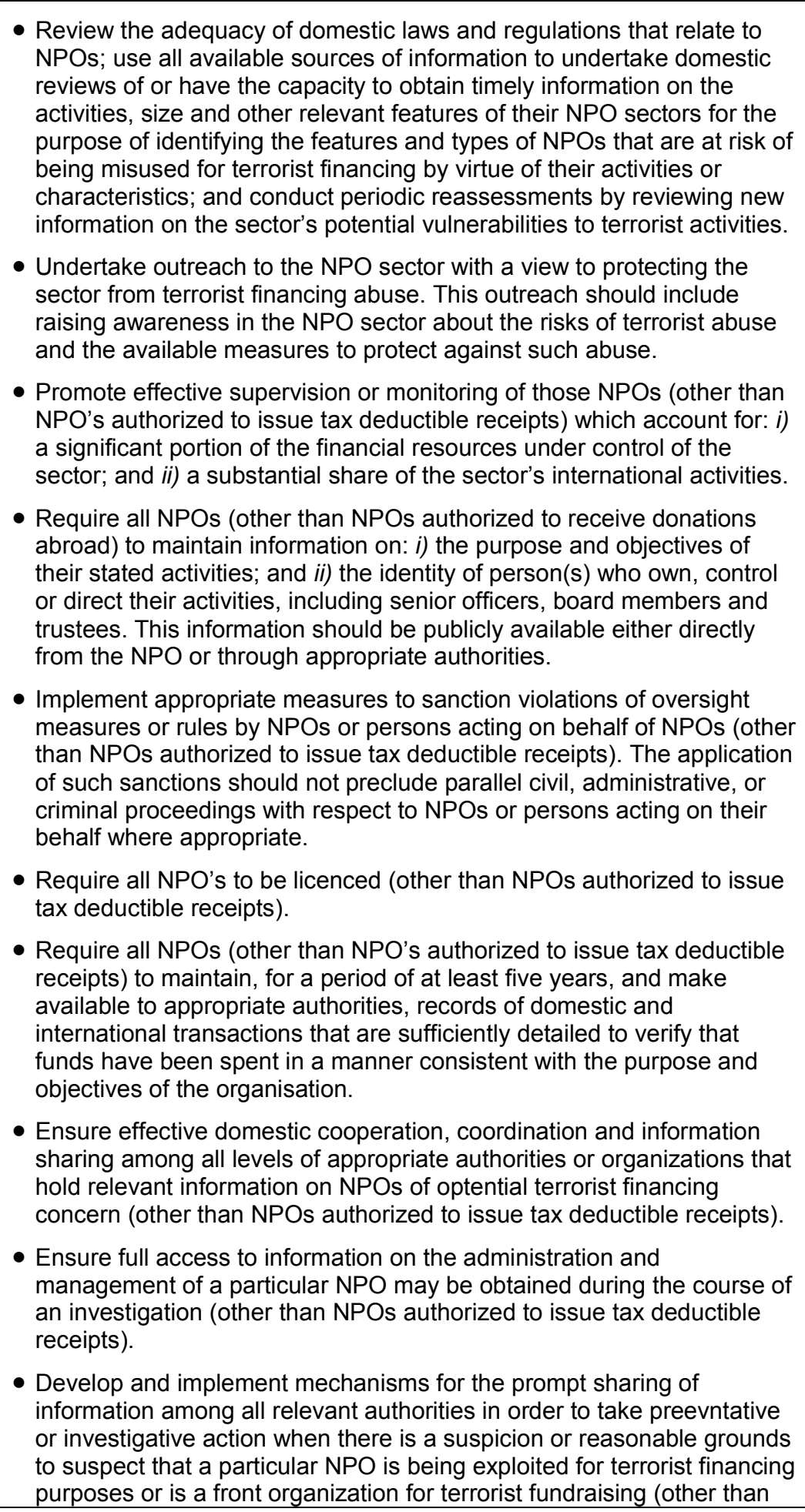 \\
\hline
\end{tabular}




\begin{tabular}{|c|c|}
\hline FATF $40+9$ Recommendations & Recommended Action (in order of priority within each section) \\
\hline & $\begin{array}{l}\text { NPOs authorized to issue tax deductible receipts). } \\
\text { Develop the investigative expertise and capabilities to examine those } \\
\text { NPOs that are suspected of either being exploited by or actively } \\
\text { supporting terrorist activity or terrorist organizations. } \\
\text { - Develop mechanisms to allow for prompt investigative or preventive } \\
\text { action against such NPOs. }\end{array}$ \\
\hline $\begin{array}{l}\text { 6. National and International } \\
\text { Cooperation }\end{array}$ & \\
\hline $\begin{array}{l}\text { National cooperation and coordination } \\
\text { (R.31) }\end{array}$ & $\begin{array}{l}\text { - Although the current arrangement whereby the PGR must } \\
\text { request information protected by banking secrecy is } \\
\text { working efficiently, it should be established under a formal } \\
\text { arrangement between the PGR and financial supervisory } \\
\text { authorities to support the relationship going forward. } \\
\text { - Joint cooperation or coordination mechanisms should be established } \\
\text { between the PGR and the Judiciary to implement common policies and } \\
\text { conduct activities aimed at fighting organized crime. } \\
\text { - Institutionalize the current practices of close collaboration among the } \\
\text { FIU and PGR authorities. } \\
\text { - Continue to strengthen the cooperative relationships between PGR and } \\
\text { the FIU addressing also cooperation at the policy level. }\end{array}$ \\
\hline $\begin{array}{l}\text { The Conventions and UN Special } \\
\text { Resolutions (R.35 \& SR.I) }\end{array}$ & $\begin{array}{l}\text { R } 35 \\
\text { - Amend Article } 400 \text { Bis of the CPF to incorporate the conduct of } \\
\text { "conversion of property" into the money laundering offense. } \\
\text { "concealment or disguise of the true nature, source, location, } \\
\text { disposition, movement, or ownership of or rights with respect to } \\
\text { property" as a primary conduct and not as a purpose. } \\
\text { - Amend Article } 400 \text { Bis of the CPF to incorporate the conduct of } \\
\text { "possession or use of property" into the money laundering offense. The } \\
\text { possession or use of property should be criminalized without a specific } \\
\text { purpose. } \\
\text { - Amend the CPF to criminalize the "conspiracy to commit" the offense } \\
\text { and make it applicable to the money laundering offense. } \\
\text { - Enact legislation to allow the use of the controlled delivery as a special } \\
\text { technique of investigation. } \\
\text { SR I } \\
\text { - Amend the terrorist financing conduct in Section } 148 \text { Bis of the CPF to } \\
\text { focus it on the intention of the act to cause death or serious bodily injury } \\
\text { rather than on what is used to commit the act. } \\
\text { - Amend the terrorist financing conduct in Section } 148 \text { Bis of the CPF to } \\
\text { require a purpose of generating alarm, fear or terror rather than a } \\
\text { showing. } \\
\text { - Amend the CPF to extend the terrorist financing conducts to the } \\
\text { financing of the acts that constitute an offense within the scope of, and } \\
\text { as defined in the treaties listed in the annex of the SFT Convention. } \\
\text { other assets of terrorists, those who finance terrorism and terrorist } \\
\text { organizations in accordance with UN SCRs relating to the prevention } \\
\text { and suppression of FT. }\end{array}$ \\
\hline
\end{tabular}




\begin{tabular}{|c|c|}
\hline FATF $40+9$ Recommendations & Recommended Action (in order of priority within each section) \\
\hline & - Adopt legislation making legal persons criminally liable for ML. \\
\hline $\begin{array}{l}\text { Mutual Legal Assistance (R.36, 37, } 38 \\
\text { \& SR.V) }\end{array}$ & $\begin{array}{l}\text { - Appropriate laws and procedures should be implemented to freeze } \\
\text { terrorist funds or other assets at the request of a foreign country. } \\
\text { - Introduce legal provisions for confiscating goods of equivalent value. } \\
\text { - Address the deficiencies in the money laundering and terrorist financing } \\
\text { offenses described under R } 1 \text { and SR II respectively, as they can } \\
\text { impact on Mexico's ability to provide MLA. } \\
\text { - Address the deficiencies in the process for freezing terrorist assets } \\
\text { described under SR.III as they impact on Mexico's capacity to freeze, } \\
\text { seize and confiscate terrorist assets at foreign request. }\end{array}$ \\
\hline Extradition (R. 39, 37 \&SR.V) & $\begin{array}{l}\text { - Mexico should address the deficiencies of the money laundering and } \\
\text { terrorist financing offense described under R } 1 \text { and SR II respectively, } \\
\text { which could impact on Mexico's ability to extradite. }\end{array}$ \\
\hline $\begin{array}{l}\text { Other Forms of Cooperation (R. } 40 \text { \& } \\
\text { SR.V) }\end{array}$ & $\begin{array}{l}\text { SR VI } \\
\text { - Mexico should address the deficiencies of the TF offense described } \\
\text { under SR II, which could impact on the law enforcement authorities' } \\
\text { ability to provide international cooperation. }\end{array}$ \\
\hline 7. Other Issues & \\
\hline Resources and Statistics (R30 \& R 32) & $\begin{array}{l}\text { EC } 30.1,30.3 \text { and } 30.3 \\
\text { - Enhanced training for risk-based supervision including for offsite } \\
\text { surveillance of ML and FT risks. } \\
\text { - Increase the focus on, and provide specialized training to inspections } \\
\text { staff, for the review of controls in FIs designed to detect noncash } \\
\text { money laundering, particularly during the structuring stages. } \\
\text { - Increase the staff of the DGPOI to enable it to better support all of the } \\
\text { CNBV's supervisory units and other outside authorities such as the FIU } \\
\text { and the PGR. }\end{array}$ \\
\hline $\begin{array}{l}\text { Other Relevant AML/CFT Measures or } \\
\text { Issues }\end{array}$ & \\
\hline General Framework-Structural Issues & $\begin{array}{l}\text { - Conduct/conclude a systemic review of ML and FT risks in the financial } \\
\text { sector and consider applying the FATF Recommendations to other } \\
\text { financial activities and non-DNFBP sectors where appropriate. } \\
\text { - More strongly encourage the use of non-cash means for conducting } \\
\text { financial transactions which could help reduce the size of the informal } \\
\text { economy. }\end{array}$ \\
\hline
\end{tabular}




\section{Annex 1. Details of All Bodies Met During the On-Site Visit}

List of ministries, other government authorities or bodies, private sector representatives and others

\section{Ministries, Government Authorities or Bodies, and Others}

1. Secretaria de Hacienda y Crédito Publico

2. Procuraduría Fiscal de la Federación

3. Procuraduría General de la República

4. Procuraduría General de la República - Dirección General de Cooperación Internacional.

5. Unidad de Inteligencia Financiera

6. Comisión Nacional Bancaria y de Valores (CNBV)

7. Comisión Nacional de Seguros y Fianzas

8. Comisión Nacional del Sistema de Ahorro para el Retiro

9. Unidad de Banca y Ahorro y Unidad de Valores, Seguros y Pensiones (CNBV)

10. Servicio de Administración Tributaria

11. Servicio de Administración Tributaria - Administración General Jurídica

12. Administración General de Aduanas

13. Public Registry of Commerce (Registro Público de la Propiedad)

14. Consejo de la Judicatura Federal

15. Dirección General de Asuntos Internacionales de la Secretaría de Seguridad Pública

16. Policía Federal Preventiva de la Secretaría de Seguridad Pública

17. Secretaria de Relaciones Exteriores

18. Servicio de Administración y Enajenación de Bienes

19. Secretaría de la Función Pública -Unidad de Vinculación para la Transparencia

20. Instituto Nacional de Ciencias Penales (INACIPE)

\section{Private Sector Representatives and Others}

\section{Financial Sector}

1. Citibank/Banamex

2. Bancomer/BBVA Group

3. American Express Bank SA 
4. Banco Azteca SA

5. Bank of Mexico

6. Banco Inbursa

7. Asociación De Bancos De México (banking association)

8. Consultoría Internacional Casa de Cambio

9. Masari Casa de Cambio

10. Asesoría Cambiaria Casa de Cambio

11. Grupo Dinámico Empresarial. Servicio Integral de Envíos (Western Union)

12. Tecno Dispersores, S.A. de C.V. (money remitter)

13. Asociación Mexicana De Casas De Cambio (association of licensed foreign exchange houses)

14. Asociación Nacional De Centros Cambiarios y Transmisores de Dinero (unlicensed/registered association of foreign exchange centers and money remitters)

15. Grupo Nacional Provincial S.A.B (insurance)

16. Seguros Atlas, S.A.

17. Marsh Brockman y Schuh Agente de Seguros y de Fianzas, S.A. de C.V

18. Asociación Mexicana de Instituciones de Seguros (association of insurance companies)

19. GBM Casa de Bolsa (securities broker)

20. Intercam Fondos (mutual/investment fund company)

21. Scotia Fondos

22. Asociación Mexicana de Intermediarios Bursátiles (association of securities intermediaries)

23. Arrendadora Banorte (leasing)

24. Factor Banorte (factoring)

25. Asociación Mexicana de Entidades Fianancieras Especializadas (association of especializad financial institutions e.g. factoring, leasing and Sofoles)

\section{Designated Non-Financial Businesses and Professions and NPOs}

26. Grupo Caliente - Centro de Apuestas Remotas y Sala de Sorteos

27. Secretaría de Gobernación - Dirección General Adjunta de Juegos y Sorteos

28. Barra Mexicana, Colegio de Abogados, A.C.

29. Dirección de Profesiones de la Secretaría de Educación Pública

30. Cámara Nacional de la Industria y Promoción de Vivienda

31. Centro Mexicano de la Filantropía 


\section{Annex 2. List of Key Laws. Regulations and Other Related Material used in the Assessment}

\begin{tabular}{|c|c|}
\hline \multicolumn{2}{|r|}{ Financial Preventive Sector and FIU } \\
\hline 1. & Ley General de Instituciones y Sociedades Mutualistas de Seguros (Insurance Companies Law) \\
\hline 2. & $\begin{array}{l}\text { Ley General de Organizaciones y Actividades Auxiliares del Crédito (Law of Auxilary Credit } \\
\text { Organizations and Activities.) }\end{array}$ \\
\hline 3. & Ley de Instituciones de Crédito (Credit Institutions Law) \\
\hline 4. & Ley para Regular las Agrupaciones Financieras (Law to Regulate Financial Groups) \\
\hline 5. & Ley de Ahorro y Crédito Popular (Popular Savings and Loans Law) \\
\hline 6. & $\begin{array}{l}\text { Ley de la Comisión Nacional Bancaria y de Valores (Law of the National Banking and Securities } \\
\text { Commission) }\end{array}$ \\
\hline 7. & Ley Federal de Instituciones de Fianzas (Federal Law of Bonding Institutions) \\
\hline 8. & Ley de los Sistemas de Ahorro para el Retiro (Law for Retirement Savings Systems) \\
\hline 9. & Ley de Sociedades de Inversión (Law of Investement Companies) \\
\hline 10. & Ley del Mercado de Valores (Securities Markets Law) \\
\hline 11. & Ley General de Sociedades Cooperativas (General Law of Credit I \\
\hline 12. & Ley del Banco de México (Bank of Mexico Law (Central Bank)) \\
\hline & 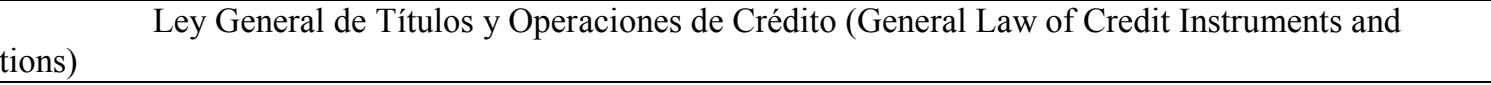 \\
\hline 14. & $\begin{array}{l}\text { Ley Para La Transparencia Y Ordenamiento De Los Servicios Financieros (Law for Transparency and } \\
\text { Regulation of Financial Services) }\end{array}$ \\
\hline 15. & $\begin{array}{l}\text { Modificaciones al Artículo 52-Bis } 4 \text { de la Ley del Mercado de Valores, actualmente Artículo } 212 \\
\text { (Revision to Art } 52 \text { Bis } 4 \text { of the Securities Market Law, currently Art 212) }\end{array}$ \\
\hline 16. & $\begin{array}{l}\text { Disposiciones de carácter general a que se refiere el artículo } 95 \text { de la Ley General de Organizaciones y } \\
\text { Actividades Auxiliares del Crédito aplicables a Casas de Cambio (AML/CFT Regulations for Casas de } \\
\text { Cambio) }\end{array}$ \\
\hline 17. & $\begin{array}{l}\text { Disposiciones de Carácter General a que se refiere el artículo } 115 \text { de la Ley de Instituciones de Crédito } \\
\text { (AML/CFT Regulations for Credit Institutions -banks and Sofoles) }\end{array}$ \\
\hline 18. & $\begin{array}{l}\text { Disposiciones De Carácter General A Que Se Refiere el artículo } 140 \text { De La Ley General De Instituciones } \\
\text { Y Sociedades Mutualistas De Seguros (AML/CFT Regulations for Insurance Institutions) }\end{array}$ \\
\hline 19. & $\begin{array}{l}\text { Disposiciones de carácter general a que se refiere el artículo } 52 \text { Bis-4 de la Ley del Mercado de Valores } \\
\text { (AML/CFT Regulations for Securities Brokers) }\end{array}$ \\
\hline 20. & $\begin{array}{l}\text { Disposiciones de carácter general a que se refiere el artículo } 95 \text { Bis de la Ley General de Organizaciones y } \\
\text { Actividades Auxiliares del Crédito aplicables a los denominados transmisores de dinero por dicho } \\
\text { ordenamiento (AML/CFT Regulations for Money Remmitters) }\end{array}$ \\
\hline 21. & $\begin{array}{l}\text { Disposiciones de carácter general a que se refieren los artículos } 108 \text { Bis de la Ley General de los Sistemas } \\
\text { de Ahorro para el Retiro y Actividades Auxiliares del Crédito aplicables a las Organizaciones Auxiliares } \\
\text { del Crédito (AML/CFT Regulations for Retirement Savings Systems) }\end{array}$ \\
\hline 22. & $\begin{array}{l}\text { Disposiciones de carácter general a que se refieren los artículos } 91 \text { de la Ley de Sociedades de Inversion } \\
\text { (AML/CFT Regulations for Mutual Fund/Invesment Companies) }\end{array}$ \\
\hline 23. & $\begin{array}{l}\text { Disposiciones de carácter general a que se refiere el artículo } 112 \text { de la Ley Federal de Instituciones de } \\
\text { Fianzas (AML/CFT Regulations for Bonding Institutions) }\end{array}$ \\
\hline 24. & $\begin{array}{l}\text { Disposiciones de carácter general a que se refiere el artículo } 124 \text { de la Ley de Ahorro y Crédito Popular } \\
\text { (AML/CFT Regulations for Popular Savings and Loans) }\end{array}$ \\
\hline 25 . & $\begin{array}{l}\text { Disposiciones De Carácter General A Que Se Refiere El Artículo } 95 \text { Bis De La Ley General De } \\
\text { Organizaciones Y Actividades Auxiliares Del Crédito Aplicables A Las Personas Que Realicen Las } \\
\text { Operaciones A Que Se Refiere El Artículo 81-A Del Mismo Ordenamiento (AML/CFT Regulations for } \\
\text { Foreign Exchange Centers-Centros Cambiarios) }\end{array}$ \\
\hline & $\begin{array}{l}\text { Resolucion por la que se expide el formato oficial para el reporte de operaciones relevantes, inusuales y } \\
\text { preocupantes contemplado en las disposiciones de carácter general que se indican, así como el instructivo } \\
\text { para su llenado (Resolution issuing the STR reporting format and instructions) }\end{array}$ \\
\hline
\end{tabular}


27. Resolución Que Modifica Las Reglas Generales Para La Integración De Expedientes Que Contengan La Información Que Acredite El Cumplimiento De Los Requisitos Que Deben Satisfacer Las Personas Que Desempeñen Empleos, Cargos O Comisiones En Entidades Financieras (Resolution amending the requirements for persons working for financial institutions)

28. Resolución por la que se reforma, deroga y adiciona la diversa que expide el formato oficial para el reporte de operaciones relevantes, inusuales y preocupantes contemplado en las Disposiciones de carácter general que se indican, así como el instructivo para su llenado (Resolution amending the format for STRs and instructions)

29. Reglamento de Agentes de Seguros y de Fianzas (Regulation for Insurance and Bonding Agents)

30. Reglamento de Inspección y Vigilancia de la Comisión Nacional de Seguros y Fianzas. (Regulation for Supervision by the National Insurance and Bonding Comission)

31. Reglamento Interior de la Comisión Nacional de Seguros y Fianzas (Internal Regulation for the National Comission for Insurance and Bonding Institutuions)

32. Reglamento Interior del Servicio de Administración Tributaria (Internal Regulation for the Tax Administration Service)

33. Reglamento de Supervisión de la Comisión Nacional Bancaria y de Valores (Regulation for Supervision by the National Banking and Securities Commission)

34. Reglamento Interior de la Comisión Nacional Bancaria y de Valores (Internal Regulation for the National Banking and Securities Commission)

35. Reglamento Interior de la Secretaria de Hacienda y Crédito Publico (Internal Regulation for the Finance Ministry-Secretariat for Finance and Public Credit)

36. Reglas A Las Que Deberán Sujetarse Las Casas De Cambio En Sus Operaciones (Rules for the operations of foreign exchange houses-Casas de Cambio)

37. Reglas Generales Para La Integración De Expedientes Que Contengan La Información Que Acredite El Cumplimiento De Los Requisitos Que Deben Satisfacer Las Personas Que Desempeñen Empleos, Cargos O Comisiones En Entidades Financieras (Rules for requirements for persons working for financial institutions)

38. Decreto por el que se reforman, adicionan y derogan diversos artículos del Reglamento Interior de la Secretaría de Hacienda y Crédito Público. (Decree amending the Internal Regulation of the Finance Ministry-Secretariat for Finance and Public Credit)

39. Acuerdo por el que el Presidente de la Comisión Nacional Bancaria y de Valores Delega Facultades en los Vicepresidentes, Directores Generales, Supervisores en Jefe y Gerentes de la Misma Comisión (Agreement by which the President of the CNBV delegates authority to its officers)

40. Acuerdo Por El Que Se Adscriben Orgánicamente Las Unidades Administrativas De La Comisión Nacional Bancaria Y De Valores (Agreement by which the Administrative Units of the CNBV established)

41. Metodología De Supervisión De Procesos Preventivos De Lavado De Dinero Y Financiamiento Al Terrorismo Aplicable A Las Personas Que Realicen Las Operaciones A Que Se Refiere El Artículo 81-A De La Ley General De Organizaciones Y Actividades Auxiliares Del Crédito (AML/CFT supervisión Methodology for foreign exchange centres)

42. Metodología De Supervisión De Procesos Preventivos De Lavado De Dinero Y Financiamiento Al Terrorismo Aplicable A Los Denominados Transmisores De Dinero Dispersores Por El Artículo 95 Bis De La Ley General De Organizaciones Y Actividades Auxiliares Del Crédito (AML/CFT supervisión Methodology for Money Remittance businesses)

43. Metodologías para la Supervisión de los Procesos Preventivos de Lavado de Dinero y Financiamiento de la Comisión Nacional Bancaria y de Valores aplicables a: Instituciones de Crédito y Entidades de Ahorro y Crédito (AML/CFT supervisión Methodology for Credit and Savings and Loan Institutions)

44. Metodologías para la Supervisión de los Procesos Preventivos de Lavado de Dinero y Financiamiento de la Comisión Nacional Bancaria y de Valores aplicables a: Casas de Bolsa y Sociedades de Inversión (AML/CFT supervisión Methodology for Securities Brokers and Mutual Fund/Investment Companies)

45. Metodologías para la Supervisión de los Procesos Preventivos de Lavado de Dinero y Financiamiento de la Comisión Nacional Bancaria y de Valores aplicables a: Casas de Cambio, Sociedades Financieras de Objeto Limitado y Organizaciones Auxiliares del Crédito (AML/CFT supervisión Methodology for casas de cambio, Sofoles and Auxiliary Credit Organizations (e.g. leasing and factoring)

46. Políticas de Seguridad de la Unidad de Inteligencia Financiera (Security policy for the FIU)

47. CIRCULAR 1/2005 emitida por el Banco de México en materia de Fideicomisos (Circular issued by the 


\begin{tabular}{|c|c|}
\hline & Bank of Mexico with respect to Trusts) \\
\hline 48. & $\begin{array}{l}\text { Inter-institutional Agreements Signed By The National Commission For Banking And Securities of } \\
\text { Mexico }\end{array}$ \\
\hline 49. & $\begin{array}{l}\text { Best practices documents (FIU) for reporting suspicious transactions by: (1) casas de cambio and (2) banks } \\
\text { ("banca multiple") }\end{array}$ \\
\hline 50. & FIU Typologies report May 2004-Dec. 2005 \\
\hline 51. & $\begin{array}{l}\text { Statistic information of the Tax Administration Service (Servicio de Administración Tributaria), } \\
\text { AML/CFT supervisory authority for money remitters and unlicensed foreign exchange centers. }\end{array}$ \\
\hline & Legal/ Law Enforcement \\
\hline 52. & Código Fiscal de la Federación (Prosecutions Code) \\
\hline 53. & Constitución Política de los Estados Unidos Mexicanos (Political Constitution of Mexico) \\
\hline 54. & Código Penal Federal (Federal Penal Code) \\
\hline 55. & Código Federal de Procedimientos Penales (Federal Penal Procedures Code) \\
\hline 56. & Código Civil Federal (Federal Civil Code) \\
\hline 57. & Ley Orgánica de la Administración Pública Federal (Organic Law for Federal Public Administration) \\
\hline 58. & Ley de Seguridad Nacional (National Securities Law) \\
\hline 59. & $\begin{array}{l}\text { Ley del Servicio Profesional de Carrera en la Administración Pública Federal (Law for Professional Career } \\
\text { Service in Federal Public Adminstration) }\end{array}$ \\
\hline 60. & $\begin{array}{l}\text { Ley Federal de Responsabilidades Administrativas de los Servidores Públicos (Federal law of } \\
\text { Administrative Responsibilities of Public Servants) }\end{array}$ \\
\hline 61. & $\begin{array}{l}\text { Ley Reglamentaria del Artículo 5o. Constitucional, relativo al Ejercicio de las Profesiones en el Distrito } \\
\text { Federal (Regulatory Law of Art. } 5^{\circ} \text {. Constitucional, related to the Professions in the Federal Distric) }\end{array}$ \\
\hline 62. & Ley de Extradición Internacional (Law on International Extradition) \\
\hline 63. & Ley Federal Contra la Delincuencia Organizada (Fec \\
\hline 64. & Ley Federal de Armas de Fuego y Explosivos (Fec \\
\hline 65. & Ley Aduanera (Customs Law) \\
\hline 66. & Ley Orgánica de la Procuraduría General de la \\
\hline 67. & $\begin{array}{l}\text { Ley Federal para la Administración y Enajenación de Bienes del Sector Público (Federal Law on the } \\
\text { Administration and Disposition of Property of the Public Sector) }\end{array}$ \\
\hline 68. & Ley del Impuesto sobre la Renta (Tax Law) \\
\hline 69. & $\begin{array}{l}\text { Reglamento de la Ley Orgánica de la Procuraduría General de la República (Regulation of the Organic } \\
\text { Law of the Attorney General's Office-PGR) }\end{array}$ \\
\hline 70. & $\begin{array}{l}\text { Reglamento de la Ley del Servicio Profesional de Carrera en la Administración Pública Federal } \\
\text { (Regulation of the Law of Professional Servce Careers in Federal Public Aministration) }\end{array}$ \\
\hline 71. & $\begin{array}{l}\text { Tipo Penal de Financiamiento al Terrorismo Internacional (Type of criminalization of the Financing of } \\
\text { International Terrorism) }\end{array}$ \\
\hline 72. & $\begin{array}{l}\text { Plan Estratégico Bilateral entre la Administración General de Aduanas de México, la Administración de } \\
\text { Aduanas y Protección Fronteriza de los EE.UU.A. y el Servicio de Aplicación de las Leyes de Inmigración } \\
\text { y Aduanas de la EE.UU.A. (Bilateral Strategic Plan between the US and Mexican Customs for border } \\
\text { administration and protection, y the application of US Immigration and Customs Laws) }\end{array}$ \\
\hline 73. & $\begin{array}{l}\text { Estrategia Integral de Prevención del Delito y Combate a la Delincuencia. (Integral strategy to prevent } \\
\text { crime and counteract delinquency), issued by the Presidency of the Republic and the Ministry of Public } \\
\text { Security. In Spanish. }\end{array}$ \\
\hline 74. & $\begin{array}{l}\text { Criterios Judiciales en Materia de Operaciones con Recursos de Procedencia Ilicita (Judicial Criteria as } \\
\text { regards to Money Laundering) Legal Study elaborated by the Financial Intelligence Unit in } 2006 \text { (in } \\
\text { Spanish) }\end{array}$ \\
\hline 75. & Code of Conduct of the Attorney General's Office and original version in the Spanish language. \\
\hline 76. & Customs declaration form for passengers leaving the country \\
\hline 77. & Formato de Internación de Valores (Customs declaration form for incoming money or value) in Spanish. \\
\hline 78. & Customs declaration form for travelers arriving from abroad \\
\hline 79. & $\begin{array}{l}\text { Overview of the Powers and Activities of the Secretaria de la Función Pública (Ministry of the Public } \\
\text { Function) in Spanish. }\end{array}$ \\
\hline 80. & $\begin{array}{l}\text { Perfil de puesto de Fiscal Ejecutivo titular de la Procuraduría General de la República (general profile } \\
\text { required for Executive Prosecutors at the General Attorney's Office) In Spanish. }\end{array}$ \\
\hline
\end{tabular}




\begin{tabular}{|ll|}
\hline 81. & $\begin{array}{l}\text { Perfil de puesto de Fiscal Ejecutivo asistente de la Procuraduría General de la República (general profile } \\
\text { required for Deputy Executive Prosecutors at the General Attorney's Office) In Spanish. }\end{array}$ \\
\hline 82. & List of Bilateral Treaties for Mutual Assistance in Criminal Matters signed by Mexico. \\
\hline 83. & List of Treaties to combat Drug Traffic ratified by Mexico. \\
\hline 84. & Bilateral Extradition Treaties ratified by Mexico. \\
\hline \multicolumn{1}{c|}{ Preventive-DNFBPs, Legal Persons and Arrangements, and NPOs } \\
\hline 85. & Ley Federal de Juegos y Sorteos (Federal Law on Gambling and Lotteries) \\
\hline 86. & $\begin{array}{l}\text { Regulations of the Federal Gambling and Drawings Law / Reglamento de la Ley Federal de Juegos y } \\
\text { Sorteos }\end{array}$ \\
\hline 87. & Ley Federal de Correduría Pública (Federal Law on Public Brokerage (e.g. real estate) \\
\hline 88. & Ley del Notariado en el Distrito Federal (Notaries Law for the Federal District) \\
\hline 89. & Ley de Instituciones de Asistencia Privada para el Distrito Federal (Law for Private Charitable Institutions) \\
\hline 90. & Ley de Asistencia Social (Law on Social Assistance) \\
\hline 91. & $\begin{array}{l}\text { Reglamento de la Ley Federal de Juegos y Sorteos (Regulation for the Federal Law of Gambling and } \\
\text { Lotteries) }\end{array}$ \\
\hline 92. & Ley General de Sociedades Mercantiles (General Law of Commercial Companies) \\
\hline & \\
\hline 93. & $\begin{array}{l}\text { Ley Federal de Transparencia y Acceso a la Información Pública Gubernamental (Federal Law on } \\
\text { Transparency and Public Access to Governmental Information) }\end{array}$ \\
\hline 94. & Ley de Concursos Mercantiles (Law on Commercial Bidding) \\
\hline 95. & Ley de Inversión Extranjera (Foreign Investments Law) \\
\hline 96. & Ley Federal de Protección al Consumidor (Federal Law on Consumer Protection) \\
\hline 97. & Ley General de Población (General Population Law) \\
\hline 98. & Ley General de Salud (General Health Law) \\
\hline 99. & $\begin{array}{l}\text { Reglas de Carácter General en Materia de Comercio Exterior para 2007 (General Rules on Foreign Trade } \\
\text { 2007) }\end{array}$ \\
\hline 100. & Mutual Evaluation Report of the United Mexican States (27 February 2004) \\
\hline 101. & Mutual Evaluation Follow up Report of the United Mexican States (2 July 2004) \\
\hline
\end{tabular}


Annex 3. Copies of Key Laws, Regulations, and Other Measures

\section{UNOFFICIAL TRANSLATION OF MEXICAN LEGISLATION RELEVANT TO THE DETAILED ASSESSMENT QUESTIONNAIRE}

\begin{tabular}{|c|c|}
\hline \multicolumn{2}{|c|}{ SUPREME LAW } \\
\hline $\begin{array}{l}\text { POLITICAL CONSTITUTION OF THE UNITED } \\
\text { MEXICAN STATES (Constitución Politica de los Estados } \\
\text { Unidos Mexicanos) }\end{array}$ & $\begin{array}{l}5 ; 14 ; 15 ; 16 ; 17 ; 18 ; 19 ; 20 ; 21 ; 22 ; 25 ; 26 ; 28 \\
49 ; 50 ; 65 ; 66 ; 67 ; 70 ; 71 ; 72 ; 74 ; 76 ; 80 ; 81 ; 82 \\
89 ; 90 ; 94 ; 102 ; 121 ; 133 ;\end{array}$ \\
\hline $\begin{array}{r}\text { Title One } \\
\text { Chapter I } \\
\text { Individual Guar }\end{array}$ & antees \\
\hline \multicolumn{2}{|c|}{$\begin{array}{l}\text { Article 5. No person may be prevented from engaging in the profession, industry, business or work of his choice, } \\
\text { provided it is lawful. The exercise of this freedom may only be banned by judicial resolution, when the rights of } \\
\text { third parties are infringed or by government order, issued under the terms set forth by the Law, when the rights of } \\
\text { society are offended. No one may be deprived from the product of his work, save by judicial resolution. }\end{array}$} \\
\hline \multicolumn{2}{|c|}{$\begin{array}{l}\text { In each State, the Law shall establish the professions which require a license for their practice, the qualifications to } \\
\text { be met in order to obtain it and the authorities who shall issue it. }\end{array}$} \\
\hline \multicolumn{2}{|c|}{$\begin{array}{l}\text { No one can be compelled to render personal services without fair compensation and without his full consent, unless } \\
\text { the work has been imposed as a penalty by a judicial authority; in which case, working conditions shall abide by } \\
\text { the provisions in sections I and II of Article } 123 \text {. Regarding public services, only the following shall be mandatory, } \\
\text { subject to the terms established in the respective laws: military and jury services, service as municipal councilman } \\
\text { and the discharge of official duties attained through direct or indirect elections. }\end{array}$} \\
\hline \multicolumn{2}{|c|}{$\begin{array}{l}\text { Electoral and census duties shall be mandatory and gratuitous, but a remuneration shall be paid for professional } \\
\text { services rendered as provided by this Constitution and any applicable laws. Professional services if a social nature } \\
\text { shall be mandatory and remunerated as provided by the Law, with the exceptions set forth therein. }\end{array}$} \\
\hline \multicolumn{2}{|c|}{$\begin{array}{l}\text { The State cannot permit the execution of any contract, compound or agreement which purpose is the demerit, loss } \\
\text { or irrevocable sacrifice of a person's liberty for whatever cause. Nor is any agreement admissible whereby the } \\
\text { person agrees to his own proscription or exile or by which he temporarily or permanently waives his right to } \\
\text { exercise a certain profession, industry or business. }\end{array}$} \\
\hline \multicolumn{2}{|c|}{$\begin{array}{l}\text { A labor contract shall only oblige to render the service agreed upon during the term set forth by the Law, which } \\
\text { may not exceed one year to the detriment of the worker, and in no case may it include the waiver, loss or } \\
\text { impairment of any political or civil right. }\end{array}$} \\
\hline \multicolumn{2}{|c|}{$\begin{array}{l}\text { Failure to perform said contract, by the worker, shall only render him answerable for applicable civil liability, but } \\
\text { never may be exerted any coercion against his person. }\end{array}$} \\
\hline
\end{tabular}


life, liberty, property, possessions or rights, unless the matter involved has been tried before previously established courts, in accordance with laws enacted before the facts and subject to due process of law.

In criminal trials it is forbidden to impose, by mere analogy or reasonable belief, any penalty which is not expressly set forth in a law applicable in every respect to the crime in question. In civil trials, final judgment must be rendered in accordance with the letter of the law, or with legal interpretation and in the absence thereof, in accordance with general principles of law.

Article 15. The celebration of treaties to extradite political convicts, or ordinary criminals considered slaves in the country where they committed the crime, or the agreements or treaties altering the rights established by this Constitution for the people and the citizen shall not be authorized.

Article 16. No one may be disturbed in his person, family, home, papers or possessions, except by written order of a competent authority, duly grounded in law and fact which sets forth the legal cause of the proceeding. No arrest warrant may be issued except by the judicial authority upon previous accusation or complaint for the commission or omission of an act which is described as a crime by the law, punishable with imprisonment, and unless there is evidence to prove that a crime has been committed and that there are sufficient elements to believe that the suspect is criminally liable.

The authority executing an arrest warrant issued by a court shall bring the suspect before the judge without any delay and under its sole responsibility. Any contravention to the foregoing shall be punished by criminal law.

In cases of flagrante delicto, ${ }^{57}$ any person may detain the suspect bringing him without delay under custody of the nearest authority and the latter, without delay, shall bring him before the Public Prosecutor. ${ }^{58}$ Only in urgent cases, when dealing with a felony qualified as such by the law and under reasonable risk that the suspect could evade the action of justice, should there not be a judicial authority available because of the hour, place or circumstance, the Public Prosecutor may, under his responsibility, order his detention, stating the grounds of law and fact and the circumstantial evidence underlying such decision.

In cases of urgency or flagrante delicto , the judge before whom the person in custody is presented shall immediately confirm the arrest or order his release, subject to the conditions established in the Law.

No one charged with a crime may be detained by the Public Prosecutor for more than forty eight hours, term whereupon his release shall be ordered or he shall be brought before a judicial authority. Such term may be duplicated in cases established by the law as organized crime. Any abuse in respect to what has hereinbefore been provided shall be punished by criminal law.

Only a judicial authority may issue a search warrant which must be in writing. Every search warrant must describe the place to be searched, the person or persons to be detained and the objects to be seized, to which this act shall be exclusively restricted, preparing in site, upon the conclusion of the search, a fact finding report, before two witnesses proposed by the occupant of the place searched or in his absence or refusal, by the acting authority.

Private communications are secret. The law shall punish according to criminal law any action against the liberty and privacy of such communications. Only a federal judicial authority may authorize the intervention of any private communication, upon request by the federal authority empowered by the law or by the Public Prosecutor of

\footnotetext{
57 Flagrante delicto is a crime discovered while in progress

58 Means Ministerio Público depending on the context.
} 
the corresponding State, wherefore the competent authority shall, in writing, ground in law and fact the legal causes of the request describing therein the class of intervention required, the subjects and the term thereof. The federal judicial authority may not grant these authorizations when the matters involved are of electoral, fiscal, commercial, civil, labor or administrative nature, nor in the case of communications of the defendant with its attorney.

Authorized interventions shall be subject to the requirements and limitations set forth in the laws. The results of interventions which do not comply with the aforesaid requirements shall not be admitted as evidence.

Administrative authorities may carry out inspections to private facilities only for ascertaining whether sanitary and police regulations have been complied with; and to require to be shown such books and papers which are indispensable to corroborate that fiscal provisions have been complied with, in which cases such authorities shall be subject to the provisions of the respective laws and to the formalities for search warrants.

The sealed correspondence circulating through the mail shall be exempt from any search and the violation thereof shall be punishable by the Law.

No member of the Army shall in times of peace be quartered in a private house against the will of the owner nor impose any requirements. In times of war the military can demand lodging, baggage, food and other requirements in the terms set forth by the applicable martial law.

Article 17. No one may take the law unto his own hands, nor resort to violence to enforce his rights. Every person has the right to petition justice before courts of law which shall be ready to provide it under the terms and conditions set forth by the laws, and shall issue their judgments in a prompt, complete and impartial manner. Their services shall be free and consequently, judicial fees are prohibited.

Federal and local laws shall provide the necessary means to guarantee the independence of the courts and the full enforcement of their judgments.

No one may be imprisoned by debts solely of a civil nature.

\footnotetext{
${ }^{59}$ In Mexican law, when the evidence was inconclusive, the matter could be disposed of by an order of absolución de la instancia, which operated as a dismissal but not as a judgment for or against either party in a civil case, or as an acquittal or conviction in a criminal case. Hence, upon discovery of more evidence the case might be revived. Similar to the Scotch verdict of not proved, and to the Roman non liquet .

${ }^{60}$ Ejido it is a concept that does not have translation. Ejido is a class of rural land tenure in the Mexican system, constituted by land communally held in common by the ejidatarios (who are the community of peasants who work it), village and cultivation lands that combine collective ownership by the ejido (a rural community) with individual use, to be exploited by the ejidatarios or individual members of the ejido. The disposal and transfer of ejido lands is subject to complex restrictions imposed by the Law. It can not be disposed of by the ejidatario, except upon compliance with certain procedures, involving several ejido and government authorities. It was instituted after the Mexican Revolution, which was the cornerstone of the Mexican land reform.

${ }^{61}$ Treasury refers to the Ministry of Finance and Public Credit

${ }^{62}$ The text in Spanish uses the term paraestatal. This term refers to several public agencies and corporations, which are under diverse levels of government control. Some dictionaries translate it as quasi-public corporations.

${ }^{63}$ The text in Spanish uses the term Jurisprudencia. This term does not refer to any judicial resolution but only to those that constitute a binding judicial precedent. Articles 94 and 107 of this Constitution regulate the way in which it is created, as well as statutes governing federal procedures. Jurisprudencia or mandatory judicial precedent is created when the Supreme Court of Justice or Collegiate Circuit Courts (Appeal courts of the Federal Judiciary) rule in the same way in five consecutive occasions, in which case all lower federal courts must abide by such holdings. The Federal Electoral Court is also able to produce jurisprudencia.
} 
Article 18. Pretrial detention may only be applied for crimes punishable by imprisonment. The place of confinement shall be different and shall be separate from the one used for convicted persons.

The governments of the States and of the Federation shall organize the prison system in their respective jurisdictions, under basis of labour, training for work, and education, as a means of social readjustment of the offender. Women shall serve their imprisonment penalties in places separated from those intended for the confinement of men.

State Governors may under the provisions established by their respective local laws, celebrate agreements of a general nature with the Federation, by which offenders convicted for crimes pertaining to State or local jurisdiction may serve their imprisonment penalties in facilities subordinated to the President of the Republic.

The Federation and State governments shall establish special institutions to deal with juvenile offenders.

Convicts of Mexican nationality who are serving imprisonment penalties in foreign countries may be brought to the Republic to serve their sentences under the grounds of the social readjustment systems provided in this Article, and convicts of foreign nationality convicted for federal crimes throughout the Republic or for crimes under the local jurisdiction of the Federal District, may be transferred to their countries of origin or of residence, provided that international treaties have been signed for that purpose. State governors may request from the President of the Republic, under the grounds of their respective local laws, the inclusion in said treaties of convicts for crimes under State jurisdiction.

In the cases and conditions provided by the Law, convicts may serve their penalties in the penitentiaries closer to their home, in order to encourage their reintegration to the community as a means of readjustment to society.

Article 19. No detention before a judicial authority may exceed a term of seventy two hours from the time the defendant is brought under its custody, without a formal order for commitment in writing, which must set forth the crime he is charged with, the place, time and circumstances of the crime; as well as the evidence furnished by the preliminary criminal inquiry, which must be sufficient to establish that a crime has been committed and the probable liability of the suspect.

Said term may be extended only upon petition by the defendant in the form established by the Law. The extension of the term of detention to his detriment shall be punished by criminal law. If within the term hereinbefore set forth, any authority in charge of the facilities where the defendant is confined, should not receive an authorized copy of the order to stand trial in confinement or a request for an extension of the aforesaid term, said authority shall bring the matter to the attention of the judge immediately upon the end of the term. If said authority should not receive the aforesaid order within the next three hours, it shall release the defendant.

Every proceeding shall be compulsorily instituted only for the crime or crimes charged in the order to stand trial in commitment or in the order to stand trial. If within the course of proceedings it should appear that another crime has been committed which is different from the one pursued, it shall be charged on a separate count, notwithstanding that a joinder of both proceedings could thereafter be ordered, if appropriate.

Any ill treatment when detaining a person or during confinement, any annoyance without legal justification, any exaction or contribution laid in jails, constitute an abuse which the laws shall correct and the authorities shall repress.

Article 20. In all criminal proceedings, the defendant, the victim or the offended party shall have the following constitutional rights. 
A. The defendant:

I. Immediately upon request by the defendant, the judge must set him at liberty on bail, provided the crime he is charged with is not a felony where the Law explicitly prohibits granting it. In case of crimes which are not felonies, the judge may deny liberty on bail, upon request by the Public Prosecutor, when the defendant has been previously convicted for a felony according to the Law or whenever the Public Prosecutor should submit to the judge, evidence establishing that freeing the accused represents, on account of his preceding behavior or of the circumstances and nature of the crime committed, a risk for the offended party or for society.

The amount and form of the bail fixed must be accessible for the accused. In certain circumstances set forth by the Law, the judicial authority may modify the amount of the bail. To determine the amount and form of the bail, the judge must consider the nature, particularities and circumstances of the crime, the character of the defendant and the possibilities of complying with his duties in respect to trial; the losses and damages caused to the offended party; as well as the fine which, if applicable, may be imposed upon the accused.

The Law shall determine the serious cases where the judge may revoke liberty on bail;

II. He cannot be forced to declare. Any denial of communication, intimidation or torture is prohibited and shall be punished by criminal law. Any confession made before any authority other than the Public Prosecutor or the judge or even before any of them without the assistance of his counselor shall have no weight as evidence;

III. He shall be informed in a hearing in open court, and within the next forty eight hours immediately following the filing of charges, the name of his accuser and the cause and nature of the accusation, so that in such hearing, the defendant may know the criminal conduct attributed to him and so that he may respond to the charges against him, in his preliminary statement;

IV. At his request he shall be confronted with the witnesses against him before the judge, except as provided under subsections V of Section B of this Article;

V. All witnesses and any other evidence submitted on his own behalf shall be admitted within the term the Law deems necessary to that end and he shall be assisted in securing the presence of those witnesses whose testimony he may request, provided they are to be found in the place where the trial is held;

VI. He shall be judged in open court by a judge or by a jury composed of citizens who can read and write and who reside in the place and district where the crime was committed, provided such crime is punishable with more than one year of imprisonment. In any case, crimes committed through the press against public order or against the Nation's foreign or domestic security, shall be tried by a jury;

VII. He shall be furnished with all the information on record in the proceedings that he shall request for his defense;

VIII. He shall be tried within a term of four months in the case of crimes punishable with a maximum penalty not exceeding two years of imprisonment; and within a term of one year if the crime is punishable with a penalty exceeding such term, unless he shall request a longer term for his defense;

IX. From the commencement of proceedings, he shall be informed of the rights provided to his benefit by this Constitution and of his right to an adequate defense, either by himself, by counsel or by a trusted person. Should he not wish or should he have no one to appoint as counsel for his defense, upon being required to do so, the judge shall appoint him a public defendant. He shall also be entitled to have his attorney present in all actions during the proceedings and he shall have the duty to appear as often as required by the court; and 
X. Prison or detention may never be extended for failure to pay attorneys' fees nor any other monetary obligation, on account of civil liability or for any other similar cause. Nor can pretrial detention be extended beyond the maximum imprisonment term established by the Law as penalty for the crime charged.

Whenever a conviction sentence imposes imprisonment the term thereof shall start running from the moment the defendant is arrested.

The constitutional rights set forth in subsections I, V, VII and IX herein shall also be respected during the preliminary criminal inquiry, subject to the terms and under the requirements and restrictions established by the laws. The provision in subsection II shall not be subject to any condition.

B. The victim or the offended party:

I. To receive legal counsel; to be informed of the rights that the Constitution establishes to his benefit and whenever he should so require it, to be informed of the developments of the criminal proceedings;

II. To assist the Public Prosecutor; to be received all the information and evidence that he furnishes, during the preliminary criminal inquiry as well as during proceedings, and for appropriate proceedings to be carried out. Whenever the Public Prosecutor does not consider necessary to carry out the proceeding, he must state the grounds of law and fact justifying his refusal.

III. To receive urgent medical and psychological attention, from the moment the crime was committed.

IV. To recover damages. Whenever it should be legally admissible, the Public Prosecutor is obliged to require restitution of damages and the judge shall not acquit the convict from making restitution if he shall have imposed on him a conviction sentence. The Law shall set forth swift and speedy procedures to enforce judgments in matters of recovery of damages.

V. Should the victim or the offended party be minors, he shall not be required to confront the defendant face to face, when the crime dealt with is rape or kidnapping. In such cases, the depositions shall be taken in the conditions established by the Law; and

VI. To require the injunctions and measures provided by the Law for his security and assistance.

Article 21. Imposition of penalties is exclusively incumbent upon the judicial authority. Investigation and prosecution of crimes is incumbent upon the Office of the Public Prosecutor, which will be aided by a police force under its authority and immediate command. The administrative authority is responsible for the application of sanctions for violations of governmental and police regulations, which will only consist of a fine or arrest and detention for a maximum of thirty-six hours; however, if the offender does not pay the fine imposed on him, this will be substituted by the corresponding period of detention, which will in no event exceed thirty-six hours.

If the offender is a day laborer or manual worker, he may not be sanctioned with a fine greater than his total daily wage or salary.

For workers not receiving a salary or wage, the fine will not exceed the equivalent of one day's earnings.

Decisions of the Office of the Public Prosecutor to not file charges or to withdrawal the criminal case may be challenged through the court system pursuant to the terms established by law.

The Federal Executive may, with the approval of the Senate in all cases, recognize the jurisdiction of the International Criminal Court. 
Public security is a function incumbent upon the Federation, the Federal District, the States and Municipalities, in the respective competences established by this Constitution. The actions of police institutions will be governed by the principles of legality, efficiency, professionalism and honesty.

The Federation, the Federal District, the States and the Municipalities, will be coordinated in the terms specified by law, to establish a national system of public security.

Article 22. Mutilation and infamous penalties, as well as branding, flogging, beating with sticks, and torture of any kind, the imposition of excessive fines, confiscation of property and any other cruel, unusual and transcendental punishments are prohibited.

The attachment of all or of a portion of a person's property made under judicial authority to make payment of civil liability resulting from the commission of a crime or for the payment of taxes or fines, shall not be deemed confiscation of property. Nor shall the seizure of property ordered by the judicial authority under the terms provided by Article 109 in case of illicit enrichment, shall be deemed confiscation; nor the seizure of goods owned by a convict for felonies typified as organized crime, or for those goods in respect to which the convict acts like an owner, unless the licit origin of these goods is proven.

The appropriations made in favor of the State of goods it has secured, which are thereafter deemed abandoned, in accordance with the terms of applicable provisions, shall not be deemed confiscation. The judiciary shall decide to take the property in favor of the State those goods secured by cause of an investigation or proceedings for organized crime, when such investigation o proceedings conclude without any resolution in regards to the goods secured. The judicial decision shall be issued upon previous proceedings where third parties are heard and there is enough evidence to fully establish that a felony typified as organized crime has been committed.

Provided, however, that the defendant in such investigation or proceedings possessed, owned or acted as possessor or owner of such goods, even if said goods were transferred to third parties, unless the latter prove to be possessors or owners in good faith.

The death penalty is forbidden for political crimes. In respect to other crimes, the death penalty may only be imposed on the traitor of the country during a foreign war, on the parricide, on the murder when using perfidy, premeditation or undue advantage, on the arsonist, on the kidnapper, on the highway robber, on the pirate, and on convicts guilty of serious military crimes.

Article 25. The State is in charge of directing national development and must guarantee that such development is comprehensive and sustainable, that it strengthen ${ }^{59}$ national sovereignty and its democratic regime, and that it enables full exercise of the liberties and dignity of the individuals, groups and social classes, whose safety is protected by this Constitution, by promoting economic growth and employment, and a more just distribution of income and wealth.

The State shall plan, conduct, coordinate and direct national economic activity and shall carry out the regulation and promotion of the activities required by public interest within the framework of liberties granted by this Constitution.

The public, social and private sectors shall concur, with social responsibility, in the economic development of the Nation, without detriment to other forms of economic activity that contribute to the development of the country.

The public sector shall be in charge, in an exclusive manner, of those strategic areas established in Article 28, paragraph fourth of the Constitution, and the Federal Government shall at all times maintain ownership and control over the entities which may be established, as appropriate. 
Likewise, the State may participate by itself or along with the social and private sectors, in accordance with the Law, to foster and organize such areas which are a priority for development. Enterprises from the social and private sector of the economy shall be supported and encouraged under criteria of social equity and productivity, subject to the particularities required by public interest and to the use, for general benefit, of the productive resources, taking care of their preservation and of the environment.

The Law shall establish mechanisms to facilitate the organization and expansion of economic activity of the social sector: ejidos ${ }^{60}$ workers' organizations, cooperatives, rural communities, enterprises which are majority or exclusively owned by workers and, in general, of all manners of social organization for production, distribution and consumption of such goods and services which are necessary for society.

The Law shall encourage and protect economic activities carried out by private persons and shall provide the conditions required so that the private sector's development contributes to national economic development, according to the terms set forth by this Constitution.

Article 26. The State shall organize a system of democratic planning for national development that gives solidity, dynamism, permanence and equity to the growth of the economy pursuant to the political, social and cultural independence and democratization of the nation.

The goals of the national project contained in this Constitution shall determine the objectives that guide planning. Planning shall be democratic. The aspirations and requirements of society shall be collected with the participation of diverse social sectors, and shall be incorporated into the development programs and to the plan. There shall be a national plan for development to which the programs of Federal Public Administration shall compulsorily be subject.

The Law shall empower the President of the Republic to establish the participation and popular consultation procedures in respect to the national democratic planning system, and the criteria to prepare, implement, control and assess the development programs and the resulting plan. The Law shall also establish the agencies that shall be responsible for the planning process and the bases under which the President of the Republic shall coordinate, through agreements with State governments, and shall induce and arrange with private persons the actions to be undertaken to prepare and to carry out the planning process.

The Law shall establish the intervention of the Congress of the Union in the democratic planning system.

Article 28. In the United Mexican States monopolies, monopoly practices, state monopolies and tax exemptions are prohibited under the terms and conditions set forth by the laws. The same treatment shall be given to prohibitions on account of protections to industry.

Consequently, the Law shall severely punish and the authorities shall efficiently prosecute, any concentration or hoarding, in one or in few hands, of essential consumer products for the purpose of raising prices; any agreement, procedure or combinations, in whatever manner they may be made, of producers, manufacturers, merchants or service providing entrepreneurs, to prevent free market or competition among themselves, in order to force consumers to pay exaggerated prices, and in general, anything constituting an exclusive and undue advantage in favor of one or more specific persons in detriment to the public in general or to any social class.

The laws shall set forth the bases to establish maximum prices for Articles, commodities or products considered essential for the country's economy or for popular consumers, as well as to impose the particularities to organize the distribution of said Articles, commodities or products, in order to prevent unnecessary or excessive intermediation from causing insufficiencies in supply, as well as price increases.

The Law shall protect consumers and encourage them to organize themselves to better protect their interests. The 
functions performed in an exclusive manner by the State in the following strategic areas shall not constitute monopolies: postal service, telegraphs and radiotelegraphy; petroleum and any other hydrocarbons; basic petrochemical; radioactive minerals and generation of nuclear energy; electricity and any other activities explicitly established by the laws enacted by the Congress of the Union. Satellite communications and railways are priority areas for national development under the terms provided in Article 25 of this Constitution.

The State, by exercising its direction over them, shall protect the security and sovereignty of the Nation, and when granting concessions or permits, it shall maintain or establish its domain over the respective means of communications and transportation in accordance with relevant statutory laws.

The State shall have the agencies and companies required to efficiently manage the strategic areas are entrusted to it and in those prioritized activities where, according to the laws, it shall participate by itself or along with the private and social sectors.

The State shall have a central bank vested with autonomy in the exercise of its duties and management. Its main objective shall be to foster stability in domestic currency's purchasing power, thus strengthening the guidance of the State in respect to national development.

No authority may order the bank to provide financing. The functions performed in an exclusive manner by the State, through the central bank, in the strategic areas of coining money and issuance of bills, do not constitute a monopoly. The central bank, under the terms provided by the laws and with the participation of other authorities with competent jurisdiction thereon, shall regulate exchange rates, as well as banking and financial services, and shall have the powers and authority required to carry out such regulating actions and to enforce their compliance. The management of the bank shall be entrusted to the persons appointed by the President of the Republic with approval by the Senate or the Permanent Commission, when applicable.

They shall hold office for terms which duration and sequences are best suited to the autonomous exercise of their duties; they may only be removed for a serious cause and may not hold any other employments, offices or commissions, except for those in which they act in the name of the bank, and pro bono activities in teaching, scientific, cultural or charitable organizations.

The persons in charge of the central bank may be subject to impeachment trials in accordance with the provisions set forth under Article 110 of this Constitution. The associations of workers constituted to protect their own interests, and producers' cooperatives or associations that, in defense of their interests or of general interest, sell directly in foreign markets, any domestic or industrial products which are the main source of wealth in the region where they are produced and which are not essential consumer products, shall not constitute a monopoly, provided such associations are under the supervision or protection of Federal or State governments and that they have been previously authorized theretofor by their respective State legislature in each case. Such Legislatures, by themselves or at the proposal of the President of the Republic or the Governor, as appropriate, may repeal when public welfare should so require it, any authorizations granted to constitute the associations in question.

The privileges granted for a certain time to authors and artists for the production of their works and those granted to inventors for the exclusive use of their inventions and improvements, shall not constitute monopoly.

The State may, in accordance with the law and in case of general interest, grant concessions for the provision of public services or for the exploitation, use and profit of property owned by the Federation, save for the exceptions established by the laws. The laws shall set forth the requisites and conditions required to guarantee the efficiency of the services rendered and the social use given to such property, and shall prevent occurrences of hoarding which contravene public interest.

The subjection to a public service regime shall abide by the provisions of the Constitution and may only be carried 
out through a law.

Subsidies may be granted to economic priority activities, when such subsidies are of a general and temporary nature and do not impact substantially the Nation's finances. The State shall supervise their application and appraise their results.

\section{Title Three \\ Chapter One \\ The Division of Powers}

Article 49. The Supreme Power of the Federation is divided for its exercise into the Legislative, Executive and Judicial branches. Two or more of these Powers may not be united in one single person or corporation, nor shall the Legislative Power be vested in one single person, except for the case where extraordinary powers are granted to the President of the Republic as provided in Article 29. In no other case, except as provided under the second paragraph of Article 131, shall extraordinary powers be granted to legislate.

\section{Chapter Two \\ The Legislative Power}

Article 50. The Legislative Power of the United Mexican States is vested in a General Congress which shall be divided into two Houses one of deputies and the other one of senators.

Article 65. The Congress shall assemble from September 1st of each year, for a first term of regular sessions and from February 1 st of each year for a second term of regular sessions.

In both session terms the Congress shall be devoted to study, discuss and vote the bills submitted thereto and to decide any other affairs pertaining to it according to this Constitution.

In each regular session term the Congress shall preferably devote itself to the issues established by its Organic Law.

Article 66. Each period of regular sessions shall continue for the time necessary to deal with the matters mentioned in the foregoing Article. The first period of sessions may not be extended beyond December 15th of the same year, except when the President of the Republic takes office, in the date provided by Article 83, in which case, the sessions may be extended until December 31st of such year. The second period of session may not be extended beyond April 30th of said year.

Should both Houses not agree on closing the sessions before the dates specified, the President of the Republic shall decide.

Article 67. The Congress or just one of the Houses, when dealing with an issue under its exclusive jurisdiction, shall assemble in extraordinary session each time the Permanent Commission summons them for such purpose; but in both cases, they shall only devote themselves to the issue or issues submitted by the Permanent Commission. These matters shall be set forth in the respective summons.

Article 70. Every resolution by the Congress shall have the nature of a law or a decree. Laws or decrees shall be communicated to the President of the Republic signed by the speakers of both Houses and by a secretary of each of them, and shall be promulgated in the following manner: "The Congress of the United Mexican States decrees: (text of the law or decree)".

The Congress shall enact the law that shall govern its internal operations and structure.

The Law shall establish the manners and procedures to group deputies according to their political party affiliation, in order to guarantee free speech to all ideological positions represented in the House of Deputies.

This Law cannot be vetoed nor shall it require promulgation by the President of the Republic to be in force. 
Article 71. The right to initiate laws or decrees corresponds to:

I. The President of the Republic;

II. The deputies and senators to the Congress of the Union; and

III. The States Legislatures.

The bills initiated by the President of the Republic, by the States Legislatures or by the delegations thereof, shall be referred to a committee; those introduced by deputies or senators shall be subject to the procedures set forth by the Rules of Procedure.

Article 72. Bills whose approval into law or decree is not the exclusive right of one of the Houses, shall be discussed successively by both, abiding by the Rules of Procedure in respect to form, intervals and manner to act in debates and casting of votes.

A. After a bill is approved in the House where it originates, it shall pass to the other House for discussion and if approved, it shall be forwarded to the President of the Republic; and if he has no objections, he shall immediately publish it.

B. A bill forwarded to the President of the Republic which is not returned with his objections to the House where it originated within ten business days after it was presented to him, shall be deemed approved; unless during the said term, the Congress shall have closed or adjourned its sessions, whereupon the return shall be made the first business day that Congress next assembles.

C. Any bill rejected in whole or in part by the President of the Republic shall be returned with his objections to the House where it originated, which shall again reconsider it, and if confirmed by two thirds of the total number of votes, it shall pass again to the other House for review; and if approved by the same majority it shall become a law or decree and return to the President of the Republic for promulgation. Votes on laws and decrees shall be cast by roll call.

D. Should any bill be rejected in whole by the reviewing House it, it shall be returned to the House where it originated with the objections made thereto. It shall be again discussed in said House and if approved by an absolute majority of its members present, it shall return again to the House that rejected it, which shall reconsider it and should it be approved by the same majority, it shall pass to the President of the Republic for the purposes of section A. Otherwise, it shall not be reintroduced in the same period of sessions.

E. If a bill is partially rejected, or amended, or added to, by the reviewing House, the House where it originated shall only debate the portion rejected, or the additions, or the amendments thereto, and the Articles which were previously approved shall not be altered in any manner. Should the additions or amendments by the reviewing House be approved by the House where it originated through absolute majority of votes of its members present, the bill in whole shall pass to the President of the Republic for the purpose of section A. Should the additions or amendments by the reviewing House not be approved by a majority of votes cast in the House where it originated, the bill in whole shall return to the reviewing House, so that the latter may consider the reasons of the other House. In this second review if the amendments or additions are again rejected by an absolute majority of the reviewing House's members present at the session, the bill, only in the portion approved by both Houses, shall pass to the President of the Republic for the purposes of section A. Should the reviewing House insist in such additions or amendments by an absolute majority of votes of its members present, the bill in whole shall not be reintroduced until the next period of sessions, unless both Houses agree, by absolute majority of votes of their present members, that the law or decree be issued only with the Articles approved, and that the Articles added to or amended, be reserved to be examined and voted in the next sessions.

F. The same procedure established to enact laws and decrees shall be followed in the interpretation, amendment or repeal thereof.

G. Bills rejected in the House where they originated may not be reentered in the sessions of the same year.

$\mathrm{H}$. The process for the enactment of laws and decrees may be indistinctively initiated in any of the two Houses, except for those bills dealing with loans, imposts or taxes, or recruitment of troops, which shall all be discussed first in the House of Deputies.

I. Bills shall be preferably discussed in the House where they are introduced, unless one month elapses after having been passed to the Reporting Committee, without resolution by the latter, whereupon the bill may be presented and 
discussed in the other House.

J. The President of the Republic may not make any observations to the resolutions of the Congress or any of the Houses when they act as election body or jury, or whenever the House of Deputies declares there are grounds to impeach a high ranking public officer of the Federation. Neither may he object the decree summoning to extraordinary sessions issued by the Permanent Commission.

Article 74. The exclusive powers of the House of Deputies are:

I. To solemnly announce throughout the Republic that the Electoral Court of the Judicial Power of the Federation has issued a declaration stating that a President has been elected;

II. To coordinate and asses, without detriment to its technical and operational autonomy, the performance of the Federation's Superior Supervising Entity, in accordance with the terms provided by the Law;

III. (Repealed).

IV. To annually approve the Federation's Expenditure Budget, upon previous examination, discussion and amendment, if applicable, of the respective bill sent by the President of the Republic, having first approved the taxes and government excises that under its judgment, must be authorized to cover the expenditures, and also to examine the General Public Accounts of the former year.

The President of the Republic shall send to the House of Deputies, the Federation's Income Bill and Expenditure Budget no later than on September 8th. The appropriate State Secretary shall appear thereat to account for said bills. The House of Deputies shall approve the Federation's Expenditure Budget no later than November 15th. Whenever the President of the Republic takes office in the date set forth in Article 83, he shall send the Federation's Income and Expenditure Budget Bills to the House of Deputies no later than on December 15th.

There shall be no other secret items than those deemed necessary and secret in said Budget; which shall be exercised by the Secretaries upon written authorization by the President of the Republic.

The purpose of reviewing the General Public Accounts is to know the results of financial performance, and to verify compliance with the criteria set forth in the Budget and the attainment of the objectives established in the programs.

To review the General Public Accounts, the House of Deputies shall rely on the Federation's Superior Supervising Entity. If, from the review made by the latter, it shall appear that there are discrepancies between the amounts pertaining to income or to expenditures, in relation to the respective items and entries, or if there were no good cause or no precision in regards to the income obtained or the expenditures made, the resulting liabilities shall be determined in accordance with the Law.

The General Public Accounts from the former year must be submitted to the House of Deputies of the Congress of the Union within the first ten days of the month of June.

The term to submit the Income Bill, the Expenditures Budget Draft, and the General Public Accounts may only be extended upon request by the President of the Republic, which request must be sufficiently justifiable at the judgment of the Houses or the Permanent Commission.

The corresponding State Secretary shall appear thereat, in any case, to inform on the causes underlying such request;

$\mathrm{V}$. To declare if it is lawful to file criminal action against those public officers who have committed a crime as provided under Article 111 of this Constitution. To know of the charges against the public officers referred un der Article 110 of this Constitution and to act as a prosecuting body in the impeachment trials brought forth against them;

VI. (Repealed).

VII. (Repealed).

VIII. Any other powers explicitly vested upon it by this Constitution.

Article 76. The exclusive powers of the Senate are:

I. To analyze the foreign policy applied by the President of the Republic on the grounds of the annual Information on the State of the country submitted to the Congress by the President of the Republic and the corresponding State Secretary; as well as to approve international treaties and diplomatic conventions

celebrated by the President of the Republic; 
II. To ratify the appointments of the General Attorney of the Republic, Justices, diplomatic agents, general consuls, high ranking employees of the Treasury, ${ }^{61}$ colonels and other superior chiefs of the Army, Navy and Air Force, made by the President of the Republic, under the terms provided by the Law;

III. To authorize the President of the Republic to allow the deployment of national troops beyond the borders of the country, the passage of foreign troops through national land territory, and the sojourn of vessels of other countries for over one month in Mexican waters;

IV. To give its consent, so that the President of the Republic may dispose of the National Guard outside its respective States, and to determine the necessary forces;

$\mathrm{V}$. Whenever the constitutional powers of a State disappear, to declare that it is necessary to appoint a Provisional Governor, who shall summon to elections in accordance with the constitutional laws of said State. The Senate shall appoint such governor chosen from a list of three candidates proposed by the President of the Republic, with the approval of two thirds of its members present in the session, and in the adjournments thereof, by the Permanent Commission according to the same rules. The officer thus appointed cannot be elected Constitutional Governor in the elections held pursuant to the summons he shall have issued. This provision shall govern whenever the constitutions of the States do not provide otherwise;

VI. To settle political issues arising between the powers of a State, whenever any of them shall apply to the Senate theretofore, or when by reason of such issues, the constitutional order has been interrupted through an armed conflict. In such event, the Senate shall issue its resolution subject to provisions establish in the Constitution of the Republic and the constitution of the State involved. The Law shall regulate the exercise of the two foregoing powers;

VII. To erect itself as a grand jury to take cognizance of impeachment trials for faults or omissions committed by public officers and which result in detriment to fundamental public interests and to their good performance in office, according to the terms established by Article 110 of this Constitution;

VIII. To appoint the Justices of the Nation's Supreme Court of Justice, selecting them from the group of three candidates submitted by the President of the Republic, as well as to grant or deny its approval to the request for leave of absence or resignation of such Justices submitted by the President of the Republic;

IX. To appoint and to remove the Chief of Government of the Federal District in the cases provided by this Constitution;

$\mathrm{X}$. Any other powers vested upon it by this Constitution;

\section{CHAPTER THREE}

\section{The Federal Executive Power}

Article 80. The exercise of the Supreme Executive Power of the Union is vested in a single individual who shall be called the "President of the United Mexican States."

Article 81. The election of the President shall be direct and in accordance with the terms set forth by the electoral law.

Article 82. The following qualifications are required to be President of the Republic:

I. To be a Mexican citizen by birth, with legal capacity to exercise his rights, born of Mexican father or mother and to have resided in the country for at least twenty years;

II. To be thirty five years old at the time of the election;

III. To have resided in the country during the entire year prior to the day of the election. Absence from the country for up to thirty days does not interrupt the term of residence;

IV. Not to be neither a member of the clergy nor a minister of any creed;

$\mathrm{V}$. Not to be in active service, in case of being a member of the army, for a period of six months before the day of the election;

VI. Not to be a State Secretary or Undersecretary, chief or Secretary General of an Administrative Department, Attorney General of the Republic, or Governor of any State, unless having resigned to such office six months prior 
to the day of the election; and

VII. Not to be subject to any disqualifications set forth under Article 83.

Article 83. The President shall begin his term in office on December 1 st and shall remain in charge for a term of six years. Any citizen, who has held the office of President of the Republic, through popular election or as interim, provisional or substitute, shall never, under any circumstance, hold such office again.

Article 89. The powers and duties of the President of the Republic are as follows:

I. To promulgate and enforce the laws enacted by the Congress of the Union providing the means required, within his administrative jurisdiction, for their faithful execution;

II. To appoint and remove State Secretaries at his sole discretion, to remove diplomatic agents and the high ranking employees of the Treasury, and to unrestrictedly appoint and remove all the other employees of the Union, whose appointment or removal is not otherwise provided for in the Constitution or the laws;

III. To appoint Justices, diplomatic agents and general consuls, with the approval of the Senate;

IV. To appoint the colonels and other superior chiefs of the Army, Navy and Air Force and high ranking employees of the Treasury, with the approval of the Senate;

V. To appoint all other officers of the Army, Navy and Air Force, as provided by the laws;

VI. To maintain national security, under the terms of the respective law, and to dispose of all permanent military forces of the Army, Navy and Air Force, for the Federation's interior security and defense;

VII. To dispose of the National Guard for the same purposes mentioned hereinbefore, in accordance with the terms set forth in Section IV of Article 76;

VIII. To declare war in the name of the United Mexican States pursuant to a law previously enacted by the Congress of the Union to that end;

IX. To appoint the General Attorney of the Republic with the ratification by the Senate;

$\mathrm{X}$. To direct foreign policy and to celebrate international treaties, subject to approval by the Senate. In conducting foreign policy, the President of the Republic shall abide by the following guiding principles: self-determination of peoples; nonintervention; pacific settlement of disputes; to refrain in their international relations from threats or use of force; of equal rights of States; international cooperation for development; and to maintain international peace and security;

XI. To summon the Congress to extraordinary sessions, in accordance with the respective resolution of the Permanent Commission;

XII. To give the Judicial Power the assistance it requires for the prompt discharge of its duties;

XIII. To enable all sorts of ports, establish maritime and frontier customhouses, and to determine their location;

XIV. To grant, according to the laws, pardons to criminals convicted for crimes under the jurisdiction of federal courts, and to individuals convicted for crimes under the local jurisdiction of the Federal District;

$\mathrm{XV}$. To grant exclusive privileges for a limited time, in accordance with the respective law, to discoverers, inventors, or improvers in any branch of industry;

XVI. When the Senate is not in session, the President of the Republic may make the appointments provided in sections III, IV and IX, with the approval of the Permanent Commission;

XVII. (Repealed);

XVIII. To submit to the Senate's approval, a proposal of three candidates to make the appointment of Justices of the Supreme Court of Justice, and to also submit thereto the requests for leaves of absence and resignations of said Justices;

XIX. (Repealed);

XX. Any others powers explicitly vested upon him by this Constitution.

Article 90. Federal Public Administration shall be centralized and decentralized ${ }^{62}, 27$ in accordance with the provisions of the Organic Law to be enacted by the Congress. Said Law shall distribute the administrative affairs of the Federation that shall be entrusted to the Secretariats of State and Administrative Departments.

It will also establish the general principles for constituting decentralized agencies and Government controlled corporations and the intervention of the President of the Republic in their operation. 
The laws shall set forth the relation between decentralized agencies and Government controlled corporations, and the President of the Republic or between such entities and the Secretariats and Administrative Departments.

\section{CHAPTER FOUR The Judicial Power}

Article 94. The exercise of the Judicial Power of the Federation is vested on the Nation's Supreme Court of Justice, in an Electoral Court, in Collegiate and Unitary Circuit Courts, and in District Courts. Management, supervision and discipline of the Judicial Power of the Federation, with the exception of the Nation's Supreme Court of Justice, shall be entrusted to the Council of the Federal Judiciary, under the terms established by the Law, in accordance with the bases set forth in this Constitution.

The Nation's Supreme Court of Justice shall be composed with eleven Justices and shall function in full court or in chambers.

In accordance with the terms provided by the Law, the sessions in full court and in chambers shall be public, and by exception, when public interest or public morals should so require it, the sessions shall be secret.

The jurisdiction of the Supreme Court, its operation in full court or in chambers, the jurisdiction of Circuit Courts, District Courts and of the Electoral Court, as well as the liabilities in which the public officers of the Judicial Power of the Federation may incur, shall be governed by the provisions set forth in the laws, in accordance with the bases established in this Constitution.

The Council of the Federal Judiciary shall establish the number, circuit division, territorial jurisdiction and, as appropriate, the specialization by subject matter of Collegiate Courts, Unitary Circuit Courts and District Courts.

The Supreme Court of Justice in full court shall have powers to issue general decrees, with the aim of attaining an adequate distribution among the chambers, of the affairs under the jurisdiction of the Court, as well as to remit to Collegiate Circuit Courts those cases where it shall have established binding judicial precedents ${ }^{63}$ for their prompt dispatch, or such cases which the Court decides to forward, in accordance with such decrees, for a better dispensation of justice. Said decrees shall be in force upon their publication.

The Law shall determine the terms under which binding judicial precedents established by the courts of the Judicial Power of the Federation shall be mandatory in respect to the interpretation of the Constitution, federal or local laws and regulations, and international treaties celebrated by the Mexican State, as well as the requirements for its interruption and amendment.

The remuneration received by the Justices of the Supreme Court, Circuit Magistrates,29 District Judges and Councillors of the Council of the Federal Judiciary, as well as the Electoral Magistrates, may not be reduced during their term in office.

The Justices of the Supreme Court of Justice shall hold their office for a term of fifteen years, and may only be removed therefrom in accordance with the terms set forth by Title Fourth of this Constitution. Justices shall be entitled to a retirement payment at the end of their term.

No individual who has been a Justice may be appointed for a new term, unless he has held the office in a provisional or interim character.

\section{Chapter IV}

\section{The Judiciary}

\section{Article 102.}

A. The law will organize the Office of the Public Prosecutor of the Federation, officials of which will be named and removed by the Executive, in accordance with respective law. The Office of the Federal Public Prosecutor will be presided over by the Attorney General of the Republic, appointed by the Chief of the Federal Executive and ratified by the Senate, or, during recesses thereof, by the Permanent Commission of Federal Congress. The Attorney General must: be a Mexican citizen by birth; be at least thirty-five years of age as of the date of appointment; hold the degree of licentiate in law, having obtained said degree at least ten years prior to appointment; possess a reputation as an upstanding citizen, and not have been convicted for any willful crime. The 
Attorney General may be removed at the discretion of the Executive.

The Office of the Public Prosecutor of the Federation is responsible for prosecution, before all courts, of all federal crimes; and, by the same token, it is incumbent upon this Office to request arrest warrants for suspects; search for and submit evidence that demonstrates the guilt of these; ensure that trials proceed regularly so that the administration of justice may be quick and expeditious; request the imposition of penalties and participate in all business as determined by law.

The Attorney General of the Republic will personally participate in the controversies and actions referred to by Article 105 of this Constitution.

In all business involving the Federation, in the cases involving diplomats and consul generals, and in other business calling for the participation of the Public Prosecutor of the Federation, the Attorney General may intervene personally or through his deputy attorney generals.

The Attorney General of the Republic and his deputy attorney generals will be responsible for any offense, omission or violation of the law they commit in the discharge of their functions.

The function of legal advisor to the Government will be incumbent upon the agency of the Federal Executive established by the law for such a purpose.

Article 121. Complete faith and credit shall be given in each State to the public acts, records and judicial proceedings of all the other States. The Congress of the Union, through general laws, shall establish the manner for proving such acts, records and proceedings and their effect, subject to the following bases:

I. The laws of a State shall have effect only within its own territory and consequently are not binding outside of that State;

II. Real and personal property shall be governed by the laws of the place of their location;

III. Judgments pronounced by the Courts of one State in respect to rights in rem or real estate property located in another State, may only be enforced in the other State when its own laws so provide it. Judgments in respect to rights in personam shall only be enforced in another State when the defendant who has lost has explicitly or by reason of domicile, submitted himself to the jurisdiction of the courts that issued such judgment and provided that he was summoned to appear in court by notice served in person;

IV. Acts pertaining to marital status according to the laws of one State shall be valid in the other States;

V. Professional degree certificates issued by the authorities of one State, subject to its laws, shall be respected in all other States.

Article 133. This Constitution, the laws of the Congress of the Union which shall be enacted in pursuance thereof and all treaties in accordance therewith, celebrated or which shall be celebrated by the President of the Republic with the approval of the Senate, shall be a supreme law of the Union. The judges of the Federal District and of the States shall be bound thereby, notwithstanding any provision to the contrary in the local constitutions or local laws.

FEDERAL CRIMINAL CODE (Código Penal Federal) $1 ; 2 ; 3 ; 4 ; 11 ; 12 ; 13 ; 24 ; 40 ; 41 ; 139 ; 139$ Bis; 139 


\section{Ter; 141; 142; 145; 148 Bis; 148 Ter; 148 Quarter; $167 ; 400 ; 400$ Bis; \\ BOOK ONE \\ PRELIMINARY TITLE}

Article 1. This Code will apply throughout the Mexican Republic to federal crimes.

Article 2. Moreover, it will apply to:

I. Crimes that are initiated, prepared or committed abroad, when these produce or are intended to produce effects in Mexican territory; or crimes that are initiated, prepared or committed abroad, where, in the case where a binding treaty to which Mexico is party stipulates the obligation of extradition or trial, the requirements stipulated in Article Four of this code are met, and the probable offender is not extradited to any country that has so required, and

II. Crimes committed in Mexican consulates or against Mexican consulate personnel, where such crimes have not been tried in the country in which they are committed.

Article 3. Continuing offenses committed abroad that are continued in the Mexican Republic, will be prosecuted pursuant to Mexican law, whether the perpetrators be Mexicans or foreigners.

The same rule will apply in the case of ongoing crimes consisting of multiple offenses.

Article 4. Crimes committed in foreign territory by a Mexican against Mexicans or against foreigners, or by a foreigner against Mexicans, will be penalized in the Mexican Republic, pursuant to federal laws, provided the following requirements are met:

I. The accused party is physically present in the Mexican Republic;

II. A final judgement has not been rendered with regard to the accused party in the country in which the offense was committed, and

III. The violation of which the offender is accused is considered a crime in the country in which it was committed, and in the Mexican Republic.

\section{TITLE ONE \\ Criminal Liability \\ CHAPTER I}

General Rules on Crimes and Liability

Article 11. When any member or representative of a legal entity, or of an association, company or corporation of any kind, except governmental institutions, commits a crime with the means provided by the foregoing entities for the purpose of committing such a crime, in such a way that the offense is committed on behalf of the entity represented or in benefit thereof, the judge may, exclusively in those cases specified by law, order, as part of the sentence, the suspension or dissolution of the grouping, when he considers it necessary for public security.

\section{CHAPTER II \\ Criminal Attempt}

Article 12. Punishable criminal attempt exists when the resolution to commit a crime is demonstrated through total or partial realization or the actions that would produce the result, or failure to perform those actions that would prevent the result, where consummation of the crime is impeded by causes outside of the will of the agent.

Regarding the imposition of the penalty for criminal attempt, the judge will consider, in addition to the provisions 
of Article 52, the degree of closeness of the attempt to the actual consummation of the crime.

If the subject, at his own initiative, desists from the execution of the crime or impedes the consummation thereof, no penalty or security measure whatsoever will be imposed with relation thereto, without prejudice to application of those penalties or public security measures that may correspond to actions executed or omissions that constitute crimes in and of themselves.

\section{CHAPTER III \\ Persons Liable for Crimes}

Article 13. The following persons are considered perpetrators or accessories to crimes:

I. Those who plan or prepare the commission of a crime.

II. Those who commit a crime individually;

III. Those who commit a crime jointly;

IV. Those who commit a crime through another person;

V. Those who intentionally lead another person to commit a crime;

VI. Those who intentionally provide aid or assist another person in the commission of a crime;

VII. Those who, after commission of the crime, assist the offender in fulfillment of a promise made before the crime, and

VIII. Those who, with no prior agreement, participate with others in the commission of a crime, where the specific results of the individual actions of each person cannot be determined.

The liability of a perpetrator or accessory to a crime as referred to in this article will be determined in accordance with the individual culpability of said perpetrator or accessory.

The punishability stipulated by Article 64 bis of this code will be applied to the subjects referred to in sections VI, VII and VIII.

\section{TITLE TWO \\ CHAPTER I \\ Penalties and Security Measures}

Article 24. Penalties and public security measures are:

1. Imprisonment.

2. Probation, prison furloughs and community service.

3. Internment or probation for persons incompetent to stand trial or with addictions

to narcotics or mind-altering drugs.

4. Confinement.

5. Stay-away order.

6. Monetary sanction.

7. (Derogated).

8. Confiscation of instruments, objects and proceeds of the crime.

9. Admonition.

10. Warning.

11. Good behavior bond.

12. Suspension or deprivation of rights.

13. Disqualification, dismissal or suspension of functions or employment.

14. Public notice of court ruling. 
15. Supervision of the authority.

16. Suspension or dissolution of companies or associations.

17. Juvenile wardship measures.

18. Confiscation of assets corresponding to illicit enrichment.

And others as established by law.

\section{CHAPTER VI \\ Confiscation of Instruments, Objects and Products of the Crime}

Article 40. The instruments of the crime, as well as the objects and products thereof, will be confiscated if their use is illegal. If their use is lawful, they will be confiscated if the crime was intentional. If they belong to a third party, they will only be confiscated if the third party that has them in its power or has acquired them by any means, falls under any of the categories referred to in Article 400 of this code, independently of the legal character of said third party owning or possessing the foregoing items, or of the relationship of the third party with the offender, if any. The competent authorities will immediately seize the assets subject to confiscation, during the investigation or trial. The terms set forth in this paragraph will be observed regardless of the nature of the instruments, objects or proceeds of the crime.

If the confiscated instruments or items are harmful or hazardous substances, they will be destroyed at the discretion of the authority hearing the case, as per the terms set forth by the Code of Criminal Procedures; however, said authority, upon deeming it appropriate, may order the preservation of the foregoing items for purposes of education or investigation. With respect to the instruments of the crime, or the items that are object or product thereof, the competent authority will determine their disposition, according to their usefulness for the administration of justice, or their destruction, as the case may be, pursuant to applicable law.

Article 41. Those objects or assets at the disposal of the investigating or judicial authorities that have not been confiscated, and that are not claimed by whomever has right thereto, in a period of ninety calendar days counted from the date notification is made to the interested party, will be sold at public auction, and the proceeds of the sale will be applied to whomever is entitled to receive them. If the foregoing party does not appear within the six months following the date of notification, the proceeds of the sale will go towards improvement in the administration of justice, after deductions of expenses caused.

Goods that are at the disposal of the authority and that should not be destroyed and cannot be preserved, or are costly to preserve, will be sold immediately at public auction, and the proceeds will be at the disposition of whomever is entitled to them for a period of six months from the date of notification; after said period, proceeds will be applied to improvement of the administration of justice.

Article $139^{64}$.- Imprisonment of six to forty years and a fine of up to one thousand two hundred days ${ }^{65}$, notwithstanding any punishments applicable to the offences that may result, shall be imposed to anyone who carries out acts utilizing toxic substances, chemical, biological or similar weapons, radioactive material or instruments that emit radiations, explosives or firearms, or through fire, flood or any other violent means against people, goods or public services that produce alarm, fear or terror in the population or in a group or sector of the population, to attempt against the national security, or to pressure the authority to make a determination.

\footnotetext{
${ }^{64}$ This article is included in the Second Book, First Title ("Offences Against the Security of the Nation"), Chapter VI ("Terrorism"), of the Federal Penal Code.

${ }^{65}$ Under the Federal Penal Code, a fine of one day is equivalent to the net daily income of the convict at the moment the crime was committed considering all income of such convict.
} 
The same punishment shall be imposed to anyone who directly or indirectly finances, contributes, or collects economic funds or resources of any nature, with knowledge that such funds or resources will be used, in whole or in part, as support of individuals or organizations that manage or carry out terrorist acts in the national territory.

Article 139 Bis.- Imprisonment of one to nine years and a fine of one hundred to three hundred days shall be imposed to anyone that hides a terrorist, having knowledge of its activities or identity.

Article 139 Ter.- Imprisonment of five to fifteen years and a fine from two hundred to six hundred days shall be imposed to anyone that threatens to commit the offence of terrorism referred to in the first paragraph of article 139 above.

\section{CHAPTER VIII Conspiracy}

Article 141. A penalty of one to nine years of prison and a fine of up to ten thousand pesos will be imposed on those who conspire to commit one or several of the crimes of this title and plot the means to carry out such conspiracy.

Article 142.- Anyone that instigates, incites, or invites to commit the offences referred to in this Title shall be punishes with the same penalties foreseen for said offences, except for articles 130, second paragraph, 131, second paragraph, and 135, fraction I, that maintain their specific penalties.

Imprisonment of five to forty years shall be imposed to anyone that instigates, incites, or invites active military personnel to commit any of the offences referred to in this Title, except for the offence of terrorism which punishment shall be of eight to forty years of imprisonment and a fine of five hundred to one thousand one hundred and fifty days.

Article 145.- Imprisonment of five to forty years and a fine of one hundred twenty to one thousand one hundred and fifty days shall be imposed to the officer or employee of federal or state governments or of municipalities, decentralized public organisms, companies with state participation or public services that commits any of the offences foreseen in this Title, except for the offence of terrorism which punishment shall be of nine to forty five years imprisonment and a fine of five hundred to one thousand one hundred and fifty days.

\section{Second Title}

\section{"Crimes Against International Law" Chapter III "International Terrorism"}

Article 148 Bis.- Imprisonment of fifteen to forty years and a fine of four hundred to one thousand two hundred days, notwithstanding any punishments applicable to other offences that may result, shall be imposed to:

I) Anyone who carries out in Mexican territory acts utilizing toxic substances, chemical, biological or similar weapons, radioactive material or instruments that emit radiations, explosives or firearms, or through fire, flood or any other violent means against goods or people of a foreign state, or of any international organization, that produce alarm, fear or terror in the population or in a group or sector of the population, to try to undermine the authority of that foreign state, or force that state or an international organization to take a determination;

II) Anyone who directly or indirectly finances, contributes, or collects economic funds or resources of any nature, with knowledge that such funds or resources will be used, in whole or in part, to carry out international terrorist acts, or as support of terrorist persons or organizations that operate abroad, and

III) Anyone who agrees or prepares in Mexican territory a terrorist act that intends to be or has been carried out 
abroad.

Article 148 Ter.- Imprisonment of five to ten years and a fine from one hundred to three hundred days shall be imposed to anyone that hides a terrorist, having knowledge of its identity or that such person carries out any of the activities foreseen in this chapter.

Article 148 Quáter.- Imprisonment of six to twelve years and a fine of two hundred to six hundred days shall be imposed to anyone that threatens to commit the offence of terrorism referred to in fraction I of article 148 Bis.

Article 167.- Imprisonment of one to five years and a fine of one hundred to ten thousand days shall be imposed to:

I. The mere fact of pulling out or altering without authorization train rails, nails, screws, plates or other similar objects used to hold or support railroads of public use;

II. Anyone that destroys or splits up posts, insulators, wires, machines or equipment used for telegraphic systems, any component of the public network of telecommunications, telephone services, commutation, or radio communication, or any component of an installation of magnetic or electromagnetic energy or its means of transmission;

III. Anyone that in order to stop vehicles in a public pathway or to hamper the march of a locomotive or derail it, clears or destroys any of the objects referred in fraction I above or places obstacles;

IV. The fire caused in a railway wagon or any other cargo vehicle that does not transport people;

V. Anyone that floods entirely or partially a public pathway or throws water so as to cause severe damage;

VI. Anyone with intent or a purpose to obtain a profit disrupts or interferes wire, wireless, or optical fiber communications, either telegraphic, telephonic or satellite, by means of which audio, video, or data signals are transmitted;

VII. Anyone that destroys entirely or partially or paralyzes through any means referred in the preceding fractions, equipment used in an iron pathway or a boat or destroys or deteriorates a bridge, dock, road or route;

VIII. Anyone with a purpose to damage or complicate communications, who modifies or alters the internal mechanism of a vehicle causing it to loose power, speed or security, and

IX. Anyone that spreads or transmits false information that may damage the security of an airplane, ship or any other vehicle used in federal public services.

\section{Title Twenty Three \\ Concealment and Transactions With Resources From Illicit Origin \\ Chapter I \\ Concealment}

Article 400. Imprisonment of three months to three years and a fine proportional to the income of the offender over fifteen to sixty days, will be applied to any person who:

I.- - With the intention of profit, after the execution of the crime and without having participated therein, acquires, receives or conceals the product thereof while aware of this circumstance.

If the person that received the item through sale, pledge or any other means, had no knowledge of the illicit origin of said item, as a result of not having taken the necessary precautions to ensure that the person from whom the item 
was received was entitled to dispose of said item, the penalty will be reduced by up to half;

II.- - Assists or collaborates in any way with the perpetrator of a crime, with knowledge of these circumstances, through agreement made after the execution of said crime;

III.- Conceals or aids in the concealment of the perpetrator of a crime, the effects, objects or instruments thereof, or impedes investigation thereof;

IV.- Does not provide assistance for the investigation of the crimes or prosecution of the offenders when so required by the authorities; and

V.- Does not undertake to prevent the consummation of crimes that he knows will be committed or that are being committed by all lawful means available to him and without risk to his person, except when under obligation to confront the foregoing risk, in which case the provisions of this article or other applicable regulations will apply.

The penalty set forth in this article will not apply in the cases of Section III, with regard to the concealment of the offender, and Section IV, in the specific cases of:

a) Ascendants and descendants by consanguinity or affinity.

b) Spouse, domestic partner, or collateral relative within the fourth degree of consanguinity, or the second degree of affinity; and

c) Those persons connected to the offender by love, respect, gratitude or close friendship for noble reasons.

The judge, considering the nature of the action, the personal circumstances of the defendant and others specified by Article 52, may impose, in the cases of concealment referred to in Section I, first paragraph, and sections II to IV of this article, instead of the sanctions specified, up to two thirds of the penalty that would correspond to the perpetrator of the crime, and the grounds for the application of the sanction authorized by this paragraph must be provided in the sentence.

\section{Chapter II \\ Transactions with resources from illicit origin}

Article 400 Bis.- A five to fifteen years penalty and a fine from one up to five thousand days of the minimum wage, shall be imposed on any individual that by himself or through a third party, carries out any of the following behaviors: purchase, management, sale, custody, warranty, investment, transportation or transfer, within national territory; from Mexico to abroad or inversely, knowing that resources, rights or assets of any nature originated from or represent the product of an illicit activity, with the purpose of, concealing or attempting to conceal, disguising or attempting to disguise, the origin, nature ownership, destination or location of the referred money or assets as well as promoting any illicit activity.

The same penalties shall be imposed on the employees and institutions' officers that integrate the financial system, that willfully assist or cooperate with a third party to carry out the behaviors mentioned in the herein above paragraph, in accordance with that foreseen in the provisions in effect that regulate the financial system.

The penalty provided in the first paragraph shall be increased to a half, in the event that a government ofcial in charge of the prevention, prosecution, investigation of said offenses, carries out an illicit behavior. Furthermore, in such case, government officials will not be able to serve or have a position at any public institution for a period equal to the length of imprisonment.

In the event that behaviors provided by this article, were carried out through services rendered by institutions that are part of the financial system, a formal accusation previously filed by the Secretariat of Finance and Public Credit shall be necessary in order to take criminal action.

In the event, that through its verifying powers, the Secretariat of Finance and Public Credit finds elements to prove 
the alleged commission of offenses provided in the preceding paragraph, it shall exercise the verifying powers legally conferred to it, in order to file a formal accusation on said offenses.

For the purposes of this article, products originated from any illicit activity are defined as the resources, rights or assets of any nature which are assumed to be directly or indirectly obtained from the commission of any offense, or that represent the asset value or any other profit thereof, in the event that its legitimate origin can not be proven.

For the same purpose, the financial system is integrated by credit, bonds and insurance institutions, bonded warehouse, leasing institutions, loan and savings corporations, limited liability financial corporations, credit unions, financial factorage enterprises, stock exchange brokers, money exchange offices, retirement fund corporations, and any other financial or exchange mediator.

FEDERAL CODE OF CRIMINAL PROCEDURES (Código Federal de Procedimientos Penales)

$1 ; 2 ; 180 ; 181 ; 182 ; 182 \mathrm{C} ; 182 \mathrm{E} ; 182 \mathrm{R} ; 194$

\section{PRELIMINARY TITLE}

Article 1. This code consists of the following procedures:

I. Pretrial investigation before filing of charges, which establishes the procedures legally necessary so that the Public Prosecutor can decide whether to file charges;

II. Pre-trial, in which proceedings are carried out to determine the facts pertaining to the process, the classification of these according to the applicable type of criminal offense and the probable guilt of the defendant, or, where appropriate, release of the defendant due to lack of grounds for trial;

III. Trial, which includes proceedings before and by the courts in order to ascertain and prove the existence of the crime, the circumstances in which it was committed and the particular circumstances of the defendant, as well as said defendant's criminal liability or absence thereof;

IV. First instance, during which the Public Prosecutor presents its case, the defendant presents his defense before the court, and the court evaluates the evidence and renders a final verdict.

V. Second instance, before the appeals court, in which proceedings and actions are carried out to adjudicate appeals;

VI. Execution, which runs from the moment the sentence ordered by the courts becomes final and conclusive until the extinction of the sanctions applied;

VII. Those procedures pertaining to persons incompetent to stand trial, juveniles and those persons addicted to narcotics or mind-altering drugs.

If, in any of the foregoing proceedings, any juvenile or person incompetent to stand trial is observed to have a connection to the events to which said proceedings pertain, whether as perpetrator, accessory, witness, victim or aggrieved party, or in any other way, the Public Prosecutor or the respective court will compensate for the absence or deficiency of arguments and grounds that lead to protection of the rights that may legally correspond to them.

Article 2. It is incumbent on the Federal Public Prosecutor's Office to carry out the investigation and, where appropriate, file charges before the courts.

In the investigation, the Public Prosecutor must:

I. Hear the accusations or complaints presented verbally or in writing on events that may constitute crimes;

II. Carry out and order the performance of all actions conducive to proof of corpus delicti and probable guilt of the 
defendant, as well as restitution.

III. Request, from judicial authority, precautionary measures of preventive detention, seizure or attachment necessary for the pretrial investigation, as well as search warrants, as appropriate;

IV. Authorize the detention or custody of suspects where appropriate;

V. Order all necessary measures to provide safety and aid to victims;

VI. Protect or provide restitution of aggrieved party's rights pursuant to Article 38;

VII. Decide whether to reserve or file charges;

VIII. Authorize and personally notify the aggrieved party if an indictment will not be filed, and, where appropriate, settle objections articulated by them;

IX. Grant or revoke, as appropriate, provisional release of the suspect;

$\mathbf{X}$. Where appropriate, promote conciliation of the parties; and

XI. Others pursuant to law.

TITLE FIVE

Regulations Common to Pretrial Investigation and Trial

\author{
CHAPTER I \\ Proof of Corpus Delicti and Probable \\ Guilt of Defendant
}

Article 180. To prove corpus delicti and probable guilt of the suspect, the Public Prosecutor and the courts will enjoy the broadest right of action to employ the means of investigation they deem appropriate, even where these methods are not defined by law, provided they do not violate the law.

The requests made by the Attorney General of the Republic or the public servant to whom he delegates this authority, or the judicial authority, as the case may be, for information or documents regarding the financial system will be made through the National Banking and Securities Commission, the National Insurance and Finance Commission, as well as the National Savings Commission and the Tax Administration Service, in their respective areas. Requests for information or documents of a fiscal nature will be made through the unit of the Department of Treasury and Public Credit determined by the head of said department.

The information and documents thus obtained may only be used in the investigation and for purposes of the criminal proceedings, and must be handled with the strictest confidentiality. Any public servant who violates the confidentiality of court proceedings or provides copies thereof or of pretrial investigation documents will be subject to criminal and administrative liability proceedings, as appropriate.

\title{
CHAPTER II
}

Traces of the Crime. Seizure of Instruments and Objects of the Crime.

Article 181. The instruments, objects or products of the crime, as well as the property on which traces may be found, or which may be related to said crime, will be seized to ensure they do not disappear nor are altered nor destroyed. The management of seized assets will be carried out pursuant to the law on the subject.

Authorities acting in assistance of the Public Prosecutor will immediately hand over the assets to which the previous paragraph refers. The Public Prosecutor, upon receiving the assets, will make a decision regarding their seizure.

In the case of fields of marijuana, opium poppies or other narcotics, the Public Prosecutor, the Judicial Police or the authorities acting in assistance thereof, will proceed to destroy these fields, preparing a report to certify: the 
field area, amount or volume of the narcotic, and samples of the narcotic will be collected, to be used in the pretrial investigation begun to the effect.

When narcotics or mind-altering drugs are seized, the Public Prosecutor will authorize and oversee their destruction, if appropriate, after inspection of the substances through which their nature, weight and other characteristics will be determined. A representative sample will be kept for the preparation of expert opinions that are to be obtained in the investigation or the trial, as the case may be.

Article 182. Upon the seizure, the federal prosecutors, with the aid of the Federal Agency of Investigations, or the court clerks and other officials designated by the judicial authority to carry out the procedure, as appropriate, must:

I. Prepare a report of the inventory of seized assets including their description and condition;

II. Identify the seized assets with seals, marks, stamps, brands, signs or other appropriate means;

III. Provide appropriate and immediate measures to prevent seized assets from being destroyed, altered, or from disappearing;

IV. Request that the seizure be recorded in the corresponding public registries pursuant to Article 182-D of this code, and

V. Once the foregoing requirements have been satisfied, turn the assets over to the competent authority for their management within seventy-two hours, on the date and at the sites agreed upon prior with said authority, in accordance with applicable law.

The authority that initiates the action of seizure is obligated to complete it pursuant to the terms of this chapter.

Assets seized during the pretrial investigation or trial that may be elements of evidence, will be managed by the Asset Management and Disposal Service, in accordance with applicable legislation.

Article 182-C. If the assets seized have previously been attached, taken under management of judicial authorities, embargoed or seized, notification of the new seizure will be made to the authorities who have ordered these actions. The assets will continue under custody of whomever has been designated for that purpose, and at the disposal of the judicial authority or of the Federal Public Prosecutor for the purposes of the criminal proceedings.

In the event prior embargo, intervention, attachment or seizure is lifted, whomever has custody of the assets will deliver them to the competent authority for effects of their management.

The seized goods may not be conveyed or pledged by their owners, custodians, government managers or administrators during the period of the seizure for the criminal proceedings, except in those cases expressly specified by the applicable regulations.

Seizure does not imply any modification whatsoever to existing pledges on assets.

Article 182-E. Proceeds or yields of the assets generated during the period of seizure will be treated in the same fashion as the seized assets that generate them.

Article 182-R. Funds obtained through disposal of assets confiscated in federal criminal proceedings, as referred to in Section I of Article 1 of the Federal Law for Management and Disposition of Public Sector Assets, as well as the disposal of yields and proceeds thereof, will be shared equally between the Federal Judiciary, the Office of the Attorney General of the Republic and the Health Department, in accordance with the provisions of Article 89.

The funds corresponding to the Health Department must go towards programs of drug addiction prevention and rehabilitation.

\section{CHAPTER IV}

\section{Detention of Accused Party}

Article 194.- The offences foreseen in the following laws are deemed serious, for all legal effects, considering that 
they severely impinge on fundamental values of the society:

I. From the Federal Penal Code, the following offences:

1) Homicide by serious culpability, foreseen in article 60, third paragraph;

2) Treason to the Nation, foreseen in articles $123,124,125$ and 126;

3) Espionage, foreseen in articles 127 and 128;

4) Terrorism, foreseen in articles 139 to 139 Ter and international terrorism foreseen in articles 148 Bis to 148 Quater;

5) Clandestine import of firearms that are reserved for exclusive use of the Army, Navy or Air force services, foreseen in article $84 \mathrm{Bis}$, first paragraph.

6) Felonies foreseen in articles 142, second paragraph and 145;

7) Piracy, foreseen in articles 146 and 147;

8) Genocide, foreseen in article 149 Bis;

9) Prisoners' evasion, foreseen in articles 150 and 152;

10) Attacks to communication means, foreseen in articles 168 and 170;

11) Illicit use of facilities destined to air traffic, foreseen in article 172 Bis third paragraph;

12) Drug related offences, foreseen in articles 194, 195, first paragraph, 195 Bis, excepting cases related to the first two rows of the table contained in appendix I, 196 Bis, 196 Ter, 197, first paragraph and 198, first part of third paragraph;

13) Corruption of minors or disabled people, foreseen in article 201; Pornography of minors or disabled people, foreseen in article 202; Sexual tourism against minors or disabled people, stated in articles 203 and 203 BIS; pimping minors or disabled people, stated in article 204; sexual abuse against minors or disabled people, established in article 205; human trafficking stated in article 207;

14) Offences foreseen in article 205 , second paragraph;

15) Sexual exploitation of minors, foreseen in article 208;

16) Falsification and alteration of currency, foreseen in articles 234, 236 and 237;

17) Falsification and undue utilization of credit instruments, foreseen in article 240 Bis, excepting for fraction III;

18) Against consume and national wealth, foreseen in article 254, fraction VII, second paragraph;

19) Rape, foreseen in articles 265,266 and 266 Bis;

20) Assault in roads or highways, foreseen in article 286, second paragraph;

21) Physical damage, foreseen in articles 291, 292 and 293, when it is committed in any of the circumstances foreseen in articles 315 and 315 Bis;

22) Homicide, foreseen in articles 302 in relation to 307, 313, 315, 315 Bis, 320 and 323;

23) Abduction, foreseen in article 366, excepting for the last two paragraphs and trafficking of minors, established in article 366 ter;

24) Aggravated robbery, foreseen in article 367 when it is committed in any of the circumstances mentioned in articles 372 and 381, fractions VII, VIII, IX, X, XI, XIII, XV and XVI;

25) Aggravated robbery, foreseen in article 367 in relation with article 370 second and third paragraphs, when it is committed in any of the circumstances mentioned in article 381 Bis; 
26) Customary commercialization of robbed objects, foreseen in article 368 Ter;

27) Subtraction or illegal exploitation of hydrocarbon or its derivatives, foreseen in article 368 Quater, second paragraph;

28) Robbery, foreseen in article 371 , last paragraph;

29) Vehicles' robbery, foreseen in article 376 Bis;

30) Felonies foreseen in article 377;

31) Extortion, foreseen in article 390;

32) Money laundering, foreseen in article $400 \mathrm{Bis}$, and

$32 \mathrm{Bis}$ ) Intentional felonies against the environment, foreseen in articles 414, first and third paragraphs, 415, last paragraph, 416, last paragraph and 418, fraction II, when the volume of the damage exceeds 2 cubic meters of timber or it is related to the conduct foreseen in articles 419 , last paragraph and 420, last paragraph;

33) Felonies related to property or author rights, foreseen in article 424 Bis;

34) Compelled disappearance of persons, foreseen in article 215-A;

35) Felonies against the environment, foreseen in article 420, fraction II Bis;

II. From the Federal Law against Organized Crime, the offence foreseen in article 2.

III. From the Federal Law of Firearms and Explosives, the following offences:

1) Transportation of firearms that are reserved for the exclusive use of the Army, Navy and Air force services, foreseen in article 83, fraction III;

2) Offences foreseen in article 83 Bis, except for the case stated in article 11, subsection i);

3) Possession of firearms that are reserved for the exclusive use of the Army, Navy and Air force services, foreseen in article 83 Ter, fraction III;

4) Felonies foreseen in article 84 , and

IV. From the Federal Law to Prevent and Sanction Torture, the torture offence foreseen in articles 3 and 5.

V. From the General Law of Population, trafficking with illegal migrants, foreseen in article 138.

VI. From the Federal Fiscal Code, the following offences:

1) Smuggling and its equivalents, foreseen in articles 102 and 105 , fractions I to IV, when they deserve the sanctions foreseen in fractions II or III of article 104, second paragraph, and

2) Tax fraud and its equivalents, foreseen in articles 108 and 109, when the defrauded amount ranks the thresholds stated in fractions II or III of article 108, exclusively when they are aggravated.

VII. From the Law of Intellectual Property, the offences foreseen in article 223, fractions II and III.

VIII. From the Law of Credit Institutions, the offences foreseen in articles 111; 112, regarding the case foreseen in the fourth paragraph, excepting fraction V and $113 \mathrm{Bis,}$, in the case described in the fourth paragraph of article 112;

IX. From the General Law of Auxiliary Credit Organizations and Activities, the offences foreseen in articles 98, in the case described in the fourth paragraph, excepting fractions IV and V, and 101;

X. From the Federal Law of Sureties Institutions, the felonies established in articles 112 Bis; 112 Bis 2, in the case described in the fourth paragraph; 112 Bis 3, fractions I and IV, in the case described in the fourth paragraph; 112 Bis 4, fraction I, in the case described in the fourth paragraph of article 112 Bis 3, and 112 Bis 6 , fractions II, IV and VII, in the case described in the fourth paragraph; 
XI. From the Federal Law of Insurance Institutions and Mutual Entities, the felonies established in articles 141, fraction I; 145, in the case described in the fourth paragraph, excepting fractions II, IV and V; 146 fractions II, IV and VII, in the case described in the fourth paragraph, and 147, fraction II subsection b), in the case described in the fourth paragraph of article 146;

XII. From the Law of the Securities Market, the offences foreseen in articles 52 and 52 Bis when the disposed amounts of the securities, titles of credit or documents mentioned in article 3 of said Act exceed the equivalent of 350 thousand "wage days";

XIII. From the Law of the Saving for Retirement Systems, the felonies foreseen in articles 103, and 104 when the disposed amounts of the funds, securities or documents manager by the workers exceed 350 thousand "wage days", and

XIV. From the Law of Bankruptcies and Suspension of Payments, the felonies established in article 96.

The punishable attempt of the felonies mentioned herein above, would also constitute a serious offence.

XV. From the General Law of Health, the offences foreseen in article 464 Ter, fractions I, II, and III.

FISCAL CODE OF THE FEDERATION (Código Fiscal $105 ; 156$ Bis

de la Federación)

Article 105. The same penalties that apply to smuggling will apply to:

I.... XVII

Persons who, when entering or leaving the country, fail to make customs declarations of cash, checks drawn on Mexican or foreign banks, payment orders or any other documents for collection, or a combination of these, over the equivalent, in currency or currencies as the case may be, of thirty thousand dollars of the United States of America will be sanctioned with a prison sentence of three months to six years. In the event a sentence against the defendant is issued by the competent authority with respect to the commission of the crime to which this paragraph makes reference, the amount in excess of the limit specified above will become property of the federal tax authorities, unless the person in question demonstrates the lawful origin of these funds.

Article 156-bis. In the event of attachment of bank deposits per the terms of Article 155, Section I hereof, the authority that has ordered the attachment will issue an official notice to the manager of the bank branch of the account, instructing the bank to freeze and hold the deposited funds.

The banking institution must inform the foregoing authority of any increase in amounts of bank deposits due to interests generated, and such information must be provided with the same frequency as normally provided to the account holder.

Funds may only be transferred to the federal tax authorities once the related tax liability becomes final, and up to the amount necessary to cover said obligation.

Until the secured tax liability becomes final, the account holder of the attached accounts may offer another form of guarantee pursuant to Article 141 of this code, in place of attachment of accounts. The authority must come to a decision and notify the taxpayer with regard to acceptance or rejection of the guarantee offered, or with regard to additional requirements, within a maximum of 10 days. The authority must communicate its resolution to the banking institution by sending this institution a copy of said resolution within 15 days following the notification of this resolution to the taxpayer; if not made within the specified period, the bank will lift the attachment on the account. 


\begin{tabular}{|l|l|}
\hline FEDERAL CIVIL CODE (Código Civil Federal) & 2180;2181;2182;2183;2184 \\
\hline CHAPTER II \\
Simulation of Legal Acts
\end{tabular}
$\begin{aligned} & \text { Article 2180. A simulated act is that in which the parties falsely represent or affirm that which in reality has not } \\
& \text { occurred or been agreed between them. }\end{aligned}$

Article 2181. Simulation is absolute when no part of the simulated act is real; it is relative when the true character of a legal act is concealed by a false appearance.

Article 2182. Absolute simulation does not produce legal effects. Upon discovery of the real act concealed by a relative simulation, said real act will not be nullified if no law exists that so nullifies it.

Article 2183. The annulment of simulated acts may be requested by third parties harmed by such a simulation, or the Public Prosecutor, when said simulation was committed in violation of the law or in prejudice to Public Treasury.

Article 2184. Upon annulment of a simulated act, restitution will be made of the thing or claim to whom it belongs, with proceeds and interests, if any; but if the thing or claim has been conveyed, for valuable consideration, to a third party of good faith, restitution may not be made.

Moreover, the pledges imposed in favor of the third party of good faith will survive.

\section{FEDERAL LAWS}

FEDERAL LAW AGAINST ORGANIZED CRIME (Ley

Federal contra la Delincuencia Organizada)

$2 ; 8 ; 9 ; 10 ; 11 ; 16 ; 29 ; 30 ; 34 ; 35$;

\section{TITLE ONE \\ GENERAL PROVISIONS}

\section{SOLE CHAPTER NATURE, OBJECT AND APPLICATION OF THE LAW}

Article 2.- When three or more persons agree to organize themselves or get organized to commit in a permanent or reiterated form conducts that individually or joined with others, have as a purpose or result the commission of any of the following offenses, those persons shall be punished for that sole fact as members of organized crime:

I. Terrorism, foreseen in articles 139 to 139 Ter and international terrorism established in articles 148 Bis to 148 Quáter; drug related felonies, established in articles 194 and 195, first paragraph; falsification and alteration of currency, established in articles 234, 236 and 237; money laundering, established in article 400 Bis; and the offence established in article 424 Bis, all those articles from the Federal Penal Code;

II. Firearms gathering and trafficking, foreseen in articles 83 bis and 84 of the Federal Law of Firearms and Explosives;

III. Trafficking with illegal migrants, foreseen in article 138 of the General Law of Population; 
IV. Human organs trafficking, established in articles 461, 462 and 462 bis of the General Law of Health, and

V. Corruption of persons of age less than eighteen years or persons that lack capacity to understand the meaning of the fact or persons that do not have capacity to resist it, foreseen in article 201; Pornography of persons of age less than eighteen years or persons that lack capacity to understand the meaning of the fact or persons that do not have capacity to resist it, foreseen in article 202; Sexual tourism against of persons of age less than eighteen years or persons that lack capacity to understand the meaning of the fact or persons that do not have capacity to resist it, foreseen in articles 203 and 203 BIS; Pandering persons of age less than eighteen years or persons that lack capacity to understand the meaning of the fact or persons that do not have capacity to resist it, foreseen in article 204; Sexual exploitation of persons of age less than eighteen years or persons that lack capacity to understand the meaning of the fact or persons that do not have capacity to resist it, foreseen in article 205; Sexual exploitation, foreseen in article 207; assault, foreseen in articles 286 and 297; abduction, foreseen in article 366; trafficking of minors or persons that lack capacity to understand the meaning of the fact, foreseen in article 366 Ter, and robbery of vehicles, foreseen in article $381 \mathrm{Bis}$, of the Federal Penal Code or corresponding provisions of state penal law.

Article 8. The Office of the Attorney General of the Republic must have a unit specialized in the investigation and prosecution of crimes committed by members of organized crime, made up of federal prosecutors, assisted by federal judicial police officers and experts.

The specialized unit will have a technical control body, that in interception of private communications will verify the authenticity of their results; establish guidelines on the characteristics of devices, equipment and systems to be authorized; as well as on the safekeeping, preservation, maintenance and use thereof.

The regulations set forth by the Organic Law of the Office of the Attorney General of the Republic will establish the profiles and requirements to be satisfied by public servants belonging to the specialized unit, to ensure a high professional level in accordance with the powers conferred upon them by this law.

Whenever mention is made in this law to the Federal Public Prosecutor's Office, it will be understood that this refers to the members of the specialized unit established by this article.

Where necessary, the head of this unit may request the collaboration of other federal public administration agencies.

Article 9. When the Federal Public Prosecutor's Office investigates activities of members of organized crime related to the crime of transactions with funds of illicit origin, it must perform said investigation in coordination with the Department of Treasury and Public Credit.

Requests from the Federal Public Prosecutor's Office, or the federal judicial authority, for information or documents regarding the banking and financial system will be made through the National Banking and Securities Commission, the National Retirement Savings Commission, and the National Insurance and Finance Commission, as appropriate; those of a fiscal nature, through the Department of Treasury and Public Credit.

The information that is obtained in accordance with the previous paragraph, may only be used in the investigation or corresponding criminal proceedings, and the strictest level of confidentiality must be kept.

Any public servant who violates the confidentiality of the court proceedings or provides copies thereof or of other documents will be subject to criminal or administrative liability proceedings, as appropriate.

Article 10. - At the request of the Federal Public Prosecutor's Office, the Department of Treasury and Public Credit may carry out audits on individuals and legal entities, when sufficient evidence exists to found the suspicion that they are members of organized crime.

Article 11. In pretrial investigations on crimes referred to by this law, the investigation must also include acquiring knowledge on organizational structures, and forms and areas of operation. For such purposes, the Office of the Attorney General of the Republic may authorize infiltration of agents.

In these cases, investigation will be performed on not only the individuals who belong to the organization in 
question, but also the legal entities they use to carry out their criminal aims.

Article 16. When, in the pretrial investigation of any of the crimes to which this law refers, or during the respective procedures, the Attorney General of the Republic or the head of the specialized unit referred to in Article 8 above consider it necessary to intercept private communications, they will make a request in writing to the district judge, expressing the objective and necessity of the interception, and the evidence founding the suspicion that a member of organized crime participates in the crimes investigated; as well as the events, circumstances, information and other elements that are attempted to be proven.

In addition, the requests for interception of communications must specify the person or people who will be investigated; the place or places where it will be performed; the type of private communication to be intercepted; length; the procedure and equipment for the interception and, where appropriate, the identification of the individual managing the services through which the communication to be intercepted is made.

The following types of private communication may be intercepted: verbal, written, by signs, signals or by means of electric, electronic, mechanical, wired or wireless devices, computer systems or equipment, or any other means or form that allows communication between one or various emitters and one or various receivers.

\section{CHAPTER FIVE SEIZURE OF CONFISCATABLE ASSETS}

Article 29. When sufficient evidence exists to found the suspicion that any person is a member of organized crime, the Federal Public Prosecutor's Office may order, upon judicial authorization, the seizure of assets of said person, as well as of those which said person purports to own, and it will be the responsibility of the owners to demonstrate the legitimate origin of said assets, in which case an order must be issued to lift the seizure.

Article 30. When sufficient evidence exists to found the suspicion that there are assets that belong to a member of organized crime, or assets which such a member of organized crime purports to own, these assets may be seized with prior judicial authorization. In the event the legitimate origin of the assets in question is demonstrated, an order must be issued to lift the seizure.

\section{CHAPTER SIX PROTECTION OF INDIVIDUALS}

Article 34. The Office of the Attorney General of the Republic will provide sufficient support and protection to judges, experts, witnesses, victims and other individuals, when so required due to participation in a criminal proceedings on offenses referred to by this law.

\section{CHAPTER SEVEN \\ COLLABORATION IN THE PROSECUTION OF ORGANIZED CRIME}

Article 35. Any member of organized crime who provides effective assistance for the investigation and prosecution of other members of organized crime may receive the following benefits:

I. When no pretrial investigation exists against him, the elements of proof he provides or which are derived through the pretrial investigation initiated due to his cooperation will not be used against him. This benefit may only be granted on a single occasion for any one person;

II. When a pretrial investigation exists in which the collaborator is implicated, and he provides evidence for the prosecution of other members of organized crime, the penalty that would correspond to him for the crimes he has committed may be reduced by up to two thirds; 
III. When, during criminal proceedings, the suspect provides conclusive evidence that is sufficient to produce guilty verdicts on other members of organized crime with administration, management or supervisory functions, the penalty that would correspond to him for the crimes for which he is tried may be reduced by up to half, and

IV. When a convicted felon provides conclusive evidence that is sufficient to produce guilty verdicts on other members of organized crime with administration, management or supervisory functions, he may be granted a partial pardon of up to two thirds of the imposed custodial measure or prison sentence.

In imposing penalties, as well as in granting the benefits referred to by this article, the judge will consider, in addition to the provisions of articles 51 and 52 of the Criminal Code for the Federal District in Matters of Local Jurisdiction, and for the entire Republic in Matters of Federal Jurisdiction, the gravity of the crimes committed by the collaborator. In the cases of Section IV of this article, the competent authority will consider the gravity of the crimes committed by the collaborator and the rules established by law on execution of penalties and security measures.

\section{FEDERAL LAW FOR MANAGEMENT AND $1 ; 12 ; 17 ; 34 ; 89$}

DISPOSITION OF PUBLIC SECTOR ASSETS (Ley

Federal para la Administración y Enajenación de Bienes del

Sector Público)

\section{TITLE ONE General Provisions}

Article 1. This law is of public order, to be observed throughout the entire Mexican Republic, with the objective of regulating, through the Asset Management and Disposal Service (SAE), management and disposition of the following assets:

I. Assets seized and confiscated in federal criminal proceedings;

$\cdots$

Article 12. Proceeds or yields of assets generated during the period of management will be treated in the same fashion as the seized assets that generate them.

In all cases, the resources obtained from asset management will go towards compensating the cost of maintenance and management thereof and any remainder will be deposited in the fund referred to by Article 89 and will be delivered to whomever demonstrates a right to said assets pursuant to the terms of applicable law.

Article 17. Custodians, liquidators, inspectors and administrators designated by the Asset Management and Disposal Service (SAE) may not dispose of nor pledge real property under their supervision. In all cases, the rights of third parties will be respected.

\section{CHAPTER II ALLOCATION AND DONATION}

Article 34. In exceptional cases, in accordance with the provisions set forth in applicable law, and after fulfilling any requirements set forth therein, as the case may be, such as those relating to amount, term and type of assets, assets may be donated or allocated, as appropriate, to the government controlled agencies and entities of the federal public administration, as well as to state and municipal governments, to be used in local public services, education and social aid, or to institutions authorized to receive deductible donations pursuant to the terms of the Income Tax Law, and for whom said funds are necessary in order for them to carry out their activities. 
With regard to assets originating in foreign trade, donation may only be made of items which are flammable, explosive, polluting, radioactive, corrosive, perishable, quickly decomposing or deteriorating, flora, live animals, those items used for prevention of or response to the effects of natural disasters, and those items that will go to specific zones determined to exhibit high degrees of marginalization.

\section{TITLE SIX}

The Asset Management and Disposal Service (SAE)

Article 89. The funds obtained through the proceeds of sale referred to in Article 38 of this law, as well as the proceeds generated by the assets managed by the Asset Management and Disposal Service (SAE), will be subject to deductions for the costs of management, maintenance and asset preservation expenses, fees of special non-public servant appointees in charge of the foregoing procedures, as well as payments of successful claims filed by buyers or third parties for hidden or tax liabilities, or other liabilities, nonexistent assets, matters in litigation, and other expenditures analogous to the foregoing, or those determined by the Internal Revenue Law of the Federation or any other applicable regulation.

The proceeds of sales together with yields generated by the assets managed by the Asset Management and Disposal Service (SAE), will be placed in a fund, which will have two general subaccounts, one for yields and the other for sales.

Each general subaccount will have specific subaccounts corresponding to each asset or group of assets taken under management, or to each of the indicated sale procedures specified in the preceding paragraph; thus, transfer of funds obtained can be made from the general subaccount to the various specific subaccounts.

The funds of the specific subaccounts will be delivered by the Asset Management and Disposal Service (SAE) to whomever is entitled to receive them, within the periods agreed upon with the transferring entity or the Federal Treasury, and in accordance with applicable law. Once said funds are delivered, the Asset Management and Disposal Service (SAE) will have no liability whatsoever in the event of claims.

\begin{tabular}{|c|c|}
\hline $\begin{array}{l}\text { ORGANIC LAW OF THE OFFICE OF THE } \\
\text { ATTORNEY GENERAL OF THE REPUBLIC } \\
\text { Orgánica de la Procuraduría General de la República) }\end{array}$ & $\begin{array}{l}4 ; 11 ; 30 ; 31 ; 34 ; 35 ; 36 ; 37 ; 38 ; 39 ; 40 ; 47 ; 48 ; \\
49 ; 50 ; 51 ; 53 ; 54 ; 55 ; 56 ; 57 ; 58 ; 60 ; 61 ; 62 ; 63 ; \\
64 ; 65 ; 66 ;\end{array}$ \\
\hline
\end{tabular}

\section{CHAPTER I \\ General Provisions}

\section{Article 4}

It is incumbent upon the Federal Public Prosecutor's Office to:

I. Investigate and prosecute federal crimes. This includes the authority to:

A) In the pretrial investigation:

a) Hear accusations or complaints regarding actions or omissions that may constitute crimes;

b) Investigate federal crimes, as well as crimes corresponding to local or state jurisdiction which may be brought under federal jurisdiction, pursuant to applicable regulations, with the aid of assisting agencies and parties referred to by Article 20 of this law, and other authorities, both federal and from the Federal District and the states of the Federation, pursuant to the terms of applicable law, and collaboration agreements and instruments executed to this 
effect;

c) Carry out the necessary actions to prove corpus delicti and the probable guilt of the suspect, as well as for restitution of damages and lost profits;

d) Order the arrest of and, where appropriate, detain probable offenders pursuant to the terms set forth by Article 16 of the Political Constitution of the United Mexican States; carry out seizure of assets in accordance with applicable law;

f) Provide provisional restitution to the aggrieved party with regard to enjoyment of rights, pursuant to the terms of the Federal Code of Criminal Procedures and other applicable regulations;

g) Grant pre-trial release to suspects pursuant to the terms set forth in Article 20, Clause A, Section I and final paragraph, of the Political Constitution of the United Mexican States;

h) Request, from judicial authority, search warrants, precautionary measures of preventive detention, seizure or attachment of assets necessary for the purposes of the pretrial investigation, as well as, as appropriate, for the due performance of the sentence rendered;

i) In those cases in which the law so permits, the Federal Public Prosecutor's Office will foster conciliation of the interests in conflict, proposing possible solutions to achieve resolution;

j) Determine incompetence to stand trial and submit the matter to the authority that should hear the case, along with all information from pretrial investigations, as appropriate;

k) Determine reservation of pretrial investigation, pursuant to applicable law;

1) Determine not to file charges, when:

1. The events known do not constitute a crime;

2. After exhausting all measures and means of evidence, corpus delicti and probable guilt of the suspect are not demonstrated;

3. Abatement of the criminal proceedings would result pursuant to the terms of applicable regulations;

4. Investigations clearly show the existence of cause for exclusion from criminal liability, pursuant to the terms established by applicable regulations;

5. Demonstration of the existence of the events constituting the offense is impossible due to an insurmountable material obstacle, and

6. Other cases as determined by applicable regulations.

m) Turn juveniles who have committed actions or omissions corresponding to crimes classified under federal criminal law over to the competent authorities.

n) Turn adults incompetent to stand trial over to the judicial authority when security measures must be applied, carrying out the corresponding actions pursuant to the terms set forth in applicable regulations.

ñ) Others as determined by applicable regulations.

When the Federal Public Prosecutor's Office becomes aware, through its own actions and observations or through the actions of assistants, of the probable commission of a crime for which prosecution requires aggrieved party to file complaint, or any other equivalent action to be made by an authority, it will immediately communicate this situation in writing to the competent authority, for adjudication with due knowledge of the events, as corresponds to its powers and duties. The authorities will notify the Federal Public Prosecutor's Office in writing of their decision.

In the event of flagrante delicto, in which a pretrial investigation is initiated with the arrested individual, the federal prosecutor will immediately request, in writing, that the competent authority file a complaint or comply with the equivalent requirement, within the period of detention established by Article 16, seventh paragraph, of the Political 
Constitution of the United Mexican States.

B) Before the judicial authority:

a) Carry out prosecution before the competent judicial authority for federal crimes where accusation or complaint has been filed, corpus delicti and the probable guilt of the suspect(s) has been proven; and, request arrest warrants or citations, as appropriate;

b) Request, from the judicial authority, search warrants, precautionary measures of preventive detention, seizure or attachment of assets, letters rogatory, or posting of bonds for purposes of restitution for damages and lost profits, except where the defendant has previously made such guarantees;

c) Turn arrested and detained persons over to the judicial authority within the periods established by law;

d) Present evidence to promote steps conducive to the due demonstration of the existence of the crime, the circumstances in which it was committed and those corresponding to the defendant, criminal liability, the existence of the damages and lost profits, as well as to establish the amount of restitution;

e) Formulate conclusions pursuant the terms specified by law, and request imposition of corresponding penalties and security measures and payment of restitution for damages and lost profits, or, where appropriate, establish the causes for exclusion from criminal liability or those which result in abatement of the criminal proceedings;

f) Raise objections to court rulings, pursuant to the terms set forth by law;

g) In general, promote that which is conducive to the proper course of processes, and perform all other duties specified by applicable regulations.

C) On the subject of attention to the victim or aggrieved party of a crime:

Provide legal advice to the victim or aggrieved party and inform him of the rights to which he is entitled as established by the Political Constitution of the United Mexican States, and, upon his request, on the course of the criminal proceedings;

b) Receive all elements of evidence that the victim or aggrieved party provides while

exercising his right of participation, to prove corpus delicti and the probable guilt of the defendant, as well as to determine, where appropriate, the amount of restitution of damages. When the Federal Public Prosecutor's Office considers that introduction of evidence is unnecessary, it must provide grounds for such a decision;

c) Facilitate the identification of the probable offender and, in the cases of crimes against personal freedom and normal psychosexual development, illegal detention, or when otherwise considered appropriate, order all necessary measures to prevent danger to the physical and psychological integrity of the victim or aggrieved party;

d) Inform the victim or aggrieved party who wishes to pardon the offender, where this is possible, of the legal meaning and significance of this act;

e) Order necessary and possible measures so that the victim or aggrieved party receives emergency medical and psychological care. When the Federal Public Prosecutor's Office considers it to be necessary, it will carry out measures to provide medical and psychological attention to other individuals;

f) Request, from the judicial authority, where appropriate, restitution of damage, and

g) Inform the victim or aggrieved party, when this person is a minor, that he is not obliged to confront the defendant for identification purposes in crimes of rape or kidnapping.

In these cases, the respective declarations will be made as established by applicable regulations.

II. Oversee the observance of constitutionality and legality in the scope of competence, without prejudice to the authority that legally corresponds to other judicial or administrative authorities. In carrying out this function the Federal Public Prosecutor's Office must:

a) Participate as party to writs of amparo, pursuant to the terms of constitutional Article 107 and in any other cases 
in which the Writ of Amparo Law, implementing articles 103 and 107 of the Political Constitution of the United Mexican States, dictates or authorizes such participation;

b) Participate as representative of the Federation in all business to which the Federation is party or in which it has legal interest. This function includes the activities necessary for the exercise of the powers conferred upon the Attorney General of the Republic by Section III, Article 105 of the Political Constitution of the United Mexican States.

With regard to matters of interest and significance for the Federation, the Attorney General of the Republic will keep the President of the Republic informed of all relevant cases, and will require his agreement in writing for discontinuance;

c) Participate in a collaborative capacity in the business to which parastatal entities of the federal public administration are party or have legal interest, at the request of the corresponding sector coordinator. The Attorney General of the Republic will make decisions considering the importance of the matter for the public interest.

Sector coordinators and, by agreement of these, parastatal entities, pursuant to the provisions of the respective law, through the bodies determined by their administrative regime, must inform the Institution of those cases which said entities are party to or in which they intervene, or of any other way in which their functions or assets are involved before foreign bodies with adjudicatory authority. In these cases the Institution will stay abreast of the respective procedures and will request corresponding information. If, in the opinion of the Attorney General of the Republic, the matter has significance for the public interest, he will formulate the observations or suggestions considered appropriate, and

d) Intervene in disputes involving diplomats and consul-generals, precisely by virtue of this fact. With regard to criminal proceedings without immunities that must be respected, the Federal Public Prosecutor's Office will act in strict compliance with legal obligations, observing the regulations established by international treaties to which the United Mexican States is party.

III. Participate in the extradition or handing over of suspects, defendants and convicted felons, pursuant to the terms of applicable regulations, as well as in fulfillment of international treaties to which the United Mexican States is party;

IV. Request reports, documents, opinions and evidence in general, from agencies and institutions of the federal public administration, from those corresponding to the Federal District and from the states of the Federation, and from other authorities and individuals who can provide elements for the proper performance of these functions.

It is obligatory to provide the reports requested by the Federal Public Prosecutor's Office in the performance of functions. Failure to comply with the requests made by the Federal Public Prosecutor's Office will be cause for liability pursuant to the terms of applicable legislation;

V. Promote the efficient, expeditious and proper administration of justice, and

VI. Others as determined by law.

\section{CHAPTER II System of Organization}

Article 11. For the realization of the functions of the Office of the Attorney General of the Republic and the Federal Public Prosecutor's Office, a system of territorial and functional specialization and decentralization will be in place, according to the following systems:

I. System of specialization:

a) The Attorney General of the Republic will have administrative units specialized in the investigation and prosecution of certain types of crimes, responding to the manifestations of organized crime, as well as to the nature, complexity and incidence of federal crimes;

b) The specialized administrative units will act throughout the entire country in coordination with the decentralized agencies and units, and 
c) The specialized administrative units, according to their organic, functional and budgetary levels, may have management offices, departments and other units as established by applicable law.

II. System of decentralization:

a) Precincts will be decentralized bodies of the Office of the Attorney General of the Republic in each state. Heading each precinct will be a deputy, who will exercise command and supervisory authority over federal prosecutors, the federal investigative police, professional and technical experts, as well as other personal assigned to the decentralized agency;

b) Precinct locations will be established taking into account: incidence of crime, population density, geographic characteristics of each state, and proper distribution of workloads;

The Office of the Attorney General may have administrative units responsible for the coordination, supervision and evaluation of precincts. Where appropriate, the Attorney General will determine, by way of formal agreement, the number of administrative units and precincts assigned to them;

d) Federal Public Prosecutor's Office precincts will have subprecinct offices and federal prosecutor's offices, which will carry out functions within the political boundaries established by the Attorney General by way of formal agreement, as well as the regional offices and other administrative units established by applicable law:

e) Precincts will attend to matters with regard to pretrial investigation,

prosecution, reservation of charges, incompetence to stand trial, joint trials, decision to not file charges, control of processes, writ of amparo, crime prevention, services to the community, administrative and other services, in accordance with the powers granted by the provisions of this law and by the Attorney General by way of formal agreement;

f) Precincts will supply measures to attend to matters incumbent upon the Federal Public Prosecutor's Office in the areas where no permanent office exists;

g) The Attorney General will issue the regulations necessary for coordination and cooperation of the precincts with central agencies and specialized units, in order to guarantee coordinated action and proper chain of command with regard to the Federal Public Prosecutor's Office.

h) There will be an information system to provide the responsible unit, as determined by the provisions of this law, with timely knowledge of state or Federal District legislation, so that, where appropriate, the Attorney General of the Republic can apply the action specified by Section II, Paragraph c) of Article 105 of the Political Constitution of the United Mexican States, as well as act in the corresponding capacity in the disputes specified in Section I of said article.

The foregoing information system will also include information enabling this unit to have timely knowledge of contradictory court opinions rendered by the Federal Judiciary, so that the head of the Institution may exercise the right to report said contradictory opinions as specified by Section XIII of Article 107 of the Political Constitution of the United Mexican States.

\section{CHAPTER V \\ FEDERAL JUSTICE ADMINISTRATION CAREER SERVICE}

Article 30. The Federal Justice Administration Career Service includes the careers of federal prosecutors, federal investigative police and technical and professional experts, and will be subject to the following:

I. It will consist of the stages of start of service, development, and termination of service:

a) Start of service will include the requirements and procedures of selection, education, training, and initial assignment;

b) Development will include the requirements and procedures of continuous education and training, specialization, awards and bonuses, changes of assignment, personal development, performance, medical and character evaluations, promotions and sanctions, and

c) Termination includes the causes and procedures of separation from service, in accordance with the provisions of this law and the regulations pertaining to the Federal Justice Administration Career Service 
II. It will be organized pursuant to the provisions of the General Law Establishing Rules for Coordination of the National System of Public Security and other applicable regulations, as well as collaboration agreements, and other agreements and resolutions, as appropriate, made between the governments of the Federal District, the states of the Federation, municipalities and other competent authorities, in accordance with the corresponding regulations;

III. It will be of a compulsory and permanent nature, and will include the programs, courses, examinations and competitions corresponding to the various stages of the fields of public prosecution, police and professional and technical expert, which will be carried out by the units and agencies specified by applicable regulations, without prejudice to the establishment of cooperation mechanisms with public and private institutions;

IV. It will be governed by the principles of legality, efficiency, professionalism, honesty, loyalty, impartiality and respect for human rights. The theoretical and practical content of training, continuing education and specialization programs will enable federal prosecutors and their assistants to carry out their functions in accordance with the foregoing principles, and will promote effective learning and comprehensive development of the knowledge and abilities necessary for performance of services;

V. There will be a system of rotation of federal prosecutors, federal investigative police and professional and technical experts within the Institution, and

VI. It will determine the profiles, categories and functions of federal prosecutors, the federal investigative police and professional and technical experts.

Article 31. To be hired and remain a federal public prosecutor, the following is necessary:

I. To be hired:

a) Be a Mexican citizen by birth, in full exercise of rights, and not have acquired another nationality;

b) Hold the degree of Licentiate in Law, legally issued and registered, and the corresponding professional license;

c) Have at least three years of professional experience counted from the issuance of the degree to the date of appointment;

d) Where necessary, have completed compulsory national military service;

e) Successfully complete the initial medical and character evaluation;

f) Satisfactorily fulfill the requirements and complete the entrance procedures specified in this law and in applicable regulations;

g) Not be subject to criminal proceedings;

h) Not be suspended nor have been dismissed nor disqualified by final resolution as a public servant, pursuant to the terms of applicable regulations;

i) Have a reputation of good conduct and not have been convicted by final verdict as guilty of a willful crime;

j) Not use, in an unlawful fashion, mind-altering drugs, narcotics, or other drugs of similar effect, nor suffer from alcoholism, and

k) Other requirements as established by applicable law.

II. To remain in the post:

a) Comply with continuing education and professional development requirements established by applicable regulations;

b) Pass continuous, periodical and compulsory medical, character and performance evaluations, established by this law and other applicable regulations;

c) Not be absent from service without justified cause for a period of three consecutive days, or five days within a period of thirty days; 
d) Participate in opportunities for promotion that are announced pursuant to applicable regulations;

e) Satisfy the entrance requirements during service,

f) Other requirements as established by applicable regulations.

Article 34. The Federal Public Prosecutor's Office will employ career prosecutors, as well as special or visiting prosecutors.

For the purposes of this law, special prosecutors are those that, not being permanently employed by the Federal Public Prosecutor's Office, are named by the Attorney General of the Republic to attend to matters as necessary due to special circumstances of these matters.

$\cdots$

Article 35. With regard to individuals with broad professional experience, the Attorney General of the Republic, pursuant to this law and the regulations regarding the Federal Justice Administration Career Service may, in exceptional cases, name special or visiting federal prosecutors as well as federal investigative police officers or special experts, waiving competitive hiring requirements. The foregoing individuals must be in full exercise of their rights and fulfill the following requirements:

- $\quad$ For prosecutors in the Federal Public Prosecutor's Office, those specified in Article 31, Section I, paragraphs a), b), c), d), e), g), h), i) and j);

Article 36. Prior to acceptance as a federal prosecutor, a federal investigative police officer or a professional or technical expert, including in those cases referred to by the foregoing article, the Institution must review the background of the individual in question in the National Registry of Public Security Personnel, pursuant to the terms established by the General Law Establishing Rules for Coordination of the National System of Public Security.

Article 37. With regard to basic-level hiring for positions of federal prosecutor, federal investigative police or professional and technical expert, internal and external competitive hiring will be carried out.

All things being equal, in competitive hiring for federal prosecutors and federal investigative police officers, preference will be given to secretarial officers of the Federal Public Prosecutor's office, subject to the conditions and requirements established by the Council of Professionalization.

Article 38. Federal prosecutors, federal investigative police officers and professional and technical experts will be assigned by the Attorney General or by other public servants of the Institution to whom this this function is delegated, to the various administrative units of the Office of the Attorney General of the Republic, in accordance with applicable law.

Moreover, they may be assigned to study, review or actions required in special cases in accordance with their level and specialty.

Article 39. Promotions to the higher levels of the Federal Public Prosecutor's Office, the federal investigative police, and for professional and technical experts, will be awarded after an internal competition, in accordance with the regulations of the Federal Justice Administration Career Service and the agreements of Council of Professionalization.

Article 40. The Council of Professionalization will act as a regulatory body, and will also be responsible for development and evaluation of the Federal Justice Administration Career Service.

\section{CHAPTER VI \\ PUBLIC SERVANT EVALUATION PROCESSES}

Article 47. Members of the Federal Justice Administration Career Service and other public servants, as determined by the Attorney General by way of formal agreement, must submit to and successful pass medical and character 
evaluation and performance evaluation processes, which will be of a compulsory nature, and applied on hire and periodically throughout the career of the public servant, pursuant to applicable law.

Performance evaluations and medical and character evaluations will consist of the following tests:

I. Pertaining to assets and social environment;

II. Psychometric and psychological;

III. Drug testing.

Others considered necessary for the evaluation of personnel.

The evaluation processes will seek to verify that the public servants referred to in the first paragraph duly fulfill the requirements of the principles of legality, effectiveness, professionalism, honesty, loyalty, impartiality, and respect of human rights.

Article 48. The provisions of this law will establish the tests to be included in the evaluation processes, which must include drug testing, as well as the procedures to be used in the testing.

The tests will be evaluated as a group, except for the drug test which will be applied and evaluated separately.

Article 49. Public servants will be notified to appear for their respective tests. Failure to appear without justified cause will result in being declared unfit.

Article 50. The results of the evaluation processes will be confidential except as established by applicable law, and in those cases where they must be presented in administrative or judicial proceedings.

Article 51. Members of the Federal Justice Administration Career Service declared unfit through the processes of evaluation to which this chapter refers, will no longer provide services to the Office of the Attorney General of the Republic, after completion of the procedure established by Article 44 of this law.

In the event that other public servants of the Institution, which the Attorney General of the Republic has determined to be subject to the evaluation processes, are determined to be unfit, they will no longer render services to the Institution, in accordance with applicable law.

\section{CHAPTER VIII}

\section{CAUSES OF LIABILITY OF FEDERAL PROSECUTORS, FEDERAL INVESTIGATIVE POLICE OFFICERS AND PROFESSIONAL AND TECHNICAL EXPERTS.}

Article 53. They following are causes of liability of federal prosecutors and, as appropriate, federal investigative police officers and professional and technical experts:

I. Failure to comply with, delaying or prejudicing through negligence of the due action of the Federal Public Prosecutor's Office;

II. Engaging in or concealing acts against the autonomy of the Federal Public Prosecutor's Office, such as accepting or exercising orders, pressure, assignments, commissions or any other action generating or involving improper subordination with respect to any person or authority.

III. Making improper use of the material items or goods under personal or institutional custody, or facilitating such use by third parties;

IV. Failure to request necessary expert opinions;

V. Failure to seize upon process of attachment assets, objects, instruments, proceeds of crimes and, where applicable, failure to confiscate assets when appropriate pursuant to the terms established by criminal law; 
VI. Failure to perform the necessary procedures in any matter;

VII. Failure to comply with any of the obligations specified in the following article, and

VIII. Other requirements as established by applicable law.

Article 54. They following are obligations of federal prosecutors, federal investigative police officers and professional and technical experts, to safeguard legality, efficiency, professionalism, honesty, loyalty, impartiality and respect of human rights in the performance of functions:

I. Adhere to the rule of law and respect human rights in all actions;

II. Render assistance to victims of crimes, and provide protection to their assets and rights, as appropriate. Actions must be consistent, timely and in proportion to events;

III. Carry out functions with absolute impartiality, without discriminating against any person for reasons of race, religion, gender, economic or social condition, sexual preference, political ideology or any other reason;

IV. Prevent, by any means available and as corresponds to functions, the perpetration, tolerance or allowance of acts of physical or psychological torture or other cruel, inhuman or degrading treatments or punishments. Public servants with any knowledge of acts of the foregoing nature must report them immediately to the competent authority;

V. Abstain from engaging in any job, post or commission or other activity specified in the following article of this law;

VI. Treat all persons respectfully, abstaining from any arbitrary act or from improperly limiting actions or demonstrations carried out by the public in the exercise of constitutional rights and in a peaceful manner;

VII. Carry out functions without soliciting nor accepting compensation, payment or rewards other than those dictated by law. Specifically, oppose any act of corruption;

VIII. Abstain from ordering or carrying out the apprehension or detention of any person without fulfilling the requirements set forth in the Political Constitution of the United Mexican States and in applicable regulations;

IX. Protect the life and physical and psychological safety of persons detained or under custody;

X. Participate in actions with other authorities or police agencies, and provide these with, as appropriate, the necessary support pursuant to law;

XI. Obey orders from superiors and fulfill all obligations, provided these are in accordance with the law;

XII. Preserve confidentiality of matters known and discovered during the performance of functions, with the exception of those determined by law;

XIII. Abstain, in the performance of functions, from obtaining assistance from persons not authorized by law;

XIV. Use the equipment under one's responsibility with the proper care and good judgment in carrying out functions, and properly maintain said equipment;

XV. Abstain from withdrawing from or failing to perform functions, commissions or services assigned without justified cause;

XVI. Submit to the processes of medical, character and performance evaluation in accordance with applicable regulations, and

XVII. Other requirements as established by applicable law.

Failure to comply with these obligations will give rise to the corresponding sanctions pursuant to the terms of this chapter.

Article 55. Federal prosecutors, federal investigative police and professional and technical experts may not: 
I. Perform jobs, posts or commissions of any nature in the federal public administration, in the governments of the Federal District or the states or municipalities of the Federation, nor jobs or services in private institutions, except for those of an educational nature and those authorized by the Institution, provided that they are not incompatible with one's functions;

II. Practice law personally or through an intermediary, except on behalf of oneself or one's spouse, domestic partner, ascendants or descendants, siblings or direct relatives through adoption;

III. Act in the capacity of legal guardian, administrator or executor, except in the capacity of heir or legatee, or when the situation involves ascendants or descendants by consanguinity or adoption, or siblings.

IV. Practice or perform the functions of custodian or attorney-in-fact, receiver, administrator, inspector in bankruptcy or insolvency, notary, broker, commission agent, referee or arbitrator.

\section{CHAPTER IX \\ SANCTIONS APPLICABLE TO FEDERAL PROSECUTORS, FEDERAL INVESTIGATIVE POLICE OFFICERS AND PROFESSIONAL AND TECHNICAL EXPERTS}

Article 56. The sanctions for violations or failure to comply with the obligations specified in articles 53 and 54 of this law, respectively, will be:

I. Public or private admonition;

II. Suspension, or

III. Dismissal.

In addition to the sanctions set forth in the foregoing sections, federal investigative police officers may be subject to disciplinary measures that may consist of arrest or denial of permission to leave premises.

Article 57. Admonition is the act by means of which the public servant is disciplined for minor violation(s) committed in the performance of his functions, compelling rectification of conduct.

Admonition may be public or private depending on the specific circumstances of the violation and, in either case, it will be made in writing to the offender, in whose personal record a copy of said communication will be filed.

Article 58. Suspension is the temporary interruption in the performance of functions, which may be applied for up to fifteen days in accordance with the decision of the superior, in the event that the violation does not merit dismissal.

Article 60. An appeal for reconsideration may be filed with the Council of Professionalization against the disciplinary measures referred to in the previous articles, within five working days following the notification of the imposition of the disciplinary measure. The foregoing appeal will express grievances and supply proof deemed to be pertinent. The appeal will be adjudicated in the following session of the Council of Professionalization.

Filing an appeal will not suspend the effects of disciplinary measure, but rather seeks to prevent these from appearing in the file or service record of the public servant in question.

Article 61. Dismissal of members of the Federal Justice Administration Career Service will proceed in cases of serious violations, in the opinion of the Council of Professionalization. In all cases, dismissal will proceed in the event of violation of the obligations set forth in Sections IV, V, VII, VIII, XII, XIII, XV and XVI of Article 54 of this law.

Article 62. The sanctions set forth in Article 56, sections I and II herein may be imposed by:

I. The Attorney General of the Republic;

II. Deputy attorney generals; 
III. The Chief of Staff;

IV. The General Inspector;

V. Coordinators;

VI. Director Generals;

VII. Prosecutors;

VIII. Delegates, and

IX. Heads of equivalent administrative units.

The Council of Professionalization, at the request of the public servants referred to in this article, may order dismissal.

Article 63. Sanctions will be imposed considering the following:

I. The seriousness of the violation;

II. The need to eliminate practices that prejudice the operation of the Institution;

III. Recurrence of violations by offender;

IV. Rank, level of education and seniority;

V. Circumstances and means of execution;

VI. Socio-economic condition of the public servant, and

VII. Where appropriate, the monetary amount corresponding to gain or damages resulting from failure to comply with obligations.

Article 64. The decision for dismissal will be made in accordance with the following procedure:

I. The procedure will be initiated by the agency or upon complaint filed by public servants as referred to in Article 62 of this law to the Council of Professionalization in charge of the examination of the facts of the case;

II. Complaints filed must be supported by documentary evidence or probative elements sufficient to demonstrate responsibility of the accused public servant;

III. A copy of the complaint and its attachments will be sent to the public servant, so that within a period of fifteen working days he may prepare a report of the events and supply corresponding evidence. The report must treat each and every one of the events included in the complaint, accepting them, denying them, expressing uncertainty with regard to those not his own, or describing them as he believes they took place. Events not explicitly disputed by the accused public servant will be presumed accepted, except in the presence evidence to the contrary.

IV. The public servant will be summoned to a hearing in which the respective evidence will be presented, if any, and his arguments will be heard, presented pro se or through an attorney.

V. Once the hearing has been carried out and the evidence presented, the Council of Professionalization will hold session to determine the existence or inexistence of responsibility, imposing the sanction of dismissal in the former case. The interested party will be notified of the decision.

VI. If the report or the hearing provides insufficient elements to adjudicate, or where other elements come to attention that indicate new responsibility of the accused or of other persons, investigations may be carried out, and, where appropriate, a new hearing or hearings may be scheduled.

VII. At any time, prior or subsequent to the hearing, the public servants referred to in Article 62 of this law may order the temporary suspension of the accused, provided that, in their opinion, such a course of action is appropriate for carrying out or continuation of investigations, which will end if the Council of Professionalization so decides, independently of the start, continuation or conclusion of the procedure referred to in this article. The suspension does not prejudge the responsibility alleged, and this will be expressly stated in the suspension order.

If the suspended public servant, pursuant to this section, is determined to not be responsible, his rights will be restored.

Article 65. An appeal for reconsideration may be filed with the Council of Professionalization against the 
decisions to impose any of the sanctions set forth in sections I and II of Article 56 herein, within five working days following notification of the decision.

The foregoing appeal will express grievances and supply proof deemed to be pertinent.

The appeal will be adjudicated in the following session of the Council of Professionalization, and the decision will be added to the corresponding file or service record.

If the suspended public servant is determined to not be responsible of the sanctions set forth in sections I and II of Article 56 herein, his rights will be restored.

Article 66. The other penalties set forth in this chapter will be imposed by the public servants referred to in Article 62 of this law, who must observe, as appropriate, the procedure established in Article 64.

LAW OF CREDIT INSTITUTIONS (Ley de Instituciones 1 1; 2; 3; 46; 46 Bis; 47; 103; 106; 115; 117

de Crédito)

\section{TITLE ONE \\ Preliminary Provisions}

Article 1. This law aims to regulate banking and credit services; the organization and operation of financial institutions; the activities and operations that these institutions may perform; their healthy and balanced development; protection of public interests; and the terms in which the State will exercise financial governance over the Mexican banking system.

Article 2. Banking and credit services may only be provided by financial institutions, which may be:

I. Full-service banking institutions, and

II. Development banking institutions.

For the purposes of the provisions of this law, banking and credit services are considered to be the securing of funds from the general public on the national market for public placement, through actions causing direct or contingent liability, where the intermediary is obliged to cover principal and, where appropriate, interest on the secured funds.

Banking and credit operations will not be considered to include those carried out by financial intermediaries other than the financial institutions duly authorized pursuant to applicable regulations. In no event may these intermediaries receive irregular checking account deposits.

Neither will Banking and credit operations include securing of funds from the general public through issuance of instruments registered in the National Securities Registry, placed through public offer, even when these funds are used for granting financing of any nature.

For the purposes of this article and of Article 103, it will be understood that securing of funds from the public exists upon: a) Solicitation, offering or promotion of the securing of funds from the general public or by mass media, or b) securing or solicitation of funds in a customary or professional manner.

Article 3. The Mexican banking system will be made up of the Bank of Mexico, full-service banking institutions, development banking institutions, the National Savings Council (PAHNAL) and the public trusts established by the federal government for economic development, as well as those established for performance of the functions entrusted by law to the Bank of Mexico.

TITLE THREE

Transactions

CHAPTER I

General Rules 
Article 46. Financial institutions may only perform the following transactions:

I. Receive bank deposits of funds:

a) Sight;

b) Fixed (pre-established withdrawal dates);

c) Savings, and

d) Term and notice;

II. Accept loans and credits;

III. Issue bank bonds;

IV. Issue subordinated debentures;

V. Establish deposits in foreign financial institutions and financial entities;

VI. Make deductions and extend loans or credits;

VII. Issue credit cards based on current account line of credit agreements;

VIII. Assume obligations on behalf of third parties, based on credit extended, through granting acceptances, endorsements or third party guarantees for credit instruments, as well as issuance of letters of credit;

IX. Conduct securities transactions pursuant to the provisions of this law and of the Securities Market Law;

$X$. Promote the organization and transformation of all types of companies and business entities, and subscribe and maintain shares or interests in these, pursuant to the terms of this law;

XI. Conduct transactions with commercial documents on own behalf;

XII. Conduct, on own behalf or on that of third parties, transactions with gold, silver and foreign currencies, including securities repurchase agreements with regard to the latter;

XIII. Provide safe-deposit box service;

XIV. Issue letters of credit contingent on payment, collect debts and make payments on behalf of customers;

XV. Conduct trust transactions as set forth in the General Law of Negotiable Instruments and Credit Operations, and carry out mandates and commissions;

XVI. Receive deposits as depository or custodian, or in escrow on behalf of third parties, of negotiable instruments or securities, and of commercial documents in general;

XVII. Act as common representative of credit instrument holders;

XVIII. Provide cash and treasury management services with respect to credit instruments on behalf of issuers;

XIX. Conduct accounting and keep minute books and records for companies and business entities;

$\mathbf{X X}$. Act as executor;

XXI. Carry out receivership or judicial or extrajudicial liquidation of business concerns, establishments, bankruptcies or inheritances;

XXII. Conduct appraisals that will have the same probatory force that the law confers upon acts by public commercial attestors or experts;

XXIII. Acquire personal property and real estate necessary for the accomplishment of objectives, and dispose of these as appropriate, and

XXIV. Enter into financial lease agreements and acquire the assets that are subject matter of such agreements.

$\mathbf{X X V}$. Conduct financial transactions known as derivatives, subject to all regulations issued by the Bank of Mexico pursuant to the decisions of the Department of Treasury and Public Credit and of the National Banking and Securities Commission;

XXVI. Conduct factoring transactions, and

XXVII. Analogous or related operations authorized by the Department of Treasury and Public Credit, pursuant to the decisions of the Bank of Mexico and the National Banking and Securities Commission.

The performance of the transactions specified in Sections XXIV and XXVI of this article, as well as fulfillment of the obligations of the parties, will be subject to the provisions of this law, and, without prejudice thereto, the General Law of Negotiable Instruments and Credit Operations.

Article 46 bis. Credit institutions, pursuant to all general regulations issued with regard thereto by the National Banking and Securities Commission, may engage third parties, including other financial institutions, in the 
rendering of services necessary for their operation. Those who render the foregoing services will be subject to applicable law in relation to privileged information set forth in articles 117 and 118 of the foregoing law.

Article 47. Development banking institutions will perform, in addition to those operations specified in Article 46 of this law, the operations necessary for providing an appropriate level of service to the corresponding sector of the national economy, and for fulfillment of the functions and objectives that are particular to them, pursuant to the conditions and exceptions determined by their organic laws with respect to the provisions in this or other laws. With regard to record keeping and accounting systems of banking transactions, Section VIII of the Organic Law of the Federal Public Administration will not be applicable.

The operations referred to in Sections I and II of Article 46 of this law will be carried out by development banking institutions in order to provide the beneficiaries of their activities with access to banking and credit services, and encourage the habit of savings and the use of the services provided by the Mexican banking system, in such a way as to avoid disturbances in the systems of securing funds from the general public.

The bank bonds issued by development banking institutions must foster the development of the capital and institutional investment market.

The Department of Treasury and Public Credit will dictate guidelines and establish measures and mechanisms towards the most appropriate use and channeling of the resources of development banking institutions, considering coordinated financing plans between this type of institution, national auxiliary financial institutions, public funds and trusts established by the federal government for economic development, and full-service banking institutions.

\section{TITLE FIVE \\ Prohibitions, Administrative Sanctions and Crimes CHAPTER I \\ Prohibitions}

Article 103. No individual or legal entity may directly or indirectly secure public funds in Mexican territory through engaging in transactions of deposits, loans, credit, mutuum or any other act causing direct or contingent liability, being obliged to cover principal and, where appropriate, interests of the funds secured.

The following are exceptions to the rule stated in the foregoing paragraph:

I. Regulated financial institutions pursuant to this law, as well as other financial intermediaries duly authorized in accordance with applicable law;

II. Issuers of instruments registered in the National Securities Registry, placed by means of public offer, with respect to the funds originating from this placement, and

III. Derogated.

IV. Derogated.

Issuers referred to in Section II using funds originating from placement for extension of credit, must adhere to the general regulations issued, as appropriate, by the National Banking and Securities Commission on the subject of financial, administrative, economic, accounting and legal information, which they must make public pursuant to the terms of the Securities Market Law.

Derogated, penultimate paragraph

Derogated, final paragraph

Text of Section IV and the penultimate and final paragraphs of Article 103 of this law, that will continue in effect until July 18, 2013:

Article 103.

I to III. 
IV. Special-purpose financial institutions authorized by the Department of Treasury and Public Credit that secure funds originating in the placement of instruments registered in the National Registry of Securities and Intermediaries, and which extend credit for a certain activity or sector.

Legal entities referred to by Section IV of this article must, at all times, have a Mexican majority of equity ownership,

and will be subject, in all cases, to the rules issued by the foregoing Department for this purpose, and the provisions regarding operations issued by the Bank of Mexico, as well as the oversight and monitoring of the National Banking Commission.

Articles of incorporation of special-purpose financial institutions, and any amendments to these, must be submitted for

prior approval by the Department of Treasury and Public Credit. Once the articles of incorporation or amendments are approved, they must be registered by the Public Registry of Commerce.

Article 106. Financial institutions are prohibited from:

I. Giving their property as collateral;

II. Giving as collateral, including as pledge, securities bonds or guarantee trusts, cash assets, accounts receivable or negotiable instruments in portfolio, except in the case of transactions with the Bank of Mexico, development banking institutions, the Institute for the Protection of Bank Savings, or the public trusts established by the federal government for economic development;

III. Giving as collateral credit instruments issued, accepted or maintained in treasury;

IV. Conducting transactions directly or indirectly with the negotiable instruments representing the entity's capital, except in the case of the provisions of the final paragraph of articles 19 and 38 of this law and Chapter IV, Title Two of the Savings Protection Law, as well as extending credit for the acquisition of such negotiable instruments;

V. Conducting transactions and providing services to customers where conditions and terms are agreed to which significantly depart from the prevailing market conditions at the moment they are granted, or from general institutional policies or good banking practices.

VI. Conducting transactions by virtue of which officers and employees of the institution can become debtors to the institution, except as corresponds to customary employment benefits granted to employees, regular or alternate statutory auditors, external auditors of the institution; or ascendants or descendants of the first degree or spouses of the foregoing persons. The Department of Treasury and Public Credit may authorize exceptions to the provisions of the section, through general rules;

VII. Accepting or paying documents or certifying checks with insufficient funds, except in the case of credit opening;

VIII. Assuming responsibilities or obligations on behalf of third parties, other than those set forth in Section VIII of Article 46 of this law and with the reservation set forth in the following section;

IX. Granting bonds or security, except where they cannot be provided by bond institutions, by virtue of amount, and with prior authorization of the Department of Treasury and Public Credit.

The guarantees to which this section refers must be for a determinate amount and will require countersecurity in cash or securities that can be acquired by financial institutions in accordance with this law.

X. Guaranteeing fulfillment of the obligations derived from domiciled documents, upon giving domicile for payments or notices. This provision must be included in the text of the documents in which the designated domicile is given;

XI. Conducting business with merchandise of any kind, except transactions with gold, silver and foreign currencies 
that can be performed pursuant to the terms of this law and the Organic Law of the Bank of Mexico;

XII. Participating in companies and business entities that are not limited liability, and operating, on own behalf, commercial or industrial establishments or ranches, without prejudice to the right to hold bonds, obligations, shares and other negotiable instruments of these companies pursuant to the terms of this law.

The National Banking Commission may authorize continued operation where the foregoing are received in payment of credit or for security of existing credits, without exceeding the periods specified in the following section;

XIII. Directly or indirectly acquiring, with funds originating from its liabilities, negotiable instruments, securities or assets as set forth in sections I and III of Article 55 of this law. The Department of Treasury and Public Credit may authorize exceptions, by means of general rules.

When a credit institution receives negotiable instruments or securities, in payment of debts or by sale at auction in legal actions related to claims in its favor, which it should not maintain as assets, or property or interests as set forth in this section, it must adhere to the general regulations established by the National Banking Commission;

XIV. Maintaining checking accounts for those persons who, in the course of two months, have issued three or more of said documents, that, if presented on time, would not have been paid due to insufficient funds, unless this lack of funds is due to a cause not attributable to the drawer.

When any person acts in the foregoing manner, the institutions will submit the name of that person to the National Banking Commission, so that this commission may give such notice to the various national financial institutions, which may not open an account for said person for a period of one year. The interested party may come before the foregoing commission to exercise the rights to which he is entitled:

XV. Advance payment, in whole or in part, of obligations owed from cash bank deposits, loans or credit;

XV bis. Advance payment of securities repurchase agreement transactions, except those carried out with the Bank of Mexico, other financial institutions or brokerage firms;

XV bis 1. Advance payment of obligations owed resulting from the issuance of bank bonds, except where these fulfill the requirements set forth to this effect in Article 63 of this law;

XV bis 2. Advance payment of obligations owed resulting from issuance of subordinate debentures, except where the institution fulfills the requirements set forth to this effect in Article 64 of this law;

XVI. Direct or indirect acquisition of negotiable instruments and securities issued or accepted, subordinate debentures issued by other financial institutions or holding companies; as well as reacquisition of credits owed by third parties that may have been assigned, except for the case of the transactions specified in Article 93 of this law;

XVII. Extending credit or loans with security of:

a) The liabilities referred to by Section IV of Article 46, whether of its own, of any credit institution or of holding companies;

b) Interests in trusts, mandates or commissions that, in turn, have as their subject the liabilities described in the preceding paragraph.

c) Shares of full-service banking institutions or financial group holding companies, owned by any person who holds five percent or more of the capital stock of the institution or company in question.

For shares other than those specified in the preceding paragraph representing the capital stock of financial institutions, holding companies and any financial entity, the institutions must give 30-day notice to the Department of Treasury and Public Credit;

XVIII. Conducting transactions and offerings on own behalf and on behalf of third parties with regard to depositors for the acquisition of goods or services, for which it is observed that, to avoid charges for the foregoing, the depositors must express their objection; 
XIX. In carrying out the transactions referred to in Section XV of Article 46 of this law:

a) Conducting transactions with the institution itself in the fulfillment of trusts, mandates or commissions. The Bank of Mexico may authorize certain transactions by means of general regulations when they do not imply a conflict of interests;

b) Assuming responsibility towards trustors or principals, with regard to the default of debtors on claims or regarding issuers, as to the securities acquired, except where at fault pursuant to the final section of Article 391 of the General Law of Negotiable Instruments and Credit Operations; or, guarantee yields by investment funds entrusted.

If, upon termination of the trust, mandate or commission established for the extension of credit, these have not been liquidated by the debtors, the institution must transfer them to the trustor or trust beneficiary, as appropriate, or to the principal, abstaining from covering the respective amount due.

In trust, mandate or commission agency agreements, this paragraph will be clearly inserted along with a statement by the trustee to the effect that it clearly represented content to the persons from whom it has received assets or interests for conveyance in trust;

c) Acting as trustees, or principals in trusts, mandates or commissions, through which funds of the general public are directly or indirectly secured, through any act causing direct or contingent liabilities, except in the case of trusts established by the federal government through the Department of Treasury and Public Credit, and trusts through which securities are issued which are registered in the National Securities Registry in accordance with the provisions of the Securities Market Law;

d) Carrying out the trusts, mandates or commissions referred to by the second paragraph of Article 88 of the Mutual Fund Company Law.

e) Acting in trusts, mandates or commissions through which limitations or prohibitions contained in the financial laws are evaded;

f) Using funds or securities of trusts, mandates or commissions assigned to the extension of credit, in which the trustee possesses discretionary authority in such extension of credit to carry out transactions in which the following persons can become debtors: trust officers; the members of the managing board or board of directors, as the case may be, both regular and alternate, whether acting or not; the employees and officers of the institution; regular or alternate statutory auditors, whether acting or not; external auditors of the institution; members of the technical committee of the respective trust; the ascendants or descendants of the first degree or spouses of the foregoing persons, business entities with majority equity ownership by these persons, or the institutions themselves, and those persons determined by the the Bank of Mexico in general regulations,

and

g) Managing rural property, except where said management has been conferred to distribute estate among heirs, legatees, associates or creditors, or to pay an obligation or guarantee its fulfillment with the value of said property or its proceeds; in these cases, management may not be provided for more than two years, except in cases of guarantee or production trusts.

Any agreement contrary to the provisions in the preceding paragraphs will be null and void.

XX. Providing information obtained in transactions with customers for sales and marketing of products or services, except in the case of the express consent of the customer involved.

The Bank of Mexico may authorize, by means of general rules, exceptions to the provisions of Sections II, XV and $\mathrm{XV}$ bis of this article, in order to promote the healthy development of the financial system.

The National Banking and Securities Commission may authorize exceptions to provisions in Section I of this article, provided that these are made with the objective of fostering the stability of financial institutions or the banking system. 
Article 115.- The cases foreseen in articles 111 to 114 of this Law shall proceed by request from the Ministry of Finance and Public Credit, who shall listen to the opinion of the National Banking and Securities Commission; and such cases could also proceed by request from the respective credit institution or from anyone that has a legal interest.

The provisions of the articles referred to in this Chapter do not exclude any other penalties that may result applicable according to other laws for the commission of other offenses.

In addition to fulfilling all other obligations that result applicable, credit institutions and limited scope financial institutions shall observe the following, in terms of the general provisions issued by the Ministry of Finance and Public Credit after listening to the previous opinion of the National Banking and Securities Commission:

I. Establish measures and procedures to prevent and detect actions, omissions, or transactions that may favor, or grant aid, support, or cooperation to commit the offenses foreseen in articles 139, 148 Bis or 400 Bis of the Federal Penal Code, and

II. Submit to the Ministry of Finance and Public Credit, through the National Banking and Securities Commission, reports relating to:

a. Actions, transactions and services performed with their customers and users relating to the preceding fraction I, and

b. Any action, transaction or service performed by members of the board of directors, directors, officers, employees, or legal representatives that may be placed in the case foreseen in fraction I of this article or that, as the case may be, may violate or jeopardize the adequate application of the general provisions referred to above.

The reports referred to in fraction II of this article, in accordance with the general provisions foreseen in such fraction, shall be elaborated and submitted taking into consideration at least the variations contemplated in such provisions, the characteristics that the actions, transactions, and services shall have in order to be reported, taking into account the amounts, frequency and nature, monetary and financial instruments with which they are carried out, and the commercial and banking practices observed in the locations in which they are carried out, as well as the frequency and the systems through which the information shall be transmitted.

In the same manner, the Ministry of Finance and Public Credit shall include in the aforementioned general provisions guidelines about the procedure and criteria that credit institutions and limited scope financial institutions shall observe with regards to:

a. The adequate knowledge about their clients and users, for which credit institutions and limited scope financial institutions shall consider the background, specific conditions, economic or professional activity, and locations in which such clients and users operate;

b. The information and documentation that credit institutions and limited scope financial institutions shall gather to open accounts or execute contracts relating to transactions and services provided by such institutions and that fully demonstrate the identity of their clients;

c. The manner in which credit institutions and limited scope financial institutions shall keep and assure the security of the information and documentation related to the identification of their present or former clients and users, as well as of that concerning the actions, transactions, and services reported in accordance with this article, and

d. The terms to provide training in credit institutions and limited scope financial institutions on the subject matter of this article. The general provisions referred to in this article shall establish the terms for due compliance of this 
provision.

Credit institutions and limited scope financial institutions shall keep, for at least ten years, the information and documentation referred to in sub-section c) of the preceding paragraph, without prejudice to the provisions of this or other laws.

The Ministry of Finance and Public Credit shall be empowered to request and collect, through the National Banking and Securities Commission, from credit institutions and limited scope financial institutions, who shall be obligated to deliver, information and documentation relating the actions, transactions, and services referred to in this article. The Ministry of Finance and Public Credit shall be empowered to obtain additional information from other persons for the same purposes and to provide such information to competent authorities.

The observance of the obligations stated in this article does not imply any breach of articles 117 and 118 of this Law [relating to bank and trust secrecy obligations].

The general provisions referred to in this article shall be observed by credit institutions and limited scope financial institutions, members of their board of directors, directors, officers, employees, or legal representatives, and therefore such institutions and persons shall be responsible for the strict observance of the obligations imposed through such general provisions.

Violation to the general provisions referred to in this article shall be penalized by the National Banking and Securities Commission, according to the procedure established under article 110 of this Law, with a fine of up to 100,000 days of the daily general minimum wage in effect in the Federal District.

The fines contemplated above may be imposed to credit institutions and limited scope financial institutions, members of their board of directors, directors, officers, employees and legal representatives and natural and legal persons who, by reason of their actions, caused or intervened so that the credit institutions incur the respective irregularity or become responsible for it. Notwithstanding the foregoing, the National Banking and Securities Commission, bearing in mind the circumstances of each particular case, could proceed in accordance with article 25 of this Law.

The public servants of the Ministry of Finance and Public Credit and the National Banking and Securities Commission, the credit institutions and limited scope financial institutions, members of their board of directors, directors, officers, employees and legal representatives, shall abstain from informing about the reports, and other documentation and information referred to in this article, to persons or authorities other than those expressly empowered to request, receive, or keep such information. Violations to these obligations shall be penalized in accordance with corresponding laws.

Article 117.- The information and documents related to operations and services, referred to in Article 46 of this Law, will be confidential. Credit institutions, in protection of the clients and users privacy rights set forth in this Article, shall not in any case give notice or information of the deposits, operations or services, including the ones foreseen in section XV of the mentioned Article 46, but to the depositor, debtor, holder, beneficiary, trustor, trustee, mandatory or mandator, to their legal representatives or to whom they have granted power to dispose of the account or to intervene in the operation or service.

As exception to the established in the previous paragraph, credit institutions will be obligated to give notice or information to referred to the above mentioned paragraph, when the judicial authority requests it by means of a decision ruled in a judicial process in which the holder or, as the case may be, the trustor, trustee, mandatory, commissary, mandator or representative being a part or defendant. For the purposes of this paragraph, the judicial authority will be able to formulate a request directly to the credit institution, or through the National Banking and Securities Commission. 
Credit institutions also shall be excepted of the prohibition foreseen in the first paragraph of this Article and, therefore, obligated to give the mentioned notice or information, in the cases in which they are requested by the following authorities:

I. The Federal General Attorney or the public officials in whom delegates powers to request information, for proving corpus delicti and the indicter's probable liability;

II. The Federal District and States' general attorneys or under-attorneys, to prove the corpus delicti and the indicter's probable liability;

III. The Military General Attorney, to prove the corpus delicti and the indicter's probable liability;

IV. The federal fiscal authorities, for fiscal purposes;

V. The Ministry of Finance and Public Credit, for effects of the established in Article 115 of this law;

VI. The Federal Treasurer, when the supervision act deserves it, in order to request bank statements and any other information regarding personal accounts of public officials, auxiliaries and, as the case may be, individuals linked to the respective investigation;

VII. The Superior Account Authority, in exercise of its supervision and auditing powers of the Federal Public Account regarding the accounts or contracts when public federal resources been manage or exercised;

VIII. The Secretary and the undersecretaries of the Ministry of the Public Function, in exercise of their investigation or audit powers in order to verify the federal public officials' patrimony, as well as the agencies in charge of the follow-up of the liabilities of the public officials of the constitutionally autonomous organisms in exercise of its investigation powers, and

IX. The Federal Electoral Institute, in exercise of its inspection powers of the public federal resources, assigned to the political parties, political national groups and associations with political and electoral purposes, regarding the accounts or contracts that such legal persons may establish in order to exercise or administer them.

The authorities mentioned in the previous sections shall request the notice or information referred to in this Article in the exercise of its powers, according with the applicable legal provisions.

The requests, referred to in the third paragraph of this article, shall be formulated duly founded and motivated through the National Banking and Securities Commission. The public officials referred in section I, should request the judicial authority to issue the corresponding order, with the purpose that the credit institution delivers the requested information, as long as the above mentioned officials specify the institution's name, account number, name of the account holder or user and other information and elements that allow its full identification, according to the respective transaction.

The personnel and officials of the credit institutions shall be responsible, in terms of the applicable provisions, by the infringement of the secret herein established and the institutions will be obliged in case of undue revelation of the secret, to repair the damages and prejudices being caused.

The abovementioned does not affect credit institutions' obligation to provide the National Banking and Securities Commission, all sort of information and documents that, in exercise of its inspection and supervision functions, requests to them regarding the operations that they celebrate and the services rendered, nor the obligation of providing information requested by the Bank of Mexico, the Institute for the Bank Savings Protection and the 
Financial Services Users Protection and Defense Commission, according to the applicable legal provisions.

It shall be understood that no violation exists of the secret applicable to the operations referred in section XV of Article 46 of this Law, in the cases in which the Superior Account Authority, according to the law that rules its functions, requires the information to which this Article refers.

The documents and data provided by the credit institutions as consequence of the exceptions to the first paragraph of this Article shall only be used in the acts that correspond in terms of law, in respect of which must be observed a strict confidentiality, although the concerned public official leaves the service. The public official who unduly breaks the reservation of his actuations, provide copy of them or of the documents related with them, or by any other means discloses information contained in them, will be subject to the corresponding administrative, civil or penal responsibilities.

The credit institutions shall answer the requirements formulated by the National Banking and Securities Commission as a result from the indicated authority's requests in this article, within the term that the same Commission determines. The Commission shall sanction the credit institutions that do not deliver within the established terms and conditions, according to Articles 108 to 110 of this law.

The Commission shall issue general provisions establishing the requirements that must be contained in the information requests or information requirements that the authorities referred in sections I to IX of this Article formulates, with the purpose that the required credit institutions are able to identify, locate and provide the requested notice or information.

SECURITIES MARKET LAW (Ley del Mercado de 212; 292;

Valores)

Article 212.- In addition to fulfilling all other obligations that result applicable, securities brokerage firms shall observe the following, in terms of the general provisions issued by the Ministry of Finance and Public Credit after listening to the previous opinion of the Commission [National Banking and Securities Commission]:

I. Establish policies and procedures to prevent and detect acts, omissions or transactions that could favor, aid, support or cooperate in the commission of the offenses foreseen in articles 139, 148 Bis or 400 Bis of the Federal Penal Code, and

II. Submit to the Ministry of Finance and Public Credit through the Commission, reports relating to:

a. Actions, transactions and services performed with customers and users relating to the preceding fraction I., and

b. Any action, transaction or service performed by securities brokerage firms, the members of their board of directors, directors, officers, employees, or legal representatives that may be placed in the case foreseen in fraction I of this article or that, as the case may be, may violate or jeopardize the adequate application of the general provisions referred to above.

The reports referred to in this fraction, in accordance with general provisions foreseen hereto, shall be elaborated and submitted taking into consideration at least the variations contemplated in such provisions, the characteristics that the actions, transactions, and services shall have in order to be reported, taking into account the amounts, frequency and nature, monetary and financial instruments with which they are carried out, and the commercial and banking practices observed in the locations in which they are carried out, as well as the frequency and the systems 
through which the information shall be transmitted.

III. The Ministry of Finance and Public Credit shall include in the aforementioned general provisions guidelines about the procedure and criteria with regards to:

a. The adequate knowledge about their clients and users, for which credit securities brokerage firms shall consider the background, specific conditions, economic or professional activity and locations in which such clients and users operate;

b. The information and documentation that securities brokerage firms shall gather to open accounts or execute contracts relating to transactions and services provided by such institutions and that fully demonstrate the identity of their clients;

c. The manner in which securities brokerage firms shall keep and assure the security of the information and documentation related to identification of their present or former clients and users, as well as of that concerning the actions, transactions and services reported in accordance with this article, and

d. The terms to provide training in securities brokerage firms on the subject matter of this article. The general provisions referred to in this article shall establish the terms for due compliance of this provision.

Securities brokerage firms shall keep, for at least ten years, the information and documentation referred to in subsection c) of this fraction, without prejudice to the provisions of this or other laws.

The Ministry of Finance and Public Credit shall be empowered to request and collect, through the Commission, from securities brokerage firms, who shall be obligated to deliver, information and documentation relating the actions, transactions and services referred to in this article. The Ministry of Finance and Public Credit shall be empowered to obtain additional information from other persons for the same purposes and to provide such information to competent authorities.

The observance of the obligations stated in this article does not imply any breach of article 192 of this Law [relating to secrecy obligations].

The general provisions referred to in this article, shall be observed by securities brokerage firms, members of their board of directors, directors, officers, employees, or legal representatives, and therefore such institutions and persons shall be responsible for the strict observance of the obligations imposed through such general provisions.

Article 292. Securities depository firms, upon court request or request from an arbitrator designated by the parties, will open special accounts with respect to securities deposited that are the subject of litigation and will freeze all related negotiable instruments and not perform any transaction upon them until notification the final sentence or judgment rendered by the arbitrator ending the dispute. The foregoing will be without prejudice to corporate rights of the institution with regard to deposit of securities in accordance with the provisions of this law, arising from the endorsement made to said depository.

LAW OF POPULAR SAVINGS AND CREDIT (Ley de 124 Ahorro y Crédito Popular)

Article 124.- In addition to fulfilling all other obligations that result applicable, cooperatives and popular financial entities shall observe the following, in terms of the general provisions issued by the Ministry of Finance and Public 
Credit after listening to the previous opinion of the National Banking and Securities Commission:

I. Establish measures and procedures to prevent and detect actions, omissions, or transactions that may favor, or grant aid, support, or cooperation to commit the offenses foreseen in articles 139, 148 Bis or 400 Bis of the Federal Penal Code, and

II. Submit to the Ministry of Finance and Public Credit, through the National Banking and Securities Commission, reports relating to:

a. Actions, transactions and services performed with their customers and users relating to the preceding fraction I, and

b. Any action, transaction or service performed by members of the board of directors, directors, officers, employees, or legal representatives that may be placed in the case foreseen in fraction I of this article or that, as the case may be, may violate or jeopardize the adequate application of the general provisions referred to above.

The reports referred in fraction II of this article, in accordance with the general provisions foreseen in such fraction, shall be elaborated and submitted taking into consideration at least the variations contemplated in such provisions, the characteristics that the actions, transactions and services shall have in order to be reported, taking into account the amounts, frequency and nature, monetary and financial instruments with which they are carried out, and the commercial and banking practices observed in the locations where they are carried out, as well as the frequency and the systems through which the information shall be transmitted.

In the same manner, the Ministry of Finance and Public Credit shall include in the aforementioned general provisions guidelines about the procedure and criteria that cooperatives and popular financial entities shall observe with regards to:

a. The adequate knowledge about their clients and users, for which cooperatives and popular financial entities shall consider the background, specific conditions, economic or professional activity and locations in which such clients and users operate;

b. The information and documentation that cooperatives and popular financial entities shall gather to open accounts or execute contracts relating to transactions and services provided by such entities and that fully demonstrate the identity of their customers and associates;

c. The manner in which cooperatives and popular financial entities shall keep and assure the security of the information and documentation related to the identification of their present or former customers and associates, as well as of that concerning the actions, transactions and services reported in accordance with this article, and

d. The terms to provide training in cooperatives and popular financial entities on the subject matter of this article. The general provisions referred to in this article shall establish the terms for due compliance of this provision.

Cooperatives and popular financial entities shall keep, for at least ten years, the information and documentation referred to in sub section c) of the preceding paragraph, without prejudice to the provisions of this or other laws.

The Ministry of Finance and Public Credit shall be empowered to request and collect, through the National Banking and Securities Commission, from cooperatives and popular financial entities, who shall be obligated to deliver, information and documentation relating the actions, transactions, and services referred to in fraction II of this article.

The observance of the obligations stated in this article does not imply any breach of article 34 of this Law [relating to secrecy obligations]. 
The general provisions referred to in this article, shall be observed by cooperatives and popular financial entities, members of their supervision committee, directors, officers, employees, or legal representatives, and therefore such entities and persons shall be responsible for the strict observance of the obligations imposed through such general provisions.

Violation to the general provisions referred to in this article shall be penalized by the National Banking and Securities Commission, according to the procedure established under article 126 of this Law, along with the fine foreseen in article 130, fraction XVI of this Law.

The fines contemplated above may be imposed to cooperatives, popular financial entities, members of their supervision committee, directors, officers, employees and legal representatives and natural and legal persons who, by reason of their actions, caused or intervened so that cooperatives and popular financial entities incur the respective irregularity or become responsible for it. Notwithstanding the foregoing, the National Banking and Securities Commission, bearing in mind the circumstances of each particular case, could proceed in accordance with article 122 of this Law.

The public servants of the Ministry of Finance and Public Credit and the National Banking and Securities Commission, the cooperatives, popular financial entities, members of their supervision committee, directors, officers, employees and legal representatives, shall abstain from informing about the reports, and other documentation and information referred to in this article, to persons or authorities other than those expressly empowered to request, receive or keep such information. Violations to these obligations shall be penalized in accordance with corresponding laws.

LAW OF THE RETIREMENT SAVINGS SYSTEMS 108 Bis

(Ley de los Sistemas de Ahorro para el Retiro)

Article 108 Bis.- In addition to fulfilling all other obligations that result applicable, administrators of pension funds shall observe the following, in terms of the general provisions issued by the Ministry of Finance and Public Credit after listening to the previous opinion of the Commission [National Commission for the Retirement Savings System]:

I. Establish measures and procedures to prevent and detect actions, omissions or transactions that may favor, or grant aid, support or cooperation to commit the offenses foreseen in articles 139, 148 Bis or 400 Bis of the Federal Penal Code, and

II. Submit to the Ministry of Finance and Public Credit, through the Commission, reports relating to:

a. Actions, transactions and services performed with their customers and users relating to the preceding fraction I., and

b. Any action, transaction or service performed by members of the board of directors, directors, officers, employees, or legal representatives that may be placed in the case foreseen in fraction I of this article or that, as the case may be, may violate or jeopardize the adequate application of the general provisions referred to above.

The reports referred to in fraction II of this article, in accordance with the general provisions foreseen in such fraction, shall be elaborated and submitted taking into consideration at least, the variations contemplated in such provisions, the characteristics that the actions, transactions, and services shall have in order to be reported, taking into account the amounts, frequency and nature, monetary and financial instruments with which they are carried 
out, and the commercial and banking practices observed in the locations in which they are carried out, as well as the frequency and systems through which the information shall be transmitted.

In the same manner, the Ministry of Finance and Public Credit shall include in the aforementioned general provisions guidelines about the procedure and criteria that pension administrators shall observe with regards to:

a. The adequate knowledge about their clients and users, for which pension administrators shall consider the background, specific conditions, economic or professional activity, and locations in which such clients and users operate;

b. The information and documentation that pension administrators shall gather to open accounts or execute contracts relating to transactions and services provided by such institutions and that fully demonstrate the identity of their clients;

c. The manner in which pension administrators shall keep and assure the security of the information and documentation related to the identification of their present or former clients and users, as well as of that concerning the actions, transactions, and services reported in accordance with this article, and

d. The terms to provide training in pension administrators on the subject matter of this article. The general provisions referred to in this article shall establish the terms for due compliance of this provision.

Pension administrators shall keep, for at least ten years, the information and documentation referred to in subsection c) of the preceding paragraph, without prejudice to the provisions of this or other laws.

The Ministry of Finance and Public Credit shall be empowered to request and collect, through the Commission, from administrators of pension funds, who shall be obligated to deliver, information and documentation relating the actions, transactions and services referred to in fraction II of this article. The Ministry of Finance and Public Credit shall be empowered to obtain additional information from other persons for the same purposes and to provide such information to competent authorities.

The observance of the obligations stated in this article does not imply any breach of secrecy obligations.

The general provisions referred to in this article shall be observed by administrators of pension funds, members of their board of directors, directors, officers, employees, or legal representatives, and therefore such institutions and persons shall be responsible for the strict observance of the obligations imposed through such general provisions.

Violation to the general provisions referred to in this article shall be penalized by the Commission, according to the procedure established under article 99 of this Law, along with the fine foreseen in article 100, fraction XXVII of this Law.

The fines contemplated above may be imposed to administrators of pension funds, members of their board of directors, directors, officers, employees and legal representatives and natural and legal persons who, by reason of their actions, caused or intervened in administrators of pension funds to incur the respective irregularity or become responsible for it. Notwithstanding the foregoing, the Commission, bearing in mind the circumstances of each particular case, could proceed in accordance with article 52 of this Law.

The public servants of the Ministry of Finance and Public Credit and the Commission, administrators of pension funds, members of their board of directors, directors, officers, employees and legal representatives, shall abstain from informing about the reports, and other documentation and information referred to in this article, to persons or authorities other than those expressly empowered to request, receive or keep such information. Violations to these obligations shall be penalized in accordance with corresponding Laws. 


\section{LAW OF INVESTMENTS SOCIETIES (Ley de 91}

Sociedades de Inversión)

Article 91.- In addition to fulfilling all other obligations that result applicable, operator entities of investment societies, distributors of securities of investment societies and investment societies shall observe the following, in terms of the general provisions issued by the Ministry of Finance and Public Credit after listening to the previous opinion of the Commission [National Banking and Securities Commission]:

I. Establish measures and procedures to prevent and detect actions, omissions or transactions that may favor, or grant aid, support or cooperation to commit the offenses foreseen in articles 139, 148 Bis or 400 Bis of the Federal Penal Code, and

II. Submit to the Ministry of Finance and Public Credit through the Commission, reports relating to:

a. Actions, transactions and services performed with their customers and users relating to the preceding in fraction I., and

b. Any action, transaction or service performed by members of the board of directors, directors, officers, employees, or legal representatives that may be placed in the case foreseen in fraction I of this article or that, as the case may be, may violate or jeopardize the adequate application of the general provisions referred to above.

The reports referred to in fraction II of this article, in accordance with the general provisions foreseen in such fraction, shall be elaborated and submitted taking into consideration at least the variations contemplated in such provisions, the characteristics that the actions, transactions, and services shall have to be reported, taking into account the amounts, frequency and nature, monetary and financial instruments with which they are carried out, and the commercial and banking practices observed in the locations in which they are carried out, as well as the frequency and the systems through which the information shall be transmitted.

In the same manner, the Ministry of Finance and Public Credit would include in the abovementioned general provisions guidelines about the procedure and criteria that operator entities of investment societies, distributors of securities of investment societies and investment societies shall observe with regards to:

a. The adequate knowledge about their clients and users, for which operator entities of investment societies, distributors of securities of investment societies and investment societies shall consider the background, specific conditions, economic or professional activity and locations in which such clients and users operate;

b. The information and documentation that operator entities of investment societies, distributors of securities of investment societies and investment societies shall gather to open accounts or execute contracts relating to transactions and services provided by such institutions and that fully demonstrate the identity of their clients;

c. The manner in which operator entities of investment societies, distributors of securities of investment societies and investment societies shall keep and assure the security of the information and documentation related to identification of their present or former clients or users, as well as of that concerning the actions, transactions and services reported in accordance with this article, and

d. The terms to provide training in operator entities of investment societies, distributors of securities of investment societies and investment societies on the subject matter of this article. The general provisions referred to in this article shall establish the terms for due compliance of this provision. 
Operator entities of investment societies, distributors of securities of investment societies and investment societies shall keep, for at least ten years, the information and documentation referred to in sub-section c) of the preceding paragraph, without prejudice to the provisions of this or other laws.

The Ministry of Finance and Public Credit shall be empowered to request and collect, through the Commission, from operator entities of investment societies, distributors of securities of investment societies and investment societies, who shall be obligated to deliver, information and documentation relating the actions, transactions, and services referred to in fraction II of this article. The Ministry of Finance and Public Credit shall be empowered to obtain additional information from other persons for the same purposes and to provide such information to competent authorities.

The observance of the obligations stated in this article does not imply any breach of article 55 of this Law [relating to secrecy obligations].

The general provisions referred to in this article, shall be observed by operator entities of investment societies, distributors of securities of investment societies and investment societies, members of their board of directors, directors, officers, employees, or legal representatives, and therefore such institutions and persons shall be responsible for the strict observance of the obligations imposed through such general provisions.

Violation to the general provisions referred to in this article shall be penalized by the Commission, according to the procedure established under article 84 of this Law, with a fine of up to 10,000 days of the daily general minimum wage in effect in the Federal District

The fines contemplated above may be imposed to operator entities of investment societies, distributors of securities of investment societies and investment societies, members of their board of directors, directors, officers, employees and legal representatives and natural and legal persons who, by reason of their actions, caused or intervened so that the operator entities of investment societies, distributors of securities of investment societies and investment societies incur the respective irregularity or become responsible for it. Notwithstanding the foregoing, the Commission, bearing in mind the circumstances of each particular case, could proceed in accordance with article 52 of this Law.

The public servants of the Ministry of Finance and Public Credit and the National Banking and Securities Commission, operator entities of investment societies, distributors of securities of investment societies and investment societies, members of their board of directors, directors, officers, employees and legal representatives, shall abstain from informing about the reports, and other documentation and information referred to in this article, to persons or authorities other than those expressly empowered to request, receive or keep such information. Violations to these obligations shall be penalized in accordance with corresponding Laws.

FEDERAL LAW OF BONDS INSTITUTIONS (Ley $\quad 5 ; 7 ; 15 ; 66 ; 70 ; 87 ; 110 ; 112$

Federal de Instituciones de Fianzas)

ARTICLE 5.- In order to function as a bonding institution or to operate exclusively the rebonding service, the Federal Government should provide authorization granted by the Department of Treasury and Public Credit.

ARTICLE 7.- The persons who require authorization to constitute a bonding institution, shall be subject to the provisions of this law and shall comply with the following requirements: 
II. Submit a list of the founding shareholders indicating their nationality, the capital that each shall contribute, the form in which such capital shall be paid as well as the source of the resources with which the subscription of said capital shall be made;

ARTICLE 15.- Bonding institutions must be organized as corporations (sociedades anónimas) with fixed or variable capital, subject to the General Law of Mercantile Companies in matters not provided in this Law, particularly the following:

$\cdots$

III. Any person may acquire through one or several simultaneous or successive transactions, the control of shares that represent the paid-in capital of a bonding company, provided that such transaction shall be previously approved from the Ministry of Finance and Public Credit who shall take into consideration the opinion of the National Insurance and Bond Commission, when such shares represent more than $5 \%$ of the paid-in capital, notwithstanding the provision of section II Bis of this article.

In the event that one or more shareholders intend to obtain control over the management of a bonding company, such persons shall attach to their request, as applicable:

a) List of the persons that, in its case, intend to obtain control of the corresponding bonding company, indicating the capital that each will subscribe, the form in which they will pay it as well as the source of the resources with which they will make such payment;

ARTICLE 66.- The inspection and audit of bonding institutions, as well as the other persons and enterprises to which this Law refers, insofar as compliance with the dispositions thereof is concerned, shall remain entrusted to the National Insurance and Bond Commission in the terms of this Law and of the regulation issued for these purposes by the Federal Executive, Commission which besides the obligations and faculties attributed by this Law, will rule in relation with bonds and other persons to which this Law refers, in terms of the inspection and supervisory provisions contained in the General Law of Insurance Institutions and Mutual Entities.

ARTICLE 70.- The bonding institutions are compelled to receive the inspection visits ordered to be performed.

Visits or inspections shall be made to all the bonding institutions in accordance with the programs elaborated by the National Insurance and Bond Commission and that are approved by the Governing Board, taking in consideration the overall situation of the sector and the necessities of each concrete case; without prejudice to those which are carried out upon request of the statutory examiners, beneficiaries or of a group of shareholders, who submit sufficient data to justify that visit in the judgment of the National Insurance and Bond Commission.

The Chairman of the Commission may appoint at any time or even permanently, inspectors in the bonding institutions, who shall review their operations and their financial situation and audit the general progress of the bonding institution, as well as delegates who shall verify the work of those inspectors.

The Commission can also order the performance of special visits or inspections, which can be undertaken by the Chairman of such Commission. When exercising its functions under this Article, the National Insurance and Bond Commission so requires, it may engage such auditors and other professionals that aid it in such functions.

ARTICLE 87.- For the purposes of this Law, individuals or legal entities which intervene in the contracting of bonds, and in the advising of the execution of contracts, their conservation or modification, for the greater convenience of the contracting parties, shall be considered bonds agents.

In order to carry out the activity of an bonding agent, authorization of the National Insurance and Bond Commission is required. The Commission can revoke the authorization, after hearing the interested party, in the 
terms of the respective Regulation.

Authorizations shall be non-transferable and may be granted to the following persons when they satisfy the requirements which are established in the respective Regulation:

(a) Individuals who are employees of bonding institutions in order to carry out that activity;

(b) Individuals who shall be carrying out that activity through mercantile contracts; and

(c) Legal entities that are incorporated in order to operate that activity.

The activities which bonding agents carry out shall be subject to the provisions of this Law and the respective Regulation, to the general policy orientations set forth by the Ministry of Finance and Public Credit in bonding matters and to the inspection and auditing provisions provided by the National Insurance and Bond Commission.

Bonding agents must meet the requirements demanded by the respective Regulation, but in no case may persons who by their position or through any other circumstance exercise coercion in the contracting of bonds, be authorized to act as bonding agents.

ARTICLE 110.- The fines corresponding to penalties for violations provided in this Law and in provisions issued in connection therewith, shall be imposed administratively by the National Insurance and Bond Commission, taking the general minimum wage in force in the Federal District at the time of commission of the violation, unless another form of penalty is set forth in applicable Law, and shall be enforced by the Ministry of Finance and Public Credit.

When imposing the corresponding penalty, the aforementioned Commission must always previously hear the interested party and shall take into account the economical conditions and intention of the violator, the importance of the violation and the convenience of avoiding practices tending to contravene the provisions of this Law and the rules arising therefrom.

In the case of bonding companies, the economical condition shall be measured by taking into consideration the net capital and the capital stock at the end of the preceding fiscal year.

In order to hear the alleged violator the National Insurance and Bond Commission shall grant it a term of 10 working days, which may be extended one time, for the interested party to manifest what it deems convenient, and submitting the evidence that he wishes. Once the term and its extension has elapsed, if the interested party did not appeared before the National Insurance and Bond Commission, the right to be heard by said authority shall be extinguished, and the corresponding resolution shall be issued based on the elements available on the respective file in terms of this Article.

Once the allegations made by the interested party have been analyzed and the evidence submitted by him has been evaluated, or in its case once the documents that form part of the respective administrative file have been analyzed, the National Insurance and Bond Commission, in order to impose the corresponding fine in the respective resolution, shall:

a) Indicate the legal provisions or administrative rules that are applicable to the case as well as the special circumstances, individual reasons or immediate causes that were taken into consideration to determine the existence of the violation; and

b) Take into account the importance of the act or omission that originated the imposition of the penalty and economical status of the violator.

When the penalty to be imposed is larger than the pre-established minimum, the corresponding resolution shall 
indicate the reasons and motives for which the National Insurance and Bond Commission considers applicable such penalty.

The penalties imposed in accordance with this law in no case shall exceed $2 \%$ of the net worth or capital stock of the bonding company. The imposition of penalties shall not discharge the violator from complying with its obligations or to cure the circumstances that originated the penalty.

Taking into consideration the special circumstances of each case, the National Insurance and Bond Commission may also admonition the violator or just reprimand it.

The provisions of this article does not exclude the imposition of penalties that in accordance with this or other laws are applicable with respect to unlawful actions or criminal offenses, nor the revocation of the authorization to the bonding company.

In protection of public interest, the National Insurance and Bond Commission shall made public any sanctions that it imposes for violations of this law or to the rules arising therefrom, once such resolutions are definitive, indicating only the sanctioned person, the violated provision and the imposed penalty.

Article 112.- The cases foreseen in articles 112 Bis to 112 Bis 7 and 112 Bis 9 of this Law shall proceed by request from the Ministry of Finance and Public Credit, who shall listen to the opinion of the National Insurance and Bonding Commission, and such cases could also proceed by request from the respective sureties institution or from anyone that has a legal interest.

Penalties foreseen in this Law would be calculated upon the base of days times the daily general minimum wage in effect in the Federal District

In addition to fulfilling all other obligations that result applicable, sureties institutions and bonding agents shall observe the following, in terms of the general provisions issued by the Ministry of Finance and Public Credit after listening to the previous opinion of the National Insurance and Sureties Commission:

I. Establish measures and procedures to prevent and detect actions, omissions, or transactions that may favor, or grant aid, support, or cooperation to commit the offenses foreseen in articles 139, 148 Bis or 400 Bis of the Federal Penal Code, and

II. Submit to the Ministry of Finance and Public Credit through the National Insurance and Sureties Commission, reports relating to:

a. Actions, transactions and services performed with their customers and users relating to the preceding fraction I., and

b. Any action, transaction or service performed by members of the board of directors, directors, officers, employees, or legal representatives that may be placed in the case foreseen in fraction I of this article or that, as the case may be, may violate or jeopardize the adequate application of the general provisions referred to above.

The reports referred in fraction II of this article, in accordance with the general provisions foreseen in such fraction, shall be elaborated and submitted taking into consideration at least the variations contemplated in such provisions, the characteristics that the actions, transactions, and services shall have in order to be reported, taking into account the amounts, frequency and nature, monetary and financial instruments with which they are carried out, and the commercial and banking practices observed in the locations in which they are carried out, as well as the frequency and the systems through which the information shall be transmitted.

In the same manner, the Ministry of Finance and Public Credit shall include in the aforementioned general provisions guidelines about the procedure and criteria that bonding institutions and bonding agents shall observe 
with regards to:

a. The adequate knowledge about their clients and users, for which sureties institutions and agents shall consider the background, specific conditions, economic or professional activity and locations in which such clients and users operate;

b. The information and documentation that sureties institutions and agents shall gather to open accounts or execute contracts relating to transactions and services provided by such institutions and that fully demonstrate the identity of their clients;

c. The manner in which sureties institutions and agents shall keep and assure the security of the information and documentation related to identification of their present or former clients and users, as well as of that concerning the actions, transactions, and services reported in accordance with this article, and

d. The terms to provide training in sureties institutions and agents on the subject matter of this article. The general provisions referred to in this article shall establish the terms for due compliance of this provision.

Sureties institutions and agents shall keep, for at least ten years, the information and documentation referred to in sub-section c) of the preceding paragraph, without prejudice to the provisions of this or other laws. The Ministry of Finance and Public Credit shall be empowered to request and collect, through the National Insurance and Sureties Commission, from sureties institutions and agents, who shall be obligated to deliver, information and documentation relating the actions, transactions and services referred to in this article. The Ministry of Finance and Public Credit shall be empowered to obtain additional information from other persons for the same purposes and to provide such information to competent authorities.

The observance of the obligations stated in this article shall not imply any breach to secrecy obligations neither violation to article 126 of this Law, nor to articles 117 and 118 in relation with article 46, fraction XV of the Law of Credit Institutions. The general provisions referred to in this article shall be observed by sureties institutions and agents, members of their board of directors, directors, officers, employees, or legal representatives, and therefore such institutions and persons shall be responsible for the strict observance of the obligations imposed in such general provisions.

Violation to the general provisions referred to in this article shall be penalized by the National Insurance and Sureties Commission, according to the procedure established under article 110 of this Law, with a fine of up to 100,000 days of the daily general minimum wage in effect in the Federal District.

The fines contemplated above may be imposed to sureties institutions and agents, members of their board of directors, directors, officers, employees and legal representatives and natural and legal persons who, by reason of their actions, caused or intervened in the sureties institutions to incur the respective irregularity or become responsible for it. Notwithstanding the foregoing, the National Insurance and Sureties Commission, bearing in mind the circumstances of each particular case, could proceed in accordance with articles 82 and 87 of this Law.

The public servants of the Ministry of Finance and Public Credit and the National Insurance and Sureties Commission, the sureties institutions and agents, members of their board of directors, directors, officers, employees and legal representatives, shall abstain from informing about the reports, and other documentation and information referred to in this article, to persons or authorities other than those expressly empowered to request, receive or keep such information. Violations to these obligations shall be penalized in accordance with corresponding Laws. 
GENERAL LAW OF INSURANCE INSTITUTIONS $15 ; 16 ; 23 ; 29 ; 32 ; 39 ; 40 ; 44 ; 106 ; 108 ; 110 ; 126$; AND MUTUAL ENTITIES (Ley General de Instituciones y $138 ; 140$; Sociedades Mutualistas de Seguros)

\section{ARTICLE 5 .}

In order to be organized and function as an insurance institution or mutual insurance company, authorization of the Federal Government is required, being the competent authority to grant such authorization the Ministry of Finance and Public Credit.

ARTICLE 16.

Persons that request an authorization to incorporate an insurance company or mutual insurance company shall be subject to the provisions of this law and shall comply with the following:

I. Submit the draft of the company's by-laws;

II. Submit a list of the founding shareholders indicating their nationality, the capital that each shall contribute, the form in which such capital shall be paid as well as the source of the resources with which the subscription of said capital shall be made;

III. Submit a strategic program for the implementation of the policies and norms referred to in paragraph 1, of section I, of article 29 of this Law.

IV. Indicate the names, nationality, domiciles and occupations of the board members, officers and normative comptroller, who shall comply with the requirements set forth in article 29, sections VII Bis and VII Bis 1 of this Law.

V. Submit an operation plan that at least shall contemplate:

a) The initial capital;

b) The basis pertaining to its internal organization and control;

c) The prospective geographic coverage and business segments;

d) The technical operation and placement of insurance programs, with respect to the operations and lines for which they are requesting authorization;

VI. Submit the corresponding receipt of having deposited with Nacional Financiera, S.N.C., such amounts in Mexican currency or in Government securities with a market value, for an amount equal to $10 \%$ of the minimum capital with which such company shall operate in accordance with this law.

The Ministry of Finance and Public Credit, after taking into consideration the opinion of the National Insurance and Bond Commission, shall issue the general rules that set forth the form and terms in which each of the foregoing requisites shall be evidenced.

The corresponding authorization shall be subject to the condition that the insurance company is organized and commences operations within the terms set forth in section I of Article 75 and section I of Article 97 of this Law. 
The deposit referenced in section VI of this article shall be reimbursed upon beginning of operations or denial of the authorization, but it shall be applied to the taxing authorities if notwithstanding that the corresponding authorization has been granted, the condition set forth in the foregoing paragraph is not complied with.

In case that the authorization is denied, the authorities may withhold from the promoter up to $10 \%$ of the deposit and shall be applied to the federal tax authorities in connection with the expenses incurred in connection with the corresponding procedure.

The authorization request to form an insurance institution to operate in the health insurance sector, in addition to the provisions of this article, must be accompanied by a provisional report issued by the Ministry of Health, after payment of the corresponding duties, which must not be more than 60 calendar days after its expedition, in which it shall be stated that the institution has the necessary elements to be able to render the services that are the matter of the insurance policies to which Article 8, section V, of this Law refers, or that it can sub-contract those services. The final resolution issued by the Ministry of Health, after the payment of the corresponding duties, must be filed in accordance with Article 75, section II Bis, letter a).

With respect to mutual insurance companies the provisions of sections III and VI shall not be applicable.

The request submitted by an insurance company or a mutual insurance company to modify the authorization under which it is operating, in order to change or expand the corresponding operations or lines, shall comply as applicable, with the requisites set forth in sections I to $\mathrm{V}$ of this article and indicating the adjustments that it shall effect with respect to such matters. In such case, it shall be subject to the provisions of article 18 of this Law.

ARTICLE 23.

For the purposes of this Law, individuals or legal entities which intervene in the contracting of insurance by means of the interchange of proposals and acceptances, and in the advising of the execution of contracts, their conservation or modification, for the greater convenience of the contracting parties, shall be considered insurance agents.

Intermediation of insurance policies that are not of the nature of adhesion contracts, is reserved exclusively to insurance agents; intermediation of those that are of the nature of adhesion contracts may also be carried out through the companies referred to in the last paragraph of Article 41 of this Law.

In order to carry out the activity of an insurance agent, authorization of the National Insurance and Bond Commission is required, which shall grant it or refuse it at its discretion and, after hearing the interested party, may suspend it for up to two years or revoke, in addition to applying admonitions and fines to such agents, in the terms of this Law and the respective Regulation. The authorizations shall be for one or more operations or lines; nevertheless, in the case of intermediation in pension insurance derived from the social security laws, authorizations shall only be granted for intermediating such insurance in respect of only one insurance institution, in addition to which they may be granted authorizations to carry out their activities in other operations or fields, with various institutions.

Authorizations shall be non-transferable and may be granted to the following persons when they satisfy the requirements which are established in the respective Regulation:

(a) Individuals who are employees of insurance institutions in order to carry out that activity; 

(b)
Individuals who shall be carrying out that activity through mercantile contracts; and
(c) Legal entities that are incorporated in order to operate that activity.

The activities which insurance agents carry out shall be subject to the provisions of this Law and the respective Regulation, to the general policy orientations set forth by the Ministry of Finance and Public Credit in insurance matters and for the due compliance of the provisions of Article 24 of this Law, and to the inspection and auditing of the National Insurance and Bond Commission. The provisions of Article 71 of this Law shall also be applicable to them.

Insurance agents must meet the requirements demanded by the respective Regulation, but in no case may persons who by their position or through any other circumstance exercise coercion in the contracting of insurance, be authorized to act as insurance agents.

Agents of insurance institutions shall give notice to the National Insurance and Bond Commission at least 10 days in advance of the change of location of the establishment or close of their offices. They shall likewise give such notice to their insured.

\section{FIRST TITLE. INSURANCE INSTITUTIONS}

\section{CHAPTER I. ORGANIZATION}

\section{ARTICLE 29.}

Insurance institutions must be organized as corporations (sociedades anónimas) with fixed or variable capital, subject to the General Law of Mercantile Companies in matters not provided in this Law, particularly the following:

I. The institutions shall have a minimum paid-in capital, expressed in Investment Units, for each authorized operation or line, which capital shall be covered, in national currency, within the term specified in this section and which shall be determined by the Ministry of Finance and Public Credit during the first quarter of every year, which determination shall be made considering, among other things, the resources that are necessary to support the adequate rendering of services that the insured activity requires, the amount of paid-in capital and capital reserves with which the group of institutions that comprise the system of insurers operates, the country's economic situation and the principle of promoting the healthy, equilibrated development of the system and adequate competition.

The minimum capital must be totally subscribed and paid up no later than June 30 of the year in which the Ministry of Finance and Public Credit had established it. When the capital stock exceeds the minimum at least $50 \%$ of it must be paid up, provided that this percentage is not less than the minimum established.

When an insurance company does not comply with the provisions of the preceding paragraph, the provisions of article 74 of this Law shall be applicable.

The capitalizations resulting from dividends and superavit from revaluation of real estate assets shall be adjusted to the general provisions issued to such effect by the National Insurance and Bond Commission.

Regarding variable capital companies, the minimum mandatory capital shall be integrated by shares with no withdrawal rights. The amount of capital with withdrawal rights shall in no case exceed the paid-in capital without withdrawal rights.

Shares shall be paid in full at the time of their subscription.

The capital stock of insurance institutions may be composed of a portion represented by shares with limited voting 
rights up to an amount equivalent to $30 \%$ of paid up capital, with the prior authorization of the Ministry of Finance and Public Credit. The acquisition of stock with limited voting rights shall not be subject to the limits established by No. 2, of section II of this article. These shares shall not be counted for the purpose of the limit established in the last paragraph of No. 1, section II of this article.

The shares with limited voting rights shall grant a voting right only in matters relative to change of purpose, merger, spin-off, transformation, dissolution and liquidation, as well as cancellation of registration on any securities exchange.

Shares with limited voting rights may confer a right to receive a preferential and accumulative dividend, as well as higher dividend than that of common stocks, provided and when it is so established in the by-laws of the issuing institution. In no case may the dividends from this type of shares be less than those of other classes of shares.

The amounts which subscribers of shares pay on their nominal value for premiums or other similar payments, shall be kept in a special reserve fund, and may only be computed as capital for the purposes of determining the minimum capital required by this Law.

The accumulated losses registered by an insurance institution shall be applied directly, and in the order indicated, to the following concepts: profits to be applied at the close of the fiscal year, provided such profits are not derived from the revaluation of investments in variable income instruments; capital reserves; and paid-in capital. At no time shall the paid-in capital may be less than the minimum determined by the Ministry of Finance and Public Credit; in the event it is, it shall be restored to such level or the provisions of Article 47 of this Law shall apply.

I bis. The institutions may classified be as follows based on the origin of the shareholders who subscribe their capital:

(a) With total or majority of Mexican capital; or

(b) With total foreign capital or with a majority thereof, in which case they shall be considered as Subsidiaries of Foreign Financial Institutions.

In all matters concerning their organization, the institutions to which letter (a) of this section refers shall be governed by that which is provided in this Chapter, whereas the institutions to which letter (b) refers, shall be governed by that which is provided in this Chapter, insofar as is applicable, with exception of section II of this article, as well as by that which is established in Chapter I Bis of the First Title of this Law.

At no time may foreign governments or official departments thereof participate in the capital of insurance institutions, whether directly or through another person.

II. $\quad$ In the case of institutions to which letter (a) of section I bis of this Law refers:

1. Credit institutions, mutual insurance companies, securities exchanges, auxiliary credit organizations, companies operating investment companies, sociedades financieras de objeto limitado, entidades de ahorro y crédito popular, administradoras de fondos para el retiro or exchange houses may not participate in their paid in capital stock, whether directly or through another person.

The provisions of the foregoing paragraph shall not be applicable when the participation results from the participation of financial holding companies referred to in the Financial Groups Law.

The Ministry of Finance may authorize banking institutions to acquire shares of insurance companies and holding companies referred to in section III of this article when acting as trustees in trusts that are not utilized as a means to contravene the provisions of this Law.

Foreign insurance, reinsurance or rebonding entities, as well as foreign individuals or legal persons, other than those excluded in the first paragraph of this item, may acquire shares that represent the capital of these insurance 
institutions. The Mexican investment must always maintain the ability to determine the management of the institution and its effective control.

For that purpose, the foreign investment must be evidenced in a special series of shares representative of the capital of the corresponding company, which in no case may exceed $49 \%$ of the paid-in capital of the company.

2. Any person may acquire through one or several simultaneous or successive transactions, the control of shares that represent the paid-in capital of an insurance company, provided that such transaction shall be previously approved from the Ministry of Finance and Public Credit who shall take into consideration the opinion of the National Insurance and Bond Commission, when such shares represent more than $5 \%$ of the paid-in capital, notwithstanding the provision of section II, point 1 of this article.

In the event that one or more shareholders intend to obtain control over the management of an insurance company, such persons shall attach to their request, as applicable:

a) List of the persons that, in its case, intend to obtain control of the corresponding insurance company, indicating the capital that each will subscribe, the form in which they will pay it as well as the source of the resources with which they will make such payment;

b) Indicate the names, nationality, domiciles and occupations of the board members, officers and normative comptroller, who shall comply with requisites set forth in sections VII Bis and VII Bis 1 of this article;

c) The activities plan of the insurance company, which shall contemplate, as applicable, the matters referred to in article 16 of this Law;

d) Strategic program for the implementation of the norms and policies referred in number 1 , of section I, of article 29 Bis of this Law;

e) Such other related documentation as required by the Ministry of Finance in order to evaluate the corresponding request.

For the purposes of this Law, it shall be deemed that the control over an insurance company is obtained when 30\% or more of the shares that represent the paid-in capital of the company are acquired, when a given person has control over the general shareholders' meeting, when a given person has the ability of appointing the majority of the members of the board or when by any other means the corresponding insurance company is controlled.

Except for the provisions contained in the Financial Groups Law, companies that have control over an insurance company shall be subject to the review and surveillance of the National Insurance and Bond Commission and such companies and their shareholders shall be subject to the provisions of this section II, section III of this article and sections III and IV of article 139 hereof.

Persons that contribute shares of one or several insurance companies to the capital to one of the companies referred to in the preceding paragraph, may retain the participation that results in the capital thereof in amount equal to the value of the shares that each of them so contributes.

Except for the provisions of the Financial Groups Law, in the capital of the above-mentioned companies, another company of the same nature, mutualist insurance companies, banking or bonding companies, brokers, sociedades financieras de objeto limitado, sociedades operadoras de sociedades de inversion, organizaciones auxiliares de crédito, administradoras de fondos para el retiro, entidiades de ahorro y crédito popular or exchange houses as well as such other companies that the Ministry of Finance determines in general provisions as incompatible by reason of their activities, may not participate in the capital of said companies.

The provisions of the foregoing three paragraphs shall be stated in the by-laws of the corresponding companies. 
Persons who acquire or transfer shares for more than $2 \%$ of the paid-in capital of an insurance company, shall give notice thereof to the Ministry of Finance within the following three working days to said acquisition or transfer.

Insurance companies shall provide to the Ministry of Finance and Public Credit and the National Insurance and Bond Commission the information that such authorities require with respect to the persons that directly or indirectly have acquired the shares that represent their paid-in capital, in the forms and subject to the conditions set forth in general provisions.

III. In order to participate in shareholders' meetings of insurance institutions or of controlling companies referred to in the Financial Groups Law or of companies that control an insurance company in terms of section II of this article, the following requirements must be fulfilled:

(a) Show in writing the capacity of the person who is to attend, whether that of shareholder, mandate, commission agent, fiduciary or any other. Mandates, commission agents or any other type of representatives may not, in any case, participate in meetings on their own behalf;

(b) Show in writing the name of the person or persons to whom the shares belong which they are representing, and set forth the number of shares which belongs to each one, in the case of a mandate, commission agent or any other type of representative, as well as in other cases which the National Insurance and Bond Commission shall determine;

Recount clerks are obligated to ascertain the observance of the provisions of this item and report thereon to the general meeting, which shall be recorded in the respective minutes.

The Ministry of Finance and Public Credit shall be enabled to issue general rules for the purpose of procuring the strict compliance with the provisions of this section and in the preceding section.

IV. The duration of the company may be stipulated to be indefinite; but may not be less than 30 years. The company may have only the purpose of functioning as an insurance institution in the terms of this Law.

V. All the assemblies and meetings of the directors shall take place at the business domicile, which must always be within the territory of the Republic.

VI. An ordinary general meeting must be held each year at least, and the right of the members which represent at least $10 \%$ of the paid in capital to request the calling of an extraordinary meeting shall be established in the articles of association. If the board does not issue the requested call, within a period of no more than one month from the date on which the petition for the meeting of the assembly was received, the statutory examiner (comisario), upon a motion of the interested shareholders, shall issue the convocation under the same conditions as the board should have done.

In extraordinary general meetings of shareholders the decisions must be taken by a majority of $80 \%$ of the paid in capital, at least, except in the case of a second call, in which case the resolutions shall be adopted by at least a vote of $30 \%$ of the paid-in capital.

The call shall contain the corresponding agenda, which shall enumerate all matters that will be discussed in the meeting, including those comprehended in the general matters that will be submitted to deliberation and that imply a resolution from the meeting.

The documentation and information regarding the matters to be discussed in the corresponding shareholders meeting, shall be delivered to the shareholders with at least fifteen days prior to its execution.

VII. The management of the insurance institution shall be performed by a board of directors and an executive officer, each with their corresponding authorities.

The organization and duties of the board of directors, shall be governed by the applicable legal provisions and in 
addition it shall be subject to the following provisions:

(a) The number of proprietary directors may not be less than five nor exceed from fifteen, from which at least the twenty-five percent shall be independent. An alternate director shall be appointed for each proprietary director, provided that the alternates of the independent directors, shall also be independent;

(b) The board of directors shall meet at least once every three months and, extraordinarily, when called by: the Chairman of the Board, at least twenty five percent of the board members or any of the statutory examiners;

(c) In order for an ordinary or extraordinary board meeting to be validly held at least fifty one percent of the board members shall be present, of which at least one shall be an independent member;

(d) Each shareholder or group of shareholders who represent at least $10 \%$ of the paid in capital of an insurance institution shall have a right to designate one member of the board. The appointment of those board members may only be revoked when all the other members is revoked as well, without prejudice to the provision in Article 31 of this Law;

(e) The chairman of the board shall have a tie-braking vote;

(f) The members shall refrain from participating in the discussions and voting of any matter which may imply a conflict of interest to them. Likewise, they shall keep absolute confidentiality with respect to any such actions or events in connection with the insurance institution to which they are members of the board, as well from all deliberation undertaken in the board, without prejudice of the obligations that the company has to provide all information that is requested to it under this Law.

In the performance of their duties the board of managers shall observe the provisions of Article 29 Bis hereof.

The general manager shall elaborate and submit to the board of directors, for its approval, the policies for the adequate employment and use of the human and material resources of the insurance company, which shall consider the rational use of such resources, restrictions for the use of certain assets, surveillance and control mechanisms and in general the application of resources to the company's activities and its corporate purpose.

The general manager shall at all times provide precise data and reports to aid the board of directors in taking adequate decisions.

VII bis. The appointments of board members and normative comptroller shall be subject to the following:

1. Appointments shall be made on individuals with technical capacity, honorability, adequate credit records as well as with a broad knowledge in financial, legal or administrative areas;

2. The normative comptroller as well as the majority of the members of the board shall reside in Mexican territory;

3. In any case, the following may not be appointed as members of the board of directors:

a) Officers or employees of the company, with exception of the general manager or his equivalent and officers of the company who occupy posts with the two immediately lower administrative hierarchies therefrom, provided that such do not compose more than one third of the board of directors;

b) Spouses of directors or persons who are related to more than two directors up to the second degree; 
c) Persons who have pending litigation with the insurance institution in question;

d) Persons convicted of intentional property crimes, those who are disqualified to carry on trade or to occupy an employment, office or commission in the public service, or in the Mexican financial system;

e) Persons who are bankrupt and insolvent persons who have not been rehabilitated;

f) Public officers of authorities in charge of the inspection and oversight of insurance institutions; or

g) Anyone who carries out functions of regulation of insurance institutions, except if the Federal Government participates in the capital thereof;

h) Public officers of the Central Bank, the Institute for the Protection of Bank Savings, National Commission of the Retirement Savings System, the National Insurance and Bond Commission and the National Commission for the Protection and Defense of Users of Financial Services; and

i) Persons who form part of the board of another insurance company, or of a controlling company of another insurance company that is engaged in the same line or operations, when the company in question does not maintain control patrimonial links among such companies in the terms of section II above.

The provisions of the foregoing paragraph shall not applicable to whomever holds at least two percent of the shares that represent the capital stock of both companies;

4. The independent members of the board as well as the normative comptrollers shall also provide evidence that they held high-decision making offices, which performance requires knowledge and experience in financial, legal, administrative matter or that is otherwise in connection with insurance activity and who in not case are:

a) Officers or employees of the company at the time of their appointment, including those persons who held such positions during the immediately preceding year;

Independent members of the board may not be appointed as an employee or officer of the company;

b) Shareholders that without being employees or officers of the company have authority powers over the officers of the company. The shareholders may not be appointed as normative comptroller of the company;

c) Partners of employees of partnerships or associations that provide consulting services to the company or to the companies that belong to the same economical group of the company, if the income received from such entities represent $10 \%$ or more of their total income;

d) Clients, suppliers, debtors, creditors, partners, board members or employees of a company that is a material client, supplier, debtor or creditor of the company.

It shall be deemed that a client or supplier is important when the services provided to the company or the sales made to it represent more than $10 \%$ of the total services or sales of the client or supplier, respectively. Likewise it shall be deemed that 
a creditor or debtor is material when the amount of the loan is more than $15 \%$ of the assets of the company or its counterpart.

e) Employees from a foundation, association or partnership that receive material donations from the company.

Material donations are those that represent more than $15 \%$ of the total donations received by the foundation, association or partnership in question;

f) Members of the board, general managers or high - ranking officers of a company in which board of directors participates the general manager or a high ranking officer of the company;

g) Spouse, significant others and relatives in the first degree with any of the persons mentioned in items c) to f) of number 3 of this section, or to the third degree in connection with the persons mentioned in paragraphs a), b) and h) of number 3 of this section;

h) Persons who have occupied a managing or administrative office in the company or in the financial or economic group to which in its case the company belongs during the preceding year at the moment in which their appointment is intended to be made, and

i) Agents, employees of agents and adjustors.

VII bis 1 . The appointment of a director general of the insurance institution or his equivalent must be given to a person who is of recognized financial and moral quality and who also meets the following requirements:

a) Be a resident on Mexican territory in terms of the Fiscal Code of the Federation;

b) For at least five years to have rendered their services in offices of high level decision-making, where their functions required knowledge and experience in financial, legal and administrative matters;

c) To not have any of the impediments to being a director which are stipulated in letters c) to f) and h) of number 3 of the preceding section; and

d) To not be carrying out functions of regulation of insurance institutions.

Officers who occupy posts with the two hierarchies below to that of the director general or his equivalent must comply with the requirements provided in the first paragraph and in items a), c) and d) of this section shall have knowledge and experience of at least five years in the matters related with the functions that are assigned to them.

The acts of the general director and of the officials who hold positions within the hierarchy immediately below the general director, which acts are committed in fulfilling their duties, shall invariably obligate the insurance institution in question, notwithstanding the civil liabilities and penalties they may incur personally.

The provisions of the foregoing paragraph shall be reproduced in the by-laws of the insurance companies.

VII bis -2. The appointments of directors of national insurance institutions shall be made by the Federal Executive through the Ministry of Finance and Public Credit, such appointments duly being made from among public officers of the federal public administration or independent professionals of recognized honorability, experience and prestige in economic and financial matters. The charge of director is personal and may not be fulfilled through representatives. In no case may the general director and the public servants of the institution who occupy offices 
within the two levels below the latter be directors, neither may the persons to whom letters b) to f), h) and i) of section VII Bis of this article be appointed as directors.

The general director of national insurance institutions shall be appointed by the Federal Executive through the Ministry of Finance and Public Credit, that appointment duly being made from among the persons who meet the requirements stipulated in the first paragraph and letters a) a d) of section VII Bis-1 of this article.

Public servants of the institution who occupy posts within the two levels below the director general shall comply in addition with the requisites set forth paragraphs a), c) and d) of section VII Bis 1 of this article shall also provide evidence of knowledge and experience of at least five years in the matters related to the functions that are assigned to them.

The National Commission of Insurance and Bonds, with the approval of its Governing Board, may determine that removal or suspension of the public officers who may obligate a national insurance institution with their signature, with the exception of the director general or equivalent, when it considers that such persons do not possess the sufficient technical or moral quality to fulfill their duties or that they have not adjusted to the applicable legal and administrative dispositions in fulfilling them, proceeding, if applicable, in the terms of article 31 of this Law.

Likewise, the Commission itself may recommend the removal of the director general of the institution to the Federal Executive, through the aforementioned Ministry, when it considers that such director general has not been adjusted to the applicable legal and administrative dispositions in the fulfillment of his duties.

VII Bis 3. In each insurance company there shall be a normative comptroller who is responsible of supervising compliance with the applicable internal and external legal provisions, in accordance with article 29 Bis 1 of this Law.

VII Bis 4. The insurance company in question shall verify, as applicable, that the persons who are appointed as members of the board, statutory examiners, normative comptroller, general manger or the equivalent thereof and officers with the two immediately hierarchies below the general manger comply with the requirements set forth in article 32 before initiating their duties as well as with sections VII Bis, VII Bis 1, VII Bis 2 and VII Bis 3 of this article.

The National Insurance and Bond Commission through generally applicable norms shall set firth the rules that insurance companies must observe to verify compliance with the respective requirements as well as the criteria through which the corresponding files that evidence compliance with this paragraph shall be integrated.

VIII. They shall separate at least $10 \%$ of their profits to constitute an ordinary reserve fund, until a sum equal to $75 \%$ of the amount of the paid-in capital is reached;

IX. The by-laws and any amendment to them, must be submitted for the approval of the Ministry of Finance and Public Credit, which shall determine whether they comply with the requirements established by the Law. After the Ministry of Finance and Public Credit gives such approval, the by-laws or their amendments may be recorded in the Public Commercial Register without a court order being necessary.

$\mathrm{X}$ The merger of two or more insurance institutions, as well as the spin-off of an insurance institution, must be effected in accordance with the provision in Article 66 of this Law; and

XI. The winding-up and liquidation of the company must be effected in accordance with the provision in Title IV of this Law. 


\section{CHAPTER SIX \\ Rendering of Services to Mutual Funds \\ Section I \\ Services}

ARTICLE 32. Mutual funds in the terms and cases set forth in this law, for the fulfillment of their institutional purpose, must engage the services listed below:

I. Mutual fund asset management;

II. Mutual fund share distribution;

III. Mutual fund share valuation;

IV. Mutual fund rating;

V. Provision of information on investment asset values;

VI. Deposit and custody of investment assets and mutual fund shares;

VII. Mutual fund accounting;

VIII. Mutual fund administrative personnel, and

IX. Others as authorized by the Commission through general provisions.

Capital investment companies will not be required to engage the services specified in Sections II, IV and V of this article, but, in all cases with regard to appraisal they must adhere to the provisions of Article 44 of this law. The Commission may grant exceptions, by means of general provisions, to special-purpose investment companies with regard to the contracting of services as dictated in this rule.

\section{Section II} Asset Management

ARTICLE 39. Asset management services will consist of the following activities:

I. Realization of the operations referred to by Article 15, Sections I, II, IV and V of this law, on behalf and in representation of the mutual fund to which services are rendered, as well as, where appropriate, management of issuance of securities referred to by Section VI of the foregoing article, and

II. Management of security portfolios for investment companies and third parties, pursuant to the Securities Market Law.

Entities rendering asset management services must be organized as mutual fund management companies, and will have all powers and obligations to manage, comparable to an agent with general power of attorney to perform acts of such a nature, and must observe, in all cases, the investment regime applicable to the mutual fund in question, as well as the prospectus provided to investors, safeguarding, at all times, the interests of the fund's shareholders by supplying information that is pertinent, adequate and necessary for purposes of decision making.

Mutual fund management companies may also render the services specified in Sections I and II of this article, and those set forth by Article 32, Sections II, VI, VII and VIII of this law, observing, as appropriate, regulations applicable to the corresponding type of services, pursuant to this law and the Securities Market Law. Moreover, these management companies may provide the service of share valuation pursuant to the terms of this law, upon prior authorization from the Commission, and adhering to the general regulations issued by the Commission in this regard.

Financial institutions, brokerage houses, secondary financial institutions, currency exchange houses, specialpurpose financial institutions and insurance companies may only offer the services specified in this article to mutual funds through managing companies organized for this purpose, pursuant to this law and the regulations applicable to said financial entities. 


\section{Section III \\ Distribution}

ARTICLE 40. Mutual fund share distribution services will include promotion, consulting to third parties, trading of shares on behalf and by order of the mutual fund in question, and, where appropriate, generation of reports and consolidated investment statements and other complementary services authorized by the Commission, through general provisions.

Distribution activities referred to in this article may be carried out by distribution companies authorized pursuant to the provisions of Article 33 of this law, and these may be entities belonging to financial group holding companies.

Financial institutions, brokerage houses, secondary financial institutions, currency exchange houses and specialpurpose financial institutions may directly provide mutual fund companies with share distribution services, without prejudice to adherence to this law and other applicable regulations, and they will, in all cases, be subject to the supervision of the Commission in the performance of these activities.

In no event may distribution companies conduct transactions on their own behalf with the public, with regard to mutual fund company shares.

Mutual fund share distribution companies may enter into agreements with individuals and legal entities containing individuals assisting them in their activities, provided that these certify compliance with the provisions of Article 35 of this law.

In no case may mutual fund share distribution be made at a price other than the current public offering price for the date of trading.

\section{Section IV \\ Valuation}

ARTICLE 44. Mutual fund share valuation services will be provided by valuation companies or mutual fund management companies authorized for this purpose, in order to determine the current public offering price of the various classes of shares pursuant to the terms of the general provisions issued by the Commission.

With regard to capital investment companies and special-purpose investment companies, public offering price may be determined by valuation companies or by valuation committees designated by these.

In order to determine public offering price, the individuals or entities responsible for this service will use current value of the securities, documents and instruments that make up the assets of the mutual fund, provided by the provider of prices for said companies; or, the prices obtained by means of any method established or authorized by the Commission regarding assets that by nature cannot be valuated by these providers.

Valuation of investments held by capital investment companies in promoted companies will adhere to the guidelines established by the Commission for this purpose in general regulations

\section{CHAPTER II. INSPECTION AND AUDIT}

\section{ARTICLE 106.}

The inspection and audit of insurance institutions and mutual companies, as well as the other persons and enterprises to which this Law refers, insofar as compliance with the dispositions thereof is concerned, shall remain entrusted to the National Insurance and Bond Commission in the terms of this Law and of the regulation issued for 
these purposes by the Federal Executive.

Insurance institutions authorized to operate in the health insurance sector shall also be subject to the inspection and supervision of the Ministry of Health, exclusively on the health services and products that are the matter of the insurance policies that they conclude. When the aforementioned Ministry detects any irregularity related with such services and products in the exercise of the aforementioned duties, it shall communicate such irregularity to the National Insurance and Bond Commission in order that it shall proceed to imposing penalties pursuant to the provisions of this Law.

The National Insurance and Bond Commission shall exercise, with respect to receivers and liquidators, the functions of surveillance which it has been attributed in relation to insurance institutions and mutual companies.

Insurance institutions and mutual companies and the other persons and enterprises subject to this Law and to the inspection and audit of the National Insurance and Bond Commission, and in its case the Ministry of Health, must cover the corresponding quotas in the terms of the applicable legal dispositions.

\section{ARTICLE 108.}

The National Commission of Insurance and Bonds is a desconcentrated agency of the Ministry of Finance and Public Credit that is subject to this Law and to the Internal Regulation issued by the Federal Executive for the purpose and shall have the following powers:

I.To carry out the inspection and audit which it is competent to do in accordance with this and other laws;

II. To function as a consultation body of the Ministry of Finance and Public Credit in the case of the insurance system and in other cases which the laws shall determine;

III. To impose administrative fines for violations to this Law and other laws that regulate the activities, institutions and persons subject to its inspection and audit, as well as to the provisions which issue therefrom.

Such penalties may be admonitions or, when the laws and provisions which emanate therefrom so establish, temporary suspensions of activities, vetoes or disqualification for carrying on activities, as well as fines.

The imposition of penalties shall correspond to the Governing Board of the Commission, which may delegate this duty to the Chairman and other public servants thereof, due to the nature of the violation or of the amount of the fines, and shall likewise have the undelegatable faculty to partially or totally pardon the fines imposed, if applicable.

The fines imposed in the terms of this Law and other laws which regulate the activities, institutions and persons subject to the inspection and audit of the aforementioned Commission, as well as the provisions which emanate therefrom, must be paid within the 15 working days from the date of their notification, and when the violator gives any kind of legal defense against the fine which had been applied to him, and the fine is confirmed totally or partially, its amount must be immediately remitted once the corresponding decision is notified to the violator.

Appeal of revocation shall proceed against the penalties, which must be interposed in writing within the 15 working days following their notification and must be exhausted before proceeding to any other method of refutation.

The appeal stipulated must be interposed before the Governing Board of the Commission, when the penalty has been issued by that collegiate body or by the Chairman of the Commission or, before the latter, in the case of penalties imposed by other public servants of the Commission. The writ in which the party affected shall interpose the appeal, must contain the expression of the act challenged and the grievances caused thereby, offering, and when possible, attaching the evidence which may be deemed convenient for the purpose.

When the challenged act is not stipulated or the grievances are not expressed, the competent authority shall reject 
the appeal due to its being improper. If the evidence is omitted, it shall be considered as not offered.

The resolution of the appeal of revocation may be rejection, confirmation, issuance of a mandate to replace the challenged decision by a new one to be substituted therefor or revocation of the challenged act, and must be issued within a period no longer than 45 working days subsequent to the day on which the appeal was presented, if it must be resolved by the Chairman of the Commission, and in the case of appeals that are within the jurisdiction of the Government Board, that period may not be longer than 60 working days.

The submission of the appeal shall suspend the enforcement of the penalty. I such is confirmed, totally or partially, the resolution of the corresponding appeal shall stipulate the provisions regarding immediate enforcement thereof after the corresponding notice.

IV. To issue the provisions necessary for the exercise of the faculties which the Law grants it and for the efficient compliance therewith, as well as with the rules and regulations which based thereon shall be issued and contributed by means of the issue of dispositions and instructions to insurance institutions and mutual companies, and the other persons and enterprises subject to its inspection and audit, with the policies which the Ministry of Finance and Public Credit is competent to issue in those matters, following the instructions which it receives therefrom;

IV Bis. Issue, within its authority, the prudential rules aimed at preserving the solvency, liquidity and financial stability of the insurance companies and mutual insurance companies;

V. To present an opinion to the Ministry of Finance and Public Credit on the interpretation of this Law and other relative matters in case of doubt with respect to its application;

VI. To make studies which shall be committed and presented to the Ministry of Finance and Public Credit, make suggestions which are deemed adequate for improving them; as well as motions and reports relative to the insurance system deemed suitable to be brought before said Ministry;

VII. To aid the Ministry of Finance and Public Credit in the development of policies adequate for the selection of technical and financial risks in relation with the operations practiced by the insurance system, following the instructions received from the same Ministry;

VIII. To intervene, in the terms and conditions that this Law stipulates, in the drawing up of the regulations and general rules to which it refers;

VIII Bis. To provide the financial foreign authorities information received from the companies and persons supervised by it, when it has entered with said authorities information exchange agreements that contemplate a reciprocity principle, refraining from providing information when in its judgment such may be used for purposes other than surveillance or by reason of public interest, national security or any other reason set forth in the respective agreements;

IX. To annually draw up their budgets which shall be submitted for the authorization of the Ministry of Finance and Public Credit;

X. To render an annual report of their labors to the Ministry of Finance and Public Credit;

XI. The quotas that pertain to the surveillance and audit services of the National Insurance and Bond Commission, referred to in Article 106 hereof, shall be destined to cover the budget thereof. In case that at the end of the fiscal year there are any remnants from amounts collected as duties, such shall be transferred to a special reserve of the National Insurance and Bond Commission, which shall be destined to cover expenses pertaining to future fiscal years in order ensure the continuity of its programs, but in no case may it be applied to make payments not set forth in the Federal Budget, reducing in its case the impact over federal resources or additional quotas for the companies or persons subject to the surveillance and audits of the National Insurance and Bond Commission, 
and

XII.Others which are attributed thereto by this Law and other legal ordinances with respect to the insurance system, provided that they do not refer to mere acts of audit or execution.

The faculties to which items VII, IX and X of this article refer, cannot be delegated.

\section{ARTICLE 110.}

Visits or inspections shall be made to all the insurance institutions and mutual companies in accordance with the programs elaborated by the National Insurance and Bond Commission and that are approved by the Governing Board, taking in consideration the overall situation of the insurance industry and the necessities of each concrete case; without prejudice to those which are carried out upon request of the statutory examiners, or of a group of shareholders or of policy-holders, who submit sufficient data to justify that visit in the judgment of the National Insurance and Bond Commission.

The visits shall have the following purpose: To review, verify, prove and evaluate the resources, obligations, net wealth, as well as the operations, functioning, systems of control and, in general, all that which might affect the financial and legal position, shown or which should be shown in the records, for the purpose of fulfilling the provisions which govern them and sound practices in the matter.

The visits may be ordinary, special or investigative. The first shall be carried out in accordance with an annual program that the Chairman of the Commission shall approve. The second shall be made if it is necessary to examine in the judgment of the Chairman, and if so, in order to correct special operational and investigational situations with the object of clarifying a specific situation.

The Chairman of the Commission may appoint at any time or even permanently, inspectors in the insurance institutions and mutual companies, who shall review their operations and their financial situation and audit the general progress of the insurance institution or mutual company, as well as delegates who shall verify the work of those inspectors.

Insurance institutions and mutual companies, as well as the other persons and enterprises subject to the inspection and audit of the Commission, shall be obligated to render all the help to the inspectors which they require, furnishing the data, reports, records, minutes books, auxiliary books, documents, correspondence and in general, the documentation, disks, tapes or any other processable media of storage of data which the institution shall have and that the inspectors deem necessary for compliance with their duties; possibly retaining access to their offices and other installations.

The visitors and inspectors shall be persons who are knowledgeable in financial matters, having the knowledge requirements determined by the Internal Regulation of the Commission, and neither them nor other personnel may obtain services from the institutions subject to inspection, or be debtors thereto under any circumstances, under the penalty of immediate dismissal. Transactions which are carried out with the express approval of the Governing Board of the Commission are excepted.

When exercising its functions under this Article, the National Insurance and Bond Commission so requires, it may engage such auditors and other professionals that aid it in such functions.

\section{CHAPTER SECOND ADMNISTRATIVE LIQUIDATION}

\section{ARTICLE 126.}

When the Ministry of Finance and Public Credit determines that an insurance institution shall be liquidated, the provisions of this chapter shall be applicable, possibly applying the Bankruptcy Law in that which is not provided herein. The Ministry of Finance and Public Credit shall deliver to a liquidator appointed by it, of all the assets, 
policies, credits, securities, real and personal property, books, files, documents and, in general, all that which is owned by the institution. The liquidator, within a period of 60 days, following the date on which he takes possession thereof, shall establish exactly the assets and liabilities of the company in liquidation and propose in writing to the Ministry of Finance and Public Credit, the manner in which said liquidation shall be conducted. In view of the preceding report, the Ministry shall establish the term within which the liquidation must be carried out. The liquidator may realize the property making up the assets of the institution, but must obtain, in each case, the express approval of the Ministry of Finance and Public Credit. From the assets realized shall be deducted the expenses and fees of the liquidation, and the rest shall be distributed among the policy holders in proportion to the technical reserve corresponding to each policy on the date of the declaration of dissolution and in proportion to the value of the policies, for due compromises. The rights of the insureds upon liquidation of the policies shall be valuated on the date of the declaration of dissolution of the company. The Ministry of Finance and Public Credit must previously approve all the calculations that serve as a base for making the distribution of the assets among the insured parties. Prior thereto, the insured parties may make the observations which shall proceed with respect to their credits. For this purpose, the liquidator shall communicate to each insured the amount of the technical that corresponds to him, or, if applicable, the value of the policy in the case of compromises due.

Neither the assets within the technical reserves to which Article 63 of this Law, nor the resources of third parties to which items III, III Bis and IV of article 34 of this Law refers, may be considered within the assets forming the estate of the concurso mercantil, nor of the administrative liquidation, as the case may be.

\section{CHAPTER III. INFRACTIONS AND CRIMINAL OFFENSES}

\section{ARTICLE 138.}

The fines corresponding to penalties for violations provided in this Law and in provisions issued in connection therewith, shall be imposed administratively by the National Insurance and Bond Commission, taking the general minimum wage in force in the Federal District at the time of commission of the violation, unless another form of penalty is set forth in applicable Law, and shall be enforced by the Ministry of Finance and Public Credit.

When imposing the corresponding penalty, the aforementioned Commission must always previously hear the interested party and shall take into account the economical conditions and intention of the violator, the importance of the violation and the convenience of avoiding practices tending to contravene the provisions of this Law and the rules arising therefrom.

In the case of insurance companies and mutual insurance companies, the economical condition shall be measured by taking into consideration the net capital and the capital stock at the end of the preceding fiscal year.

In order to hear the alleged violator the National Insurance and Bond Commission shall grant it a term of 10 working days, which may be extended one time, for the interested party to manifest what it deems convenient, and submitting the evidence that he wishes. Once the term and its extension has elapsed, if the interested party did not appeared before the National Insurance and Bond Commission, the right to be heard by said authority shall be extinguished, and the corresponding resolution shall be issued based on the elements available on the respective file in terms of this Article.

Once the allegations made by the interested party have been analyzed and the evidence submitted by him has been evaluated, or in its case once the documents that form part of the respective administrative file have been analyzed, the National Insurance and Bond Commission, in order to impose the corresponding fine in the respective resolution, shall:

a) Indicate the legal provisions or administrative rules that are applicable to the case as well as the special circumstances, individual reasons or immediate causes that were taken into consideration to determine the existence of the violation; and

b) Take into account the importance of the act or omission that originated the imposition of the penalty and economical status of the violator. When the penalty to be imposed is larger than the 
minimum, the corresponding resolution shall indicate the reasons and motives for which the National Insurance and Bond Commission considers applicable such penalty.

The penalties imposed in accordance with this law in no case shall exceed $2 \%$ of the net worth or capital stock of the insurance company or mutual insurance company. The imposition of penalties shall not discharge the violator from complying with its obligations or to cure the circumstances that originated the penalty.

Taking into consideration the special circumstances of each case, the National Insurance and Bond Commission may also admonition the violator or just reprimand it.

The provisions of this article does not exclude the imposition of penalties that in accordance with this or other laws are applicable with respect to unlawful actions or criminal offenses, nor the revocation of the authorization to the company or mutual insurance company.

In protection of public interest, the National Insurance and Bond Commission shall made public any sanctions that it imposes for violations of this law or to the rules arising therefrom, once such resolutions are definitive, indicating the sanctioned person, the violated provision and the imposed penalty.

Article 140.- The cases foreseen in articles 141 to 146 and 147 to 147 Bis 2 of this Law shall proceed by request from the Ministry of Finance and Public Credit, who shall listen to the opinion of the National Insurance and Sureties Commission, and such cases could also proceed by request from the respective insurance institution, mutual entity or agent or from anyone that has a legal interest.

Penalties foreseen in this Law shall be calculated upon the base of days times the daily general minimum wage in effect in the Federal District

In addition to fulfilling all other obligations that result applicable, insurance institutions, mutual entities or agents shall observe the following, in terms of the general provisions issued by the Ministry of Finance and Public Credit, after listening to the previous opinion of the National Insurance and Sureties Commission:

I. Establish measures and procedures to prevent and detect actions, omissions, or transactions that may favor, or grant aid, support, or cooperation to commit the offenses foreseen in articles 139, 148 Bis or 400 Bis of the Federal Penal Code, and

II. Submit to the Ministry of Finance and Public Credit through the National Insurance and Sureties Commission, reports relating to:

a. Actions, transactions and services performed with customers and occasional users relating to the preceding fraction I., and

b. Any action, transaction or service performed by members of the board of directors, directors, officers, employees, or legal representatives that may be placed in the case foreseen in fraction I of this article or that, as the case may be, may violate or jeopardize the adequate application of the general provisions referred to above.

The reports referred to in fraction II of this article, in accordance with the general provisions foreseen in such fraction, shall be elaborated and submitted taking into consideration at least the variations contemplated in such provisions, the characteristics that the actions, transactions, and services shall have in order to be reported, taking into account the amounts, frequency and nature, monetary and financial instruments with which they are carried out, and the commercial and banking practices observed in the locations in which they are carried out, as well as the frequency and the systems through which the information shall be transmitted.

In the same manner, the Ministry of Finance and Public Credit shall include in the aforementioned general provisions guidelines about the procedure and criteria that insurance institutions, mutual societies or agents shall 
observe with regards to:

a. The adequate knowledge about their clients and users, for which insurance institutions, mutual societies or agents shall consider the background, specific conditions, economic or professional activity and locations in which such clients and users operate;

b. The information and documentation that insurance institutions, mutual entities or agents shall gather to open accounts or execute contracts relating to transactions and services provided by such institutions and that fully demonstrate the identity of their clients;

c. The manner in which insurance institutions, mutual societies or agents shall keep and assure the security of the information and documentation related to the identification of their present or former clients and users, as well as of that concerning the actions, transactions, and services reported in accordance with this article, and

d. The terms to provide training in insurance institutions, mutual societies or agents on the subject matter of this article. The general provisions referred to in this article shall establish the terms for due compliance of this provision.

Insurance institutions, mutual funds or agents shall keep, for at least ten years, the information and documentation referred to in sub-section c) of the preceding paragraph, without prejudice to the provisions of this or other laws.

The Ministry of Finance and Public Credit shall be empowered to request and collect, through the National Insurance and Sureties Commission, from insurance institutions, mutual societies or agents, who shall be obligated to deliver, information and documentation relating the actions, transactions and services referred to in fraction II of this article. The Ministry of Finance and Public Credit shall be empowered to obtain additional information from other persons for the same purposes and to provide such information to competent authorities.

The observance of the obligations stated in this article does not imply any breach of secrecy obligations neither violation of any restriction agreed contractually, nor of articles 117 and 118 in relation with article 46, fraction XV of the Law of Credit Institutions.

The general provisions referred to in this article shall be observed by insurance institutions, mutual societies or agents, members of their board of directors, directors, officers, employees, or legal representatives, and therefore such institutions and persons shall be responsible for the strict observance of the obligations imposed through such general provisions.

Violation to the general provisions referred to in this article shall be penalized by the National Insurance and Sureties Commission, according to the procedure established under article 138 of this Law, with a fine of up to 100,000 days of the daily general minimum wage in effect in the Federal District.

The fines contemplated above may be imposed to insurance institutions, mutual entities or agents, members of their board of directors, directors, officers, employees and legal representatives and natural and legal persons who, by reason of their actions, caused or intervened in the institution to incur the respective irregularity or become responsible for it. Notwithstanding the foregoing, the National Insurance and Sureties Commission, bearing in mind the circumstances of each particular case, could proceed in accordance with articles 23 and 31 of this Law.

The public servants of the Ministry of Finance and Public Credit and the National Insurance and Sureties Commission, insurance institutions, mutual entities or agents, members of their board of directors, directors, officers, employees and legal representatives, shall abstain from informing about the reports, and other documentation and information referred to in this article, to persons or authorities other than those expressly empowered to require, receive or conserve said information. Violations to these obligations shall be penalized in 
accordance with corresponding laws.

Law of the Contract of Insurance

154

ARTICLE 154.- The policy of the contract for insurance can not be issued to the bearer. The possession of such policy can be transferred to other person by a written declaration of both parties notified to the insurance company. The payable policy insurance can be transferred by means of an endorsement which shall include: date, name and address of the person who is receiving the insurance policy and the signature of the person who is transferring such policy.

In case of irrevocable designation of beneficiary, this latter can transmit this right upon written declaration notified to the insurance company, as foreseen by article 19 of the present Law.

\begin{tabular}{|l|l|}
\hline GENERAL LAW OF AUXILIARY CREDIT & 81; 81-A; 87-B; 87-E; 87-F; 87-J; 87-K; 87-L; 87- \\
ORGANIZATIONS AND ACTIVITIES (Ley General de & M; 87-N; 87-Ñ 95; 95 Bis \\
Organizaciones y Actividades Auxiliares del Crédito) & \\
\hline
\end{tabular}

Article 81-A.- No authorization is required, when the following transactions are performed only with foreign currency:

I. Purchase and sale of paper money, minted pieces and common metals of legal circulation in the country of issuance, for an amount equivalent or not exceeding of ten thousand Dollars of the United States of America per client per day.

II. Purchase and sale of travelers checks issued in foreign currency, for an amount equivalent or not exceeding of ten thousand Dollars of the United States of America per client per day.

III. Purchase and sale of metallic pieces minted in coin shape, for an amount equivalent or not exceeding of ten thousand Dollars of the United States of America per client per day.

IV. Purchase and sale of money market documents (documentos a la vista) issued and payable in foreign currency issued by a financial institution, for an amount equivalent or not exceeding of ten thousand Dollars of the United States of America per client per day. These documents can only be sold to Credit Institutions or to Money Exchange Companies.

V. Repealed.

In the performance of the above mentioned transactions referred to in sections I through IV of the present article, the agreed value should be delivered in the same act in which the transactions are undertaken and they can only be paid with cash, travelers checks or checks payable in national currency. In any case, it is prohibited to perform transference or transmission of funds in order to complete such transactions.

Article 87-B. Extension of credit, as well as execution of financial leasing or factoring may be conducted in a regular and professional manner by any person or entity, without no need for authorization by the federal government.

Those stock companies which, in their bylaws, expressly indicate as their main corporate purpose the regular and professional realization of one or more activities indicated in the preceding paragraph, will be considered multiplepurpose financial institutions. These companies will be regarded financial entities, and may be: 
I. Regulated multiple-purpose financial institutions, o
II. Non-regulated multiple-purpose financial institutions.

The companies specified in Section I above are those that, pursuant to the terms of this law, maintain lending institution or financial group holding company equity participation. These companies must add to their corporate name the phrase: "sociedad financiera de objeto múltiple" [multiple-purpose financial institution], or its acronym "SOFOM," followed by the words, "entidad regulada" [regulated entity] or its abbreviation "E.R." Regulated multiple-purpose financial institutions will be subject to the oversight of the National Banking and Securities Commission.

Companies considered by Section II of this article will be those without capital participation of any of the entities described in the preceding paragraph. These companies must add to their corporate name the phrase: "sociedad financiera de objeto múltiple" [multiple-purpose financial institution], or its acronym "SOFOM," followed by the words, "entidad no regulada" [non-regulated entity] or its abbreviation "E.N.R." Non-regulated multiple-purpose financial institutions will not be subject to the oversight of the National Banking and Securities Commission.

Article 87-E. In financial leasing agreements, factoring and loans by multiple-purpose financial institutions, in which agreement is made to the effect that the lessee, seller in factoring, or loan recipient may dispose of the credit or loan amount in partial sums, or is authorized to make repayments prior to the expiration of the term specified in the agreement, the account statement certified by the corresponding company's accountant will so certify, except in the presence of evidence to the contrary, at the respective determination of the outstanding balance of the debtor.

Article 87-F. The agreement corresponding to the credit, financial lease or factoring granted by multiple-purpose financial institutions, provided that said instrument is accompanied by the respective account statement referred to in the preceding article, will be an executory commercial instrument, without need of signature or any other requirement whatsoever.

With regard to factoring, in addition to the respective agreement, multiple-purpose financial institutions must have documents demonstrating the claims conveyed through the operation, as well as the notification to the debtor of said conveyance when such notification is required pursuant to applicable regulations.

The account statement referred to in the first paragraph of this article must contain identifying information of the contract or agreement corresponding to the loan, factoring or financial lease entered into; the initial capital stipulated or, where appropriate, the determined rental amount; outstanding capital or, where appropriate, overdue rental payments; capital or, where appropriate, rent nearing due date or maturation; loan interest rates or, where appropriate, rent variation applicable to rental amounts determined for each payment period; past-due interest generated; interest rate applicable to past-due interest, and charges generated.

Article 87-J. Financial leasing, factoring and credit agreements executed by multiple-purpose financial institutions must expressly indicate that, for their establishment and performance as such, no authorization is required by the Department of Treasury and Public Credit. The foregoing must also be stated in any information used by multiplepurpose financial institutions for purposes of promotion of their operations and services.

In addition to the foregoing, non-regulated multiple-purpose financial institutions must state, in the documentation and information referred to in the preceding paragraph, that they are not subject to the supervision and oversight of the National Banking and Securities Commission.

Article 87-K. The National Commission for the Protection and Defense of Users of Financial Services will be responsible for the protection and defense of the rights and interests of the public using the services provided by multiple-purpose financial institutions in conducting transactions specified in Article 87-B of this law, pursuant to the terms of the Law of Protection and Defense of Users of Financial Services. With regard to the foregoing 
services, multiple-purpose financial institutions will be subject to the aforementioned law, pursuant to the terms specified therein applicable to financial institutions. In such a capacity, the National Commission for the Protection and Defense of Users of Financial Services may exercise, with respect to multiple-purpose financial institutions providing the aforementioned services, the authority conferred upon it by the foregoing law, and the corresponding sanctions set forth in said law will be applicable to these financial institutions.

Multiple-purpose financial institutions, upon organization in such a capacity, must communicate this fact in writing to the National Commission for the Protection and Defense of Users of Financial Services, within ten working days after registration of the corresponding incorporation papers in the Public Registry of Commerce.

Article 87-L. Without prejudice to the provisions of this chapter, the authority conferred by the Law of Transparency and Promotion of Competition to the National Banking and Securities Commission, with respect to financial institutions that extend secured credit in the terms of this law, will also be conferred upon to the National Commission for the Protection and Defense of Users of Financial Services, with respect to non-regulated multiplepurpose financial institutions.

(Second paragraph repealed).

Article 87-M. With regard to credit, financial leasing and factoring transactions, multiple-purpose financial institutions must:

I. Provide advance notice to customers regarding consideration; installment amounts, and the manner and frequency of these; financing charges; fees; amount and detail of any charges, as appropriate; number of installments to be made, and frequency; where appropriate, the right to advance payment for the operation and applicable conditions, interest, including past-due interest, manner of calculation and rate type and, as appropriate, discount rate.

II. If a fixed rate is applied, the customer will also be informed of the amount of interest to be paid in each period. If a variable rate is applied, the customer will be informed of the rate adjustment rule, which may not depend on unilateral decisions of the respective multiple-purpose financial institutions, but rather on variations in the interest rate representative of the cost of the transaction to the customer, which must be easily verifiable by the customer;

III. Inform the client of the total amount due in the transaction in question, and, where appropriate, number and amount of installments, interest, and corresponding charges and fees, including those set for advance payments or cancellation; provide properly itemized descriptions of payments;

IV. (Derogated).

The National Commission for the Protection and Defense of Users of Financial Services may issue recommendations to multiple-purpose financial institutions for the compliance of the provisions of this article.

Article 87-N. In addition to the provisions set forth by articles 87-K, 87-L and 87-M of this law, the National Commission for the Protection and Defense of Users of Financial Services will be responsible for oversight and supervision of compliance by multiple-purpose financial institutions with the provisions of articles 87-I, 87-M and $87-\tilde{N}$ of this law, pursuant to the determinations of the Commission with regard to the exercise of this authority.

The foregoing Commission may exercise this authority at the sites of operation of the multiple-purpose financial institutions in question, pursuant to the terms of procedure set forth by the Federal Law of Administrative Procedure. Moreover, the Commission may exercise such authority through visits and requests for information or documentation. For the purposes of the provisions of this article, multiple-purpose financial institutions, as well as their representatives and employees, are required to allow official Commission personnel to access the site or sites to be inspected.

Article 87-Ñ. The multiple-purpose financial institutions will be subject, as regards guarantee trust transactions managed pursuant to Section II of Chapter V of Title II of the General Law of Negotiable Instruments and Credit Operations, to the provisions of Articles 79 and 80 of the Financial Institutions Law applicable to these institutions. 
In guarantee trust agreements referred to by Article 395 of the General Law of Negotiable Instruments and Credit Operations, and in the performance of these, multiple-purpose financial institutions will be prohibited from:

I. Acting as trustees in any trusts other than those of the guarantee;

II. Using the cash, property, claims or securities of the trusts to conduct transactions in which they may become debtors or beneficiaries of their trust officers; administrators, regular or alternate members of the board of directors, whether acting or not; managers or employees; regular or alternate statutory auditors, whether acting or not; external auditors; members of the technical committee of the respective trust; ascendants or descendants of the first degree or spouses of the foregoing persons. companies with majority equity ownership by these persons, or the multiple-purpose financial institutions themselves;

III. Conducting transactions on own behalf;

IV. Acting in trusts through which limitations or prohibitions contained in this or other laws are evaded;

V. Assuming responsibility towards trustors or beneficiaries with regard to default of debtors on assets, claims or securities of the trust, except where at fault pursuant to the final section of Article 391 of the General Law of Negotiable Instruments and Credit Operations;

If, upon termination of the trust, the assets, claims or securities have not been paid by the debtors, the trust company must transfer them together with the cash, property and other claims or securities that make up the trust property, to the trustor or the trust beneficiary, as appropriate, and abstain from covering the respective amount due.

In trust agreements, the stipulations of this paragraph will be clearly inserted along with a statement by the trustee to the effect that it clearly represented content to the persons from whom it has received cash, assets, interest or securities for conveyance in trust;

VI. Acting as trustees in trusts through which, directly or indirectly, funds of the public are secured through any action causing direct or contingent liability;

VII. Acting in trusts through which limitations or prohibitions contained in this or other laws are evaded;

VIII. Acting as trustees in trusts referred to by the second paragraph of Article 88 of the Mutual Funds Law, and

IX. Managing rural property, except where said management has been conferred to guarantee for trust beneficiary the performance of an obligation and payment preference with the value of said property or its proceeds.

Any agreement contrary to the provisions in the preceding sections will be null and void

Article 95.- The cases foreseen in articles 96, 97, 98, 99, 99 Bis, 101, 101 Bis and 101 Bis 2 of this Law shall proceed by request from the Ministry of Finance and Public Credit, who shall listen to the opinion of the National Banking and Securities Commission; and such cases could also proceed by request from the respective auxiliary credit organizations and foreign exchange firms or from anyone that has a legal interest.

Penalties foreseen in this Law shall be calculated upon the base of days times the daily general minimum wage in effect in the Federal District.

In addition to fulfilling all other obligations that result applicable, auxiliary credit organizations and foreign exchange firms shall observe the following, in terms of the general provisions issued by the Ministry of Finance and Public Credit after listening to the previous opinion of the National Banking and Securities Commission:

I. Establish measures and procedures to prevent and detect actions, omissions, or transactions that may favor, or grant aid, support, or cooperation to commit the offenses foreseen in articles 139, 148 Bis or 400 Bis of the Federal Penal Code, and

II. Submit to the Ministry of Finance and Public Credit through the National Banking and Securities Commission, reports relating to:

a. Actions, transactions and services performed with their customers and users relating to the preceding fraction I., and 
b. Any action, transaction or service performed by members of the board of directors, directors, officers, employees, or legal representatives that may be placed in the case foreseen in fraction I of this article or that, as the case may be, may violate or jeopardize the adequate application of the general provisions referred to above.

The reports referred to in fraction II of this article, in accordance with the general provisions foreseen in such fraction, shall be elaborated and submitted taking into consideration at least the variations contemplated in such provisions, the characteristics that the actions, transactions, and services shall have in order to be reported, taking into account the amounts, frequency and nature, monetary and financial instruments with which they are carried out, and the commercial and banking practices observed in the locations in which they are carried out, as well as the frequency and the systems through which the information shall be transmitted.

In the same manner, the Ministry of Finance and Public Credit shall include in the aforementioned general provisions guidelines about the procedure and criteria that auxiliary credit organizations and foreign exchange firms shall observe with regards to:

a. The adequate knowledge about their clients and users, for which auxiliary credit organizations and foreign exchange firms shall consider the background, specific conditions, economic or professional activity, and locations in which such clients and users operate;

b. The information and documentation that auxiliary credit organizations and foreign exchange firms shall gather to open accounts or execute contracts relating to transactions and services provided by such institutions and that fully demonstrate the identity of their clients;

c. The manner in which auxiliary credit organizations and foreign exchange firms shall keep and assure the security of the information and documentation related to the identification of their present or former clients and users, as well as of that concerning the actions, transactions, and services reported in accordance with this article, and

d. The terms to provide training in auxiliary credit organizations and foreign exchange firms on the subject matter of this article. The general provisions referred to in this article would establish the conditions for due compliance of this provision.

Auxiliary credit organizations and foreign exchange firms shall keep, for at least ten years, the information and documentation referred to in sub-section c) of the preceding paragraph, without prejudice to the provisions of this or other laws.

The Ministry of Finance and Public Credit shall be empowered to require and collect, through the National Banking and Securities Commission, from auxiliary credit organizations and foreign exchange firms, who shall be obligated to deliver, information and documentation relating the actions, transactions and services referred to in fraction II of this article. The Ministry of Finance and Public Credit shall be empowered to obtain additional information from other people for the same purposes and to provide such information to competent authorities.

The observance of the obligations stated in this article shall not imply any breach of secrecy obligations neither violation of any restriction agreed contractually.

The general provisions referred to in this article shall be observed by auxiliary credit organizations and foreign exchange firms, members of their board of directors, directors, officers, employees, or legal representatives, and therefore such institutions and persons shall be responsible for the strict observance of the obligations imposed through such general provisions.

Violation to the general provisions referred to in this article shall be penalized by the National Banking and Securities Commission, according to the procedure established under article 88 of this Law, with a fine of up to 
100,000 days of the daily general minimum wage in effect in the Federal District.

The fines contemplated above may be imposed to auxiliary credit organizations and foreign exchange firms, members of their board of directors, directors, officers, employees and legal representatives and natural and legal persons who, by reason of their actions, caused or intervened in the auxiliary credit organizations and foreign exchange firms to incur the respective irregularity or become responsible for it. Notwithstanding the foregoing, the National Banking and Securities Commission, bearing in mind the circumstances of each particular case, could proceed in accordance with article 74 of this Law.

The public servants of the Ministry of Finance and Public Credit and the National Banking and Securities Commission, auxiliary credit organizations and foreign exchange firms, members of their board of directors, directors, officers, employees and legal representatives, shall abstain from informing about the reports, or other documentation and information referred to in this article, to persons or authorities other than those expressly empowered to request, receive or keep such information. Violations to these obligations shall be penalized in accordance with corresponding laws.

Article 95 Bis.- In addition to fulfilling all other obligations that result applicable, multiple scope financial institutions, persons that perform the activities stated in article 81-A of this Law [unlicensed foreign exchange centers], and money remitters shall observe the following, in terms of the general provisions issued by the Ministry of Finance and Public Credit after listening the previous opinion of the Tax Administration Service:

I. Establish measures and procedures to prevent and detect actions, omissions, or transactions that may favor, or grant aid, support, or cooperation to commit the offenses foreseen in articles 139, 148 Bis or 400 Bis of the Federal Penal Code, and

II. Submit to the Ministry of Finance and Public Credit through the Tax Administration Service, reports relating to:

a. Actions, transactions and services performed with customers and users relating to the preceding fraction I, and

b. Any action, transaction or service performed by members of the board of directors, directors, officers, employees, or legal representatives that may be placed in the case foreseen in fraction I of this article or that, as the case may be, may violate or jeopardize the adequate application of the general provisions referred to above.

To the effect of this article, a money remitter is defined as the person that, on a customary manner and in exchange of a payment, fee, benefit, or profit, receives in Mexican territory rights or funds in local or foreign currency, directly or in the offices of that person, or by wire, fax, courier service, electronic means, or electronic transfers of funds, so that, in accordance with the instructions from the originator, it transfers such rights or funds abroad or to a different location within Mexican territory or it delivers such rights or funds in the same place in which it received them, to the designated beneficiary.

The reports referred to in fraction II of this article, in accordance with the general provisions foreseen in such fraction, shall be elaborated and submitted taking into consideration at least the variations contemplated in such provisions, the characteristics that the actions, transactions, and services shall have in order to be reported, taking into account the amounts, frequency and nature, monetary and financial instruments with which they are carried out, and the commercial and banking practices observed in the locations in which they are carried out, as well as the frequency and the systems through which the information shall be transmitted.

In the same manner, the Ministry of Finance and Public Credit shall include in the aforementioned general provisions guidelines about the procedure and criteria that multiple scope financial institutions, persons that perform the activities stated in article 81-A of this Law and money remitters shall observe with regards to:

a. The adequate knowledge about their clients and users, for which multiple scope financial institutions, people 
performing the activities referred to in article 81-A of this Law and money remitters shall consider the background, specific conditions, economic or professional activity and locations in which such clients and users operate;

b. The information and documentation that multiple scope financial institutions, persons that perform the activities referred to in article 81-A of this Law and money remitters shall gather to open accounts or execute contracts relating to transactions and services provided by such institutions and that fully demonstrate the identity of their clients;

c. The manner in which multiple scope financial institutions, persons that perform the activities referred to in article 81-A of this Law and money remitters shall keep and assure the security of the information and documentation related to the identification of their present or former clients and users, as well as of that concerning the actions, transactions, and services reported in accordance with this article, and

d. The terms to provide training in multiple scope financial institutions, persons that perform the activities referred to in article 81-A of this Law and money remitters on the subject matter of this article. The general provisions referred to in this article shall establish the terms for due compliance of this provision.

Multiple scope financial institutions, persons that perform the activities referred to in article 81-A of this Law and money remitters shall keep, for at least ten years, the information and documentation referred to in sub-section c) of the preceding paragraph, without prejudice to the provisions of this or other laws.

The Ministry of Finance and Public Credit shall be empowered to request and collect, through the Tax Administration Service, from multiple scope financial institutions, persons that perform the activities referred to in article 81-A of this Law and money remitters, who shall be obligated to deliver, information and documentation regarding the actions, transactions, and services referred to in fraction II of this article.

The observance of the obligations stated in this article does not imply any breach of secrecy obligations neither violation of any restriction agreed contractually.

The general provisions referred to in this article shall be observed by multiple scope financial institutions, persons that perform the activities referred to in article 81-A of this Law and money remitters, members of their board of directors, directors, officers, employees, or legal representatives, and therefore such institutions and persons shall be responsible for the strict observance of the obligations imposed through such general provisions.

Violation to the general provisions referred to in this article shall be penalized by the Tax Administration Service, according to the procedure foreseen in its Law, with a fine of up to 100,000 days of the daily general minimum wage in effect in the Federal District.

The fines contemplated above may be imposed to multiple scope financial institutions, persons that perform the activities referred to in article 81-A of this Law and money remitters, members of their board of directors, directors, officers, employees and legal representatives and natural and legal persons who, by reason of their actions, caused or intervened in the institutions to incur the respective irregularity or become responsible for it.

The Tax Administration Service shall have the power to supervise, oversee and inspect the observance and duly compliance of the obligations foreseen in this article and the general provisions issued by the Ministry of Finance and Public Credit.

The public servants of the Ministry of Finance and Public Credit and the Tax Administration Service, multiple scope financial institutions, persons that perform the activities referred to in article 81-A of this Law and money remitters, members of their board of directors, directors, officers, employees and legal representatives, shall abstain from informing about the reports, or other documentation and information referred to in this article, to persons or authorities other than those expressly empowered to require, receive or keep such information. Violations to these 
obligations shall be penalized in accordance with corresponding laws.

\section{CHAPTER II}

\section{Powers}

ARTICLE 4. The Commission has the authority to:

(3) I. Oversee financial institutions, related entities, as well as individuals and other legal entities that carry out activities specified in the laws corresponding to the financial system;

II. Issue, in the area under its competence, prudential regulations to which entities will be subject;

III. Dictate transaction recording regulations applicable to the entities;

IV. Establish rules for calculation of assets and, where appropriate, obligations and liabilities of the entities, pursuant to the terms established by law;

$\mathrm{V}$. Issue regulations with respect to the information entities must periodically provide;

VI. Establish general regulations on the conditions and requirements for auditors of the entities, as well as their reports;

VII. Establish the criteria referred to by Article 2 of the Securities Market Law, as well as those of general application in the financial sector on actions and operations considered contrary to commercial, banking and stockexchange standards or healthy practices in the financial markets, and dictate necessary measures so that activities and operations of entities adhere to the laws applicable to them, general provisions derived from these, and the foregoing standards and healthy practices;

VIII. Act as consulting body for the federal government on financial matters;

IX. Ensure proper and effective fulfillment of entities in transactions and services with financial service users pursuant to the agreed-upon terms and conditions, through established procedures and the laws regulated the financial system;

${ }^{(2)} \mathrm{X}$. Derogated.

XI. Authorize organization and operation, and determine minimum capital of entities pursuant to law;

(3) XII. Grant authorization to individuals who conduct consulting, promotion, and securities trading transactions with the general public, as securities market intermediary agents, pursuant to the terms set forth by regulations applicable to these individuals;

(3) XIII. Order or recommend admonition, suspension or dismissal and, as appropriate, disqualification of the advisors, managers, statutory auditors, trust officers, agents, officers, independent external auditors and other individuals who can cause obligations for entities, pursuant to the provisions of applicable law.

XIV. Order the suspension of operations of entities pursuant to the provisions of this law;

$\mathrm{XV}$. Intervene in administration or management of entities, in order to suspend, control, or terminate any operations that place at risk the solvency, stability or liquidity of entities, or those operations in violation of the regulatory laws or general provisions derived therefrom, pursuant to the terms of applicable regulations;

XVI. Investigate actions of individuals and legal entities who do not belong to the financial sector and who are suspected of conducting operations violating the laws that govern the sector, ordering inspection visits of the suspected violators as appropriate;

XVII. Order the suspension of operations, intervene in administration or management, or order the closing down of business concerns, establishments or companies of sole proprietors or legal entities that, without the corresponding authorization, conduct activities that require such authorization pursuant to the terms of the regulatory provisions applying to financial sector entities;

(3) XVIII. Investigate actions or events that violate the provisions set forth by the Securities Market Law, for which 
it is permitted to carry out visits with regard to these actions or events, as well as cite, require information from or require appearance of suspected violators and other persons that may contribute to the proper realization of the investigation;

(3) XIX. Impose administrative sanctions for violations of the regulations pertaining to activities, entities and individuals subject to oversight of the Commission, or of rules arising therefrom, and, where appropriate, assist the public prosecutor's office with respect to violations of financial system laws;

$\mathrm{XX}$. Hear and render decisions on motions for reconsiderations filed against applied sanctions, and render decisions on total or partial waiver of the fines imposed;

XXI. Participate in liquidation proceedings of entities pursuant to the terms of the law;

XXII. Set dates on which entities must close doors or suspend operations;

XXIII. Prepare and publish financial statistics regarding entities and markets;

XXIV. Execute agreements with national and international agencies with supervisory and regulatory functions similar to those of the Commission, and participate in fora involving national and international financial oversight and regulation agencies;

XXV. Provide any assistance requested by foreign supervisory and regulatory agencies, for which any information and documentation requested on any person may be obtained in the exercise of its powers of inspection and oversight;

XXVI. Participate in issuance, drawing and cancellation of negotiable instruments or securities of entities, pursuant to the law, to ensure that circulation of these does not exceed legal limits;

XXVII. Apply, to public servants of full-service banking institutions in which the Federal Government has control through equity participation, and to development banking institutions, the regulations and sanctions set forth in the Federal Law regarding Responsibilities of Public Servants corresponding to internal comptrollerships, without prejudice to those sanctions which the Department of the Comptroller and Administrative Development is responsible for applying pursuant to the terms of the foregoing law;

XXVIII. Keep the National Registry of Securities and Intermediaries certifying registrations in said registry;

XXIX. Authorize, suspend or cancel securities and stock-exchange specialist registrations in the National Registry of Securities and Intermediaries, and suspend the foregoing registration with regard to brokerage houses;

XXX. Oversee securities issuers registered in the National Registry of Securities and Intermediaries, with regard to their obligations pursuant to the Securities Market Law;

XXXI. Dictate general regulations with regard to the manner and terms in which issuing companies possessing privileged information must make such information public;

XXXII. Issue standards which set minimum public disclosure requirements for securities rating firms with regard to the credit quality of issuances rated and on other aspects towards improving services provided to users;

XXXIII. Establish rules applicable to brokerage houses in transactions with stockholders, advisors, executives and employees;

XXXIV. Authorize and oversee systems used for compensation, centralized information and securities rating and other mechanisms towards efficiency in transactions and improvement of the securities market;

XXXV. Order the suspension of securities quotations when disorderly conditions exist in the market or transactions are conducted which are contrary to healthy practices;

(8) XXXVI. Issue regulations necessary for the exercise of the authority conferred by this and other laws, and for the effective enforcement of these and of the rules established based hereon;

(8) XXXVII. Regulate adhesion contracts, publicity and account statements used by the financial institutions as referred to by the Law for Transparency and Financial Service Regulations, pursuant to the terms of the foregoing law, and

(9) XXXVIII.- Other powers as granted by this law, the Regulatory Law of Subsection XIII bis of Section B, Article 123 of the Political Constitution of the United Mexican States and by other laws.

ARTICLE 6. For the effects of Section II of Article 4, the Commission, pursuant to the provisions set forth by financial system laws, will establish prudential regulations towards preserving the liquidity, solvency and stability of financial institutions. 


\section{SECONDARY REGULATIONS}

ORGANIC LAW REGULATIONS OF THE OFFICE $1 ; 2 ; 15 ; 16 ; 27 ; 28$;

OF THE ATTORNEY GENERAL OF THE REPUBLIC

(Reglamento de la Ley Orgánica de la Procuraduría General de la República)

\section{CHAPTER ONE ORGANIZATION OF THE OFFICE OF THE ATTORNEY GENERAL}

\section{Article 1.}

These regulations intend to establish the organization and operation of the Office of the Attorney General of the Republic, for the resolution of matters entrusted thereto, to the Attorney General and to the Federal Public Prosecutor by the Political Constitution of the United Mexican States, its Organic Law and other regulations.

\section{Article 2.}

For the fulfillment of matters under the competence of the Office of the Attorney General, its Chief and the Federal Public Prosecutor will have the following administrative units and decentralized bodies:

- Deputy Attorney General's Office for Special Investigations into Organized Crime;

$\cdots$

- Specialized Unit for Investigation of Terrorism, Arms Stockpiling and Trafficking;

- Specialized Unit for Investigation of Operations with Funds of Illicit Origin and Counterfeiting or Alteration of Currency;

\section{CHAPTER FOUR DEPUTY ATTORNEY GENERALS}

\section{Article 15}

The Deputy Attorney General's Office for Special Investigation into Organized Crime is the specialized unit referred to by Article 8 of the Federal Law against Organized Crime, and will exercise the powers that said regulation confers upon it.

This Deputy Attorney General's Office will have specialized units and a technical control body that will perform the functions specified in Article 8, second paragraph, of the Federal Law against Organized Crime.

\section{Article 16.}

The public servants of the Deputy Attorney General's Office for Special Investigation into Organized Crime and of the administrative units assigned thereto, must meet the requirements set forth in Articles 31, 32 and 33 of the Organic Law, as appropriate, and, additionally, the following:

I. Successfully complete the courses in the specialization of organized crime established by the Career Service for each level;

II. Pass the initial and periodic evaluations for entrance and continuance in the foregoing deputy attorney general's office, and, as appropriate, in the Institution, applied by the Evaluation and Human Development Center, and

III. Not have been sanctioned with a suspension of more than 15 days, dismissal or disqualification through a final 
decision during career.

\section{CHAPTER TEN \\ SPECIALIZED UNITS}

\section{Article 27.}

At the head of each of the specialized units will be a Director, who will hold the authority to:

I. Exercise of the functions set forth in Article 4 of the Organic Law, with respect to the crimes under unit's competence, in coordination with the administrative units and competent agencies;

II. Hear matters under the responsibility of the precincts related to the crimes under unit's competence, in accordance with applicable law and institutional policies, or when ordered by the Attorney General or respective deputy attorney general;

III. Exercise the authority to bring matters under own jurisdiction for the investigation and prosecution of crimes of state jurisdiction connected to federal crimes under unit's competence;

IV. Submit to precincts, through the Bureau of Control of Pretrial Investigations, investigations related to the crimes under unit's competence, for their prosecution, pursuant to institutional regulations and policies, or when so ordered by the Attorney General or respective deputy attorney general;

V. Authorize decisions of reservation of action, incompetence to stand trial, joining or separation of pretrial investigations under its responsibility.

VI. Establish coordination mechanisms with administrative units responsible for the control and follow-up of pretrial investigations and federal criminal proceedings, in order to optimize criminal prosecutions, and facilitate the procedural actions that must be filed before judicial authorities;

VII. Coordinate with precincts in the investigations and proceedings carried out in the territorial jurisdiction of the respective precinct, related to those crimes under unit's competence, in accordance with applicable law and institutional policy, or when so directed by the Attorney General or respective deputy attorney general, and provide assistance and support to precincts;

VIII. Propose, in coordination with the competent administrative units of the Institution, policies, strategies and courses of action to fight crimes under unit's competence;

IX. Participate, in coordination with the competent administrative units of the Institution, with international organizations and groups responsible for or involved in investigation and control of crimes under their respective competences;

X. Provide competent administrative units of the Institution with information and statistics on the crimes under unit's competence;

XI. Exercise direct and immediate command over assigned personnel.

XII. Others conferred by regulations applying to the Attorney General.

\section{Article 28.}

The units specialized in organized crime will be competent in the following matters:

...

II. The Specialized Unit for Investigation of Terrorism, Arms Stockpiling and Trafficking will hear crimes as established in Article 2 of the Federal Law against Organized Crime, in relation to the crimes listed below:

a) Terrorism, as set forth in Article 139, first paragraph, of the Federal Criminal Code, and

b) Arms stockpiling and trafficking, as set forth in articles 83 bis and 84 of the Federal Firearms and Explosives Law. 
III. - The Specialized Unit for Investigation of Operations with Funds of Illicit Origin and Counterfeiting or Alteration of Currency, will hear crimes as established in Article 2 of the Federal Law against Organized Crime, in relation to the crimes listed below:

a) Operations with funds of illicit origin, contemplated in Article 400 bis of the Federal Criminal Code, and

$\cdots$

The Specialized Units referred to in this article will hear investigations for crimes under their competence, even when these have not been committed by members of organized crime. In these cases, they will not be authorized to apply the provisions of the Federal Law Against Organized Crime.

The foregoing is without prejudice to hearing other illegal actions connected to those described in the previous sections, in accordance with the guidelines issued by the Attorney General.

INTERNAL BYLAW OF THE MINISTRY OF 15

FINANCE AND PUBLIC CREDIT (Reglamento Interior de la Secretaría de Hacienda y Crédito Público)

Article 15. The Financial Intelligence Unit is empowered to:

I. Propose and issue opinion to other administrative units of the Ministry [of Finance and Public Credit] about general provisions that, on terms of the applicable legislation, the latter shall emit related to:

a) The establishment of measures and procedures in order to prevent and detect acts or transactions that might favour, give aid, help or cooperation of any kind to carry out terrorism, its financing or money laundering offences;

b) The report of acts, transactions and services that could be related to the offences described hereinabove concerning customers and users or managers, officials, employees and attorneys of said individuals, and

c) The guidelines concerning the proceedings and criteria that reporting entities shall observe, regarding due knowledge and identification of customers and users; the information and documentation that said entities shall compile in order to celebrate contracts, perform transactions, render services and verify customer's identity; the means by which reporting entities shall protect and guarantee the security of the information and documentation contained in the files of users and customers and the terms to provide guidance and training to reporting entities, among others;

II. Participate in coordination with other administrative units of the Ministry, in the analysis and production of laws and decrees draft initiatives regarding terrorism, its financing and money laundering offences;

III. Issue legal opinions to other administrative units of the Ministry regarding the interpretation for administrative purposes of the general provisions set forth on section I hereinabove, or the legal provisions derived from said provisions;

IV. Design the official formats to submit the transaction reports referred on the general provisions mentioned on preceding section I;

V. Verify in coordination with other agencies of the Ministry, due compliance with the general provisions 
referred to above in section I;

VI. Receive and analyze the transaction reports foreseen in the general provisions mentioned hereinabove in section I, and the customs reports referred to in article 9 of the Customs Law. Additionally, provide feedback on the usefulness of said reports to reporting entities and competent authorities;

VII. Request and compile either directly from the reporting entities or through the supervisory authorities channels, additional information and documentation related to the just-mentioned reports;

VIII. Negotiate with other administrative units the suitable and timely approach to information or documentation that may be helpful to exercise its powers, including the access to private databases;

IX. Assess and approve the working schedules, information technology and other technical criteria that reporting entities shall establish and monitor their observance;

X. Receive, compile and analyze the evidence, reports, documents and informs regarding conducts that might favour, give aid, help or cooperation of any kind to carry out terrorism, its financing or money laundering offences, integrating the respective files;

XI. Perform, in coordination with tax authorities, supervisory procedures, within the powers granted in this article;

XII. Provide and request to competent domestic authorities, the information and documentation that may be useful to develop their functions;

XIII. Present accusations or penal complaints to the Public Prosecutor regarding conducts that might favour, give aid, help or cooperation of any kind to carry out terrorism, its financing or money laundering offences, providing case evidence elements;

XIV. Cooperate with the competent authorities, in representation of the Ministry, on criminal procedures related to conducts that might favour, give aid, help or cooperation of any kind to carry out terrorism, its financing or money laundering offences;

XV. Monitor and follow-up the penal procedures in which the Ministry may have an interest;

XVI. Attend the requirements and resolutions rendered by jurisdictional or administrative authorities, including the Public Prosecutor;

XVII. Link up administrative units and supervisory agencies of the Ministry with other agencies and entities of the Federal Public Administration and negotiate, celebrate and implement agreements with those agencies;

XVIII. Inform the supervisory agencies of the Ministry about incompliance with the general provisions referred to in section I of this article

XIX. Request to the supervisory agencies, reports about the findings of their supervisory activities;

XX. Participate in the negotiation of international treaties within the scope of its attributions and subscribe the international agreements that do not require to be signed by the Minister;

XXI. Participate in national and international fora and events on the subjects related to its attributions; 
XXII. Perform as linkage between the Ministry and foreign countries, international or intergovernmental organizations, with whom international treaties or agreements have been subscribed and implement the agreements reached with those entities;

XXIII. Exchange information and documentation with foreign authorities of the countries with which international treaties or agreements have been subscribed, within the subjects of its attributions;

XXIV. Spread typologies and guidelines within the subjects of its attributions;

XXV. Notify resolutions, engagements, requirements, requests of information and other administrative acts, related to the exercise of its powers;

XXVI. Issue certificates of the files concerning the subjects of its attributions;

XXVII. Use, exploit and safeguard the information generated within the scope of its attributions. Promote and supervise the observance of security policies in accordance with the rules and guidelines set forth by the General Coordination on Information Quality and Security;

XXVIII. Establish statistic and economic models that support the analysis of transaction reports and customs declarations;

XXIX. Define policies to cluster and categorize the information with a risk-based approach;

XXX. Record statistics within the scope of its attributions, so as to present reports and informs;

XXXI. Establish policies and programs regarding reception and analysis of the information obtained within the general provisions referred to in subsection I hereinabove and the customs declarations. Encourage the reporting entities to observe their compliance and feedback on the usefulness of said reports and declarations.

XXXII. Exercise the powers referred to in article 7, subsections XIII to XIX of this Internal Regulation, and

XXXIII. Exercise the powers conferred to in other legal provisions and those directly granted by the Minister [of Finance and Public Credit].

Bylaw of Inspection and Surveillance of the National $3 ; 7 ; 8$; Insurance and Bonds Commission.

ARTICLE 3.- The persons subject to the inspection and audit of the Commission, shall be obligated to render all the help to the inspectors which they require, furnishing the data, reports, records, minutes books, auxiliary books, documents, correspondence and in general, the documentation, disks, tapes or any other processable media of storage of data which the institution shall have and that the inspectors deem necessary for compliance with their duties; possibly retaining access to their offices and other installations.

The information referred to in the preceding paragraph, includes that contained in the processing and conservation of data systems, as well as any other technical proceeding settled for such means, such as magnetic files, microfilmed documents files, optical processes for consultation or of any other nature.

The information requested by the Commission for the exercise of its surveillance and inspection functions, should 
be submitted through the standard request forms established for such means and in terms of the present Bylaw and of the General Provisions issued by the Commission.

The information provided in order to fulfil that foreseen in the present Bylaw will exclusively be used to perform the inspection and surveillance functions attributed to the Commission by the legal and administrative provisions.

The public servants of the National Insurance and Bonds Commission, auditors and other professionals who aid the Commission according to that foreseen in article 110 of the General Law of Insurance Institutions and Mutual Entities and article 70 of the Federal Law of Bonds Institutions, who according to their functions have access to the information referred to in this article, are constrained to keep due secrecy of such documentation. The breach of this provision might result in the imposition of the sanctions foreseen by the applicable laws.

ARTICLE 7. - The Commission will perform the inspection functions referred to in this Bylaw to the persons mentioned in article 1, through ordinary, special or investigative visits.

In the elaboration of the Annual Program of Ordinary Visits for consideration and approval of the President of the Commission, its general scopes shall be included, as well as the terms in which it will be performed. This Program will be elaborated on the basis of proved experience, in order to allow these visits to take place with the necessary frequency.

The special visits shall be made if it is necessary to correct special operational situations; and those investigative with the scope of clarifying or asses a specific situation.

ARTICLE 8.- The inspection performed by the Commission to the persons subject to its inspection and surveillance functions will be performed by visits which will have the purpose of review, verify, prove and evaluate the resources, obligations, net wealth, as well as the operations, functioning, control systems and in general, all that which might affect the financial, actuary, reinsurance and legal position, shown or which should be shown in the records, for the purpose of fulfilling the legal, regulating and administrative provisions which govern them and best practices in the functioning and operation, by undertaking the following actions:

I. Verify the timely, appropriate, complete and accurate registration of the transactions, by which responsibilities or contingent liabilities are or might be originated;

II. Prove the existence of the properties which are part of the fixed assets, the documentation that prove the existence of their obligations as well as the creation of reserves and other components which integrate the liabilities; as well as the accurate integration of the capital, capital reserves and other patrimonial accounts;

III. Verify the accurate valuation of the concepts referred to by the preceding fractions;

IV. Verify and prove that the financial statements reflect the situation and results of the operations;

V. Evaluate the organizational structure and the accountancy and internal control systems, aimed at preserving its solvency and financial stability;

VI. Analyze the determined deviations in relation with the applicable provisions, uses and best practices, and prove that these are properly corrected;

VII. Investigate or clarify situations observed throughout the surveillance action;

VIII. Investigate or clarify situations observed by the external auditors, the normative comptroller and, if applicable, the medical comptroller;

IX. Investigate or clarify situations presented by the commissioner, persons insured, beneficiaries of bonds, or a 
group of shareholders, who submit sufficient data to justify in the judgment of the National Insurance and Bond Commission a visit as foreseen in the first paragraph of this article;

X. Prove the performance of corrective actions ordered by the Commission or by other authorities, as well as the regularization plans or programs of autocorrecting which may have been implemented;

XI. Evaluate the existence of the necessary systems, proceedings and administrative infrastructure to provide the services pertaining to its business area, and

$\mathrm{X}$. Review, verify, prove and evaluate any other aspect in which it is deemed necessary on a case by case basis.

In the theoretical hypothesis foreseen by this article, the aim will consist in stimulating the fulfilment, correction and observance deemed necessary by each case.

\section{AML/CFT GENERAL PROVISIONS (SECONDARY REGULATIONS)}

General Provisions Referred To In Article 95bis Of The General Law of Auxiliary Credit Organizations and Activities Applicable To The Persons Who Perform Operations Referred To In Article 81-A Of Such Legal Ordinance

\section{CHAPTER I DEFINITIONS}

First.- The present Provisions have the purpose to set forth, according to that foreseen in article 95 BIS of the Credit Institutions Law, minimum measures and procedures that the persons who perform Transactions referred in article 81-A of the mentioned legal ordinance shall observe to prevent, detect and report acts, omissions or Transactions that may favor, help, provide aid or cooperation of any kind for the commission of the offense foreseen in article 139 of the Federal Penal Code, or that may correspond to assumptions referred to in article 400 Bis of the same Code.

Second.- For the purposes of the present Provisions, it will be understood as:

I. "Beneficial owner", the person who obtains by means of other person, a profit derived from a Transaction. It also refers to those people who exercise ultimate control over a legal person or legal contract.

II. "Client", in singular or plural, any legal or natural person who undertakes in conjunction with the Entities, the Transactions referred to in article 81-A of the present Law.

III. "Monetary Instrument", the coins and paper money of the United Mexican States, or any other country of legal circulation, minted pieces and common paper money of legal circulation in the country of issuance; travelers checks issued in foreign currency, metallic pieces minted in coin shape, money orders issued and payable in foreign currency by a financial institution.

IV. "Law", the Credit Institutions Law;

V. "Transactions", those referred in article 81-A of the Law;

VI. "Unusual Transaction", the Transaction, activity, conduct or behavior that is not in line with the background, known or declared activity of the Client, or with his/her usual Transactional behavior pattern regarding the amount, frequency, type or nature of the Transaction(s) concerned, when there is not a reasonable justification for such behavior, or that which, for any other reason, the Entities consider that the funds may be destined to favor, provide aid or cooperation of any kind for the commission of the offense 
foreseen in article 139 of the Federal Penal Code, or that may belong to any of the possibilities referred to in article 400 Bis of the same legal ordinance; or when it is considered that the funds may be destined to favor the commission of the offenses mentioned in this paragraph and the sufficient elements are available to

make the report;

VII. "Concerning Transaction", the Transaction, activity, conduct or behavior by directors, officials, employees and legal representatives of the Entities that, due to their characteristics, may jeopardize the compliance or make vulnerable the enforcement of what is foreseen in the Law and the present Provisions, or that which for any other reason are dubious to the Entities;

VIII. "Relevant Transaction", the Transactions performed with Monetary Instruments set forth in section III of this Provision, for an amount equal or exceeding the equivalent in national currency of three thousand Dollars of the United States of America.

To calculate the Transactions amounts in domestic currency, it shall be considered the exchange rate applicable to pay liabilities in a foreign currency payable in the United Mexican States, published by Bank of Mexico in the Official Gazette, on the immediate preceding date when the Transaction is performed;

IX. "Politically exposed person", individuals who are or have been entrusted with prominent public functions in a foreign country or national territory, considering among others, heads of state or government, senior politicians, senior government officials, senior judicial or military officials, senior executives of state owned corporations or important political parties' officials;

It is similar to a Politically exposed person, spouses and blood relatives up to the second degree, as well as companies in which the Politically exposed person has financial interests;

X. "Risk", the possibility for Entities to be used by their Clients to perform acts or Transactions that may be destined to favor, provide aid or cooperation of any kind for the commission of the offense foreseen in article 139 of the Federal Penal Code, or that may apply in any of the possibilities referred to in article 400 Bis of the same legal ordinance;

XI. "SAT", Tax Administration Service (Servicio de Administración Tributaria);

XII. "Secretariat", the Secretariat of Finance and Public Credit, and

XIII. "Entities", the persons who perform activities referred to in article 81-A of the Law.

\section{CHAPTER II}

\section{CLIENT IDENTIFICATION POLICY}

Third.- Entities shall establish and comply with a Client identification policy, which shall include at least, the guidelines set forth in the present Chapter, as well as the criteria, measures and procedures required for their identification compliance, including those related to the verification and actualization of information provided by Clients. 
Fourth.- Entities shall integrate a Client identification file prior to the performing of Transactions for an amount equal or exceeding the equivalent in national currency of three thousand Dollars of the United States of America, which shall include at least the following:

I. In the case of Mexican natural persons, the following data shall be filed: last and first names; domicile; (street, number, neighborhood, zip code, delegation or municipality, city or town and federal entity), date of birth, nationality, occupation or profession, activity or business purpose, telephone(s) in which said individual could be located, e-mail when available, and the Population Register Code and/or the Federal Tax Register when the said individual have them.

Furthermore, it shall be required the presentation of the following documents:

a) Personal identification, which shall be in all cases an original official document issued by the competent authority, current on the date being filed, bearing a photograph, domicile and signature of the holder.

For this purpose, it shall be deemed as valid personal identification documents, among others, the Federal Voting Card issued by the Federal Electorate Institute, passport issued by the Secretariat of Foreign Affairs, professional certificate, national military service card and the military identity card.

It also shall be considered as valid the member card of the National Institute for Elder People, cards and carnets issued by the Mexican Institute of Social Welfare cards issued by superior education public institutions, driver's license, Consular ID, cards issued by federal and local entities, and other document issued by a competent authority with the scope to obtain resources or different kind of economic support derived from federal, local or municipal governmental programs. According to the characteristics and the place in which the Transaction takes place, the entities can establish measures which help them to verify in a reasonable way, the identity of their clients, such as, testimony rendered to a competent jurisdictional authority, eye witnesses or verifying questions.

b) Proof of the Population Register Code issued by the Secretariat of the Interior and/or the Fiscal Identification Carnet issued by the Secretariat, when the Client has them.

c) Domicile proof, when the domicile stated on a contract does not match the one on the identification or the latter does not have a domicile, it will be necessary for the Client to present a document that gives proof of his/her domicile, which may be, among others, the utilities bill, telephone, residential property tax bills, bank statements, all current within a three months period from the date of emission, or rent/leasing contract registered before the competent fiscal authority.

The documents included in the preceding subsection a) which contain the domicile, can also be considered as documents to prove such information.

In the case of legal representatives, Entities shall request the original power of attorney letter or a certified copy of the document issued by the public notary pursuant to the terms set forth in the legislation, which states the powers granted to the legal representative, as well as an official identification and proof of domicile of the latter, with independence between the data and the documents of who granted the power of attorney. 
II. Regarding Mexican national legal persons, the following data shall be filed: trade or legal name, commercial occupation, activity or business purpose, Federal Tax Register, domicile (street, number, neighborhood, zip code, city or town and federal entity); telephone(s), e-mail when available, the company's date of incorporation, nationality and name of the manager(s), director, general director, or legal representative who may, with his/her signature, force the legal entity to perform the Transactions involved.

Likewise, it shall be requested, at least, the presentation of the following documents:

a) Testimony or certified copy of the incorporation certificate registered at the Commercial Public Register, which thoroughly certifies its legal existence;

b) Fiscal Identification Carnet issued by the Secretariat;

c) Proof of domicile;

d) Testimony or certified copy of the document containing the powers granted to the representative or legal representatives issued by a public notary in the event that such powers are not stated in the incorporation certificate, as well as personal identification of the latter, pursuant to subsection a) of the preceding section I, and

e) In the event of a legal person of recent incorporation not registered in the Commercial Public Register, Entities shall request a signed document by a legal empowered individual that certified his/her legal personality in terms of the corresponding testimony, manifesting that the proper registration shall be performed and the resulting information provided to the Entity in due time.

III. In case of foreigners, they shall:

a) Natural persons, submit original passport and document authorizing their legal stay in the country, when available, or any similar document referred to in subsection I of the present Provision; as well as information on their domicile in their country of origin and where they may be located while residing in national territory; and

b) Legal persons, present a certified copy or apostille of the document that duly proofs their legal incorporation, as well as the document stating the individual designated as legal representative, and in the event that said individual is also a foreigner, he/she shall submit the documents outlined on the previous section.

IV. In the event of companies and entities referred to in Annex 1 of the present Provisions, the Entities shall implement simplified Client identification measures; integrating the file with at least the following information:

Trade or legal name, activity or business purpose; Federal Tax Register; domicile; (street, number, neighborhood, zip code, city, town or federal entity); telephone(s), e-mail when available, and the name of the administrator(s), director, general director or legal representative who may, with his/her signature, force the legal entity to perform the involved Transaction.

Likewise, it shall be requested, at least, as may apply, the filing of the testimony or certified copy of the document containing the powers granted to the representative or legal representatives issued by a public notary, proof of appointment certificate issued by a competent official, according to article 90 of the Credit Institutions Law, as well as their personal identification pursuant to subsection a) of the preceding section I.

When there are reasons or certainty that the identification documents presented by the Clients are false or have 
scratches or corrections, the Entities shall file another identification file or request two banking or commercial references and two personal references, which shall include: name, domicile and telephone number of who presented them, which authenticity shall be confirm by the latter, prior to the performance of the Transaction.

Entities shall keep in the Client's identification file, a copy of documents mentioned in this Provision, prior verification with their originals.

Fifth.- Entities shall only be able to perform Transactions of any kind until their Clients have satisfactorily complied with the identification requirements set forth in this Chapter.

Sixth.- The Entities shall take reasonable measures and establish procedures to identify Beneficial Owners and comply with the requirements referred to in sections I and II of the Fourth of these Dispositions, for which they shall:

1. In the case of legal commercial persons, know its corporate structure and controlling interests;

2. With regards to legal persons who are companies or civil associations, identify their partners, associates or equivalents.

Seventh.-The Entities should adopt measures in order to keep updated the information and documentation contained in the identification file. During the Transactional relation with the Client, Entities should verify and ask the client to update the information and documentation, specifically when they notice significant changes in his or her habitual behavior or when the Entity has doubts regarding the veracity of such information or documentation.

The Entities shall apply measures in order to update the identification files at least one time per year, when the Client is a person ranked as high risk or when he or she is a Politically exposed person.

Additionally, Entities shall randomly ask to the Clients to hand in copy of their personal identification with domicile included, in order to verify that this address coincides with the one contained in the identification file. If it does not coincide, the Entity shall proceed to update such information.

The internal procedures shall foresee the cases in which depending on the level of risk, the Entity shall perform visits to the domicile of the Client, having to include in the identification file the evidence and records of such visits.

\section{CHAPTER III}

\section{CLIENT DUE DILIGENCE POLICY}

Eight. - Entities must elaborate and observe a Client due diligence policy, which shall include, at least, the guidelines established in the present Dispositions, as well as the required criteria, measures and procedures for their due compliance.

Ninth.- The implementation of the Client due diligence policy shall be based on the Transactional Risk that a Client may represent, so that when the Risk level is higher, it shall be required additional information and tighter monitoring of the Client's Transactional behavior.

For the latter, Entities must classify Clients per their Risk level, establishing at least two classifications, high and low Risk. Entities may establish in between Risk levels, in addition to those previously mentioned.

To determine the Risk level where Clients should be located, as well as whether the Client is considered a 
Politically exposed person or not, Entities shall establish internal criteria for which, among other things, they shall take into consideration the Client's background, profession, activity or business purpose, origin of funds involved, and other circumstances determined by Entities.

The Entities shall establish mechanisms to determine the Risk level of Transactions performed with a Mexican politically exposed person, and determine whether the Transactional behavior reasonably matches with his/her functions, level and responsibility.

Furthermore, Entities shall establish a preemptive alarm system to verify and detect changes in the Client's Transactional behavior and apply the necessary measures.

Tenth.- In Transactions classified as of high Risk, Entities shall implement reasonable measures to know about the origin of funds involved and try to obtain the information and documents pointed out in Chapter II of the present Provisions, regarding their spouse and economic dependants, as well as companies or associations with which the Client maintains patrimonial links in the case of natural persons; and in the case of legal persons, their corporative structure and main shareholders.

Transactions shall be classified as high Risk, among others, when performed with foreign Politically exposed persons.

The performance of Transactions whose characteristics could represent a high Risk for the Entity must be approved at the director's level and be made of the knowledge of the persons referred to in Provision Ninetieth, for the mentioned effects.

Eleventh.- If an Entity considers or has sufficient grounds to believe that -when performing a particular Transaction- the funds may be the result of an illicit activity in terms of that foreseen in article 400 Bis of the Federal Penal Code or may be destined to favor, help or provide aid or cooperation of any kind for the commission of an offense as foreseen in article 139 of the same legal ordinance, must, when accepting the Transaction, immediately inform the persons mentioned in the Provision Nineteenth, who within the following twenty-four hours shall submit to the Secretariat, through the SAT, the Unusual Transaction Report and duly inform the Secretariat.

Twelfth.- When doubts arise about whether a Client is acting on behalf of a third party, Entities shall, to the extent possible, identify the true Client or Beneficial owner of the Transactions, without prejudice to its confidentiality obligations towards third parties imposed by contractual or conventional means.

In the assumption foreseen in the previous paragraph, as well as in cases where doubt arise regarding the information or documents provided by the Client for identification purposes, or about his/her Transactional behavior, the monitoring of the Transactions must be tighten, and if necessary, submit them for consideration of the persons mentioned in Provision Nineteenth who shall rule, and if applicable, produce the Unusual Transaction Report.

Thirteenth.- The identification and Client due diligence policies of each Entity shall include, at least:

1. Procedures for the Client due diligence compliance, including its update, according to that stipulated in the present Provisions;

2. Procedures for Entities to do a follow-up to its Client Transactions;

3. Cases where Transactions deviate from Transactional profiles; 

4. Identification of possible Unusual Transactions, and
5. Considerations to, when applicable, modify the Risk level previously determined.

The Clients' Transactional profile shall be based on the information they must provide to the Entity, and when necessary, on information obtained by the Entity, regarding the number, type, nature and frequency of Transactions commonly carry out by said Clients, the origin and destination of funds, relying on the knowledge that the Entity's employee or official may have regarding his/her clientele base and additional elements and criteria determined by the Entities.

Fourteenth.- The Entities shall send to the SAT and the Secretariat, a document with the criteria, measures and procedures about the Client identification and due diligence policies for the effects stipulated in the Thirtieth Second and Thirtieth Third of these Provisions. With the purpose of uniformity, the Entities may elaborate a reference document, through the Association to which they belong to. The modifications shall also be sent to the authorities mentioned.

\section{CHAPTER IV \\ REPORTS ON RELEVANT TRANSACTIONS}

Fifteenth.- Entities shall submit, on a quarterly basis to the Secretariat, through the SAT, their reports on Relevant Transactions, no latter than ten business days after the closing of the business day from the last month of the quarter concerned, in the official format that for that effect publishes the Secretariat, through an electronic device or any other type, according to terms and specifications pointed out by the latter.

The Entities, in which Relevant Transactions did not take place during the quarter concerned, shall notify the Secretariat, through the SAT, about such situation.

To facilitate the submission of reports to the Secretariat referred to by the present Provisions, the SAT, previous request by Entities, shall be able to determine the sequence that these shall follow, within the terms pointed out in this Provision.

\section{CHAPTER V \\ REPORTS OF UNUSUAL TRANSACTIONS}

Sixteenth.- The Entities shall submit to the Secretariat, through the SAT, their Unusual Transactions Reports, within the following thirty natural days starting from the day the Transaction is detected by the Entity's system, model, process or the Entity's employee, which ever comes first, in the official format that for such purpose publishes said Secretariat, through the electronic means or any other, according to terms and specifications established by the latter.

The Entities, in order to determine whether a Transaction is Unusual, shall consider, among other things, the following circumstances that may occur in an isolated or combined manner:

I. The specific conditions, background and classification of each of their Clients, their professional and/or commercial activity or business purpose;

II. The types, amounts, frequency and nature of Transactions commonly carried out by their Clients and their relation with the Clients' own background and known economic activity;

III. The unusually high amounts, the complexity and uncommon characteristics of Transactions performed by the 
Clients;

IV. The Transactions performed in the same account, in Monetary Instruments for multiple or fractional amounts that when added in five days equals or exceeds the equivalent to three thousand dollars of the United States of America;

V. Commercial or exchange practices and customs offered in the location where they operate;

VI. When Clients refuse to provide identification documents stated in the Fourth of the present Provisions or when it is detected that apocryphal information is being presented;

VII. When Clients try to bribe or intimidate personnel from the Entities, with the purpose of obtaining its cooperation to perform activities or Unusual Transactions, or contravene the present Provisions, other legal norms or criteria, measures and procedures of the Entities on this matter;

III. When Clients notoriously seek to avoid the parameters used by Entities to report Transactions refer to by the present Provisions;

IX. When indications or extraordinary events of difficult explanation occur, which generate any type of suspicion about the origin, handling or destination of funds or when suspicion arise of whether those indications or events may be related to acts, omissions or operations that may favor, provide aid or cooperation of any kind for the commission of the offense foreseen in article 139 of the Federal Penal Code, or that may belong to any of the possibilities referred to in article 400 Bis of the same legal ordinance;

X. When the Transactions that Clients seek to carry out involve countries and jurisdictions:

a) In which the Mexican legislation considers as preferential tax systems, or

b) In which in the opinion of international organizations of which the United Mexican States is part, do not have measures to prevent, detect and combat Transactions with funds of illicit origin or terrorist financing, or when the application of such measures is deficient.

On this respect, the Secretariat shall provide to Entities the lists containing the names of such countries and jurisdictions;

XI. When it is presumed or doubts arise about whether a Client acts on behalf of a third party, and,

XII. The conditions under which other Clients operate, who indicated being involved in similar activities, profession or commercial occupation or having the same business purpose.

The Entities shall examine the background and purpose of the Transactions presented to the persons referred to in Provision nineteenth, for their ruling as Unusual, establishing in writing the results of such evaluation, which shall be available to competent authorities.

To facilitate the process for identifying Unusual Transactions, the Secretariat shall periodically advise Entities and provide guidelines, information and typologies that allow detecting Transactions that shall be reported according to the present Provisions.

Additionally, in this process, Entities shall rely on their criteria, measures and internal procedures, and consider the guidelines provided by the Secretariat elaborated by foreign authorities or by international organizations of which the United Mexican States is part of. 
Seventeenth.- Under the assumption that a Relevant Transaction also has the characteristics for being considered as Unusual, Entities shall formulate separately both reports regarding the same Transaction highlighting such situation in the Unusual Transaction Report.

\section{CHAPTER VI CONCERNING TRANSACTIONS REPORTS}

Eighteenth.- The Entities shall submit to the Secretariat, through the SAT, the reports on Concerning Transactions within the following thirty natural days starting from the day the Transaction was detected, through the system, model, process or the Entity's employee, which ever happens first, in the official format that for such effect publishes the Secretariat, through the electronic device or any other type, according to terms and specifications pointed out by the latter.

The Entities, in order to determine a Transaction as Concerning, shall consider, among other things, the following circumstances that may occur in an isolated or combined manner:

I. When it is detected that a director, official, employee or legal representative of the Entity maintains a life style notoriously superior to that which would correspond according with his/her income perceived;

II. When, without a justified reason, a director, official, employee or legal representative has intervened in a reiterated manner in the performance of certain Transactions reported as Unusual;

III. When suspicion arise about whether a director, official, employee or legal representative has performed acts, omissions or operations that may favor, provide aid or cooperation of any kind for the commission of the offense foreseen in article 139 of the Federal Penal Code, or that may belong to any of the possibilities referred to in article $400 \mathrm{Bis}$ of the same legal ordinance, and

IV. When, without a justified reason, there is lack of correlation between the functions invested to a director, official, employee or legal representative and the activities that in fact he/she performs.

\section{CHAPTER VII INTERNAL STRUCTURES}

Ninetieth.- The Committee will designate from within its members, an official who will carry out, at least, the functions and obligations stipulated as follows:

I. Determine the identification and Client due diligence policies, that should be elaborated by the Entities, according to that established in the present Provisions, and the criteria, measures and procedures developed for due compliance, and to verify its right performance.

II. Act as competent area to be aware of the results regarding the assessment on the effectiveness of the policies, criteria, measures and procedures pointed out in the previous section, in order to correct the flaws, deficiencies or omissions.

III. Be informed of the performance of Transactions whose characteristics could represent a high Risk for the Entity, according to reports presented and, when applicable, elaborate the recommendations it deems appropriate;

IV. Be informed of the behavior performed by its directors, officials, employees or legal representatives of the Entities, which may cause it to incur in the breach of that foreseen in the present Provisions, or cases where 
such directors, officials, employees or legal representatives contravene what is foreseen in the policies, criteria, measures and procedures stated in section I of this Provision.

V. Establish and disseminate the criteria for Client classification on the basis of their Risk level, as stipulated in the Ninetieth Provision;

VI. Disseminate among personnel responsible of applying the present Provisions, the officially recognized lists released by international organizations or authorities from other countries, of people linked to terrorism or its financing, or to other illegal activities;

VII. In relation with the Transactions referred to in the following section, received in order to rule them as Unusual or Concerning, coordinate the activities needed to be performed as follow up, such as needed investigations.

VIII. Rule on the Transactions that shall be reported to the Secretariat, through the SAT, as Unusual or Concerning, in terms established in the present Provisions;

IX. Document the adopted resolutions, as well as the arguments considered to rule over a Transaction put to his/her consideration to be determined as Unusual or Concerning.

X. Approve the training programs for the Entities' personnel on matters of prevention, detection and behavior report directed towards favoring, provide aid or cooperation of any kind for the commission of an offense as foreseen in article 139 of the Federal Penal Code, or that may be referred to in article 400 bis of the same legal ordinance;

XI. Inform the competent area of the Entity, regarding behavior performed by its directors, officials, employees or legal representatives, which may cause it to incur in the breach of that foreseen in the present Provisions, or cases where such directors, officials, employees or legal representatives contravene what is foreseen in the policies, criteria, measures and procedures stated in section I of the Twenty Seventh of these Provisions, in order to impose the disciplinary measures that may apply;

XII. Act as an internal organ of consultation regarding the application of the present Provisions, Client identification and due diligence policies, as well as the criteria, measures and procedures that for such effects are established by the Entities;

XIII. Act as liaison between the Secretariat and the SAT for matters related to these Provisions and,

XIV. Solve other matters presented for its evaluation regarding the implementation of the present Provisions.

Twentieth.- The administrator of the Entity shall appoint the person or persons who will have the competence and obligations referred to in the previous disposition, and shall inform of such information and of their respective substitutes to the Secretariat, through the SAT, within fifteen business days following the date in which said appointment was made.

\section{CHAPTER VIII \\ TRAINING AND DISSEMINATION}

Twentieth one The Entities shall develop training and dissemination programs, which shall cover, at least, the following:

I. Give training courses at least once a year, which shall be especially designed for those persons referred to in the Nineteenth Provision as well as for directors, officials, employees or legal representatives of the Entities that work in areas of attention to the public. These courses shall include in its content Client identification and 
due diligence policies, as well as the criteria, measures and procedures developed by the Entity for a diligent compliance of these Provisions is oversee, and

II. The dissemination of the present Provisions and its modifications, as well as on information about techniques, methods and tendencies to prevent, detect and report Transactions that could be destined to favor, provide aid or cooperation of any kind for the commission of an offense as foreseen in article 139 of the Federal Penal Code or that may apply according to article 400 Bis of the same legal ordinance.

Twentieth two.- The Entities shall have records on the participation in the courses of the persons referred to in the Ninetieth Provision, as well as directors, officials, employees or legal representatives of the Entities, to whom evaluations must be given on acquired knowledge, establishing measures to be adopted regarding those who do not obtain satisfactory results.

Prior to their entrance period, Entities shall assure and record the fact that the Officials and employees that are going to work in areas of attention to the public or managing funds are duly trained on this matter.

\section{CHAPTER IX AUTOMATED SYSTEMS}

Twentieth third.- Entities shall have automated systems that perform, among other things, the following functions:

I. Maintain and update information records registered in the Clients' due diligence files;

II. Generate, codify, encrypt and transmit in a secured manner to the Secretariat, through the SAT, information pursuant to Relevant, Unusual and Concerning Transaction reports, in terms and according to the period of times provided by the present Provisions;

III. Classify Transactions based on the criteria established by the Entities, in order to detect possible Unusual Transactions;

IV. Detect and monitor Transactions carried out by a single Client in Monetary Instruments, in multiple or fractional amounts, that in five days equals or exceeds the equivalent in national currency of three thousand dollars from the United States of America;

V. Contribute to the follow-up and analysis of possible Unusual and Concerning Transactions, considering at least access to historical records of Transactions made by Clients, Transactional behavior, average of Transactions and any another parameter that could contribute to the analysis of this type of Transactions;

VI. Group in a consolidated data base the different Transactions of a single Client, in order to control and perform an integral monitoring of his/her data and Transactions;

VII. Retain historical records of possible Unusual and Concerning Transactions;

VIII. Function as means for the personnel of the Entities to report in a secure, confidential and auditable manner, possible Unusual or Concerning Transactions, and

IX. Maintain security schemes for processed information that guarantees its integrity, availability, auditability and confidentiality.

CAPITULO $\mathrm{X}$ 
Twentieth Fourth.- Members of the Board of Directors, persons designated under Ninetieth Provision, as well as directors, officials, employees and legal representatives from the Entities, must maintain the most absolute confidentiality regarding the information on the reports foreseen in the present Provisions, except when requested by authorities expressively authorized, having also strictly forbidden to alert or inform their Clients about their incorporation into said reports.

Twentieth Fifth.- The compliance of the obligation invested to Entities, to members of its Board of Directors, the persons designated under Ninetieth Provision, as well as directors, officials, employees and legal representatives, to send to the Secretariat, through the SAT, the reports and information referred to in the present Provisions, shall not constitute a violation to restrictions on disclosure of information imposed by contractual means or any legal disposition, and shall not imply any type of responsibility.

Furthermore, the reports and information generated by the Entities in order to comply with the present Provisions, will not be considered an indication of an established offense.

\section{CHAPTER XI OTHER OBLIGATIONS}

Twentieth Sixth.- The Entities shall provide to the Secretariat, through the SAT, all information and documentation requested related to reports foreseen in the present Provisions.

Twentieth Seventh.- The Entities, when in doubt of the accuracy of the Fiscal Identification Carnet of their Clients, shall verify the authenticity of the data contained in it within 30 natural days of being presented, according to procedures established by the Secretariat for that effect.

Twentieth Eight.- The Entities shall adopt a selection procedure to assure that their personnel have the technical quality and necessary experience, as well as honorability to carry out activities given to them. For the effects of this Provision, a person without honorability means those who have been sentenced for crimes against property, those have been disqualified to perform commercial activities or to hold public positions or posts pertaining to the Mexican financial system.

Thirtieth Nineth.- Entities shall make reasonable efforts to implement the present Provisions, as may apply, in their offices, branches, agencies and subsidiaries located abroad, especially in those located in countries where measures to prevent, detect and combat Transactions with funds of illicit origin or for financing terrorism do not exist or are applied in an insufficient manner.

When it is impossible to apply the present Provisions in their offices, branches, agencies and subsidiaries located abroad, as may apply, the Entities shall inform in writing about such situation to the Secretariat, through the SAT, in a period not longer than twenty business days after the conclusion of the proceedings that for this effect they carried out.

In those cases in which the Provisions of the country where the Entity's offices, branches, agencies and subsidiaries are located establish enhanced requirements on this matter, they will be complied by informing the SAT of such situation, in order for it to evaluate its relation with the present Provisions.

Thirtieth.- The copies of reports foreseen in the present Provisions and of the registrations of Transactions that occurred, shall be kept for a period of not less than ten years after their conclusion.

The documents that integrate the Client due diligence files shall be kept for a period of not less than ten years. 
For such effect, Entities shall comply with the criteria, which according to the Commerce Code, regarding microfilming, recording, conservation and document destruction.

\section{CHAPTER XII GENERAL PROVISIONS}

Thirtieth one.- The Secretariat shall be able to interpret, for administrative effects, the content of the present Provisions, as well as determine the scope of their implementation, while listening to the opinion of the SAT.

Thirtieth two.- The SAT shall be authorized to request directly to the Entities, or through the Association that represents them, when applicable, to make modifications to their Client identification and due diligence policies, and to the criteria, measures and procedures that they elaborated according to that foreseen in the present Provisions, when to its judgment, it is considered necessary for their correct implementation.

Thirtieth third.- The SAT, in exercise of the supervisory powers conferred to it by the Law and other legal ordinances shall oversee that Entities, including when applicable, their offices, branches, agencies and subsidiaries in national and foreign territory, comply with the obligations established in the present Provisions, in their Client identification and due diligence policies, and in the criteria, measures and procedures that they shall elaborate according to that foreseen in the present Provisions, and shall impose the sanctions that may apply for the lack of compliance to the mentioned obligations in terms established in the Law, while being able to request at any time, the information or necessary documentation for the enforcement of its duties.

Thirtieth fourth.- With regards to the application of sanctions, it shall also be considered as noncompliance, those cases in which Entities present incomplete information, illegible, or with errors, or when the electronic or magnetic device do not comply with the technical specifications stipulated by the Secretariat.

Thirtieth fifth.- The Entities shall hand in to the SAT, through the Local Attention Taxpayers Office which corresponds attending to the domicile, a document in the official format that for that effect establishes the Secretariat, in which they inform that due to the activities they perform, they should be considered as those cases mentioned in article 81-A of the Law. This document shall contain:

I. Trade or legal name;

II. Name of the owner or in case, of the principal shareholders;

III. Domiciles of the offices, agencies, establishments or branches in which the Transactions are performed;

IV. Fiscal Identification Carnet, and

V. The activities performed by which they are located under article 81-A of the Law.

The document referred to in the present Provision shall be presented within the first fifteen days after the Entities perform the activities mentioned in article 81-A of the Law.

According to the precedent paragraph, the Entities shall give notice to the authorities of any change of information provided or of the cease of performance of the activities referred to in article 81-A of the Law. This notice shall take place within the first fifteen days in which either circumstance occurs.

This information shall be updated at least once a year, and with the sequence specified by the Secretariat in order to be complied by the Entities. 


\section{T R A N S I T O R I E S}

First.- The present Provisions shall enter into effect the following day they are published in the Official Gazette.

Second.- The Entities, when performing the Transactions, shall have thirty natural days starting from the date the present Provisions enter into effect, to compose the Client identification files refered to by the Fourth of the present Provisions.

Third.- The policies referred to in Provision Third should be elaborated within thirty natural days starting from the date the present Provisions enter into effect. The same period of time applies for the implementation and fullfilment of Chapters II, III, VII and VIII of the present Provisions as well as the procedures foreseen in the Twentieth Eight Provission.

Fourth.- Within a period of six months, starting from the date the present Provisions enter into effect, implementation and fullfillment of that forseen in in Chapter IX of the present Provisions should be performed.

Fifth.- The Entities shall have one hundred and twenty natural days starting from the date the present Provisions enter into effect, to present to the SAT and the Secretariat the document regarding the criteria, measures and uniform procedures on the Client identification and due diligence policy refered to by the Fourthteenth of the present Provisions.

Sixth.- The persons that prior to the enter into force of the present Provisions perform the activities referred to by article 81-A of the Law, shall have thirty working days starting from the date the present Provisions enter into effect, to perform the notification referred to by the Thirtieth Fifth of the present Provisions.

\section{Annex 1}

The simplified regime shall apply to the following Entities when they carry out Transactions as Clients:

Holding Companies of Financial Groups

Investment Companies

Investment Companies Specialized in Pension Funds

Investment Management Companies

Investment Stock Distributing Companies

Credit Institutions

Brokerage Companies

Money Exchange Companies

Pension Fund Administration Companies

Insurance Companies

Mutual Insurance Companies

Bonding Companies

General Deposit Warehouses Companies

Financial Leasing Companies

Savings and Loans Companies

Popular Financial Companies

Limited Scope Financial Institutions

Credit Unions

Financial Factoring Companies

Securities Issuing Companies*

Foreign Financial Institutions** 
Federal, State and Municipal Public Companies and Entities

Securities Trading Companies

Security Depository

Companies that administer mechanisms to facilitate securities’ Transactions

\section{Central Counterparts}

* Those whose securities are registered in the National Securities Register.

** Those which are established in countries or territories where measures are implemented to prevent, detect and combat Transactions with funds of illicit origin and financing of terrorism, and that are supervised regarding the fulfillment of such measures. 